Prepared in cooperation with the Wyoming State Engineer's Office

\title{
Water Resources of Carbon County, Wyoming
}

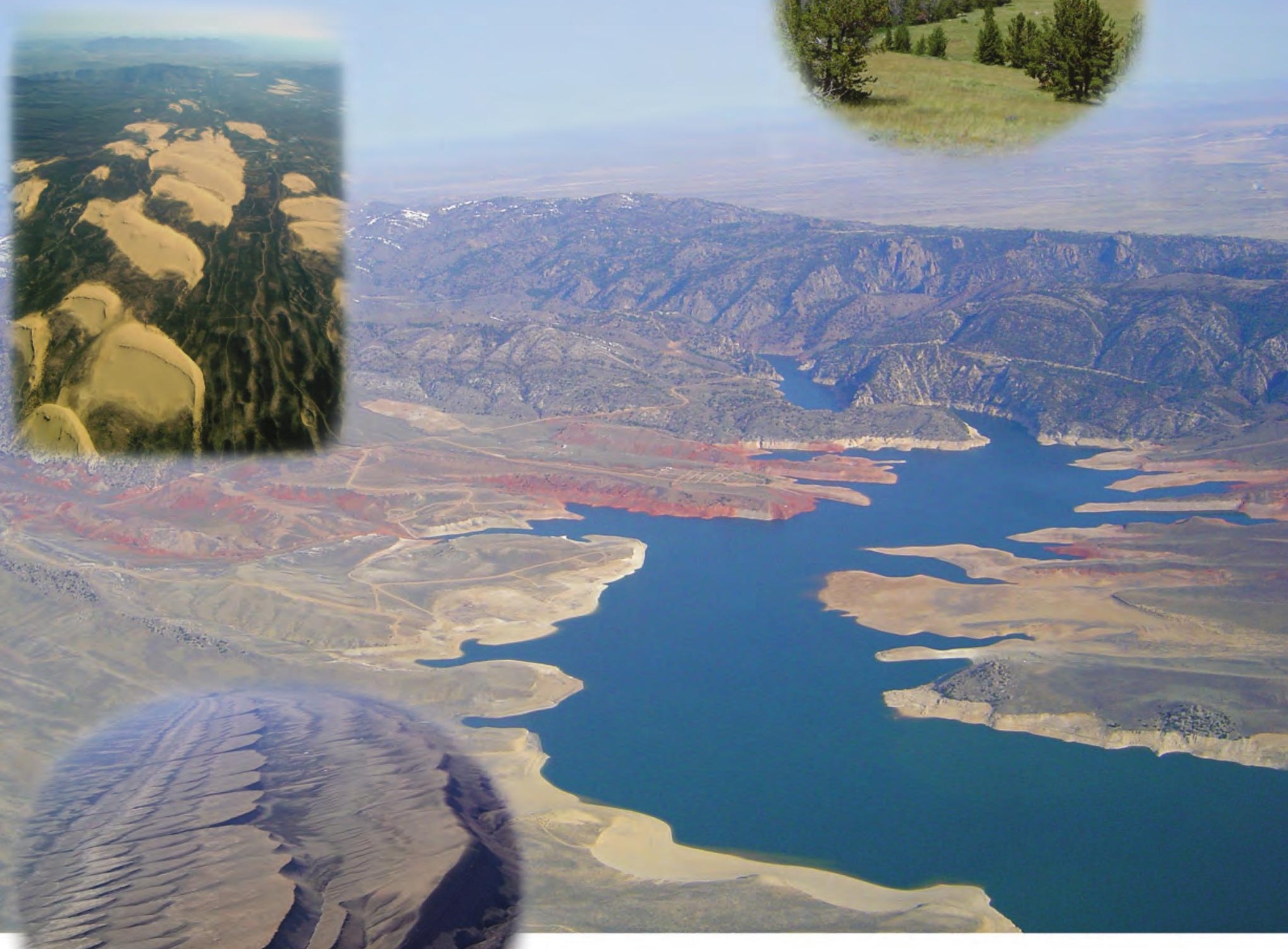

Scientific Investigations Report 2006-5027 
Front cover photographs:

Upper left: Looking northeast at dune field near Ferris, Wyoming; lower left: looking south at Brown Canyon Rim, north of Rawlins, Wyoming; upper right: looking north from the slopes of the Ferris Mountains near Pete Creek, Wyoming; center: looking north at Seminoe Reservoir, Wyoming.

Back cover photograph:
Looking south at Seminoe Mountains, Wyoming.

Photographs by Jon P. Mason and Jodi R. Norris, USGS hydrologists. 


\section{Water Resources of Carbon County, Wyoming}

By Timothy T. Bartos, Laura L. Hallberg, Jon P. Mason, Jodi R. Norris, and Kirk A. Miller

Scientific Investigations Report 2006-5027 


\section{U.S. Department of the Interior \\ Gale A. Norton, Secretary \\ U.S. Geological Survey \\ P. Patrick Leahy, Acting Director}

\section{U.S. Geological Survey, Reston, Virginia: 2006}

For product and ordering information:

World Wide Web: http://www.usgs.gov/pubprod

Telephone: 1-888-ASK-USGS

For more information on the USGS--the Federal source for science about the Earth, its natural and living resources, natural hazards, and the environment:

World Wide Web: http://www.usgs.gov

Telephone: 1-888-ASK-USGS

Any use of trade, product, or firm names is for descriptive purposes only and does not imply endorsement by the U.S. Government.

Although this report is in the public domain, permission must be secured from the individual copyright owners to reproduce any copyrighted materials contained within this report.

Suggested citation:

Bartos, T.T., Hallberg, L.L., Mason, J.P., Norris, J.R., and Miller, K.A., 2006, Water resources of Carbon County, Wyoming: U.S. Geological Survey Scientific Investigations Report 2006-5027, 191 p. 


\section{Contents}

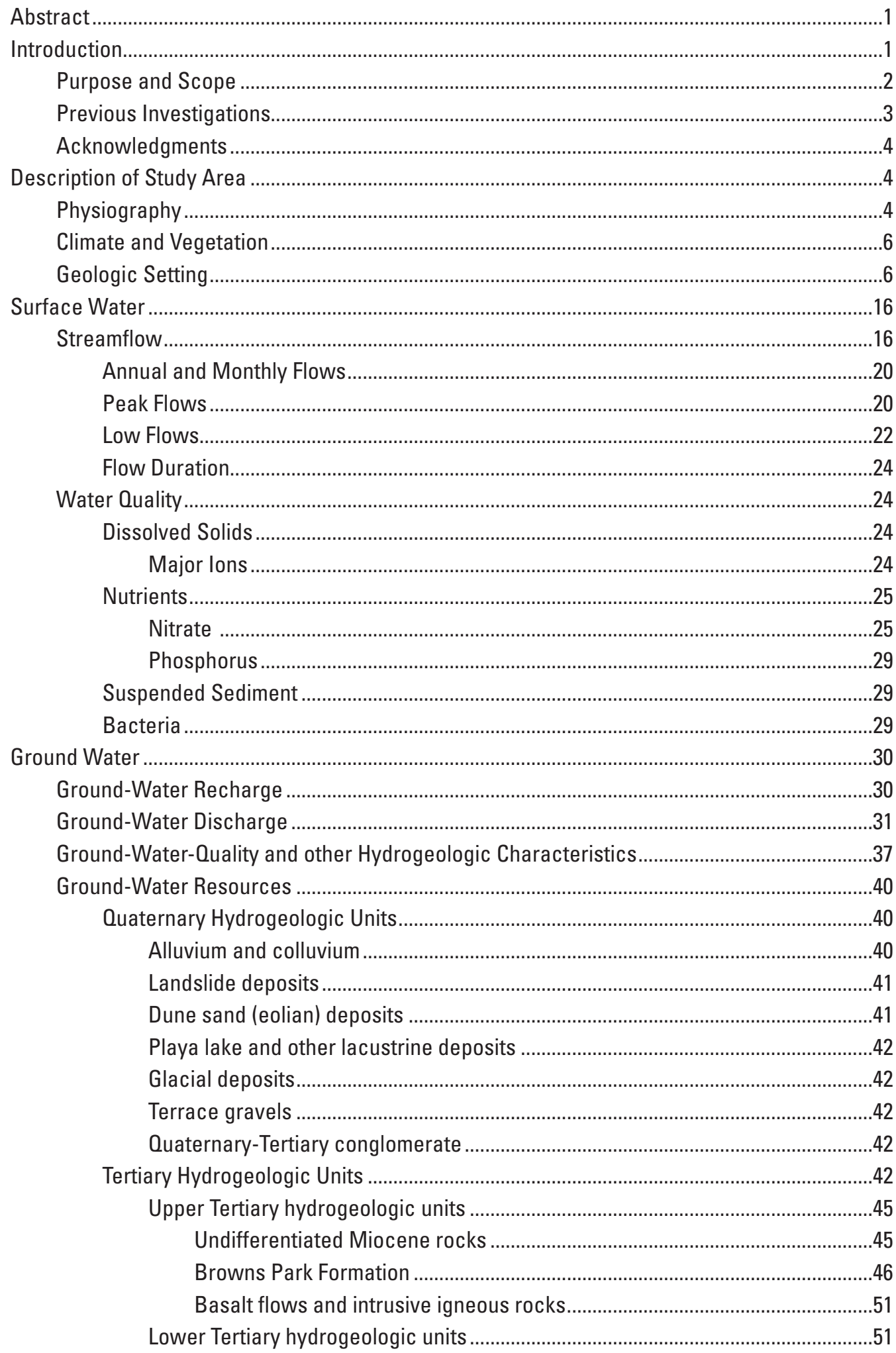




\section{Contents-Continued}

\begin{tabular}{|c|c|}
\hline & White River Formation ......................................... \\
\hline & Washakie Formation......... \\
\hline & Wagon Bed Formation ..... \\
\hline & Green River Formation .................. \\
\hline & Wasatch Formation ................... \\
\hline & Battle Spring Formation.......... \\
\hline & Wind River Formation.......... \\
\hline & Coalmont Formation ....... \\
\hline & Hanna Formation............. \\
\hline & Fort Union Formation........ \\
\hline & Ferris Formation ............... \\
\hline & sozoic Hydrogeologic Units ................. \\
\hline & Medicine Bow Formation ............... \\
\hline & Lance Formation .................. \\
\hline & Fox Hills Sandstone ................ \\
\hline & Lewis Shale.................. \\
\hline & Mesaverde Group or Formation ............ \\
\hline & Cody Shale ................... \\
\hline & Steele Shale............. \\
\hline & Niobrara Formation ........ \\
\hline & Frontier Formation .......... \\
\hline & 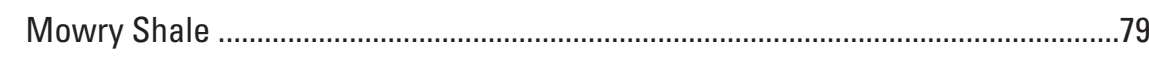 \\
\hline & Thermopolis Shale and Muddy Sandstone \\
\hline & Cloverly Formation ......................... \\
\hline & Morrison Formation....... \\
\hline & Sundance Formation ................ \\
\hline & Nugget Sandstone .......................... \\
\hline & 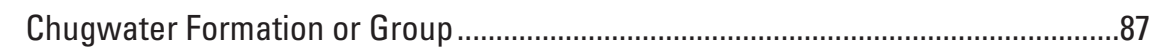 \\
\hline & 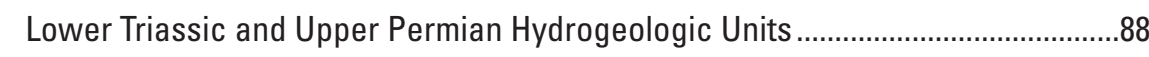 \\
\hline Pale & eozoic Hydrogeologic Units \\
\hline & Casper and Fountain Formations \\
\hline & Tensleep Sandstone \\
\hline & 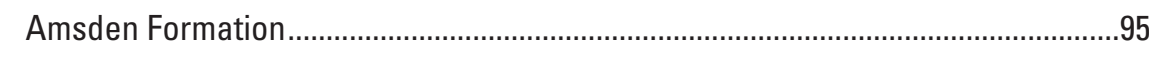 \\
\hline & 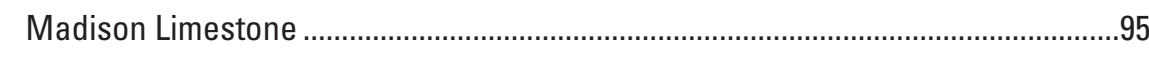 \\
\hline & 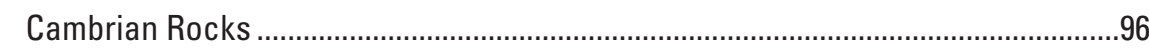 \\
\hline & 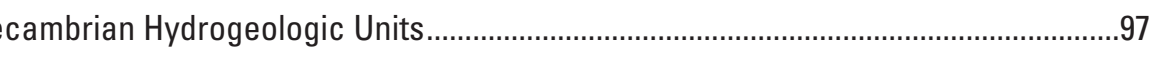 \\
\hline & (1) \\
\hline v & \\
\hline erences....... & 100 \\
\hline $\begin{aligned} \operatorname{dix} 1 . \\
\text { Carb }\end{aligned}$ & amflow characteristics, selected sites in and near \\
\hline
\end{tabular}




\section{Contents-Continued}

Appendix 2. Peak-flow characteristics, selected streamflow-gaging stations, in and near Carbon County, Wyoming.

Appendix 3. Annual low-flow characteristics, selected sites in and near Carbon County,

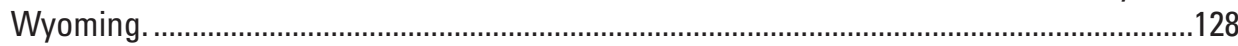

Appendix 4. Streamflow duration statistics, selected sites in and near Carbon County, Wyoming.

Appendix 5. Graphs showing statistical summaries of major-ion concentrations in analyses of water-quality samples, selected surface-water sites in and near Carbon County, Wyoming.

Appendix 6. Ground-water quality data, Carbon County, Wyoming.

Appendix 7. Boxplots showing concentrations of constituents in water samples collected from aquifers in hydrogeologic units, Carbon County, Wyoming.

Appendix 8. Selected ground-water quality constituents in relation to well depth, Carbon County, Wyoming.

\section{Figures}

1-3. Maps showing:

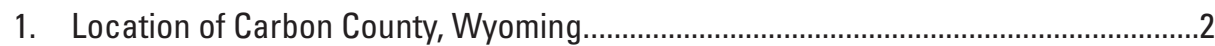

2. Generalized geology, faults, and structural features in Carbon County, Wyoming.

3. General climate classifications for Carbon County......................................................

4. Modified Walter-Lieth diagram showing monthly means of precipitation and mean daily minimum, maximum, and mean temperatures for Rawlins (National Weather Service Station No. 487533) for 1951-2004.

5. Map showing mean annual precipitation, 1961-1990, and location of selected weather stations, Carbon County, Wyoming....

6. Graph showing annual precipitation for Rawlins, Wyoming .........................................9

7. Map showing structural configuration of the Precambrian-basement rock in Carbon County, Wyoming.

8. Stratigraphic chart showing nomenclature of Paleozoic and Precambrian rocks in Carbon County, Wyoming.

9. Stratigraphic chart showing nomenclature of Mesozoic rocks in Carbon County, Wyoming.

10. Stratigraphic chart showing nomenclature of Cenozoic rocks in Carbon County, Wyoming.

11. Map showing location of hydrologic regions and active (2004) and discontinued streamflow-gaging stations, active (2004) and discontinued surface-water-quality stations, and peak-flow-gaging stations in and around Carbon County, Wyoming. .......17

12. Graphs showing statistics of $A$, total dissolved-solids concentrations (water years 1966-86); $B$, dissolved nitrite plus nitrate concentrations (water years 1974-86); C, total phosphorus concentrations (water years 1974-86); and $D$, suspended-sediment concentrations (water years 1966-86) from selected sites, in or near Carbon County, Wyoming. 


\section{Figures-Continued}

\section{3-18. Maps showing:}

13. Potential for recharge by direct infiltration of precipitation to the aquifers in Mesozoic hydrogeologic units within the Upper Colorado River Basin.

14. Potentiometric surface and inferred flow paths for the Wasatch zone of the Wasatch-Fort Union aquifer, Carbon County and surrounding area.

15. Generalized potentiometric surface, recharge and discharge areas, and inferred flow paths in the Mesaverde aquifer in parts of Wyoming, Colorado, and Utah.

16. Potentiometric surface of the Tensleep aquifer in parts of Wyoming, Colorado, and Utah.

17. Potentiometric surface of the Madison aquifer in parts of Wyoming, Colorado, and Utah.

18. Ground-water quality sample locations and Cenozoic rocks in Carbon County, Wyoming.

19. Trilinear diagrams showing major-ion composition and dissolved-solids concentrations for ground-water samples from aquifers in Quaternary hydrogeologic units, Carbon County, Wyoming.

20. Map showing potentiometric surface of aquifers in undifferentiated Miocene rocks north of Ferris and Seminoe Mountains, Carbon County, Wyoming.

21. Trilinear diagrams showing major-ion composition and dissolved-solids concentrations for ground-water samples from aquifers in upper Tertiary hydrogeologic units, Carbon County, Wyoming.

22-23. Maps showing:

22. Potentiometric surface of the Browns Park aquifer (Formation) in the Saratoga Valley area, Carbon County, Wyoming.

23. Pre-mining potentiometric surface of aquifers in Tertiary hydrogeologic units for a part of the Shirley Basin, Carbon County, Wyoming.

24. Trilinear diagrams showing major-ion composition and dissolved-solids concentrations for ground-water samples from aquifers in lower Tertiary hydrogeologic units, Carbon County, Wyoming...

25. Map showing ground-water quality sample locations and Mesozoic rocks in Carbon County, Wyoming.

26. Trilinear diagrams showing major-ion composition and dissolved-solids concentrations for ground-water samples from aquifers in Upper Cretaceous hydrogeologic units, Carbon County, Wyoming.

27. Trilinear diagrams showing major-ion composition and dissolved-solids concentrations for ground-water samples from aquifers in Lower Cretaceous hydrogeologic units, Carbon County, Wyoming.

28. Trilinear diagrams showing major-ion composition and dissolved-solids concentrations for ground-water samples from aquifers in Triassic and Jurassic hydrogeologic units, Carbon County, Wyoming.

29. Map showing ground-water quality sample locations and Paleozoic rocks in Carbon County, Wyoming.

30. Trilinear diagrams showing major-ion composition and dissolved-solids concentrations for ground-water samples from aquifers in Paleozoic hydrogeologic units, Carbon County, Wyoming. 


\section{Figures-Continued}

31. Trilinear diagram showing major-ion composition and dissolved-solids concentrations for ground-water samples from aquifers in Precambrian hydrogeologic units, Carbon County, Wyoming..............................................................99

\section{Tables}

1. Characteristics of selected streamflow, peak-flow, and water-quality sites in and near Carbon County, Wyoming .....................................................................................18

2-1. Equations for estimating peak-flow characteristics, Rocky Mountains Region,

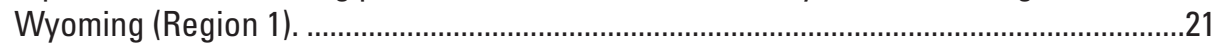

2-2. Equations for estimating peak-flow characteristics, Eastern Basins and Eastern Plains Region, Wyoming (Region 3).........................................................................22

2-3. Equations for estimating peak-flow characteristics, High Desert Region, Wyoming (Region 6).

3. Median concentrations of constituents in water-quality samples, selected surface-water sites in and near Carbon County, Wyoming, water years 1966-86...........28

4. Estimated water use in 2000 in Carbon County, Wyoming...............................................98 


\section{Conversion Factors and Datums}

\begin{tabular}{|c|c|c|}
\hline Multiply & By & To obtain \\
\hline \multicolumn{3}{|c|}{ Length } \\
\hline inch (in.) & 2.54 & centimeter $(\mathrm{cm})$ \\
\hline foot $(\mathrm{ft})$ & 0.3048 & meter $(\mathrm{m})$ \\
\hline mile (mi) & 1.609 & kilometer $(\mathrm{km})$ \\
\hline \multicolumn{3}{|c|}{ Area } \\
\hline acre & 4,047 & square meter $\left(\mathrm{m}^{2}\right)$ \\
\hline section (640 acres or 1 square mile) & 259.0 & square hectometer $\left(\mathrm{hm}^{2}\right)$ \\
\hline square mile $\left(\mathrm{mi}^{2}\right)$ & 259.0 & hectare (ha) \\
\hline square mile $\left(\mathrm{mi}^{2}\right)$ & 2.590 & square kilometer $\left(\mathrm{km}^{2}\right)$ \\
\hline \multicolumn{3}{|c|}{ Volume } \\
\hline gallon (gal) & 3.785 & liter $(\mathrm{L})$ \\
\hline gallon (gal) & 0.003785 & cubic meter $\left(\mathrm{m}^{3}\right)$ \\
\hline cubic foot $\left(\mathrm{ft}^{3}\right)$ & 0.02832 & cubic meter $\left(\mathrm{m}^{3}\right)$ \\
\hline acre-foot (acre-ft) & 1,233 & cubic meter $\left(\mathrm{m}^{3}\right)$ \\
\hline \multicolumn{3}{|c|}{ Flow rate } \\
\hline cubic foot per second $\left(\mathrm{ft}^{3} / \mathrm{s}\right)$ & 0.02832 & cubic meter per second $\left(\mathrm{m}^{3} / \mathrm{s}\right)$ \\
\hline gallon per minute (gal/min) & 0.06309 & liter per second $(\mathrm{L} / \mathrm{s})$ \\
\hline million gallons per day (Mgal/d) & 0.04381 & cubic meter per second $\left(\mathrm{m}^{3} / \mathrm{s}\right)$ \\
\hline \multicolumn{3}{|c|}{ Radioactivity } \\
\hline picocurie per liter $(\mathrm{pCi} / \mathrm{L})$ & 0.037 & becquerel per liter $(\mathrm{Bq} / \mathrm{L})$ \\
\hline \multicolumn{3}{|c|}{ Specific capacity } \\
\hline $\begin{array}{l}\text { gallon per minute per foot } \\
[(\mathrm{gal} / \mathrm{min}) / \mathrm{ft})]\end{array}$ & 0.2070 & liter per second per meter $[(\mathrm{L} / \mathrm{s}) / \mathrm{m}]$ \\
\hline \multicolumn{3}{|c|}{ Hydraulic conductivity } \\
\hline foot per day $(\mathrm{ft} / \mathrm{d})$ & 0.3048 & meter per day $(\mathrm{m} / \mathrm{d})$ \\
\hline \multicolumn{3}{|c|}{ Hydraulic gradient } \\
\hline foot per mile (ft/mi) & 0.1894 & meter per kilometer $(\mathrm{m} / \mathrm{km})$ \\
\hline \multicolumn{3}{|c|}{ Transmissivity* } \\
\hline foot squared per day $\left(\mathrm{ft}^{2} / \mathrm{d}\right)$ & 0.09290 & meter squared per day $\left(\mathrm{m}^{2} / \mathrm{d}\right)$ \\
\hline
\end{tabular}

Temperature in degrees Celsius $\left({ }^{\circ} \mathrm{C}\right)$ may be converted to degrees Fahrenheit $\left({ }^{\circ} \mathrm{F}\right)$ as follows:

$$
{ }^{\circ} \mathrm{F}=\left(1.8 x^{\circ} \mathrm{C}\right)+32
$$

Temperature in degrees Fahrenheit $\left({ }^{\circ} \mathrm{F}\right)$ may be converted to degrees Celsius $\left({ }^{\circ} \mathrm{C}\right)$ as follows:

$$
{ }^{\circ} \mathrm{C}=\left({ }^{\circ} \mathrm{F}-32\right) / 1.8
$$

Vertical coordinate information is referenced to the National Geodetic Vertical Datum of 1929 (NGVD 29). Horizontal coordinate information is referenced to the North American Datum of 1983 (NAD 83).

Altitude, as used in this report, refers to distance above the vertical datum.

*Transmissivity: The standard unit for transmissivity is cubic foot per day per square foot times foot of aquifer thickness $\left[\left(\mathrm{ft}^{3} / \mathrm{d}\right) / \mathrm{ft}^{2}\right] \mathrm{ft}$. In this report, the mathematically reduced form, foot squared per day $\left(\mathrm{ft}^{2} / \mathrm{d}\right)$, is used for convenience.

Specific conductance is given in microsiemens per centimeter at 25 degrees Celsius $\left(\mu \mathrm{S} / \mathrm{cm}\right.$ at $\left.25^{\circ} \mathrm{C}\right)$.

Concentrations of chemical constituents in water are given either in milligrams per liter $(\mathrm{mg} / \mathrm{L})$ or micrograms per liter $(\mu \mathrm{g} / \mathrm{L})$.

Water year is 0 ctober 1 through September 30 and is designated by the year in which it ends. 


\section{Abbreviations, acronyms, and symbols used in this report}

$\mathrm{mL} \quad$ milliliter

CBM coalbed methane

E. coli Escherichia coli

GIS geographical information system

GPS global positioning system

HAL Lifetime Health Advisory Level

MCL Maximum Contaminant Level

N. North

NWIS National Water Information System

PWD Produced Waters Database

R. Range

RASA Regional Aquifer System Analysis

Rs. Ranges

SAR sodium-adsorption ratio

Sec. Section

SMCL Secondary Maximum Contaminant Level

SNOTEL Natural Resources Conservation Service SNOwpack TELemetry

T. Township

TDS total dissolved solids

Tps. Townships

USEPA U.S. Environmental Protection Agency

USGS U.S. Geological Survey

W. West

WDEO Wyoming Department of Environmental Quality

WDM watershed data management

WOGCC Wyoming Oil and Gas Conservation Commission

WRDS Water Resources Data System

7010 7-day, 10-year low flow

$<\quad$ less than

$>\quad$ greater than 



\title{
Water Resources of Carbon County, Wyoming
}

\author{
By Timothy T. Bartos, Laura L. Hallberg, Jon P. Mason, Jodi R. Norris, and Kirk A. Miller
}

\section{Abstract}

Carbon County is located in the south-central part of Wyoming and is the third largest county in the State. A study to describe the physical and chemical characteristics of surface-water and ground-water resources in Carbon County was conducted by the U.S. Geological Survey in cooperation with the Wyoming State Engineer's Office. Evaluations of streamflow and stream-water quality were limited to analyses of historical data and descriptions of previous investigations. Surface-water data were not collected as part of the study. Forty-five ground-water-quality samples were collected as part of the study and the results from an additional 618 historical ground-water-quality samples were reviewed. Available hydrogeologic characteristics for various aquifers in hydrogeologic units throughout the county also are described.

Flow characteristics of streams in Carbon County vary substantially depending on regional and local basin characteristics and anthropogenic factors. Precipitation in the county is variable with high mountainous areas receiving several times the annual precipitation of basin lowland areas. For this reason, streams with headwaters in mountainous areas generally are perennial, whereas most streams in the county with headwaters in basin lowland areas are ephemeral, flowing only as a result of regional or local rainfall or snowmelt runoff. Flow characteristics of most perennial streams are altered substantially by diversions and regulation.

Water-quality characteristics of selected streams in and near Carbon County during water years 1966 through 1986 varied. Concentrations of dissolved constituents and suspended sediment were smallest at sites on streams with headwaters in mountainous areas because of resistant geologic units, large diluting streamflows, and increased vegetative cover compared to sites on streams with headwaters in basin lowlands.

Both water-table and artesian conditions occur in aquifers within the county. Shallow ground water is available throughout the county, although much of it is only marginally suitable or is unsuitable for domestic and irrigation uses mainly because of high total dissolved solids (TDS) concentrations. Suitable ground water for livestock use is available in most areas of the county. Ground-water quality tends to deteriorate with increasing distance from recharge areas and with increasing depth below land surface. Ground water from depths greater than a few thousand feet tends to have TDS concentra- tions that make it moderately saline to briny. In some areas, even shallow ground water is moderately saline. Specific constituents in parts of some aquifers in the county occur in relatively high concentrations when compared to U.S. Environmental Protection Agency drinking-water standards; for example, relatively high concentrations of sulfate, chloride, fluoride, boron, iron, manganese, and radon were found in several aquifers.

The estimated mean daily water use in Carbon County in 2000 was about 320 million gallons per day. Water used for irrigation accounted for about 98 percent of this total. About 98 percent of the total water used was supplied by surface water and about 2 percent by ground water. Excluding irrigation, ground water comprised about 78 percent of total water use in Carbon County. Although ground water is used to a much lesser extent than surface water, in many areas of the county it is the only available water source.

\section{Introduction}

Carbon County covers 7,896 square miles $\left(\mathrm{mi}^{2}\right)$ and is the third largest county in Wyoming. It was the eleventh most populated county in Wyoming in the 2000 census with a population of 15,639 (U.S. Census Bureau, 2003). Carbon County is located in the south-central part of the State (fig. 1).

Ten communities (municipalities) are present in Carbon County and about 87 percent of the population lives within these 10 communities (Pedersen Planning Consultants, 2005). Based on the 2000 Census, only three towns have populations greater than 500: Rawlins (population 8,538); Saratoga (population 1,726); and Hanna (population 873) (U.S. Census Bureau, 2003).

The population of Carbon County has fluctuated with changes in natural-resource development (oil and gas extraction and refinement, coal and uranium mining, timber harvesting and milling) and agriculture (ranching and farming) (Pedersen Planning Consultants, 2005). These industries provide many of the jobs in the county, comprising a large part of the economy. The largest population fluctuations generally have occurred in relation to changes in the energy extraction industries (oil and gas development and mining) (Pedersen Planning Consultants, 2005). The smallest communities in the county generally are more vulnerable to these population changes (Pedersen Planning Consultants, 2005). 


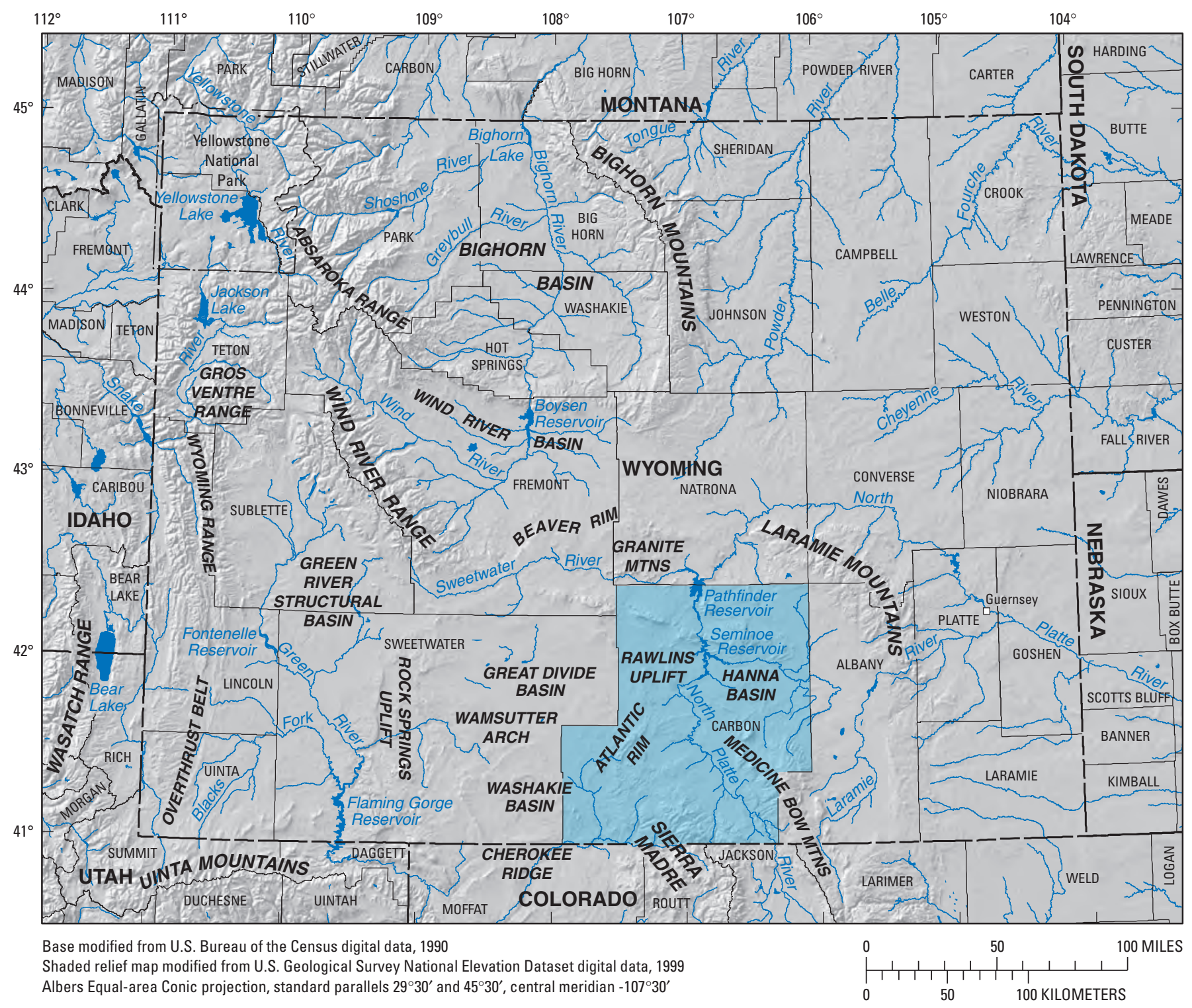

Figure 1. Location of Carbon County, Wyoming.

Although Carbon County's population decreased 6.1 percent between 1990 and 2000 (U.S. Census Bureau, 2003), the demand for water is expected to increase in the county. Extraction of the county's abundant natural resources commonly requires large quantities of water. Major uses of water in the extraction industry include water used for drilling fluid, secondary recovery of oil, and dust control. Water also is produced in mine dewatering. A new industry based on the extraction of methane from coal, also known as coalbed methane (CBM) extraction, is beginning to be developed in the county. CBM extraction requires dewatering of coal deposits in order to release methane gas. Abundant coal deposits in the county make widespread CBM development a possibility.

Increased water development has the potential to affect the quantity and quality of water resources in Carbon County.
To address this concern, the U.S. Geological Survey (USGS) conducted a study in cooperation with the Wyoming State Engineer's Office to describe the water resources of Carbon County. Results of this study will aid water-resource managers in future development of the county's water resources.

\section{Purpose and Scope}

This report describes the availability and chemical quality of surface-water and ground-water resources in Carbon County. This report is one in a series of reports on the water resources of Wyoming counties.

Characteristics of surface-water resources of Carbon County described in this report include the flow and quality of water in streams. Flow and water-quality data are described for 
the purpose of characterizing temporal variability at specific sites, as well as the general spatial variability of streamflows in the county. Descriptions include statistics of annual, monthly, peak, and low flows for selected USGS streamflowgaging stations. Water-quality characteristics of streams are described by summaries of daily and periodic samples of physical properties, dissolved solids, major ions, nutrients, suspended sediment, and bacteria collected from selected USGS sites. Surface-water data were not collected as part of this study; thus, descriptions of streamflow and stream-water quality are limited to analyses of historical data collected as part of other programs and summaries of analyses in previous publications. Because few surface-water data are available and because many streams flow into Carbon County from surrounding areas, data from sites outside the county were included.

Characteristics of ground-water resources in Carbon County described in this report include ground-water recharge, discharge, water quality, and geologic and hydrogeologic characteristics. Ground-water resources are discussed mainly in terms of geologic formations. The extent, composition, and resources of hydrogeologic units in geologic formations also are described in the report. Existing water quality, quantity, availability, and hydraulic data were compiled and analyzed from numerous sources and results from 618 ground-water quality samples were included in the study. In addition, 45 ground-water quality samples were collected as part of this study during 2002 and 2003 to fill gaps in the existing data. Comparisons of ground-water quality are made among selected geologic formations.

\section{Previous Investigations}

There have been many previous investigations related to the surface-water resources of Carbon County. Following is a brief description of a few of these investigations. One of the earliest investigations was an inventory of irrigation resources in the Upper North Platte River Basin presented by Newell (1893). More recently, Lowry and others (1973) presented streamflow characteristics for several streams in Carbon County, including flow-duration curves and low-flow frequency curves for three gaging stations on the North Platte River. Water-quality data for the North Platte and Medicine Bow Rivers in Carbon County also are presented in Lowry and others (1973). Larson and Zimmerman (1981) described the principal stresses that affected water quantity and quality in the upper Separation Creek Basin (drainage basin) in the west central part of Carbon County. The headwaters of Separation Creek are on the Atlantic Rim just south of Separation Peak. Separation Creek is mainly ephemeral and generally flows north where it eventually terminates in a small lake on Separation Flats in the northwest part of the county. Eschner and others (1983) discussed the hydrologic and morphologic effects of water development for agricultural, municipal, and industrial uses in the Platte River Basin. Carbon County was only a small part of this regional investigation; however, Eschner and others (1983) provide a broad context in which to understand the water-development issues of the Upper North Platte River in Carbon County.

Numerous regional ground-water studies have been conducted that included all or parts of Carbon County. Selected results from several of the following reports describing regional ground-water resources are discussed in this report. Two of the most comprehensive early regional groundwater studies completed in the area are the USGS Hydrologic Investigations Atlas by Welder and McGreevy (1966), which described ground-water occurrence and quality in the Great Divide and Washakie Basins, and the USGS Hydrologic Investigations Atlas by Lowry and others (1973) that described ground-water occurrence and quality in the Laramie, Shirley, and Hanna Basins and adjacent areas. Collentine and others (1981) described the occurrence and characteristics of ground water in the Great Divide and Washakie Basins. Richter (1981) described the occurrence and characteristics of ground water in the Laramie, Shirley, and Hanna Basins. As part of the USGS Coal Hydrology Program, several regional hydrology studies (including ground-water resources) were conducted for drainage basins that included parts of Carbon County (Kuhn and others, 1983; Driver and others, 1984; and Lowham and others, 1985). Several ground-water studies have been completed for the Upper Colorado River Basin (which includes the eastern parts of the Great Divide and Washakie Basins in western Carbon County) as part of the USGS Regional Aquifer System Analysis (RASA) Program. The RASA Program was started in 1977 to provide quantitative regional assessments of ground-water resources. Freethey and others (1988) and Freethey and Cordy (1991) described the hydrogeology of Mesozoic rocks in the Upper Colorado River Basin. LindnerLunsford and others (1989) described the hydrogeology of Paleozoic rocks in the Upper Colorado River Basin. Martin (1996) described the hydrogeology of Tertiary rocks in the Green River Basin. Naftz (1996) described the hydrogeology and geochemistry of selected Tertiary rocks in the Upper Colorado River Basin. Glover and others (1998) described the hydrogeology of Tertiary rocks in the Upper Colorado River Basin. Geldon (2003) described hydrologic properties and ground-water flow systems in Paleozoic rocks in the Upper Colorado River Basin.

Descriptions of the water chemistry of selected oil-field water within Carbon County were presented in several early studies. Crawford (1940) discussed oil-field water of Wyoming, including fields within Carbon County. Crawford and Davis (1962) discussed oil-field water from Cretaceous formations in Wyoming, including fields within Carbon County. Oilfield water in the Laramie and Hanna Basins was discussed in Crawford (1953).

Local ground-water investigations also have been completed for specific areas within Carbon County. Visher (1952) discussed the geology and ground-water resources of the Pass Creek Flats area. Saulnier (1968) described the groundwater resources and geomorphology of the Pass Creek Basin 
area within Albany and Carbon Counties. Harshman (1972) examined geology, uranium deposits, and related ground-water characteristics in the Shirley Basin area. Borchert (1977) constructed a preliminary ground-water flow model for the Sweetwater River Basin. Freudenthal (1979) presented groundwater-quality data for the Hanna and Carbon Basins. Larson (1984, p. 22-23) summarized dissolved-solids concentrations of historical ground-water-quality samples in Carbon County. Lenfest (1986) examined ground-water levels in relation to irrigation withdrawals in the Saratoga Valley area. Borchert (1987) constructed a potentiometric map of the shallow ground-water flow system in the Sweetwater River Basin. Larson (1988) presented coal-spoil and ground-water-quality data for a coal mine in the Hanna Basin. Crist (1990) described the shallow ground-water flow system along the North Platte River, including the Saratoga Valley area. Huntoon and others (1993) examined the effects of reduced streamflows on ground-water recharge and discharge in the Little Snake River drainage basin. Johnson and Huntoon (1994) examined ground-water movement and permeability characteristics in aquifers located in the northern Hanna Basin.

In addition, numerous reports have been produced in relation to development of water supplies for various communities in Carbon County. Selected results of some of these studies are discussed later in this report.

\section{Acknowledgments}

The authors gratefully acknowledge the assistance and cooperation of farmers, ranchers, and landowners of Carbon County. Individuals from the Rawlins Field Office of the Bureau of Land Management provided invaluable assistance in locating ground-water sampling sites. The USGS hydrologic technicians and hydrologists who collected streamflow and water-quality data are acknowledged; without their dedication, this study would not have been possible. Kendra Remley is recognized for exceptional help with data collection. Sue Roberts is acknowledged for skillful preparation of the report figures and text. Finally, all the local, State, and Federal agencies that contribute to the operation of the streamflow gages and collection of water-quality samples are acknowledged.

\section{Description of Study Area}

Physiography (physical geography), climate, and geology are directly related to the availability and quality of water resources within Carbon County. Physiography affects the movement of both surface water and ground water in the county, whereas climate affects the water budget. The complex geologic history of the county that has resulted in the accumulation of abundant natural resources such as coal, oil, natural gas, uranium, and precious minerals also influences the movement and quality of surface water and ground water.

\section{Physiography}

Carbon County is located in the Wyoming Basin Physiographic Province of the Rocky Mountain Region (Raisz, 1972). The physiography of an area is determined by physical features of the landscape such as landforms, topography, soils, and water bodies. Topographic features such as mountains and basins often coincide with structural uplifts and basins, which are formed by faulting and folding of the earth's crust. In some cases, erosion of a structural uplift or filling in of a structural basin can subdue or even reverse the topographic expression of a structural feature. In Carbon County, structural uplifts and basins generally coincide with the topography of the county, although the surface expression of the Rawlins Uplift has been reduced by erosion, and much of the Shirley Basin is higher in altitude than adjacent areas because of erosion of Bates Hole to the north and the erosion in the Muddy Creek drainage to the south (fig. 2).

Carbon County is topographically dominated by the Medicine Bow Mountains and Sierra Madre in the southern part of the county; however, the remaining areas of the county have substantial local relief because of smaller mountains such as the Ferris, Seminoe, and Shirley Mountains, as well as numerous ridges and scarps (fig. 2). The county includes part or all of several topographic and structural basins, including all of the Saratoga Valley, the Kindt, Hanna, and Shirley Basins as well as parts of the Laramie and Great Divide Basins.

The altitude of the highest point in Carbon County is 11,920 feet (ft) on mountain slopes near Medicine Bow peak, which lies just across the county line in Albany County. The lowest point in the county is in the underwater channel in Pathfinder Reservoir; the surface altitude of the reservoir is approximately $5,850 \mathrm{ft}$. The areas outside the mountain ranges are topographically varied, with several landforms commonly occurring in Carbon County including sand dunes, both vegetated and active; playas (salt flats); ridges formed by sedimentary rock outcrops; river valleys with associated floodplains; and land surfaces dissected by erosion, ranging from branching stream erosion patterns to intensely eroded badlands.

Carbon County watersheds drain in three distinct directions (fig. 2). The North Platte River is the largest stream in Carbon County, carrying more water and having a larger watershed than any other stream in the county. The Medicine Bow River, a tributary of the North Platte River, forms the second largest stream by discharge and by watershed size. The Continental Divide crosses Carbon County along the crest of the Sierra Madre, and splits north of the Sierra Madre to form the Great Divide Basin. The Washakie Basin and the part of the Sierra Madre west of the divide drain into the Little Snake River and eventually to the Colorado River. The Great Divide Basin has no external drainage; the single perennial stream within the basin is the upper part of Separation Creek, which flows from its headwaters along the Atlantic Rim in westcentral Carbon County (Bureau of Land Management, 2002, p. 34). 




\section{Climate and Vegetation}

The climate of Carbon County has been broadly classified by Martner (1986) (fig. 3). Most of the county is classified as steppe with smaller areas classified as desert, alpine, and alpine tundra. This report follows Martner's terminology for the use of the terms "alpine" and "alpine tundra"; however, in most vegetation glossaries, Martner's "alpine" would correspond to "subalpine", and Martner's "alpine tundra" would correspond to "alpine". In the central and western parts of the county, areas identified as steppe generally are dominated by one of two subspecies of big sagebrush, Wyoming big sagebrush (Artemisia tridentata ssp. wyomingensis) or Mountain big sagebrush (Artemisia tridentata ssp. vaseyana), although in the northeastern part of the county areas classified as steppe support mixed-grass prairie (Merrill and others, 1996). Small amounts of land classified as desert occur in the county, corresponding roughly to the area of the Great Divide Basin. Areas identified as desert generally receive less than 10 inches (in.) of precipitation annually (Martner, 1986, p. 6) and are characterized by dryland vegetation such as saltbush, greasewood, and desert shrub. The predominance of sagebrush and desert shrub vegetation is due to low summer precipitation and low annual precipitation. Driese and others (1997) report a shift from grassland to shrub-dominated communities such as Wyoming big sagebrush as summer (May-October) precipitation decreases to less than $11.1 \mathrm{in.}$. For the large areas of rangeland in the county, climatic conditions alternate annually between cold winter temperatures, which prevent substantial plant growth, and summer water deficits (fig. 4). The alpine tundra occurs in high parts of the Medicine Bow Mountains above the treeline and is characterized by cold temperatures, a short growing season, and often strong winds. Alpine areas are dominated by coniferous forests, in particular lodgepole pine forests (Pinus contorta), which occur in the Ferris, Seminoe, and Shirley Mountains and cover large expanses of the Sierra Madre and Medicine Bow Mountains. Smaller amounts of spruce and fir forest occur in alpine areas of the Sierra Madre and Medicine Bow Mountains, as well as aspen forests, which cover large areas of the west slope of the Sierra Madre and occur in smaller patches elsewhere. These alpine areas are the only areas in the county that receive enough precipitation to support closed-canopy forests, although in river valleys and along streams, shallow ground water and streamflow can support closed-canopy riparian forests, often called gallery forests. Except for streamsides and mountains, most of Carbon County is treeless, although scattered trees form woodlands on ridges in several areas.

The Rawlins weather station has an annual mean 106-day frost-free period, 1951-2004, and monthly station records of precipitation and temperature over the period of record (19512004) indicate water stress through much of the frost-free period when the mean daily maximum temperature is greater than the mean monthly precipitation (fig. 4). Mean annual precipitation in the county ranges from about $7.3 \mathrm{in}$. in the southern parts of the Great Divide Basin to about 56 in. in the Sierra

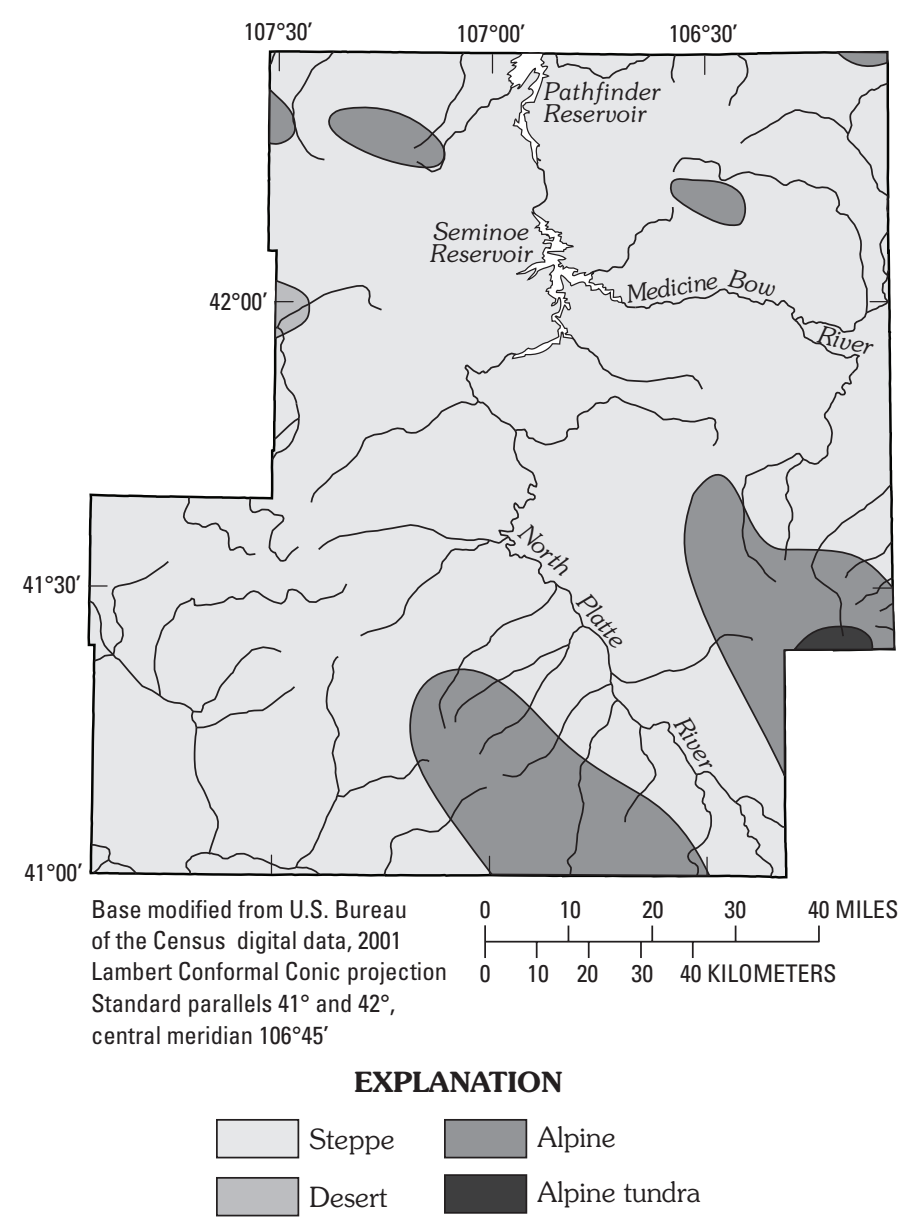

Figure 3. General climate classifications for Carbon County (modified from Martner, 1986).

Madre (fig. 5). Mean annual precipitation data came from a gridded geodataset in which precipitation was estimated using spatial regression methods that incorporated precipitation data from traditional weather stations and high-altitude meteorological sites (Daly and others, 1994). The weather station recording the highest average precipitation in the county is the Old Battle station in the Sierra Madre, which is part of the Natural Resources Conservation Service SNOwpack TELemetry (SNOTEL) network (Natural Resources Conservation Service, 2005). The 30-year (1971-2000) mean annual precipitation for the Old Battle station was 51.51 in. Precipitation also varies temporally in the county (fig. 6). At the Rawlins Airport station, the lowest annual precipitation recorded was 4.90 in. in 1954, whereas the highest annual precipitation was $12.63 \mathrm{in}$. in 1998 , and the mean annual precipitation based on the 51 years of complete data was 9.19 in.

\section{Geologic Setting}

As described previously in the Physiography section, Carbon County is dominated by six geologic structural basins 


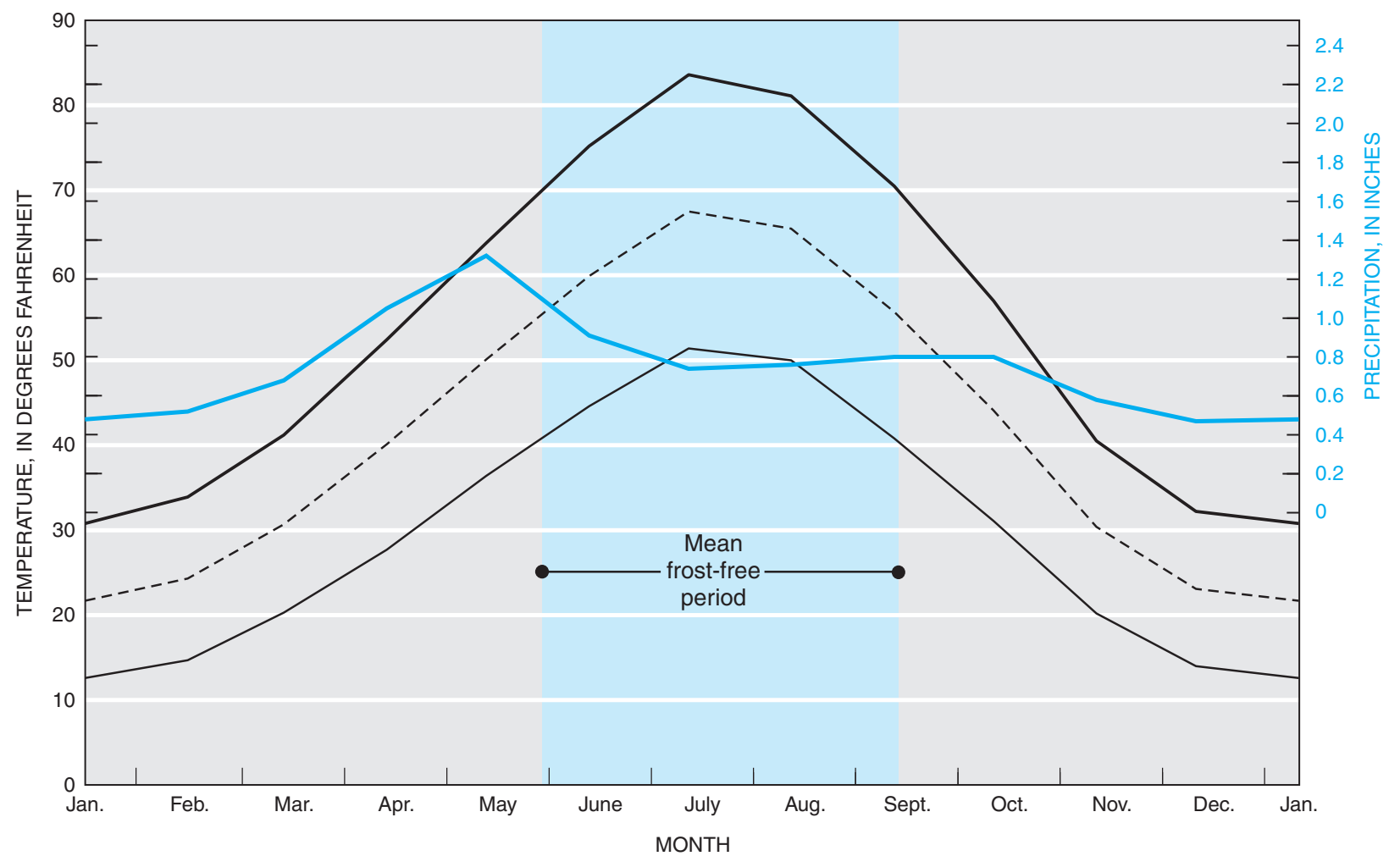

EXPLANATION

Temperature

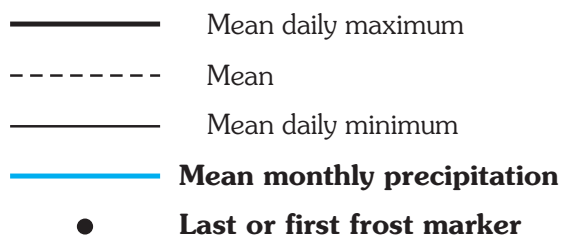

Figure 4. Modified Walter-Lieth diagram showing monthly means of precipitation and mean daily minimum, maximum, and mean temperatures for Rawlins (National Weather Service Station No. 487533) for 1951-2004. The temperature and precipitation axes are scaled to show periods of water stress when the mean daily maximum temperature line falls above the mean monthly precipitation line (blue) during the frost-free period (Walter and Leith, 1967). The mean days of last spring frost and first autumn frost are shown as black circles, with light blue background marking the mean 106-day frost-free period for 1951-2004. Data from Western Regional Climate Center, 2005a.

(Hanna, Great Divide, Washakie, Kindt, Laramie, and Shirley Basins) and by five major uplifts (Rawlins Uplift, Sweetwater Arch (including the Ferris and Seminoe Mountains), ShirleyFreezeout Mountains, Medicine Bow Mountains, and Sierra Madre) (fig. 2). The structural configuration on top of basement rocks of Precambrian age is shown in figure 7. Depressions that constitute the basins in the county are clearly visible on this map, as are the uplifts. Stratigraphic nomenclature charts for the major structural features are shown in figures 8 , 9, and 10 .

All of the Hanna Basin lies within Carbon County, and is separated from the Laramie Basin by the Carbon Basin (fig. 2). According to Blackstone (1993a), the top of the Pre- cambrian rocks in the deepest part of the Hanna Basin is about 30,000 ft below National Geodetic Vertical Datum of 1929 (NGVD 29). Based on Precambrian structure contours (fig. 7) and the present altitude of the land surface in the basin, the thickest sequence of sedimentary rocks in the Hanna Basin is estimated to be about 35,000 ft.

Most of the Great Divide Basin lies within Sweetwater County, with a sliver of its eastern edge occurring in Carbon County. It is separated from the Washakie Basin by the Wamsutter Arch and from the Hanna Basin by the Rawlins Uplift (fig. 2). According to Blackstone (1993a), the top of the Precambrian rocks in the deepest part of the Great Divide Basin within Sweetwater County is about 20,000 ft below NGVD 29, 


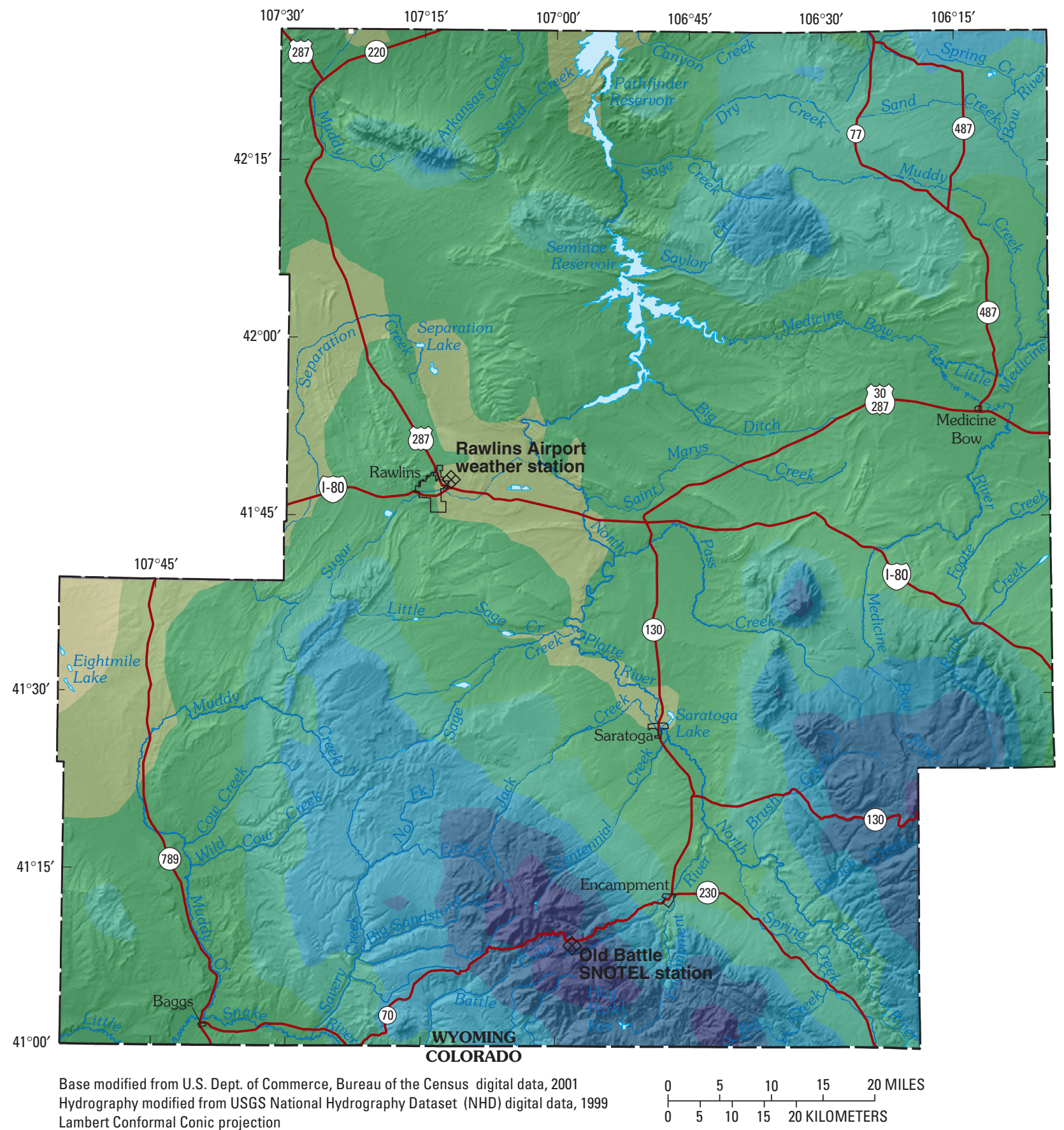

Lambert Conformal Conic projection

Standard parallels $41^{\circ}$ and $42^{\circ}$, central meridian $106^{\circ} 45^{\prime}$

\section{EXPLANATION}

Annual precipitation, in inches

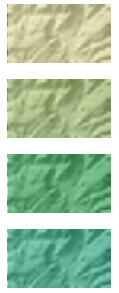

7 to 8

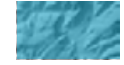

22.1 to 32

8.1 to 10

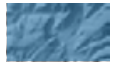

32.1 to 44

10.1 to 14

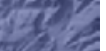

Greater than 44

14.1 to 22

Figure 5. Mean annual precipitation, 1961-1990, and location of selected weather stations, Carbon County, Wyoming. Mean annual precipitation for Carbon County was estimated using spatial regression methods that incorporated precipitation data from traditional weather stations and high-altitude meteorological sites (Daly and others, 1994). 


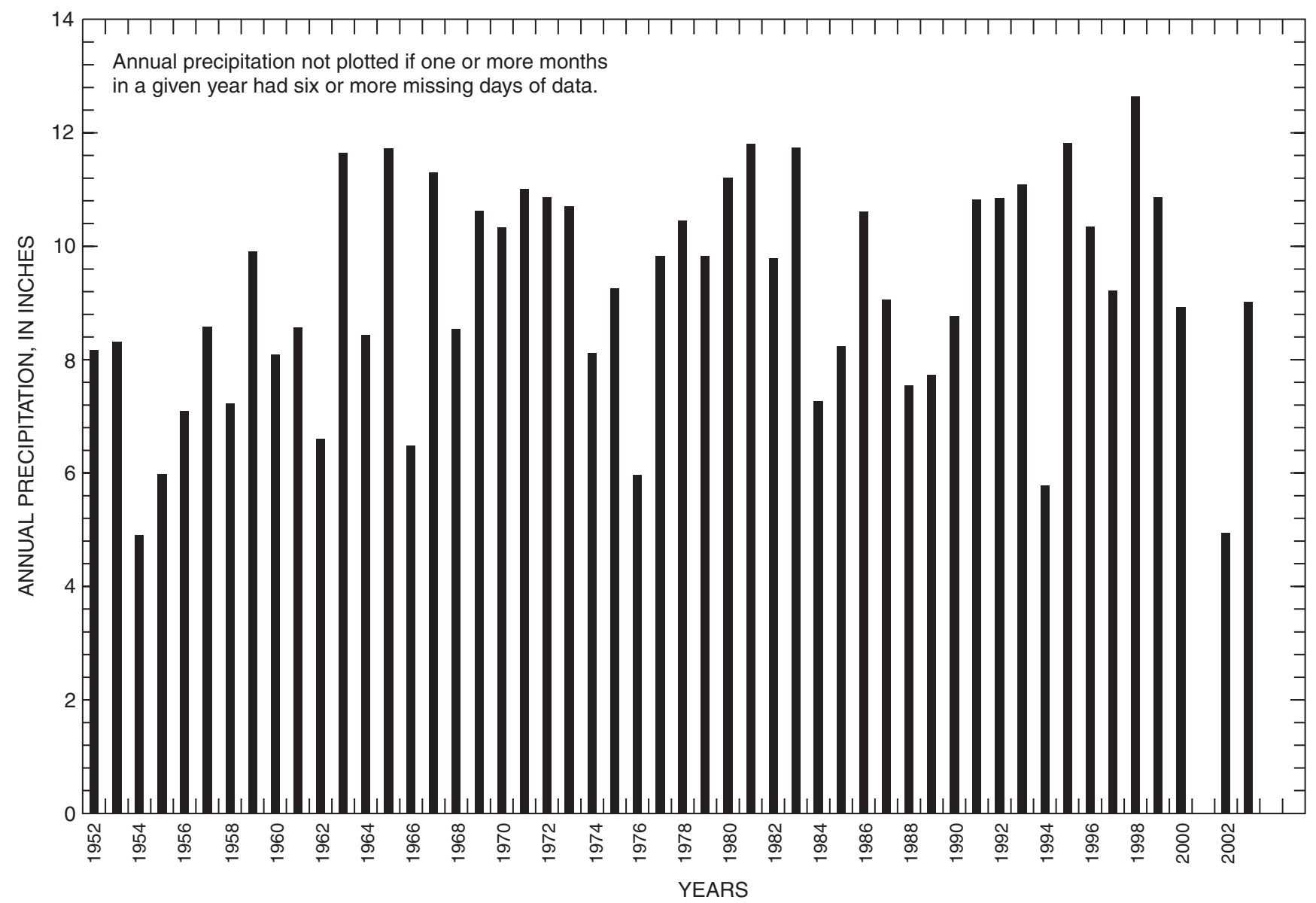

Figure 6. Annual precipitation for Rawlins, Wyoming (modified from Western Regional Climate Center, 2005b).

which is just across the county line in the southeastern part of the basin. Using the Precambrian structure contours (fig. 7) and the present altitude of the land surface in the basin, the thickest sequence of sedimentary rocks in the Great Divide Basin is estimated to be about $27,000 \mathrm{ft}$.

The Washakie Basin also lies mostly within Sweetwater County, with a small part of the basin occurring in southwestern Carbon County. As stated above, the Wamsutter Arch separates the Washakie Basin from the Great Divide Basin. According to Blackstone (1993a), the top of the Precambrian rocks in the Washakie Basin is not as deep as in the Great Divide Basin. Using Precambrian structure contours (fig. 7) and the present altitude of the land surface in the basin, the thickest sequence of sedimentary rocks in the Washakie Basin is estimated to be about $22,000 \mathrm{ft}$, which is just across the county line in the central part of the basin.

All of Kindt Basin lies within Carbon County, and is separated from the Hanna Basin by the Rawlins Uplift and the Haystack Hills (fig. 2). The Kindt Basin is small and no longer has a Tertiary fill. The youngest bedrock formation exposed is the Upper Cretaceous-age Lewis Shale. According to Blackstone (1993a), the top of the Precambrian rocks in the deepest part of the Kindt Basin is about 5,000 ft below NGVD 29. Using the Precambrian structure contours in figure 7 and the present altitude of the land surface in the basin, the thickest sequence of sedimentary rocks in the Kindt Basin is estimated to be about $11,500 \mathrm{ft}$.

Part of the Laramie Basin (Cooper Lake Basin of Blackstone, 1993b) lies within Carbon County. It is separated from the Hanna Basin by the Carbon Basin and from the Shirley Basin by a series of anticlines (see Como Bluff, Flat Top, and Freezeout Mountains area on fig. 2). According to Blackstone (1993a), the top of the Precambrian rocks in the deepest part of the Laramie Basin within the county is about 2,000 ft below NGVD 29. Using the Precambrian structure contours in figure 7 and the present altitude of the land surface in the basin, the thickest sequence of sedimentary rocks in the Laramie Basin is estimated to be about 9,500 ft.

Most of the Shirley Basin lies within Carbon County. It is separated from the Laramie Basin by a series of anticlines (see Como Bluff, Flat Top, and Freezeout Mountains area on fig. 2). According to Blackstone (1993a), the top of the Precambrian rocks in the deepest part of the Shirley Basin within the county is about mean sea level (NGVD 29 in this 


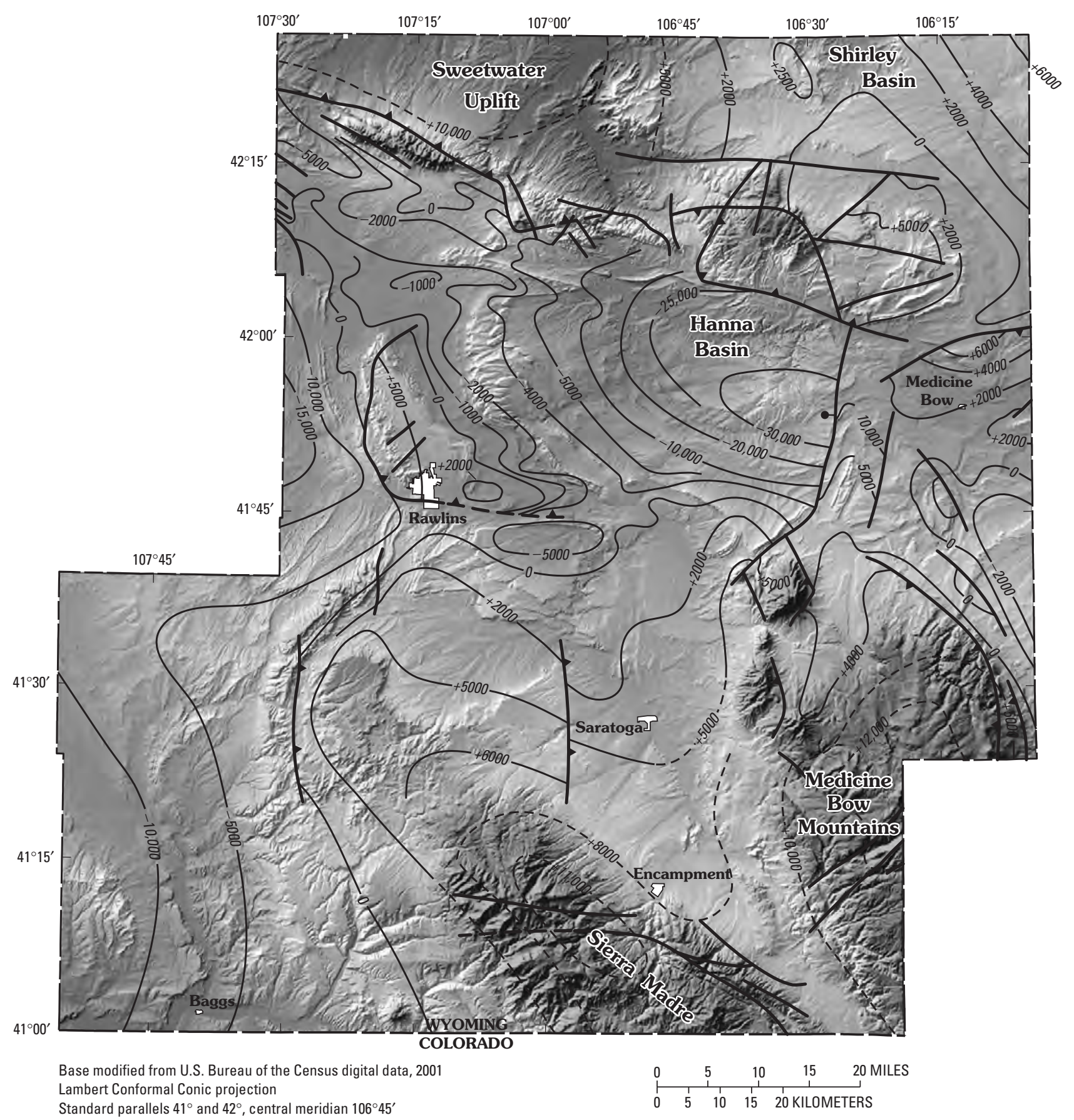

\section{EXPLANATION}

Structure contour-Top of Precambrian basement, in feet above (+) or below (-) National Geodetic Vertical Datum of 1929. Contour interval varies. Dashed where contour has been restored to pre-erosion altitude

? - - Fault-Bar and ball on downthrown side. Dashed where inferred

_ $\_$- Thrust fault-Sawteeeth on upthrown side. Dashed where inferred

Figure 7. Structural configuration of the Precambrian-basement rock in Carbon County, Wyoming (modified from Blackstone, 1989). 
report). Using the Precambrian structure contours in figure 7 and the present altitude of the land surface in the basin, the thickest sequence of sedimentary rocks is estimated to be about 7,200 ft.

The Rawlins Uplift is a north-south trending thrustfaulted anticline (Berry, 1960) (fig. 2). The uplift is somewhat asymmetric, with the western flank (thrust fault side) steeper than the eastern flank. The core of the uplift has been eroded to Precambrian basement rocks (fig. 7).

The Sweetwater Arch or Uplift is an east-west trending anticline that extends eastward for about 75 miles (mi) from the southern end of the Wind River Range (Keefer and Van Lieu, 1966). The core of the uplift, the Granite Mountains, has eroded to Precambrian basement rocks and subsequently has dropped 2,000 ft by normal faulting due to crustal extension (Blackstone, 1991). The southern boundary of the Sweetwater Arch is marked by the Ferris, Seminoe, and Shirley Mountains where they have been thrust southward over rocks of Cretaceous age and some lower Tertiary rocks of the Hanna Basin (Love, 1963). The cores of the uplifts have been eroded to Precambrian basement rocks (figs. 2 and 7).

The Medicine Bow Mountains consist of a large northsouth trending asymmetrical anticline bounded on the east by westward dipping thrust faults (Houston and others, 1968). The northern part of the mountains is split into two anticlinal arms that are separated by a synclinal valley (Houston and others, 1968). The Sierra Madre is a large northwest-southeast trending anticline separated from the Medicine Bow Mountains by the Saratoga Valley. The cores of the uplifts have been eroded to Precambrian basement rocks (figs. 2 and 7). The Precambrian rocks are divided by the southwest-northeast trending Cheyenne Belt (formerly Mullen Creek-Nash Fork shear zone), with older Precambrian (Archean) rocks north of the belt and younger Precambrian (Proterozoic) rocks south of the belt (Houston and others, 1968; Snoke, 1993).

The Precambrian history of Wyoming is poorly understood. According to Hoffman (1988), the Wyoming province is one of seven Archean provinces that presently form the North American craton. The Medicine Bow Mountains and Sierra Madre expose the suture zone where the Early Proterozoic Colorado Province was accreted to where the rifted Archean Wyoming craton had been covered by passive margin deposits in the Early Proterozoic Era (Snoke, 1993). During the Middle Proterozoic Era, Wyoming was marked by widespread magmatism, but its cause is unknown (Snoke, 1993, p. 11). Precambrian rocks are exposed in all of the major uplifts of Carbon County.

The Precambrian basement rocks in Wyoming had low relief during the early to middle Paleozoic Era, allowing a thin accumulation of sedimentary rocks (Snoke, 1993, p. 13). During the late Paleozoic Era, southeastern Wyoming was affected by the uplift of the ancestral Rocky Mountains, specifically the Pathfinder Uplift and the ancestral Front Range (Snoke, 1993, p. 15). The Pathfinder Uplift is defined by the lack of deposition of the Mississippian- and Pennsylvanian-age Amsden Formation (Mallory, 1963). The Precambrian cores of both the southern Pathfinder Uplift and the ancestral Front Range were exposed (Mallory, 1963). Paleozoic sediment in the county was deposited mainly in shallow seas on a stable Wyoming shelf; however, in the late Paleozoic Era, there was enough relief in the southeastern part of the county from the ancestral Rocky Mountains for formation of arkosic deposits (Mallory, 1967). Changes in sea level or tectonic activity periodically left some areas above sea level, resulting in erosion and unconformities.

As during the Paleozoic Era, marine sediment was deposited in shallow seas between periods of land emergence during much of the Mesozoic Era in Wyoming. The stable depositional and structural conditions during the Paleozoic Era apparently continued during the Mesozoic Era until the Late Cretaceous Period (Krueger, 1960, p. 199). During the Triassic Period, land emergence again resulted largely in erosion and unconformities. Periodic emergence of the land during the Jurassic Period resulted in the deposition of the non-marine Nugget Sandstone and Morrison Formation (Snoke, 1993, p. 16-17). In Wyoming, the Cretaceous Period was dominated by an epicontinental sea. Erosion of highlands to the west of the sea resulted in thick accumulations of sediment in the marine basin. These deposits are major sources of oil, gas, and coal in the Rocky Mountain region (Snoke, 1993, p. 17). In Wyoming, the Late Cretaceous Period was marked by tectonic activity. The Sevier orogeny created a fold and thrust belt in the western part of the State, while the Laramide orogeny deformed much of the rest of Wyoming. In Carbon County, most basins (Hanna, Laramie, Shirley, Great Divide, and Washakie Basins), uplifts (Rawlins and Sweetwater Uplifts) and mountain ranges (Medicine Bow Mountains and Sierra Madre) were formed during the Laramide orogeny (Snoke, 1993).

The most notable development during the Tertiary Period in southwestern Wyoming was the formation of Lake Gosiute during the middle Eocene Epoch. The maximum extent of the lake covered nearly all of Sweetwater County (Bradley, 1964, p. A36). Lacustrine sediment deposited in the lake formed what now is known as the Green River Formation. The lake formed in an intermontane basin that continued to subside throughout much of the middle Eocene Epoch. During the period of Lake Gosiute, fluvial sediment accumulated around the lake margin in a belt that narrowed when the lake expanded and widened when the lake contracted (Bradley, 1964, p. A18). This continual shift of the shoreline resulted in a complicated intertonguing of lacustrine sediment belonging to the Green River Formation and fluvial sediment belonging to the Wasatch and Bridger Formations. Formation of Lake Gosiute may have been caused by a reversal of drainage when east-flowing streams of the Paleocene and early Eocene Epochs changed direction in response to westward tilting of the Wyoming foreland (Love and others, 1963). Lake Gosiute was infilled with sediment during the middle Eocene Epoch (Hansen, 1986, p. 24).

In the late Eocene and early Oligocene Epochs, fluvial sediment and tephra were deposited in the region, marking the 
end of intensive erosion that affected most of Wyoming late in the Eocene (Snoke, 1993, p. 34-35). A broad aggradational plain was formed that stretched across the Rocky Mountains and onto the Great Plains, filling the basins and in some cases completely burying the mountains (Snoke, 1993, p. 36). Regional uplift occurred in two pulses between the late Oligocene and late Pleistocene Epochs (Flanagan and Montagne, 1993, p. 600). In the late Miocene Epoch, large river systems began to develop and erode older sediment from Wyoming basins (Flanagan and Montagne, 1993, p. 597). This development initiated a degradational regime in Wyoming that continues to the present, and was the beginning of modern drainage systems throughout the State (Flanagan and Montagne, 1993, p. 597).

A unique feature of many of Wyoming's mountain ranges is a high-level erosion surface, such as the Libby Flats surface of the Medicine Bow Mountains. The age of these surfaces is unknown; they may be late Eocene or late Tertiary (Snoke, 1993, p. 38-39).

Glaciers during the Pleistocene Epoch occurred on the high-level erosional surfaces of the Medicine Bow Mountains and in some of the valleys of the Sierra Madre. Glaciation in the Medicine Bow Mountains in Wyoming extended from the high peaks of the Snowy Range, across the flats of the erosion surface, and down the valleys of Libby, Brush, French, Pass, and Rock Creeks, and the Medicine Bow River (Atwood, 1937; Ray, 1940; Mears, 1953, 2001) (not all shown in fig. 2). The Sierra Madre had valley glaciers around the summit upland near Bridger Peak in the drainages of Cow, Battle,
Haggerty, Jack, North and South Spring, Smith, and East Fork and West Fork of Hasking Creeks (Mears, 2001) (not all shown in fig. 2). In the southern Sierra Madre, Hog Park has some glacial deposits that originated in the higher peaks of the Park Range in Colorado (Mears, 2001). The higher altitudes have many features indicative of intensive frost action, such as felsenmeer (or block fields with jumbles of large angular frostshattered rock) and patterned ground (or stone nets that exhibit a polygonal appearance from a border of stones surrounding a finer material). Mears (2001) reported that patterned ground is only from the colder Pleistocene Epoch, whereas the block fields are still somewhat active at the present time.

During the Quaternary Period, headward erosion by streams continued in the county. Sediment was eroded from basin and uplift areas and conveyed, through fluvial transport, to the Gulfs of California and Mexico. Headward erosion continues today, but the sediment is trapped in man-made reservoirs.

Quaternary sand dunes are found in parts of Carbon County (Love and Christiansen, 1985). Some of these dune fields have been intermittently active for at least the last 10,000 years and provide a record of climatic fluctuations associated with the stades and interstades of glaciation (Gaylord, 1982, 1989). Pleistocene playa lake and other lacustrine deposits in the county occur north of Rawlins (Case and others, 1998). A geology map of Carbon County and a separate shaded relief map overlaid with geology and structural features are combined and shown in figure 2. 


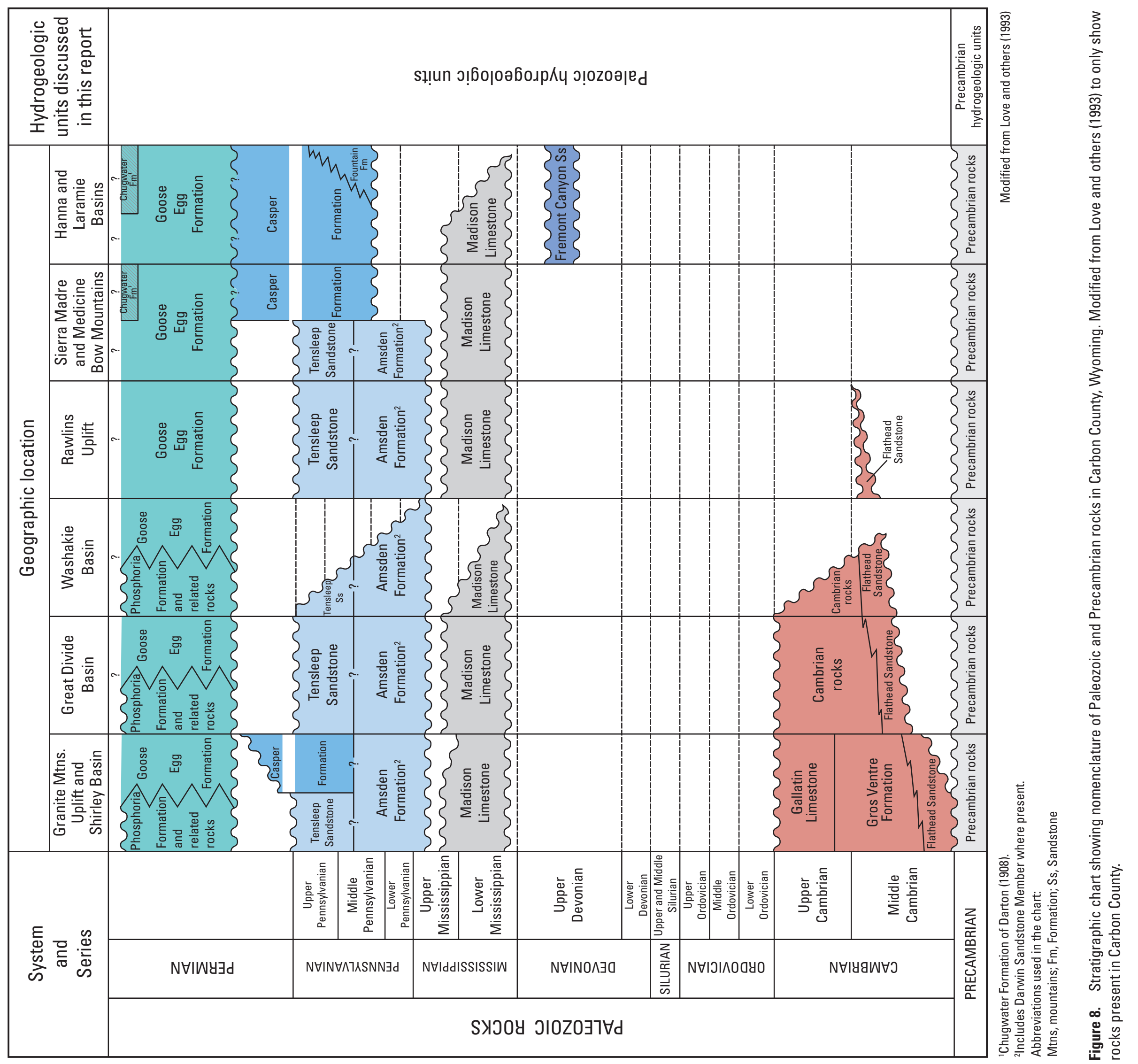




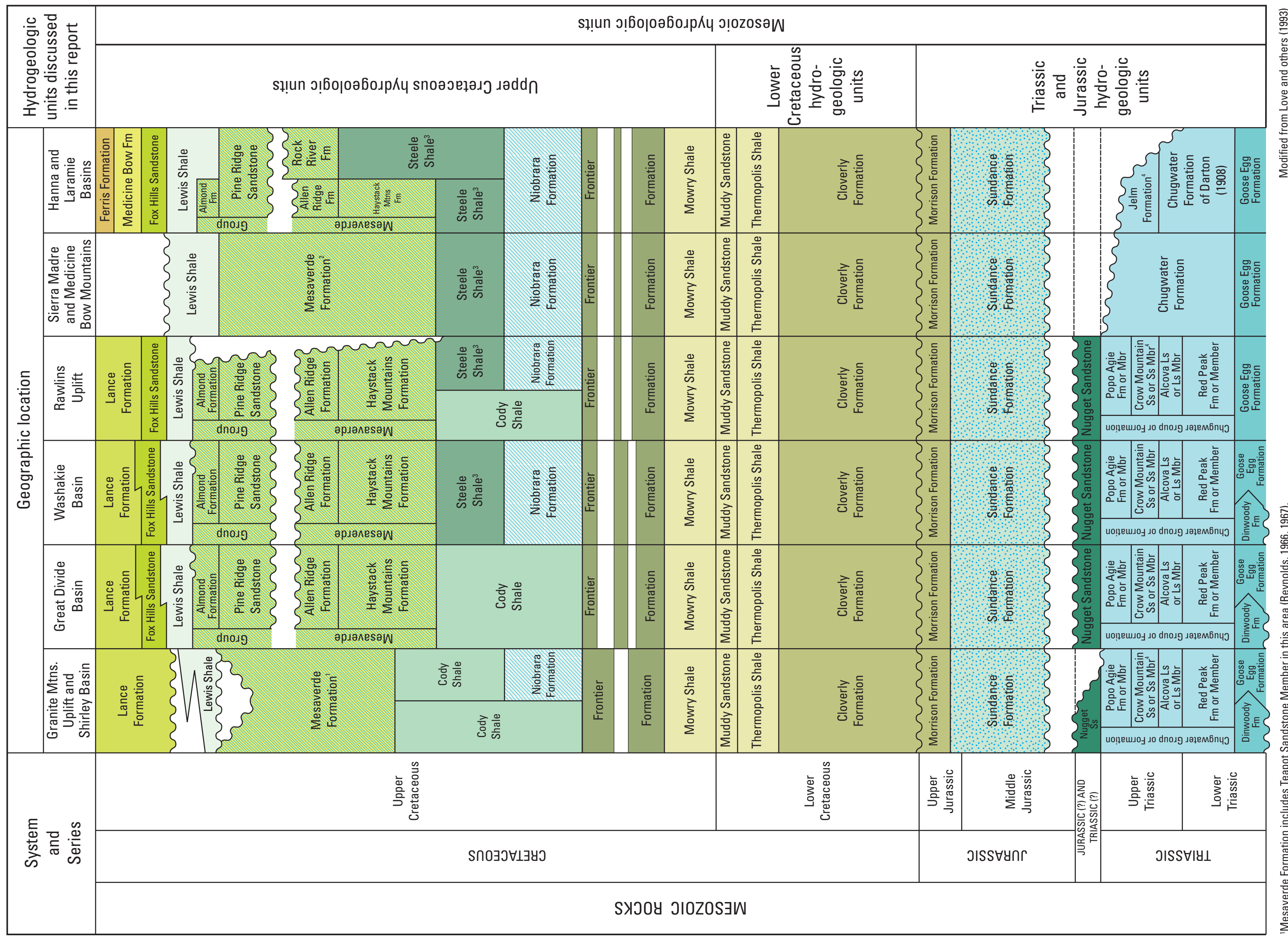




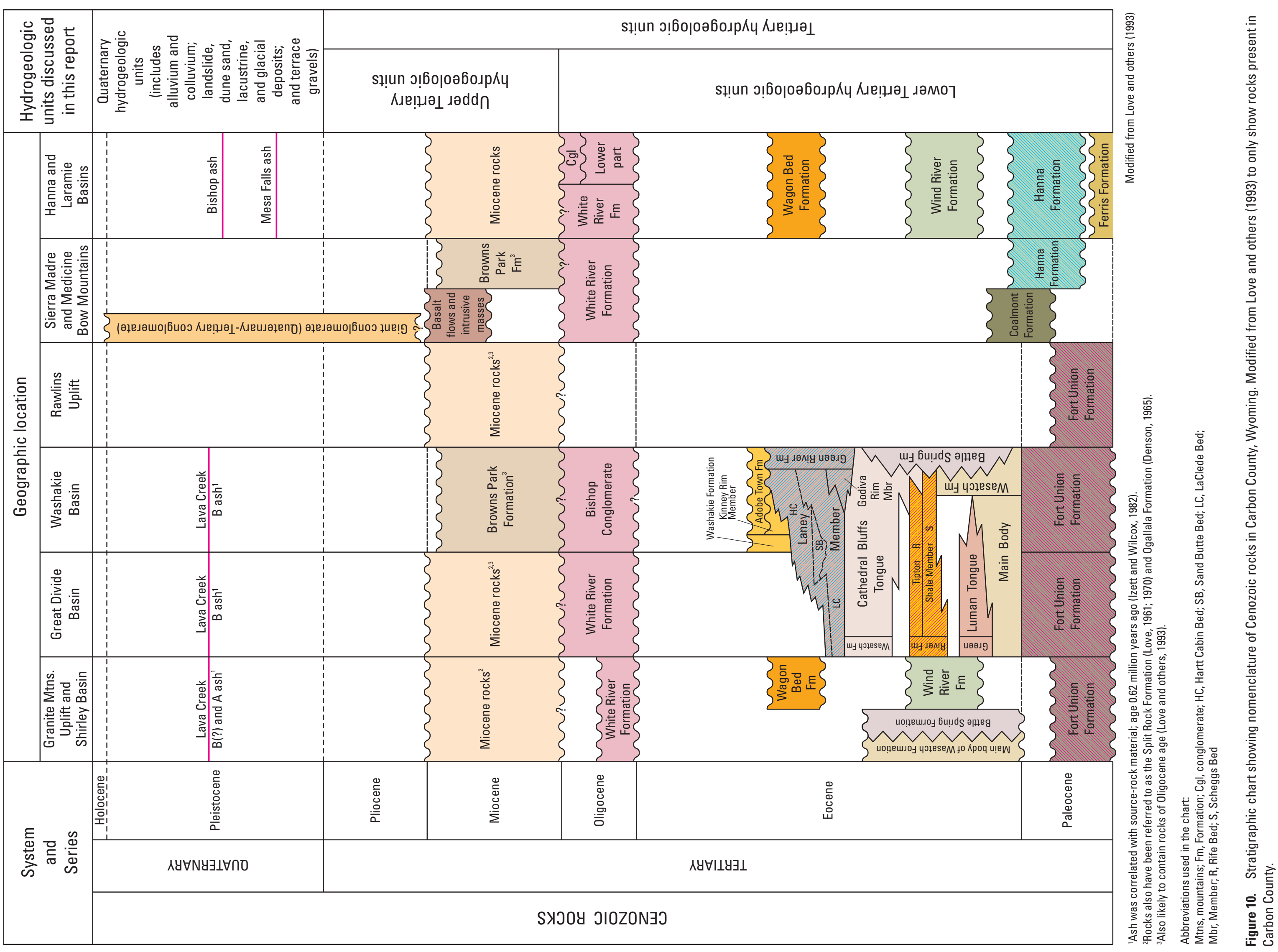




\section{Surface Water}

The North Platte River and Pathfinder and Seminoe Reservoirs are the dominant perennial surface-water features in Carbon County (figs. 1, 2, and 11). The North Platte River flows into the southeast corner of the county from its headwaters in the mountains of northern Colorado. The river flows out the northern edge of the county through Pathfinder Reservoir. It continues through Natrona, Converse, Platte, and Goshen Counties before flowing into Nebraska (fig. 1). It is eventually joined by the South Platte River near the city of North Platte, Nebraska (not shown on a figure). At the confluence, the two rivers combine to form the Platte River, a major tributary to the Missouri River. The river has had an important part in the settlement and development of Carbon County and the State of Wyoming. In the early part of the 19th century, fur traders in search of beaver were attracted to the North Platte Valley. By the end of the 19th century, ranchers and farmers had moved into the area to utilize water from the North Platte River for livestock and crops. The river remains an important surfacewater resource for the region today, providing water for irrigation, industry, municipal, and hydroelectric uses.

The largest use of water from the North Platte River is for irrigation. Irrigation along the North Platte probably began with crude ditches used to irrigate irregular patches of land on the flood plain (Eschner and others, 1983, p. A2). By 1889, extensive development of the North Platte had taken place and by 1901, summer flows in the upper North Platte and its tributaries had been overappropriated (Eschner and others, 1983, p. A7). To help mitigate this problem, reclamation projects were constructed over the next several decades. The two most notable of these affecting Carbon County are the North Platte and Kendrick Reclamation Projects.

Pathfinder Dam was constructed between 1905 and 1909 as part of the North Platte Reclamation Project. The dam is located in Natrona County, but much of the reservoir that formed behind the dam lies in Carbon County (figs. 2 and 11). The water stored in Pathfinder Reservoir is used to help irrigate about 226,000 acres in an 111-mile stretch along the North Platte River from Guernsey, Wyoming (fig. 1), to Bridgeport, Nebraska (not shown on a figure) (Bureau of Reclamation, 2005a). Seminoe Dam was constructed in the northcentral part of the county between 1936 and 1939 (fig. 2) as part of the Kendrick Reclamation Project. Water stored in Seminoe Reservoir is used to help irrigate about 24,000 acres west of Casper, Wyoming (Bureau of Reclamation, 2005b). Seminoe Dam also has a powerplant capable of producing 45,000 kilowatts of power. Between 1946 and 1951, Kortes Dam was constructed between Seminoe and Pathfinder Reservoirs to generate power from water flowing between the two reservoirs (fig. 2). The powerplant at Kortes Dam is capable of producing 36,000 kilowatts of power (Bureau of Reclamation, 2005c). Although development of water resources from the North Platte River and its tributaries has helped to make the region productive economically, it also has substantially changed streamflow characteristics causing a deterioration of riverine habitat (Eschner and others, 1983, p. A34-A35).

Flow characteristics of streams in Carbon County vary and are influenced by the diverse physiography and climate of south central Wyoming, as well as anthropogenic factors. Moderate to large flows in major perennial streams are a result of runoff from snowmelt in mountainous areas in the southern part of the county and mountainous areas of northern Colorado. Reservoirs and diversions substantially alter flow characteristics of most of the major perennial streams. Low flow, where present, in most streams is the result of ground-water discharge, irrigation return flow, and reservoir releases. Waterquality characteristics of streams in the county also vary as a result of streamflow, geologic, and land-cover characteristics. Anthropogenic factors also influence water-quality characteristics to varying degrees.

\section{Streamflow}

Stream types in Carbon County include perennial, ephemeral, and intermittent. Major perennial streams either have headwaters in the Sierra Madre or Medicine Bow Mountains in the southern part of the county or flow into the county from mountainous areas in northern Colorado. The North Platte River is an example of a perennial stream in the county (figs. 1, 2, and 11). Many of the smaller streams in the county that have headwaters in lowland areas are ephemeral, and flow only as a result of local snowmelt and rainfall runoff. Streamflows in intermittent streams vary depending on reach characteristics. Snowmelt runoff, ground-water inflows, and(or) springs maintain streamflows throughout most years in some perennial reaches, whereas ephemeral reaches exist where streamflows are less than the losses to seepage, evaporation, and(or) diversions.

Streamflow data from selected sites and periods are summarized to describe annual, monthly, low, and peak-flow characteristics and flow duration of streams in and near Carbon County (table 1, appendixes 1-4). Sites with 10 or more complete water years (water years begin on October 1 and end on September 30 of the following year) of data were used to describe flow characteristics. The complete period of record was used for each site unless specified otherwise.

Streamflow data, statistics, and analyses described in this report should be considered in the context of the lengths of the streamflow records prior to using this information for planning purposes. The longest annual streamflow record included in this report is 88 years (site 1); the average record length is 45 years (median is 46 years; records shorter than 10 years were not used in this report). Streamflows in some basins may include periods of substantially wetter or drier conditions; as such, statistics and analyses of those data might not be considered representative of long-term conditions. In addition, streamflows in most basins have been altered as a result of diversions and impoundments. The first irrigation ditches were constructed in the Upper North Platte River Basin more than 


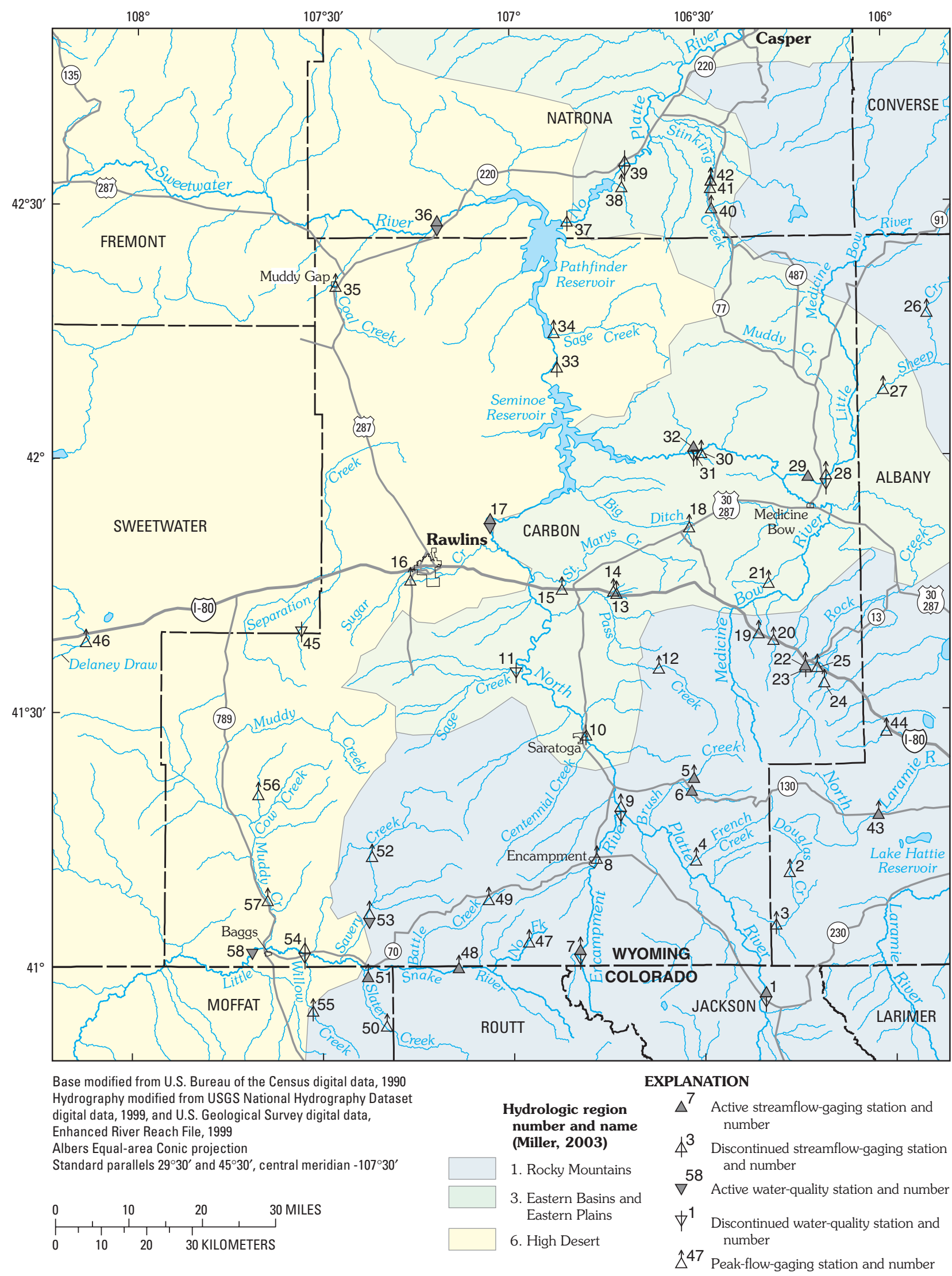

Figure 11. Location of hydrologic regions and active (2004) and discontinued streamflow-gaging stations, active (2004) and discontinued surface-water-quality stations, and peak-flow-gaging stations in and around Carbon County, Wyoming. Station information provided in Table 1. 
100 years prior to the most recent data included in this report. Thus, representative conditions often are difficult to determine with existing data. Additional research in streamflow record reconstruction is needed to enable water users and planners to better interpret recent streamflow data.

Additional streamflow information is available from the USGS. Methods for streamflow data collection are described by Rantz and others (1982). Streamflow data used in this report for computing streamflow statistics can be retrieved from the World Wide Web (internet) at http://waterdata.usgs. gov/nwis/. USGS computer programs and supporting documentation used to compute streamflow statistics also can be retrieved from the internet at http://water.usgs.gov/software/.

Table 1. Characteristics of selected streamflow, peak-flow, and water-quality sites in and near Carbon County, Wyoming.

[NGVD 29, National Geodetic Vertical Datum of 1929; --, not determined]

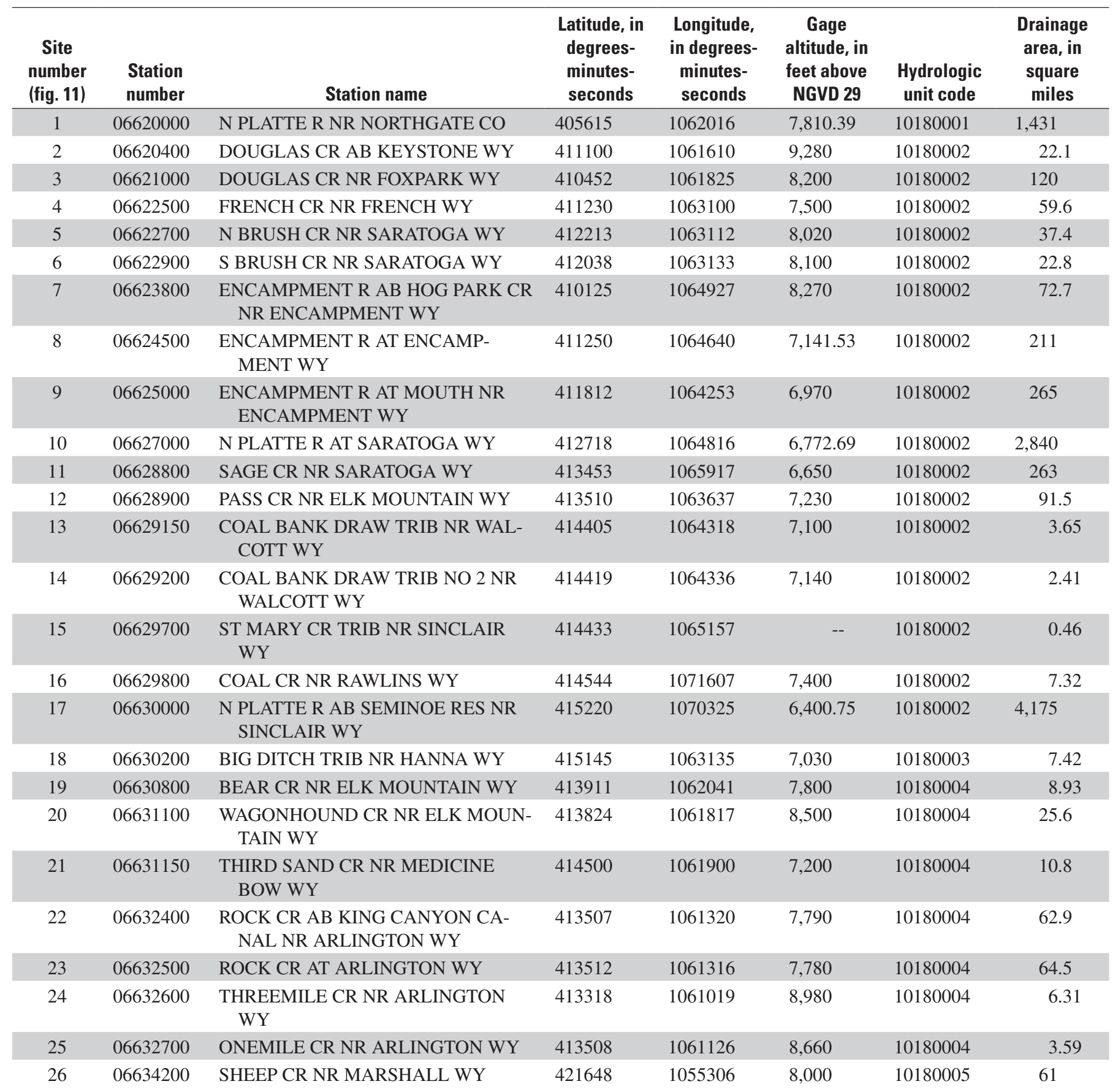


Table 1. Characteristics of selected streamflow, peak-flow, and water-quality sites in and near Carbon County, Wyoming.-Continued

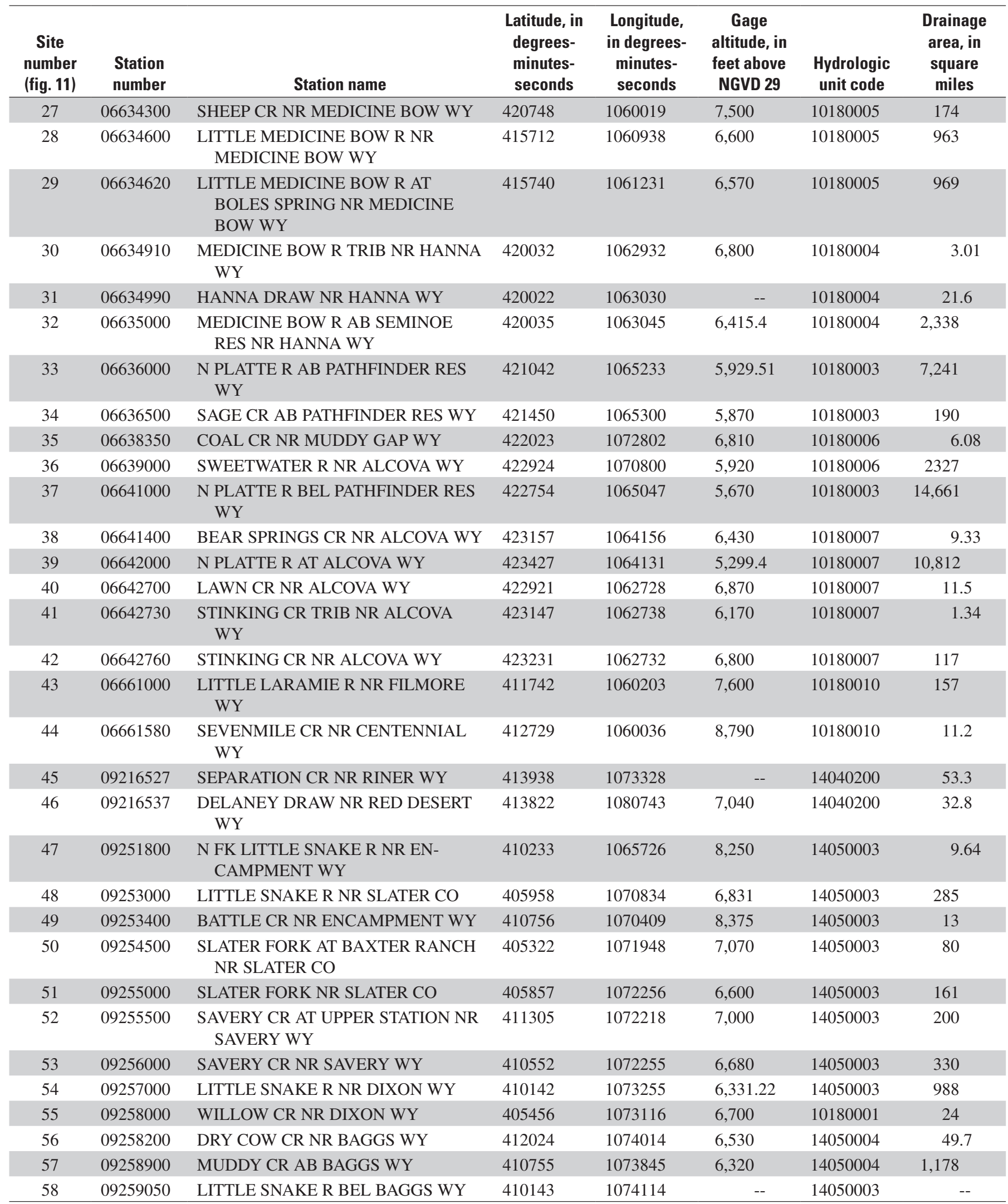




\section{Annual and Monthly Flows}

Annual and monthly statistics of streamflow data are useful in describing the distribution and timing of flows in streams. Annual and monthly streamflow statistics were determined from daily streamflow data for selected stations in and near Carbon County with more than 10 years of streamflow record (appendix 1). Daily mean streamflow data for the period of record through water year 2003 were retrieved for complete months for selected stations from the USGS National Water Information System (NWIS) database. Statistics were calculated for each month. Annual statistics were calculated using complete water years only. For site 9 (Encampment River at mouth near Encampment, Wyoming), annual and monthly flow statistics were determined for the periods before and after an upstream diversion structure was emplaced.

Mean annual flows for the periods of record at selected sites in and near Carbon County varied, ranging from 10.3 cubic feet per second $\left(\mathrm{ft}^{3} / \mathrm{s}\right)$ at site 55 on Willow Creek to $1,624 \mathrm{ft}^{3} / \mathrm{s}$ at site 33 on the North Platte River (appendix 1). Mean monthly flows for the periods of record at selected sites in and near Carbon County varied, ranging from $1.34 \mathrm{ft}^{3} / \mathrm{s}$ for January at site 28 to $6,596 \mathrm{ft}^{3} / \mathrm{s}$ for June at site 33 (appendix 1). For most streams in the region, the smallest flows generally were observed during the fall and early winter months and represent base flow from ground-water discharge. Mean runoff during individual fall or early winter months represents less than 1 percent of the mean annual runoff in many streams in the region (appendix 1). Because of low temperatures during these months, precipitation generally occurs as snow, and substantial surface-runoff events are infrequent. There are many ephemeral streams in Carbon County although none are listed in appendix 1. Extended periods of no flow are common for ephemeral streams in the region. For most streams in the region, the largest flows generally are observed during the spring and early summer months as a result of runoff from melting low-altitude and mountain snowpacks. Mean runoff during individual spring or early summer months represents more than 40 percent of the mean annual runoff for some streams in the region (appendix 1).

Mean monthly flows often are affected by reservoir storage in stream reaches with upstream reservoirs. A comparison of mean monthly flows from site 33 (North Platte River above Pathfinder Reservoir) and site 36 (Sweetwater River near Alcova, Wyoming) with those of site 37 (North Platte River below Pathfinder Reservoir) provides an example. Sites 33 and 36 represent major inflows into Pathfinder Reservoir, and site 37 represents streamflow out of the reservoir. The three sites were in simultaneous operation for a 10 -year period between 1914 and 1924. During this period, the combined mean monthly inflow to Pathfinder Reservoir from sites 33 and 36 for April was 2,878 ft $3 / \mathrm{s}$, whereas the mean monthly flow at site 37 (below the reservoir) for April was $722 \mathrm{ft}^{3} / \mathrm{s}$. Conversely, the combined mean monthly inflow to Pathfinder Reservoir from sites 33 and 36 for August was $756 \mathrm{ft}^{3} / \mathrm{s}$, whereas the mean monthly flow at site 37 (below the reser- voir) for August was $4,131 \mathrm{ft}^{3} / \mathrm{s}$. This is a qualitative comparison and ignores streamflow gains between the sites, such as ground-water discharge and overland runoff from rain storms or snowmelt. It also ignores losses between sites, such as seepage and evaporation. However, these gains and losses are probably minor when compared to the mean monthly streamflows measured at the sites.

\section{Peak Flows}

Peak-flow characteristics of streams are used by engineers and other professionals in various water-resources investigations including flood studies, bridge design, and reservoir operations. Peak-flow characteristics at any given site generally are based on annual peak flows. Annual peak flow is the maximum instantaneous discharge measured at a site during the water year. For a series of annual peak flows at a site, a statistical relation can be defined describing the mean annual probability of those flows being equaled or exceeded. Expressed in percentages, a peak flow with an exceedance probability of 0.01 , for example, has a 1 percent chance on average of being equaled or exceeded in any given year. The reciprocal of the exceedance probability is the recurrence interval (expressed in years); for example, a peak flow with an exceedance probability of 1 percent has a recurrence interval of 100 years.

Annual peak flows for most streams in Carbon County generally are the result of runoff from regional-scale rainfall and snowmelt. Peak-flow characteristics were determined by Miller (2003) for 42 streamflow-gaging stations in Carbon County and the surrounding areas (appendix 2). Because reservoir operations, irrigation diversions, and other anthropogenic activities can alter peak flows substantially, only stations in basins with minimal or no anthropogenic effects were used. Additionally, only stations with at least 10 annual peaks were analyzed. Additional information describing the methods used to determine peak-flow characteristics are summarized by Miller (2003).

Regression equations for estimating peak-flow characteristics for ungaged streams in Wyoming were developed for hydrologic regions with similar peak-flow and basin characteristics (Miller, 2003). The reasons for developing hydrologic regions were to ensure that the equations were reasonable from a hydrologic perspective and to reduce the uncertainty in estimates calculated with the equations. Carbon County includes parts of three different hydrologic regions: the Rocky Mountains, Eastern Basins and Eastern Plains, and High Desert (Regions 1, 3, and 6, respectively; Miller, 2003). The equations also can be used in combination with gaging-station frequency analyses to estimate more accurate peak-flow characteristics at both ungaged and gaged sites.

Equations for estimating peak-flow characteristics for unregulated streams with basins located entirely within the Rocky Mountains Region are listed in table 2-1, Eastern Basins and Eastern Plains Region are listed in table 2-2, or High Desert Region are listed in table 2-3. For streams in 
basins that cross region boundaries, peak-flow characteristics can be estimated using a weighting procedure (Miller, 2003, p. 31-32) and equations from the individual regions. Descriptions of the other regional equations and example applications of other scenarios are described in Miller (2003).

Applications of the regional equations are limited by the hydrologic conditions and basin characteristics of the gaging stations used to define them. Anthropogenic developmentssuch as diversions for irrigation, regulation by reservoirs, and urbanization-alter natural hydrologic conditions and change the characteristics of annual peak flows. Applications of the equations are limited to drainages with little or no development. Because the set of basins used to define the relations is a relatively small sample of a larger population, the set likely does not define the entire range in values of that population. Thus, the regional relations only are defined for the range of values sampled. Additional information on the limitations of the regional equations is presented in Miller (2003, p. 26-30).

Table 2-1. Equations for estimating peak-flow characteristics, Rocky Mountains Region, Wyoming (Region 1).

$\left[\mathrm{SE}_{\mathrm{E}}\right.$, average standard error of estimate; $\mathrm{SE}_{\mathrm{p}}$, average standard error of prediction; $Q_{T}$, estimated peak flow, in cubic feet per second for recurrence interval of $T$ years; $A R E A$, total drainage area, in square miles; $E L E V$, mean basin elevation, in feet; $L N G$, longitude of basin outlet location, in decimal degrees]

\begin{tabular}{|c|c|c|c|c|c|}
\hline \multirow[b]{2}{*}{ Equation } & \multirow{2}{*}{$\underset{\text { (percent) }}{\mathrm{SE}_{\mathrm{E}}}$} & \multirow{2}{*}{$\underset{\text { (percent) }}{\mathrm{SE}_{\mathrm{p}}}$} & \multirow{2}{*}{$\begin{array}{c}\text { Average } \\
\text { equivalent } \\
\text { years } \\
\text { of record }\end{array}$} & \multicolumn{2}{|c|}{$\begin{array}{l}\text { 95-percent prediction } \\
\text { interval factor }\end{array}$} \\
\hline & & & & Lower limit & Upper limit \\
\hline$Q_{1.5}=0.126\left(A R E A^{0.885}\right)\left(\left(\frac{E L E V-3,000}{1,000}\right)^{2.56}\right)\left((L N G-100)^{0.032}\right)$ & 55 & 56 & 1.0 & 0.354 & 2.82 \\
\hline$Q_{2}=0.313\left(\right.$ AREA $\left.^{0.866}\right)\left(\left(\frac{E L E V-3,000}{1,000}\right)^{2.32}\right)\left((L N G-100)^{-0.069}\right)$ & 49 & 50 & 1.2 & .396 & 2.53 \\
\hline$Q_{2.33}=0.458\left(A R E A^{0.858}\right)\left(\left(\frac{E L E V-3,000}{1,000}\right)^{2.22}\right)\left((L N G-100)^{-0.110}\right)$ & 46 & 47 & 1.3 & 414 & 2.42 \\
\hline$Q_{5}=1.89\left(A R E A^{0.829}\right)\left(\left(\frac{E L E V-3,000}{1,000}\right)^{1.85}\right)\left((L N G-100)^{-0.262}\right)$ & 38 & 39 & 2.4 & .476 & 2.10 \\
\hline$Q_{10}=4.71\left(A R E A^{0.810}\right)\left(\left(\frac{E L E V-3,000}{1,000}\right)^{1.60}\right)\left((L N G-100)^{-0.357}\right)$ & 35 & 36 & 3.8 & .503 & 1.99 \\
\hline$Q_{25}=12.1\left(A R E A^{0.790}\right)\left(\left(\frac{E L E V-3,000}{1,000}\right)^{1.34}\right)\left((L N G-100)^{-0.451}\right)$ & 34 & 35 & 5.4 & .509 & 1.96 \\
\hline$Q_{50}=22.3\left(A R E A^{0.776}\right)\left(\left(\frac{E L E V-3,000}{1,000}\right)^{1.16}\right)\left((L N G-100)^{-0.510}\right)$ & 35 & 36 & 6.3 & .500 & 2.00 \\
\hline$Q_{100}=38.6\left(A R E A^{0.764}\right)\left(\left(\frac{E L E V-3,000}{1,000}\right)^{1.00}\right)\left((L N G-100)^{-0.562}\right)$ & 37 & 38 & 6.9 & .486 & 2.06 \\
\hline$Q_{200}=64.3\left(A R E A^{0.752}\right)\left(\left(\frac{E L E V-3,000}{1,000}\right)^{0.857}\right)\left((L N G-100)^{-0.611}\right)$ & 39 & 40 & 7.2 & .467 & 2.14 \\
\hline$Q_{500}=120\left(A R E A^{0.738}\right)\left(\left(\frac{E L E V-3,000}{1,000}\right)^{0.674}\right)\left((L N G-100)^{-0.670}\right)$ & 42 & 43 & 7.3 & .440 & 2.28 \\
\hline
\end{tabular}




\section{Water Resources of Carbon County, Wyoming}

Table 2-2. Equations for estimating peak-flow characteristics, Eastern Basins and Eastern Plains Region, Wyoming (Region 3).

$\left[\mathrm{SE}_{\mathrm{E}}\right.$, average standard error of estimate; $\mathrm{SE}_{\mathrm{p}}$, average standard error of prediction; $Q_{T}$, estimated peak flow, in cubic feet per second for recurrence interval of $T$ years; AREA, total drainage area, in square miles; SOIL, mean basin soils hydrologic index, unitless]

\begin{tabular}{|c|c|c|c|c|c|}
\hline \multirow[b]{2}{*}{ Equation } & \multirow{2}{*}{$\begin{array}{c}\mathrm{SE}_{\mathrm{E}} \\
\text { (percent) }\end{array}$} & \multirow{2}{*}{$\underset{\text { (percent) }}{\mathrm{SE}_{\mathrm{p}}}$} & \multirow{2}{*}{$\begin{array}{c}\text { Average } \\
\text { equivalent } \\
\text { years } \\
\text { of record }\end{array}$} & \multicolumn{2}{|c|}{$\begin{array}{l}\text { 95-percent prediction } \\
\text { interval factor }\end{array}$} \\
\hline & & & & Lower limit & Upper limit \\
\hline$Q_{1.5}=1.12\left(\right.$ AREA $\left.^{0.401}\right)\left(\right.$ SOIL $\left.^{3.01}\right)$ & 122 & 127 & 2.0 & 0.140 & 7.12 \\
\hline$Q_{2}=2.28\left(\right.$ AREA $\left.^{0.402}\right)\left(\right.$ SOIL $\left.^{2.90}\right)$ & 94 & 98 & 2.6 & .193 & 5.18 \\
\hline$Q_{2.33}=3.10\left(\right.$ AREA $\left.^{0.403}\right)\left(\right.$ SOIL $\left.^{2.84}\right)$ & 85 & 89 & 3.1 & .218 & 4.58 \\
\hline$Q_{5}=10.1\left(A R E A^{0.407}\right)\left(S_{O I L}{ }^{2.60}\right)$ & 58 & 61 & 7.7 & .324 & 3.08 \\
\hline$Q_{10}=21.9\left(\right.$ AREA $\left.^{0.410}\right)\left(\right.$ SOIL $\left.^{2.44}\right)$ & 48 & 51 & 14.4 & .384 & 2.61 \\
\hline$Q_{25}=48.8\left(A R E A^{0.416}\right)\left(\right.$ SOIL $\left.^{2.27}\right)$ & 43 & 46 & 23.6 & .413 & 2.42 \\
\hline$Q_{50}=80.9\left(A R E A^{0.423}\right)\left(S_{S I L}^{2.16}\right)$ & 44 & 48 & 28.0 & .405 & 2.47 \\
\hline$Q_{100}=127\left(\right.$ AREA $\left.^{0.432}\right)\left(\right.$ SOIL $\left.^{2.05}\right)$ & 47 & 51 & 29.5 & .382 & 2.62 \\
\hline$Q_{200}=193\left(\right.$ AREA $\left.^{0.441}\right)\left(\right.$ SOIL $\left.^{1.94}\right)$ & 52 & 56 & 28.9 & .350 & 2.86 \\
\hline$Q_{500}=323\left(\right.$ AREA $\left.^{0.454}\right)\left(\right.$ SOIL $\left.^{1.80}\right)$ & 60 & 66 & 26.6 & .302 & 3.31 \\
\hline
\end{tabular}

\section{Low Flows}

Low-flow characteristics are used by regulators in permitting wastewater discharges and by scientists in investigating surface-and ground-water interactions. Traditional low-flow characteristics also have been used in determining minimum streamflows for aquatic life; however, these characteristics alone are not appropriate for this use (National Research Council, 1999; Annear and others, 2002). Low-flow statistics for selected periods of consecutive days ( $n$-day low flows) are described in this section. The annual $n$-day low flow is the lowest daily mean streamflow that is not exceeded for $n$ consecutive days during a year.

Annual low flows in streams in Carbon County vary substantially by stream type and anthropogenic effects. Annual low flows in ephemeral streams are zero by definition. Annual low flows in perennial streams are sustained by ground-water inflows, reservoir releases, and irrigation returns. Annual low flows in intermittent streams vary between reaches depending on local geology, land use, and other basin characteristics. For example, annual low flows can be sustained by perennial springs in the upstream reaches of a stream. Downstream reaches of the same stream, however, can be ephemeral 
Table 2-3. Equations for estimating peak-flow characteristics, High Desert Region, Wyoming (Region 6).

$\left[\mathrm{SE}_{\mathrm{E}}\right.$, average standard error of estimate; $\mathrm{SE}_{\mathrm{P}}$, average standard error of prediction; $Q_{T}$, estimated peak flow, in cubic feet per second of recurrence interval for $T$ years; $A R E A$, total drainage area, in square miles; $L A T$, latitude of basin outlet location, in decimal degrees]

\begin{tabular}{|c|c|c|c|c|c|}
\hline \multirow[b]{2}{*}{ Equation } & \multirow{2}{*}{$\underset{\text { (percent) }}{\mathrm{SE}_{\mathrm{E}}}$} & \multirow{2}{*}{$\underset{\text { (percent) }}{S E_{p}}$} & \multirow{2}{*}{$\begin{array}{l}\text { Average } \\
\text { equivalent } \\
\text { years of } \\
\text { record }\end{array}$} & \multicolumn{2}{|c|}{$\begin{array}{l}\text { 95-percent prediction } \\
\text { interval factor }\end{array}$} \\
\hline & & & & Lower limit & Upper limit \\
\hline$Q_{1.5}=12.7\left(A R E A^{0.626}\right)\left((L A T-40)^{-1.18}\right)$ & 66 & 72 & 3.2 & 0.266 & 3.76 \\
\hline$Q_{2}=22.2\left(A R E A^{0.608}\right)\left((L A T-40)^{-1.24}\right)$ & 60 & 66 & 3.2 & .292 & 3.43 \\
\hline$Q_{2.33}=28.1\left(A R E A^{0.600}\right)\left((L A T-40)^{-1.26}\right)$ & 59 & 64 & 3.3 & .301 & 3.32 \\
\hline$Q_{5}=66.4\left(A R E A^{0.567}\right)\left((L A T-40)^{-1.35}\right)$ & 53 & 59 & 4.7 & .328 & 3.05 \\
\hline$Q_{10}=116\left(A R E A^{0.544}\right)\left((L A T-40)^{-1.40}\right)$ & 52 & 57 & 6.4 & .336 & 2.98 \\
\hline$Q_{25}=204\left(A R E A^{0.520}\right)\left((L A T-40)^{-1.44}\right)$ & 52 & 58 & 8.5 & .331 & 3.02 \\
\hline$Q_{50}=290\left(A R E A^{0.504}\right)\left((L A T-40)^{-1.46}\right)$ & 53 & 60 & 9.7 & .320 & 3.13 \\
\hline$Q_{100}=394\left(A_{R E A^{0.489}}\right)\left((L A T-40)^{-1.47}\right)$ & 56 & 63 & 10.4 & .304 & 3.29 \\
\hline$Q_{200}=519\left(A R E A^{0.476}\right)\left((L A T-40)^{-1.48}\right)$ & 59 & 67 & 10.9 & .286 & 3.49 \\
\hline$Q_{500}=719\left(A R E A^{0.459}\right)\left((L A T-40)^{-1.49}\right)$ & 64 & 73 & 11.1 & .261 & 3.83 \\
\hline
\end{tabular}

because annual low flows are less than total losses to seepage, diversions, and evaporation.

Annual $n$-day low flows were determined from daily streamflow data for selected streamflow-gaging stations in and near Carbon County with more than 10 years of streamflow record. Daily mean streamflow data for the period of record through water year 2003 were retrieved for selected stations from the USGS NWIS database and compiled in a watershed data management (WDM) file using the USGS computer program IOWDM (Lumb and others, 1990). Because the water year usually divides the annual low-flow period, annual $n$-day low-flow characteristics generally are determined for the climate year (from April 1 through March 31 of the following year) (Searcy, 1959). Annual $n$-day low flows were compiled using the USGS computer program SWSTAT (Wilbert Thomas, Jr., U.S. Geological Survey, written commun., 1997) for 3-, 7-, 10-, 30-, 60-, and 90-day periods.

Annual low-flow statistics were determined from frequency analyses of the $n$-day series for the selected streamflow-gaging stations (appendix 3). Similar to peak flows, for a series of annual $n$-day low flows at a site, a statistical relation can be defined describing the mean annual non-exceedance probability of a given flow during $n$ consecutive days. The Pearson Type III probability distribution was fit to the loga- 
rithms (base 10) of the $n$-day series using SWSTAT. For $n$-day series that included values of zero flow, SWSTAT incorporates a conditional probability adjustment (Wilbert Thomas, Jr., U.S. Geological Survey, written commun., 1997). Nonexceedance probabilities can be expressed in percent chance; alternatively, the reciprocal of the non-exceedance probability is the recurrence interval (expressed in years). For example, for a 7-day low-flow value with a non-exceedance probability of 0.10 (commonly referred to as the 7-day, 10-year flow and abbreviated as $7 \mathrm{Q} 10$ ), there is a 10 percent chance that the maximum of the seven lowest consecutive daily mean streamflows will be less than that value in any given year. Values of annual $n$-day low flows were determined for the 1.01-, 1.11-, 1.25-, 2-, 5-, 10-, and 20-year recurrence intervals. For stations with more than 25 years of streamflow record, values of annual $n$-day low flows also were determined for the 50 -year recurrence interval. For site 9, low-flow statistics were determined for the periods before and after construction of an upstream diversion structure.

\section{Flow Duration}

Flow duration is the time during which a given discharge is recorded at a site. For all discharges at a site during the period of record or interest, flow duration can be summarized as the cumulative exceedance probability (in percent) for each discharge. The result is a statistical measure of streamflow variability expressed as the percentage of time during which a range of flows were equaled or exceeded without consideration for the chronology of the individual flows. Flow-duration statistics are useful for evaluating spatial and temporal differences in streamflow variability resulting from natural and anthropogenic factors as well as for estimating streamflow distributions for water-quality assessments (Searcy, 1959).

Flow-duration statistics were determined from daily streamflow data for selected streamflow-gaging stations in and near Carbon County with more than 10 complete water years of streamflow record (appendix 4). Daily mean streamflow data for the period of record through water year 2003 were retrieved for selected stations from the USGS NWIS database and compiled in a WDM file using the USGS computer program IOWDM (Lumb and others, 1990). Flow-duration statistics were computed using the USGS computer program SWSTAT (Wilbert Thomas, Jr., written commun., 1997). The program counts occurrences of daily mean streamflow within logarithmically uniform intervals. Thirty-five intervals were calculated based on unique minimum and maximum daily values for each station. To compute streamflows for discrete exceedances, the program linearly interpolates between the streamflow intervals (Kathleen Flynn, U.S. Geological Survey, written commun., 2004). For site 9, flow-duration statistics were computed for the periods before and after completion of an upstream diversion structure because operations of diversion structures alter downstream flow durations.

\section{Water Quality}

Periodic water-quality data were retrieved from the USGS NWIS database for selected sites and periods, and summarized to describe the status and occurrence of major ions, nutrients, suspended sediment, and bacteria in streams in and near Carbon County. Concentrations of many stream waterquality constituents are dependent on basin and streamflow characteristics. Because basin and streamflow characteristics can vary non-uniformly with time, concentrations of stream water-quality constituents from different sites collected during non-concurrent time periods might not be comparable for describing regional characteristics. Additionally, streamflow characteristics at any given site can vary substantially within and between years. Thus, common time periods were selected where frequent water-quality analyses were available at several sites for multiple concurrent years. In Carbon County, frequent analyses of major ions and suspended sediment at several sites for multiple years occurred during the common period of water years 1966 through 1986 and frequent analyses for nutrients occurred during the common period 1974 through 1986.

Data in this report are summarized using parametric and nonparametric statistics. Descriptive summary statistics were computed using standard methods. Some constituent concentrations were less than laboratory reporting levels (censored data). Statistics of constituent concentrations that included censored data were estimated using robust methods (Helsel and Cohn, 1988; Helsel and Hirsch, 1992). Robust methods use distributions fit to data that are greater than the reporting level(s) to estimate summary statistics. In this report, summary statistics for most data sets with censored values were estimated using log-probability regression. In some cases, data were censored to a consistent reporting level in order to compare data through time or between constituents. Summary statistics are shown using boxplots for some constituents. The highest minimum reporting level shown with the box in figure 12 indicates the highest minimum reporting level used among the laboratories that analyzed samples in the data set.

\section{Dissolved Solids}

Dissolved solids is an operational definition that refers to water-quality constituents that will pass through a 0.45 -micrometer filter. In most surface waters, the major ions calcium, magnesium, sodium, potassium, bicarbonate, chloride, and sulfate compose the majority of dissolved solids.

\section{Major lons}

Dissolved solids in water samples from streams in and near Carbon County include the major ions calcium, magnesium, sodium, potassium, bicarbonate, chloride, and sulfate. Silica (an uncharged species) also is present as a major constituent in samples from streams. Concentrations of total dissolved solids (TDS) and individual major ions can vary 
substantially within and between streams. Much of the variability in TDS concentrations within streams results from the source and timing of flows in the streams. Streamflows resulting primarily from snowmelt runoff from mountainous areas are characterized by low TDS concentrations. Resistant geologic formations weather slowly and large streamflow volumes dilute concentrations of dissolved constituents. Streamflows resulting primarily from rainfall runoff from non-mountainous areas can have large TDS concentrations depending on local soil characteristics, precipitation characteristics, and land-use activities. Streamflows resulting from springs and seeps from non-mountainous areas also can have large TDS concentrations depending on local geologic features and land-use activities.

Median TDS concentrations for samples collected during water years 1966 through 1986 from selected sites in and near Carbon County varied, ranging from 46 milligrams per liter (mg/L) at site 7 at the Encampment River to $1,950 \mathrm{mg} / \mathrm{L}$ at site 31 at Hanna Draw (table 3; fig. 12A). Median concentrations for selected individual dissolved major ions also varied as listed in table 3 and illustrated in appendix 5. The smallest median major-ion concentrations mostly were for samples from site 7 on the Encampment River; the largest median major-ion concentrations mostly were for samples from site 31 on Hanna Draw.

Site 7 on the Encampment River (fig. 11) is located in the Sierra Madre (fig. 2). Because of resistant geologic units and mountain vegetative cover, TDS concentrations are low in stream samples from this site. TDS concentrations in alluvial aquifers that contribute to base flows also are low.

Site 31 (Hanna Draw) (fig. 11) is located on an ephemeral stream in the Hanna Basin (fig. 2). The sources of the ephemeral streamflows in the reach at site 31 probably are rainfall and snowmelt runoff events. Hanna Draw, like other ephemeral streams within arid basins in the county, likely concentrates salts from the land it drains. The intermittent flows in these streams likely are not high enough to flush salts through the system fast enough to prevent accumulation.

\section{Nutrients}

Nutrient concentrations in stream samples collected from 14 selected sites during water years 1974 through 1986 were evaluated to describe general surface-water quality characteristics of Carbon County. Nitrogen and phosphorus are essential nutrients for healthy plant and animal populations (Fuhrer and others, 1999). Excessive nutrient concentrations, however, can degrade or facilitate degradation of water quality. Concerns for nitrogen in streams include nitrate concentrations larger than ambient conditions resulting in human-health issues for drinking water and eutrophication and subsequent hypoxic conditions for streams and other receiving waters. Eutrophication is the primary concern for phosphorus in streams (Fuhrer and others, 1999). Nutrients are the third leading pollutant in impaired rivers and streams in the United States (U.S. Environmental Protection Agency, 2000).
Nitrogen in solution in most streams is primarily in the form of nitrate. Inorganic nitrogen in solution also includes other compounds such as nitrite and ammonia. In most streams, concentrations of these reduced forms are much smaller than nitrate concentrations and often are near or less than laboratory reporting levels. Laboratory reported concentrations of dissolved nitrite plus nitrate are assumed to be mostly nitrate; for brevity, concentrations of dissolved nitrite plus nitrate are referred to as concentrations of dissolved nitrate and reported as nitrogen. Pathways of nitrogen to streams include atmospheric deposition, overland runoff, ground-water discharge, and point discharges. Sources of nitrogen in streams include natural biological and chemical reactions, plant material, and anthropogenic activities such as fertilizer application to crops and lawns and sewage disposal from urban centers.

Phosphorus in solution is primarily in the form of orthophosphate. Phosphates, however, sorb strongly to soil and sediment particles (Fuhrer and others, 1999). Total phosphorus, which includes phosphates and particulate forms, is the only form of phosphorus evaluated in this report. Pathways of phosphorus to streams include overland runoff and point discharges. Natural sources of phosphorus in streams in the western United States include soil and sediment derived from marine sedimentary rocks. Because phosphorus is essential in metabolism, anthropogenic sources of phosphorus include animal and human waste (Hem, 1985). Phosphorus also is a necessary plant nutrient and sometimes is added as a fertilizer.

Various reference conditions and water-quality criteria are included in the evaluation of nutrient concentrations in stream samples. Clark and others (2000) estimated median flow-weighted mean nutrient concentrations for streams in relatively undeveloped basins of the United States. Flowweighted mean concentrations are analogous to the mean concentration of the annual mass flux. Because flow-weighted concentrations are not directly comparable to discrete sample concentrations, the estimates by Clark and others (2000) are included in this report only for qualitative purposes. The U.S. Environmental Protection Agency (USEPA) has established a standard (Maximum Contaminant Level, or MCL) of $10 \mathrm{mg} / \mathrm{L}$ for nitrate concentrations in drinking water (U.S. Environmental Protection Agency, 2002a) and a recommendation of $0.1 \mathrm{mg} / \mathrm{L}$ for total phosphorus concentrations for prevention of nuisance plant growth (U.S. Environmental Protection Agency, 1986). Applicability of the USEPA standards or criteria is dependent on the use for which the stream has been classified by the State.

\section{Nitrate}

Median dissolved nitrate concentrations for samples collected during water years 1974 through 1986 from selected sites in and near Carbon County were low, ranging from $0.028 \mathrm{mg} / \mathrm{L}$ at site 7 on the Encampment River to $0.580 \mathrm{mg} / \mathrm{L}$ at site 11 on Sage Creek (table 3; fig. 12B). The median of the median nitrate concentrations for the 14 selected sites 


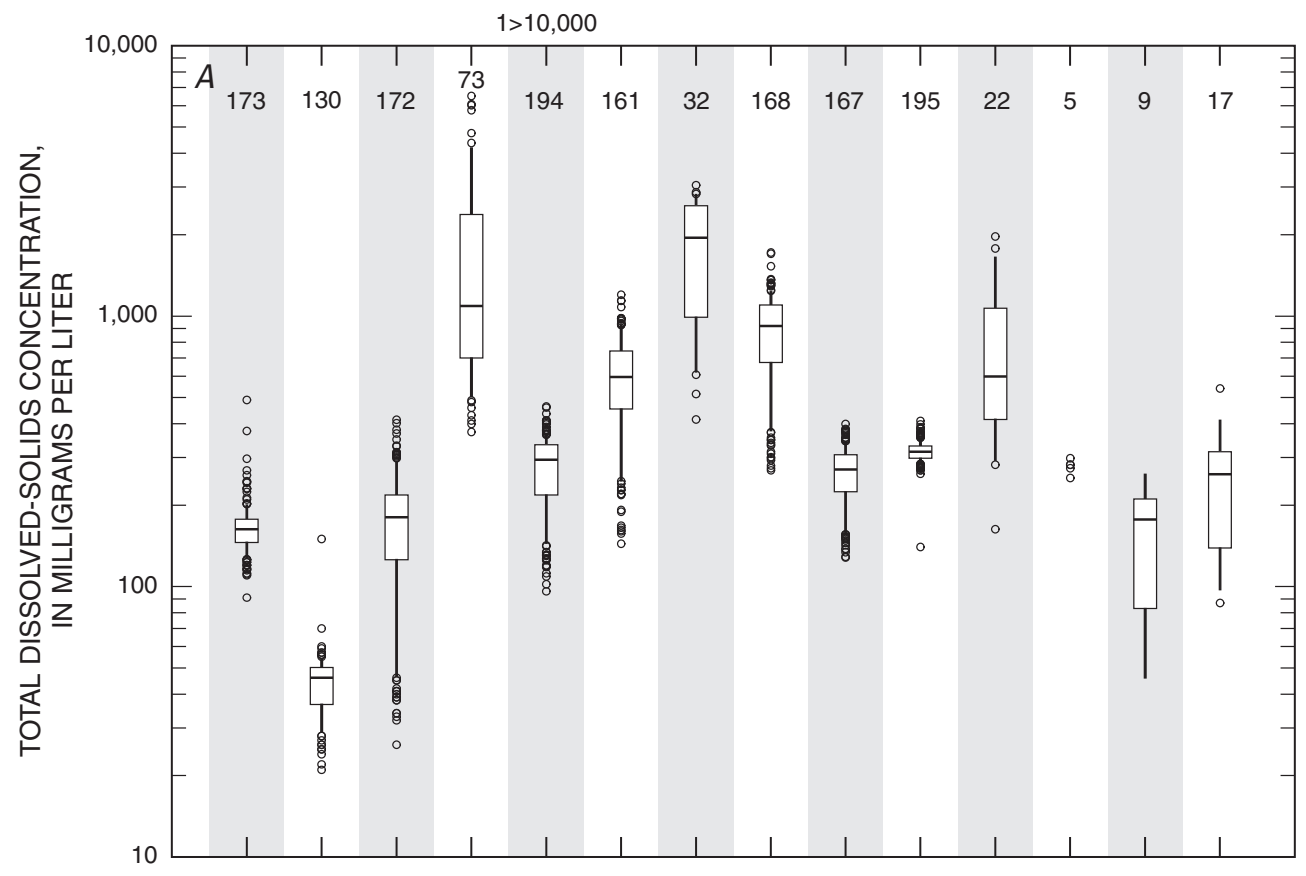

\section{EXPLANATION}

1>10,000 Number of samples with concentrations greater than the graphed concentrations

33 Number of samples

- Value outside 10th or 90th percentile

* More than one-half the samples were censored

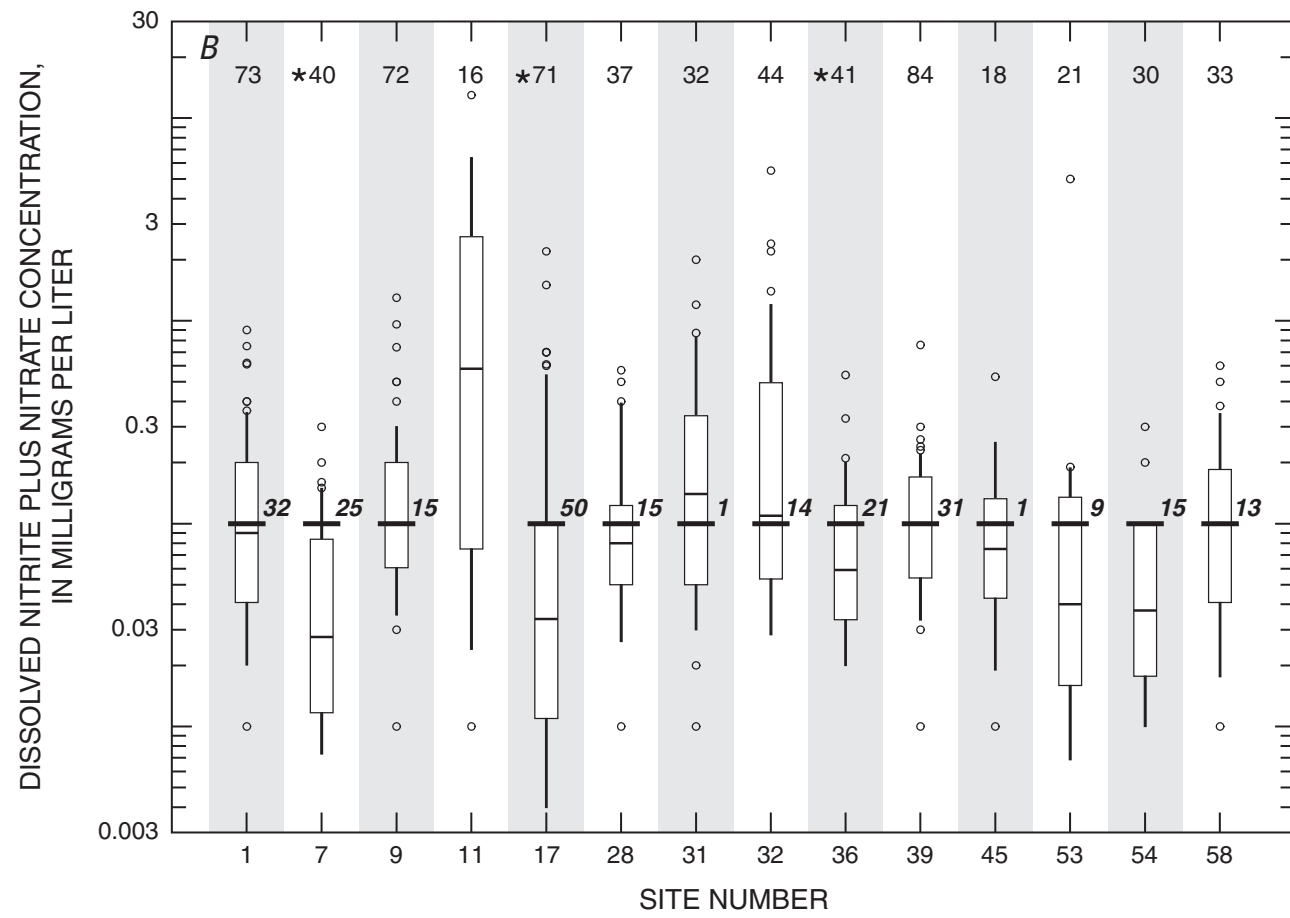

90th percentile

75th percentile

Median

25th percentile

10th percentile

${ }^{13}$ Highest minimum reporting level and number of censored samples

Figure 12. Statistics of A, total dissolved-solids concentrations (water years 1966-86); B, dissolved nitrite plus nitrate concentrations (water years 1974-86); C, total phosphorus concentrations (water years 1974-86); and D, suspended-sediment concentrations (water years 1966-86) from selected sites, in or near Carbon County, Wyoming. 


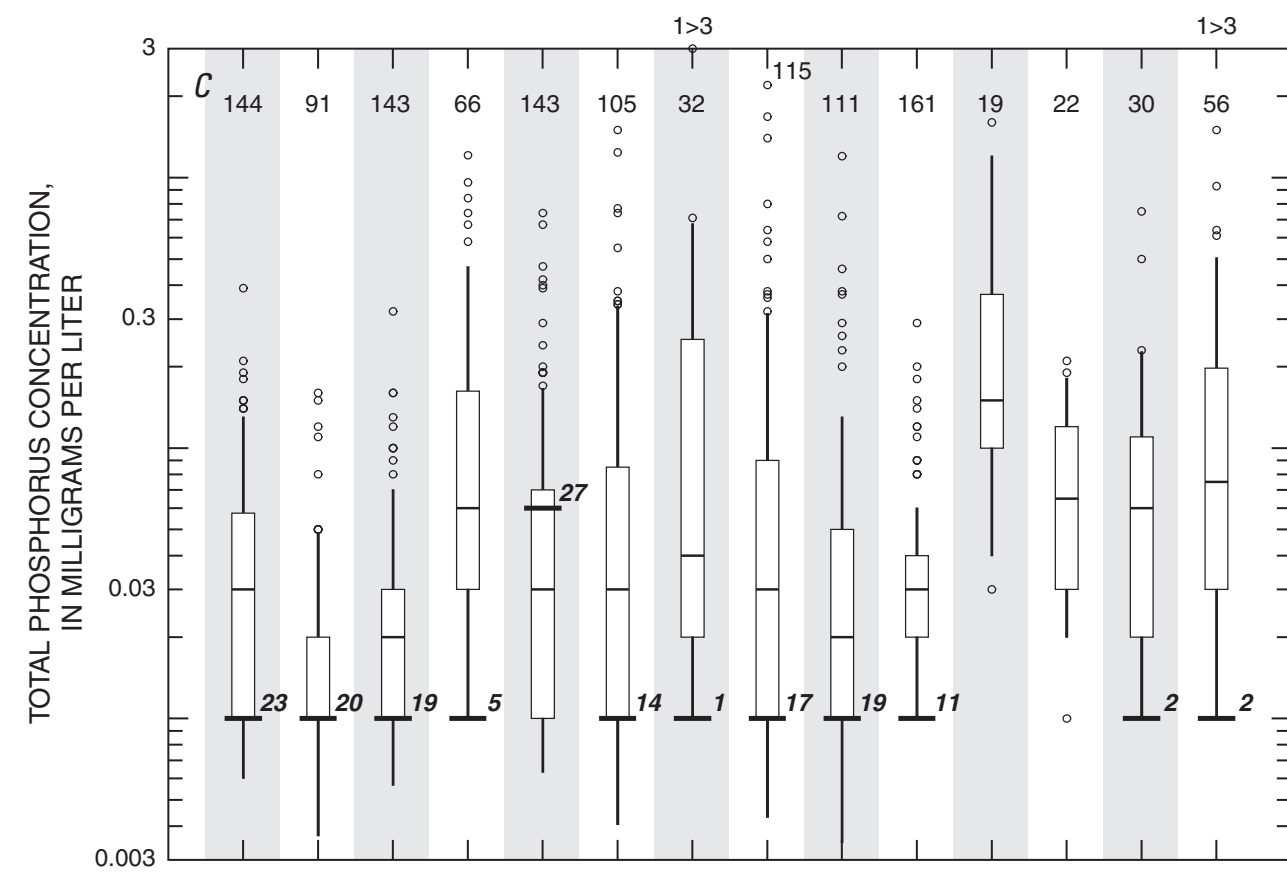

\section{EXPLANATION}

$1>10,000$ Number of samples with concentrations greater than the graphed concentrations

88 Number of samples

- Value outside 10th or 90 th percentile

* More than one-half the samples were censored 90th percentile

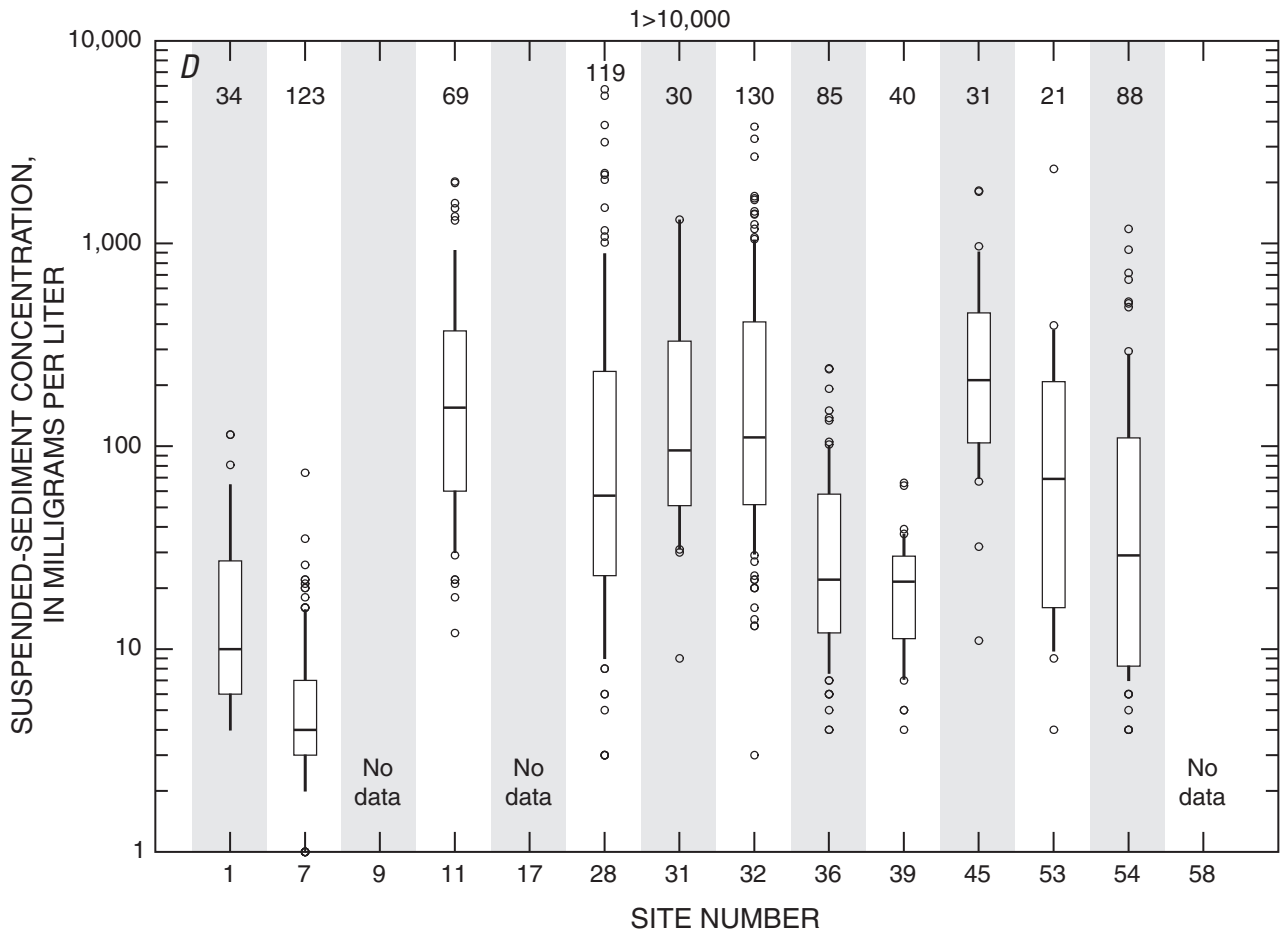

Figure 12. Statistics of $A$, total dissolved-solids concentrations (water years 1966-86); $B$, dissolved nitrite plus nitrate concentrations (water years 1974-86); C, total phosphorus concentrations (water years 1974-86); and D, suspended-sediment concentrations (water years 1966-86) from selected sites, in or near Carbon County, Wyoming.-Continued 


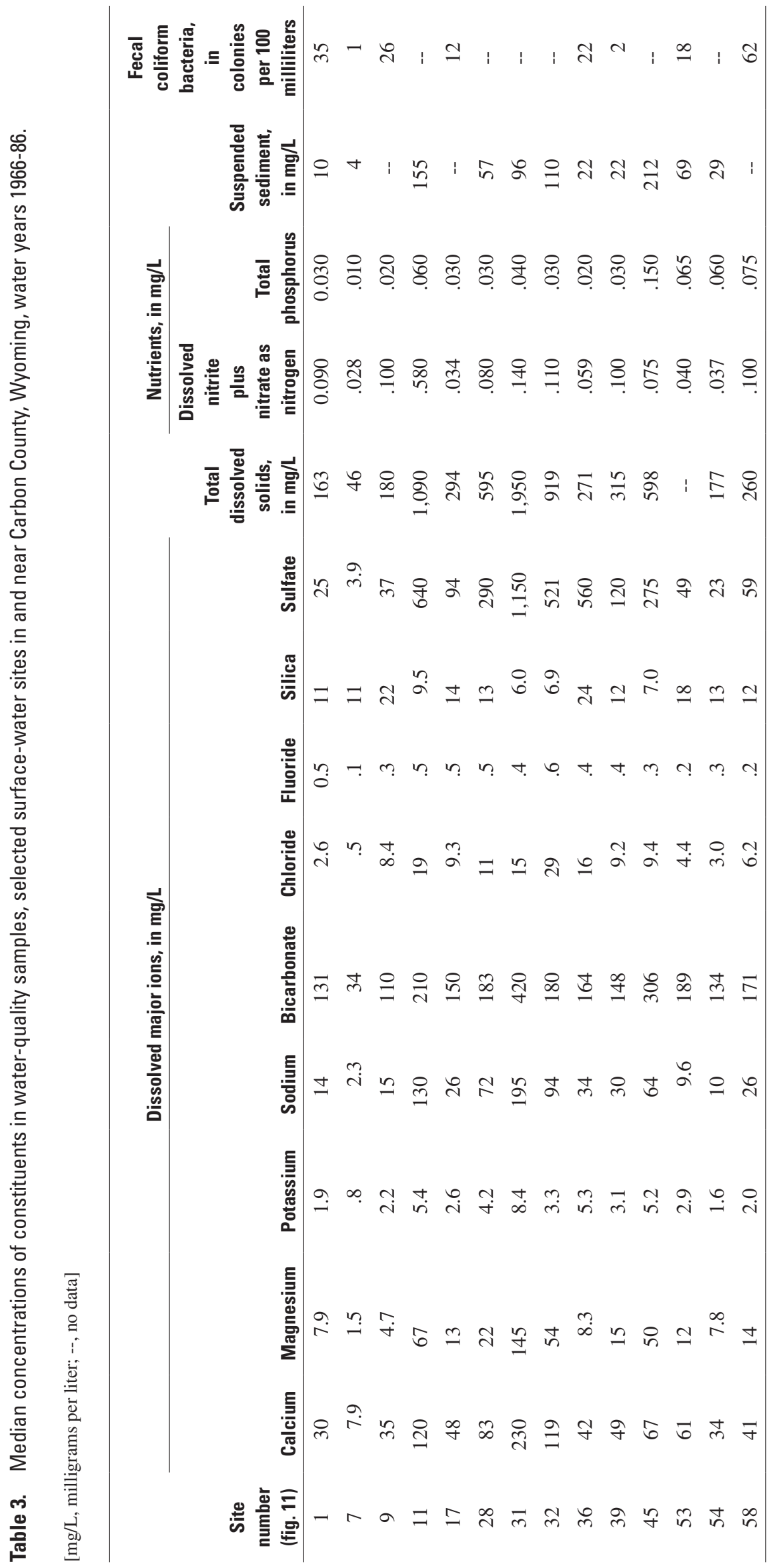


was $0.085 \mathrm{mg} / \mathrm{L}$. For comparison, Clark and others (2000) estimated the median flow-weighted mean nitrate concentration for streams in relatively undeveloped basins of the United States as $0.087 \mathrm{mg} / \mathrm{L}$. Site 11 was the only site to have a median nitrate value substantially higher than the Clark and others (2000) estimate (fig. 12B). One nitrate sample collected at site 11 also had a concentration that exceeded the USEPA MCL of $10 \mathrm{mg} / \mathrm{L}$ (U.S. Environmental Protection Agency, 2002a). At the other 13 sites, all water-quality samples had nitrate concentrations less than the MCL.

\section{Phosphorus}

Median total-phosphorus concentrations for samples collected during water years 1974 through 1986 from selected sites in and near Carbon County were low, ranging from $0.010 \mathrm{mg} / \mathrm{L}$ at site 7 on the Encampment River to $0.15 \mathrm{mg} / \mathrm{L}$ at site 45 on Separation Creek (table 3; fig. 12C). The median of the median total-phosphorus concentrations for the 14 selected sites was $0.030 \mathrm{mg} / \mathrm{L}$. For comparison, Clark and others (2000) estimated the median flow-weighted mean phosphorus concentration for streams in relatively undeveloped basins of the United States as $0.022 \mathrm{mg} / \mathrm{L}$. Although the median total-phosphorus concentrations from water-quality samples collected at the sites generally were higher than the Clark and others (2000) estimate, only water-quality samples collected at one site (site 45) had a median value for total-phosphorus concentrations that exceeded the USEPA recommendation of $0.1 \mathrm{mg} / \mathrm{L}$ for prevention of nuisance plant growth (U.S. Environmental Protection Agency, 1986).

\section{Suspended Sediment}

Suspended-sediment concentrations in stream samples collected from selected sites during water years 1966 through 1986 were evaluated to describe general surface-water-quality characteristics of Carbon County. Sediment in streams is part of the natural fluvial processes of erosion, transport, and deposition (siltation). As with other dissolved and particulate constituents in streams, however, excessive sediment transport can be cause for concern. These concerns include degradation of water quality and aquatic habitat and reduction of reservoir capacity. For example, siltation is the leading pollutant in impaired rivers and streams in the United States (U.S. Environmental Protection Agency, 2000). In addition to siltation, sediment in streams can facilitate the transport of other water-quality constituents/contaminants, including nutrients, bacteria, trace elements, and pesticides. Conversely, decreased sediment delivery also can affect aquatic habitat (Hem, 1985). Large reservoirs are sediment sinks; decreased velocities result in settling of particulates and removal of nearly all suspended sediment (Meade and others, 1990, p. 267). Diminished sediment transport—either through removal of the sediment source or through reduction of streamflow transporting the sediment - can result in channel changes including increased aggradation or degradation and changes in particle-size dis- tribution, all of which are detrimental to endemic fish populations (Muth and others, 2000).

Median suspended-sediment concentrations in samples collected during water years 1966 through 1986 from selected sites in and near Carbon County varied, ranging from $4 \mathrm{mg} / \mathrm{L}$ at site 7 on the Encampment River to $212 \mathrm{mg} / \mathrm{L}$ at site $45 \mathrm{on}$ Separation Creek (table 3; fig. 12D). Analyses for suspended sediment were available for 11 of the 14 selected sites. The median of the median suspended-sediment concentrations for the 11 selected sites was $57 \mathrm{mg} / \mathrm{L}$. Site 7 (fig. 11) is located in a high mountain stream with a bedrock channel, in a densely vegetated basin, where there is little fine-grained sediment readily available for transport. In contrast, site 45 (fig. 11) is located on an ephemeral stream in the arid Great Divide Basin (fig. 2), with sparse vegetation; fine-grained sediment is readily available for transport when runoff occurs.

Suspended-sediment characteristics observed in streams in Carbon County probably were the result of both natural and anthropogenic factors. On average, the largest suspended-sediment yields ${ }^{1}$ occur naturally in regions where precipitation is sufficient for producing runoff but insufficient for sustaining dense vegetation - a concept referred to as the "LangbeinSchumm rule" (Langbein and Schumm, 1958; also, Schumm and Hadley, 1961; Wilson, 1973). According to Martner (1986), most of Carbon County can be classified as either having a steppe or alpine climate (fig. 3). In most of the county classified as steppe, mean annual precipitation ranges from about 8 to 22 in. (figs. 3 and 5). Larger suspended-sediment yields might be expected from these areas of the county. In most of the county classified as alpine, mean annual precipitation ranges from about 32 to greater than 44 in. (figs. 3 and 5). Smaller suspended-sediment yields might be expected from these areas of the county. Human activities such as agriculture, logging, road construction, urbanization, and channelization of stream reaches often contribute to suspended-sediment concentrations in streams.

\section{Bacteria}

Bacteria concentrations in stream samples collected from selected sites during water years 1966 through 1986 were evaluated to describe historical concentrations of bacteria in surface water of Carbon County. Bacteria are from natural and anthropogenic sources. Excessive concentrations of bacteria in streams, however, are a human-health concern because bacteria have been correlated with the presence of disease-causing organisms (pathogens). Because sampling for pathogens is problematic, bacteria are used as indicators of the possible presence of pathogens in streams (Hem, 1985). Pathogens are the second leading pollutant in impaired rivers and streams in the United States (U.S. Environmental Protection Agency, 2000).

\footnotetext{
${ }^{1}$ Yield is equal to the product of streamflow and concentration, per unit drainage area and unit conversion factor.
} 
Historical monitoring of pathogen indicators in streams in and near Carbon County included sampling for fecal coliform bacteria. The primary sources of fecal coliform are fecal waste from wildlife and livestock and sewage effluent from municipalities and septic systems. Other non-fecal sources of fecal coliform exist (U.S. Environmental Protection Agency, 1986); as such, specific bacteria are preferable as pathogen indicators (Myers and Sylvester, 1997). For example, the presence of the fecal coliform Escherichia coli (E. coli) in water is direct evidence of fecal waste from warm-blooded animals (Dufour, 1977). In a synoptic study of three basins in Wyoming, however, Clark and Gamper (2003) found that most of the fecal coliform in stream samples were $E$. coli. The finding demonstrates the utility of fecal coliform data in analyses of pathogen indicators.

The State of Wyoming fecal coliform water-quality criteria are based on the geometric means of multiple samples during different time periods. The State criteria values have changed over time, as have their implementation with regard to different classes of streams and times of year as well as proximity of sewage outfalls (Wyoming Department of Environmental Quality, 1976, 2001). For the purposes of this report, samples are compared with the USEPA recommended criterion of 400 colonies per 100 milliliter (mL) for single samples (U.S. Environmental Protection Agency, 1976). USEPA studies determined that contact-associated gastrointestinal illnesses were statistically significant when fecal coliform counts were greater than 400 colonies per $100 \mathrm{~mL}$.

Analyses for fecal coliform were available for 8 of the 14 selected sites in and near Carbon County during water years 1966 through 1986 (table 3). Median fecal coliform counts in samples were low, ranging from 1 colony per $100 \mathrm{~mL}$ at site 7 on the Encampment River to 62 colonies per $100 \mathrm{~mL}$ at site 58 on the Little Snake River. The median of the median fecal coliform counts for the 8 sites was 20 colonies per $100 \mathrm{ml}$. At all 8 sites, at least 75 percent of the water-quality samples analyzed for fecal coliform bacteria had fecal coliform counts less than the USEPA recommended criterion of 400 colonies per $100 \mathrm{~mL}$, and at sites 7, 36, and 39, all fecal coliform counts were less than the criterion.

\section{Ground Water}

The terms aquifer and hydrogeologic unit are used in this report to describe saturated geologic units. In this report, the term aquifer refers to bodies of rock or sediment that yield economic quantities of water to wells or springs. Saturated geologic formations can consist of several types of hydrogeologic units, including aquifers. The term hydrogeologic unit is more general and refers to all bodies of rock or sediment that are hydrologically important, including aquifers, semi-confining units, and confining units. Most of the saturated geologic formations in Carbon County are heterogeneous, consisting of aquifers, semi-confining units, and confining units. For this reason the term hydrogeologic unit (figs. 8-10) is used when discussing characteristics of several geologic units as a whole. However, the term aquifer is used when discussing characteristics of a specific water-bearing unit or units within the hydrogeologic units listed in figures 8-10; for example, the Madison aquifer (Limestone) is within the Paleozoic hydrogeologic units. Discussions on ground water in the following sections are organized by hydrogeologic units.

Estimates of water used in Carbon County indicate that ground water only accounts for about 2 percent of the overall water used (Hutson and others, 2004; U.S. Geological Survey, 2005); however, in many parts of the county it is the only supply of water available. Aquifers in hydrogeologic units of lower Tertiary age are the most widely used. Rocks that contain these aquifers occur at or near land surface in much of the county (fig. 2). Aquifers in unconsolidated deposits of Quaternary age can be important water supplies locally but are not widespread.

Ground water in the county occurs under both watertable (unconfined) and artesian (confined) conditions. Under water-table conditions, permeable material extends from the land surface to the saturated zone, allowing vertical movement of water. Aquifers in Quaternary unconsolidated deposits consisting of alluvium, dune sand (eolian), lacustrine, and gravel deposits generally are unconfined. In some locations, shallow aquifers in other hydrogeologic units also may be unconfined. Artesian aquifers are composed of permeable rock or sediment confined by relatively impermeable rocks (semi-confining or confining units). Water in an artesian aquifer is under hydraulic pressure and will rise above the top of the aquifer when the overlying confining bed is penetrated (for example, by a well) or fractured (for example, at a spring). If sufficient hydraulic pressure exists, water from a well completed in an artesian aquifer can flow to the land surface even though the aquifer is deeply buried. Most aquifers in Tertiary and deeper hydrogeologic units in the county contain water under artesian conditions (except at or near the surface, especially where formations are exposed).

\section{Ground-Water Recharge}

Recharge to aquifers in Carbon County occurs by infiltration of precipitation on outcrop areas, infiltration of snowmelt runoff from the mountains, and leakage of streamflow (Martin, 1996, p. 25; Welder and McGreevy, 1966, p. 2; Collentine and others, 1981; Richter, 1981; Geldon, 2003). Fisk (1967, p. 6567 ) identified major recharge areas to aquifers in the Great Divide Basin as the high area in the northeast part of the basin (Townships (Tps.) 26 and 27 North (N.) between Ranges (Rs.) 90 and 94 West (W.)), the southwest part of the basin where rocks are upturned on the Rock Springs Uplift, the Rawlins Uplift (fig. 1), and the high area around Creston Junction in Sweetwater County (not shown). Potentiometric levels in hydrogeologic units are higher in these areas than other parts of the basin, probably because the higher altitude of these fea- 
tures results in slightly higher annual precipitation. Welder and McGreevy (1966, p. 2) reported that most streams in the Great Divide Basin are losing streams.

Fisk (1967, p. 66-68) identified major recharge areas to aquifers in the Washakie Basin as the upturned outcrops flanking the Rock Springs Uplift, the outcrop area southwest of Rawlins (Atlantic Rim area in Carbon County) (fig. 2), and the high area around Creston Junction in Sweetwater County (not shown). Again, these high areas probably receive more annual precipitation than the lower parts of the basin. Fisk (1967, p. 66-68) also identified Muddy Creek (figs. 2 and 13) where it crosses the permeable Late Cretaceous-age Fox Hills Sandstone and Lance Formation and the Tertiary-age Fort Union Formation (Township 17 North (T. 17 N.), Range 91 West (R. 91 W.)) in Carbon County as a recharge area for the basin. Most streams in the Washakie Basin also are losing streams (Welder and McGreevy, 1966, p. 2).

Even though the Great Divide and Washakie Basins are separated structurally, Fisk (1967, p. 19) reported that aquifers are in direct hydraulic connection across the Wamsutter Arch. Fisk (1967, p. 69) estimated total recharge to both basins to be a minimum of $15 \mathrm{ft}^{3} / \mathrm{s}$. Using recharge and storage estimates, Fisk (1967, p. 73) estimated that it would take more than 50,000 years to fill the fresh-water parts of the basins with ground water.

Freethey and Cordy (1991, p. C81) presented a map of potential recharge by direct infiltration of precipitation to aquifers in Mesozoic hydrogeologic units within the Upper Colorado River Basin. The Carbon County part of this map (fig. 13) shows the potential for direct infiltration of precipitation to Mesozoic geologic formations in the Great Divide and Washakie Basins.

Johnson and Huntoon (1994, p. 4) examined groundwater movement through aquifers of the Troublesome and Difficulty Creek area in the northern Hanna Basin, an area described by the investigators as the "southern flank of the Shirley Mountains in the hanging wall block of the Shirley thrust fault" (Difficulty Creek shown on fig. 2). As part of the study, recharge to aquifers in Paleozoic rocks (Tensleep Sandstone and Madison Limestone) in the area was examined. The investigators reported that recharge to the Tensleep Sandstone, the "major aquifer" in the area, was by direct infiltration of precipitation and snowmelt through intergranular pores, fractures, and joints in surface exposures in the Shirley Mountains, Freezeout Mountains, and outcrops in the area. Recharge to the Tensleep Sandstone also was through the overlying Madison Limestone exposed in the Shirley Mountains. Water from precipitation and runoff (streamflow) into sinkholes and fractures of the Madison Limestone eventually moves to the underlying Tensleep Sandstone through vertical extensional fractures and faults along the flanks of the basin, allowing hydraulic connection, and recharge, between the two formations.

\section{Ground-Water Discharge}

Ground-water discharge in Carbon County occurs mainly as seepage to streams, discharge to springs and seeps, pumpage from wells, evapotranspiration, and underflow along streams and in aquifers that extend out of the area (Welder and McGreevy, 1966; Lowry and others, 1973; Collentine and others, 1981; Richter, 1981; Geldon, 2003). Ground water in Mesozoic and Paleozoic hydrogeologic units also may leave the county as underflow in parts of the county (Freethey and Cordy, 1991, plate 5E; Geldon, 2003, p. B127 and B134).

A potentiometric surface map of the Wasatch zone of the Wasatch-Fort Union aquifer in Carbon County (Wasatch zone is composed of the Tertiary-age Wasatch and Battle Spring Formations) is shown in figure 14. Within Carbon County, most of the aquifer is located in the Wamsutter Arch and Washakie Basin areas. Ground-water movement in the Wamsutter Arch area generally is to the west. In the Washakie Basin area, ground-water in the aquifer appears to move towards a small discharge area along the Little Snake River drainage in the southwest part of the county. Fisk (1967, p. 6970) reported that some ground water in the Washakie Basin is lost to the westward flowing Bitter Creek and the southward flowing Muddy Creek, Vermillion Creek, and other tributaries to the Little Snake River. Fisk (1967, p. 70) also stated that some ground water likely flows south out of the Great Divide Basin over the Wamsutter Arch and into the Washakie Basin.

Figure 15 from Freethey and Cordy (1991, pl. 5E) is a generalized potentiometric surface map of the Mesaverde aquifer (Mesaverde Group or Formation), which is contained in Upper Cretaceous rocks in Carbon County. The map is not detailed enough to accurately show all of the flow directions out of Carbon County in the Mesaverde aquifer, but it does indicate that at least some of the water in the Washakie Basin flows across the southern county line near the Little Snake River. Regionwide development of ground-water resources in Mesozoic hydrogeologic units in the Upper Colorado River Basin (including Carbon County) was reported as negligible by Freethey (1988, p. 64). Locally, water produced from Mesozoic hydrogeologic units in conjunction with oil and gas production may be substantial.

According to Geldon (2003, p. B126), highly variable topography forces ground water in Paleozoic hydrogeologic units of the Upper Colorado River Basin to flow toward local and subregional outlets, rather than to regional discharge areas. Geldon (2003, p. B141) reported that water produced in conjunction with oil and gas production is the largest withdrawal from Paleozoic hydrogeologic units in the Upper Colorado River Basin. Production of water in this way probably is responsible for local declines in water levels within the basin. The potentiometric-surface map (fig. 16) of the Tensleep aquifer (Sandstone), which is contained in upper Paleozoic rocks, indicates that a 1,000-ft ground-water cone of depression occurs around the Lost Soldier-Wertz-Mahoney oil fields in and near the northwest corner of Carbon County. Geldon (2003, p. B134) reported that most of the ground water 


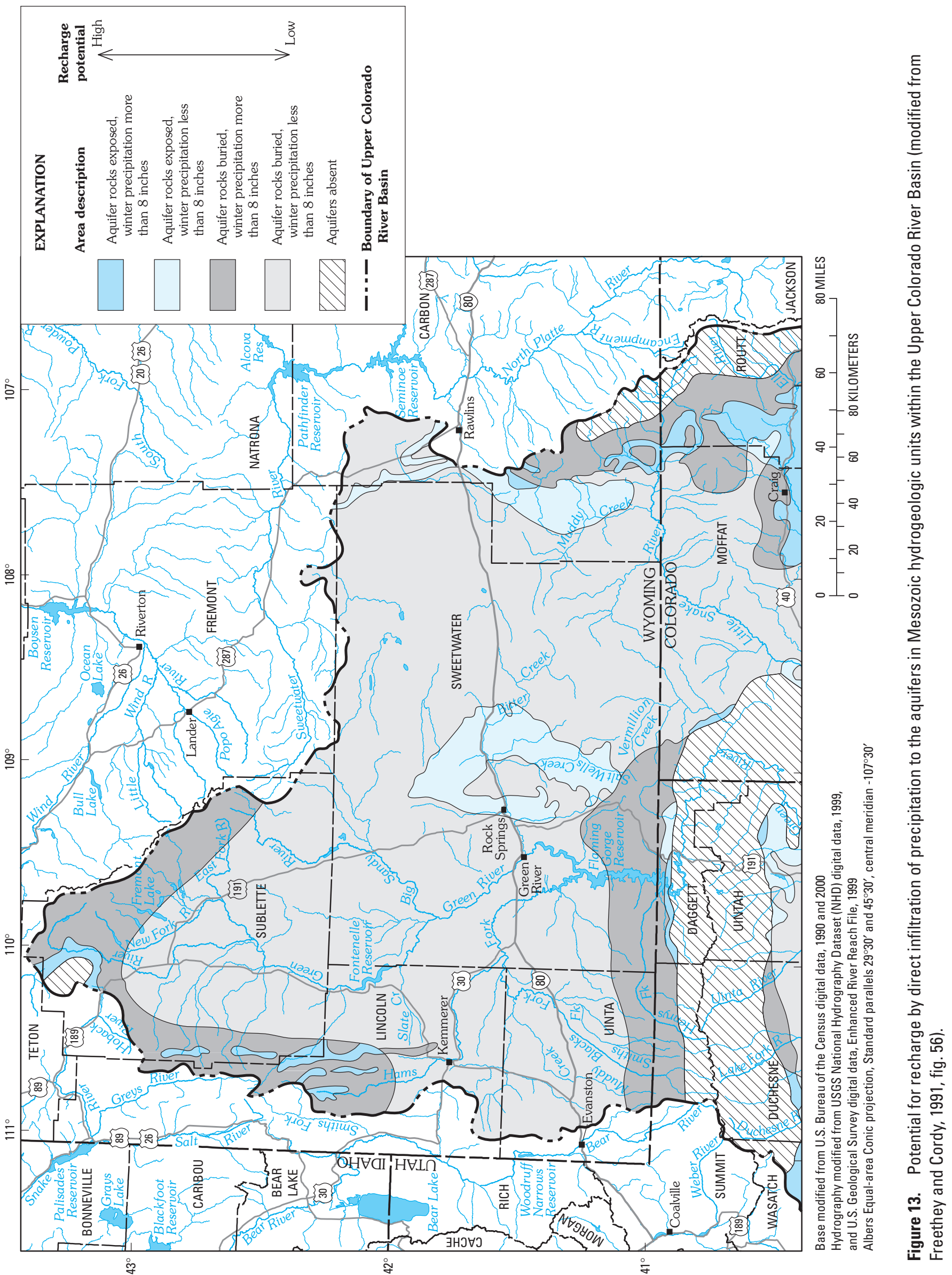


in upper Paleozoic hydrogeologic units north of the Uinta-Park Divide (fig. 16) that is not pumped from wells or discharged to springs, probably rises into Mesozoic or Tertiary hydrogeologic units or flows into the Hanna Basin through a gap between the Rawlins Uplift and the Sierra Madre.

Figure 17 shows the potentiometric surface of the Madison aquifer (Limestone), which is contained in middle Paleo- zoic rocks, in Carbon County. Like upper Paleozoic hydrogeologic units, ground water in middle Paleozoic hydrogeologic units north of the Uinta-Park Divide (fig. 17) could flow toward a gap between the Rawlins Uplift and the Sierra Madre (fig. 2). Some of the water in these hydrogeologic units also is lost to water wells and oil and gas field pumpage (Geldon, 2003, p. B127).

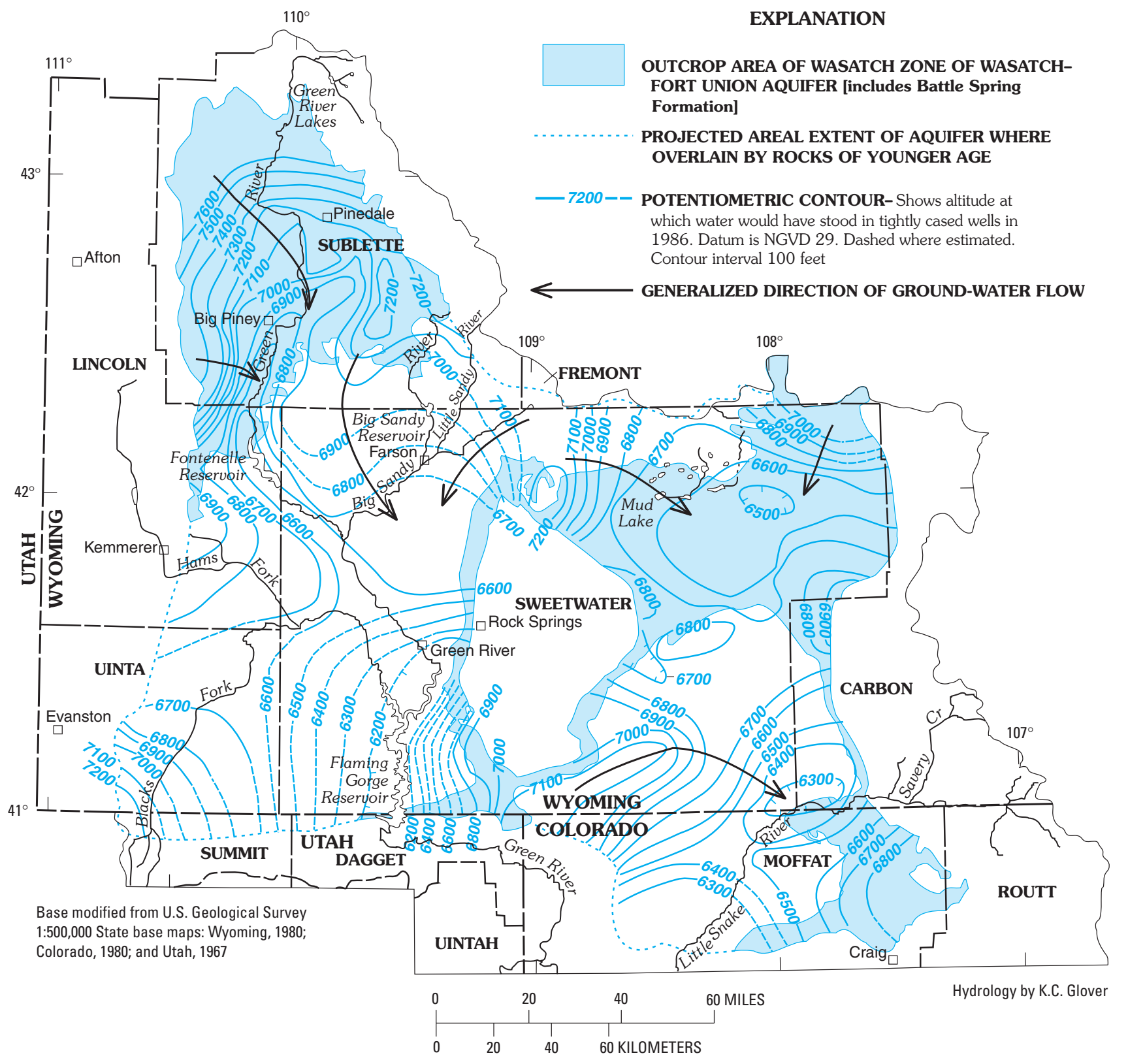

Figure 14. Potentiometric surface and inferred flow paths for the Wasatch zone of the Wasatch-Fort Union aquifer, Carbon County and surrounding area (from Naftz, 1996, fig. 22). 

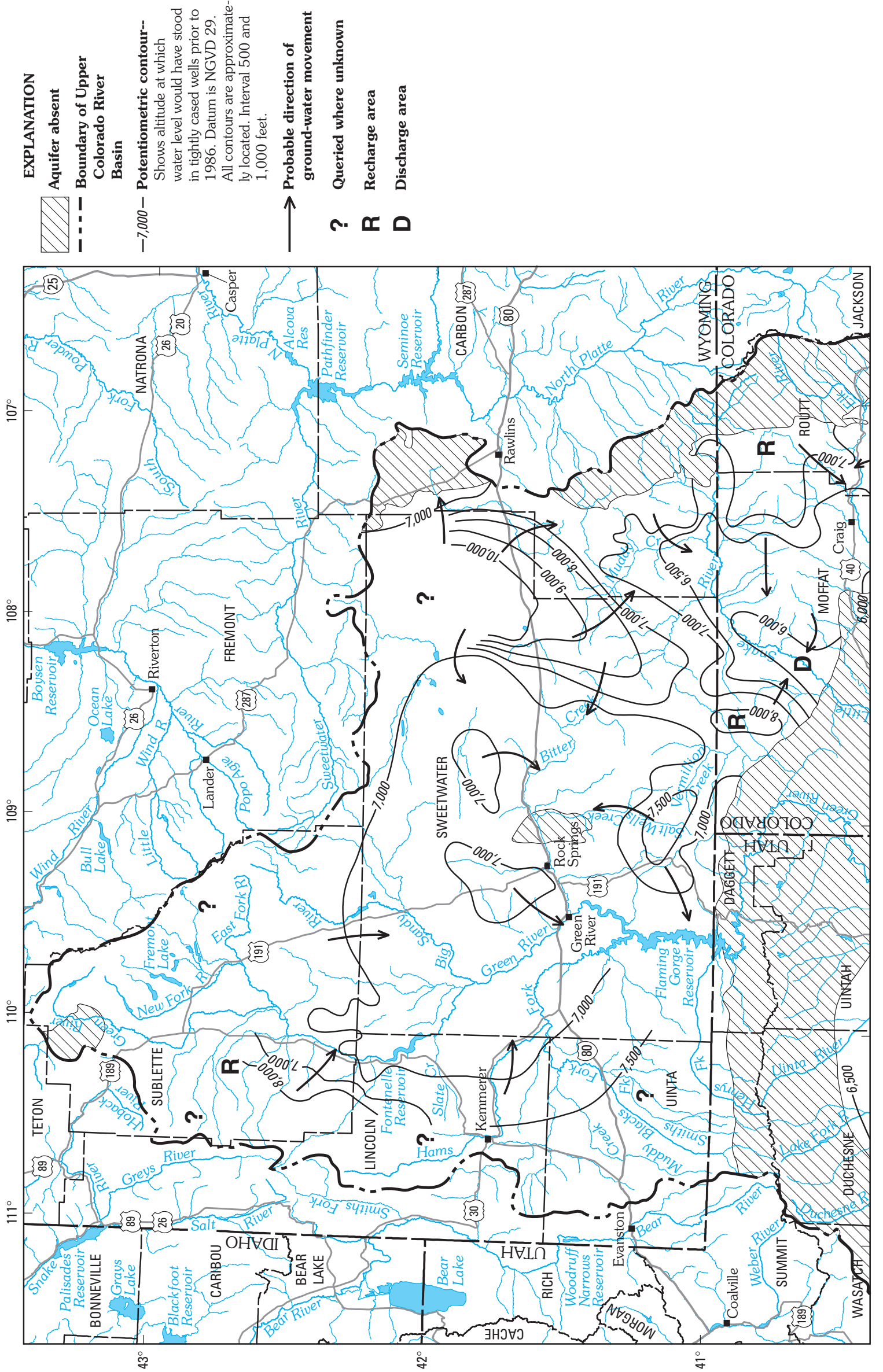

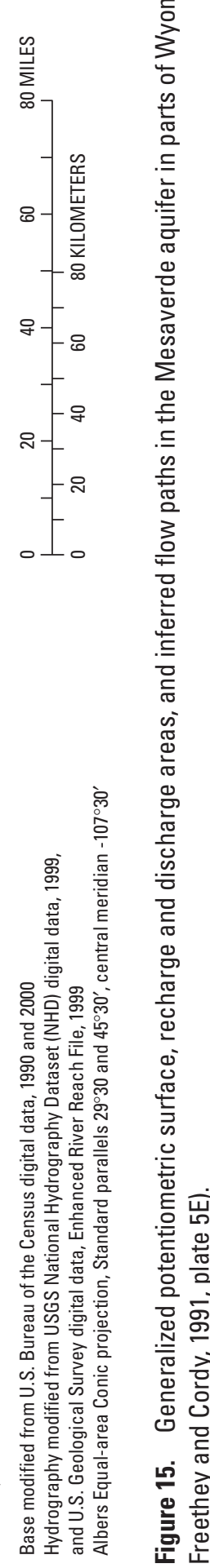




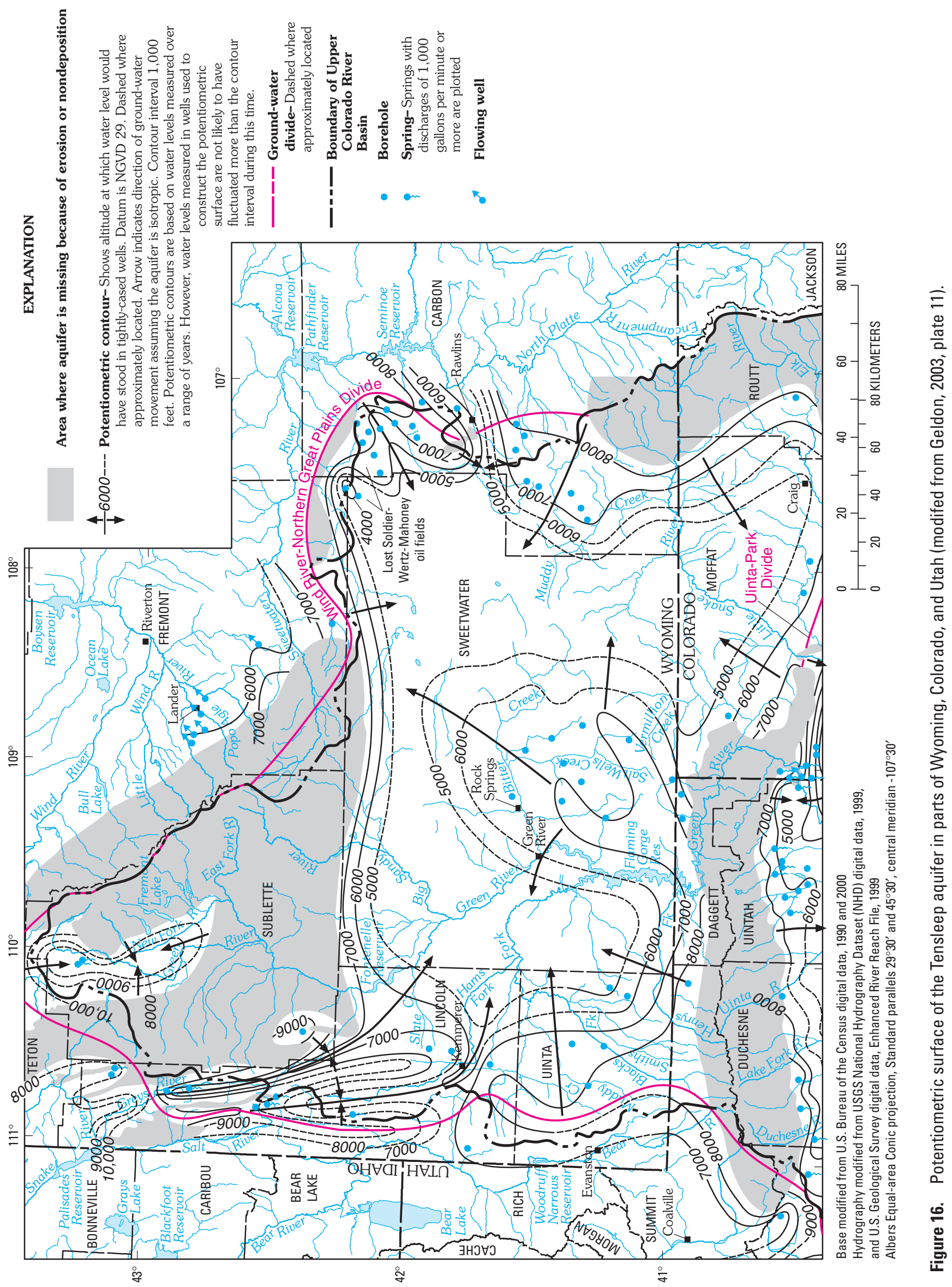




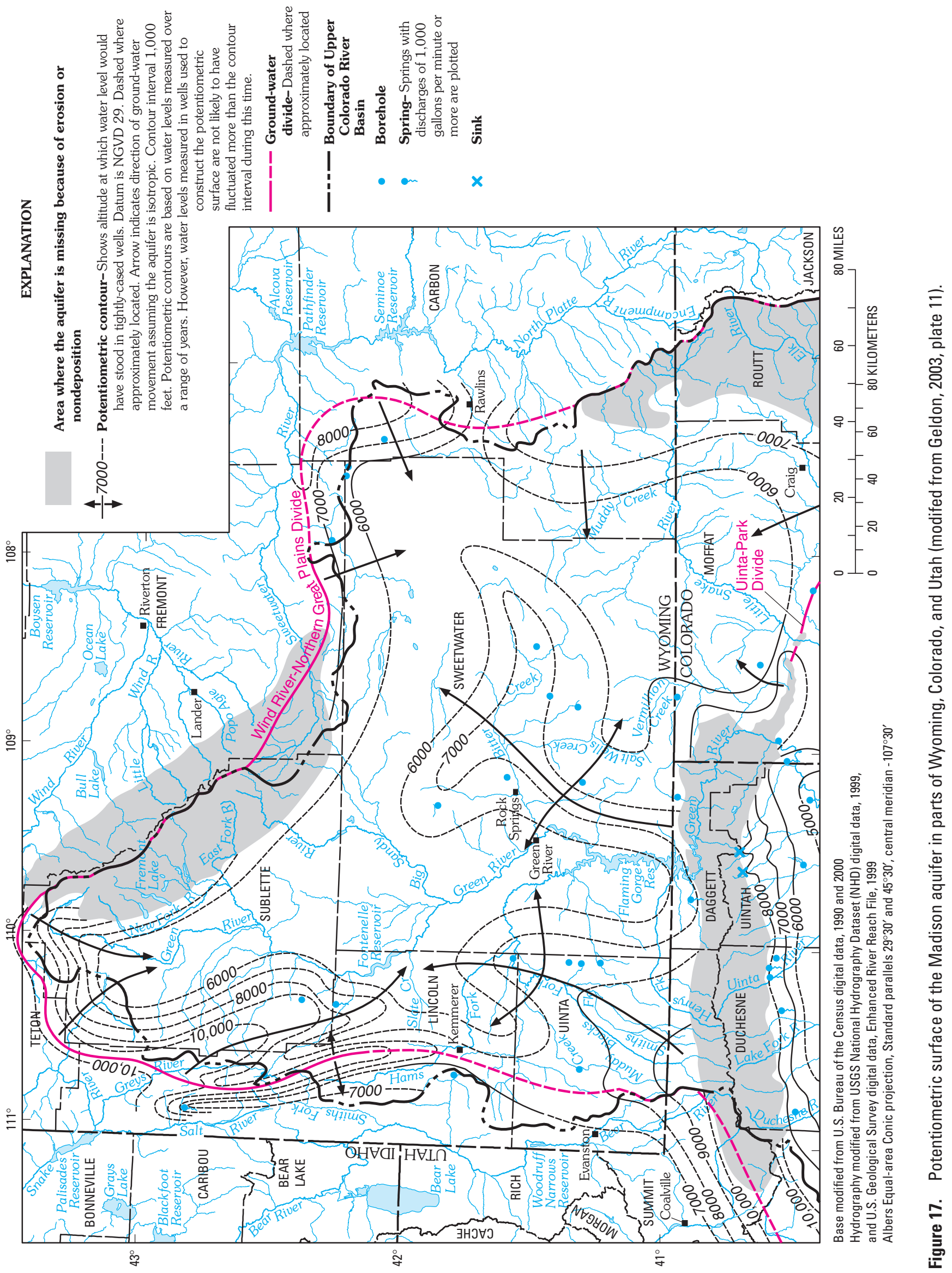




\section{Ground-Water-Quality and other Hydrogeologic Characteristics}

Ground-water quality data included in this report came from the USGS NWIS database, the USGS Produced Waters Database (PWD), the Wyoming Oil and Gas Conservation Commission (WOGCC), and the University of Wyoming Water Resources Data System (WRDS) database. Detailed methods used to "screen" data are described for each data source. However, the overall objective for all data sources was to find and remove samples that (1) were duplicates;

(2) were not assigned to hydrogeologic units or were assigned to hydrogeologic units that contradicted local geologic information, particularly for shallow wells; (3) had inconsistent water-chemistry information such as poor ion balances or substantially different values between total dissolved solids and the sum of major ions; or (4) were unlikely to represent the water quality of a hydrogeologic unit because of known anthropogenic effects such as samples from wells monitoring known or potential point-source contamination sites or mining spoils sites.

Many Carbon County ground-water sites were sampled more than once; however, only one ground-water sample from a given site was included in this study to avoid biasing the results towards multiple-sample sites. An exception to this rule was the case of some PWD samples that had been collected from the same well, but came from different depths and different hydrogeologic units. For the PWD samples, a single sample per well per hydrogeologic unit (well-hydrogeologic unit) was included. When choosing between multiple samples from a site or well-hydrogeologic unit, either the most recent sample or the sample with the most complete analysis was retained in the final data set.

Data in this report are summarized using different statistical methods. Descriptive summary statistics for constituents and hydrogeologic units were computed using standard methods. Summary statistics are shown using boxplots for some constituents and hydrogeologic units. Some constituent concentrations were smaller than method detection limits of the measurement instrument. In those cases, the values were reported as less than the laboratory reporting level (for example, $<0.01 \mathrm{mg} / \mathrm{L}$ ), and are referred to as "censored values." Statistics of data sets that included censored data were estimated using robust methods (Helsel and Cohn, 1988; Helsel and Hirsch, 1992). Robust methods use distributions that are fit to data greater than reporting level(s) to estimate summary statistics less than reporting level(s). In this report, summary statistics for ground-water quality data sets with censored values were estimated using log-probability regression. Kendall's Tau values (a correlation coefficient based on the ranks of values within the data set) were calculated using data censored to the highest reporting level for each hydrogeologic unit-constituent group, except in the case where the highest reporting level matched the value of an uncensored value, in which case the data were censored to a level 0.001 below the highest reporting level.
A total of 329 ground-water-quality samples from the NWIS database are included in this report, of which 45 samples were collected specifically for this study to improve understanding of ground-water quality in Carbon County. The NWIS database included 348 ground-water sites with waterquality analyses within Carbon County; however, 13 sites were excluded from this study because no hydrogeologic information was available, and an additional 6 sites were excluded because of their proximity to potential contamination sources.

The hydrogeologic unit was determined for each of the 45 wells from which new samples were collected. This was determined by first obtaining the latitude and longitude of the sampling site using a global positioning system (GPS) and plotting the site using a geographical information system (GIS) on the statewide 1:500,000 geologic bedrock map (Love and Christiansen, 1985) or other available geologic maps. If the sampling site was a spring, the geologic formation that the spring plotted in was assumed to be the source of the sampled water. For shallow wells, drilling logs and well-completion information from the Wyoming State Engineer's Office well permits were reviewed, when available, to ensure that the well was completed in bedrock and not in unconsolidated surficial deposits. These steps also were taken for deep wells, but in addition, available geologic formation thickness data were reviewed to determine if the well was screened in the formation that occurred at the land surface or if it was screened in a deeper formation. The remaining sample locations were reviewed using a GIS, the statewide 1:500,000 geologic bedrock map, or other geologic maps to check for proper assignment of the hydrogeologic unit.

A total of 212 ground-water-quality samples from the USGS PWD are included in this report. The PWD is available online at http://energy.cr.usgs.gov/prov/prodwat/data.htm. The PWD included 575 samples within Carbon County; however, not all samples were suitable for inclusion in this study because some methods of sample collection are less likely to provide samples that reflect aquifer water chemistry. Only those PWD samples collected from the wellhead or from a drill stem test were included. This limited the resulting dataset to 439 samples, 12 of which were removed because no hydrogeologic information was available. The PWD samples were then screened to retain a single sample per well-hydrogeologic unit combination, resulting in 215 samples. Finally, three samples were removed because their water chemistry was identical to that of other samples, indicating probable duplication of sample records. PWD documentation indicated that samples were screened to remove samples with ion balances greater than 15 percent. The PWD contains chemical analyses for major ions and TDS. According to PWD documentation, some sample analyses may have reported the sum of sodium and potassium concentrations as sodium concentration alone. There were no potassium values for 112 samples used in this report, so those sample analyses may be reporting combined sodium and potassium concentrations. A few samples reported trace quantities of a constituent. To calculate statistical sum- 
maries for these samples, the value of "trace" was changed to $<1 \mathrm{mg} / \mathrm{L}$.

A total of 92 ground-water-quality samples were included from the WOGCC database. The WOGCC database included 222 samples from Carbon County; however, not all samples were suitable for inclusion in this study. Thirty-one samples were removed because ion balances were greater than 10 percent. Seventy-eight samples were removed because one or more major-ion analyses were missing, preventing calculation of ion balances. Eleven samples were removed to retain a single sample for each well-hydrogeologic unit combination. Five sample-pairs had identical water chemistry, so one sample from each pair was removed. Four samples were removed because they either had missing or unidentifiable hydrogeologic codes. One sample was removed because its location description plotted outside of Carbon County.

A total of 30 ground-water-quality samples were included from the WRDS database. The WRDS database included 846 non-USGS ground-water or spring samples from 611 sites in Carbon County. Of the 611 sites, 162 had hydrogeologic unit assignments. Of the 162 sites, 56 were sites monitored by the Wyoming Department of Environmental Quality (WDEQ). WDEQ monitoring wells generally are located at sites of known or potential ground-water contamination. Because the objective of this report is to describe general groundwater quality based on conditions such as geologic formation and well depth, it was determined that WDEQ monitoring sites would not meet that objective and those samples were removed from the data set. At this stage, ion balances were checked for the remaining 235 samples from 106 sites. Samples with ion balances greater than 10 percent were removed from the data set. To calculate ion balances, concentrations for all major ions must be available. One-hundred thirty-five samples had sufficient major-ion data to calculate ion balances, and of these, 23 had poor ion balances. Because poor ion balance was relatively common, samples were excluded from the data set if there were not enough major-ion analyses to calculate an ion balance. An exception was made to include some sites from the Wyoming State Laboratory that had nutrient, bacteria, and TDS data and little or no major-ion data. This resulted in 55 sites remaining. Site names were checked for the remaining 55 sites, and 18 sites were discarded because the site name indicated that the well was associated with a coal mine, and without additional information, it could not be determined if the sample came from an active coal mine where ground-water quality may have been affected by mining. The remaining 37 sites were plotted on a 1:500,000 scale geologic map, and hydrogeologic unit assignments were compared with information on the map. Seven sites were discarded because the hydrogeologic unit designation did not match where the site plotted on the map.

The methods described in the USGS National Field Manual for the Collection of Water-Quality Data (U.S. Geological Survey, 1997 to 2003) were used for the collection of the 45 new samples used in the study described in this report.
A field blank and a replicate sample were collected as qualityassurance samples.

All 45 samples were analyzed for physical characteristics, major ions and related characteristics, nutrients, and trace elements. In addition, some of these samples were analyzed for selected radionuclides including 42 samples analyzed for radon-222; 2 samples analyzed for radium-224; 6 samples analyzed for radium-226, radium-228, gross-alpha activity, and gross-beta activity; and 4 samples analyzed for tritium. All samples were analyzed by the USGS National Water Quality Laboratory in Denver, Colorado. Methods for the major-ion analyses are described in Fishman and Friedman (1989), Fishman (1993), and American Public Health Association (1998). Methods for the nutrient analyses are described in Fishman (1993). Methods for the trace-element analyses are described in Garbarino (1999), Faires (1993), McLain (1993), and Fishman and Friedman (1989). Methods for the radon-222 analyses are described in American Society for Testing and Materials (1996). Methods for the radium isotopes, and grossalpha and gross-beta activity analyses are described in U.S. Environmental Protection Agency (1980) method 900.0 with modification ${ }^{2}$. Results from analyses for all 45 new groundwater-quality samples collected during this study are tabulated in appendix 6.

The methods used to collect the 42 radon- 222 samples were designed to prevent degassing of the sample. However, not all aspects of sample collection could be controlled. Specifically, cascading water in some wells, and some degassing from springs, may have occurred. Springs were sampled only when upwelling of ground water was visible and the water temperature and dissolved oxygen content indicated that the water was not stagnant. Spring samples were collected from below the water surface directly in plumes of upwelling. Because it is possible that some degassing of radon-222 could have taken place in these samples, all radon- 222 concentrations should be considered minimum values.

In the following discussion of characteristics of aquifers, comparisons are made between water-quality-sample results and various water-quality standards. Water-quality standards used for comparisons will be explained here rather than in each of the individual sections that follow.

For water-quality comparisons, three types of USEPA standards are used: MCL, Secondary Maximum Contaminant Level (SMCL), and Lifetime Health Advisory Level (HAL). The USEPA MCLs (U.S. Environmental Protection Agency, 2002a) are legally enforceable standards that apply to public water systems, which provide water for human consumption through at least 15 service connections, or regularly serve at least 25 individuals. The purpose of MCLs is to protect public health by limiting the levels of contaminants in drinking

\footnotetext{
${ }^{2}$ Modifications to U.S. Environmental Protection Agency method 900.0 included sample preparation and counting within 72 hours of sample collection and recounting after 30 days. In addition, gross-alpha activities were based on a thorium-230 curve and gross-beta activities were based on a cesium-137 curve (Ann Mullin, U.S. Geological Survey, written commun., 2004)
} 
water. MCLs do not apply to ground water used for livestock, irrigation, or self-supplied domestic use. They are, however, a valuable reference when assessing the suitability of water for these uses. USEPA SMCLs (U.S. Environmental Protection Agency, 2002a) are non-enforceable guidelines regulating contaminants that may cause cosmetic effects (such as skin or tooth discoloration) or aesthetic effects (such as taste, odor, or color) in drinking water. HALs are based on the concentration of a chemical in drinking water that is expected to cause any adverse noncarcinogenic effects resulting from a lifetime of exposure (U.S. Environmental Protection Agency, 2002a).

Quality standards for Wyoming class II and class III ground water (Wyoming Department of Environmental Quality, 1993) also are used for comparisons in this report. Class II ground water is water that is suitable for agricultural (irrigation) use where soil conditions and other factors are adequate. Class III ground water is water that is suitable for livestock. These Wyoming standards are designed to protect ground water that meets the criteria of a given class from being degraded by anthropogenic activity. They are not meant to prevent ground water that does not meet the standards from being used for a particular use. Like the USEPA standards, they serve only as a reference in this report to help assess the suitability of ground water for various uses.

In this report, results from the 663 ground-water-quality samples used in this study are discussed in terms of the water's suitability for domestic, irrigation, and livestock use based on the USEPA and WDEQ standards. When discussing the suitability for domestic use, USEPA health-based MCL and HAL standards were used, even though they are not legally enforceable for any of the sampling sites used in this study. USEPA SMCL aesthetic standards for domestic use and WDEQ ground-water class II standards for agriculture and class III standards for livestock use only were used as a guide. The 663 samples used in this study were not analyzed for every constituent for which a standard exists. When water from a sampling site is reported as suitable for a given use, it is based only on the constituents that were analyzed. It is possible that the concentration of some other constituent not analyzed could make the water unsuitable for the given use.

Ground-water quality in Carbon County is highly variable, even within a single hydrogeologic unit. Water quality in any given hydrogeologic unit tends to be better near outcrop areas where recharge occurs and deteriorates as the distance from these areas increases (and residence time increases). The water quality of a given hydrogeologic unit also usually deteriorates with depth.

Many of the water-quality samples collected from Quaternary and Tertiary hydrogeologic units used in this study came from wells and springs that were being used to supply water for livestock and wildlife. Wells that do not produce usable water are usually abandoned, and springs that do not produce usable water typically are not developed. In addition, where hydrogeologic units are deeply buried, they usually are not used for a water supply when a shallower supply is available. For these reasons the ground-water-quality samples from the Quaternary, Tertiary, and some Cretaceous hydrogeologic units used in this study are most likely biased toward better water quality, and do not represent a random sampling of the units. Although the possible bias of these data likely does not allow for a complete characterization of the water quality of these hydrogeologic units as a whole, it probably allows for a more accurate characterization of the units in areas where they are shallow enough to be economically used.

Many of the ground-water quality samples used in this study to characterize Mesozoic and Paleozoic hydrogeologic units were co-produced oil and gas water samples from the USGS PWD and WOGCC databases. Although these samples were collected only where oil and gas production has occurred, they probably have less bias in representing ambient ground-water quality than samples used to characterize Quaternary and Tertiary hydrogeologic units.

Ground-water quality from various hydrogeologic units that occur within the county is discussed in the sections that follow. For the most part, comparisons are not made between the ground-water quality within the different structural features in the county such as the Hanna, Shirley, Great Divide, and Washakie Basins or the Rawlins Uplift. In general, not enough ground-water-quality data were available to make accurate comparisons between the structural features given the large variation in water quality within the features. Given the proximity of the structural features to each other, it is likely that the differences in ground-water quality due to the distance from recharge areas or depth are more important factors than the structural features themselves.

TDS concentrations in ground water within the county tend to be marginally high to high in comparison with the USEPA SMCL in most areas, even in shallow wells. This is not surprising given the arid climate and limited recharge that occurs within the county. Even though there is no USEPA MCL for TDS, this constituent can adversely affect the taste and odor of drinking water (U.S. Environmental Protection Agency, 2003), and high TDS concentrations in irrigation water have a negative effect on crop production. High TDS concentrations also can cause scale build up in pipes and boilers. The USEPA SMCL for TDS is $500 \mathrm{mg} / \mathrm{L}$ (U.S. Environmental Protection Agency, 2002a). The TDS concentration commonly is called salinity. TDS concentrations in groundwater samples in this report are classified according to the USGS salinity classification (Heath, 1983) as follows: fresh, 0-1,000 mg/L; slightly saline, 1,000-3,000 mg/L; moderately saline, 3,000-10,000 mg/L; very saline, 10,000-35,000 mg/L; and briny, more than $35,000 \mathrm{mg} / \mathrm{L}$.

The sodium-adsorption ratio (SAR) is used to predict the degree to which irrigation water enters into cation-exchange reactions in the soil. High SARs are typical of water produced from some hydrogeologic units within the county, making the water unsuitable for irrigation. High SAR values can result in sodium replacing adsorbed calcium and magnesium in soil, causing damaged soil structure and reduced permeability of the soil to water infiltration (Hem, 1985). However, the SAR should be used in conjunction with information about the 
soil characteristics and irrigation practices in the area being examined.

Many ground-water quality samples reviewed for this study also contained relatively high concentrations of sulfate, chloride, fluoride, boron, iron, and manganese, when compared to USEPA and WDEQ water-quality standards. As expected, co-produced oil and gas water commonly exceeded many USEPA and WDEQ standards. Sulfate can adversely affect the taste and odor of drinking water, and the ingestion of water containing high concentrations of sulfate may cause diarrhea (U.S. Environmental Protection Agency, 2003). The USEPA SMCL for sulfate is $250 \mathrm{mg} / \mathrm{L}$ (U.S. Environmental Protection Agency, 2002a). Large chloride concentrations can adversely affect the taste of drinking water, increase the corrosiveness of water, and damage salt-sensitive crops. The USEPA SMCL for chloride is $250 \mathrm{mg} / \mathrm{L}$ (U.S. Environmental Protection Agency, 2002a), the WDEQ agricultural standard is $100 \mathrm{mg} / \mathrm{L}$, and the WDEQ livestock standard is 2,000 mg/L. Many, but not all of the exceedances, were in co-produced oil and gas water samples. High chloride concentrations commonly are associated with co-produced water from deep hydrogeologic units in sedimentary structural basins. Small concentrations of fluoride in diets have been shown to promote dental health, but higher doses can cause health problems including dental fluorosis, a discoloring and pitting of the teeth (U.S. Environmental Protection Agency, 2003). A diet high in fluoride also can lead to bone disease (U.S. Environmental Protection Agency, 2003). The USEPA SMCL for fluoride is $2.0 \mathrm{mg} / \mathrm{L}$, and the MCL is $4.0 \mathrm{mg} / \mathrm{L}$. The human health effects of boron are not fully understood. Mastromatteo and Sullivan (2003) report that some dietary studies indicate that boron in small doses may be essential for humans. They also reported that several toxicity studies on animals have shown that higher doses of boron cause testicular cell damage and atrophy in male test animals. The USEPA has proposed an HAL of 600 micrograms per liter ( $\mu \mathrm{g} / \mathrm{L})$ for boron (U.S. Environmental Protection Agency, 2002a). According to Hem (1985, p. 129), small amounts of boron are essential to plant growth, but greater concentrations in soil and irrigation water are harmful. For some plants, the toxic concentration is as low as $1 \mathrm{mg} / \mathrm{L}$. Both iron and manganese can adversely affect the taste and odor of drinking water and cause staining. The USEPA has established SMCLs for iron $(300 \mu \mathrm{g} / \mathrm{L})$ and manganese $(50 \mu \mathrm{g} / \mathrm{L})$ (U.S. Environmental Protection Agency, 2002a). High concentrations of iron and manganese in irrigation water also can have a detrimental effect on crop production.

\section{Ground-Water Resources}

In this section of the report, the geologic, hydrogeologic, and water-quality characteristics of each hydrogeologic unit in Carbon County are described. Water-quality characteristics are described in the text, figures, and appendixes. Analytical results for the 45 new ground-water-quality samples collected for this study are presented in appendix 6 . The reader can examine broad comparisons of selected water-quality constituents among all hydrogeologic units, and groups of hydrogeologic units, in boxplots and plotting of individual values presented in appendixes 7-1 to 7-4; however, the reader should note that selected constituents are only plotted for samples from hydrogeologic units with three or more values. In some cases where less than three values were available for a given hydrogeologic unit-constituent combination, the values were grouped with other hydrogeologic units for plotting purposes.

\section{Quaternary Hydrogeologic Units}

Quaternary unconsolidated deposits that contain hydrogeologic units in the county include alluvium and colluvium sediment, landslide deposits, dune sand (eolian), lacustrine sediments, glacial deposits, and terrace gravels (Welder and McGreevy, 1966, sheet 3; Lowry and others, 1973, sheet 3; Love and Christiansen, 1985). Quaternary unconsolidated deposits in Carbon County generally are less than $70 \mathrm{ft}$ thick and occur only in about 16 percent of the land area of the county (fig. 18). In the rest of the county, bedrock is exposed at the surface (for example, mountain uplifts and basin margins) or is buried by a thin veneer of soil (for example, central basin areas). Locations of samples collected from aquifers in Quaternary hydrogeologic units are shown on figure 18.

\section{Alluvium and colluvium}

Alluvium and colluvium can be found in major drainages of the county, such as the North Platte River, Little Snake River, Medicine Bow River, and Rock Creek. This sediment also is found in minor drainages, such as Brush Creek, Sage Creek, Muddy Creek, Savery Creek, and many others (fig. 18) (Love and Christiansen, 1985). These surficial deposits consist of silt, sand, and gravel, with coarser materials and cobbles occurring near the mountains (Berry, 1960; Harshman, 1972; Lowry and others, 1973). Lowry and others (1973, sheet 3) indicated that alluvium and colluvium generally are 10 to $20 \mathrm{ft}$ thick in the Hanna and Shirley Basins and surrounding areas, with a maximum reported thickness of $100 \mathrm{ft}$ along Rock Creek. Welder and McGreevy (1966, sheet 3) indicated that alluvium and colluvium range in thickness from 0 to $50 \mathrm{ft}$ in the Great Divide and Washakie Basins. Alluvium and colluvium may be a source of sand and gravel for construction materials (Harris and Meyer, 1986; Harris, 1996).

Alluvium in Carbon County can contain alluvial aquifers where saturated. In Carbon County, alluvial aquifers are local, unconfined aquifers that have a small areal extent along 
streams. Alluvial aquifers generally are in hydraulic connection with streams. Huntoon and others (1993) indicated that alluvium along the Little Snake River is in direct connection with the stream. Many wells are installed in the alluvium of the Little Snake River Valley and Richter (1981, p. 48) reported that yields for wells completed in alluvial aquifers commonly range from 25 to 50 gallons per minute (gal/min). Well yields are directly related to the size and sorting of materials comprising the deposits, as well as the saturated thickness of the deposits. Recharge to alluvial aquifers is from direct precipitation on the deposits and streamflow. Ground-water flow in most alluvial aquifers is towards streams or in the direction of streamflow.

Spring-discharge and well-yield measurements from the USGS NWIS database were reviewed for this study. Eleven measurements of well yields for pumped wells ranged from 1 to $800 \mathrm{gal} / \mathrm{min}$ with a median yield of $5 \mathrm{gal} / \mathrm{min}$. Three measured discharges for springs ranged from 1 to $30 \mathrm{gal} / \mathrm{min}$, with a median discharge of $15 \mathrm{gal} / \mathrm{min}$.

The chemical composition of ground water in alluvial aquifers in Carbon County was characterized and the quality evaluated on the basis of new and historical samples collected from wells and springs. TDS concentrations for all samples were fresh except for one well completed in the alluvial aquifers, which was classified as moderately saline (fig. 19A). Calcium was the predominant cation in most samples, and bicarbonate was the predominant anion in most samples. The water that was classified as moderately saline was a sodiumsulfate type. Hardness ranged from soft to very hard, although most water was classified as very hard.

Concentrations of some characteristics and constituents in alluvial aquifers approached or exceeded applicable USEPA or State of Wyoming water-quality standards and could limit the suitability of waters for some intended uses. Compared to health-based standards, all waters were suitable for domestic use with the exception of concentrations of one constituent in five samples: radon (proposed 300-picocuries per liter (pCi/L) MCL exceeded in 5 of 6 samples) (appendixes 7-1 to 7-4). Some aesthetic standards for domestic use were exceeded by concentrations of some characteristics and constituents, including TDS (SMCL exceeded in 13 of 25 samples), sulfate (SMCL exceeded in 5 of 25 samples), and iron and manganese (SMCLs exceeded in 1 of 3 samples).

In relation to suitability for agricultural and livestock use, values of three measured characteristics and constituents exceeded State of Wyoming agricultural and livestockuse standards (appendixes 7-1 to 7-4). Many characteristics and constituents were measured at concentrations greater than agricultural-use standards and included TDS (standard exceeded in 4 of 25 samples); SAR (standard exceeded in 1 of 17 samples); sulfate (standard exceeded in 10 of 25 samples); chloride (standard exceeded in 1 of 24 samples); iron and manganese (standards exceeded in 1 of 3 samples). Water from some of the alluvial aquifers was unsuitable for livestock use and one characteristic and one constituent were measured at concentrations greater than livestock standards: TDS and sulfate (standards exceeded in 3 of 25 samples).

\section{Landslide deposits}

Landslide deposits throughout the county have been mapped (Case and others, 1998). Because of mapped scale and limited areal extent, the deposits can not be seen in figure 18. Composition, size, and distribution of the material present depends on the source formation. Berry (1960) indicated a thickness range of 0 to $200 \mathrm{ft}$ in the Rawlins area. He also indicated that while the deposits do not yield water to wells, small springs commonly occur at the base of the deposits.

No wells are known to be completed in landslide deposits in Carbon County. One spring was inventoried in the USGS NWIS database and the measured discharge was $5 \mathrm{gal} / \mathrm{min}$.

The chemical composition of ground water in landslide deposits in Carbon County was characterized and the quality evaluated on the basis of only one water sample from a spring. Based on the TDS concentration, the water was classified as fresh (fig. 19B). The sample was a calcium-bicarbonate type water (fig. 19B). Hardness was very hard. Based on the few analyses available for this spring, the water generally was suitable for domestic, agricultural, and livestock use.

\section{Dune sand (eolian) deposits}

Eolian sand and loess deposits (dune sand) are found in northwestern and southern parts of the county (Love and Christiansen, 1985) (fig. 18). The largest area of dunes consists of the Ferris and Seminoe dune fields in the northwestern part of the county near Lamont and Ferris (fig. 2). The Sand Hills occur north of Baggs in the southwestern part of the county. Dune composition can range from clay to coarse sand, but is primarily well sorted fine-grained sand in the large dunes (Lowry and others, 1973; Gaylord, 1982, 1989). The primary source for the Ferris and Seminoe dunes is the Eocene-age Battle Spring Formation to the west, with a secondary source being the Killpecker dune field that is west of the Battle Spring Basin in Sweetwater County (Gaylord, 1982, 1989). The Cretaceous and Paleocene rocks exposed along the Lost Soldier divide also contributed a minor amount of material to the dunes (Gaylord, 1982). The dunes develop in regions characterized by cool annual temperatures, low precipitation, and persistent strong winds (Gaylord, 1989). These deposits range in thickness from 0 to about $140 \mathrm{ft}$ in the Ferris and Seminoe dune fields (Rioux and Staatz, 1974; Gaylord, 1989, p. 270). Dune sand deposits may be a source of sand for construction materials (Harris and Meyer, 1986; Harris, 1996).

Dune sand deposits are not widely used as a source of water in Carbon County and few wells are completed in the deposits. Spring-discharge and well-yield measurements from the USGS NWIS database were reviewed for this study. Two measurements of well yields for pumped wells were 2 and 3 $\mathrm{gal} / \mathrm{min}$. Two measured discharges for springs were 1 and 20 $\mathrm{gal} / \mathrm{min}$. Richter (1981) reported well and spring yields ranging from 1 to $20 \mathrm{gal} / \mathrm{min}$ for dune sand deposits south of the 
Ferris Mountains (assumed to be Ferris and Seminoe Dune Fields) and Green Mountains.

The chemical composition of ground water in dune sand deposits in Carbon County was characterized and the quality evaluated on the basis of historical samples collected from two wells and three springs. TDS concentrations indicated that water was either fresh or slightly saline (fig. 19C). The samples that were classified as fresh were mixed cation-bicarbonate water types. The water classified as slightly saline was sodium-bicarbonate type. Hardness ranged from hard to very hard. Based on the few analyses available, most water generally was suitable for domestic, agricultural, and livestock use.

\section{Playa lake and other lacustrine deposits}

Playa lake and other lacustrine deposits in Carbon County are found mainly in the Great Divide and Washakie Basins, but a few deposits occur north and east of the Rawlins Uplift in the Lost Soldier-Separation Flats area (Gaylord, 1982; Case and others, 1998). Welder and McGreevy (1966, sheet 3) described the lacustrine deposits in the Great Divide Basin as being clay, silt, and sand that is less than about $25 \mathrm{ft}$ thick and unlikely to yield usable ground water in most areas. The deposits in the Separation Flats area (Ferris-Seminoe dune field) may be a source of sodium salt evaporites (Harris and others, 1985).

Because of limited areal extent and thickness, and lack of hydrogeologic and water-quality data, the playa lake and other lacustrine deposits in Carbon County were not assessed as a part of this study.

\section{Glacial deposits}

Glacial deposits (fig. 18) can be found in the Sierra Madre and Medicine Bow Mountains (fig. 2) (Love and Christiansen, 1985). Lowry and others (1973, sheet 3) described these materials as poorly sorted silt, sand, gravel, and boulders. These deposits may be a source of sand and gravel construction materials (Harris and Meyer, 1986; Harris, 1996).

Few wells are completed in glacial deposits in Carbon County. Spring-discharge and well-yield measurements from the USGS NWIS database were reviewed for this study, but no measurements were available for glacial deposits in Carbon County.

The chemical composition of ground water in glacial deposits in Carbon County was characterized and the quality evaluated on the basis of only one historical water sample. Based on the dissolved-solids concentration, the water was classified as fresh (fig. 19D). The sample was a calcium-bicarbonate type water (fig. 19D). Hardness was soft. Based on the few analyses available for this well, the water generally was suitable for domestic, agricultural, and livestock use.

\section{Terrace gravels}

Terrace deposits can be found along uplands bordering principal streams of the county (Love and Christiansen, 1985). Because of mapped scale and limited areal extent, the deposits can not be seen in figure 18. They are composed of sand, gravel, cobbles, and some boulders derived from older sedimentary and crystalline rocks (Dobbin, Bowen, and Hoots, 1929; Dobbin, Hoots, and others, 1929; Lowry and others, 1973). Lowry and others (1973, sheet 3 ) indicated that the deposits generally are less than $20 \mathrm{ft}$ thick in the Hanna and Shirley Basins and surrounding areas. They noted that thicknesses greater than $100 \mathrm{ft}$ are known. These deposits may be a source of sand and gravel construction materials (Harris and Meyer, 1986; Harris, 1996). Some of these deposits are saturated and can produce enough water locally for stock or domestic use.

Terrace gravel in Carbon County generally is unsaturated "except in areas of recharge from irrigation water" (Lowry and others, 1973, sheet 3). Because of limited areal extent and thickness, lack of saturation, and lack of hydrogeologic and water-quality data, terrace gravels in Carbon County could not be assessed as a part of this study.

\section{Quaternary-Tertiary conglomerate}

Quaternary-Tertiary conglomerate ("Giant conglomerate" on fig. 10) is located in two locations in the Medicine Bow Mountains of Carbon County. One is on Kennaday Peak and the other is in secs. 14 and 23, T. 17 N., R. 78 W. (fig. 18). Love and Christensen (1985) described the deposits as giant granite boulders in an arkose matrix. These deposits may be a source of gravel for construction materials (Harris and Meyer, 1986; Harris, 1996).

Because of limited areal extent and thickness, and lack of hydrogeologic and water-quality data, the Quaternary-Tertiary conglomerate in Carbon County was not assessed as a part of this study.

\section{Tertiary Hydrogeologic Units}

Tertiary hydrogeologic units (fig. 18) composed of sedimentary rock contain the most abundant and widely used shallow aquifers in Carbon County. They occur in almost 40 percent of the land area of the county. Water quality in these aquifers is highly variable, in part reflecting the complex geology of the Tertiary hydrogeologic units in the county.

Tertiary hydrogeologic units in the western part of Carbon County comprising the eastern boundary of the Great Divide and Washakie Basins are part of a large, regional, multiaquifer system known as the Upper Colorado Regional Aquifer System. Many of these formations receive recharge in Carbon County. Locations of samples from aquifers in Tertiary hydrogeologic units are shown on figure 18. 


A. Alluvium

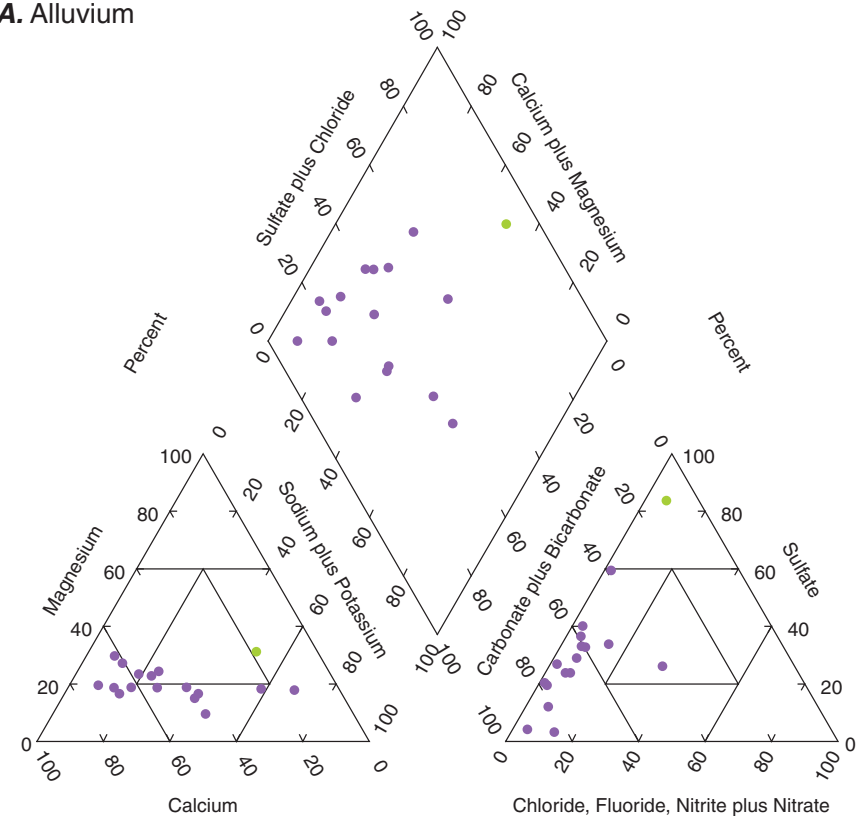

Percent

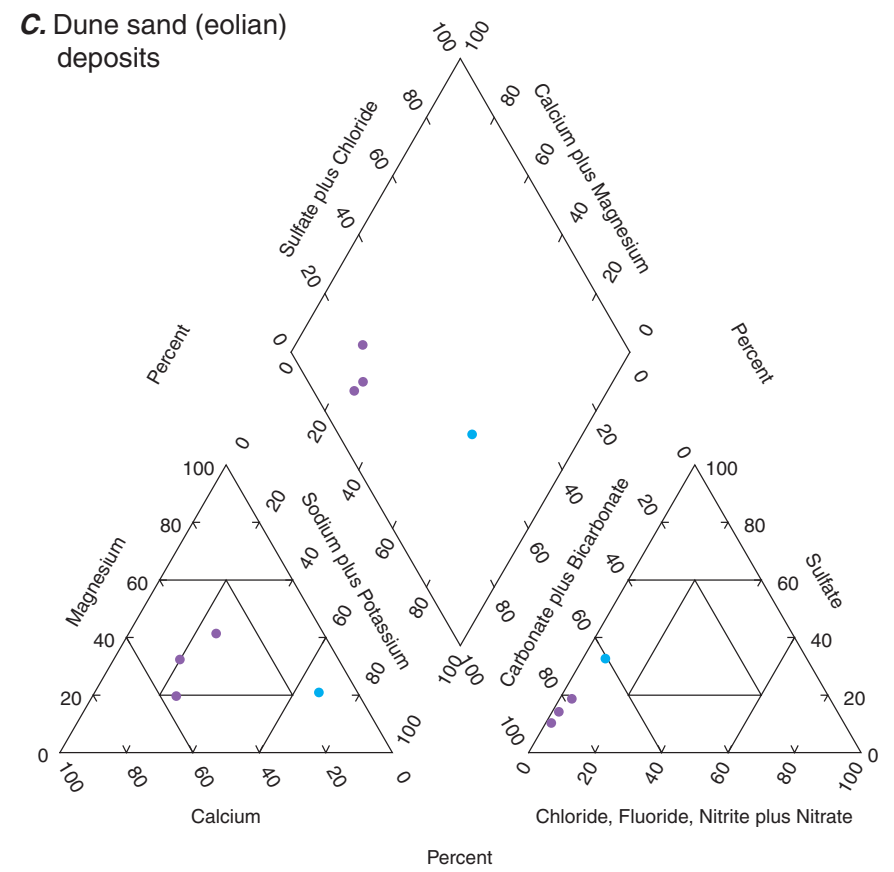

EXPLANATION

D. Glacial deposits

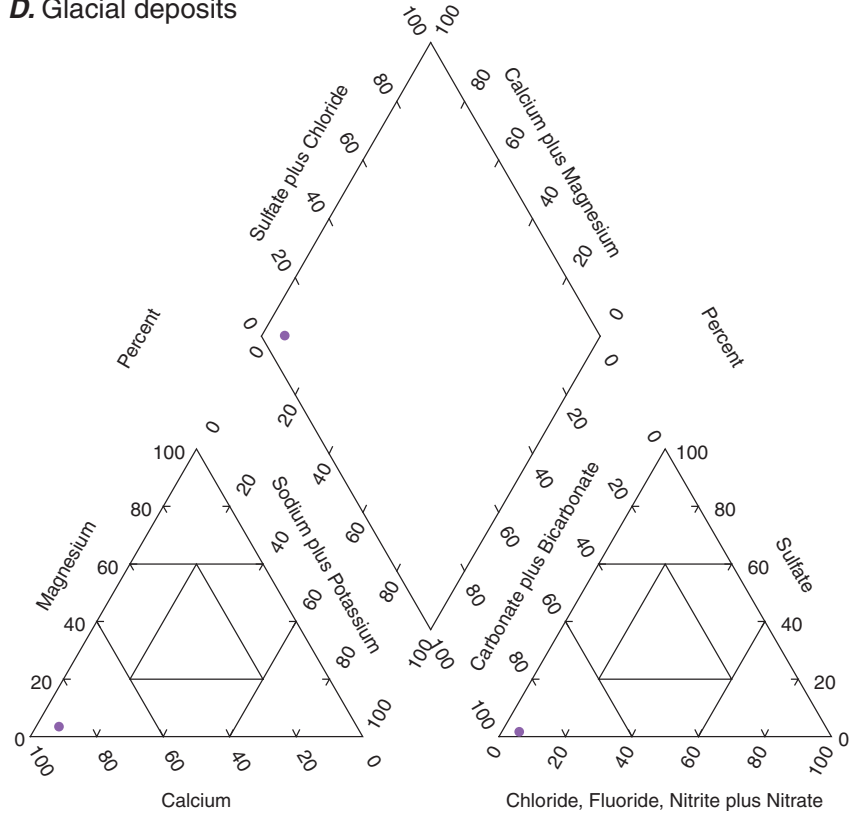

Percent

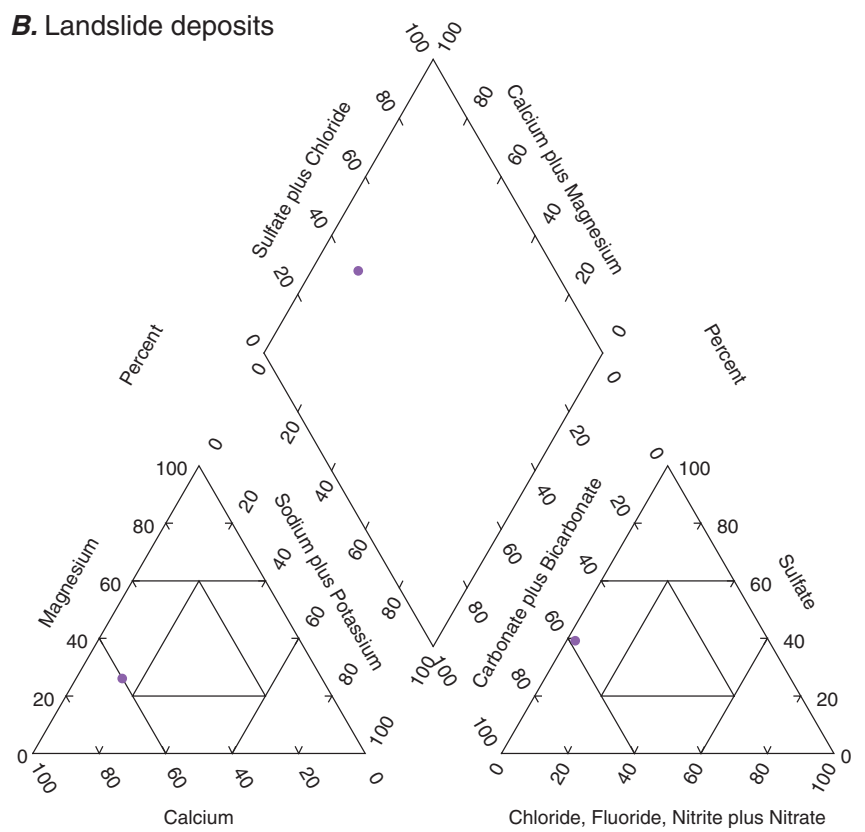

Percent

Total dissolved-solids concentration, in milligrams per liter, and U.S. Geological Survey salinity classification

- Less than 1,000; fresh

- 1,000-3,000; slightly saline

- 3,000-10,000; moderately saline

Figure 19. Trilinear diagrams showing major-ion composition and dissolved-solids concentrations for ground-water samples from aquifers in Quaternary hydrogeologic units, Carbon County, Wyoming. 


\section{Upper Tertiary hydrogeologic units}

Whitehead (1996, p. 111) reported that aquifers in upper Tertiary hydrogeologic units (Pliocene and Miocene age) are less extensive than aquifers in lower Tertiary hydrogeologic units (Oligocene, Eocene, and Paleocene age), but commonly have greater permeability and are important sources of water. Undifferentiated rocks and the Browns Park Formation (fig. 18) of Miocene age occur in about 20 percent of the count. Bradley (1964, p. A56) reported that because younger Tertiary rocks in southwestern Wyoming are: (1) prevailingly white or very light colored; (2) generally tuffaceous and sandy; and (3) lacking in diagnostic fossils, a variety of opinions about their identity, geologic age, and correlations exists.

\section{Undifferentiated Miocene rocks}

Different names have been applied to the upper Tertiary rocks (fig. 18) of northern Carbon County, leading to confusion in the nomenclature of the area (fig. 8) (Snoke, 1993, p. 35-36). Love and Christiansen (1985) showed undifferentiated Miocene rocks in the northern part of the county (fig. 18). McGrew (1951, p. 56) suggested that the deposits that covered much of Carbon County comprise the Browns Park Formation. He suggested that lithologic differences between the Sweetwater Arch/Granite Mountains area and southern Carbon County are attributable to different local sediment sources. Pipiringos (1955, 1961) referred to rocks of McGrew's (1951) depositional sheet that have remnants left in the north-central part of the Great Divide Basin as Browns Park Formation.

In the Granite Mountains, Love (1961) named the undifferentiated Miocene rocks the Moonstone (Pliocene-age) and the Split Rock (Miocene-age) Formations. The name Split Rock was discontinued by Denson (1965). Denson (1965) used the name Ogallala Formation (Pliocene and late Mioceneage) to replace the Moonstone Formation and the upper part of the Split Rock Formation. He also used the Arikaree (middle and early Miocene-age) and the upper part of the White River (late Oligocene-age) Formations to replace the lower part of the Split Rock Formation. The Split Rock Formation of Love (1961) was mapped as Ogallala Formation by Denson and Harshman (1969) and by Lowry and others (1973). Whitcomb and Lowry (1968) mapped the unit as Moonstone and Arikaree Formations. Jason Lillegraven (University of Wyoming, written commun., 2004) noted that the use of Ogallala and Arikaree is unjustified because of the "hundreds of miles of no exposures and involving very different kinds of lithologic characteristics" between central Wyoming and the Nebraska type localities for those names. Love and others (1993) have assigned the age of the Arikaree Formation to early Miocene and late Oligocene and the age of the Ogallala Formation to late Miocene. Because of the disagreement in the naming conventions in the area, this report refers to rocks of the Granite Mountains area as undifferentiated Miocene rocks.

In the Granite Mountains area, the undifferentiated Miocene rocks (Split Rock Formation of Love (1961, 1970); Ogallala Formation of Denson (1965)) are gray to white sandstone, siltstones, and tuff that contain white pumicite beds and white pumiceous limestone ledges (Denson, 1965). These rocks grade mountainward into sandstones, conglomerates, and gravels. The coarser facies includes a conglomerate containing chalcedony pebbles (Love, 1961). The rocks contain a large percentage of volcanic ash. The formation probably was deposited by a combination of fluvial, lacustrine, and eolian processes. This unit is a potential source of agate and abrasive pumice (Harris and others, 1985; Harris and Meyer, 1986; Harris, 1996).

The undifferentiated Miocene rocks in the Shirley Basin area consist of tuffaceous siltstone, sandstone, conglomerate, and limestone (Arikaree Formation of Denson (1965); Harshman, 1968, 1972; Denson and Harshman, 1969). The deposits were formed by a combination of fluvial, lacustrine, and eolian processes. Most of the deposits were removed by erosion during the Quaternary period, but Denson (1965) estimated that lower and middle Miocene rocks in Central Wyoming were approximately 1,000 ft thick. Harshman (1972) mapped a total thickness of as much as $180 \mathrm{ft}$ in the Shirley Basin.

The upper Tertiary rocks (fig. 18) of the Rawlins Uplift have not been mapped with a formal name. Berry (1960) noted that at one time the Browns Park Formation covered the Rawlins area, but he did not correlate the Browns Park Formation that is south of Rawlins to the Miocene and Pliocene rocks on the eastern part of the Rawlins Uplift. Berry (1960) and Welder and McGreevy (1966) considered upper Tertiary rocks of the Rawlins Uplift to be of Pliocene and Miocene age. Love and Christiansen (1985) defined the rocks as Miocene age, because of a change in the Miocene age definition. Love and others (1993) defined the rocks as the Split Rock Formation of Miocene age. Jason Lillegraven (University of Wyoming, written commun., 2004) suggested that because of lithologic continuity, the name Browns Park Formation should be applied to these exposures. Because the name Split Rock Formation has been abandoned, this report refers to these units as undifferentiated Miocene rocks.

According to Berry (1960), the Miocene rocks of the Rawlins Uplift consist of gray to brown sandstone with lenses and beds of conglomerates. The sandstone can be tuffaceous, calcareous (ranging from calcareous sandstone to sandy limestone), and cross-bedded. The conglomerates have chert and quartz pebbles, with sporadic Precambrian cobbles. The basal conglomerate has Precambrian, Paleozoic, and Mesozoic-derived pebbles, cobbles, and boulders in a matrix of fine-to coarse-grained yellow-brown sandstone that is calcareous to partly tuffaceous. Berry (1960) also noted thin beds of tuffaceous light-gray limestone that had grains of chert, quartz, and feldspar, as well as some pebbles derived from Precambrian rocks. He noted a maximum thickness of approximately $624 \mathrm{ft}$.

Berry (1960, p. 25) reported that undifferentiated Miocene rocks in the Rawlins Uplift area "yield adequate water for domestic and stock use." He also reported that the rocks were "sufficiently permeable to allow free movement of water, and, because the water table generally lies at a relatively shallow 
depth, moderate to large amounts of water can be obtained from the thick saturated sections of the formation" (Berry, 1960, p. 25-26).

The Wyoming Department of Economic Planning and Development (1982) reported the results of an aquifer test conducted in undifferentiated Miocene rocks (referred to as the Split Rock aquifer in the report, composed of the White River, Split Rock, and Ogallala Formations) north of the Ferris Mountains (T. 28 N., R. 86 W., sec. 16). The test was conducted using one production well and three observation wells. Transmissivity at the three observation wells was estimated to be $12,285,6,716$, and 13,800 feet squared per day $\left(\mathrm{ft}^{2} / \mathrm{d}\right)$ with associated storage coefficients of $1.6 \times 10^{-3}, 4.4 \times 10^{-3}$, and $1.6 \times 10^{-2}$, respectively. In addition, transmissivity was estimated to be $10,720 \mathrm{ft}^{2} / \mathrm{d}$ at the production well.

As part of a study of the Sweetwater River Basin, Borchert (1987) constructed a potentiometric map for aquifers in undifferentiated Miocene rocks north of the Ferris and Seminoe Mountains and west of Pathfinder Reservoir. The potentiometric map (Borchert, 1987), reproduced in figure 20, shows that ground water in aquifers in the undifferentiated Miocene rocks generally flows to the north and northeast, away from the Ferris and Seminoe Mountains.

Spring-discharge and well-yield measurements from the USGS NWIS database were reviewed for this study. Five measurements of well yields for pumped wells ranged from 4 to $15 \mathrm{gal} / \mathrm{min}$ with a median yield of $6 \mathrm{gal} / \mathrm{min}$. There were no measured discharges for springs from undifferentiated Miocene rocks.

The chemical composition of ground water in aquifers in the undifferentiated Miocene rocks in Carbon County was characterized and the quality evaluated on the basis of new and historical samples collected from wells and springs. TDS concentrations indicated that all but one water sample was fresh; the remaining sample was moderately saline (fig. 21A). Ionic compositions indicated that all but one sample were calcium-bicarbonate types (fig. 21A). The remaining sample, classified as moderately saline, was a calcium-sodium-sulfate water type. Hardness varied considerably and ranged from soft to very hard.

Concentrations of some characteristics and constituents in samples from aquifers in the undifferentiated Miocene rocks approached or exceeded applicable USEPA or State of Wyoming water-quality standards and could limit the suitability of water for some intended uses. Most water was suitable for domestic use, but concentrations of two constituents exceeded health-based standards (appendixes 7-1 to 7-4): radon (proposed 300-pCi/L MCL exceeded in both samples) and uranium (MCL exceeded in 1 of 2 samples). Some aesthetic standards for domestic use were exceeded by concentrations of some characteristics and constituents, including TDS (SMCL exceeded in 5 of 13 samples); sulfate (SMCL exceeded in 3 of 13 samples); and chloride (SMCL exceeded in 1 of 13 samples).

In relation to suitability for agricultural and livestock use, concentrations of three constituents exceeded State of
Wyoming agricultural-use standards and two exceeded State of Wyoming livestock standards (appendixes 7-1 to 7-4). Characteristics and constituents measured at concentrations greater than agricultural-use standards included TDS (standard exceeded in 1 of 13 samples); sulfate (standard exceeded in 3 of 13 samples); and chloride (standard exceeded in 1 of 13 samples). In general, almost all water from aquifers in the undifferentiated Miocene rocks was suitable for livestock use because only one characteristic and one constituent were infrequently measured at concentrations greater than livestock standards: TDS and chloride (standards exceeded in 1 of 13 samples).

\section{Browns Park Formation}

The Browns Park Formation occurs in the southern part of the county (fig. 18) (Love and others, 1993) and contains both fluvial and eolian deposits. Love and others (1985) showed the Miocene-age Browns Park Formation as well as the late Miocene-age North Park Formation. Vine and Prichard (1959) used the name "North Park (?) Formation" to describe the Miocene rocks of the Miller Hill area. No fossils were found to date the formation, and they felt it could be either the Browns Park Formation or the North Park Formation. Montagne (1991) combined the units as the Browns Park Formation because of the difficulty in establishing a mappable boundary between the two units. The hydrogeologic unit described herein includes the Browns Park Formation as well as the North Park Formation.

The Browns Park Formation of southern Carbon County, which includes the Browns Park aquifer, has varicolored (gray, green, tan, or white) calcareous to siliceous to tuffaceous siltstones and sandstones that contain white pumicite beds, white chalcedonic and algal lacustral limestone ledges, and shaly lacustrine rocks (Powell, 1876; Hansen, 1984; Honey and Izett, 1989; Montagne, 1991). Along the uplifts, there is usually a conglomerate layer (sometimes referred to as the "basal conglomerate") primarily derived from Precambrian rocks in a cross-bedded calcareous sandy matrix (Powell, 1876; Hansen, 1984; Honey and Izett, 1989; Montagne, 1991). The formation probably was deposited by a combination of fluvial, lacustrine, and eolian processes. The Browns Park Formation is as much as 2,500 ft thick in the Saratoga Valley (Montagne, 1991). This formation is a potential source for brick clay (there is an inactive quarry near Riverside) and zeolites (Harris and others, 1985; Harris and Meyer, 1986; Harris, 1996). This formation is a source for uranium, with the major areas occurring at the Poison Basin Uranium District west of Baggs and the Ketchum Buttes Uranium District northeast of Baggs (Vine and Prichard, 1954, 1959; Harris and others, 1985; Harris, 1996).

The Browns Park aquifer is developed as a water supply for domestic, stock, and agricultural use. Sandstone and conglomerate units primarily yield water to wells completed in the aquifer. Most investigators consider the formation to contain one of the most important aquifers in Carbon County. The Browns Park aquifer in the county has been defined as a 

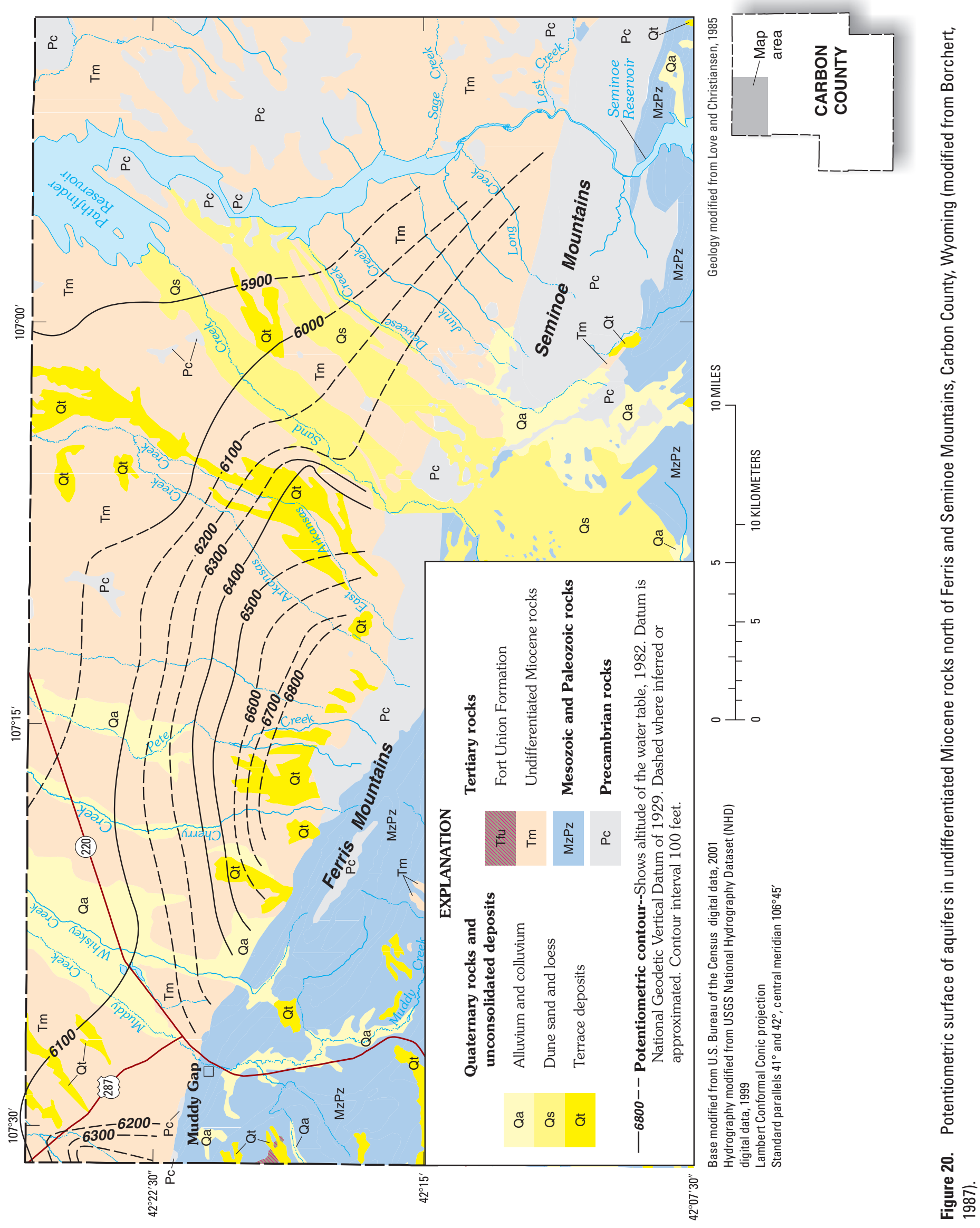

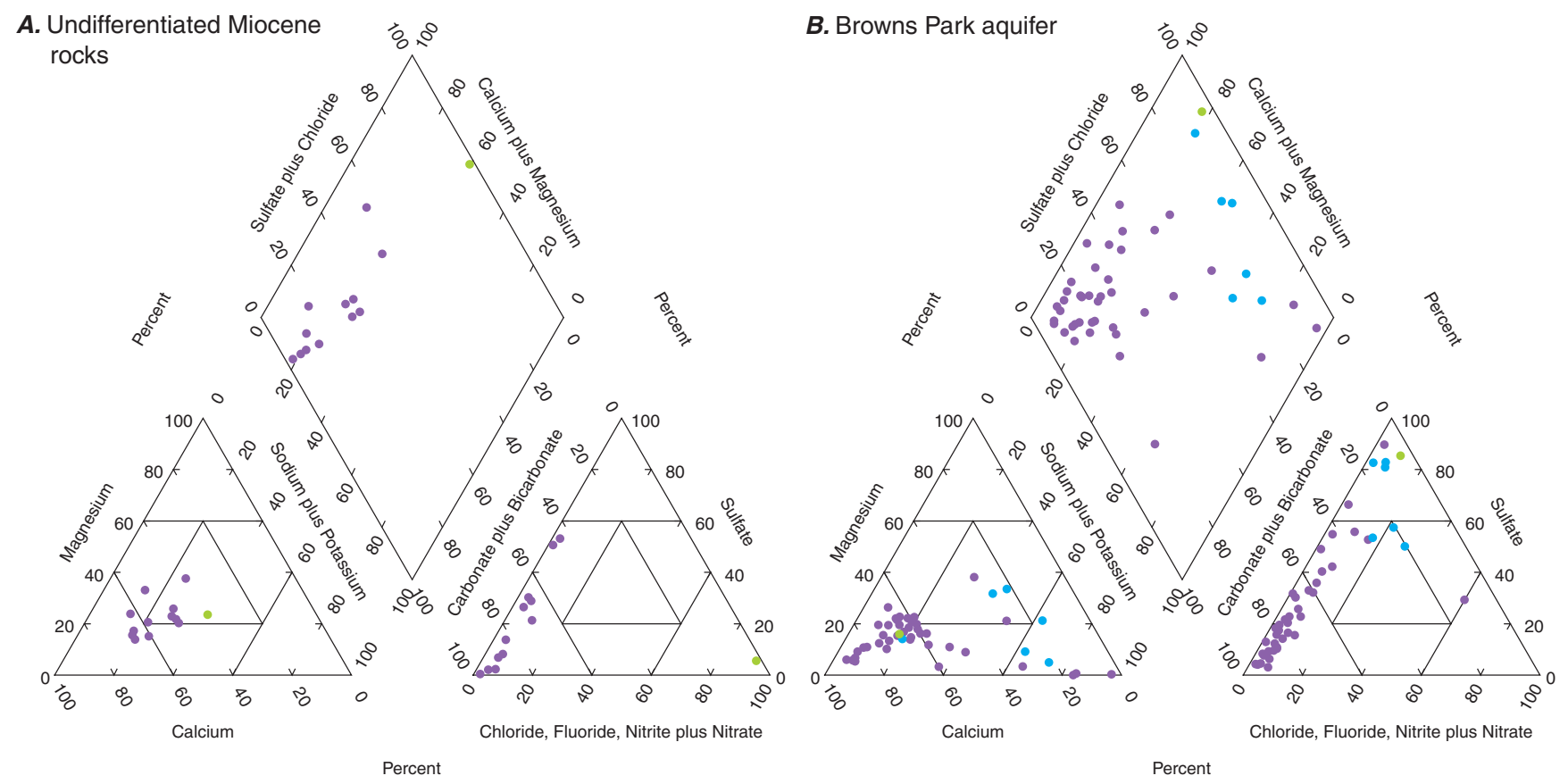

EXPLANATION

Total dissolved-solids concentration, in milligrams per liter, and U.S. Geological Survey salinity classification

- Less than 1,000; fresh

- 1,000-3,000; slightly saline

- 3,000-10,000; moderately saline

Figure 21. Trilinear diagrams showing major-ion composition and dissolved-solids concentrations for ground-water samples from aquifers in upper Tertiary hydrogeologic units, Carbon County, Wyoming.

"major aquifer" (Kuhn and others, 1983) or "principal aquifer" (Richter, 1981). In the general vicinity of the Laramie, Shirley, and Hanna Basins (including Carbon County), Richter (1981) grouped the Browns Park Formation with other Tertiary-age formations into a single hydrogeologic unit defined as the "Tertiary aquifer." The USGS also defined the aquifer as a "principal aquifer" (Whitehead, 1996) and referred to the aquifer as part of the "Wyoming Tertiary aquifers" category on the national Principal Aquifers map (U.S. Geological Survey, 2003).

Variable spring discharges, well yields, and specific capacity have been reported or measured for the Browns Park aquifer. Visher (1952) reported discharges of 100, 500, and $1,300 \mathrm{gal} / \mathrm{min}$ for three springs discharging in the Pass Creek Flats area (figs. 2 and 18); the high spring discharges were attributed to faults. Richter (1981) referred to the spring discharging 1,300 gal/min as the "Lake Creek Spring" and noted that the spring has been developed by the Wyoming Game and Fish Department to supply water to the Saratoga Fish Hatchery. Lowry and others (1973, sheet 3) reported yields of 500 to $1,000 \mathrm{gal} / \mathrm{min}$ for wells completed in Tertiary hydrogeologic units in the Laramie, Shirley, and Hanna Basins, including the Browns Park Formation in Carbon County. In addition to interstitial permeability, Lowry and others (1973, sheet 3) noted that high yields reported for some wells and springs were likely attributable to development of secondary permeability. Richter (1981) reported well yields ranging from 1 to $300 \mathrm{gal} / \mathrm{min}$, and Collentine and others (1981) reported well yields ranging from 2.5 to $30 \mathrm{gal} / \mathrm{min}$. In the Saratoga Valley area (figs. 2, 18, and 22), wells yielding hundreds of gallons of water per minute are used for agriculture to supplement surface-water irrigation (Lenfest, 1986; Crist, 1990). Lowry and others (1973, sheet 3) attributed the high yields to the large saturated thickness of the formation in the area. Springdischarge and well-yield measurements from the USGS NWIS database were reviewed for this study. Fifty measurements of well yields for pumped wells ranged from 2 to $1,480 \mathrm{gal} / \mathrm{min}$ with a median yield of $25 \mathrm{gal} / \mathrm{min}$. The yield for one flowing well was $16 \mathrm{gal} / \mathrm{min}$. Fifteen measured discharges for springs ranged from 0 to $1,300 \mathrm{gal} / \mathrm{min}$ with a median discharge of $40 \mathrm{gal} / \mathrm{min}$. 
$107^{\circ} 00^{\prime}$

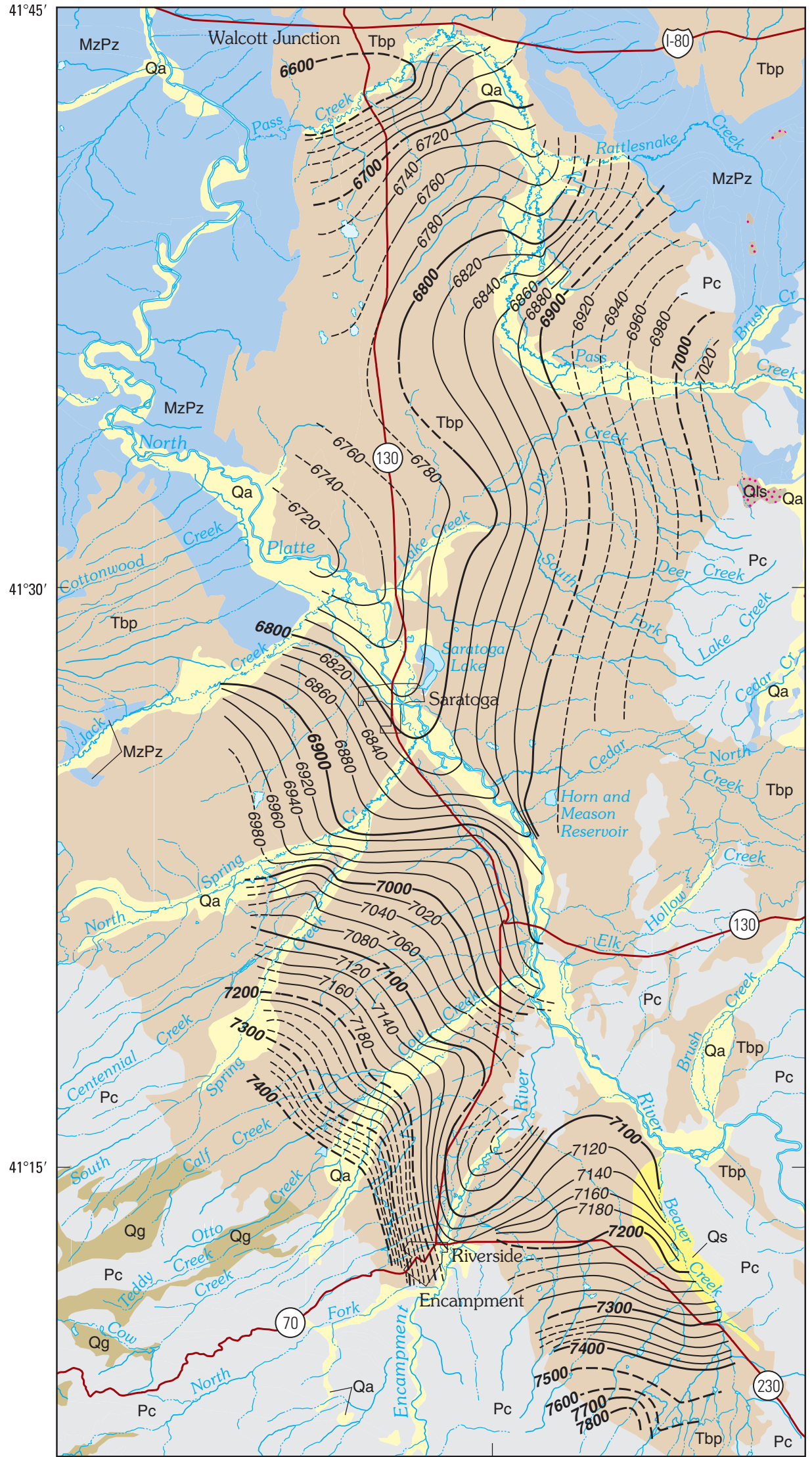

EXPLANATION

Quaternary

unconsolidated deposits

\begin{tabular}{cl} 
Qa & Alluvium and colluvium \\
Qg & Glacial deposits \\
\hdashline Qles & Landslide deposits \\
Qs & Dune sand and loess
\end{tabular}

\section{Tertiary rocks}

Top Browns Park Formation

$\mathrm{MzPz} \quad$ Mesozoic and Paleozoic rocks

$\mathrm{Pc} \quad$ Precambrian rocks

-7400-- Potentiometric contour--

Shows altitude of the waterlevel surface October-November 1980. Datum is National Geodetic Vertical Datum of 1929. Dashed where inferred or approximated. Contour interval 20 and 100 feet. 100-foot contours and values shown in bold
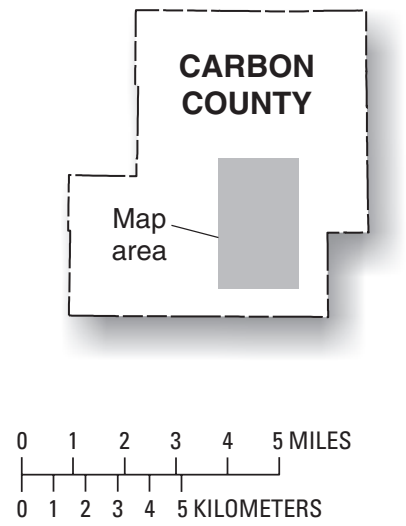

Base modified from U.S. Dept. of Commerce, Bureau of the Census digital data, 2001 Hydrography modified from USGS National Hydrography Dataset (NHD) digital data, 1999 Lambert Conformal Conic projection Standard parallels $41^{\circ}$ and $42^{\circ}$, central meridian $106^{\circ} 45^{\prime}$

Geology modified from Love and Christiansen, 1985

Figure 22. Potentiometric surface of the Browns Park aquifer (Formation) in the Saratoga Valley area, Carbon County, Wyoming (modified from Crist, 1990). 
In the vicinity of the Miller Hill and upper Sage Creek areas south of Rawlins (figs. 2 and 18), medium to large springs supplied much of the water supply for the city of Rawlins. Consequently, Berry (1960, p.24) reported that "the Browns Park Formation is one of the best aquifers in the Rawlins area." He noted that one spring flowed at a rate as high as $343 \mathrm{gal} / \mathrm{min}$. Berry (1960, p. 24) attributed all spring flows to the "basal conglomerate" of the formation and noted that the springs "maintain the base (low) flow of streams in the southern part of the area." Berry (1960, p. 24-25) speculated that the "basal conglomerate" of the Browns Park Formation in the area had much water production potential and noted that the upper part of the Browns Park Formation in the same area had the potential to "yield moderate to large supplies of water." Subsequent investigation of the "basal conglomerate" in the same area has noted little potential for development of the unit in the same Miller Hill/upper Sage Creek area. Exploratory drilling indicated that the basal conglomerate was a poorer aquifer than the overlying upper part of the Browns Park Formation in the area, as low fluid losses and lithologies encountered during drilling indicated low permeability and poor yield for development as a public water supply (James M. Montgomery, Consulting Engineers, 1983, p. 3-11). In addition, upon review of earlier work by Vine and Prichard (1959), the investigators believed the springs actually discharge from the upper part of the Browns Park Formation, not the basal conglomerate as reported by Berry (1960). These springs are still an important part of the water supply for Rawlins, but wells have been drilled into other formations in the Rawlins Uplift area to provide additional water for the city (James M. Montgomery, Consulting Engineers, 1983, 1986, and references therein).

Aquifer tests for wells completed in the Browns Park aquifer have been reported by several previous investigators. Lowry and others (1973, sheet 3 ) reported transmissivity of $5,000 \mathrm{ft}^{2} / \mathrm{d}$ from two aquifer tests and an estimate of $4,000 \mathrm{ft}^{2} / \mathrm{d}$ based on "surface-and ground-water relations in the reach of the Encampment River between Encampment and Baggot Rocks." Richter (1981) reported transmissivity from four aquifer tests in the Saratoga Valley area. Transmissivity estimated from one test was $2,278 \mathrm{ft}^{2} / \mathrm{d}$, whereas both transmissivity and storage coefficients were estimated for the other three tests-reported transmissivity values were $1,742,1,876$, and $1,206 \mathrm{ft}^{2} / \mathrm{d}$ with associated storage coefficients of $0.01,0.0015$, and 0.001 , respectively. Specific capacity from the four aquifer tests reported by Richter (1981) ranged from 7.2 to 11 gallons per minute per foot $(\mathrm{gal} / \mathrm{min} / \mathrm{ft})$ of drawdown. Transmissivity values for the Browns Park aquifer west of the Saratoga Valley (west of R. 86 W.) appear to be lower than transmissivity values in the Saratoga Valley area (Collentine and others, 1981). The investigators reported that transmissivity values ranged from about 13 to $201 \mathrm{ft}^{2} / \mathrm{d}$ for 12 aquifer tests in the area (Collentine and others, 1981, appendix C, p. C-3). Specific capacity values calculated from these tests were low and ranged from 0.03 to $6.25 \mathrm{gal} / \mathrm{min} / \mathrm{ft}$ of drawdown, although 10 of 12 tests had less than $1 \mathrm{gal} / \mathrm{min} / \mathrm{ft}$ of drawdown. Simons, Li, and Associates (1982) estimated transmissivity from aquifer tests conducted in wells in and near the town of Riverside, which is near Encampment (figs. 2 and 22). Transmissivity estimates for five wells ranged from 5 to $400 \mathrm{ft}^{2} / \mathrm{d}$, and associated storage coefficients ranged from 0.004 to 0.07. Howard, Needles, Tammen, and Bergendoff (1984) reported the results from one aquifer test in Encampment; transmissivity for this test was estimated to range from 56 to $100 \mathrm{ft}^{2} / \mathrm{d}$ with an associated storage coefficient of 0.0006. Both Simons, Li, and Associates (1982) and Howard, Needles, Tammen, and Bergendoff (1984) noted that the tests indicated that the aquifers were confined or semi-confined.

The direction of ground-water flow in the Browns Park Formation in the Saratoga Valley area is shown on potentiometric maps by Lenfest (1986, plate 2) and Crist (1990, plate 2). Simons, Li, and Associates (1982) constructed a potentiometric map for part of the area mapped by Lenfest (1986) and Crist (1990), including the area near Encampment and Riverside. The interpreted direction of ground-water flow is similar in all three maps. The potentiometric map from Crist (1990) is reproduced in figure 22. Ground-water flow is assumed to be perpendicular to the water-level contours and the direction of "movement generally is from the edges of the valley toward the North Platte River" (Crist, 1990, p. 9). All investigators noted that aquifers in Quaternary unconsolidated deposits along streams were in hydraulic connection with the Browns Park aquifer, so they mapped both units as a single aquifer in the Saratoga Valley area.

Vine and Prichard (1959) collected samples from 25 springs discharging from the Browns Park Formation (referred to as North Park Formation in the report) in the Miller Hill area. The investigators were evaluating the uranium potential of the formation in the area, so all samples were analyzed for uranium. Reported uranium concentrations for the 25 springs ranged from 2 to $14 \mu \mathrm{g} / \mathrm{L}$.

The chemical composition of ground water in the Browns Park aquifer in Carbon County was characterized and the quality evaluated on the basis of new and historical samples collected from wells and springs. TDS concentrations indicated that most water was fresh, although some water was slightly saline and one sample was moderately saline (fig. 21B). Ionic compositions indicated that although many different water types were represented, calcium and bicarbonate were the most common ions (fig. 21B). In general, calcium and bicarbonate were the predominant ions in fresh water, whereas sodium and sulfate were predominant in slightly saline and moderately saline water. TDS and concentrations of most ions (sodium, potassium, sulfate, chloride, and fluoride) significantly increased with increasing well depth (appendix 8). Hardness varied considerably and ranged from soft to very hard, although slightly more than one-half of samples were classified as very hard.

Concentrations of some characteristics and constituents in the Browns Park aquifer approached or exceeded applicable USEPA or State of Wyoming water-quality standards and could limit the suitability of water for some intended uses. 
Most water was suitable for domestic use but concentrations of four constituents exceeded health-based standards (appendixes 7-1 to 7-4): fluoride (MCL exceeded in 2 of 48 samples), arsenic (MCL exceeded in 2 of 7 samples), boron (proposed HAL exceeded in 1 of 42 samples), and radon (proposed 300-pCi/L MCL exceeded in all seven samples). Aesthetic standards for domestic use were exceeded by more characteristics and constituents and more frequently and included $\mathrm{pH}$ (less than the SMCL lower limit in 1 of 22 samples); TDS (SMCL exceeded in 25 of 64 samples); sulfate (SMCL exceeded in 17 of 65 samples); fluoride (SMCL exceeded in 4 of 48 samples); and manganese (SMCL exceeded in 4 of 17 samples).

In relation to suitability for agricultural and livestock use, concentrations of five characteristics and constituents exceeded State of Wyoming agricultural-use standards (appendixes 7-1 to 7-4) and included TDS (standard exceeded in 3 of 64 samples), SAR (standard exceeded in 2 of 50 samples), sulfate (standard exceeded in 20 of 65 samples), chloride (standard exceeded in 4 of 51 samples), and boron (standard exceeded in 1 of 42 samples). In general, almost all water from the Browns Park aquifer is suitable for livestock use because only two characteristics were infrequently measured at concentrations greater than livestock standards: $\mathrm{pH}$ (less than the lower limit standard in 1 of 22 samples) and TDS (standard exceeded in 1 of 64 samples).

\section{Basalt flows and intrusive igneous rocks}

There are only a few outcrops of basalt flows and intrusive igneous rocks in the county (Love and Christiansen, 1985). All of the outcrops are east of Savery Creek (fig. 18). Water-supply potential for these rocks is limited, so basalt flows and intrusive igneous rocks in Carbon County were not assessed as a part of this study.

\section{Lower Tertiary hydrogeologic units}

Lower Tertiary hydrogeologic units occur at the surface (fig. 18) in almost 20 percent of the county. Lower Tertiary hydrogeologic units include the Oligocene-age White River Formation; the Eocene-age Washakie, Wagon Bed, Green River, Battle Spring, and Wasatch Formations; the Eoceneand Paleocene-age Coalmont Formation; the Paleocene-age Fort Union and Hanna Formations; and the Paleocene- and late Cretaceous-age Ferris Formation.

The stratigraphy of lower Tertiary rocks in the southwestern part of the county is complicated where the rocks associated with Eocene Lake Gosiute (Green River and Wasatch Formations) are located. Lake-level oscillations through the early and middle Eocene Epoch led to a complicated intertonguing of lacustrine deposits with fluvial sediment. These oscillations also ultimately had an effect on the present day ground-water quality within the lacustrine deposits. During low lake levels, salts such as trona, nahcolite, shortite, dawsonite, and halite were deposited within the lacustrine sediment. The later dissolution of these salts into the ground water adversely affected its quality. During high lake stands, when a flow-through lake system existed, salts were not concentrated nor deposited in the lacustrine sediments.

\section{White River Formation}

The White River Formation, which contains the White River aquifer, occurs only in the northeastern part of Carbon County including the Shirley Basin (fig. 18) (Love and Christiansen, 1985). Harshman (1968, 1972) and Denson and Harshman (1969) showed the upper part of the formation to be interbedded light-tan to light-brown tuffaceous siltstone, sandstone, and conglomerate, and the lower part of the formation as light-pink to light-tan tuffaceous siltstone and claystone. Harshman $(1968,1972)$ noted that the basal layer in some areas is a red, brown, or green claystone and in other areas the layer is a tuff and sandstone. The upper part is of fluvial origin and the lower part is of fluvial and lacustrine origin. The upper and lower parts are separated by a short interval of non-deposition (Harshman, 1968, 1972). The formation is as much as $850 \mathrm{ft}$ thick.

The White River Formation contains an important aquifer in the Shirley Basin, and Richter (1981, p. 54) defined the formation, along with the Wind River Formation, as a "principal water-bearing unit in the Shirley Basin.” Richter (1981) also considered the formation to contain a "principal aquifer" and grouped the White River Formation with other formations of Tertiary age in the Laramie, Shirley, and Hanna Basins into a single hydrogeologic unit defined as the "Tertiary aquifer." The USGS also defined the White River aquifer as a "principal aquifer" (Whitehead, 1996) and referred to the aquifer as part of the "Lower Tertiary aquifers" category on the national Principal Aquifers map (U.S. Geological Survey, 2003).

Harshman (1972) examined the ground-water hydrology and quality of aquifers in the White River, Wind River, and Wagon Bed Formations in the Shirley Basin because of the discovery of uranium in the Wind River Formation. As part of the study, potentiometric contours were constructed showing ground-water flow in the aquifers (reproduced with modifications in fig. 23). Aquifers in all three formations were mapped as a single aquifer in the area, inferring hydraulic connection among the formations in the area. Harshman noted that ground water in the White River aquifer, and in aquifers in the other formations, was unconfined and that shallow ground water in the White River aquifer was perched (fig. 23). He also stated that Spring Creek "is fed from and flows on a perched body of water" and that "it is a gaining stream with respect to the perched water, but it may be a losing stream with respect to the main body of ground water" (Harshman, 1972, p. 37). Harshman collected ground-water samples from eight springs discharging from the formation and all but three were in Carbon County; the remaining three samples were just outside the county but are included in the subsequent discussion because they are close to the county boundary and help to further characterize waters from the aquifer in the area. TDS ranged from 178 to $235 \mathrm{mg} / \mathrm{L}$, and water was classified into two groups. Ground-water samples from the first group (group 1) were 
collected near the base of the upper member of the formation and samples from the second group (group 2) were collected near the base of the lower member. Although ionic composition was similar in both groups, and bicarbonate was the predominant anion in both groups, Harshman (1972, p. 41) noted that water from the lower member (group 2) "contains more sodium, sulfate, and uranium and somewhat less phosphate than does that from the upper member." Total radium concentrations ranged from less than 0.1 to $3.5 \pm 0.7 \mathrm{pCi} / \mathrm{L}$, and uranium concentrations ranged from $7.8 \pm 0.8$ to $52 \pm 5 \mu \mathrm{g} / \mathrm{L}$. One reported uranium concentration exceeded the USEPA uranium MCL (30 $\mu \mathrm{g} / \mathrm{L})$, although several other reported concentrations approached but did not exceed the standard.

Spring-discharge and well-yield measurements from the USGS NWIS database were reviewed for this study. Three measured discharges for springs ranged from 32 to $440 \mathrm{gal} / \mathrm{min}$, with a median discharge of $220 \mathrm{gal} / \mathrm{min}$. The well yield for one pumped well was $50 \mathrm{gal} / \mathrm{min}$.

The chemical composition of ground water in the White River aquifer in Carbon County was characterized and the quality evaluated on the basis of historical samples collected from wells and springs. TDS concentrations indicated that all samples were fresh water (fig. 24A). Ionic compositions indicated that the water was calcium-bicarbonate type (fig. 24A). Hardness varied considerably and ranged from soft to very hard, although one-half of samples were classified as moderately hard.

Based on the few characteristics and constituents analyzed, the quality of water from the White River aquifer was better than that from other Tertiary hydrogeologic units in Carbon County, assuming areas with known elevated concentrations of radionuclides are eliminated from the comparison (as described previously from Harshman (1972)). When this is done, no characteristics or constituents in the White River aquifer approached or exceeded applicable USEPA or State of Wyoming domestic, agriculture, or livestock water-quality standards (appendixes 7-1 to 7-4).

\section{Washakie Formation}

Only a small (approximately one-quarter $\mathrm{mi}^{2}$ ) outcrop of the Washakie Formation is present in southwestern Carbon County (T. 14 N., R. 93 W., section (sec.) 6 and T. 15 N., R. 93 W., sec. 31) (fig. 18) (Love and Christiansen, 1985). The Washakie Formation is composed of fluvial, middle and upper Eocene rocks in the Washakie Basin. According to Roehler (1973, p. 12), "the Washakie Formation is exposed in an area of about $680 \mathrm{mi}^{2}$ in the central part of the Washakie Basin, where it has a maximum thickness of about $3,200 \mathrm{ft}$. The formation is principally a sequence of irregularly interbedded gray and green mudstone; gray, green, or brown tuffaceous and arkosic sandstone; and minor thin beds of tuff, limestone, conglomerate, shale, and siltstone." Roehler (1973) divided the Washakie Formation into two members. He named the upper part (approximately 2,300 ft thick) the Adobe Town Member, and named the lower part (approximately $900 \mathrm{ft}$ thick) the
Kinney Rim Member. The two members are separated by a basin-wide unconformity, as well as by minor lithological differences.

Because of limited areal extent and lack of hydrogeologic and water-quality data, the Washakie Formation in Carbon County was not assessed as a part of this study.

\section{Wagon Bed Formation}

The Wagon Bed Formation occurs only in the northeastern part of Carbon County (Love and Christiansen, 1985) and contains the Wagon Bed aquifer. Harshman $(1968,1972)$ and Denson and Harshman (1969) described the formation as light-tan to light-gray, very coarse-grained sandstone that is well cemented with a clay binder, and pale-green silicified claystone. Thin-bedded freshwater limestone is present in the lower part of the formation (Harshman, 1968, 1972). Van Houten (1964) reported that the formation was deposited on warm, humid, poorly drained lowlands, floodplains, and lakes of the middle and late Eocene Epoch. The formation is as much as $160 \mathrm{ft}$ thick in the county.

Harshman (1972) examined the ground-water hydrology and quality of aquifers in the White River, Wind River, and Wagon Bed Formations in the Shirley Basin because of the discovery of uranium in the Wind River Formation. As part of the study, potentiometric contours were constructed showing ground-water flow in the aquifers (reproduced with modifications in fig. 23). Aquifers in all three formations were mapped as a single aquifer in the area, inferring hydraulic connection among the formations in the area. The potentiometric contours constructed near the Little Medicine Bow River show that the stream gains flow from the Wagon Bed Formation in the area (fig. 23). Spring-discharge and well-yield measurements from the USGS NWIS database were reviewed for this study, but no measurements were available for the Wagon Bed aquifer in Carbon County.

The chemical composition of ground water in the Wagon Bed aquifer in Carbon County was characterized and the quality evaluated on the basis of only three historical water-quality samples collected from springs. Dissolved-solids concentrations indicated that all water was fresh (fig. 24B). Ionic compositions indicated that all waters were calcium-bicarbonate types (fig. 24B). Hardness ranged from moderately hard to very hard.

Based on the few characteristics and constituents analyzed, the quality of water from the Wagon Bed aquifer generally was better than that from aquifers in most Tertiary hydrogeologic units in Carbon County; however, water-quality samples were only available for three springs because of the limited areal extent of the formation in the county, and it is unknown how representative these three samples were of the aquifer. No characteristics or constituents in the Wagon Bed aquifer approached or exceeded applicable USEPA or State of Wyoming domestic, agricultural, or livestock water-quality standards (appendixes 7-1 to 7-4). 

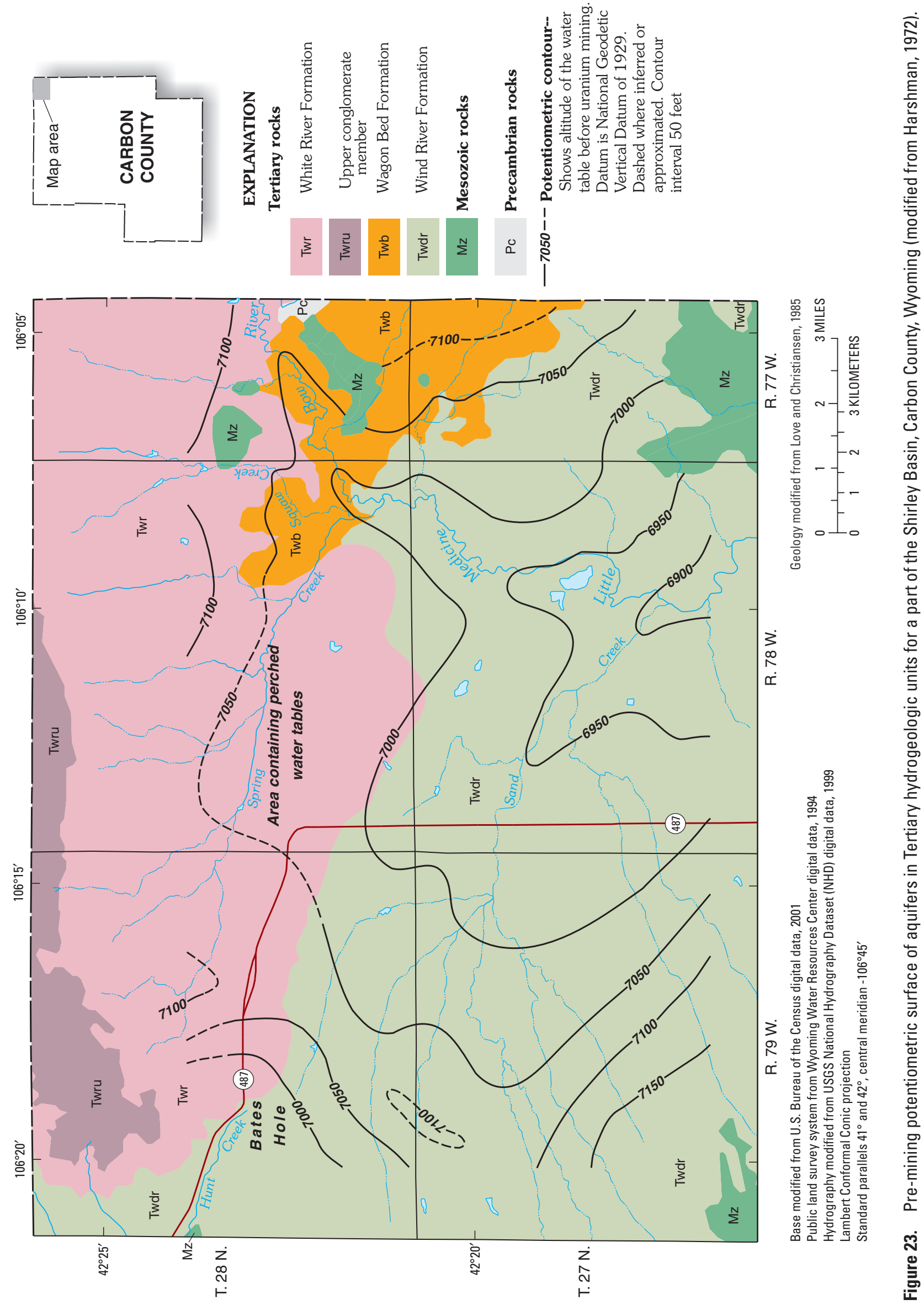

㐫 
A. White River aquifer

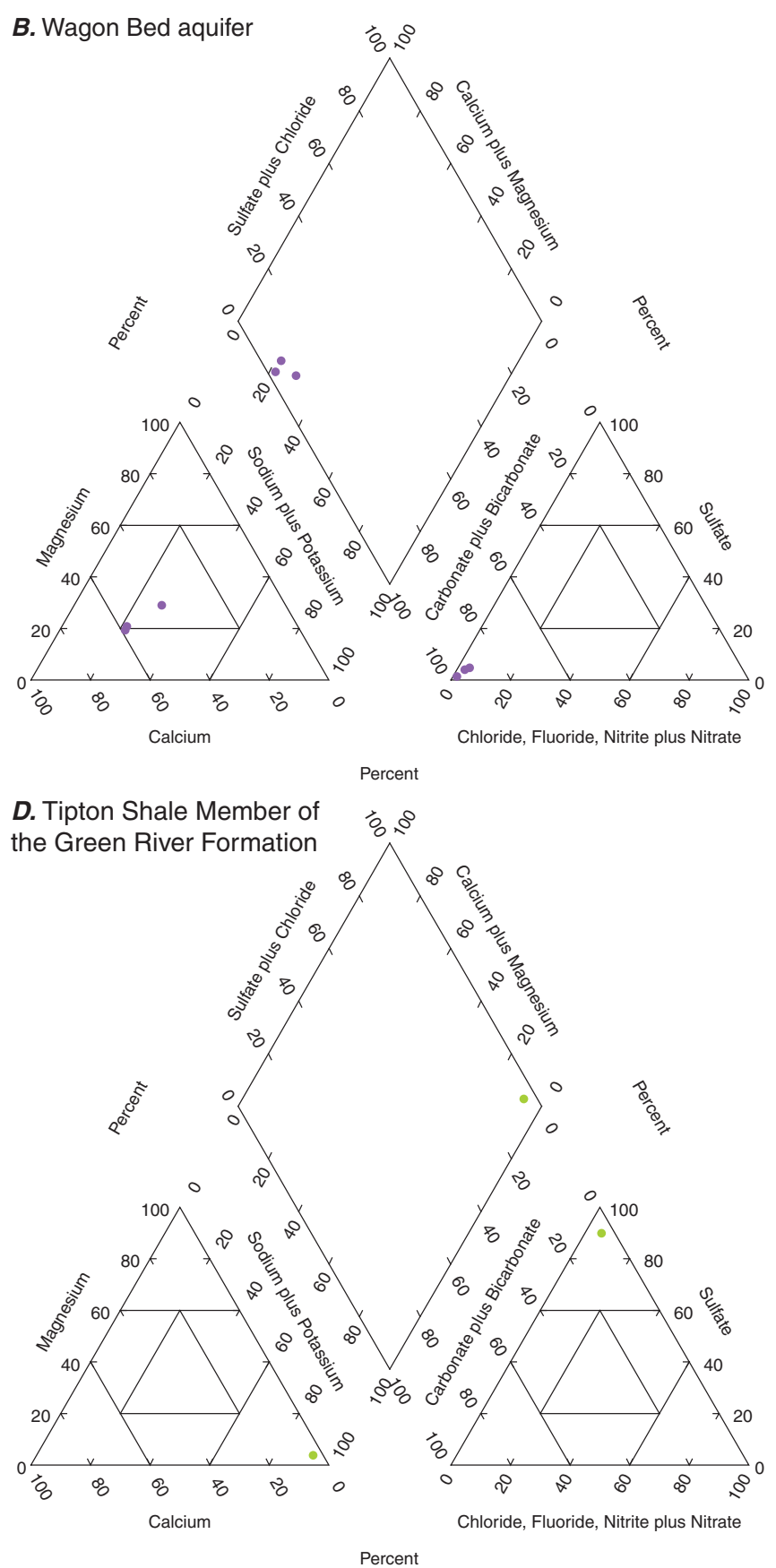

EXPLANATION

Total dissolved-solids concentration, in milligrams per liter, and U.S. Geological Survey salinity classification

- Less than 1,000; fresh

- 1,000-3,000; slightly saline

- 3,000-10,000; moderately saline

Figure 24. Trilinear diagrams showing major-ion composition and dissolved-solids concentrations for ground-water samples from aquifers in lower Tertiary hydrogeologic units, Carbon County, Wyoming. 

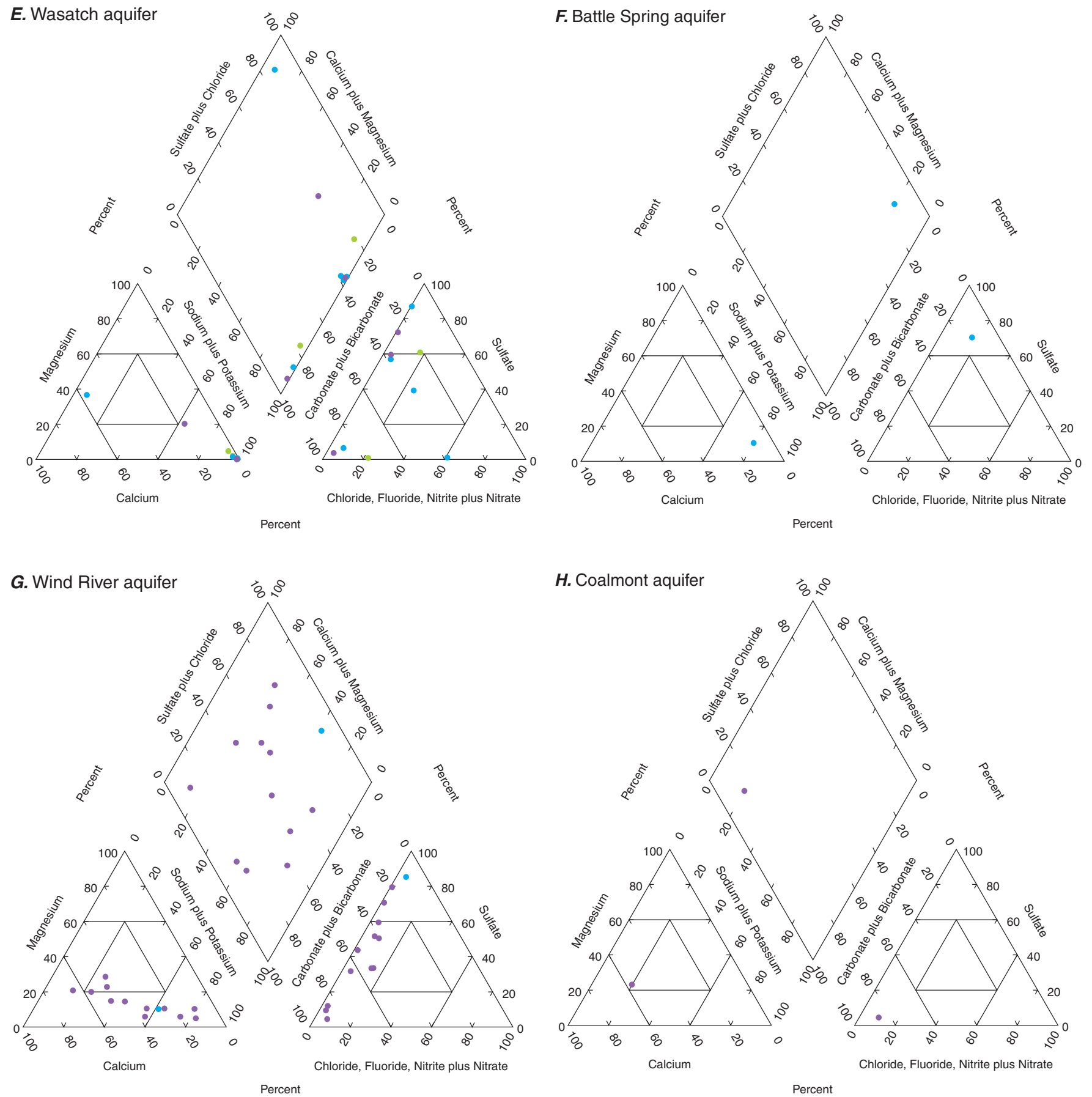

\section{EXPLANATION}

Total dissolved-solids concentration, in milligrams per liter, and U.S. Geological Survey salinity classification

- Less than 1,000; fresh

- 1,000-3,000; slightly saline

- 3,000-10,000; moderately saline

Figure 24. Trilinear diagrams showing major-ion composition and dissolved-solids concentrations for ground-water samples from aquifers in lower Tertiary hydrogeologic units, Carbon County, Wyoming.-Continued 


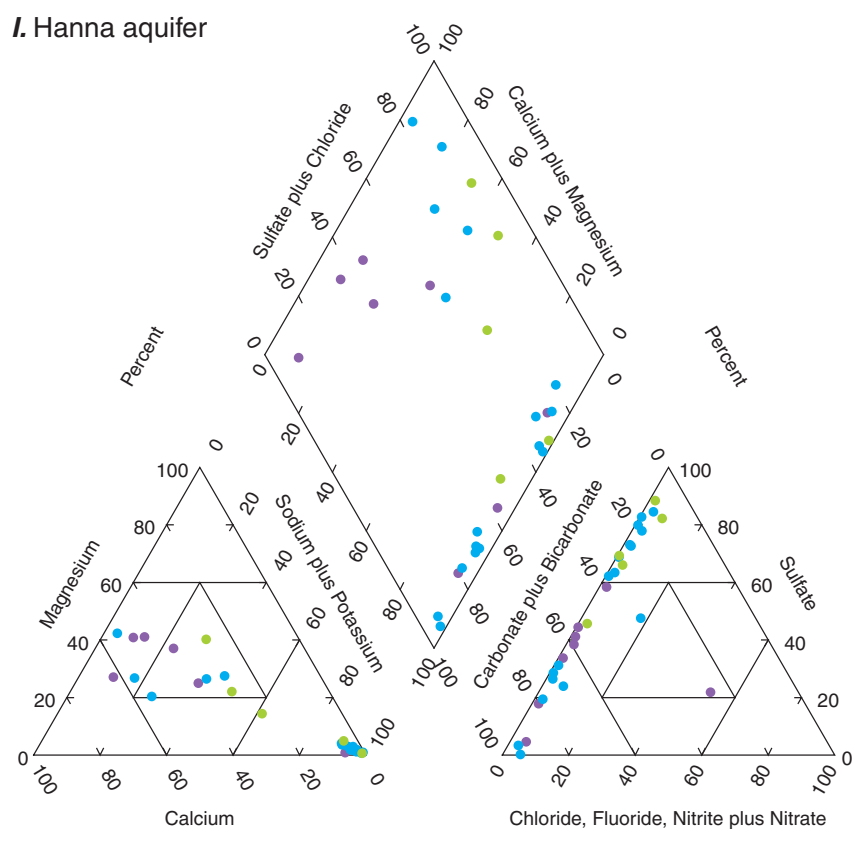

Percent

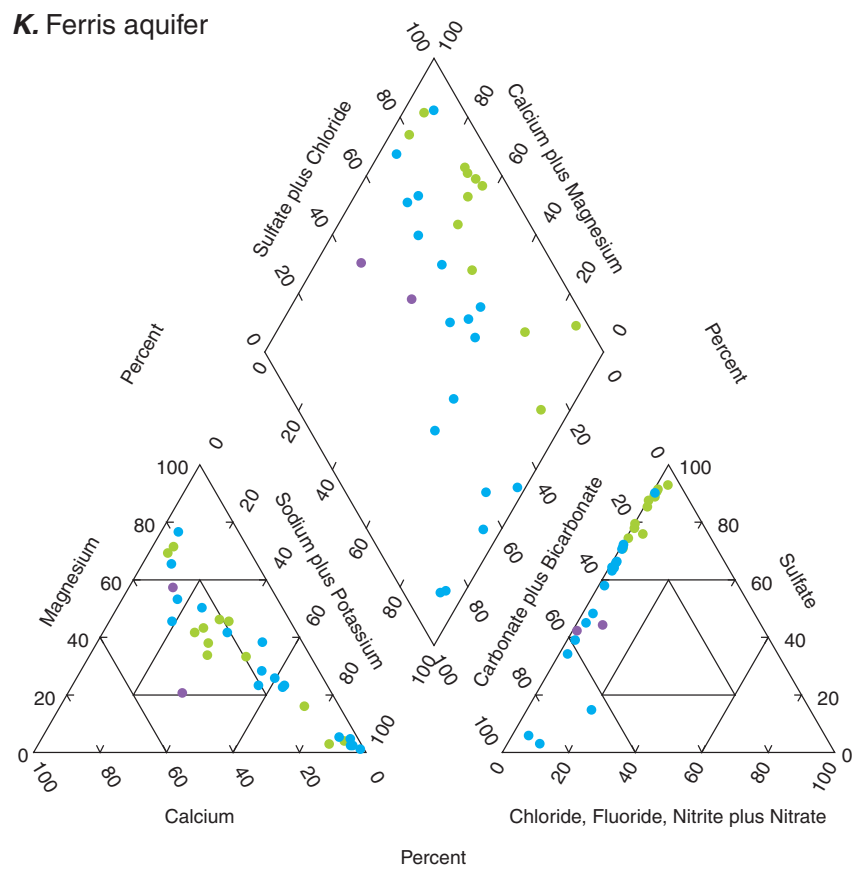

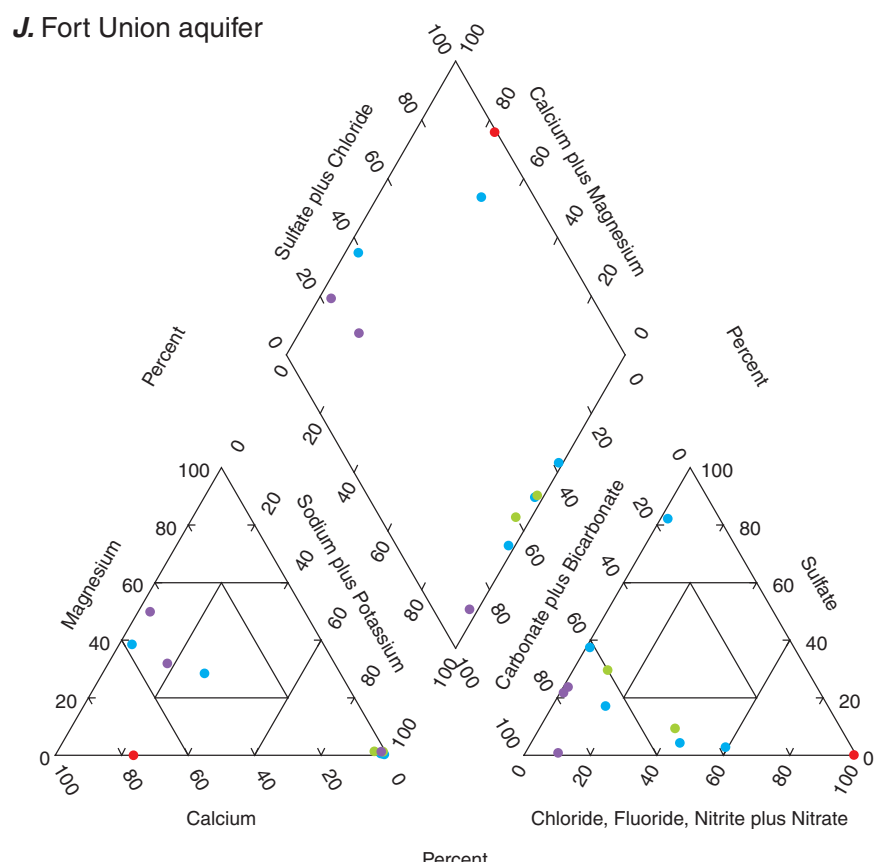

Percent
EXPLANATION

Total dissolved-solids concentration, in milligrams per liter, and U.S. Geological Survey salinity classification

- Less than 1,000; fresh

- 1,000-3,000; slightly saline

- 3,000-10,000; moderately saline

- 10,000-35,000; very saline

- More than 35,000; briny

Figure 24. Trilinear diagrams showing major-ion composition and dissolved-solids concentrations for ground-water samples from aquifers in lower Tertiary hydrogeologic units, Carbon County, Wyoming.-Continued 


\section{Green River Formation}

The Green River Formation was named by Ferdinand Vandiveer Hayden (1869, p. 90) for exposures along the Green River west of Rock Springs. The formation was deposited during the Eocene Epoch when Lake Gosiute was present in southwestern Wyoming. At its maximum extent, Lake Gosiute covered nearly all of Sweetwater County (Bradley, 1964, p. A36). Bradley (1964, p. A18) described the Green River Formation as "a huge lens of fine-grained generally calcareous sedimentary rock embedded in a thick body of somewhat sandy mudstone that fills a large intermontane basin." Roehler (1992, p. E45) reported that the depositional environments and composition of stratigraphic units in the basins of Lake Gosiute appear to be directly related to regional Eocene climate changes. The Green River Formation has been subdivided into five members and one tongue: the Laney, Godiva Rim, Wilkins Peak, Tipton Shale, and Farson Sandstone Members, and the Luman Tongue (Love and others, 1993). Roehler (1992, p. E45) reported that the Laney Member was deposited during a wet and hot climate, the Wilkins Peak Member was deposited during a dry and hot climate, the Tipton Shale Member was deposited during a moist and warm and moist and hot climate, and the Luman Tongue was deposited during a moist and warm climate. The Farson Sandstone Member was deposited at the same time as the Tipton Shale Member, but the member is present in the Green River Basin outside Carbon County (Love and others, 1993). The Laney Member, Tipton Shale Member, and Luman Tongue have exposures in Carbon County (Love and Christianson, 1985).

The Laney Member, which contains the Laney aquifer, was named by Schultz (1920, p. 27-28) from exposures along the Laney Rim (now called DeLaney Rim) in the Washakie Basin. The Laney Member occurs at or near the land surface in the southwestern part of the county in a band around the margin of the Washakie Basin (fig. 18). Bradley (1961) described the Laney Member as a "massive to thinly laminated buff, gray, and brown, marlstone, shale, and muddy sandstone; white to brown tuff and tuffaceous sandstone; low grade to rich beds of oil shale and, in shore facies, algal deposits and oolite beds." The Laney Member was deposited during a humid climate when Lake Gosiute was a freshwater lake with an outlet (Bradley, 1964, p. A2). The thickness ranges from 0 to about 1,900 ft (Bradley, 1961).

In the county, the Tipton Shale Member occurs at or near the land surface in a thin band around the Washakie Basin (fig. 18). Bradley (1961) described the Tipton Shale Member as "soft brown to buff shale and organic marlstone in lower half-upper half chippy to flaky, light bluish gray organic marlstone in upper half; algal layers of great lateral extent are characteristic of middle part and shore facies." The Tipton Shale Member was deposited when Lake Gosiute was a large fresh water lake with an outlet (Bradley 1964, p. A1) and the climate was either moist and warm or moist and hot (Roehler, 1992, p. E45). Welder (1968, sheet 2) and Welder and McGreevy (1966, sheet 3) reported that the Tipton Shale Member ranges in thickness from 0 to about $400 \mathrm{ft}$.

The Luman Tongue of the Green River Formation occurs at or near the land surface in a thin band around the northern margin of the Washakie Basin (fig. 18). Bradley (1961) described the Luman Tongue as a "series of brown, flaky shale, oil shale, marlstone, carbonaceous shale, and limy sandstone beds that locally contain a few thin beds of coal." According to Roehler (1992, p. E28-E29), the Luman Tongue was deposited mostly in a freshwater lake that occupied a trough on the north side of the Uinta Mountains. The lake was only 13 to 40 mi wide (north-south) just north of the Uinta Mountains, but it expanded eastward across the Rock Springs Uplift area, and was more than 60 mi wide in the Great Divide and Washakie Basins (Roehler, 1992, p. E29). The thickness of the tongue ranges from 0 to more than $400 \mathrm{ft}$, with a maximum recorded thickness of $455 \mathrm{ft}$ having been measured in the southwestern Washakie Basin (T. 13 N., R. 100 W.) (Roehler, 1992, p. E29).

As described previously, three members of the Green River Formation are present in Carbon County (the Laney, Tipton Shale, and Luman Tongue) and crop out in a small area in the Washakie Basin in the southwestern part of the county (fig. 18). Of the three members in Carbon County, the Laney is the only member considered an aquifer (Collentine and others, 1981; Naftz, 1996); the Tipton Shale and Luman Tongue typically are defined as confining units. Few wells are completed in the formation in the county, so with the exception of a brief summary of yields of wells present in the county, hydrogeologic characteristics will not be described herein because most information describing the formation is from outside the county. However, reports by previous investigators describe the hydrogeologic characteristics of the formation in areas outside the county in the Great Divide and Washakie Basins, so the reader is referred to Welder and McGreevy (1966), Collentine and others (1981), Taylor and others (1986), Naftz (1996), and Mason and Miller (2005).

Spring-discharge and well-yield measurements from the USGS NWIS database were reviewed for this study. The measurement of well yield for one pumped well in the Green River Formation was $16 \mathrm{gal} / \mathrm{min}$. The measured discharge for one spring discharging from the Laney aquifer was $1 \mathrm{gal} / \mathrm{min}$.

The chemical composition of ground water in the Green River Formation in Carbon County was characterized and the quality evaluated on the basis of only one historical spring water-quality sample from the Laney Member and one new well water-quality sample from the Tipton Shale Member (appendix 6). Dissolved-solids concentrations indicated that both samples were moderately saline (figs. 24C and 24D). Ionic compositions indicated that both samples were sodiumsulfate type (figs. 24C and 24D). Hardness for both samples was very hard. Based on the few analyses available for this spring, the water from the Laney aquifer generally was unsuitable for domestic, agricultural, and livestock use. Based on the analyses available for this well, the water from the Tipton Shale Member generally was suitable for livestock use. 


\section{Wasatch Formation}

The Wasatch Formation, which contains the Wasatch aquifer, is composed of fluvial sediment that was deposited at the same time as the Green River Formation. In the early and middle Eocene Epoch, Lake Gosiute repeatedly expanded and contracted. Fluvial sediments of the Wasatch Formation were deposited around the margins of the lake basin in a belt that narrowed when the lake expanded and widened when the lake contracted (Bradley, 1964, p. A18). The Wasatch Formation has been subdivided into several units within the region that includes Carbon County. The Cathedral Bluffs Tongue and main body have large areal extents within the southwestern part of the county. The Niland Tongue, Alkali Creek Tongue, and Chappo Member are absent in the county.

The Cathedral Bluffs Tongue of the Wasatch Formation occurs in Carbon County at or near land surface in a band around the margin of the Washakie Basin (fig. 18). The Cathedral Bluffs Tongue intertongues to a lesser extent with other rocks in the region (Roehler, 1992, p. E37-E38). Roehler (1992, p. E37) described the Cathedral Bluffs Tongue as "composed of variegated (mostly red) fluvial rocks that intertongue with and are replaced from the margins toward the center of the greater Green River basin by rocks of mostly lacustrine origin that constitute the Wilkins Peak Member" (of the Green River Formation). Bradley (1961) described the rocks of the tongue as being composed of "gray and greenishgray sandy mudstone banded with pink and red layers; contains massive lenses and beds of brown to yellowish muddy sandstone; makes badland slopes.” Roehler (1992, p. E38) reported that the thickness of the Cathedral Bluffs Tongue ranges from 0 to more than 2,000 ft.

The main body of the Wasatch Formation occurs at or near land surface around the perimeter of the Washakie Basin (fig. 18). Masursky (1962, p. 10-11) believed that the Battle Spring Formation mapped by Pipiringos $(1955,1961)$ was really just a mountainward fluvial facies of the main body of the Wasatch Formation. Love (1970, p. C33-C34) supported this assessment. The Battle Spring Formation occurs at or near land surface in much of the eastern part of the Great Divide Basin (fig. 18). The upper parts of the main body of the Wasatch Formation intertongue with tongues and members of the Green River Formation. The lower part of the main body of the Wasatch Formation predates Lake Gosiute, and underlies the Green River Formation, rather than intertonguing with it. Love and Christiansen (1985) described the main body of the Wasatch Formation in southwest Wyoming as "drab sandstone, drab to variegated claystone and siltstone; locally derived conglomerate around basin margins." Like the rest of the Wasatch Formation in the county, the main body of the Wasatch Formation is composed of fluvial sediment deposited in the same basin occupied by Lake Gosiute. The main body of the Wasatch Formation is more than 4,000 ft thick in parts of the Green River and Washakie Basins (Roehler, 1992, p. E26-E27).
The Wasatch Formation is a source for natural gas, by both conventional and coalbed methane extraction methods, in the southwestern corner of the state (De Bruin, 2002; Wyoming Oil and Gas Conservation Commission, 2004).

The Wasatch Formation contains an important aquifer in the Great Divide and Washakie Basins. Collentine and others (1981, fig. III-6, p. 28) combined the Wasatch and Battle Spring Formations into a single hydrogeologic unit and defined the combined unit as a "principal aquifer" in the Great Divide and Washakie Basins. Similarly, Naftz (1996) and Glover and others (1998) also combined the Wasatch and Battle Spring Formations into a single hydrogeologic unit, but also included the Fort Union Formation; this unit was defined as the "Wasatch-Fort Union aquifer" and the Wasatch and Battle Spring Formations were combined and defined as a subaquifer defined as the "Wasatch zone" of the Wasatch-Fort Union aquifer. The USGS also define the Wasatch aquifer as a "principal aquifer" (Whitehead, 1996) and combined the aquifer with many others that comprise the "Colorado Plateaus aquifers" category on the national Principal Aquifers map (U.S. Geological Survey, 2003).

Individual discontinuous sandstone beds or lenses compose the Wasatch aquifer (Welder and McGreevy, 1966; Collentine and others, 1981). Welder and McGreevy (1966) reported that well yields for 90 wells in the Great Divide and Washakie Basins and surrounding areas ranged from 5 to $250 \mathrm{gal} / \mathrm{min}$. The investigators also noted that "the maximum yield of a favorably located well might be as much as $500 \mathrm{gal} / \mathrm{min}$ " (Welder and McGreevy, 1966, sheet 3). They also noted that artesian conditions occur in many sandstone lenses in the lower part of the formation, especially in the northwestern Great Divide Basin.

Collentine and others (1981, table V-1, p. 44) summarized hydrogeologic characteristics of the Wasatch aquifer throughout the Great Divide and Washakie Basins, including the eastern perimeters of the basins in Carbon County. Reported well yields ranged from 5 to $250 \mathrm{gal} / \mathrm{min}$, but most yields ranged from 30 to $50 \mathrm{gal} / \mathrm{min}$. Transmissivity values for 9 aquifer tests ranged from about 20 to $1,340 \mathrm{ft}^{2} /$ day, and associated specific capacity ranged from 0.17 to greater than $10(\mathrm{gal} / \mathrm{min}) / \mathrm{ft}$.

A potentiometric surface map of the Wasatch zone of the Wasatch-Fort Union aquifer constructed by Naftz (1996) shows the direction of ground-water flow for the entire aquifer, including the eastern perimeter in western Carbon County (fig. 14). Based on this map, Naftz (1996) reported:

"recharge occurs in upland areas, and outcrop areas adjacent to mountain ranges, and discharge occurs along major streams and rivers of the study area. Springs in the northern part of the Great Divide-Washakie-Sand Wash Basins aquifer system serve as major discharge points; to a lesser degree, springs associated with faulting near the Little Snake River in the southern part of the basin act as discharge points."

Naftz (1996) also examined major-ion geochemistry to identify areas of recharge, discharge, and interaquifer leakage in the Wasatch zone of the Wasatch-Fort Union aquifer. He 
noted that recharge areas were characterized by small dissolved-solids concentrations, positive $\log (([\mathrm{Ca}]+[\mathrm{Mg}]) /[\mathrm{Na}])^{2}$ values, and small sodium and fluoride concentrations. Sulfate concentrations generally increased along projected groundwater flowpaths, and water with dissolved-solids concentrations greater than $1,500 \mathrm{mg} / \mathrm{L}$ was predominant in sodium and chloride. Examining calcium-to-chloride ratios, he concluded that ratios that exceed the local precipitation ratio are indicative of recharge areas, and ratios less than the local precipitation ratio are indicative of discharge areas.

Spring-discharge and well-yield measurements from the USGS NWIS database were reviewed for this study. Five measurements of well yields for pumped wells ranged from 4 to $30 \mathrm{gal} / \mathrm{min}$ with a median yield of $20 \mathrm{gal} / \mathrm{min}$. Three measurements of well yield for flowing wells ranged from 0.5 to $4.5 \mathrm{gal} / \mathrm{min}$ with a median yield of $1.5 \mathrm{gal} / \mathrm{min}$. The measured discharge for one spring was $5 \mathrm{gal} / \mathrm{min}$.

The chemical composition of ground water in the Wasatch aquifer in Carbon County was characterized and the quality evaluated on the basis of new and historical samples collected from wells and one spring. TDS concentrations were highly variable and indicated that water was fresh, slightly saline, or moderately saline (fig. 24E). Ionic compositions indicated that water was either calcium-sulfate type, sodiumsulfate type, or sodium-bicarbonate type (fig. 24E). No relation was apparent between water type and salinity. Sulfate concentrations significantly decreased with increasing well depth (appendix 8). Hardness varied considerably and ranged from soft to very hard.

Concentrations of some characteristics and constituents in the Wasatch aquifer approached or exceeded applicable USEPA or State of Wyoming water-quality standards and could limit the suitability of water for some intended uses. Most water was suitable for domestic use, but concentrations of two constituents exceeded health-based standards (appendixes 7-1 to 7-4): fluoride (MCL exceeded in 1 of 8 samples), and radon (proposed 300-pCi/L MCL exceeded in both samples). Aesthetic standards for domestic use were exceeded by more characteristics and constituents and more frequently and included $\mathrm{pH}$ (SMCL upper limit exceeded in 4 of 7 samples), TDS (SMCL exceeded in all 11 samples), sulfate (SMCL exceeded in 7 of 11 samples), chloride (SMCL exceeded in 4 of 11 samples), fluoride (SMCL exceeded in 2 of 8 samples), iron (SMCL exceeded in 2 of 5 samples), and manganese (SMCL exceeded in 1 of 5 samples).

In relation to suitability for agricultural and livestock use, concentrations of five characteristics and constituents exceeded State of Wyoming agricultural-use standards and concentrations of one characteristic exceeded State of Wyoming livestock standards (appendixes 7-1 to 7-4). Characteristics and constituents measured at concentrations greater than agricultural-use standards included $\mathrm{pH}$ (upper limit standard exceeded in 1 of 7 samples), TDS (standard exceeded in 6 of 11 samples), SAR (standard exceeded in 5 of 7 samples), sulfate (standard exceeded in 7 of 11 samples), and chloride (standard exceeded in 4 of 11 samples). In general, water from the Wasatch aquifer is suitable for livestock use, but some measured $\mathrm{pH}$ values were greater than livestock standards: (upper limit standard exceeded in 4 of 7 samples).

\section{Battle Spring Formation}

The Battle Spring Formation, which contains the Battle Spring aquifer, occurs at or near land surface in parts of the eastern part of the Great Divide Basin in Carbon County (fig. 18). Bradley (1961) described the Battle Spring Formation as being composed of "light gray to brown, coarsegrained to pebbly arkosic sandstone with a lesser amount of greenish gray sandy clay and mudstone; locally contains large spheroidal concretions; interfingers with the Wasatch and Green River Formations." Pipiringos (1961, p. A34-A35) suggested that the sediments composing the Battle Spring Formation were deposited in deltaic sheets associated with one of the ancient Green River lakes, and that the source of the sediment was the Granite Mountains. However, Masursky (1962, p. 10-11) and Love (1970, p. C33-C34) believed that the Battle Spring Formation mapped by Pipiringos $(1955,1961)$ was a mountainward fluvial facies of the main body of the Wasatch Formation and should not be considered a separate formation. Welder and McGreevy (1966, sheet 3) reported that the Battle Spring Formation ranges in thickness from " $1,000($ ?) to about 4,500 ft."

The Battle Spring Formation contains an important aquifer in the Great Divide Basin, although its extent is limited in Carbon County. As noted previously in the description of the Wasatch Formation section of the report, Collentine and others (1981, fig. III-6, p. 28) combined the Wasatch and Battle Spring Formations into a single hydrogeologic unit and defined the combined unit as a "principal aquifer" in the Great Divide and Washakie Basins. Similarly, Naftz (1996) and Glover and others (1998) also combined the Wasatch and Battle Spring Formations into a single hydrogeologic unit, but also included the Fort Union Formation; this unit was defined as the "Wasatch-Fort Union aquifer," and the Wasatch and Battle Spring Formations were combined and defined as a subaquifer defined as the "Wasatch zone" of the Wasatch-Fort Union aquifer. The USGS also defined the Battle Spring aquifer as a "principal aquifer" (Whitehead, 1996) and combined the aquifer with many others that comprise the "Colorado Plateaus aquifers" category on the national Principal Aquifers map (U.S. Geological Survey, 2003).

Welder and McGreevy (1966) and Collentine and others (1981) described the hydrogeologic characteristics of the Battle Spring aquifer throughout the Great Divide Basin. Welder and McGreevy (1966, sheet 3) reported good development possibilities in the northeast part of the Great Divide Basin and noted "maximum yields of wells penetrating the entire formation might exceed 1,000 gal/min." Collentine and others (1981, p. 52) reported that the aquifer is "capable of yielding at least $150 \mathrm{gal} / \mathrm{min}$ to water wells, though most yields generally range from 30 to $40 \mathrm{gal} / \mathrm{min}$." Transmissivity values for 26 water wells were reported to range from about 4 to about $423 \mathrm{ft}^{2} / \mathrm{day}$, 
and the storage coefficient was estimated to be about $1 \times 10^{-3}$ (Collentine and others, 1981).

Additional information describing hydrogeologic characteristics of the Battle Spring aquifer as part of the Wasatch zone of the Wasatch-Fort Union aquifer was presented earlier in the Wasatch Formation discussion. The reader is referred to that section of the report for additional information about the Battle Spring aquifer.

Spring-discharge and well-yield measurements from the USGS NWIS database were reviewed for this study. Three measurements of well yields for pumped wells ranged from 10 to $20 \mathrm{gal} / \mathrm{min}$ with a median yield of $10 \mathrm{gal} / \mathrm{min}$. There were no measured flows for springs discharging from the Battle Spring Formation in Carbon County.

The chemical composition of ground water in the Battle Spring aquifer in Carbon County was characterized and the quality evaluated on the basis of only one new water-quality sample (appendix 6). The TDS concentration indicated that the water was slightly saline (fig. 24F). The sample was a sodiumsulfate type water (fig. 24F). Hardness was very hard. Based on the few analyses available for this well, the water generally was suitable for livestock use.

\section{Wind River Formation}

The Wind River Formation, which contains the Wind River aquifer, occurs primarily in the Shirley Basin, with a smaller extent in the northern part of the Medicine Bow Mountains (fig. 18). The formation consists of green or green-gray and locally red claystone and siltstone, gray medium to very coarse-grained arkosic sandstone, and pebble conglomerate (Van Houten, 1964; Harshman, 1968, 1972; and Denson and Harshman, 1969). Harshman (1968, 1972) noted that a basal conglomerate in some areas contains boulders of Precambrian material as much as $25 \mathrm{ft}$ in diameter. He also stated that the claystone and siltstone contain carbonaceous material or are interbedded with lignite. Van Houten (1964) noted that the formation was deposited in a humid, warm-temperate to subtropical environment. In the Shirley Basin (fig. 2), the formation is as much as $550 \mathrm{ft}$ thick. The Wind River Formation is the host formation for the Shirley Basin Uranium District, which had several large open pit mines and uranium processing mills (Harris and others, 1985; Harris, 1996).

Harshman (1972) examined the ground-water hydrology and quality of aquifers in the White River, Wind River, and Wagon Bed Formations in the Shirley Basin because of the discovery of uranium in the Wind River Formation. As part of the study, potentiometric contours were constructed showing ground-water flow in the aquifers (reproduced with modifications in fig. 23). Aquifers in all three formations were mapped as a single aquifer in the area, inferring hydraulic connection among the formations in the area. Harshman noted that ground water in the Wind River aquifer, and in aquifers in the other formations, was unconfined. Potentiometric contours show "that the Little Medicine Bow River and the lower reach of Sand Creek have cut below the main ground-water body, and they are gaining streams" (Harshman, 1972, p. 37). Harshman also noted that individual upper and lower sandstone layers and lenticular beds in the formation were in hydraulic connection. He also reported that ground water in the area generally was moving south with a hydraulic gradient of 20 feet per mile. Ground-water samples were collected from 1 flowing well, 15 pumped wells, 1 spring, and 14 drill holes in Carbon County. In an approach similar to that presented previously in the discussion of the White River Formation, Harshman classified the water from the Wind River aquifer into two groups. Ground-water samples from group 1 were "collected from the ore-bearing sandstone in the vicinity of large ore bodies and from 200-300 feet below the water table;" he noted that the water was "similar in composition and contains calcium, sodium, bicarbonate, and sulfate as the principal constituents" and noted "average uranium content is the same as that in the water samples from the lower part of the White River Formation, but the radium content is greater by almost two orders of magnitude" (Harshman, 1972, p. 41). Group 2 samples were collected "from exploratory drill holes in the western part of the Shirley Basin, where uranium ore lies near the base of the Wind River Formation and at or slightly below the groundwater table;" constituents in water from group 2 were similar to group 1 but Harshman reported that the "amounts present ranged widely" (Harshman, 1972, p. 41). Although ionic composition was similar in both groups, and bicarbonate was the predominant anion in both groups, Harshman (1972, p. 41) noted that water from the lower member (group 2) "contains more sodium, sulfate, and uranium and somewhat less phosphate than does that from the upper member." Total radium concentrations for all ground-water samples ranged from less than 0.1 to $3.5 \pm 0.7 \mathrm{pCi} / \mathrm{L}$ and uranium concentrations ranged from $7.8 \pm 0.8$ to $52 \pm 5 \mu \mathrm{g} / \mathrm{L}$. Total radium concentrations in more than one-half (16 of 31) the ground-water samples exceeded the current summed radium-226 and radium-228 MCL of $5 \mathrm{pCi} / \mathrm{L}$. Eight reported uranium concentrations exceeded the current USEPA uranium MCL of $30 \mu \mathrm{g} / \mathrm{L}$.

Richter (1981, table IV-3, p. 55) reported transmissivity values from three aquifer tests in the Wind River aquifer in the Shirley Basin area. Based upon well locations, it appears that the investigator incorrectly assigned the wells to the White River aquifer in the report. Reported transmissivity values were $1,742,2,948$, and $1,876 \mathrm{ft}^{2} / \mathrm{d}$, and associated specific capacity values were $6.7,11.1$, and 6.8 (gal/min)/ft of drawdown, respectively.

Spring-discharge and well-yield measurements from the USGS NWIS database were reviewed for this study. Seventeen measurements of well yields for pumped wells ranged from 2 to $610 \mathrm{gal} / \mathrm{min}$, with a median yield of $65 \mathrm{gal} / \mathrm{min}$. The measured discharge for one spring was $4 \mathrm{gal} / \mathrm{min}$.

The chemical composition of ground water in the Wind River aquifer in Carbon County was characterized and the quality evaluated on the basis of historical samples collected from wells and springs. TDS concentrations indicated that all samples were fresh with the exception of one sample, which was slightly saline (fig. 24G). Ionic compositions indicated 
that although many different water types were represented, calcium and bicarbonate or sodium and sulfate were the most common ions (fig. 24G). Concentrations of sodium significantly increased with increasing well depth (appendix 8). Hardness varied considerably and ranged from soft to very hard.

Based on the few characteristics and constituents analyzed, the concentrations of some constituents in the Wind River aquifer approached or exceeded applicable USEPA or State of Wyoming water-quality standards and could limit the suitability of water for some intended uses. Excluding samples in Carbon County collected in areas with known elevated concentrations of radionuclides greater than USEPA MCLs (as described previously from Harshman (1972)), and compared to health-based standards, all water was suitable for domestic use with the exception of the boron concentration in one sample (proposed HAL exceeded in 1 of 4 samples) (appendixes 7-1 to 7-4). Only three aesthetic standards for domestic use were exceeded: TDS and sulfate (SMCLs exceeded in 4 of 13 samples); and aluminum (SMCL lower and upper limits exceeded in the one sample).

In relation to suitability for agricultural and livestock use, concentrations of one constituent exceeded State of Wyoming agricultural-use standards and no characteristics or constituents exceeded State of Wyoming livestock standards (appendixes 7-1 to 7-4). Sulfate was the only constituent measured at concentrations greater than agricultural-use standards (standard exceeded in 4 of 13 samples). Based on the sparse waterquality data, water from the Wind River aquifer is suitable for livestock use.

\section{Coalmont Formation}

The Coalmont Formation, which contains the Coalmont aquifer, occurs in Carbon County in the southern Saratoga Valley in T. 13 N., Rs. 81 and 82 W. (fig. 18). Montagne (1991, p. 16) described the exposure as "brown coarse-grained arkosic sandstone with a waxy clay matrix." He also stated that the formation can be correlated to the Hanna Formation because of their similar age, structural relations, and similar lithologies. South of Saratoga Valley, the Coalmont Formation is at least 7,000 ft thick in the central part of the North Park Basin of Colorado (Montagne, 1991, p.17).

Little hydrogeologic information is available for the Coalmont aquifer in the county because of limited areal extent. Well-yield measurements from the USGS NWIS database were reviewed for this study. The measurement of well yield for one pumped well was $25 \mathrm{gal} / \mathrm{min}$. There were no reported discharges for springs in the Coalmont Formation in Carbon County.

The chemical composition of ground water in the Coalmont aquifer in Carbon County was characterized and the quality evaluated on the basis of only one new water-quality sample collected during this study (appendix 6). The TDS concentration indicated that the water was fresh (fig. 24H). The sample was a calcium-bicarbonate type water (fig. 24H).
Hardness was moderately hard. Based on the analyses from this one well sample, the water was suitable for domestic, agricultural, and livestock use. The radon concentration measured in this sample did exceed the proposed 300-pCi/L MCL.

\section{Hanna Formation}

The Hanna Formation, which contains the Hanna aquifer, occurs at or near the land surface in the Hanna, Carbon, and Laramie Basins, and the Medicine Bow Mountains (fig. 18). The formation was named by Bowen (1918). Hyden and others (1965) replaced the name Hanna Formation with Dutton Creek Formation in the northern part of the Laramie Basin. Gill and others (1970) determined that the Dutton Creek Formation was one of the many coarse-grained tongues of the Hanna Formation and reinstated the name Hanna Formation.

The formation consists of alternating beds of sandstone, conglomerate, shale, and coal (Bowen, 1918; Dobbin, Bowen and Hoots, 1929; Gill and others, 1970; and Lowry and others, 1973). Bowen (1918) and Dobbin, Bowen and Hoots (1929) noted that the fine-grained sandstones are brown in color, whereas the coarse-grained sandstones are buff to grayish white. The sandstones are massive to thin-bedded, with ripple marks and cross-bedding common. They also noted that the formation was highly feldspathic. The dark-gray, yellowish, and carbonaceous shale occur in alternating beds (Bowen, 1918). Bowen (1918) and Dobbin, Bowen and Hoots (1929) noted that the conglomerates and conglomeratic sandstones contain pebbles of chert, granite, quartzite, sandstone, shale from the Mowry shale, and conglomerate from the Cloverly Formation. Montagne (1991) described the Hanna Formation on Kennaday Peak and Pass Creek Basin as a conglomerate of boulders, cobbles, and pebbles, with a matrix of yellow friable medium-grained sandstone. Dobbin, Bowen and Hoots (1929) also noted that there were locally massive conglomerates. Love and Christiansen (1985) noted the giant quartzite boulders near the Medicine Bow Mountains. Houston and others (1968) mapped the feldspathic sandstone, arkose, carbonaceous shale, conglomeratic sandstone, and thick beds of conglomerate as Hanna and Ferris Formations undivided on the flanks of the Medicine Bow Mountains. Love and Christiansen (1985) mapped the unit as the Hanna Formation in the Medicine Bow Mountains. Gill and others (1970) believe that the formation could be as much as $13,500 \mathrm{ft}$ thick in the deepest part of the Hanna Basin.

Many of the coal beds in the Hanna and Carbon Basins are thick enough and of good enough quality for mining (Dobbin, Bowen and Hoots, 1929). The area was heavily mined in the early twentieth century by the Union Pacific Railroad near the towns of Hanna and Carbon. Today the mining occurs in large strip mines near Hanna (Jones, 1991). The formation also is a source for coalbed methane in the Hanna and Carbon Basins (De Bruin, 2002; Wyoming Oil and Gas Conservation Commission, 2004), and is a potential source for lightweight aggregate (Harris and others, 1985; Harris and Meyer, 1986; Harris, 1996). 
Most wells completed in the Hanna aquifer are for stock use or for monitoring near coal mines. Richter (1981) defined the formation as a "principal aquifer" and grouped the Hanna Formation with other formations of Tertiary age in the Laramie, Shirley, and Hanna Basins into a single hydrogeologic unit defined as the "Tertiary aquifer." The USGS also defined the Hanna aquifer as a "principal aquifer" (Whitehead, 1996) and referred to the aquifer as part of the "Lower Tertiary aquifers" category on the national Principal Aquifers map (U.S. Geological Survey, 2003).

The Hanna aquifer is composed of individual discontinuous sandstone, conglomerate, and coal beds or lenses (Lowry and others, 1973; Richter, 1981). Permeability in the sandstones is intergranular, whereas permeability in the coalbeds is from fractures (Lowry and others, 1973; Richter, 1981). Richter (1981, table IV-2, p. 53) reported that yields from "selected pumping wells completed in channel sandstones and conglomerates produce from 1 to $100 \mathrm{gal} / \mathrm{min}$, whereas wells completed in coal seams generally produce less than 20 gal/min.” In addition, Richter (1981) reported that artesian conditions can occur locally in the Hanna aquifer with flows as large as $20 \mathrm{gal} / \mathrm{min}$.

Richter (1981) summarized hydraulic properties estimated from 10 aquifer tests at or near coal mines in the Hanna Basin. Transmissivity estimates ranged from about 54 to $3,886 \mathrm{ft}^{2} / \mathrm{d}$. Reported yields associated with these tests ranged from 7 to $23 \mathrm{gal} / \mathrm{min}$ and specific capacity values ranged from 0.2 to $14.3(\mathrm{gal} / \mathrm{min}) / \mathrm{ft}$.

Spring-discharge and well-yield measurements from the USGS NWIS database were reviewed for this study. Eight measurements of well yields for pumped wells ranged from 1.3 to $45 \mathrm{gal} / \mathrm{min}$, with a median yield of about $7 \mathrm{gal} / \mathrm{min}$. There were no measured flows for springs discharging from the Hanna Formation in Carbon County.

Dewatering of the Hanna Formation near coal mines in the Hanna Basin was discussed by Kuhn and others (1983, p. 70-71). Examination of water levels in wells in and near dewatered mine pits indicated very complex hydrogeologic conditions. Hydraulic connection between individual permeable beds (sandstone and coal) was highly variable and unpredictable. The investigators also suggested that faulting in the area may provide hydraulic connection between individual permeable beds separated by rocks with low vertical permeability.

The chemical composition of ground water in the Hanna aquifer in Carbon County was characterized and the quality evaluated on the basis of new and historical samples collected from wells. TDS concentrations were highly variable and indicated that the water was fresh, slightly saline, and moderately saline (fig. 24I). Ionic compositions indicated that cation composition was mixed and anion composition generally was dominated by bicarbonate or sulfate. In general, sulfate was the predominant anion in water classified as moderately saline (fig. 24I). Hardness, TDS, and sulfate concentrations significantly increased with increasing well depth (appendix 8).
Hardness varied considerably and ranged from soft to very hard.

Concentrations of some characteristics and constituents in the Hanna aquifer approached or exceeded applicable USEPA or State of Wyoming water-quality standards and could limit the suitability of water for some intended uses. Constituents measured at concentrations greater than health-based standards included fluoride (MCL exceeded in 1 of 29 samples), arsenic (MCL exceeded in 1 of 22 samples), beryllium (MCL exceeded in 5 of 21 samples, although concentrations for an additional 14 samples were reported as being less than $10 \mu \mathrm{g} / \mathrm{L}$ and may or may not exceed the $4 \mu \mathrm{g} / \mathrm{L}$ limit), boron (proposed HAL exceeded in 2 of 24 samples), and radon (proposed 300-pCi/L MCL exceeded in the one sample) (appendixes 7-1 to 7-4). Aesthetic standards for domestic use were exceeded by concentrations of some characteristics and constituents, including $\mathrm{pH}$ (SMCL upper limit exceeded in 6 of 29 samples), TDS (SMCL exceeded in 30 of 39 samples), sulfate (SMCL exceeded in 22 of 34 samples), fluoride (SMCL exceeded in 5 of 29 samples), aluminum (SMCL lower limit exceeded in 2 of 21 samples and SMCL upper limit exceeded in 1 of 21 samples), iron (SMCL exceeded in 5 of 23 samples), and manganese (SMCL exceeded in 12 of 21 samples).

In relation to suitability for agricultural and livestock use, concentrations of 8 characteristics and constituents exceeded State of Wyoming agricultural-use standards and concentrations of 4 exceeded State of Wyoming livestock standards (appendixes 7-1 to 7-4). Characteristics and constituents measured at concentrations greater than agricultural-use standards included $\mathrm{pH}$ (upper limit standard exceeded in 2 of 29 samples), TDS (standard exceeded in 8 of 39 samples), SAR (standard exceeded in 17 of 29 samples), sulfate (standard exceeded in 24 of 34 samples), chloride (standard exceeded in 2 of 30 samples), boron (standard exceeded in 1 of 24 samples), iron (standard exceeded in 1 of 23 samples), and manganese (standard exceeded in 4 of 21 samples). In general, water from the Hanna aquifer was suitable for livestock use but four characteristics and constituents were measured at concentrations greater than livestock standards: $\mathrm{pH}$ (upper limit standard exceeded in 6 of 29 samples), TDS (standard exceeded in 1 of 39 samples), sulfate (standard exceeded in 1 of 34 samples), and chromium (standard exceeded in 1 of 22 samples).

\section{Fort Union Formation}

The Fort Union Formation, which contains the Fort Union aquifer, occurs at or near land surface in the northeast corner of the Great Divide Basin, and west of the town of Rawlins (fig. 18). Harshman (1972, p. 19) speculated that the Fort Union Formation may be present in the southern part of the Shirley Basin in channels eroded into the Steele Shale. The few remnants found are sequences of varicolored soft sandy siltstones that are in part carbonaceous, but no fossils or pollen were recovered for dating. Love and Christiansen (1985) described the Fort Union Formation as "brown to gray sandstone, gray to black shale, and thin coal beds." The forma- 
tion was deposited during the Paleocene Epoch and Laramide Orogeny. During this time, mountain ranges such as the Sierra Madre and the Granite Mountains were rising at the same time structural basins were subsiding. Love (1970, p. C115) reported that during the Paleocene Epoch, the Great Divide Basin was subsiding, but because the deposition of sediment derived from uplift areas filled the basin at the same rate, the surface of the basin remained at nearly the same altitude throughout the epoch. The same thing was happening in and around other basins in Carbon County during the Paleocene Epoch. The climate was warm and humid, and swamps were common. These swamps eventually would become the numerous coal deposits found in the Fort Union Formation today. Welder and McGreevy (1966, sheet 3) reported that the thickness ranges from 700 to about 2,700 ft in the Great Divide and Washakie Basins. There have been numerous small coal mines and prospects, as well as some larger proposed coal mining operations, in the Fort Union Formation of the Wamsutter Arch and Washakie Basin areas (Jones, 1991). The formation also is a source for natural gas, by both conventional and coalbed-methane extraction methods, in the southwestern corner of the State (De Bruin, 2002; Wyoming Oil and Gas Conservation Commission, 2004). Uranium has been reported in the formation west of Rawlins (Harris and others, 1985; Harris, 1996).

The Fort Union Formation contains an important aquifer in the Great Divide and Washakie Basins. As noted previously, Naftz (1996) and Glover and others (1998) combined the Wasatch, Battle Spring, and Fort Union Formations into a single hydrogeologic unit defined as the Wasatch-Fort Union aquifer. The USGS also defined the Fort Union aquifer as a "principal aquifer" (Whitehead, 1996) and combines the formation with many others that compose the "Colorado Plateaus aquifers" category on the national Principal Aquifers map (U.S. Geological Survey, 2003).

Welder and McGreevy (1966) and Collentine and others (1981) described the hydrogeologic characteristics of the Fort Union aquifer throughout the Great Divide and Washakie Basins. Collentine and others (1981, p. 54) noted that many of the individual discontinuous sandstone beds or lenses are hydraulically isolated, although the investigators noted that sandstone and conglomerate beds in the lower part of the formation in some locations may be hydraulically connected because of fractures. Welder and McGreevy (1966, sheet 3) reported that well yields for 11 wells ranged from 3 to 300 $\mathrm{gal} / \mathrm{min}$ and noted "a well penetrating the entire formation where the sandstones are thickest might yield as much as 500 gal/min." Collentine and others (1981) reported that well yields generally are less than $100 \mathrm{gal} / \mathrm{min}$, although yields as high as $300 \mathrm{gal} / \mathrm{min}$ have been reported. Transmissivity generally is less than $335 \mathrm{ft}^{2} /$ day (Collentine and others, 1981).

Most published hydrogeologic and water-quality information describing the Fort Union aquifer is from areas west of Carbon County, including the Great Divide, Washakie, and Green River Basins. The reader is referred to publications by Welder and McGreevy (1966), Collentine and others (1981),
Taylor and others (1986), Naftz (1996), and Mason and Miller (2005) for hydrogeologic and water-quality information describing characteristics of the aquifer outside of Carbon County. Although the publications describe areas outside of the county, they can provide information that may be of some use to readers interested in broader descriptions of the aquifer.

Spring-discharge and well-yield measurements from the USGS NWIS database were reviewed for this study. Five measurements of well yields for pumped wells ranged from 3 to $60 \mathrm{gal} / \mathrm{min}$, with a median yield of $12 \mathrm{gal} / \mathrm{min}$. The yield for one flowing well was $10 \mathrm{gal} / \mathrm{min}$. The measured discharge for one spring was $1 \mathrm{gal} / \mathrm{min}$.

The chemical composition of ground water in the Fort Union aquifer in Carbon County was characterized and the quality evaluated on the basis of new and historical samples collected from wells and one spring. TDS concentrations were highly variable and indicated that water ranged from fresh to briny (fig. 24J). Water that was classified as either moderately saline or briny was co-produced oil and gas water. Ionic compositions indicated that water was either calcium-bicarbonate type, calcium-sulfate type, calcium-chloride type, or sodiumbicarbonate type (fig. 24J). No relation was apparent between water type and salinity. TDS and potassium concentrations significantly increased with increasing well depth (appendix 8). Hardness varied considerably and ranged from soft to very hard, although one-half of samples were classified as very hard and no samples were classified as moderately hard.

Concentrations of some characteristics and constituents in the Fort Union aquifer approached or exceeded applicable USEPA or State of Wyoming water-quality standards and could limit the suitability of waters for some intended uses. Based on a comparison of concentrations to health-based standards, all water was suitable for domestic use with the exception of a beryllium concentration (MCL exceeded in 1 of 4 samples, although one additional concentration was reported as being less than $10 \mu \mathrm{g} / \mathrm{L}$ and may or may not exceed the $4 \mu \mathrm{g} / \mathrm{L}$ MCL) and radon (proposed 300-pCi/L MCL exceeded in the one sample) (appendixes 7-1 to 7-4). Concentrations of several characteristics and constituents exceeded aesthetic standards for domestic use and included pH (SMCL upper limit exceeded in 5 of 11 samples), TDS (SMCL exceeded in all 12 samples), sulfate (SMCL exceeded in 3 of 12 samples), chloride (SMCL exceeded in 4 of 12 samples), fluoride (SMCL exceeded in 1 of 5 samples), and iron and manganese (SMCLs exceeded in 3 of 5 samples). Many characteristic and constituent exceedances were attributable to co-produced oil and gas water samples.

In relation to suitability for agricultural and livestock use, concentrations of 6 characteristics and constituents exceeded State of Wyoming agricultural-use standards and concentrations of 3 exceeded State of Wyoming livestock standards (appendixes 7-1 to 7-4). Characteristics and constituents measured at concentrations greater than agricultural-use standards included TDS and chloride (standards exceeded in 6 of 12 samples); SAR, iron and manganese (standards exceeded in 1 of 5 samples); and sulfate (standard exceeded 
in 4 of 12 samples). In general, water from the Fort Union aquifer was suitable for livestock use, but three characteristics and constituents were measured at concentrations greater than livestock standards: $\mathrm{pH}$ (upper limit standard exceeded in 5 of 11 samples), and TDS and chloride (standards exceeded in 1 of 12 samples). Many characteristic and constituent exceedances were attributable to co-produced oil and gas water samples.

\section{Ferris Formation}

The Ferris Formation, which contains the Ferris aquifer, occurs at or near the land surface around the Hanna Basin and on the northern margin of the Carbon Basin (fig. 18). The formation is both Paleocene (Cenozoic) and Cretaceous (Mesozoic) in age and was named by Bowen (1918). The formation primarily consists of intertonguing beds of gray, brown, and yellow sandstone, light-colored, dark-gray and carbonaceous shale, and numerous thick beds of coal (Bowen, 1918; Dobbin, Bowen and Hoots, 1929; Gill and others, 1970; Lowry and others, 1973). Bowen (1918) and Dobbin, Bowen and Hoots (1929) noted that the basal part of the formation has a zone that is about $1,100 \mathrm{ft}$ thick containing pockets, lenses, and thin beds of conglomerate in a massive buff to yellow sandstone. Dobbin, Bowen and Hoots (1929) noted that the pebbles usually are less than an inch in diameter and are composed of quartzite, chert, jasper, rhyolite, and porphyry. The lower $300 \mathrm{ft}$ of the formation also includes a dark shale (Dobbin, Bowen, and Hoots, 1929). The formation could be as much as $6,500 \mathrm{ft}$ thick.

Many of the coals in the Hanna and Carbon Basins are thick enough and of good enough quality for mining (Dobbin, Bowen and Hoots, 1929). The area was heavily mined in the early twentieth century by the Union Pacific Railroad near the towns of Hanna and Carbon. Today the mining occurs in large strip mines near Hanna (Jones, 1991).

Most wells completed in the Ferris aquifer are for stock use or for monitoring near coal mines. Richter (1981) defined the formation as a "principal aquifer" and grouped the Ferris Formation with other formations of Tertiary age in the Laramie, Shirley, and Hanna Basins into a single hydrogeologic unit defined as the "Tertiary aquifer." The USGS also defined the Ferris aquifer as a "principal aquifer" (Whitehead, 1996) and referred to the aquifer as part of the "Lower Tertiary aquifers" category on the national Principal Aquifers map (U.S. Geological Survey, 2003).

The Ferris aquifer is composed of individual discontinuous sandstone, conglomerate, and coal beds or lenses (Lowry and others, 1973; Richter, 1981). Permeability in the sandstones is intergranular, whereas permeability in the coalbeds is from fractures (Lowry and others, 1973; Richter, 1981). Richter (1981, table IV-2, p. 53) reported well yields ranging from 1 to $100 \mathrm{gal} / \mathrm{min}$.

Richter (1981) summarized hydraulic properties estimated from 10 aquifer tests at or near coal mines. Transmissivity estimates ranged from about 54 to $1,286 \mathrm{ft}^{2} / \mathrm{d}$.
Reported yields associated with these tests ranged from 0.1 to $40 \mathrm{gal} / \mathrm{min}$, and specific capacity values ranged from 0.2 to 20.5 (gal/min)/ft.

A generalized potentiometric-surface map constructed by the Bureau of Land Management (1975, fig. 10, p. 149) shows the direction of ground-water flow for the Ferris aquifer between Seminoe Reservoir and the outcrop of the Hanna Formation (area in Tps. 22 to 24 N., Rs. 83 to 84 W.). Based on this map, ground-water in the aquifer in this area flows to the west towards Seminoe Reservoir.

Spring-discharge and well-yield measurements from the USGS NWIS database were reviewed for this study. Twenty-two measurements of well yields for pumped wells ranged from 0.14 to $300 \mathrm{gal} / \mathrm{min}$, with a median yield of about $4.6 \mathrm{gal} / \mathrm{min}$. There were no measured flows for springs discharging from the Ferris Formation in Carbon County.

The chemical composition of ground water in the Ferris aquifer in Carbon County was characterized and the quality was evaluated on the basis of historical samples collected from wells. TDS concentrations were highly variable and indicated that the water was fresh, slightly saline, and moderately saline; however, only 2 of 31 samples were classified as fresh (fig. 24K). Ionic compositions indicated that cation composition was relatively mixed, and anion composition generally was dominated by bicarbonate or sulfate. In general, sulfate was the predominant anion in waters classified as moderately saline (fig. 24K). Hardness varied considerably and ranged from soft to very hard, although no samples were classified as hard and about 87 percent of the samples were classified as very hard.

Concentrations of some characteristics and constituents in the Ferris aquifer approached or exceeded applicable USEPA or State of Wyoming water-quality standards and could limit the suitability of water for some intended uses. Constituents measured at concentrations greater than health-based standards included arsenic (MCL exceeded in 1 of 27 samples), beryllium (MCL exceeded in 7 of 26 samples, although concentrations in an additional 19 samples were reported as being less than $10 \mu \mathrm{g} / \mathrm{L}$ and may or may not exceed the $4 \mu \mathrm{g} / \mathrm{L}$ MCL), boron (proposed HAL exceeded in 2 of 28 samples), selenium (MCL exceeded in 1 of 23 samples), and zinc (HAL exceeded in 1 of 27 samples) (appendixes 7-1 to 7-4). Aesthetic standards for domestic use were exceeded by concentrations of several characteristics and constituents including $\mathrm{pH}$ (less than the SMCL lower limit in 1 of 29 samples and greater than SMCL upper limit in 1 of 29 samples), TDS (SMCL exceeded in all 31 samples), sulfate (SMCL exceeded in 27 of 31 samples), fluoride (SMCL exceeded in 2 of 31 samples), aluminum (SMCL lower limit exceeded in 2 of 27 samples, although concentrations in an additional 9 samples were reported as being less than $100 \mu \mathrm{g} / \mathrm{L}$ and may or may not exceed the $50 \mu \mathrm{g} / \mathrm{L}$ lower limit), iron (SMCL exceeded in 15 of 28 samples), manganese (SMCL exceeded in 20 of 27 samples), and zinc (SMCL exceeded in 1 of 27 samples).

In relation to suitability for agricultural and livestock use, concentrations of 10 characteristics and constituents exceeded 
State of Wyoming agricultural-use standards and concentrations of 5 exceeded State of Wyoming livestock standards (appendixes 7-1 to 7-4). Characteristics and constituents measured at concentrations greater than agricultural-use standards included TDS (standard exceeded in 22 of 31 samples), SAR (standard exceeded in 10 of 31 samples), sulfate (standard exceeded in 29 of 31 samples), chloride (standard exceeded in 2 of 31 samples), boron (standard exceeded in 2 of 28 samples), iron (standard exceeded in 5 of 28 samples), manganese (standard exceeded in 11 of 27 samples), selenium (standard exceeded in 2 of 23 samples), vanadium (standard exceeded in 2 of 19 samples), and zinc (standard exceeded in 1 of 27 samples). In general, water from the Ferris aquifer was suitable for livestock use but five characteristics and constituents were measured at concentrations greater than livestock standards: $\mathrm{pH}$ (less than the lower limit standard in 1 of 29 samples and greater than the upper limit standard in 1 of 29 samples), TDS and sulfate (standards exceeded in 7 of 31 samples), selenium (standard exceeded in 1 of 23 samples), and vanadium (standard exceeded in 2 of 19 samples).

\section{Mesozoic Hydrogeologic Units}

Mesozoic rocks of Late Cretaceous age occur at or near land surface throughout Carbon County (fig. 25). Mesozoic rock outcrops account for approximately 29 percent of the surface exposures in the county.

The water quality of aquifers in Mesozoic hydrogeologic units varies greatly throughout the county. Recharge to these aquifers generally occurs where the formations are exposed. Near recharge areas, water in these aquifers can be relatively fresh and may be suitable for most uses. These areas are where most domestic, municipal supply, or stock wells are completed. Elsewhere, and with increasing depth (as indicated by co-produced oil and gas water samples) and as the water moves away from the outcrop, the water can have TDS concentrations several times that of seawater and is not suitable for most uses or is only marginally suitable for livestock use. Where deeply buried, only oil or gas wells are completed in Mesozoic hydrogeologic units. Locations of samples from aquifers in Mesozoic hydrogeologic units are shown on figure 25 .

\section{Medicine Bow Formation}

The Medicine Bow Formation, which contains the Medicine Bow aquifer, occurs at or near the land surface around the margins of the Hanna, Carbon, and Laramie Basins (fig. 25). When the formation was named by Bowen (1918), several hundred feet of marine strata were included that have since been assigned to the Fox Hills Sandstone (Dorf, 1938, Gill and others, 1970). Hyden and others (1965) replaced the name Medicine Bow Formation with Foote Creek Formation in the northern part of the Laramie Basin. Gill and others (1970) determined that the rocks assigned to the Foote Creek
Formation are remnants of the lower coal-bearing part of the Medicine Bow Formation.

The Medicine Bow Formation, as described by Bowen (1918) and Dobbin, Bowen and Hoots (1929), contains yellow, gray, and carbonaceous shale, coal, and gray to brown sandstone. The investigators also described some massive white sandstones in the main body of the formation, and a coarsegrained, massive, friable, and easily eroded sandstone that is interbedded with beds of dark-gray shale at the top of the unit. Gill and others (1970) noted that the Medicine Bow Formation is a thick continental unit that was deposited after the withdrawal of the Cretaceous sea. The unit is 400 to $6,200 \mathrm{ft}$ thick. There have been some small coal mines and prospects in the Medicine Bow Formation of the Hanna Basin (Jones, 1991).

Little hydrogeologic information is available for the Medicine Bow aquifer in Carbon County, and few wells are installed in the aquifer. Regardless, Richter (1981) defined the formation as a "principal aquifer" and grouped the Medicine Bow Formation with formations of Tertiary age in the Laramie, Shirley, and Hanna Basins into a single hydrogeologic unit defined as the "Tertiary aquifer." Richter (1981, table IV-2, p. 53) reported that the formation "locally yields water to springs and shallow wells along outcrops, south flank of Freezeout Mountains." The USGS also defined the Medicine Bow aquifer as a "principal aquifer" (Whitehead, 1996) and referred to the aquifer as part of the "Upper Cretaceous aquifers" category on the national Principal Aquifers map (U.S. Geological Survey, 2003). Sandstone and coal beds would likely compose the aquifer in the formation.

Spring-discharge and well-yield measurements from the USGS NWIS database were reviewed for this study. Five measurements of well yields for pumped wells ranged from 4 to $50 \mathrm{gal} / \mathrm{min}$, with a median yield of $25 \mathrm{gal} / \mathrm{min}$. The yield for one flowing well was $1 \mathrm{gal} / \mathrm{min}$. There were no measured discharges for springs in the Medicine Bow Formation in Carbon County.

The chemical composition of ground water in the Medicine Bow aquifer in Carbon County was characterized and the quality was evaluated on the basis of only three historical water-quality samples collected from wells. TDS concentrations indicated that two samples were fresh and one sample was slightly saline (fig. 26A). Ionic compositions indicated that the fresh water was either calcium-bicarbonate type or calcium-sodium-bicarbonate type, whereas the slightly saline water was sodium-sulfate type (fig. 26A). Hardness ranged from moderately hard to very hard.

The quality of water from the Medicine Bow aquifer generally was better than that from most Cretaceous hydrogeologic units in Carbon County. Water-quality samples were only available for three wells in the limited areal extent of the formation in the county, and it is unknown how representative these three samples are of the aquifer. Concentrations of few characteristics and constituents exceeded standards. Based on only three samples, the aesthetic standards (SMCLs) for TDS and sulfate were exceeded in 1 of 3 samples. The State of Wyoming agricultural standard for sulfate was exceeded in 
66 Water Resources of Carbon County, Wyoming
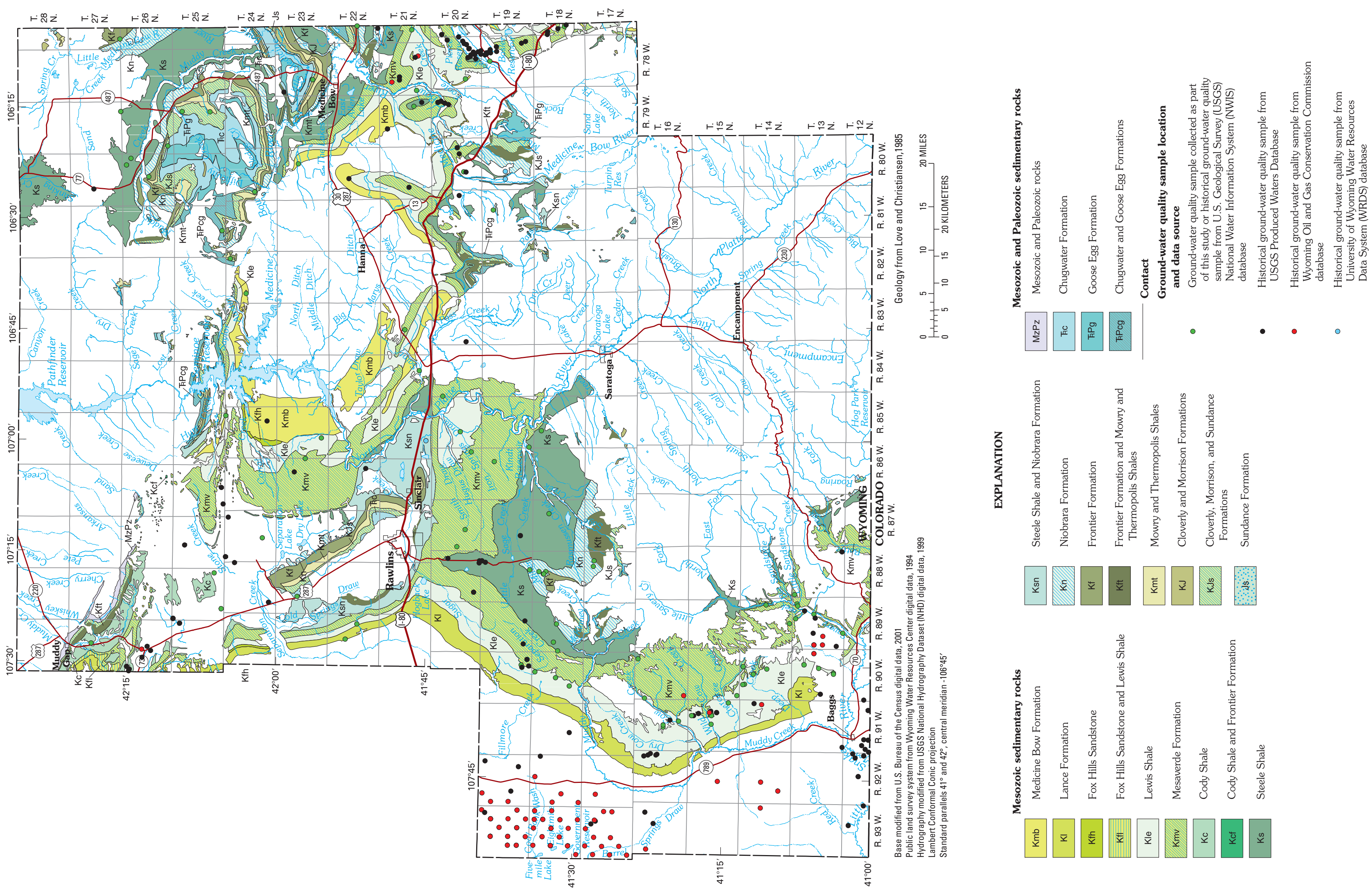
1 of 3 samples. Based on concentrations from only one sample that was analyzed for selected trace elements, the SMCL for iron, and both the SMCL and the State of Wyoming agricultural-use standard for manganese were exceeded.

\section{Lance Formation}

The Lance Formation, which contains the Lance aquifer, occurs at or near the land surface around the margins of the Great Divide and Washakie Basins (fig. 25). The formation consists of fissile, dark-gray, brown, and carbonaceous shale; brown to light brown, very fine-to fine-grained, clayey, calcareous sandstone; coal; and lignite (Berry, 1960, Welder and McGreevy, 1966). It was deposited in a fluvial environment. The unit is as much as 4,540 ft thick (Berry, 1960). There have been some small coal mines, prospects, and proposed mines in the Lance Formation west and north of Rawlins (Jones, 1991). It is also a source for natural gas in the Washakie Basin area (De Bruin, 2002).

Collentine and others (1981) defined the Lance Formation as a "minor aquifer" and "minor water-bearing unit" and grouped the Late Cretaceous-age Lance and Fox Hills Formations with formations of Tertiary age in the Great Divide and Washakie Basins into a hydrogeologic unit defined as the "Tertiary aquifer system." The USGS defined the aquifer as a "principal aquifer" (Whitehead, 1996) and referred to the aquifer as part of the "Upper Cretaceous aquifers" category on the national Principal Aquifers map (U.S. Geological Survey, 2003).

Welder and McGreevy (1966) reported that the groundwater development possibilities of the Lance aquifer in the Great Divide and Washakie Basins were largely unknown. They reported that yields from seven stock wells on the west flank of the Rawlins Uplift ranged from 5 to $30 \mathrm{gal} / \mathrm{min}$ and noted that "it is unlikely that maximum yields of favorably located wells would be as large as $300 \mathrm{gal} / \mathrm{min}$ " (Welder and McGreevy, 1966, sheet 3).

Collentine and others (1981) summarized hydraulic properties for the Lance aquifer throughout the Great Divide and Washakie Basins. The investigators noted that well yields were generally less than $25 \mathrm{gal} / \mathrm{min}$, and transmissivity was low, generally less than $2.7 \mathrm{ft}^{2} / \mathrm{d}$.

Spring-discharge and well-yield measurements from the USGS NWIS database were reviewed for this study. Two measurements of well yields for pumped wells were both $6 \mathrm{gal} / \mathrm{min}$. There were no measured discharges for springs in the Lance Formation in Carbon County.

The chemical composition of ground water in the Lance aquifer in Carbon County was characterized and the quality evaluated on the basis of new and historical samples collected from wells. One ground-water sample was collected during this study from a stock well, but all other samples were historical samples from co-produced oil and gas water. TDS concentrations were highly variable and indicated that water was slightly saline, moderately saline, or very saline (fig. 26B). The one sample that was not a co-produced oil and gas water was a calcium-sulfate water type. Ionic compositions indicated that co-produced oil and gas waters were either sodium-bicarbonate type or sodium-chloride type (fig. 26B). Hardness varied considerably and samples were classified as soft, moderately hard, or very hard.

Based on the few characteristics and constituents analyzed, the concentrations of some characteristics and constituents in the Lance aquifer approached or exceeded applicable USEPA or State of Wyoming water-quality standards and could limit the suitability of water for some intended uses. Most available water-quality analyses were from co-produced oil and gas water, so many characteristic and constituent analyses were not available and could not be compared with health-based, aesthetic, or State of Wyoming agricultural and livestock-use standards (appendixes 6, 7-1 to 7-2). The radon concentration in the one available sample exceeded the proposed 300-pCi/L MCL. Some concentrations from available characteristic and constituent analyses exceeded aesthetic standards for domestic use including $\mathrm{pH}$ (SMCL upper limit exceeded in 2 of 8 samples), TDS (SMCL exceeded in all 8 samples), sulfate (SMCL exceeded in 2 of 8 samples), chloride (SMCL exceeded in 6 of 8 samples), and iron and manganese (SMCLs exceeded in 1 sample).

For available samples, water quality was evaluated in relation to suitability for agricultural and livestock use. Concentrations of 5 characteristics and constituents exceeded State of Wyoming agricultural-use standards and concentrations of 3 exceeded State of Wyoming livestock standards (appendixes 6, 7-1 to 7-2). Characteristics and constituents measured at concentrations greater than agricultural-use standards included TDS (standard exceeded in 7 of 8 samples), sulfate (standard exceeded in 2 of 8 samples), chloride (standard exceeded in 7 of 8 samples), and iron and manganese (standards exceeded in 1 sample). In general, water from the Lance aquifer was suitable for livestock use, but some concentrations of three characteristics and constituents were greater than livestock standards: $\mathrm{pH}$ (upper limit of standard exceeded in 2 of 8 samples), TDS (standard exceeded in 4 of 8 samples), and chloride (standard exceeded in 2 of 8 samples).

\section{Fox Hills Sandstone}

The Fox Hills Sandstone, which contains the Fox Hills aquifer, occurs at or near the land surface throughout the county, although little of it has been mapped (Lowry and others, 1973). Several hundred feet of marine strata that had been assigned to the lower Medicine Bow Formation were renamed as the Fox Hills Sandstone (Dorf, 1938; Gill and others, 1970). It also has been mapped with the Lewis Shale (Lowry and others, 1973; Love and Christiansen, 1985). The Fox Hills Sandstone is pale yellowish-gray, very fine-to finegrained sandstone with a few beds of olive-gray to dark-gray sandy shale, thin carbonaceous shale, and thin impure beds of coal (Gill and others, 1970). It is a shallow-marine, barrier-bar, and beach deposit that reflects the transition from the underlying marine shale (Lewis Shale) to overlying fluvial 
(Lance and Medicine Bow Formations) units. Gill and others (1970) reported the thickness of the Fox Hills Sandstone as 200-700 ft.

Richter (1981) defined the Lance Formation as a "minor aquifer" and grouped the Late Cretaceous-age Lance and Fox Hills Formations with Tertiary-age formations in the Great Divide and Washakie Basins into a hydrogeologic unit defined as the "Tertiary aquifer system." The USGS defined the aquifer as a "principal aquifer" (Whitehead, 1996) and referred to the aquifer as part of the "Upper Cretaceous aquifers" category on the national Principal Aquifers map (U.S. Geological Survey, 2003).

Little hydrogeologic information is available for the Fox Hills aquifer in Carbon County. Collentine and others (1981) reported that transmissivity values ranged from about 1.3 to about $2.7 \mathrm{ft}^{2} / \mathrm{d}$, based on oil-field data in the Great Divide and Washakie Basins. Spring-discharge and well-yield measurements from the USGS NWIS database were reviewed for this study, but no measurements were available for the Fox Hills aquifer in Carbon County.

The chemical composition of ground water in the Fox Hills aquifer in Carbon County was characterized and the quality was evaluated on the basis of only one co-produced oil and gas sample. Based on the TDS concentration, the water was classified as moderately saline (fig. 26C). The sample was a sodium-bicarbonate type water (fig. 26C). Hardness was soft. Based on the few analyses available for this one sample, the water was not suitable for domestic or agricultural use.

\section{Lewis Shale}

The Lewis Shale occurs at or near the land surface between the basins and uplifts of the county (fig. 25). It is a gradational change from the overlying Fox Hills Sandstone and the underlying Almond Formation (Mesaverde Group) (fig. 9). The middle sandy unit, called the Dad Sandstone Member (Gill and others, 1970), is a tongue of the Fox Hills Sandstone. The Lewis Shale is a dark-gray to olive-gray to buff, silty to sandy shale with dark-gray to brown carbonaceous deposits, fossiliferous limestone, siltstone concretions, very fine-to medium-grained, yellowish-gray to brown sandstones, and yellowish-gray non-resistant siltstones (Berry, 1960; Welder and McGreevy, 1966; Gill and others, 1970; Lowry and others, 1973). The Lewis Shale was deposited in a marine environment. The thickness is difficult to determine because of its gradational contact with the Fox Hills Sandstone, and because the two formations are sometimes mapped together and sometimes separately. Gill and others (1970) measured 2,300 ft of Lewis Shale in the northwestern part of the Hanna Basin and 2,600 ft in the southeastern part of the Carbon Basin. The formation is a source of natural gas in the Washakie Basin-Wamsutter Arch area and a source of oil in the northwestern part of the Hanna Basin (De Bruin, 2002).

Because shale is the predominant lithology in the Lewis Shale, and shale generally yields small quantities of water, the formation generally is considered to contain a poor aquifer in the Great Divide and Washakie Basin areas (Berry, 1960; Welder and McGreevy, 1966). It is usually defined as a confining unit in the Great Divide and Washakie Basins (Collentine and others, 1981) and in the area of the Laramie, Shirley, and Hanna Basins (Richter, 1981). In the Great Divide and Washakie Basins, Collentine and others (1981) defined the Lewis Shale as a regional confining layer (aquitard) between the underlying Mesaverde aquifer and the overlying Tertiary aquifer system. These previous investigators also noted that some sandstone lenses in the formation will yield small quantities of water to wells.

Little hydrogeologic information is available for the Lewis Shale in Carbon County. Collentine and others (1981) reported transmissivity values ranging from less than 1 to about $6.7 \mathrm{ft}^{2} / \mathrm{d}$, based on oil-field data in the Great Divide and Washakie Basins.

Spring-discharge and well-yield measurements from the USGS NWIS database were reviewed for this study. Four measurements of well yields for pumped wells ranged from 1.5 to $18 \mathrm{gal} / \mathrm{min}$, with a median yield of about $2 \mathrm{gal} / \mathrm{min}$. Three measured discharges for springs ranged from 1 to $2 \mathrm{gal} / \mathrm{min}$ with a median discharge of $1 \mathrm{gal} / \mathrm{min}$.

The chemical composition of ground water in the Lewis Shale in Carbon County was characterized and the quality evaluated on the basis of new and historical samples collected from wells and springs. About one-half of the samples were co-produced oil and gas water. TDS concentrations were highly variable and indicated that water was fresh to briny (fig. 26D). Water that was classified as either very saline or briny was co-produced oil and gas water. Ionic compositions indicated that cation composition generally was dominated by sodium, and anion composition was highly variable (fig. 26D). TDS, sodium, and chloride concentrations significantly increased with increasing well depth (appendix 8). Hardness varied considerably and ranged from soft to very hard, although more than one-half of samples were classified as very hard and no samples were classified as hard.

Concentrations of some characteristics and constituents in the Lewis Shale approached or exceeded applicable USEPA or State of Wyoming water-quality standards and could limit the suitability of water for some intended uses. Constituents measured at concentrations greater than health-based standards included fluoride (MCL exceeded in 2 of 9 samples), boron (proposed HAL exceeded in 4 of 9 samples), radon (proposed 300-pCi/L MCL exceeded in both samples), and uranium (MCL exceeded in 1 of 2 samples) (appendixes 6, 7-1 to 7-4). Concentrations for some characteristics and constituents exceeded aesthetic standards for domestic use including $\mathrm{pH}$ (less than SMCL lower limit in 2 of 16 samples and greater than SMCL upper limit in 3 of 16 samples), TDS (SMCL exceeded in all 19 samples), sulfate (SMCL exceeded in 7 of 19 samples), chloride (SMCL exceeded in 6 of 19 samples), fluoride (SMCL exceeded in 5 of 9 samples), aluminum (SMCL exceeded in 1 of 3 samples), and manganese (SMCL exceeded in 3 of 6 samples). Most characteristic and constitu- 
ent exceedances were attributable to co-produced oil and gas water samples.

In relation to suitability for agricultural and livestock use, concentrations of 8 characteristics and constituents exceeded State of Wyoming agricultural-use standards and concentrations of 4 exceeded State of Wyoming livestock standards (appendixes 7-1 to 7-4). Many characteristics and constituents were measured at concentrations greater than agriculturaluse standards and included $\mathrm{pH}$ (upper limit exceeded in 1 of 16 samples), TDS (standard exceeded in 12 of 19 samples), SAR (standard exceeded in 5 of 9 samples), sulfate (standard exceeded in 7 of 19 samples), chloride (standard exceeded in 10 of 19 samples), aluminum (SMCL lower limit exceeded in 1 of 3 samples), boron (standard exceeded in 3 of 9 samples), and manganese (standard exceeded in 1 of 6 samples). Some water from the Lewis Shale was unsuitable for livestock use and four characteristics and constituents were measured at concentrations greater than livestock standards: $\mathrm{pH}$ (less than lower limit in 2 of 16 samples and greater than upper limit in 3 of 16 samples), TDS (standard exceeded in 8 of 19 samples), sulfate (standard exceeded in 3 of 19 samples), and chloride (standard exceeded in 4 of 19 samples). Many characteristic and constituent exceedances were attributable to co-produced oil and gas water samples.

\section{Mesaverde Group or Formation}

The Mesaverde Group or Formation, which contains the Mesaverde aquifer, occurs at or near the land surface between the basins and uplifts of the county (fig. 25). It is a gradational change from the underlying Steele and Cody Shales to the overlying Lewis Shale (fig. 9). The Mesaverde Formation occurs in the Lamont area, where much of the formation was eroded prior to and following the deposition of the Teapot Sandstone Member (Reynolds, 1966, 1967). Reynolds (1966, 1967) indicated that the Mesaverde Formation was completely eroded from areas north and west of Lamont. The rest of the county has rocks of the Mesaverde Group, as assigned by Gill and others (1970), which consists of the Almond Formation, Pine Ridge Sandstone (Teapot Sandstone Member equivalent), Allen Ridge Formation (western and central Carbon County), Rock River Formation (eastern Carbon County), and Haystack Mountains Formation (fig. 9). In the greater Green River Basin, the Ericson Sandstone is equivalent to the Pine Ridge and Allen Ridge Formations (Love and others, 1993). Previous studies (Bowen, 1918; Dobbin, Bowen and Hoots, 1929) referred to an upper sequence (sandstone, shale, carbonaceous shale, and coal), a middle sequence (sandstone, carbonaceous shale, and coal of fresh-and brackish-water origin), and a lower sequence (marine sandstone and shale).

The undifferentiated Mesaverde Formation in the northwest corner of the county is described as light gray to brown, very fine-to medium-grained sandstone interbedded with gray to dark-gray shale, siltstone, lenses of carbonaceous shale, thin lenses of lignite, and thick sections of coal (Berry, 1960; Reynolds, 1966; Welder and McGreevy, 1966). Reynolds
$(1966,1967)$ described the Teapot Sandstone Member as a lower light-gray to white sandstone and an upper sequence of reddish-brown to white weathered carbonaceous siltstone and sandstone beds. Reynolds (1966) indicated that the Mesaverde Formation is of littoral, shallow marine, brackish, and nonmarine origins. Berry (1960) and Welder and McGreevy (1966) gave a maximum thickness of 2,800 ft.

The Almond Formation of the Mesaverde Group intertongues with the overlying Lewis Shale (fig. 9) (Gill and others, 1970). The Almond Coal Group was described by Schultz (1909) and raised to formation rank by Sears (1926). It is described as interbedded sandstone, siltstone, shale, and coal (Welder and McGreevy, 1966; Gill and others, 1970). The very fine-grained sandstone is white to pale yellowish-gray to dusky yellow, and it weathers to brown (Schultz, 1909; Gill and others, 1970). The shales are dark-gray to olive-gray or brownish-gray to brownish-black and carbonaceous to coaly (Schultz, 1909; Gill and others, 1970). Gill and others (1970) indicated that the lower part is fluvial sandstone, shale, and coal, whereas the upper part is shallow-water marine sandstone, lagoonal or brackish-water rocks, and marine shale (tongues of Lewis Shale). The formation ranges from 0 to $600 \mathrm{ft}$ thick.

The Pine Ridge Sandstone of the Mesaverde Group is a white to pale yellowish-gray to light-gray, fine-to mediumgrained, non-marine sandstone (Dobbin, Hoots, and others, 1929; Gill and others, 1970). Gill and others (1970) indicate that this formation is equivalent to the Teapot Sandstone Member of the Mesaverde Formation. The Pine Ridge Sandstone also contains beds of light-gray carbonaceous shale, gray sandy shale, and beds of impure coal (Dobbin, Hoots and others, 1929; Gill and others, 1970). Gill and others (1970) noted that this is a fluvial deposit during the eastward regressive tongue of the Mesaverde Group, with a thickness of 60 to $450 \mathrm{ft}$.

The Allen Ridge Formation of the Mesaverde Group intertongues with the Rock River Formation in the northwestern Laramie Basin (fig. 9). It consists of an upper unit of reddish-brown carbonaceous shale, shallow-water marine sandstone, and dark brownish-gray ironstone-bearing shale (Bergstrom, 1959; Gill and others, 1970). The middle unit consists of fossiliferous shale, siltstone, and sandstone (Bergstrom, 1959; Gill and others, 1970). The lower unit consists of brown to rusty-brown fluvial sandstone and shale that contains many beds of carbonaceous shale, very little coal, and numerous ironstone concretions (Bergstrom, 1959; Gill and others, 1970). Gill and others (1970) noted that the unit is entirely non-marine in the Great Divide and Washakie Basins. They also indicated the formation has a thickness of 0 to $1,275 \mathrm{ft}$.

Darton and Siebenthal (1909) first described the rocks of the Rock River Formation of the Mesaverde Group in the northern Laramie Basin, but the formation was named by Gill and others (1970). It grades westerly into the Allen Ridge Formation (fig. 9) and easterly into the Pierre Shale (Gill and others, 1970). Gill and others (1970) described it as light-gray to light-brown, very fine-to fine-grained sandstone that is 

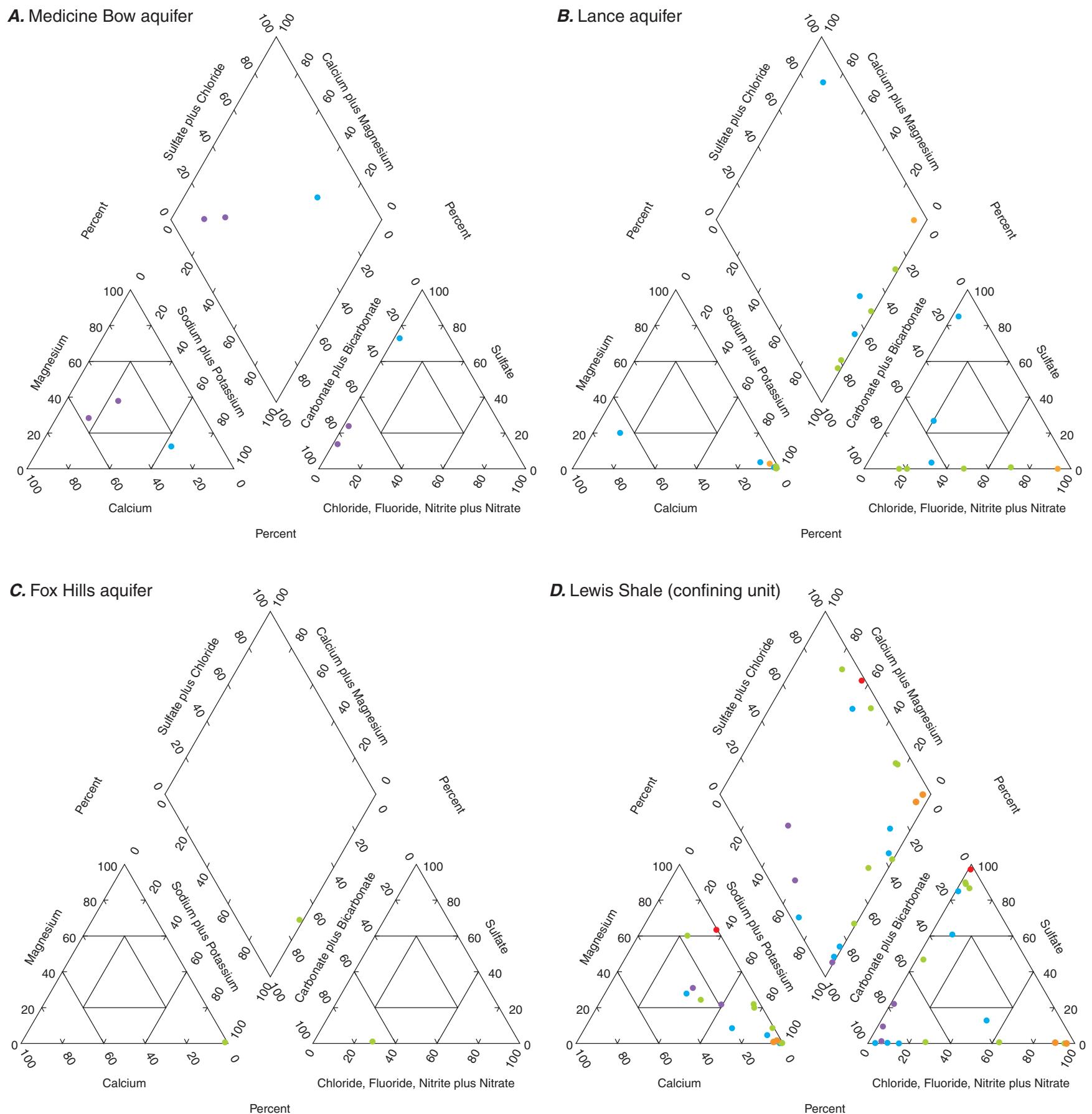

EXPLANATION

Total dissolved-solids concentration, in milligrams per liter, and U.S. Geological Survey salinity classification

- Less than 1,000; fresh

- 1,000-3,000; slightly saline

- 3,000-10,000; moderately saline

- 10,000-35,000; very saline

- More than 35,000; briny

Figure 26. Trilinear diagrams showing major-ion composition and dissolved-solids concentrations for ground-water samples from aquifers in Upper Cretaceous hydrogeologic units, Carbon County, Wyoming. 
E. Mesaverde aquifer

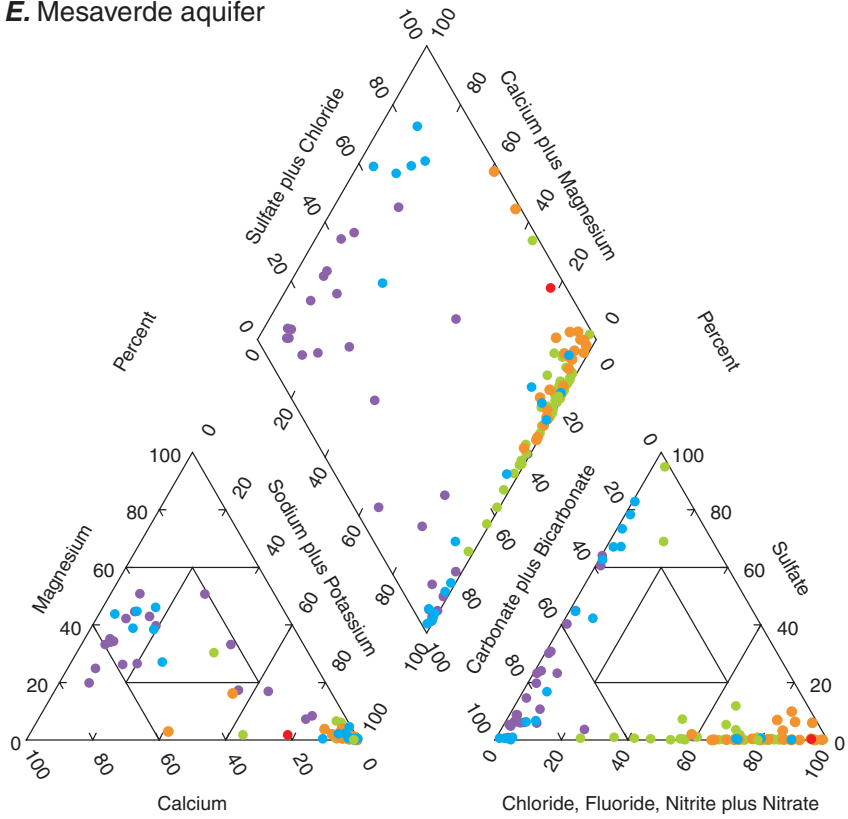

Percent

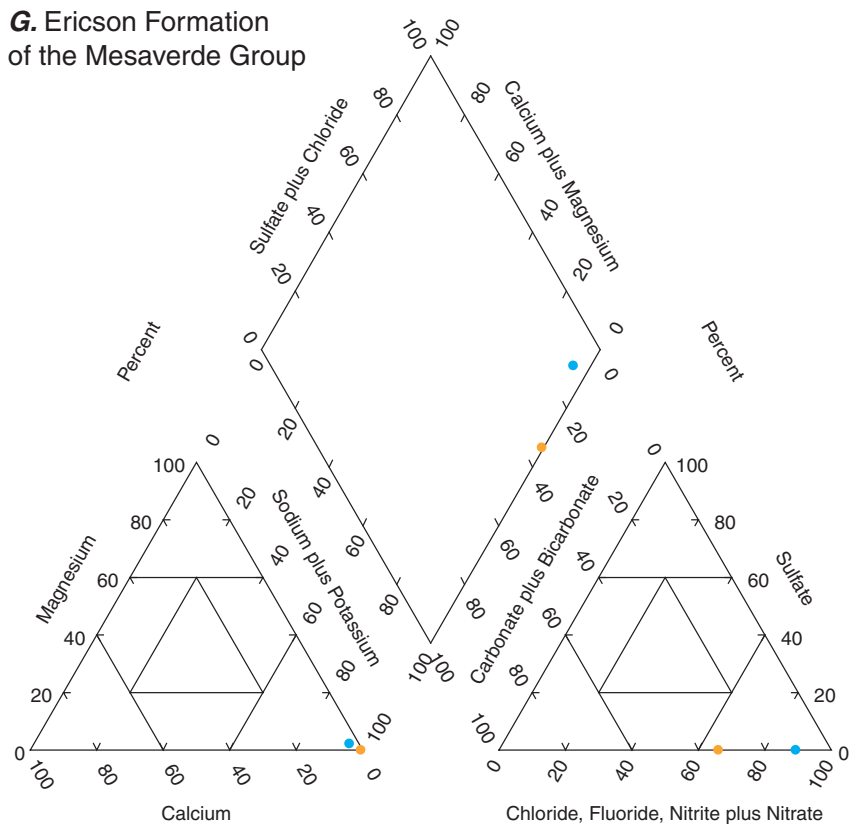

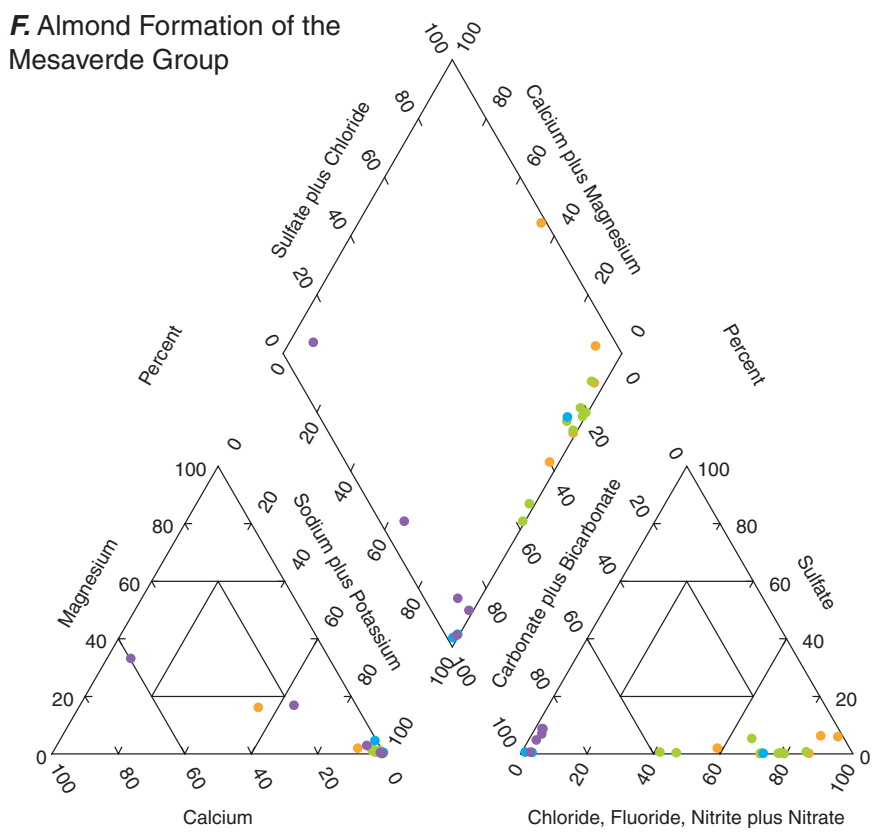

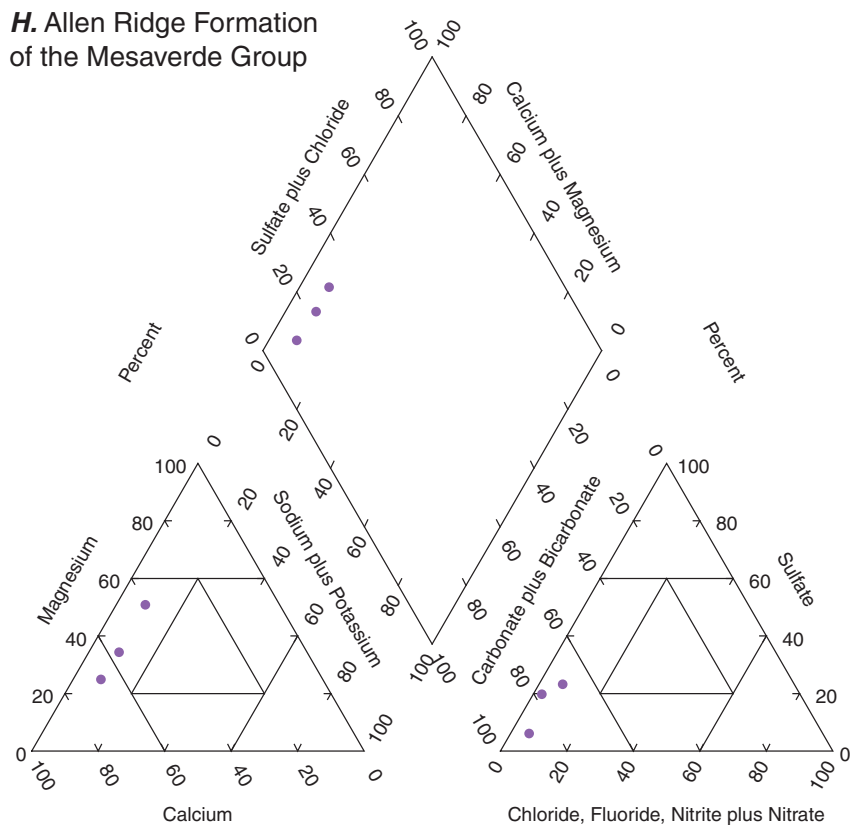

Percent

Percent

\section{EXPLANATION}

Total dissolved-solids concentration, in milligrams per liter, and U.S. Geological Survey salinity classification

- Less than 1,000; fresh

- 1,000-3,000; slightly saline

- 3,000-10,000; moderately saline

- 10,000-35,000; very saline

- More than 35,000; briny

Figure 26. Trilinear diagrams showing major-ion composition and dissolved-solids concentrations for ground-water samples from aquifers in Upper Cretaceous hydrogeologic units, Carbon County, Wyoming.-Continued 

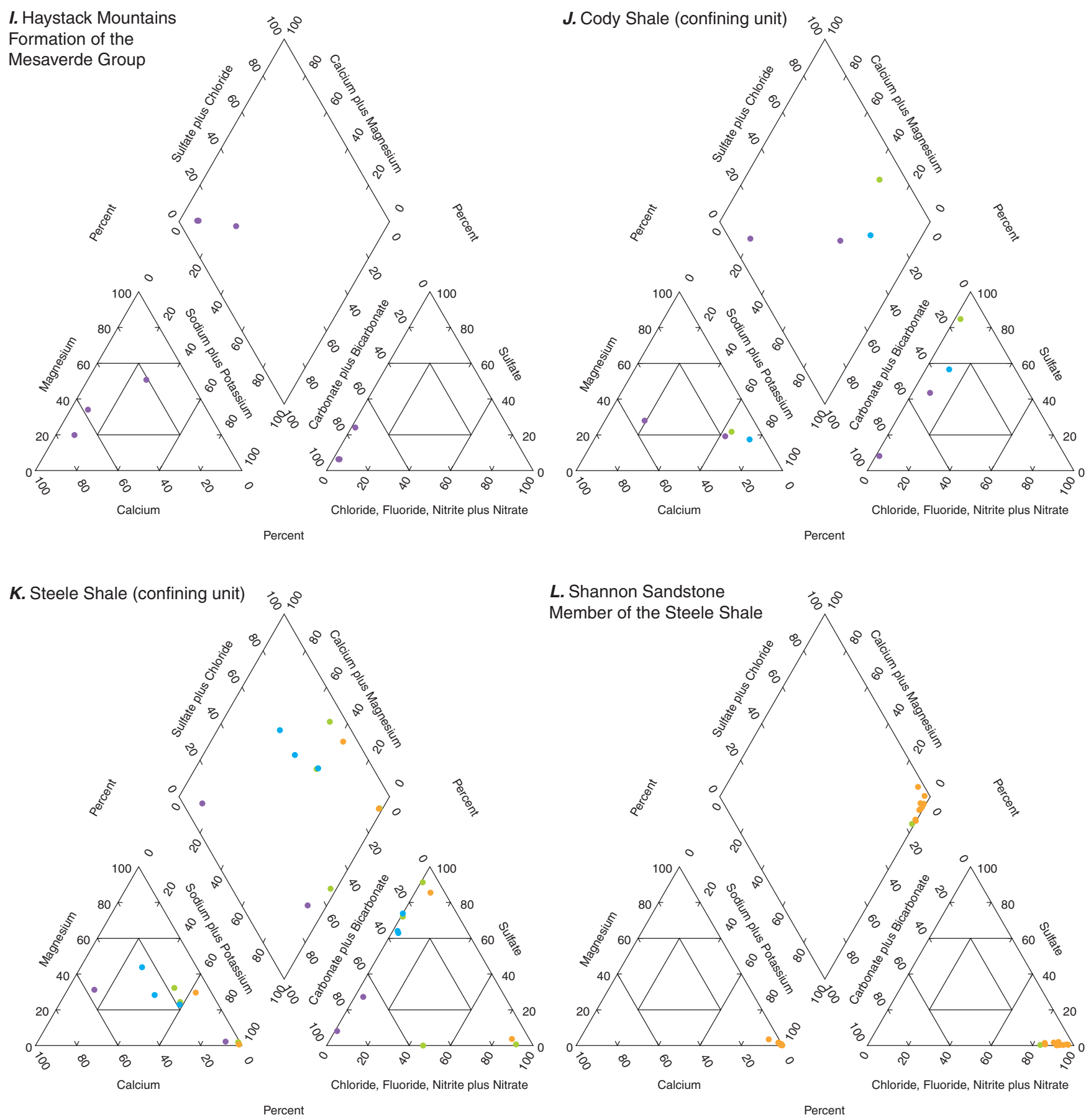

\section{EXPLANATION}

Total dissolved-solids concentration, in milligrams per liter, and U.S. Geological Survey salinity classification

- Less than 1,000; fresh

- 1,000-3,000; slightly saline

- 3,000-10,000; moderately saline

- 10,000-35,000; very saline

Figure 26. Trilinear diagrams showing major-ion composition and dissolved-solids concentrations for ground-water samples from aquifers in Upper Cretaceous hydrogeologic units, Carbon County, Wyoming.-Continued 

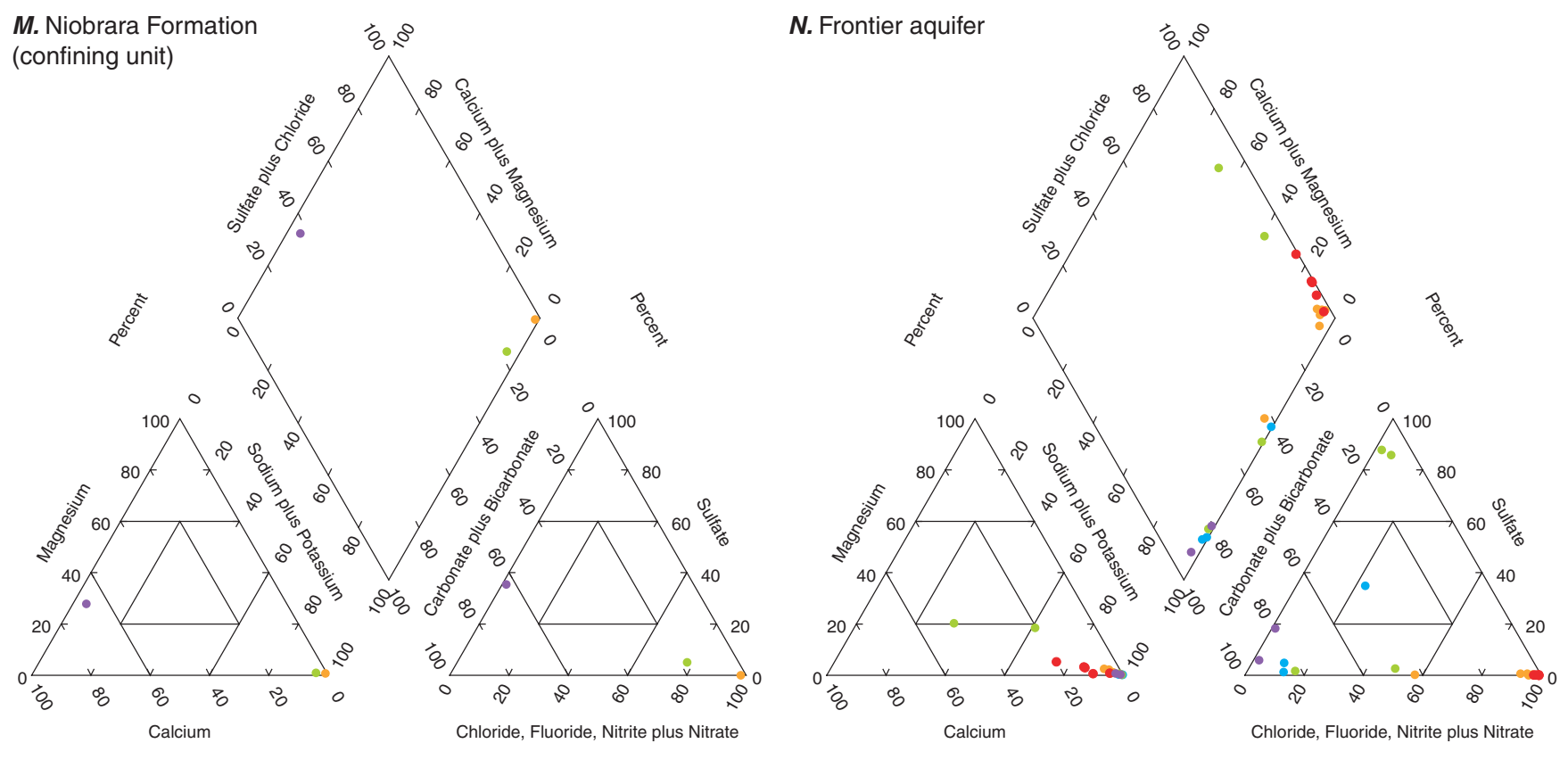

Percent

\section{EXPLANATION}

Total dissolved-solids concentration, in milligrams per liter, and U.S. Geological Survey salinity classification

- Less than 1,000; fresh

- 1,000-3,000; slightly saline

- 3,000-10,000; moderately saline

- 10,000-35,000; very saline

- More than 35,000; briny

Figure 26. Trilinear diagrams showing major-ion composition and dissolved-solids concentrations for ground-water samples from aquifers in Upper Cretaceous hydrogeologic units, Carbon County, Wyoming.-Continued

locally shaly, with a few beds of soft sandy shale. They noted that this shallow-water marine unit has a maximum thickness of about $1,565 \mathrm{ft}$.

The Haystack Mountains Formation is the oldest unit of the Mesaverde Group and has a gradational contact with the underlying Steele Shale (fig. 9). Gill and others (1970) named three sandstone members of the unit: Hatfield (in upper part), O'Brien Spring (in middle part), and Tapers Ranch (at base) Sandstone Members. They described the unit as pale yellowish-gray, very fine to fine-grained sandstone interbedded with gray to brownish-gray shale and sandy shale containing fossiliferous concretions of ironstone, limestone, or argillaceous sandstone. The sandstone is a near-shore to off-shore marine deposit, whereas the shales are deep marine deposits. Gill and others (1970) gave the thickness as 850 to $2,550 \mathrm{ft}$.

There have been numerous small coal mines, prospects, and proposed mines in the Mesaverde Formation or Group in the western part of Carbon County (Jones, 1991). The Mesaverde Group is a source of natural gas, by both conventional and coalbed-methane extraction methods, in the Washakie and Hanna Basins and the Wamsutter Arch (De Bruin, 2002; Wyoming Oil and Gas Conservation Commission, 2004). In the Washakie Basin, the production zones are separable into the Almond Formation and the Ericson Sandstone, which is the greater Green River Basin equivalent to the Pine Ridge and Allen Ridge Formations (Love and others, 1993; De Bruin, 2002). The Mesaverde Formation or Group has been a source of oil in the Carbon Basin area (De Bruin, 2002) and also is a potential source for refractory clay and dimensional or ornamental stone near Rawlins (Harris and others, 1985; Harris and Meyer, 1986; Harris, 1996).

The Mesaverde Group or Formation is defined as an aquifer by all previous investigators, even though hydrogeologic characteristics of the individual formations composing the unit can vary. Collentine and others (1981) defined the formation as a "major aquifer" in the Great Divide and Washakie Basins, and Richter (1981) defined the formation as a "secondary aquifer" in the general vicinity of the Laramie, Shirley, and Hanna Basins (including Carbon County). Domestic or stock wells generally are completed only in areas where the forma- 
tion is exposed. The USGS defined the Mesaverde aquifer as a "principal aquifer" (Whitehead, 1996) and referred to the formation as part of the "Upper Cretaceous aquifers" category on the national Principal Aquifers map (U.S. Geological Survey, 2003).

In the Rawlins Uplift area, Berry (1960) noted limited potential for development of the Mesaverde aquifer. He noted that much of the formation was unsaturated in the area, although the formation was saturated downdip in some locations and that "the sandstone beds probably will yield water to wells along the western flank of the Rawlins Uplift" (Berry, 1960 , p. 22). He also noted that the area in which wells could be located in the saturated zone of the formation in the Rawlins Uplift area was small because of the steep dip of the beds in the area.

Welder and McGreevy (1966) reported that the groundwater development possibilities of the undifferentiated Mesaverde Formation in the Great Divide and Washakie Basins were largely unknown. They reported that yields from two wells were 5 and $40 \mathrm{gal} / \mathrm{min}$. They also noted that groundwater development possibilities in the Almond Formation of the Mesaverde Group "are largely unknown but probably fair" and noted that yields of 20 to $100 \mathrm{gal} / \mathrm{min}$ were possible (Welder and McGreevy, 1966, sheet 3).

Collentine and others (1981) summarized hydraulic properties for the Mesaverde aquifer throughout the Great Divide and Washakie Basins, including a discussion describing hydraulic characteristics of the aquifer within western Carbon County (eastern margin of the Great Divide and Washakie Basins). The investigators reported that well yields in this area ranged from 15 to $40 \mathrm{gal} / \mathrm{min}$, and that specific capacity values estimated from aquifer tests on these same wells ranged from less than 2 to greater than $20(\mathrm{gal} / \mathrm{min}) / \mathrm{ft}$. Transmissivity values estimated from two of these wells were reported to be less than $402 \mathrm{ft}^{2} / \mathrm{d}$. Transmissivity values estimated from five drill stem tests were low and ranged from about 0.5 to about $9 \mathrm{ft}^{2} / \mathrm{d}$. In addition, the investigators constructed a generalized potentiometric map for the same area within Carbon County (Collentine and others, 1981, p. 61). The map shows that ground-water flow in the area generally is towards the west, away from the outcrop areas (and source of recharge), and towards the Great Divide and Washakie Basin centers.

Richter (1981) summarized hydraulic properties for the Mesaverde aquifer in the Laramie, Shirley, and Hanna Basin areas. In these areas, they reported that the Mesaverde Group contained a good aquifer that was laterally continuous and semi-confined. The investigators reported that intergranular and fracture permeabilities were "large" and that yields from wells commonly ranged from 1 to $33 \mathrm{gal} / \mathrm{min}$. They also noted that faulted and fractured zones within the group were much more productive. The Pine Ridge Sandstone was reported to be the most productive unit within the Mesaverde Group; reported yields ranged from 1 to $50 \mathrm{gal} / \mathrm{min}$, and springs discharged 1 to $5 \mathrm{gal} / \mathrm{min}$.

A potentiometric map constructed by Freethey and Cordy (1991, plate 5E) shows the direction of ground-water flow in the Mesaverde aquifer including parts within Carbon County (fig. 15). The investigators defined the Mesaverde aquifer as consisting not only of rocks of the Mesaverde Group, but also of rocks from the Lance Formation, Fox Hills Sandstone, and the Lewis Shale.

Spring-discharge and well-yield measurements from the USGS NWIS database were reviewed for this study. Sixteen measurements of well yields for pumped wells ranged from 2 to $100 \mathrm{gal} / \mathrm{min}$, with a median yield of about $18 \mathrm{gal} / \mathrm{min}$. Four measurements of discharge for flowing wells in the Mesaverde aquifer ranged from 5 to $57 \mathrm{gal} / \mathrm{min}$, with a median yield of about $35 \mathrm{gal} / \mathrm{min}$. Five measurements of discharge for flowing wells in the Almond Formation ranged from 6 to $120 \mathrm{gal} / \mathrm{min}$, with a median yield of $13.5 \mathrm{gal} / \mathrm{min}$. Fourteen measured discharges for springs ranged from 0.2 to $35 \mathrm{gal} / \mathrm{min}$, with a median discharge of about $4 \mathrm{gal} / \mathrm{min}$.

The chemical composition of ground water in the Mesaverde aquifer in Carbon County was characterized and the quality evaluated on the basis of new and historical samples collected from wells and springs. Samples collected from aquifers in formations composing the Mesaverde Group are plotted on the same trilinear diagram (fig. 26E), and if possible, on individual trilinear diagrams (figs. $26 \mathrm{~F}$ to $26 \mathrm{I}$ ). The following discussion describing ionic composition is based on the trilinear diagram showing all samples from aquifers in the various formations comprising the Mesaverde Group (fig. 26E). More than one-half of the samples were co-produced oil and gas water. TDS concentrations were highly variable and indicated that water was fresh to briny (fig. 26E). Water that was classified as moderately saline to briny was co-produced oil and gas water. In fresh or slightly saline water, cation composition was relatively mixed but sulfate or bicarbonate were the predominant anions (fig. 26E). In the moderately saline to briny water associated with co-produced oil and gas water, sodium and chloride were the predominant ions (fig. 26E). TDS, sodium, potassium, bicarbonate and chloride concentrations significantly increased with increasing well depth (appendix 8). Hardness, magnesium, and sulfate concentrations significantly decreased with increasing well depth (appendix 8). Hardness varied considerably and ranged from soft to very hard.

For comparison to water-quality standards, characteristics and constituents for aquifers in the various formations comprising the Mesaverde Group were not separated for the following discussion; however, some characteristic and constituent boxplots are presented for both the entire Mesaverde aquifer and aquifers in individual formations comprising the Mesaverde Group (appendixes 6, 7-1 to 7-4). Concentrations of some characteristics and constituents in the Mesaverde aquifer approached or exceeded applicable USEPA or State of Wyoming water-quality standards and could limit the suitability of waters for some intended uses. Constituents measured at concentrations greater than health-based standards included fluoride (MCL exceeded in 3 of 27 samples), boron (proposed HAL exceeded in 5 of 26 samples), radon (proposed 300-pCi/L MCL exceeded in 4 of 6 samples), and zinc 
(HAL exceeded in 1 of 11 samples). Many aesthetic standards for domestic use were exceeded by concentrations of some characteristics and constituents, and included $\mathrm{pH}$ (less than the SMCL lower limit in 13 of 119 samples and greater than the SMCL upper limit in 14 of 119 samples), TDS (SMCL exceeded in 117 of 130 samples), sulfate (SMCL exceeded in 20 of 128 samples), chloride (SMCL exceeded in 85 of 130 samples), fluoride (SMCL exceeded in 6 of 27 samples), iron (SMCL exceeded in 33 of 62 samples), and manganese (SMCL exceeded in 7 of 20 samples). Most characteristic and constituent exceedances were attributable to co-produced oil and gas water samples.

In relation to suitability for agricultural and livestock use, concentrations of 8 characteristics and constituents exceeded State of Wyoming agricultural-use standards and concentrations of 4 exceeded State of Wyoming livestock standards (appendixes 7-1 to 7-4). Many characteristics and constituents were measured at concentrations greater than agriculturaluse standards and included TDS (standard exceeded in 88 of 130 samples), SAR (standard exceeded in 13 of 38 samples), sulfate (standard exceeded in 22 of 128 samples), chloride (standard exceeded in 87 of 130 samples), boron (standard exceeded in 4 of 26 samples), iron (standard exceeded in 19 of 62 samples), manganese (standard exceeded in 5 of 20 samples), and zinc (standard exceeded in 1 of 9 samples). Some water from the Mesaverde aquifer was unsuitable for livestock use and four characteristics and constituents were measured at concentrations greater than livestock standards: $\mathrm{pH}$ (less than the standard lower limit in 13 of 119 samples and greater than the standard upper limit in 14 of 119 samples), TDS (standard exceeded in 70 of 130 samples), sulfate (standard exceeded in 2 of 128 samples), and chloride (standard exceeded in 63 of 130 samples). Many characteristic and constituent exceedances were attributable to co-produced oil and gas water samples.

\section{Cody Shale}

The Cody Shale is equivalent to the Steele Shale and Niobrara Formations (fig. 9) and occurs in the northwestern part of Carbon County where the Niobrara Formation is poorly developed or missing (fig. 25) (Weitz and Love, 1952; Reynolds, 1966; Gill and others, 1970). It is described as gray soft shale with thin gray sandstone and siltstone beds (Weitz and Love, 1952; Weimer and Guyton, 1961; Welder and McGreevy, 1966). Weitz and Love (1952) noted a smoky-gray limy shale at the base of the unit. There is a minor amount of bentonite in the unit (Weimer and Guyton, 1961, Welder and McGreevy, 1966). Weimer and Guyton (1961) indicated that this marine shale is $4,500 \mathrm{ft}$ thick.

Because shale is the predominant lithology in the Cody Shale, and shale generally yields small quantities of water, the formation generally is considered to contain a poor aquifer in the Great Divide and Washakie Basin areas (Welder and McGreevy, 1966). In the Great Divide and Washakie Basins west of the Rawlins Uplift, Collentine and others (1981) defined the Cody Shale as a regional confining layer (aquitard) between the overlying Mesaverde aquifer and the underlying Frontier aquifer. The USGS defined the formation as a "confining unit" (Whitehead, 1996). These previous investigators also noted that some sandstone lenses are present in the formation and will yield small quantities of water to wells, although water likely is highly mineralized.

Little hydrogeologic information is available for the Cody Shale in Carbon County. Spring-discharge and wellyield measurements from the USGS NWIS database were reviewed for this study. Seven measurements of well yields for pumped wells ranged from 1.5 to $33 \mathrm{gal} / \mathrm{min}$, with a median yield of about $11 \mathrm{gal} / \mathrm{min}$. The yield for one flowing well was $10 \mathrm{gal} / \mathrm{min}$. There were no measured discharges for springs in the Cody Shale in Carbon County.

The chemical composition of ground water in the Cody Shale in Carbon County was characterized and the quality evaluated on the basis of only three new and two historical water-quality samples collected from wells. TDS concentrations were highly variable and indicated that water ranged from fresh to moderately saline (fig. 26J). Fresh water was classified as either calcium-bicarbonate or sodium-bicarbonate-sulfate type. The water samples classified as slightly saline or moderately saline were sodium-sulfate types (fig. 26J). Hardness for all samples was very hard.

Concentrations of some characteristics and constituents in the Cody Shale approached or exceeded applicable USEPA or State of Wyoming water-quality standards and could limit the suitability of water for some intended uses. Most water was suitable for domestic use but concentrations of one constituent exceeded health-based standards (appendixes 6, 7-1 to 7-4). Radon was the only constituent measured at concentrations greater than health-based standards (proposed 300-pCi/L MCL exceeded in all three samples), although the arsenic concentration in one sample equaled the MCL (based on only three samples). Compared to health-based standards, aesthetic standards for domestic use were exceeded by more characteristics and constituents and more frequently and included TDS (SMCL exceeded in 3 of 5 samples), sulfate (SMCL exceeded in 2 of 5 samples), and manganese (SMCL exceeded in all 3 samples).

In relation to suitability for agricultural and livestock use, concentrations of 5 characteristics and constituents exceeded State of Wyoming agricultural-use standards and concentrations of 2 exceeded State of Wyoming livestock standards (appendixes 6, 7-1 to 7-4). Characteristics and constituents measured at concentrations greater than agricultural-use standards included TDS (standard exceeded in 2 of 5 samples), SAR (standard exceeded in 2 of 4 samples), sulfate (standard exceeded in 3 of 5 samples), chloride (standard exceeded in 1 of 4 samples), and manganese (standard exceeded in 1 of 3 samples). In general, almost all water from the Cody Shale is suitable for livestock use because only TDS and sulfate (standards exceeded in 1 of 5 samples) were infrequently measured at concentrations exceeding livestock standards. 


\section{Steele Shale}

The Steele Shale occurs throughout the basins of Carbon County, except in the northwestern part of the county, where it cannot be differentiated from the underlying Niobrara Formation and both units are referred to as the Cody Shale (fig. 25). It has gradational contacts with the overlying Mesaverde Formation as well as with the underlying Niobrara Formation (fig. 9). It is a dark-gray shale with some layers of limestone, sandstone, siltstone, and bentonite (Dobbin, Bowen and Hoots, 1929; Weitz and Love, 1952; Berry, 1960; Harshman, 1968, 1972; Gill and others, 1970; Naftz and Barclay, 1991). Sandstone is more common in the upper parts of the formation. The formation was deposited in a marine environment. The thickness varies from 2,300 to 5,000 ft, depending on how the upper and lower gradational contacts are chosen (Gill and others, 1970). The formation is a source for oil and natural gas in the county, with two named production zones-the Shannon and Sussex Sandstones (De Bruin, 2002). The Washakie Basin area has mostly gas production, whereas the Kindt, Hanna, Carbon and Laramie Basins have mostly oil production (De Bruin, 2002). The formation also is a potential source for brick clay and bentonite, which had been mined at the Owyhee historic bentonite (wilkinite) mining area (Harris and others, 1985; Harris, 1996).

Because shale is the predominant lithology in the Steele Shale, and shale generally yields small quantities of water, the formation generally is considered to contain a poor aquifer in the Rawlins Uplift and the Great Divide and Washakie Basin areas, and throughout Carbon County (Berry, 1960; Welder and McGreevy, 1966; Lowry and others, 1973). In the Great Divide and Washakie Basins west of the Rawlins Uplift, Collentine and others (1981) defined the Steele Shale as a regional confining layer (aquitard) between the overlying Mesaverde aquifer and the underlying Frontier aquifer. The USGS defined the formation as a "confining unit" (Whitehead, 1996). These previous investigators also noted that some sandstone lenses are present in the formation and will yield small quantities of water to wells, although water likely was highly mineralized.

Little hydrogeologic information is available for the Steele Shale in Carbon County. Within the Steele Shale, Richter (1981, p. 73) considered the Shannon Sandstone Member to be a "reliable, but undeveloped, source of ground water." The investigator reported that water in the unit was under confined conditions, and artesian flows ranged from 1 to $25 \mathrm{gal} / \mathrm{min}$ at selected petroleum wells.

Spring-discharge and well-yield measurements from the USGS NWIS database were reviewed for this study. Seven measurements of well yields for pumped wells ranged from 5 to $30 \mathrm{gal} / \mathrm{min}$, with a median yield of $20 \mathrm{gal} / \mathrm{min}$. Two measured discharges for springs were 0 and $2 \mathrm{gal} / \mathrm{min}$.

The chemical composition of ground water in the Steele Shale in Carbon County was characterized and the quality evaluated on the basis of new and historical samples collected from wells and springs. TDS concentrations were highly variable and indicated that water ranged from fresh to very saline (fig. 26K). Cation composition in most waters generally was mixed (fig. 26K). Anion composition was predominantly bicarbonate in fresh water, predominantly sulfate in slightly saline water, and predominantly either chloride or sulfate in moderately saline or very saline water (fig. 26K). In three coproduced oil and gas water samples, sodium was the predominant cation and bicarbonate and chloride were the predominant anions. Chloride concentrations significantly increased with increasing well depth (appendix 8). Hardness varied considerably and ranged from soft to very hard, although more than one-half of the samples were classified as very hard.

Concentrations of some characteristics and constituents in the Steele Shale approached or exceeded applicable USEPA or State of Wyoming water-quality standards and could limit the suitability of water for some intended uses. Concentrations of seven characteristics and constituents exceeded health-based standards (appendixes 7-1 to 7-4). Constituents measured at concentrations greater than health-based standards included antimony, arsenic, selenium, and uranium (MCLs exceeded in 1 of 3 samples); boron (proposed HAL exceeded in 2 of 8 samples); molybdenum and nickel (HALs exceeded in 1 of 3 samples); radon (proposed 300-pCi/L MCL exceeded in 1 of 3 samples); and nitrate (MCL exceeded in 1 of 7 samples). In comparison to health-based standards, aesthetic standards for domestic use were exceeded by more characteristics and constituents and more frequently, including pH (SMCL upper limit exceeded in 1 of 10 samples), TDS (SMCL exceeded in 12 of 13 samples), sulfate (SMCL exceeded in 8 of 13 samples), chloride (SMCL exceeded in 4 of 11 samples), iron (SMCL exceeded in 1 of 4 samples), manganese (SMCL exceeded in 2 of 4 samples), and selenium (SMCL exceeded in 1 of 3 samples).

In relation to suitability for agricultural and livestock use, concentrations of 10 characteristics and constituents exceeded State of Wyoming agricultural-use standards and concentrations of 5 exceeded State of Wyoming livestock standards (appendixes 7-1 to 7-4). Characteristics and constituents measured at concentrations greater than agricultural-use standards included TDS (standard exceeded in 6 of 13 samples); SAR (standard exceeded in 4 of 8 samples); sulfate (standard exceeded in 8 of 13 samples); chloride (standard exceeded in 4 of 11 samples); boron (standard exceeded in 2 of 8 samples); cobalt, lithium, nickel, and selenium (standards exceeded in 1 of 3 samples); and manganese (standard exceeded in 2 of 4 samples). In general, water from the Steele Shale is suitable for livestock use; however, five characteristics and constituents were measured at concentrations greater than livestock standards: $\mathrm{pH}$ (upper limit standard exceeded in 1 of 10 samples), TDS (standard exceeded in 4 of 13 samples), sulfate (standard exceeded in 2 of 13 samples), chloride (standard exceeded in 2 of 11 samples), and selenium (standard exceeded in 1 of 3 samples).

The chemical composition of ground water in the Shannon Sandstone Member of the Steele Shale in Carbon County was characterized and the quality evaluated on the basis of historical samples collected from wells. All of the samples were 
co-produced oil and gas water. TDS concentrations were high and all but one water sample was classified as very saline; the remaining sample was classified as moderately saline (fig. 26L). Ionic compositions indicated that all co-produced water was sodium-chloride type (fig. 26L). TDS, sodium, and chloride concentrations significantly increased with increasing well depth (appendix 8). Hardness varied considerably and ranged from soft to very hard, although more than two-thirds of samples were classified as very hard. Because of very high salinity (TDS) and chloride concentrations (appendix 7-2), co-produced oil and gas water from the Shannon Sandstone Member generally is unsuitable for all uses.

\section{Niobrara Formation}

The Niobrara Formation occurs throughout the basins of Carbon County (fig. 25), except in the northwestern part of the county where it cannot be differentiated from the overlying Steele Shale and both units are referred to as the Cody Shale (fig. 9). It has a gradational contact with the overlying Steele Shale (fig. 9). It is a dark-gray calcareous shale with some light-colored layers of limestone, chalk, and sandstone, (Dobbin, Bowen and Hoots, 1929; Weitz and Love, 1952; Berry, 1960; Harshman, 1968, 1972). There are some thin layers of white crystalline calcite (Dobbin, Bowen and Hoots, 1929). Hale (1961) noted that the Niobrara Formation is lighter in color and more calcareous than the overlying Steele Shale. The formation was deposited in a marine environment. The thickness varies from $700 \mathrm{ft}$ in the Hanna and Carbon Basins (Dobbin, Bowen and Hoots, 1929) to 2,000 ft in the Washakie Basin (Welder and McGreevy, 1966). The formation is a source for oil in the western part of the county, as well as a source for natural gas in the Washakie Basin (De Bruin, 2002).

Like the previously discussed Lewis, Cody, and Steele Shales, shale is the predominant lithology in the Niobrara Formation and the formation generally is considered to contain a poor aquifer in the Rawlins Uplift and Great Divide and Washakie Basin areas and throughout Carbon County (Berry, 1960; Welder and McGreevy, 1966; Lowry and others, 1973). In the Great Divide and Washakie Basins west of the Rawlins Uplift, Collentine and others (1981) defined the Niobrara Formation as a regional confining layer (aquitard) between the overlying Mesaverde aquifer and the underlying Frontier aquifer. The USGS defined the formation as a "confining unit" (Whitehead, 1996). These previous investigators also noted that sandstone lenses are present in the formation and will yield small quantities of water to wells, although water is likely highly mineralized.

Little hydrogeologic information is available for the Niobrara Formation in Carbon County. Richter (1981, table IV-4, p. 62) reported a transmissivity value of about $10 \mathrm{ft}^{2} /$ day for one well in an oil and gas field in Carbon County (T. 24 N., R. 86 W.). Spring-discharge and well-yield measurements from the USGS NWIS database were reviewed for this study. There were no measured well yields in the Niobrara
Formation in Carbon County. The measured discharge for one spring was $0.1 \mathrm{gal} / \mathrm{min}$.

The chemical composition of ground water in the Niobrara Formation in Carbon County was characterized and the quality evaluated on the basis of only three historical waterquality samples collected from two wells and one spring. Ionic compositions indicated that the fresh water sample was classified as calcium-bicarbonate type (fig. 26M). The moderately saline and very saline water were co-produced oil and gas water and were classified as sodium-chloride type (fig. 26M). Hardness for all three samples was very hard.

Based on the few characteristics and constituents analyzed, the water sample classified as fresh (from a spring) is suitable for domestic, agricultural, and livestock use-the only domestic standard exceeded was manganese (aesthetic SMCL) and no agricultural or livestock-use standards were exceeded (appendixes 7-1 and 7-2). Based on the few characteristics and constituents analyzed, TDS and chloride concentrations in the remaining two co-produced oil and gas water samples exceeded both State of Wyoming agricultural and livestockuse standards. The sulfate concentration in one sample exceeded the agricultural-use standard. Water-quality analyses were available only for three samples in the county and it is unknown how representative these three samples are of the formation.

\section{Frontier Formation}

The Frontier Formation, which contains the Frontier aquifer, is present throughout the basins of the county, with outcrops occurring near the uplifts (fig. 25). It is predominately a dark-gray shale with beds of sandstone near the top (Wall Creek Sandstone Member). In the Shirley Basin, Harshman $(1968,1972)$ described the lower part of the formation as dark-gray carbonaceous shale and the upper part as similar shale with interbedded gray to brownish-gray fine to medium-grained sandstone. At the top, Harshman (1968, 1972) described the Wall Creek Sandstone as a series of fine to coarse-grained buff to greenish-gray sandstone beds that are interbedded with dark-gray shale. He also noted that the basal part can be a reddish to purplish-gray siltstone or sandy siltstone in some areas, whereas other areas have a basal part that is a gray silty sandstone and shale. In the Hanna and Carbon Basins, the Frontier Formation is described as a darkgray to black shale and the Wall Creek Sandstone Member is described as sandstone interbedded with some shale (Dobbin, Bowen and Hoots, 1929). In the western part of the county, the Frontier Formation is described as gray to grayish-brown calcareous silty to sandy shale that has lenses of bentonite and beds of fine-to medium-grained sandstone (Berry, 1960; Merewether and Cobban, 1972). Merewether and Cobban (1972) referred to the lower part as the Belle Fourche Shale Member and the upper part as the Wall Creek Sandstone Member. They described an unnamed middle member as brownish-gray carbonaceous siltstone and shale or silty very fine to fine-grained sandstone. 
The Frontier Formation is a marine deposit that accumulated on shallow shelves as channel deposits and near-shore and offshore bars (Merewether and others, 1979). The Frontier Formation ranges from 500 to 1,230 ft thick (Merewether and Cobban, 1972). The Wall Creek Sandstone Member ranges from $40 \mathrm{ft}$ in the eastern part of the county (Dobbin, Hoots and others, 1929) to about $350 \mathrm{ft}$ in the western part of the county (Merewether and Cobban, 1972).

The Frontier Formation is a source for oil and gas in the county (De Bruin, 2002). Most of the gas production occurs north of Rawlins and in the Washakie Basin, whereas most of the oil production occurs in the area of the Hanna, Carbon and Laramie Basins (De Bruin, 2002). The formation also is a potential source for iron and manganese in the Como Bluff area (Harris and others, 1985; Harris, 1996).

The Frontier Formation is defined as an aquifer by previous investigators. Collentine and others (1981) defined the formation as a "secondary aquifer" confined above by shale of the Cody Shale or Niobrara Formation and below by the Mowry Shale in the Great Divide and Washakie Basins. Similarly, Richter (1981) defined the formation as a "secondary aquifer" in the general vicinity of the Laramie, Shirley, and Hanna Basins (including Carbon County). Domestic or stock wells generally are completed only in areas where the formation is exposed.

In the Rawlins Uplift area, Berry (1960, p. 20) noted that sandstone beds in the Frontier Formation "yield moderate amounts of water." He noted that water in the Frontier aquifer generally is under confined conditions (artesian pressure) and that wells completed in the aquifer will flow at some locations. He reported that one well in the Miller Hill area south of the Rawlins Uplift area yielded $50 \mathrm{gal} / \mathrm{min}$ and that as much as $100 \mathrm{gal} / \mathrm{min}$ might be obtained from other locations.

Richter (1981) reported that little hydraulic information was available describing the Frontier aquifer in the general vicinity of the Laramie, Shirley, and Hanna Basins, but development potential for ground-water supplies was "good." $\mathrm{He}$ reported that water in the aquifer was semiconfined or artesian depending on confining layer continuity.

Collentine and others (1981) summarized hydraulic properties for the Frontier aquifer in the Great Divide and Washakie Basins. The area of the aquifer within Carbon County, on the eastern margin of the Great Divide and Washakie Basins, was considered the most "productive." Reported yields ranged from 1 to $100 \mathrm{gal} / \mathrm{min}$. Transmissivity values from water wells were estimated to range from 2,010 to $2,680 \mathrm{ft}^{2} /$ day. Reported specific capacity values ranged from 0.3 to 30 (gal/min)/ft. Transmissivity values estimated from drill stem tests generally were less than about $13 \mathrm{ft}^{2} / \mathrm{day}$, although a maximum value of $871 \mathrm{ft}^{2} /$ day was reported. Transmissivity variation was attributed to varying percentages of bentonite and shale within tested open intervals. In addition, the investigators constructed a generalized potentiometric map for the Frontier aquifer within the basins, including Carbon County (Collentine and others, 1981, figure V-4, p. 63). The map shows that ground-water flow in the area generally is towards the west, away from the outcrop areas (and source of recharge), and towards the Great Divide and Washakie Basin centers.

Spring-discharge and well-yield measurements from the USGS NWIS database were reviewed for this study. Four measurements of well yields for pumped wells ranged from 5 to $50 \mathrm{gal} / \mathrm{min}$, with a median yield of about $35 \mathrm{gal} / \mathrm{min}$. The yield for one flowing well was $1 \mathrm{gal} / \mathrm{min}$. There were no measured flows for springs discharging from the Frontier Formation in Carbon County.

The chemical composition of ground water in the Frontier aquifer in Carbon County was characterized and the quality evaluated on the basis of historical samples collected from wells and one spring. TDS concentrations were highly variable and indicated that salinity ranged from fresh to briny (fig. 26N). Sodium was the predominant cation in all but one water sample, regardless of salinity classification. Water samples classified as either very saline or briny were coproduced oil and gas water, and chloride was the predominant anion. Bicarbonate was the predominant anion in all water samples classified as fresh and in most water samples classified as slightly saline. The predominant anion in moderately saline waters was bicarbonate, sulfate, or a mixture of bicarbonate and chloride. Concentrations of most characteristics and constituents (TDS, hardness, calcium, magnesium, sodium, potassium, sulfate, and chloride) significantly increased with increasing well depth (appendix 8). Hardness was either soft or very hard; more than one-half of samples were classified as very hard.

Based on the few characteristics and constituents analyzed, some concentrations in samples from the Frontier aquifer approached or exceeded applicable USEPA or State of Wyoming water-quality standards and could limit the suitability of water for some intended uses. Although most measured salinities would preclude domestic use, boron was the only measured constituent with a concentration that exceeded a health-based standard (proposed HAL exceeded in 1 of 5 samples) (appendixes 7-1 to 7-4). Aesthetic standards for domestic use were exceeded by concentrations of some characteristics and constituents, including $\mathrm{pH}$ (SMCL upper limit exceeded in 4 of 17 samples), TDS (SMCL exceeded in 20 of 21 samples), sulfate (SMCL exceeded in 3 of 21 samples), chloride (SMCL exceeded in 14 of 21 samples), and fluoride (SMCL exceeded in 1 of 5 samples). Most characteristic and constituent exceedances were attributable to co-produced oil and gas water samples.

In relation to suitability for agricultural and livestock use, concentrations of 5 characteristics and constituents exceeded State of Wyoming agricultural-use standards and concentrations of 3 exceeded State of Wyoming livestock standards (appendixes 7-1 to 7-4). Characteristics and constituents measured at concentrations greater than agricultural-use standards included TDS (standard exceeded in 17 of 21 samples), SAR (standard exceeded in 4 of 5 samples), sulfate (standard exceeded in 3 of 21 samples), chloride (standard exceeded in 17 of 21 samples), and boron (standard exceeded in 1 of 
5 samples). In general, water from the Frontier aquifer is suitable for livestock use, but three characteristics and constituents were measured at concentrations greater than livestock standards: $\mathrm{pH}$ (upper limit standard exceeded in 4 of 17 samples), and TDS and chloride (standards exceeded in 12 of 21 samples). Most characteristic and constituent exceedances were attributable to co-produced oil and gas water samples.

\section{Mowry Shale}

The Mowry Shale is present throughout the basins of the county, with outcrops occurring near the uplifts (fig. 25). It is a gray to deep-brown to black siliceous shale with beds of bentonite (Dobbin, Bowen and Hoots, 1929; Berry, 1960; Welder and McGreevy, 1966; Harshman, 1972). Harshman (1972) noted that some of the bentonite beds are 2 to $3 \mathrm{ft}$ thick and some are associated with shale beds that contain considerable calcium carbonate. The Mowry Shale is a marine shale that contains numerous fish scales. It ranges in thickness from 110 to $525 \mathrm{ft}$ (Welder and McGreevy, 1966; Harshman, 1972). The Mowry Shale is a source for oil and some natural gas in the Ferris-Lost Soldier and Laramie Basin areas (De Bruin, 2002). The formation also is a source of bentonite (Harris and others, 1985; Harris, 1996).

Like the previously discussed Lewis, Cody, and Steele Shales, and Niobrara Formation of Mesozoic age, shale is the predominant lithology in the Mowry Shale and it generally is considered to contain a poor aquifer in the Rawlins Uplift, Great Divide and Washakie Basin areas and throughout Carbon County (Berry, 1960; Welder and McGreevy, 1966; Lowry and others, 1973). In the Great Divide and Washakie Basins west of the Rawlins Uplift, Collentine and others (1981) defined the Mowry Shale as a regional confining layer (aquitard). The USGS defined the formation as a "confining unit" (Whitehead, 1996). Little to no hydrogeologic and waterquality information was available to characterize the Mowry Shale in Carbon County, so the formation was not assessed as a part of this study.

\section{Thermopolis Shale and Muddy Sandstone}

The Thermopolis Shale is present throughout the basins of the county, with outcrops occurring near the uplifts (fig. 25). It is a gray to black shale with thin beds of sandstone, siltstone, and bentonite (Dobbin, Bowen and Hoots, 1929; Berry, 1960; Welder and McGreevy, 1966; Harshman, 1972). The Muddy Sandstone, sometimes referred to as the Muddy Sandstone Member of the Thermopolis Shale, is a buff to gray silty fine to medium-grained sandstone (Berry, 1960; Harshman, 1972). Harshman (1972) described four parts of the Thermopolis Shale: (1) a basal gray to black carbonaceous shale; (2) the Muddy Sandstone; (3) a brown to gray finegrained sandstone interbedded with siltstone and shale that has a lignite bed at the top with associated thin, limy sandstone beds; and (4) an interval of sandy siltstone and shale at the top interbedded with siliceous shale that is typical of the Mowry Shale. The Thermopolis Shale primarily is of marine origin; an exception is the third unit of Harshman (1972), which is of paludal (marsh-like) origin. Curry (1962) indicated that the Muddy Sandstone is of shallow marine origin in some parts and terrestrial and fresh-water origin in other parts. The Thermopolis Shale (including the Muddy Sandstone) is 100 to $250 \mathrm{ft}$ thick (Lowry and others, 1973). The Muddy Sandstone is a source for oil and natural gas in the county, with most of the natural gas production occurring in the southwestern part of the county (De Bruin, 2002). The Thermopolis Shale also is a potential source for iron and manganese in the Como Bluff area (Harris and others, 1985; Harris, 1996).

Like the previously discussed Late Cretaceous-age Lewis, Cody, Steele, and Mowry Shales, and Niobrara Formation in Carbon County, shale is the predominant lithology in the Early Cretaceous-age Thermopolis Shale, with the exception of the Muddy Sandstone. The formation generally is considered to contain a poor aquifer in the Rawlins Uplift, Great Divide and Washakie Basin areas and throughout Carbon County (Berry, 1960; Welder and McGreevy, 1966; Lowry and others, 1973). In the Great Divide and Washakie Basins west of the Rawlins Uplift, Collentine and others (1981) defined the Thermopolis Shale as a leaky confining unit. Similarly, Richter (1981) defined the formation as a leaky confining unit in the Laramie, Shirley, and Hanna Basin areas. The USGS defined the formation as a "confining unit" (Whitehead, 1996).

In Carbon County, most wells in the Thermopolis Shale are completed in the Muddy Sandstone within oil and gas fields. Little hydrogeologic and water-quality information was available to characterize the Thermopolis Shale (including the Muddy Sandstone). Richter (1981) reported that transmissivity values for three oil and gas wells completed in the Muddy Sandstone in Carbon County ranged from less than 1 (two wells) to $1.34 \mathrm{ft}^{2} /$ day. Spring-discharge and well-yield measurements from the USGS NWIS database were reviewed for this study. The measured yield for one pumped well was less than $1 \mathrm{gal} / \mathrm{min}$. No discharges were measured for springs in the Muddy Sandstone in Carbon County.

The chemical composition of ground water in the Muddy Sandstone in Carbon County was characterized and the quality evaluated on the basis of historical samples collected from wells. All but one sample was co-produced oil and gas water. TDS concentrations were highly variable and indicated that waters were fresh to very saline (fig. 27A). The one sample that was not a co-produced water was classified as fresh and was a sodium-bicarbonate water type. Sodium was the predominant cation regardless of salinity classification. Chloride was the predominant anion in water classified as either moderately saline or very saline. The predominant anion in slightly saline water was bicarbonate, sulfate, or a mixture of bicarbonate, sulfate and chloride. Hardness varied considerably and ranged from soft to very hard, although no samples were classified as hard.

Based on the few characteristics and constituents analyzed, the concentrations of some characteristics and constituents in the Muddy Sandstone approached or exceeded applicable USEPA or State of Wyoming water-quality standards 
and could limit the suitability of water for some intended uses. Most available water-quality analyses were from co-produced water samples, so many characteristic and constituent analyses were not available and could not be compared with healthbased, aesthetic, or State of Wyoming agricultural and livestock-use standards (appendixes 7-1 to 7-4). Although most measured salinities would preclude domestic use, no measured constituents exceeded a health-based standard (appendixes 7-1 and 7-2). Aesthetic standards for domestic use were exceeded by some characteristics or constituents including $\mathrm{pH}$ (less than SMCL lower limit in 2 of 17 samples and greater than SMCL upper limit in 2 of 17 samples), TDS (SMCL exceeded in 17 of 18 samples), sulfate (SMCL exceeded in 4 of 17 samples), and chloride (SMCL exceeded in 15 of 18 samples).

In relation to suitability for agricultural and livestock use, concentrations of three measured characteristics and constituents exceeded State of Wyoming agricultural and livestockuse standards (appendixes 7-1 to 7-4). Several characteristics and constituents were measured at concentrations greater than agricultural-use standards and included TDS and chlo- ride (standards exceeded in 16 of 18 samples), and sulfate (standard exceeded in 4 of 17 samples). Many water samples from the Muddy Sandstone were unsuitable for livestock use, and three characteristics and constituents were measured at concentrations greater than livestock standards: $\mathrm{pH}$ (less than lower limit in 2 of 17 samples and greater than upper limit in 2 of 17 samples), and TDS and chloride (standards exceeded in 11 of 18 samples).

\section{Cloverly Formation}

The Early Cretaceous-age Cloverly Formation, which contains the Cloverly aquifer, is present throughout the basins of the county, with outcrops occurring near the uplifts (fig. 25B). The Cloverly Formation in Carbon County can be divided into three parts: (1) an upper fine-to coarse-grained white to buff to gray quartzose sandstone, (2) a middle sequence of green shale to gray carbonaceous shale with interbedded buff fine-grained well-cemented silty sandstone and some thin bentonite layers, and (3) a lower light-gray to white fine to medium-grained to conglomeratic sandstone with chert

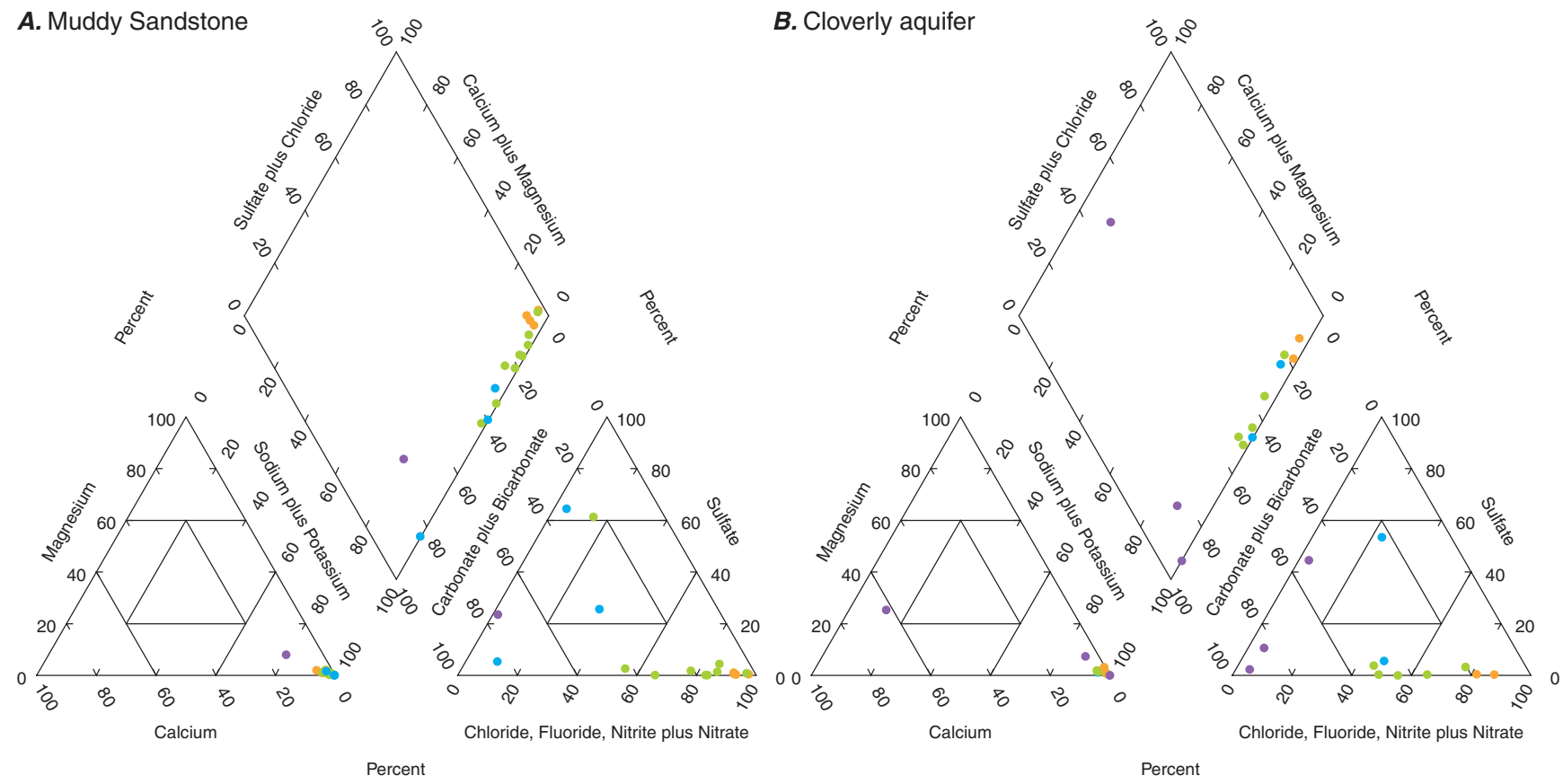

EXPLANATION

Total dissolved-solids concentration, in milligrams per liter, and U.S. Geological Survey salinity classification

- Less than 1,000; fresh

- 1,000-3,000; slightly saline

- 3,000-10,000; moderately saline

- 10,000-35,000; very saline

Figure 27. Trilinear diagrams showing major-ion composition and dissolved-solids concentrations for ground-water samples from aquifers in Lower Cretaceous hydrogeologic units, Carbon County, Wyoming. 
pebbles (Dobbin, Bowen and Hoots, 1929; Dobbin, Hoots and others, 1929; Berry, 1960; Harshman, 1972). The upper part of the formation is equivalent to the Dakota Sandstone, the middle part to the Fuson Shale, and the lower part to the Lakota Sandstone of adjacent areas (Agatston, 1951).

Based on fossil assemblages, Curry (1962, p. 118) reported that terrestrial and fresh-water depositional environments probably persisted during the Early Cretaceous Epoch in central Wyoming. He also stated that considerable evidence exists that the uppermost fluvial deposits of the Cloverly Formation were partially reworked by the advancing Cretaceous seas (Curry, 1962, p. 118). The Cloverly Formation is as much as $200 \mathrm{ft}$ thick in the Shirley Basin (Harshman, 1972).

The Cloverly Formation is a source of oil and natural gas in the county, with mostly gas production in the southwestern part of the county and mostly oil production in the eastern part (De Bruin, 2002). Convention by many oil and gas producers is to discuss the Cloverly Formation in Carbon County as the Dakota and Lakota Sandstones.

The Cloverly Formation is defined as an aquifer by many previous investigators (Berry, 1960; Welder and McGreevy, 1966; Lowry and others, 1973; Collentine and others, 1981; Richter, 1981). Collentine and others (1981) defined the formation as a "major aquifer" in the Great Divide and Washakie Basins. Similarly, Richter (1981) defined the formation as a "major aquifer" in the general vicinity of the Laramie, Shirley, and Hanna Basins (including Carbon County). The USGS also defined the formation as a "principal aquifer" (Whitehead, 1996) and referred to the aquifer as part of the "Lower Cretaceous aquifers" category on the national Principal Aquifers map (U.S. Geological Survey, 2003). Domestic or stock wells generally are completed in the Cloverly aquifer only in areas where the formation is exposed.

In the Rawlins Uplift area, Berry (1960, p. 19) described the Cloverly Formation as an artesian aquifer with "sufficient pressure to flow at the land surface." He reported yields for five flowing wells in the Miller Hill area ranging from 25 to $85 \mathrm{gal} / \mathrm{min}$. Aquifer tests conducted at three wells in the Miller Hill area were described. Transmissivity at one well (later defined as the "Pine Grove Ranch well" in James M. Montgomery Consulting Engineers (1983)) was estimated to be about $214 \mathrm{ft}^{2} /$ day with an associated specific capacity of $0.86(\mathrm{gal} / \mathrm{min}) / \mathrm{ft}$ using the recovery method. The same aquifer test was reanalyzed using the discharge (flow) method, and the transmissivity was estimated to be $228 \mathrm{ft}^{2} /$ day. Transmissivity values at the other two wells estimated using recovery methods were about 60 and $228 \mathrm{ft}^{2} /$ day, with associated specific capacity values of 0.26 and 1.36 , respectively. The well with the $60 \mathrm{ft}^{2} /$ day estimate was later defined as the "RawlinsCloverly well" in James M. Montgomery Consulting Engineers (1983). Berry (1960, p. 35) also stated that the $228 \mathrm{ft}^{2} /$ day estimate was "not very reliable." He also reported that water from the Cloverly aquifer was the best quality for domestic and municipal use in all formations he examined in the Rawlins Uplift area.
In a study evaluating further development of the municipal water supply for the city of Rawlins, James M. Montgomery Consulting Engineers (1983) conducted a new aquifer test on the "Rawlins-Cloverly well" previously examined by Berry (1960). The effective transmissivity was initially estimated to be about $147 \mathrm{ft}^{2} /$ day, but later parts of the discharge (flow) and recovery tests indicated an estimate of about $201 \mathrm{ft}^{2} /$ day. The investigators noted that the estimate obtained using later data produced an estimate very close to the $228 \mathrm{ft}^{2} /$ day estimated by Berry (1960), an estimate that the earlier investigator considered unreliable. They reported that the similarity in transmissivity estimates suggests "regional homogeneity" for the Cloverly aquifer in the area. Assuming an effective well radius of $0.25 \mathrm{ft}$, the investigators (James M. Montgomery Consulting Engineers, 1983, p. 3-8) estimated storativity to range from $5 \times 10^{-4}$ to $2 \times 10^{-7}$, but noted that "the actual storage coefficient is believed to be about $1\left[\times 10^{-4}\right]$ to $5 \times 10^{-4}$."

Richter (1981) described the Cloverly aquifer in the Laramie, Shirley, and Hanna Basin areas. The investigator reported that the aquifer was confined throughout the area and had "good" intergranular porosity and permeability. Richter (1981) also stated that there were two permeable zones within the formation - the Lakota and Dakota Sandstones separated by the Fuson Shale. He considered the Lakota and Dakota Sandstones as "subaquifers" within the Cloverly Formation, separated by the Fuson Shale, which he defined as a leaky confining layer allowing hydraulic connection through faults and fractures. He also noted that transmissivity was larger in "tectonically deformed areas." Reported water- and petroleum-well yields ranged from 1 to $150 \mathrm{gal} / \mathrm{min}$. Richter also stated that the Lakota Sandstone was the most productive zone within the Cloverly Formation. Reported transmissivity values for the Lakota Sandstone ranged from less than 1 to $201 \mathrm{ft}^{2} /$ day, whereas transmissivity values for the Dakota Sandstone ranged from less than 1 to about $3 \mathrm{ft}^{2} /$ day.

Collentine and others (1981) described the hydrogeology of the Cloverly aquifer in the Great Divide and Washakie Basins. The area of the aquifer within Carbon County, on the eastern margin of the Great Divide and Washakie Basins in the vicinity of the Rawlins Uplift, was defined as a "major Mesozoic aquifer." The investigators noted that the formation was deeply buried throughout most of the Great Divide and Washakie Basin areas. Reported well yields ranged from 25 to more than $120 \mathrm{gal} / \mathrm{min}$ with specific capacity values ranging from 0.26 to 1.36 (gal $/ \mathrm{min}) / \mathrm{ft}$. Transmissivity values from water wells were estimated to range from about 46 to about $228 \mathrm{ft}^{2} /$ day, whereas transmissivity values from drill stem tests were estimated to range from less than 1 to about $24 \mathrm{ft}^{2} /$ day. In addition, the investigators constructed a generalized potentiometric map for the Cloverly aquifer within the basins, including Carbon County (Collentine and others, 1981, figure V-5, p. 65). The map shows that ground-water flow in the aquifer in Carbon County generally is towards the west, away from the outcrop areas (and source of recharge), and towards the Great Divide and Washakie Basin centers. 
The Cloverly aquifer is the only source of drinking water for the town of Elk Mountain (fig. 2). Consequently, the Cloverly aquifer in the vicinity of the town received a "solesource aquifer" designation by the USEPA in 1998 (U.S. Environmental Protection Agency, 2005). This is the only "solesource aquifer" designation in the entire State of Wyoming.

Two wells completed in the Cloverly aquifer provide the municipal water supply for the town of Elk Mountain. Weston Engineering (1994) conducted single-well aquifer tests at both wells. In one well, transmissivity was estimated at about $88 \mathrm{ft}^{2} /$ day using constant discharge data, and about $76 \mathrm{ft}^{2} /$ day using recovery data. In the second well, transmissivity was estimated at about $133 \mathrm{ft}^{2} /$ day using constant discharge data, and about $139 \mathrm{ft}^{2} /$ day using recovery data.

Spring-discharge and well-yield measurements from the USGS NWIS database were reviewed for this study. Four measurements of well yield for pumped wells ranged from 2 to $65 \mathrm{gal} / \mathrm{min}$, with a median yield of about $20 \mathrm{gal} / \mathrm{min}$. Two measurements of well yields for flowing wells were 42.8 and $60 \mathrm{gal} / \mathrm{min}$. Three measured discharges for springs ranged from 3 to $5 \mathrm{gal} / \mathrm{min}$, with a median discharge of $3 \mathrm{gal} / \mathrm{min}$.

The chemical composition of ground water in the Cloverly aquifer in Carbon County was characterized and the quality evaluated on the basis of new and historical samples collected from wells and one spring. Many of the samples were co-produced oil and gas water. TDS concentrations were highly variable and indicated that water was fresh to very saline (fig. 27B). Samples that were not co-produced water were classified as fresh and were either calcium-bicarbonate or sodium-bicarbonate water types. Sodium was the predominant cation in almost all water, regardless of salinity classification. The predominant anion in slightly saline water was either sulfate, or a mixture of bicarbonate and chloride. Chloride was the predominant anion in water classified as either moderately saline or very saline. Hardness varied considerably and ranged from soft to very hard.

Concentrations of some characteristics and constituents in the Cloverly aquifer approached or exceeded applicable USEPA or State of Wyoming water-quality standards and could limit the suitability of water for some intended uses. Most available water-quality analyses were from co-produced water, so many characteristic and constituent analyses were not available and could not be compared with health-based, aesthetic, or State of Wyoming agricultural and livestock-use standards (appendixes 6, 7-1 to 7-4). Although most measured salinities would preclude domestic use (appendix 7-1), radon was the only measured constituent with a concentration that exceeded a health-based standard (proposed 300-pCi/L MCL and proposed 4,000-pCi/L alternate MCL exceeded in the one sample) (only one radon sample available from Cloverly aquifer (appendix 6)). Concentrations of some characteristics and constituents exceeded aesthetic standards for domestic use and included TDS (SMCL exceeded in 10 of 14 samples), sulfate (SMCL exceeded in 1 of 14 samples), and chloride (SMCL exceeded in 8 of 14 samples).
In relation to suitability for agricultural and livestock use, concentrations of 4 characteristics and constituents exceeded State of Wyoming agricultural-use standards and concentrations of 2 exceeded State of Wyoming livestock standards (appendixes 7-1 to 7-4). Characteristics and constituents that were measured at concentrations greater than agricultural-use standards included TDS (standard exceeded in 8 of 14 samples), SAR (standard exceeded in 1 of 3 samples), sulfate (standard exceeded in 2 of 14 samples), and chloride (standard exceeded in 9 of 14 samples). Some water samples from the Cloverly aquifer were unsuitable for livestock use and one characteristic and one constituent were measured at concentrations greater than livestock standards: TDS and chloride (standards exceeded in 5 of 14 samples).

\section{Morrison Formation}

The Late Jurassic-age Morrison Formation is present throughout the basins of the county, with outcrops occurring near the uplifts (fig. 25). It consists of interbedded buff, gray, green, maroon, and red shale; clayey siltstone; buff to yellow siltstone; buff to brown, partly calcareous, fine to mediumgrained sandstone; and some thin limestone lenses (Dobbin, Bowen and Hoots, 1929; Dobbin, Hoots and others, 1929; Berry, 1960; Harshman, 1972). Based on fossil assemblages, Curry (1962, p. 118) reported that terrestrial and fresh-water depositional environments probably persisted during the Late Jurassic Epoch in central Wyoming. The Morrison Formation has a maximum thickness of $325 \mathrm{ft}$ in the Rawlins area (Berry, 1960). The formation is a source for oil and natural gas in the county (De Bruin, 2002). It also is a source for uranium, vanadium, and silica sand in the Freezeout and Shirley Mountains (Harris and others, 1985; Harris, 1996).

Because of predominantly fine-grained composition and inferred low permeability, the Morrison Formation generally is considered to contain a poor aquifer in the Rawlins Uplift area (Berry, 1960) and the Great Divide and Washakie Basin areas (Welder and McGreevy, 1966). In the Great Divide and Washakie Basins west of the Rawlins Uplift, Collentine and others (1981) defined the Morrison Formation as a confining layer (aquitard) between the overlying Cloverly aquifer and the underlying Sundance-Nugget aquifers (contained in the Sundance and Nugget Formations in hydraulic connection). Richter (1981) defined the formation as a "leaky confining layer" or "confining layer" in the general vicinity of the Laramie, Shirley, and Hanna Basins (including Carbon County). These previous investigators also noted that some sandstone lenses are present in the formation and will yield small quantities of water to wells, although water likely is highly mineralized.

Little hydrogeologic information is available for the Morrison Formation in Carbon County. Richter (1981, table IV-2, p. 51) reported that some "saturated discontinuous basal sandstone lenses had been encountered in petroleum test wells near Medicine Bow." The investigator also noted that well yields commonly were less than $5 \mathrm{gal} / \mathrm{min}$. Spring-discharge and 
well-yield measurements from the USGS NWIS database were reviewed for this study, but no measurements were available for the Morrison Formation in Carbon County.

The chemical composition of ground water in the Morrison Formation in Carbon County was characterized and the quality evaluated on the basis of only three historical waterquality samples collected from wells. All of the samples were co-produced oil and gas water. TDS concentrations were very high, and two water samples were classified as moderately saline, and the remaining sample was classified as very saline (fig. 28A). Sodium was the predominant cation in all water. Bicarbonate or sulfate was the predominant anion in moderately saline water, whereas chloride was the predominant anion in very saline water. Hardness varied considerably and ranged from soft to very hard, although no samples were classified as hard.

Water-quality samples were only available for three wells from the Morrison Formation in Carbon County (appendixes 7-1 and 7-2) and it is unknown how representative these three samples are of water produced from the formation. Compared to applicable USEPA or State of Wyoming water-quality standards for the few characteristics and constituents analyzed, few concentrations of characteristics and constituents exceeded standards. Based on only three samples, the aesthetic standards (SMCLs) for $\mathrm{pH}$ (upper limit) and chloride were exceeded in one of the samples, and the SMCLs for TDS and sulfate were exceeded in all samples. The State of Wyoming agricultural standards for TDS, sulfate, and chloride were exceeded in all three samples. The State of Wyoming livestock standards for $\mathrm{pH}$ (upper limit), TDS, and chloride were exceeded in 1 of the 3 samples. Based on these three samples, water from the Morrison Formation is unsuitable for domestic and agricultural uses.

\section{Sundance Formation}

The Sundance Formation, which contains the Sundance aquifer, is present throughout the basins of the county, with outcrops occurring near the uplifts (fig. 25). Seven members of the Sundance Formation have been described in Carbon County: Windy Hill, Redwater Shale, Pine Butte, Lak, Hulett, Stockade Beaver Shale, and Canyon Springs Members (Pipiringos, 1968; Harshman, 1972). The uppermost Windy Hill Member is a buff to gray, very fine to medium-grained, thin-bedded, limy oolitic sandstone or a fine to coarse-grained calcite-cemented sandstone with gray-green to dark-gray shale partings (Pipiringos, 1968; Harshman, 1972). Peterson (1994) reassigned the Windy Hill Member to the base of the Morrison Formation, even though this member is a marine unit, whereas most of the Morrison is non-marine. The Redwater Shale Member is greenish or yellowish-gray shale and clayey siltstone with some firmly lime-cemented coquinoid sandstone or sandy coquinoid limestone (Pipiringos, 1968; Harshman, 1972). The Pine Butte Member is greenish white, firmly limecemented sandstone with interbedded greenish to yellowishgray glauconitic siltstone and clay shale (Pipiringos, 1968;
Harshman, 1972). The Lak Member is pink to reddish-brown to yellowish-white fine to medium-grained sandstone, sandy siltstone, and siltstone (Pipiringos, 1968; Harshman, 1972). The Hulett Sandstone Member is fine to medium-grained, buff to white sandstone with some shale and glauconite (Pipiringos, 1968, Harshman, 1972). The Stockade Beaver Shale Member is greenish-gray to greenish-yellow shale and siltstone (Pipiringos, 1968; Harshman, 1972). The Canyon Springs Member, is light gray fine-grained oolitic to yellowish-white fine to medium-grained sandstone with chert pebbles at the base in some areas (Pipiringos, 1968; Harshman, 1972). The Sundance Formation was deposited in a marine environment and is 195 to $365 \mathrm{ft}$ thick (Pipiringos, 1968). The Sundance Formation is a source of oil and natural gas in the northwestern and east-central parts of the county (De Bruin, 2002).

Early investigators (Berry, 1960; Welder and McGreevy, 1966; and Lowry and others, 1973) had little information available to describe the hydrogeology of the Sundance aquifer. Collentine and others (1981) defined the Sundance Formation as a "minor aquifer" in the Great Divide and Washakie Basins. Similarly, Richter (1981) defined the formation as a "secondary aquifer" in the general vicinity of the Laramie, Shirley, and Hanna Basins (including Carbon County). Both Collentine and others (1981) and Richter (1981) stated that the Sundance aquifer is in hydraulic connection with the underlying Nugget aquifer. Consequently, Collentine and others (1981) combined the Sundance Formation and Nugget Sandstone in the Great Divide and Washakie Basins into a single aquifer defined as the "Sundance-Nugget aquifer."

In Carbon County, most wells completed in the formation are oil wells and most information describing the hydrogeologic characteristics of the Sundance aquifer are from these type of wells. Berry (1960) reported artesian conditions for one well in the Rawlins Uplift area and the well flowed $28 \mathrm{gal} / \mathrm{min}$. An aquifer test was conducted at this well, and Berry (1960) reported that transmissivity was estimated to be about $32 \mathrm{ft}^{2} /$ day with a specific capacity of $0.17(\mathrm{gal} / \mathrm{min}) / \mathrm{ft}$.

In the Great Divide and Washakie Basins, Collentine and others (1981) also noted artesian conditions in wells installed in the Sundance Formation in the Rawlins Uplift area. The investigators reported that yields for three wells in the Sundance aquifer ranged from 27 to $35 \mathrm{gal} / \mathrm{min}$. Reported transmissivity values ranged from about 1.6 to about $469 \mathrm{ft}^{2} /$ day.

In the Laramie, Shirley, and Hanna Basins, Richter (1981, table IV-2, p. 50) reported that basal sandstones of the Sundance Formation have "large intergranular porosity and permeability" and "upper sands are well cemented and have low permeabilities." He reported artesian conditions in the basal sandstones with flows ranging from 1 to $50 \mathrm{gal} / \mathrm{min}$. The investigator also reported transmissivity estimates for nine wells completed in oil and gas fields, eight of which were in Carbon County. Transmissivity values for the eight wells in Carbon County ranged from about 2.7 to about $50 \mathrm{ft}^{2} /$ day (Richter, 1981, table IV-4, p. 62).

Spring-discharge and well-yield measurements from the USGS NWIS database were reviewed for this study. Two 

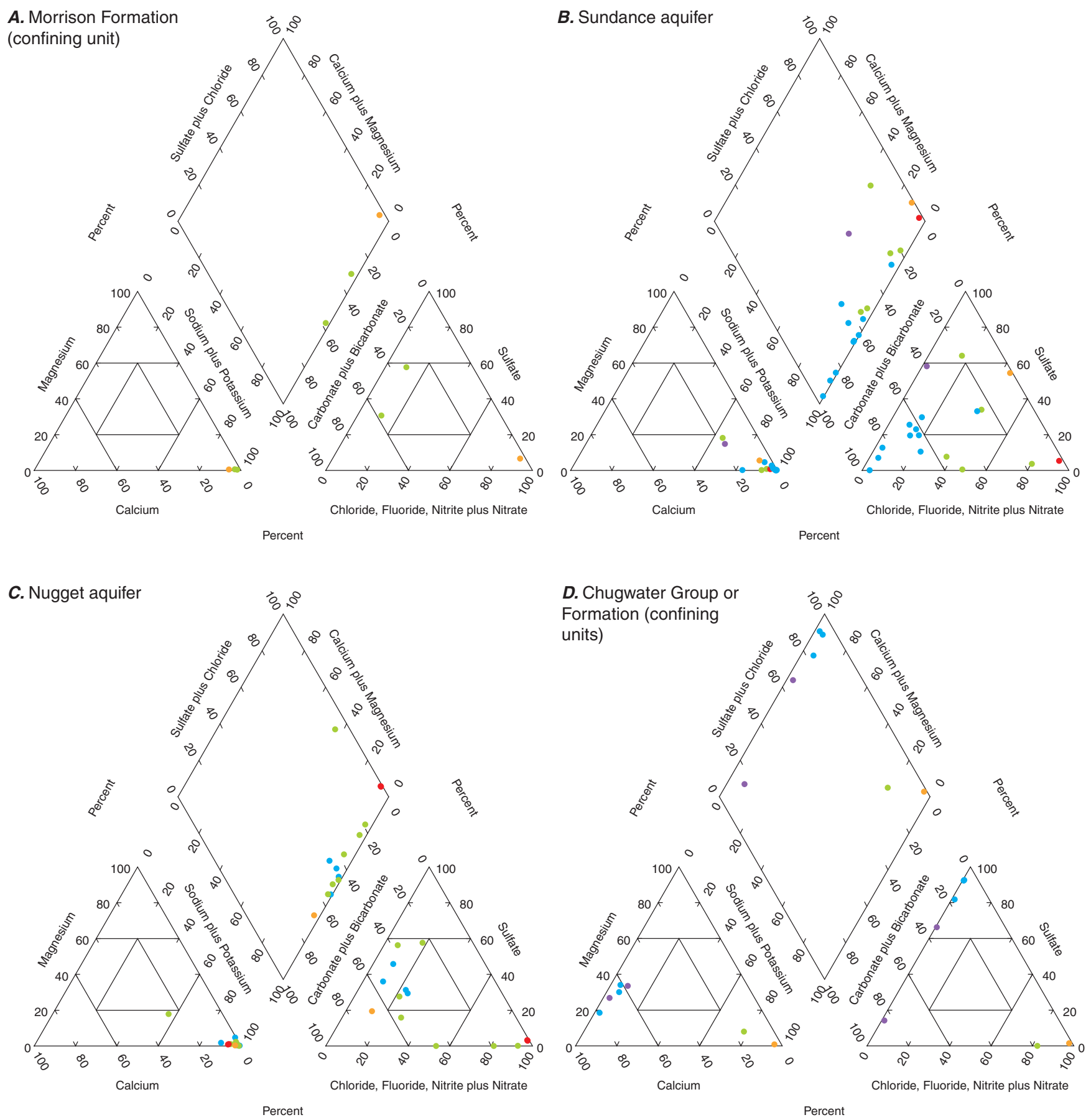

\section{EXPLANATION}

Total dissolved-solids concentration, in milligrams per liter, and U.S. Geological Survey salinity classification

- Less than 1,000; fresh

- 1,000-3,000; slightly saline

- 3,000-10,000; moderately saline

- 10,000-35,000; very saline

- More than 35,000; briny

Figure 28. Trilinear diagrams showing major-ion composition and dissolved-solids concentrations for ground-water samples from aquifers in Triassic and Jurassic hydrogeologic units, Carbon County, Wyoming. 
E. Jelm Formation of the Chugwater Group

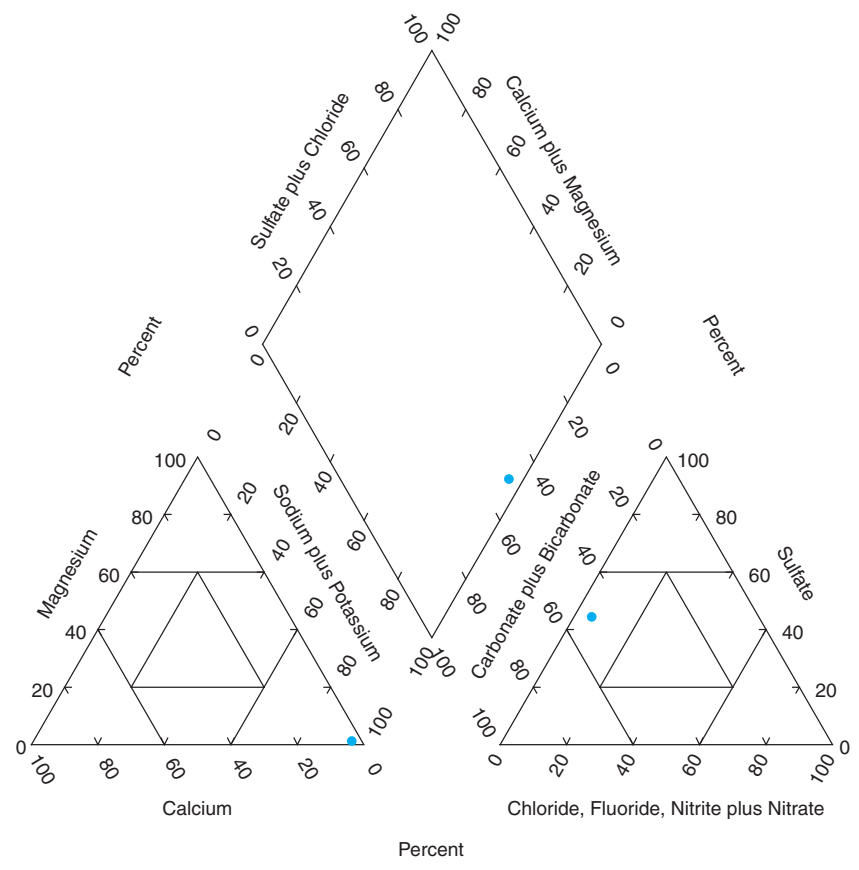

EXPLANATION

Total dissolved-solids concentration, in milligrams per liter, and U.S. Geological Survey salinity classification

- 1,000-3,000; slightly saline

Figure 28. Trilinear diagrams showing major-ion composition and dissolved-solids concentrations for ground-water samples from aquifers in Triassic and Jurassic hydrogeologic units, Carbon County, Wyoming.-Continued

measurements of well yields for pumped wells were 2 and $27 \mathrm{gal} / \mathrm{min}$. Four measured discharges for springs ranged from 5 to $15 \mathrm{gal} / \mathrm{min}$, with a median discharge of about $11 \mathrm{gal} / \mathrm{min}$.

The chemical composition of ground water in the Sundance aquifer in Carbon County was characterized and the quality evaluated on the basis of new and historical samples collected from wells and one spring. All but four of the samples were co-produced oil and gas water. TDS concentrations were highly variable and indicated that water was fresh to briny (fig. 28B). The spring sample that was classified as fresh was a sodium-sulfate-bicarbonate water type. Sodium was the predominant cation in all samples, regardless of salinity classification. With one exception, slightly saline water was classified as sodium-bicarbonate type. Anion composition in moderately saline water varied. Sulfate was the predominant anion in the water classified as very saline, whereas chloride was the predominant anion in the water classified as briny. Hardness varied considerably and ranged from soft to very hard.

Concentrations of some characteristics and constituents in the Sundance Formation approached or exceeded applicable
USEPA or State of Wyoming water-quality standards and could limit the suitability of water for some intended uses. Most available water-quality analyses were from co-produced water, so many characteristic and constituent analyses were not available and could not be compared with health-based, aesthetic, or State of Wyoming agricultural and livestock-use standards (appendixes 7-1 to 7-3). Constituents measured at concentrations greater than health-based standards included fluoride (MCL exceeded in 1 of 3 samples), boron (proposed HAL exceeded in 2 of 4 samples), and radon (proposed $300-\mathrm{pCi} / \mathrm{L}$ MCL exceeded in the 1 sample analyzed) (appendixes 6, 7-1 to 7-4). Aesthetic standards for domestic use were exceeded by concentrations of some characteristics and constituents, including pH (SMCL upper limit exceeded in 5 of 15 samples), TDS (SMCL exceeded in all 18 samples), sulfate (SMCL exceeded in 11 of 18 samples), chloride (SMCL exceeded in 9 of 18 samples), fluoride (SMCL exceeded in 1 of 3 samples), and manganese (SMCL exceeded in 1 of 2 samples).

In relation to suitability for agricultural and livestock use, concentrations of 6 characteristics and constituents exceeded State of Wyoming agricultural-use standards and concentrations of 5 exceeded State of Wyoming livestock standards (appendixes 7-1 to 7-3). Many characteristics and constituents were measured at concentrations greater than agriculturaluse standards and included TDS (standard exceeded in 12 of 18 samples), SAR (standard exceeded in 3 of 4 samples), sulfate (standard exceeded in 12 of 18 samples), chloride (standard exceeded in 14 of 18 samples), boron (standard exceeded in 2 of 4 samples), and selenium (standard exceeded in 1 of 2 samples). Some samples from the Sundance aquifer were unsuitable for livestock use and five characteristics and constituents were measured at concentrations greater than livestock standards: $\mathrm{pH}$ (upper limit standard exceeded in 5 of 15 samples), TDS (standard exceeded in 3 of 18 samples), sulfate (standard exceeded in 1 of 18 samples), chloride (standard exceeded in 3 of 18 samples), and chromium (standard exceeded in 1 of 2 samples).

\section{Nugget Sandstone}

The Nugget Sandstone, which contains the Nugget aquifer, is present in the subsurface of the western part of the county, with some outcrops occurring near the Rawlins Uplift and Freezeout Mountains. Because of mapping scale, the few outcrops in Carbon County are too small to see on figure 25. The formation is a very fine to coarse-grained buff to white to pink highly porous sandstone (Pipiringos, 1957, 1968; Berry, 1960). Pipiringos (1968) also described a lower Bell Springs Member that is red and gray sandstone with red, green, and pale-purplish-red to pale-red siltstone and shale. Pipiringos (1957) noted that the formation may be of eolian and (or) subaqueous origin. Berry (1960) estimated a maximum thickness of $110 \mathrm{ft}$ in the subsurface. The Nugget Sandstone is a source of oil in the northwestern part of the county and a source of 
gas in the southwestern and east-central parts of the county (De Bruin, 2002).

Early investigators (Berry, 1960; Welder and McGreevy, 1966; and Lowry and others, 1973) had little information available to describe the hydrogeology of the Nugget aquifer. Collentine and others (1981) defined the Nugget Sandstone as a "minor aquifer" in the Great Divide and Washakie Basins. Similarly, Richter (1981) defined the formation as a "secondary aquifer" in the general vicinity of the Laramie, Shirley, and Hanna Basins (including Carbon County). Both Collentine and others (1981) and Richter (1981) stated that the Nugget aquifer is in hydraulic connection with the overlying Sundance aquifer. Consequently, Collentine and others (1981) combined the Sundance and Nugget aquifers in the Great Divide and Washakie Basins into a single aquifer defined as the "Sundance-Nugget aquifer."

Data describing the hydrogeologic characteristics of the Nugget aquifer primarily are from oil wells. In the Great Divide and Washakie Basins, Collentine and others (1981) reported well yields of 35 and $200 \mathrm{gal} / \mathrm{min}$ for two wells. The investigators reported that the maximum transmissivity from drill stem tests was about $290 \mathrm{ft}^{2} /$ day. In the Laramie, Shirley, and Hanna Basins, Richter (1981, table IV-2, p. 50) reported that basal sandstones have "large intergranular porosity and permeability." He reported artesian conditions in "deep basin wells" with flows ranging from 50 to $100 \mathrm{gal} / \mathrm{min}$.

In Carbon County, several municipal supply wells for the city of Rawlins are completed in the Nugget aquifer in the Miller Hill area. Anderson and Kelly (1984) and James M. Montgomery Consulting Engineers (1986) described the hydrogeologic characteristics in the area on the basis of three municipal supply wells completed in the aquifer. Anderson and Kelly (1984) completed a 1,730-ft deep well into the Nugget aquifer. They noted that water flowed from the well at $350 \mathrm{gal} / \mathrm{min}$ from a thin zone in the upper part of the Nugget Sandstone. Subsequently, James M. Montgomery Consulting Engineers (1986) completed two additional wells to a similar depth in the same area. Like Anderson and Kelly (1984), the investigators noted that ground-water flow to the wells was primarily from thin zones within the Nugget Sandstone. Aquifer tests were conducted at all three wells using both constantdrawdown and recovery methods. They reported that the aquifer was "highly productive" in the area. Although estimates varied based on analytical method, James M. Montgomery Consulting Engineers (1986, p. 6-1) reported that transmissivity near the tested wells ranged from 2,010 to $2,679 \mathrm{ft}^{2} /$ day and associated storage coefficients ranged from $4 \times 10^{-5}$ to $6 \times 10^{-5}$. Based on conditions encountered during drilling and subsequent aquifer tests, James M. Montgomery Consulting Engineers (1986) concluded that localized fracture zones (and therefore, secondary permeability) are responsible for most of the water yielded to wells completed in the Nugget aquifer in the Miller Hill area. They stated that the fracture zones are not present throughout the formation in the area but are localized.
Spring-discharge and well-yield measurements from the USGS NWIS database were reviewed for this study, but no measurements were available for the Nugget aquifer in Carbon County.

The chemical composition of ground water in the Nugget aquifer in Carbon County was characterized and the quality evaluated on the basis of historical samples collected from wells. All of the samples were co-produced oil and gas water. TDS concentrations were highly variable and indicated that water was slightly saline to briny (fig. 28C). Sodium was the predominant cation in all water samples, regardless of salinity classification. In water classified as slightly saline the predominant anion was either bicarbonate or sulfate, or a mixture of the two. Anion composition in moderately saline water varied. Bicarbonate was the predominant anion in the water classified as very saline, whereas chloride was the predominant anion in the water classified as briny. Concentrations of many characteristics and constituents (hardness, calcium, sodium, sulfate, and TDS) significantly increased with increasing well depth (appendix 8). Hardness varied considerably and ranged from soft to very hard.

Concentrations of some characteristics and constituents in the Nugget aquifer approached or exceeded applicable USEPA or State of Wyoming water-quality standards and could limit the suitability of waters for some intended uses. Most available water-quality analyses were from co-produced waters so many characteristic and constituent analyses were not available and could not be compared with health-based, aesthetic, or State of Wyoming agricultural and livestock-use standards. Although most measured salinities would preclude domestic use, no concentrations of measured constituents exceeded healthbased standards (appendixes 7-1 to 7-2). Aesthetic standards for domestic use were not met by concentrations of some characteristics and constituents, including $\mathrm{pH}$ (less than the SMCL lower limit in 1 of 14 samples and greater than the SMCL upper limit in 4 of 14 samples), TDS (SMCL exceeded in all 15 samples), sulfate (SMCL exceeded in 11 of 14 samples), and chloride (SMCL exceeded in 12 of 15 samples).

In relation to suitability for agricultural and livestock use, concentrations of 4 characteristics and constituents exceeded State of Wyoming agricultural-use standards and concentrations of 3 exceeded State of Wyoming livestock standards (appendixes 7-1 to 7-4). Several characteristics and constituents were measured at concentrations greater than agriculturaluse standards and included $\mathrm{pH}$ (standard upper limit exceeded in 1 of 14 samples), TDS and chloride (standards exceeded in 14 of 15 samples), and sulfate (standard exceeded in 11 of 14 samples). Some sampled water from the Nugget aquifer was unsuitable for livestock use, and three characteristics and constituents were measured at concentrations that did not meet livestock standards: $\mathrm{pH}$ (less than lower limit in 1 of 14 samples and greater than upper limit in 4 of 14 samples), TDS (standard exceeded in 7 of 15 samples), and chloride (standard exceeded in 4 of 15 samples). 


\section{Chugwater Formation or Group}

The Chugwater Formation or Group is present throughout the basins of the county, with outcrops occurring near the uplifts (fig. 25). The Chugwater Group is divided into the Popo Agie, Jelm, Crow Mountain Sandstone, Alcova Limestone, and Red Peak Formations (fig. 9). The undivided Chugwater Formation is described as red shale and sandstone, with some purple, pink, green, and buff beds, and a few limestone and gypsum beds (Dobbin, Bowen and Hoots, 1929; Dobbin, Hoots and others, 1929; Berry, 1960). It is of fluvial, lacustrine, eolian, and marine origin (Pipiringos and O'Sullivan, 1978). The maximum thickness noted by Dobbin, Hoots, and others (1929) is $1,350 \mathrm{ft}$.

The uppermost member of the Chugwater Group is the Popo Agie Formation. The Popo Agie Formation is absent in the eastern part of the county. It is a purple to pale-red to ochre siltstone, analcime-rich claystone, silty claystone, and grayish-yellow sandstone (Pipiringos, 1968; Pipiringos and O'Sullivan, 1978). North and west of the Ferris Mountains, the Popo Agie Formation is divided into the Lyons Valley and Brynt Draw Members (Pipiringos, 1968; Pipiringos and O'Sullivan, 1978). It is a fluvial and lacustrine deposit (Pipiringos and O'Sullivan, 1978). The formation ranges from 0 to about $100 \mathrm{ft}$ thick (Pipiringos, 1968).

The Jelm Formation was included in the Chugwater Group by Pipiringos (1968). He also divided it into Sips Creek and Red Draw Members. The Jelm Formation occurs southeast of the Granite Mountains (Pipiringos, 1968). The Sips Creek member is a greenish-white to reddish-brown and yellow sandstone that is in part conglomeratic with pebbles of siltstone, limestone, and shale, and fragments of fossil wood and bone (Pipiringos, 1968; Pipiringos and O'Sullivan, 1978). The upper part of the Sips Creek is a reddish-brown siltstone (Pipiringos, 1968; Pipiringos and O'Sullivan, 1978). In the Shirley Basin, the Sips Creek Member is a tan to buff well-cemented sandstone (Harshman, 1972). It is a fluvial and lacustrine deposit (Pipiringos and O'Sullivan, 1978) that is 0 to $315 \mathrm{ft}$ thick (Pipiringos, 1968). The Red Draw Member is reddish-brown shale, siltstone, and sandstone that is interbedded with some greenish-gray siltstone (Pipiringos, 1968; Harshman, 1972; Pipiringos and O'Sullivan, 1978). It is a fluvial deposit (Pipiringos and O'Sullivan, 1978) that is 0 to $140 \mathrm{ft}$ thick (Pipiringos, 1968). The undivided Jelm Formation is as much as $360 \mathrm{ft}$ thick (Pipiringos, 1968).

The Crow Mountain Sandstone of the Chugwater Group of Pipiringos (1968) occurs north and west of the Granite Mountains. In the area southeast of the Granite Mountains, the name Crow Mountain was replaced with Jelm by Pipiringos (1968). The upper part of the Crow Mountain Sandstone is white to reddish-brown sandstone and siltstone with minor amounts of pale-red and green shale (Pipiringos and O'Sullivan, 1978). The lower part of the unit is salmon-red to reddish-brown sandstone with minor amounts of sandstone, siltstone, and some sandy clay shale (Pipiringos and O'Sullivan, 1978). The upper part is of fluvial origin, whereas the lower part is of marine origin (Pipiringos and O'Sullivan, 1978). Pipiringos (1968, p. D11) showed a section that is $192 \mathrm{ft}$ thick.

The Alcova Limestone is identified as part of the Chugwater Group by some investigators (Pipiringos, 1968; Harshman, 1972; Pipiringos and O'Sullivan, 1978) and as a member of the Crow Mountain and Jelm Formations by others (High and Picard, 1969). It is a gray, purple, greenish-gray, brownish-gray, and greenish-brown limestone that is sandy in its upper and lower parts (Harshman, 1972; Pipiringos and O'Sullivan, 1978). It is of marine origin (Pipiringos and O'Sullivan, 1978). The formation is missing locally due to non-deposition or erosion. Where present, it has a maximum thickness of $20 \mathrm{ft}$ (High and Picard, 1969).

The Red Peak Formation is the lowest unit of the Chugwater Group of Pipiringos (1968). It is a pale to moderate reddish-brown to red siltstone with some interbedded thin yellowish-gray to white to pink, very fine to fine-grained calcareous sandstone (Harshman, 1972; Lowry and others, 1973; Pipiringos and O'Sullivan, 1978). It is of marine origin (Pipiringos and O'Sullivan, 1978). Lowry and others (1973) reported a thickness of 600 to $700 \mathrm{ft}$.

The Chugwater Formation or Group is a source of oil in the northwestern part of the county, whereas the Alcova Limestone (defined as "Thaynes" by producers) is a source of oil and natural gas in the southwestern part of the county (De Bruin, 2002). The Red Peak Formation also is a source for natural gas in the Washakie Basin (De Bruin, 2002). The Alcova Limestone also is a source of limestone aggregate in the northwestern part of the county (Harris and others, 1985; Harris and Meyer, 1986; Harris, 1996).

Little hydrogeologic information is available for the Chugwater Formation or Group in Carbon County. Few wells are completed in the formation in Carbon County. In the Rawlins Uplift area, Berry (1960, p. 17) reported that no known wells were completed in the Chugwater Formation in the area although "sandstone beds probably will yield small domestic and stock supplies," but then noted that "the water would probably be highly mineralized." Welder and McGreevy (1966, sheet 3) reported that "ground-water possibilities were not known, but probably poor." Collentine and others (1981) defined the Chugwater Formation as an "aquitard" and "confining unit" in the Great Divide and Washakie Basins, separating the overlying "Sundance-Nugget aquifer" from the underlying "Paleozoic aquifer system." Similarly, Richter (1981) defined the formation as a "leaky confining layer" in the general vicinity of the Laramie, Shirley, and Hanna Basins (including Carbon County). However, he noted that basal sandstones were "water-bearing" in the Laramie Basin, but well yields were low (less than $10 \mathrm{gal} / \mathrm{min}$ ). Richter (1981) also noted that artesian conditions in basal sandstone and conglomerate of the Jelm Formation of the Chugwater Group could produce flows of 10 to $25 \mathrm{gal} / \mathrm{min}$.

Spring-discharge and well-yield measurements from the USGS NWIS database were reviewed for this study. The measured yield for one pumped well was $9 \mathrm{gal} / \mathrm{min}$. Five measured 
discharges for springs ranged from 0.5 to $150 \mathrm{gal} / \mathrm{min}$ with a median discharge of $43 \mathrm{gal} / \mathrm{min}$.

The chemical composition of ground water in the Chugwater Formation or Group in Carbon County was characterized and the quality evaluated on the basis of new and historical samples collected from three wells and four springs. Two of three well samples were co-produced oil and gas water. TDS concentrations were highly variable and indicated that water was fresh to very saline (fig. 28D). Samples that were classified as fresh were either calcium-sulfate or calciumbicarbonate water types. Samples classified as moderately saline or very saline were co-produced oil and gas water and were classified as sodium-chloride water type. Hardness for all water was very hard.

Based on the few characteristics and constituents analyzed, the concentrations of some characteristics and constituents in the Chugwater Formation or Group approached or exceeded applicable USEPA or State of Wyoming waterquality standards and could limit the suitability of water for some intended uses. Although most measured salinities would preclude domestic use, radon was the only measured constituent with concentrations that exceeded a health-based standard (proposed 300-pCi/L MCL exceeded in both samples) (appendixes 7-1 to 7-4). Aesthetic standards for domestic use were exceeded by concentrations of some characteristics and constituents, including TDS (SMCL exceeded in 6 of 7 samples), sulfate (SMCL exceeded in 5 of 7 samples), and chloride (SMCL exceeded in 2 of 7 samples).

In relation to suitability for agricultural and livestock use, concentrations of 3 characteristics and constituents exceeded State of Wyoming agricultural-use standards and concentrations of 2 exceeded State of Wyoming livestock standards (appendixes 7-1 to 7-4). Several characteristics and constituents were measured at concentrations greater than agriculturaluse standards and included TDS (standard exceeded in 4 of 7 samples), sulfate (standard exceeded in 5 of 7 samples), and chloride (standard exceeded in 2 of 7 samples). Some water from the Chugwater Formation or Group was unsuitable for livestock use, and one characteristic and one constituent were measured at concentrations greater than livestock standards: TDS and chloride (standards exceeded in 2 of 7 samples).

The chemical composition of ground water in the Jelm Formation of the Chugwater Group in Carbon County was characterized and the quality evaluated on the basis of only one co-produced oil and gas water sample. Based on the TDS concentration, the water was classified as slightly saline (fig. 28E). The sample was a sodium-bicarbonate-sulfate type water (fig. 28E). Hardness was moderately hard. Based on the few analyses available for this well sample, the water generally was suitable for agricultural or livestock use.

\section{Lower Triassic and Upper Permian Hydrogeologic Units}

Rocks of Early Triassic (Mesozoic) and Late Permian age (Paleozoic) occur throughout Carbon County and are at or near surface around the uplifts (figs. 25 and 29). This series of rocks (figs. 8 and 9) is complicated by intertonguing of formations and by facies changes owing to a series of transgressions and regressions of the Phosphoria Sea (McKelvey and others, 1959, Maughan, 1964). In the western part of the county, the sequence is Dinwoody Formation, Ervay Member of Park City Formation, Tosi Chert Member and Retort Phosphatic Shale Tongues of the Phosphoria Formation, Franson Member of the Park City Formation, greenish-gray shale that may or may not be a member of the Park City Formation, and the Grandeur Tongue of the Park City Formation (McKelvey and others, 1959). In the eastern part of the county, the sequence is made up of members of the Goose Egg Formation: Little Medicine, Freezeout Shale, Ervay Member, Difficulty Shale, Forelle Limestone, Glendo Shale, Minnekahta Limestone, and Opeche Shale Members (Maughan, 1964). The Dinwoody Formation and the Little Medicine and Freezeout Shale Members of the Goose Egg Formation are of Early Triassic age, whereas the rest seem to be of Permian age.

The Dinwoody Formation is described by Berry (1960) and Pipiringos and O'Sullivan (1978) as gray to olive-gray siltstone and shale. Pipiringos and O'Sullivan (1978) also noted thin brown limestone beds near the base of this marine unit. Berry (1960) reported a thickness of $80 \mathrm{ft}$ in the subsurface with no recognizable outcrops in the Rawlins area.

The Park City Formation is represented by three sequences of carbonate rocks and possibly by a sequence of greenish-gray siltstone (the information presented in this paragraph is from McKelvey and others, 1959). The Ervay Member is a dolomite in its eastern extent and a limestone to the west. It is a marine unit that is $50 \mathrm{ft}$ thick at the Conant Creek anticline in Fremont County. The Franson Member is light gray and grayish-brown limestone or dolomite that is part cherty or sandy, and calcareous sandstone. It is a shallow marine deposit that is $35 \mathrm{ft}$ thick at the Conant Creek anticline in Fremont County. The Grandeur Member is interbedded limestone or dolomite, cherty limestone or dolomite, carbonate sandstone, and carbonate siltstone. It is a marine unit that is $60 \mathrm{ft}$ thick at the Conant Creek anticline in Fremont County. The greenish-gray siltstone that may or may not be a part of the Park City Formation is $170 \mathrm{ft}$ thick at the Conant Creek anticline in Fremont County.

The Phosphoria Formation is represented by a sequence of chert and phosphatic shale (unless otherwise noted, the following information about the Phosphoria Formation is from McKelvey and others, 1959). The Tosi Chert Member is thin, dark to light-colored chert beds. The Retort Phosphatic Shale Tongue is a sequence of soft, dark-brownish-gray carbonaceous mudstone and pelletal phosphorite. The Phosphoria Formation in this area is a shallow marine unit. The Tosi Chert Member and Retort Phosphatic Shale Tongues are each about $15 \mathrm{ft}$ thick at the Conant Creek anticline in Fremont County. The formation is a source of oil south of Rawlins (De Bruin, 2002).

The Goose Egg Formation is represented by a sequence of gypsum, limestone, dolomite, and moderately reddishorange siltstone and shale (unless otherwise noted, the 

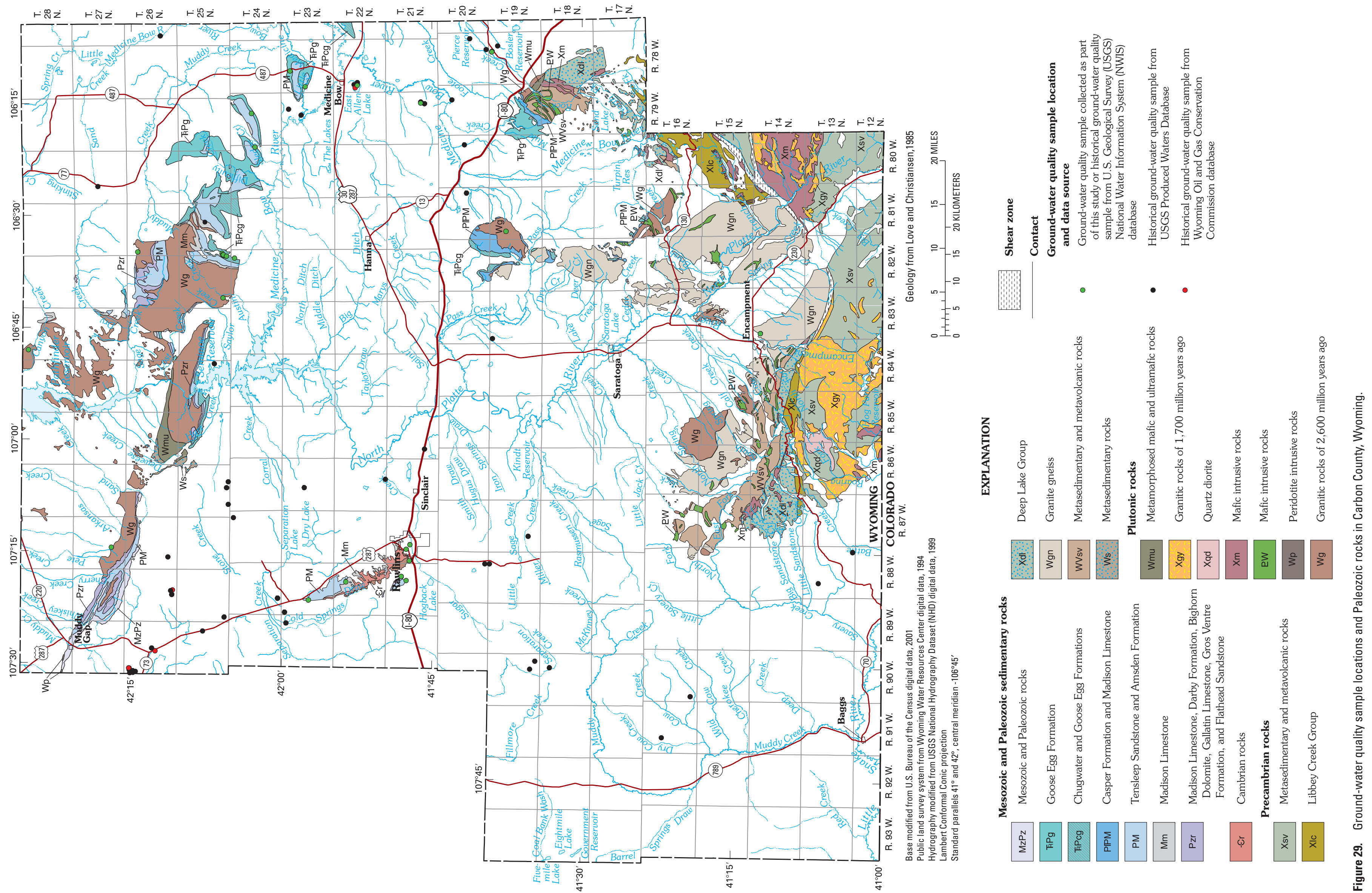
following information about the Goose Egg Formation is from Maughan, 1964). The rocks were deposited in a marginal marine environment with high salinity and a warm arid climate, such as a vast shallow lagoon or tidal flat. The Little Medicine Member is the uppermost member of the Goose Egg Formation and correlates westward into part of the Dinwoody Formation. It is a gypsiferous and argillaceous dolomite or limestone with thin beds of reddish siltstone and claystone. It is between 5 and $25 \mathrm{ft}$ thick. The Freezeout Shale Member is a moderately reddish-orange mudstone and siltstone with gypsiferous siltstone and thin beds of gypsum in its upper part. It is between 10 and $50 \mathrm{ft}$ thick and correlates with the Dinwoody Formation to the west. The Ervay Member of the Goose Egg Formation is the eastern gypsum facies of the limestone facies (western Wyoming) and the dolomite facies (central Wyoming) of the Park City Formation. The Ervay Member consists of beds of gypsum and anhydrite interstratified with thin beds of reddish claystone or mudstone and ranges in thickness from 5 to $10 \mathrm{ft}$. The Difficulty Shale Member is a moderately reddish-orange mudstone and siltstone that is about $50 \mathrm{ft}$ thick and grades westward into part of the carbonate rock of the Franson Member of the Park City Formation. The Forelle Limestone Member is a gray finely crystalline dolomitic or argillaceous limestone with some interbedded limy sandstone, red sandy siltstone and sandstone, and sandy dolomitic limestone (Maughan, 1964; Harshman, 1972). It is about $30 \mathrm{ft}$ thick and correlates to part of the carbonate rock of the Franson Member of the Park City Formation. The Glendo Shale Member is a moderately reddish-orange mudstone and siltstone that is mottled yellowish-gray to light greenish-gray and has some anhydrite and gypsum lenses near the top of the unit (Maughan, 1964; Harshman, 1972). It is as much as $80 \mathrm{ft}$ thick and intertongues with the carbonate rock of the Franson Member of the Park City Formation in central Wyoming. The Minnekahta Limestone is a finely crystalline pinkish and purplish-gray dolomitic limestone with thin beds of purplish-red claystone, sandy siltstone, and purple limy sandstone in the lower part and lenses of gypsum in the upper part (Maughan, 1964; Harshman, 1972). It is about 10 to $30 \mathrm{ft}$ thick and intertongues with the carbonate rock of the Franson Member of the Park City Formation in central Wyoming. The lowest member of the Goose Egg Formation is the Opeche Shale, which is a moderately reddish-orange to purplish claystone that may be silty or sandy and may include beds of dolomite or gypsum (Maughan, 1964; Harshman, 1972). It is about 20 to $70 \mathrm{ft}$ thick and intertongues with the Park City Formation in central Wyoming around the stratigraphic level of the Meade Peak Phosphatic Shale Member of the Phosphoria Formation (Maughan, 1964). The Goose Egg Formation is a potential source of alabaster in the Freezeout and Shirley Mountains area (Harris and others, 1985; Harris and Meyer, 1986; Harris, 1996).

Little hydrogeologic information is available for the Lower Triassic and Upper Permian hydrogeologic units in Carbon County (Dinwoody Formation, Park City Formation, Phosphoria Formation, and Goose Egg Formation). Few wells are completed in these formations in Carbon County. Collentine and others (1981) and previous investigators (Berry, 1960; Welder and McGreevy, 1966; Lowry and others, 1973; Richter, 1981) stated that little was known about the water-bearing properties of these formations, but that they likely were poor aquifers because of low permeability of rocks composing the formations. Consequently, Collentine and others (1981) defined the Dinwoody, Goose Egg, Park City, and Phosphoria Formations as "aquitards" in the Great Divide and Washakie Basins, whereas Richter (1981) defined the Goose Egg Formation as a "leaky confining layer" or "regional confining layer" in the Laramie, Shirley, and Hanna Basins. The USGS defined these formations as "confining units" (Whitehead, 1996). Spring-discharge and well-yield measurements from the USGS NWIS database were reviewed for this study, but no measurements were available for the Phosphoria Formation in Carbon County.

The chemical composition of ground water in the Phosphoria Formation in Carbon County was characterized and the quality evaluated on the basis of only two co-produced oil and gas water samples. Based on the TDS concentrations, the water was classified as moderately saline (fig. 30A). The samples were classified as sodium-sulfate type water (fig. 30A). Hardness was very hard. Based on the few analyses available for these samples, the water generally was unsuitable for domestic or agricultural use.

Spring-discharge and well-yield measurements from the USGS NWIS database were reviewed for this study and two measurements of well yields for pumped wells in the Goose Egg Formation were 1 and $20 \mathrm{gal} / \mathrm{min}$. There were no measured discharges for springs in the Goose Egg Formation in Carbon County.

The chemical composition of ground water in the Goose Egg Formation in Carbon County was characterized and the quality evaluated on the basis of only two new water samples. Based on the TDS concentrations, the water was classified as slightly saline (fig. 30B). The samples were classified as calcium-sulfate type water (fig. 30B). Hardness was very hard (appendix 6). Based on the few analyses available for these samples, the water generally was suitable for livestock use.

The chemical composition of ground water in the Forelle Limestone Member of the Goose Egg Formation in Carbon County was characterized and the quality evaluated on the basis of only one water sample from a spring. Based on the TDS concentration, the water was classified as fresh (fig. 30C). The sample was a calcium-bicarbonate type water (fig. 30C). Hardness was very hard. Based on the few analyses available for this spring sample, the water was suitable for domestic, agricultural, and livestock use.

\section{Paleozoic Hydrogeologic Units}

Rocks of Paleozoic age occur throughout Carbon County and are at or near surface around the uplifts (fig. 29). Paleozoic outcrops account for approximately 2 percent of the surface exposures in Carbon County. 
A. Phosphoria Formation and related rocks

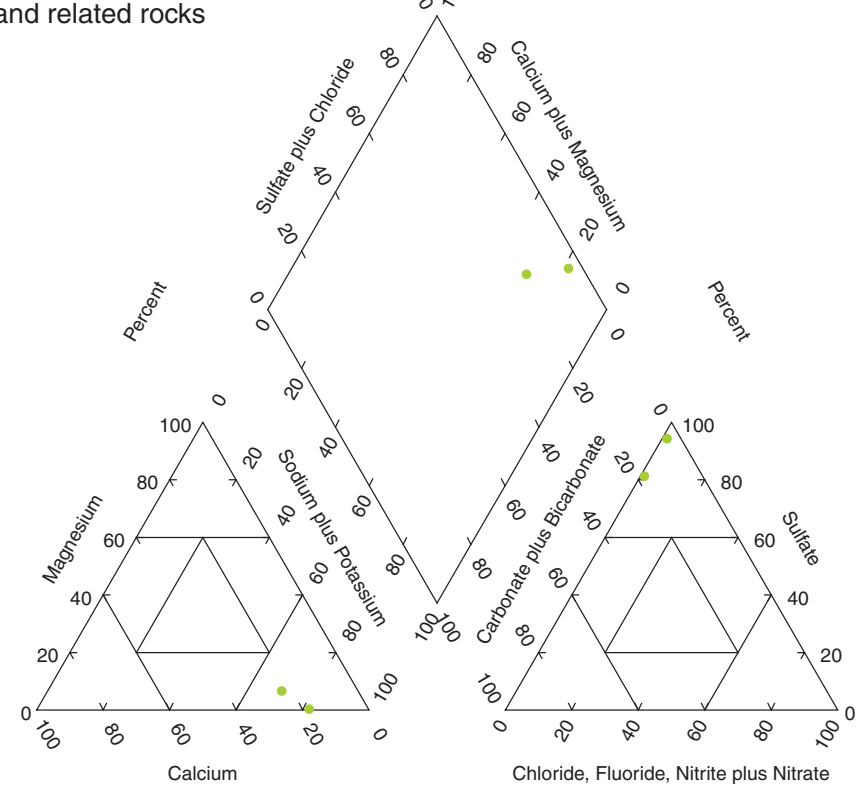

Percent

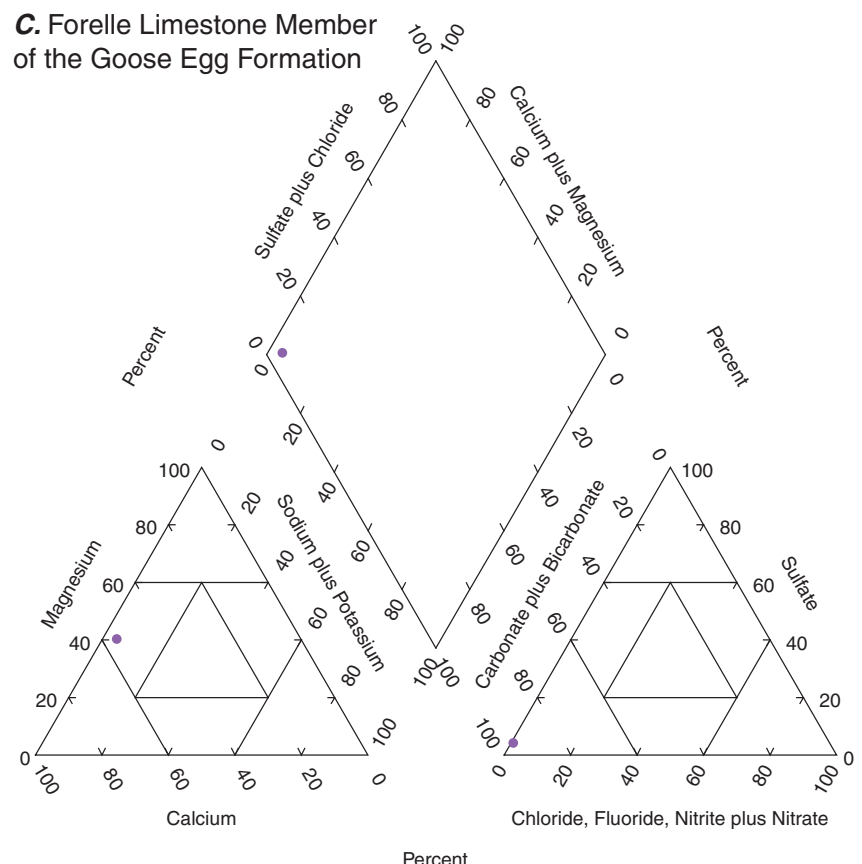

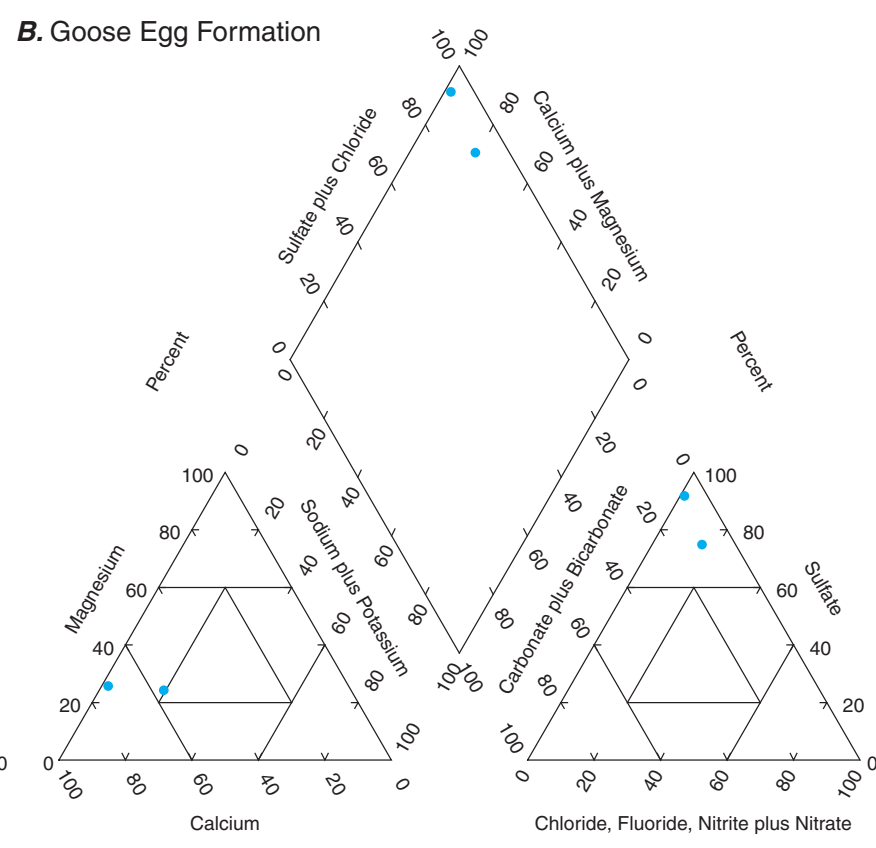

D. Tensleep aquifer

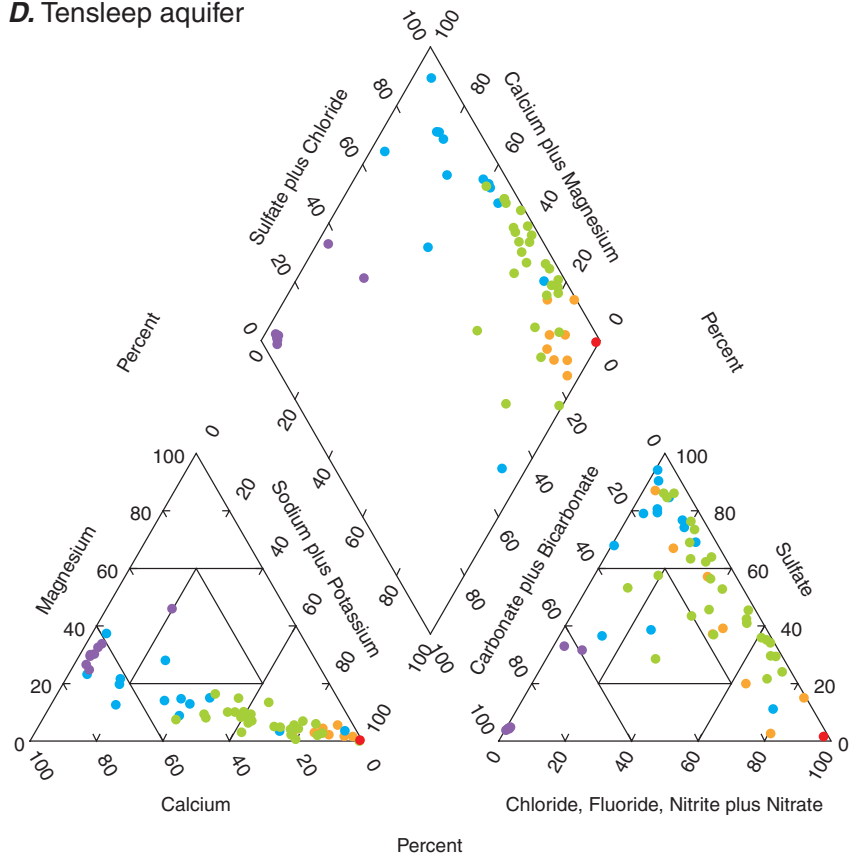

\section{EXPLANATION}

Total dissolved-solids concentration, in milligrams per liter, and U.S. Geological Survey salinity classification

- Less than 1,000; fresh

- 1,000-3,000; slightly saline

- 3,000-10,000; moderately saline

- 10,000-35,000; very saline

- More than 35,000; briny

Figure 30. Trilinear diagrams showing major-ion composition and dissolved-solids concentrations for ground-water samples from aquifers in Paleozoic hydrogeologic units, Carbon County, Wyoming. 

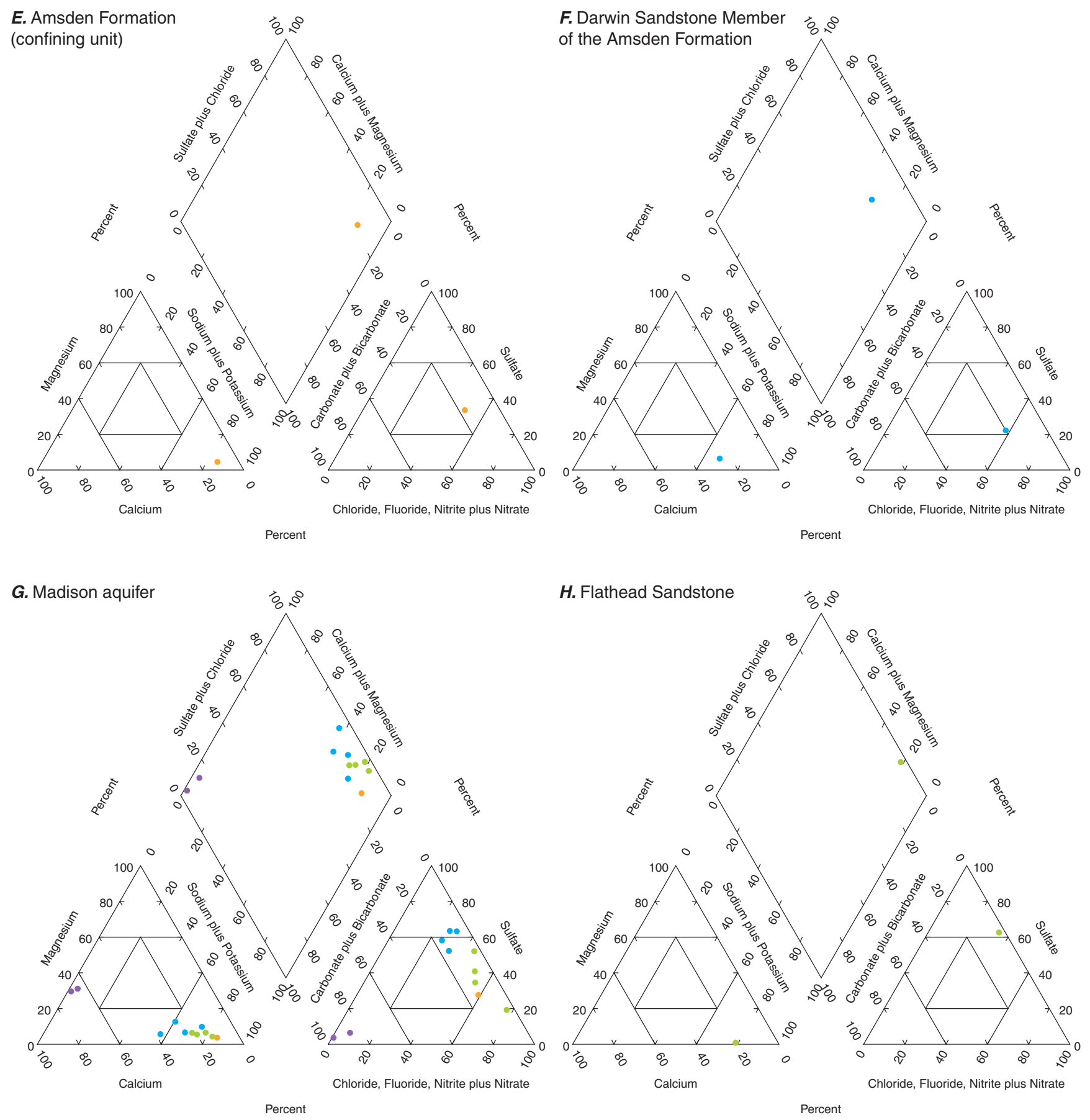

\section{EXPLANATION}

Total dissolved-solids concentration, in milligrams per liter, and U.S. Geological Survey salinity classification

- Less than 1,000; fresh

- 1,000-3,000; slightly saline

- 3,000-10,000; moderately saline

- 10,000-35,000; very saline

Figure 30. Trilinear diagrams showing major-ion composition and dissolved-solids concentrations for ground-water samples from aquifers in Paleozoic hydrogeologic units, Carbon County, Wyoming.-Continued 


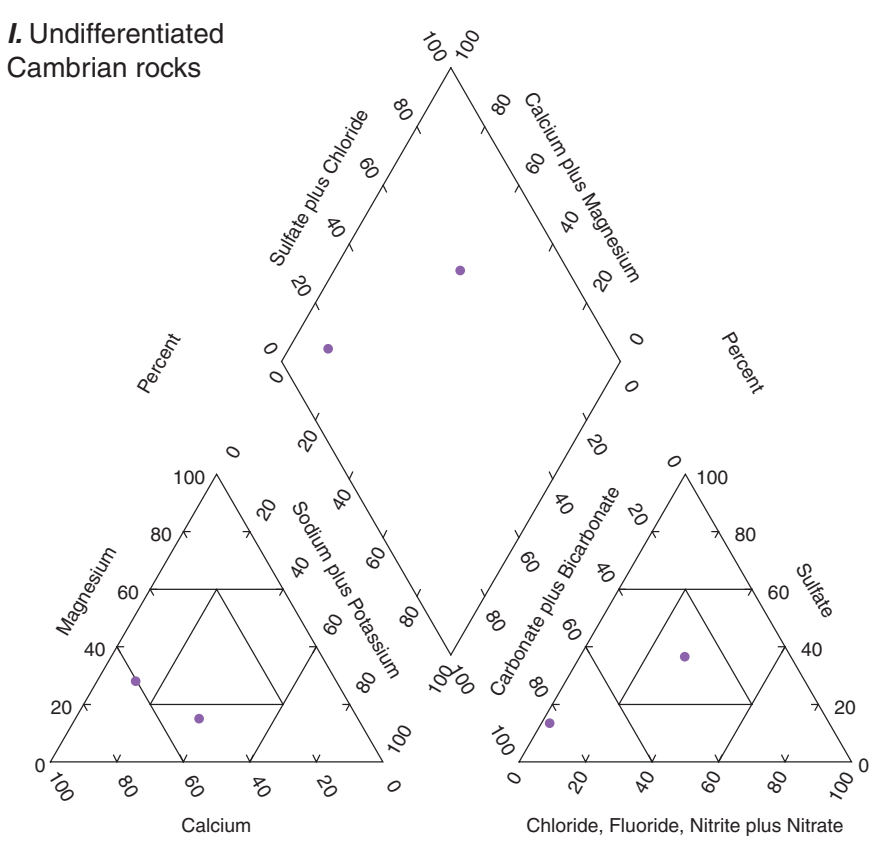

Percent

\section{EXPLANATION}

Total dissolved-solids concentration, in milligrams per liter, and U.S. Geological Survey salinity classification

- Less than 1,000; fresh

Figure 30. Trilinear diagrams showing major-ion composition and dissolved-solids concentrations for ground-water samples from aquifers in Paleozoic hydrogeologic units, Carbon County, Wyoming.-Continued

The water quality of aquifers contained in Paleozoic hydrogeologic units varies greatly throughout the county. Recharge to these units generally occurs where the formations crop out. Near recharge areas, water in these hydrogeologic units can be relatively fresh and may be suitable for most uses. This is where most domestic, municipal supply, or stock wells are completed. Elsewhere, and with increasing depth (as indicated by co-produced oil and gas water samples) and as the water moves away from the outcrop, the water can have TDS concentrations several times that of seawater and is not suitable for most uses or is only marginally suitable for livestock use. Where deeply buried, only oil or gas wells are completed in Paleozoic hydrogeologic units. Locations of samples from aquifers in Paleozoic hydrogeologic units are shown on figure 29.

\section{Casper and Fountain Formations}

The Casper Formation of Permian and Pennsylvanian age occurs in eastern and southern Carbon County, where the upper part of the formation is equivalent to the Tensleep Sandstone and the lower part is equivalent to the Amsden
Formation of the northwestern part of the County (fig. 10) (Mallory, 1967). Arkosic beds in the lower part of the Casper Formation may be tongues of the Fountain Formation, which is at its thickest extent in southern Albany County (Mallory, 1967; Lowry and others, 1973). The upper part of the Casper Formation generally is buff, tan, or reddish-brown, fine to medium-grained, siliceous, well-cemented sandstone (Dobbin, Hoots and others, 1929; Harshman, 1972; Lowry and others, 1973). It grades down to interbedded pink, purple and gray dolomitic limestone and dolomite and tan to reddish-brown dolomitic sandstone, sandstone, and quartzite (Dobbin, Hoots and others, 1929; Harshman, 1972; Lowry and others, 1973). The Fountain Formation is a sequence of reddish sandstone, arkose, and conglomerate, with red to purple arenaceous shale and fine-grained sandstone near the base (Mallory, 1967). The Casper Formation is a shallow marine, beach, and eolian deposit, whereas the Fountain Formation is a fanglomerate from the ancestral Front Range and southern Pathfinder Uplift (Mallory, 1975). The Casper Formation generally is 600 to $800 \mathrm{ft}$ thick (Lowry and others, 1973). The Fountain Formation is 0 to $300 \mathrm{ft}$ thick (Mallory, 1967). The Casper Formation is a source of oil in the Laramie Basin area (De Bruin, 2002). Because of limited areal extent and lack of hydrogeologic and water-quality data, the Casper Formation in Carbon County was not assessed as a part of this study.

\section{Tensleep Sandstone}

The Tensleep Sandstone, which contains the Tensleep aquifer, of Pennsylvanian age occurs in the northwestern part of the county and is at or near surface around the uplifts (fig. 29). It is a white to buff, gray, and pink, fine to mediumgrained sandstone with some thin interbedded tan, white, gray, and pink, finely crystalline, dense limestone and dolomite (Dobbin, Bowen and Hoots, 1929; Berry, 1960; Mallory, 1967, 1975). The Tensleep Sandstone was deposited mostly as dunes, but also was deposited in fluvial, beach, and shallow marine environments (Maughan, 1967; Mallory, 1975). Berry (1960) reported a maximum thickness of $850 \mathrm{ft}$. It is a source of oil, natural gas, and hydrogen sulfide in the northwestern part of the county (De Bruin, 2002). It also is a potential source of uranium in the Shirley Mountains and a potential source of silica sand in the Flat Top area (Harris and others, 1985; Harris, 1996).

Early investigators (Berry, 1960; Welder and McGreevy, 1966; and Lowry and others, 1973) had little information available to describe the hydrogeology of the Tensleep aquifer. Collentine and others (1981) defined the Tensleep Sandstone as a "major aquifer" in the Great Divide and Washakie Basins. In addition, the investigators combined the aquifer with the aquifers in the underlying Amsden Formation and Madison Limestone into a regional aquifer system defined as the "Paleozoic aquifer system." Similarly, Richter (1981) defined the formation as a "principal aquifer" in the general vicinity of the Laramie, Shirley, and Hanna Basins (including Carbon County). Because the Casper Formation in the Laramie Basin 
is considered equivalent to the Tensleep Sandstone, Richter (1981) often referred to aquifers in both formations as the "Casper-Tensleep aquifer." The USGS also defined the formation as a "principal aquifer" (Whitehead, 1996) and referred to the aquifer as part of the "Paleozoic aquifers" category on the national Principal Aquifers map (U.S. Geological Survey, 2003).

Permeability in the Tensleep aquifer is both primary (intergranular) and secondary (fractures) (Collentine and others, 1981; Richter, 1981; Johnson and Huntoon, 1994, and references therein). The Tensleep aquifer is composed of individual sandstone beds separated (confined) by low permeability beds of limestone and dolomite. Fractures in these low permeability lithologies can provide hydraulic connection between the water-bearing layers. Permeability enhancement in areas of structural deformity also has been noted. In the Laramie Basin in adjacent Albany County, Huntoon (1976) and Lundy (1978) reported that hydraulic conductivity in areas of enhanced fracture permeability (structurally deformed areas) was much larger (about 100 times larger) than for relatively undeformed areas. In addition, in a study of the same general area, Huntoon and Lundy (1979) reported that all major springs are located on or near faults and folds, which are areas commonly associated with fracture permeability.

Collentine and others (1981) described the hydrogeology of the Tensleep aquifer in the Great Divide and Washakie Basins. Reported yields for 28 wells throughout the Great Divide and Washakie Basins (primarily from oil wells) ranged from 24 to $400 \mathrm{gal} / \mathrm{min}$. The investigators noted transmissivity values ranging from less than 1 to about $50 \mathrm{ft}^{2} /$ day. In addition, the investigators constructed a generalized potentiometric map for the Tensleep aquifer within the basins, including Carbon County (Collentine and others, 1981, fig. V-7, p. 70). The map shows that ground-water flow in Carbon County generally is towards the west, away from the outcrop areas (and source of recharge), and towards the Great Divide and Washakie Basin centers, although the map does show some flow to the east on the eastern side of the Rawlins Uplift.

The direction of ground-water flow in the Tensleep aquifer, including parts within Carbon County, is shown on a potentiometric map constructed by Geldon (2003, plate 11). The potentiometric map is reproduced in figure 16 and, like the less-detailed map by Collentine and others (1981, fig. V-7, p. 70), shows that ground-water flow generally is towards the west, away from the outcrop areas and towards the Great Divide and Washakie Basin centers, as well as to the east on the eastern side of the Rawlins Uplift. The reader also should note that Geldon (2003, table 1, p. B3) referred to the Tensleep Sandstone as part of the "Weber-De Chelly zone" of the Canyonlands aquifer.

Permeability of the Tensleep aquifer in Carbon County was examined in greater detail by Johnson and Huntoon (1994). The investigators studied permeability of the aquifer in the northern Hanna Basin, in the vicinity of Troublesome and Difficulty Creeks. As noted previously, the investigators reported permeability to be both intergranular and fracture enhanced. In addition, they noted that movement of water in the aquifer primarily is parallel to bedding, although fractures provide vertical hydraulic connection between permeable units when present. The investigators also noted that in some locations, permeability in the aquifer is enhanced by dissolutional enlargements of fractures and bedding planes.

Spring-discharge and well-yield measurements from the USGS NWIS database were reviewed for this study. Three measurements of well yields for pumped wells in the Tensleep aquifer ranged from 8 to $80 \mathrm{gal} / \mathrm{min}$, with a median yield of $18 \mathrm{gal} / \mathrm{min}$. Four measured discharges for springs ranged from 15 to $400 \mathrm{gal} / \mathrm{min}$, with a median discharge of about $211 \mathrm{gal} / \mathrm{min}$.

The chemical composition of ground water in the Tensleep aquifer in Carbon County was characterized and the quality evaluated on the basis of new and historical samples collected from wells and springs. Many of the samples were co-produced oil and gas water. TDS concentrations were highly variable and indicated that water was fresh to briny (fig. 30D). The samples classified as fresh were calcium-bicarbonate water type. Most samples classified as slightly saline were calcium-sulfate types. Water classified as moderately saline was calcium-sodium-sulfate, sodium-sulfate, or sodiumchloride type. Water classified as very saline was sodium-chloride or sodium-sulfate type. The sample classified as briny was a sodium-chloride type. Concentrations of many characteristics and constituents (bicarbonate, sodium, potassium, chloride, and TDS) significantly increased with increasing well depth (appendix 8). Hardness varied considerably and ranged from soft to very hard, but most samples were very hard.

Concentrations of some characteristics and constituents in the Tensleep aquifer approached or exceeded applicable USEPA or State of Wyoming water-quality standards and could limit the suitability of water for some intended uses. Most available water-quality analyses were from co-produced water, so many characteristic and constituent analyses were not available and could not be compared with health-based, aesthetic, or State of Wyoming agricultural and livestock-use standards (appendixes 7-1 to 7-4). Although most measured salinities would preclude domestic use, concentrations of only two measured constituents exceeded health-based standards: boron (proposed HAL exceeded in 2 of 7 samples) and radon (proposed 300-pCi/L MCL exceeded in 2 of 3 samples and proposed 4,000-pCi/L alternate MCL exceeded in 1 of 3 samples) (appendixes 6, 7-1 to 7-4). Aesthetic standards for domestic use were exceeded by concentrations of some characteristics and constituents, including pH (SMCL upper limit exceeded in 6 of 44 samples), TDS (SMCL exceeded in 49 of 57 samples), sulfate (SMCL exceeded in 47 of 57 samples), chloride (SMCL exceeded in 38 of 57 samples), fluoride (SMCL exceeded in 2 of 11 samples), and iron and manganese (SMCLs exceeded in 1 of 2 samples).

In relation to suitability for agricultural and livestock use, concentrations of 7 characteristics and constituents exceeded State of Wyoming agricultural-use standards and concentrations of 4 exceeded State of Wyoming livestock standards 
(appendixes 7-1 to 7-4). Many characteristics and constituents were measured at concentrations greater than agricultural-use standards and included TDS and sulfate (standards exceeded in 47 of 57 samples), SAR (standard exceeded in 2 of 12 samples), chloride (standard exceeded in 44 of 57 samples), fluoride (SMCL exceeded in 2 of 11 samples), boron (standard exceeded in 1 of 7 samples), and iron (standard exceeded in 1 of 2 samples). Some water from the Tensleep aquifer was unsuitable for livestock use, and four characteristics and constituents were measured at concentrations greater than livestock standards: $\mathrm{pH}$ (upper limit standard exceeded in 6 of 44 samples), TDS (standard exceeded in 28 of 57 samples), sulfate (standard exceeded in 10 of 57 samples), and chloride (standard exceeded in 16 of 57 samples).

\section{Amsden Formation}

The Amsden Formation of Pennsylvanian and Mississippian age occurs in the northwestern part of the county and is at or near surface around the uplifts (fig. 29). It consists of three members: an upper Ranchester Limestone Member, a middle Horseshoe Shale Member, and a lower Darwin Sandstone Member (Mallory, 1967, 1975; Sando and others, 1975). The Amsden Formation is a source of hydrogen sulfide in the Lost Soldier area north of Rawlins (De Bruin, 2002).

The Ranchester Limestone Member is a sequence of gray, tan, pink, or purple, dense or finely crystalline, cherty dolomite, dolomitic limestone, and limestone (Mallory, 1967, 1975; Sando and others, 1975). They also described some interbedded pink to dark-red to green shale or shaly limestone, and white to gray fine to medium-grained sandstone, siltstone, and claystone. It is a marine deposit that is as much as $280 \mathrm{ft}$ thick in the county (Mallory, 1967, 1975; Sando and others, 1975).

According to Mallory $(1967,1975)$ and Sando and others (1975), the Horseshoe Shale Member is a red to purple or maroon shale, siltstone, and mudstone that is locally yellowish and light pinkish-gray with some beds and lenses of red fine-grained commonly calcareous sandstone, and silty, sandy, or argillaceous limestone. Sando and others (1975) proposed that the Horseshoe Shale Member was deposited in a lagoonal environment. It is as much as $150 \mathrm{ft}$ thick in the county (Mallory, 1967; Sando and others, 1975).

The Darwin Sandstone Member is a gray, white, cream, to salmon-colored fine to medium-grained quartz sandstone with silica and locally calcite cement (Mallory, 1967; Sando and others, 1975). The sandstone was deposited in a complicated network of dunes, beaches, and bars during a dominantly eastward transgressing shoreline following the drowning of a fluvial system that was associated with the karst topography of an eroding Madison Limestone (Mallory, 1967; Sando and others, 1975).

Little hydrogeologic information is available for the Amsden Formation in Carbon County. Few wells are completed in the formation in Carbon County. In the Rawlins Uplift area, Berry (1960, p. 15), stated that little was known about the water-bearing properties of the formation, and that the formation likely "would yield very little water" because of low permeability rocks. Welder and McGreevy (1966) stated that "ground-water possibilities not known, but probably poor" in the Great Divide and Washakie Basins. Similarly, Collentine and others (1981, table V-1, p. 46) defined the Amsden Formation as an "aquitard" between the Tensleep aquifer and underlying Madison aquifer in the Great Divide and Washakie Basins, and stated that the "unit probably has poor waterbearing potential due to predominance of fine-grained sediments." Spring-discharge and well-yield measurements from the USGS NWIS database were reviewed for this study, but no measurements were available for the Amsden Formation in Carbon County.

The chemical composition of ground water in the Amsden Formation in Carbon County was characterized and the quality evaluated on the basis of only two co-produced oil and gas water samples. One sample was from the Amsden Formation and one sample was from the Darwin Sandstone Member. Based on the TDS concentrations, water from the Amsden Formation was classified as very saline, whereas the water from the Darwin Sandstone Member was classified as slightly saline (figs. 30E and 30F). Both samples were classified as sodium-sulfate type water (figs. $30 \mathrm{E}$ and $30 \mathrm{~F}$ ). Hardness was very hard for both samples. Based on the few analyses available for these two samples, water from the Amsden Formation generally was unsuitable for domestic, agricultural, or livestock use, whereas water from the Darwin Sandstone Member generally was suitable for livestock use.

\section{Madison Limestone}

The Mississippian-age Madison Limestone, which contains the Madison aquifer, occurs in all but the southeastern part of the county and is at or near surface around the uplifts (fig. 29). Most of the Madison Limestone is pink, purple, and gray limestone, dolomitic limestone and dolomite, with some sandy beds and lenses or beds of greenish-gray to brownishgray chert (Berry, 1960; Harshman, 1972). Units that overlie the Madison Limestone were deposited on a well-developed karst topography (Harshman, 1972; Sando and others, 1975). It is a shallow to moderately deep marine deposit that ranges from 0 to about $500 \mathrm{ft}$ thick (Maughan, 1963; Mallory, 1979).

The basal Madison Limestone is a dark brown or dark reddish-brown arkosic sandstone and conglomerate that grades to a fine-grained red to brown sandstone in the Rawlins area (Berry, 1960; Maughan, 1963; Harshman, 1972; Mallory, 1979). Sando and Sandberg (1987) suggested that parts of this sandstone may be the Englewood Formation and (or) Fremont Canyon Sandstone. Macke (1993, p. M93) suggested that this actually is the Cambrian-age Flathead Formation. This sandstone was deposited in nearshore marine environments around the ancestral Front Range that was an emergent lowland in southeastern Carbon County at this time (Mallory, 1979; Sando and Sandberg, 1987). Sando and Sandberg (1987) 
measured as much as $186 \mathrm{ft}$ of Fremont Canyon Sandstone and as much as $45 \mathrm{ft}$ of Englewood Formation in their study.

The Madison Limestone is a source of hydrogen sulfide in the Lost Soldier area north of Rawlins and is a source of natural gas in the Washakie Basin area (De Bruin, 2002). It also is a source of limestone and limestone aggregate in the Rawlins Uplift (Harris and others, 1985; Harris and Meyer, 1986; Harris, 1996). In the Rawlins Uplift and Elk Mountain areas, the formation also is a potential source of iron, uranium, copper, gold, and silver (Harris and others, 1985; Harris, 1996).

Collentine and others (1981) defined the Madison Limestone as a "major aquifer" in the Great Divide and Washakie Basins. In addition, the investigator combined the aquifer with aquifers in the overlying Amsden Formation and Tensleep Sandstone and underlying undifferentiated Cambrian rocks into a regional aquifer system defined as the "Paleozoic aquifer system." In contrast, Richter (1981) did not define the formation as an aquifer in the general vicinity of the Laramie, Shirley, and Hanna Basins (including Carbon County). The USGS defined the Madison Limestone as a "principal aquifer" (Whitehead, 1996) and referred to the aquifer as part of the "Paleozoic aquifers" category on the national Principal Aquifers map (U.S. Geological Survey, 2003).

Permeability in the Madison aquifer is primarily secondary and well-developed in places (Berry, 1960; Collentine and others, 1981; Johnson and Huntoon, 1994, and references therein). Solution cavities and channeling, caverns, and fractures (karstic features) have been noted by these previous investigators. Berry (1960) reported that "outside the Rawlins area, many large springs issue from this formation, and wells that yield more than 1,000 gal/min have been developed." Collentine and others (1981) reported well yields ranging from 4 to $400 \mathrm{gal} / \mathrm{min}$ for the aquifer in the Great Divide and Washakie Basins, and reported specific capacity values of 100 (gal/min)/ft at two wells. The investigators also noted low transmissivity from drill-stem tests (associated with oil wells) with values ranging from about 1.3 to about $2.7 \mathrm{ft}^{2} / \mathrm{day}$. They also reported a high transmissivity value $\left(26,800 \mathrm{ft}^{2} /\right.$ day $)$ at one water well in Carbon County (T. 21 N., R. 87 W., section 9).

The direction of ground-water flow in the Madison aquifer, including parts within Carbon County, is shown on a potentiometric-surface map constructed by Geldon (2003, plate 11). The potentiometric-surface map is reproduced in figure 17 and shows that ground-water flow in the Madison aquifer in Carbon County generally is towards the west, away from the outcrop (and source of recharge), and towards the Great Divide and Washakie Basin centers.

Spring-discharge and well-yield measurements from the USGS NWIS database were reviewed for this study. Four measurements of well yields for pumped wells ranged from 6 to $193 \mathrm{gal} / \mathrm{min}$, with a median yield of about $58 \mathrm{gal} / \mathrm{min}$. The measured discharge for one spring was $35 \mathrm{gal} / \mathrm{min}$.

The chemical composition of ground water in the Madison aquifer in Carbon County was characterized and the quality evaluated on the basis of new and historical samples collected from wells and one spring. All but three of the samples were co-produced oil and gas water. TDS concentrations were highly variable and indicated that water was fresh to very saline (fig. 30G). Two samples classified as fresh (the one new well sample and the spring sample) were calciumbicarbonate water type. Samples classified as slightly saline were sodium-sulfate type. The samples classified as moderately saline and very saline were sodium-chloride type. Concentrations of many characteristics and constituents (hardness, calcium, sodium, chloride, sulfate, and TDS) significantly increased with increasing well depth (appendix 8). Hardness ranged from hard to very hard, although only one sample was classified as hard.

Concentrations of some characteristics and constituents in the Madison aquifer approached or exceeded applicable USEPA or State of Wyoming water-quality standards and could limit the suitability of waters for some intended uses. Most available water-quality analyses were from co-produced water samples, so many characteristic and constituent analyses were not available and could not be compared with healthbased, aesthetic, or State of Wyoming agricultural and livestock-use standards (appendixes 7-1 to 7-4). Although most measured salinities would prevent domestic use, the only two measured constituents that exceeded health-based standards were boron (proposed HAL exceeded in 1 of 3 samples) and radon (proposed 300-pCi/L MCL exceeded in one sample) (appendixes 6, 7-1 to 7-4). Aesthetic standards for domestic use were exceeded by concentrations of some characteristics and constituents, including $\mathrm{pH}$ (less than the SMCL lower limit in 1 of 6 samples), TDS and sulfate (SMCLs exceeded in 9 of 11 samples), and chloride (SMCL exceeded in 8 of 11 samples).

In relation to suitability for agricultural and livestock use, concentrations of 4 characteristics and constituents exceeded State of Wyoming agricultural-use standards and concentrations of 3 exceeded State of Wyoming livestock standards (appendixes 7-1 to 7-4). Several characteristics and constituents were measured at concentrations greater than agriculturaluse standards and included TDS (standard exceeded in 7 of 11 samples), sulfate and chloride (standards exceeded in 9 of 11 samples), and boron (standard exceeded in 1 of 3 samples). Some water from the Madison Limestone was unsuitable for livestock use, and three characteristics and constituents were measured at concentrations that did not meet livestock standards: $\mathrm{pH}$ (less than the lower limit standard in 1 of 6 samples), TDS (standard exceeded in 4 of 11 samples), and chloride (standard exceeded in 1 of 11 samples).

\section{Cambrian Rocks}

Rocks of Cambrian age in Carbon County usually are undifferentiated (fig. 8). They occur in the western part of the county near Rawlins (fig. 29). The rocks are described as an upper sequence of red to reddish-brown shale and green glauconitic sandstone, and a lower sequence of medium-grained 
quartzitic sandstone that is in part cemented by silica and in part conglomeratic (Berry, 1960; Welder and McGreevy, 1966). The upper part seems to correspond to the sandy facies of the Gros Ventre Formation, whereas the lower part seems to correspond to the Flathead Sandstone (fig. 8) as reported by Keefer and Van Lieu (1966). The limestones of the Gallatin and Gros Ventre Formations appear to be absent in Carbon County. The lower sands are a shore and near-shore deposit in front of a transgressive sea, and the upper unit is a shallow marine and non-marine unit (Keefer and Van Lieu, 1966). Berry (1960) reported a thickness range from 0 to $600 \mathrm{ft}$. The Flathead Sandstone is a source of oil in the Lost Soldier area north of Rawlins (De Bruin, 2002). It also is a source of dimension stone and a potential source of mineral pigments, iron, and uranium in the Rawlins Uplift (Harris and others, 1985; Harris and Meyer, 1986; Harris, 1996).

Early investigators (Berry, 1960; Welder and McGreevy, 1966; and Lowry and others, 1973) had little information available to describe the hydrogeology of undifferentiated Cambrian rocks in the Carbon County area. Collentine and others (1981) defined the undifferentiated Cambrian rocks as a "major aquifer" and "major water-bearing zone" in the Great Divide and Washakie Basins. In addition, the investigator combined the rocks with the overlying Madison and Tensleep aquifers into a regional aquifer system defined as the "Paleozoic aquifer system." The USGS also defined the Cambrian rocks as a "principal aquifer" (Whitehead, 1996) and referred to the rocks as part of the "Paleozoic aquifers" category on the national Principal Aquifers map (U.S. Geological Survey, 2003).

Few wells are completed in undifferentiated Cambrian rocks in Carbon County. Berry (1960, p. 14) reported that sandstones and conglomerates in undifferentiated Cambrian rocks in the Rawlins Uplift area "yield moderate supplies of water to wells." Collentine and others (1981) reported that 13 wells were completed in the Rawlins Uplift area, with yields for water wells ranging from 4 to $250 \mathrm{gal} / \mathrm{min}$. Aquifer transmissivity values estimated from drill stem tests of oil wells ranged from less than 1 to about $3.6 \mathrm{ft}^{2} /$ day. In addition, the investigators reported two specific capacity values of less than 1 and 150 (gal/min)/ft.

Spring-discharge and well-yield measurements from the USGS NWIS database were reviewed for this study. Two measurements of well yields for pumped wells were 5 and $150 \mathrm{gal} / \mathrm{min}$. The measured discharge for one spring was $100 \mathrm{gal} / \mathrm{min}$.

The chemical composition of ground water in the Flathead Sandstone in Carbon County was characterized and the quality evaluated on the basis of only one co-produced oil and gas water sample. Based on the TDS concentration, the water was classified as moderately saline (fig. $30 \mathrm{H}$ ). The sample was a sodium-sulfate type water (fig. $30 \mathrm{H}$ ). Hardness was very hard. Based on the few analyses available for this sample, the water generally was suitable for livestock use.

The chemical composition of ground water in undifferentiated rocks of Cambrian age in Carbon County was character- ized and the quality evaluated on the basis of only two water samples (one well and one spring). Based on the dissolved-solids concentrations, the water was classified as fresh (fig. 30I). The spring sample was classified as calcium-bicarbonate type water, whereas the well sample was classified as calciumsodium-mixed anion type water (fig. 30I). Based on the few analyses available for these samples, the water generally was suitable for domestic, agricultural, and livestock use.

\section{Precambrian Hydrogeologic Units}

Rocks of Precambrian age occur throughout Carbon County and are exposed at land surface as the core rocks of the largest of the uplifts (fig. 29). Precambrian rocks account for approximately 13 percent of the surface exposures in Carbon County. Granitic rocks comprise more than one-half of the Precambrian outcrops, whereas metasedimentary and metavolcanic rocks comprise more than one-third of the Precambrian outcrops (Love and Christiansen, 1985). Precambrian rocks are buried in the Hanna Basin by more than $37,000 \mathrm{ft}$ of overlying sediment.

The Precambrian rocks in the county are highly mineralized. They are even a source of produced oil in the Lost Soldier area north of Rawlins (Harris and others, 1985; Harris and Meyer, 1986; Harris, 1996; De Bruin, 2002). The Seminoe District in the Seminoe Mountains is a source of iron, copper, gold, asbestos, and jade (Harris and others, 1985). There are three mineralized districts in the Medicine Bow Mountains of Carbon County: Cooper Hill (gold, iron, copper, lead, and silver), Gold Hill (gold), and Big Creek (thorium, uranium, rare earth elements, vermiculite, copper, and potassium feldspar) (Harris and others, 1985). The Sierra Madre are split into the northern and southern Encampment Districts, which are a source for gold, silver, copper, lead, zinc, tellurium, uranium, cobalt, nickel, and barium, as well as potassium feldspar, kyanite, garnet, mica, vermiculite, and tourmaline (Harris and others, 1985). Dimensional and ornamental stone also is available in the Medicine Bow Mountains (quartzite, marble, and dolomite), Sierra Madre (orbicular granite), and Ferris Mountains (orbicular granite) (Harris and others, 1985; Harris and Meyer, 1986; Harris, 1996). Precambrian granites also are used for crushed aggregate and ballast (Harris and Meyer, 1986). Precambrian rocks in the county are potential sources of arsenic, boron, beryl, graphite, corundum, lanthanum, lithium, manganese, molybdenum, sapphire, tin, sillimanite, titanium, and tungsten (Harris and others, 1985).

Precambrian hydrogeologic units are used locally for domestic wells. Wells are completed at relatively shallow depths where the rocks crop out and permeability is attributable to weathered, fractured, or faulted rocks (Berry, 1960; Lowry and others, 1973; Collentine and others, 1981; Richter, 1981). Lowry and others (1973) noted that the shallow permeable zone typically is less than $100 \mathrm{ft}$ deep. They also noted that fractures decreased in both size and number at greater depths. Collentine and others (1981) reported that well yields in the Great Divide and Washakie Basins ranged 
from 2 to $150 \mathrm{gal} / \mathrm{min}$, but that most well yields were 10 to $20 \mathrm{gal} / \mathrm{min}$. Reported specific capacity values ranged from less than 1 to 150 (gal/min)/ft, but most ranged from less than 1 to 2 (gal/min)/ft. Aquifer transmissivity values were reported to range from less than 1 to $536 \mathrm{ft}^{2} /$ day, but most were less than $134 \mathrm{ft}^{2} /$ day. In the Laramie, Shirley, and Hanna Basins, Richter (1981) reported that yields for springs and wells ranged from 1 to $25 \mathrm{gal} / \mathrm{min}$.

Spring-discharge and well-yield measurements from the USGS NWIS database were reviewed for this study. Three measurements of well yields for pumped wells ranged from 9 to $50 \mathrm{gal} / \mathrm{min}$, with a median yield of $20 \mathrm{gal} / \mathrm{min}$. Five measured discharges for springs ranged from 1 to $100 \mathrm{gal} / \mathrm{min}$ with a median discharge of $10 \mathrm{gal} / \mathrm{min}$.

The chemical composition of ground water in the Precambrian hydrogeologic units in Carbon County was characterized and the quality evaluated on the basis of new and historical samples collected from three wells and four springs. TDS concentrations indicated that the water was fresh (fig. 31). All but one sample was classified as calcium-bicarbonate type; the remaining sample was classified as mixed cation-bicarbonate type. Hardness ranged from soft to hard.

With the exception of some radionuclide concentrations, water from the Precambrian rocks was suitable for domestic, agricultural, and livestock use. Gross-alpha activities in both samples analyzed for radionuclides (appendix 6) exceeded the USEPA MCL and State of Wyoming standards for agricultural and livestock use. In addition, the USEPA proposed 300-pCi/L MCL for radon was exceeded in all three samples analyzed, and the USEPA proposed 4,000-pCi/L alternate MCL was exceeded in 1 of 3 samples.

\section{Water Use}

The USGS performs a nationwide water-use survey every 5 years to estimate water use by categories, and total water use for each State and county. The most recent survey was completed for the year 2000 (Hutson and others, 2004; U.S. Geological Survey, 2005). Table 4 summarizes the estimated water use in 2000 for Carbon County. The numerical data in table 4 are the mean daily quantities used, and were calculated by taking the total annual quantities used and dividing by 366 (2000 was a leap year). In most cases, the actual water used in a category was not measured directly, but estimated based on some other known related value (for example, acres irrigated, tons of ore produced, or population). For this reason, the water-use numbers described here should be considered gross approximations.

The estimated mean daily water use in Carbon County in 2000 was 320.12 million gallons per day (Mgal/d). About 98 percent of the total water used was supplied by surface water, with ground water supplying about 2 percent. Irrigation was the largest use of water in the county, with an estimated 312.21 Mgal/d used to irrigate about 74,200 acres in 2000.
Hay (alfalfa and grass) used more than 99 percent of the irrigated acres and irrigation consumptive water use in 2000, with barley and oats using less than 1 percent of the irrigation consumptive water use on less than 1 percent of the irrigated acres. Water used for irrigation accounted for about 98 percent of total water use. Surface water comprised more than 99 percent of the irrigation water in the county, whereas ground water accounted for less than 1 percent of the irrigation water used. Excluding irrigation, ground water comprised about 74 percent of total water use in Carbon County.

Table 4. Estimated water use in 2000 in Carbon County, Wyoming (Hutson and others, 2004; U.S. Geological Survey, 2005).

\begin{tabular}{lccc}
\hline & \multicolumn{3}{c}{ Water use, in million gallons per day } \\
\cline { 2 - 4 } \multicolumn{1}{c}{ Use } & Surface water & Ground water & Total \\
\hline Irrigation & 312.21 & 1.07 & 313.28 \\
Public supply & 1.57 & 1.81 & 3.38 \\
Mining & 0.14 & 3.01 & 3.15 \\
Industrial & 0.07 & 0.13 & 0.20 \\
Domestic & 0.00 & 0.11 & 0.11 \\
Thermoelectric & 0.00 & 0.00 & 0.00 \\
Totals & $\mathbf{3 1 3 . 9 9}$ & $\mathbf{6 . 1 3}$ & $\mathbf{3 2 0 . 1 2}$ \\
\hline
\end{tabular}

Public supply was the second largest water use with an estimated $3.38 \mathrm{Mgal} / \mathrm{d}$ used in 2000. The public supply category includes community water systems, non-transient noncommunity water systems (for example, schools and factories), and transient non-community water systems (for example, campgrounds and rest areas), but community water systems generally account for most of the public supply water used. The USEPA lists 11 community water systems, with one system for all 10 municipalities in Carbon County, and one additional system for the Deer Haven Mobile Home Park (U.S. Environmental Protection Agency, 2002b). These 11 community water systems provide water to about 90 percent of the county's population. Six community water systems exclusively use surface water (Baggs, Dixon, Encampment, Hanna, Saratoga, and Sinclair), whereas four exclusively use ground water (Deer Haven Mobile Home Park, Elk Mountain, Medicine Bow, and Riverside (served by the Sierra Madre Water and Sewer Joint Powers Board)). Rawlins uses both surface and ground water.

Mining was the third largest use of water in the county in 2000 with an estimated mean daily use of $3.15 \mathrm{Mgal} / \mathrm{d}$. Ground water supplied about 96 percent of the water used for mining. Only about 16 percent of the total water used was fresh water, the rest was saline. Oil and gas production comprised 81 percent of the water used, coal comprised slightly less than 18 percent, and crushed stone comprised slightly more than 1 percent. CBM extraction was not considered as part of the mining category. In 2000, water produced by CBM extraction in the county was estimated to be 20,111 gallons per day (Wyoming Oil and Gas Conservation Commission, 2003). 


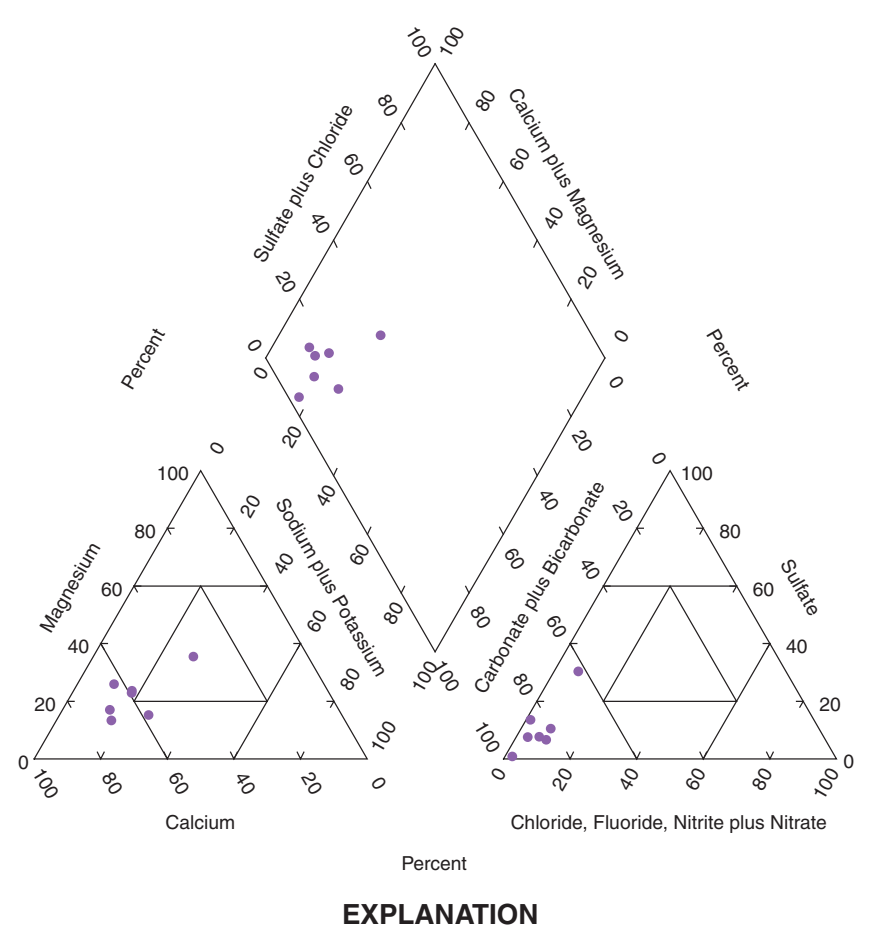

Total dissolved-solids concentration, in milligrams per liter, and U.S. Geological Survey salinity classification

- Less than 1,000; fresh

Figure 31. Trilinear diagram showing major-ion composition and dissolved-solids concentrations for ground-water samples from aquifers in Precambrian hydrogeologic units, Carbon County, Wyoming.

Industrial and domestic water uses in the county were the smallest in the 2000 survey with a combined estimated $0.31 \mathrm{Mgal} / \mathrm{d}$ used. The industrial water-use category accounted for water used by industries that supplied their own water. Water used by industries supplied from municipal water systems was counted under the public supply category. The domestic category accounted for self-supplied (supplied by private wells) water used in private homes. Water used in homes connected to municipal water systems was counted as part of the public supply category.

Livestock water use was not reported in the 2000 survey. The 1995 estimate for livestock usage in the county was 1.21 Mgal/d (U.S. Geological Survey, 2005).

Thermoelectric power generation was the one additional water-use category estimated in the 2000 survey for all counties in Wyoming. No water was used for thermoelectric power generation in Carbon County.

\section{Summary}

Carbon County occupies a physiographically diverse region with a complex geologic past that has resulted in the accumulation of abundant natural resources such as coal, oil, natural gas (both conventional and coalbed methane), minerals, and uranium. Extraction and development of these natural resources are an important part of the economies of Carbon County and the State of Wyoming. Continued extraction and development of these natural resources likely will increase the demand for water use in the county. Increased water development has the potential to affect the quantity and quality of water resources in Carbon County. To address this concern, a study was conducted by the U.S. Geological Survey in cooperation with the Wyoming State Engineer's Office to describe the water resources of Carbon County. Surface-water data were not collected as part of the study. Evaluations of streamflow and stream-water quality were limited to analyses of historical data and descriptions of previous investigations. Forty-five new ground-water-quality samples were collected as part of the study, and the results from an additional 618 historical ground-water-quality samples were included in the study.

Regional and local drainage basin characteristics vary substantially within Carbon County. Mountainous areas generally are characterized by steep, high-altitude basins with relatively high precipitation, resistant geology, and dense vegetative cover, whereas lowland areas generally are characterized by lower altitude, relatively flat basins with low precipitation, less resistant geology, and sparse vegetative cover. Every possible combination of these drainage basin characteristics likely occur within the county, resulting in a wide variety of streamflow characteristics. In addition, anthropogenic influences such as reservoirs and diversions further alter streamflow characteristics.

Water-quality characteristics of selected streams in and near Carbon County during water years 1966 through 1986 varied. Concentrations of dissolved constituents and suspended sediment were smallest at sites on streams with headwaters in mountainous areas because of resistant geologic units, increased vegetative cover, and large diluting streamflows compared to structural basin areas. Nutrient and bacteria concentrations measured at selected sites generally were low when compared to various water-quality standards. Historical and recent anthropogenic activities contributed to natural sources of many dissolved constituents and suspended sediment.

Ground water occurs in the county under both watertable and artesian conditions. Discharge from aquifers occurs mainly as seepage to streams, discharge to springs and seeps, pumpage from wells, evapotranspiration, and underflow along streams and in aquifers that extend out of the area.

The ground-water quality in the county is highly variable, in part reflecting the complex geologic history of the region. Shallow ground water is available throughout the county. 
In most areas, shallow ground water is at least suitable for livestock use, but in many areas the water is only marginally suitable or unsuitable for domestic and irrigation uses, mainly because of high total-dissolved solids (TDS) concentrations.

Ground-water quality tends to deteriorate as the distance from recharge areas increases, and as the depth below land surface increases. Ground water from depths greater than a few thousand feet tends to have TDS concentrations that make it moderately saline to briny. In some areas, even shallow ground water is moderately saline. In parts of some aquifers, other constituents in the ground water occur in high concentrations when compared to U.S. Environmental Protection Agency drinking-water standards and when compared to Wyoming Department of Environmental Quality agricultural and livestock standards; for example, high concentrations of sulfate, chloride, fluoride, boron, iron, manganese, and radon were found in several aquifers.

The estimated mean daily water use in Carbon County in 2000 was 320.12 million gallons per day. Water used for irrigation accounted for about 98 percent of this total. About 98 percent of the total water used was supplied by surface water, and about 2 percent by ground water. Excluding irrigation, ground water comprised about 74 percent of total water use in Carbon County. Although ground water is used to a much lesser extent than surface water, in many areas of the county it is the only available water source.

\section{References}

Agatston, R.S., 1951, Catalog of formation names of southcentral Wyoming and adjacent areas, in Brinker, W.F., and Blackstone, D.L., Jr., eds., South Central Wyoming: Casper, Wyo., Wyoming Geological Association 6th Annual Field Conference Guidebook, 1951, p. 128-130.

American Public Health Association, 1998, Standard methods for the examination of water and wastewater (20th ed.): Washington, D.C., American Public Health Association, American Water Works Association, and Water Environment Federation, p. 3-37-3-43.

American Society for Testing and Materials, 1996, Annual book of ASTM standards, section 11, Water and environmental technology: v. 11.02, D5072-92, p. 674-676.

Anderson and Kelly, Inc., 1984, Hydrogeologic evaluation of the Nugget aquifer near Rawlins, Wyoming: Laramie, Wyoming, report prepared for the Wyoming Water Development Commission, variable pagination.
Annear, T.C., Chisolm, Ian, Beecher, Hal, Locke, Allan, Aarestad, Peter, Coomer, Chuck, Estes, Christopher, Hunt, Joel, Jacobson, Rick, Jobsis, Gerrit, Kauffman, John, Marshall, John, Mayes, Kevin, Stalnaker, Clair, and Wentworth, Rod, 2002, Instream flows for riverine resource stewardship: Instream Flow Council, 440 p.

Atwood, W.W., Jr., 1937, Records of Pleistocene glaciers in the Medicine Bow and Park Ranges: Journal of Geology, v. 45, no. 2, p. 113-140.

Bergstrom, J.R., 1959, Generalized composite section of "Mesaverde" rocks of southeastern Wyoming, in Haun, J.D., and Weimer, R.J., eds., Symposium on Cretaceous Rocks of Colorado and Adjacent Areas-Washakie, Sand Wash and Piceance Basins: Denver, Rocky Mountain Association of Geologists 11th Annual Field Conference Guidebook, 1959, p. 114.

Berry, D.W., 1960, Geology and ground-water resources of the Rawlins area, Carbon County, Wyoming: U.S. Geological Survey, Water-Supply Paper 1458, 74 p., 1 pl., scale $1: 63,360$.

Blackstone, D.L., Jr., 1989, Precambrian basement map of Wyoming-Outcrop and structural configuration: Laramie, Geological Survey of Wyoming Map Series MS-27, 1 sheet, scale $1: 1,000,000$.

Blackstone, D.L., Jr., 1991, Tectonic relationships of the southern Wind River Range, southwestern Sweetwater uplift, and Rawlins uplift, Wyoming: Laramie, Wyoming State Geological Survey Report of Investigations 47, 24 p., $2 \mathrm{pl}$.

Blackstone, D.L., Jr., 1993a, Precambrian basement map of Wyoming, in Snoke, A.W., Steidtmann, J.R., and Roberts, S.M., eds., Geology of Wyoming: Laramie, Geological Survey of Wyoming Memoir No. 5, Map Series MS-43, scale $1: 1,000,000$.

Blackstone, D.L., Jr., 1993b, Overview of the Hanna, Carbon, and Cooper Lake Basins: Laramie, Geological Survey of Wyoming Report of Investigations RI-48, 20 p., scale $1: 250,000$.

Borchert, W.B., 1977, Preliminary model of the Arikaree aquifer in the Sweetwater River Basin, central Wyoming: U.S. Geological Survey Water-Resources Investigations/OpenFile Report 77-107, 19 p.

Borchert, W.B., 1987, Water-table contours and depth to water in the southeastern part of the Sweetwater River Basin, central Wyoming, 1982: U.S. Geological Survey WaterResources Investigations Report 86-4205, 1 sheet.

Bowen, C.F., 1918, Stratigraphy of the Hanna Basin, Wyoming: U.S. Geological Survey Professional Paper 108-L, p. 227-235. 
Bradley, W.H., 1961, Geologic map of a part of southwestern Wyoming and adjacent States: U.S. Geological Survey Miscellaneous Geologic Investigations Map I-332, scale 1:250,000.

Bradley, W.H., 1964, Geology of Green River Formation and associated Eocene rocks in southwestern Wyoming and adjacent parts of Colorado and Utah: U.S. Geological Survey Professional Paper 496-A, $86 \mathrm{p}$.

Bureau of Land Management, 1975, Resource and potential reclamation evaluation, Hanna Basin study site, Hanna Coal Field, Wyoming: U.S. Bureau of Land Management EMRIA report No. 2-1975, 176 p.

Bureau of Land Management, 2002, Great Divide Basin/Ferris \& Seminoe Mountain Watersheds Standards \& Guidelines Assessment: digital data accessed March 29, 2005, at http://www.wy.blm.gov/rfo/standards02/

Bureau of Reclamation, 2005a, North Platte project Nebraska and Wyoming: U.S. Bureau of Reclamation, online version accessed March 16, 2005, at http://www.usbr.gov/dataweb/ html/northplatte.html

Bureau of Reclamation, 2005b, Kendrick project Wyoming: U.S. Bureau of Reclamation, online version accessed March 16, 2005, at http://www.usbr.gov/dataweb/html/kendrick. html

Bureau of Reclamation, 2005c, Kortes Dam: U.S. Bureau of Reclamation, online version accessed March 16, 2005, at http://www.usbr.gov/dataweb/dams/wy01294.htm

Case, J.C., Arneson, C.S., and Hallberg, L.L., 1998, Preliminary 1:500,000-scale digital surficial geology map of Wyoming: Laramie, Wyoming State Geological Survey Hazards Section Digital Map HSDM 98-1, scale 1:500,000.

Clark, G.M., Mueller, D.K., and Mast, M.A., 2000, Nutrient concentrations and yields in undeveloped stream basins of the United States: Journal of the American Water Resources Association, v. 35, no. 4, p. 849-860.

Clark, M.L., and Gamper, M.E., 2003, A synoptic study of fecal-indicator bacteria in the Wind River, Bighorn River, and Goose Creek Basins, Wyoming, June-July 2000: U.S. Geological Survey Water-Resources Investigations Report 03-4055, 43 p.

Collentine, Michael; Libra, Robert; Feathers, K.R., and Hamden, Latif, 1981, Occurrence and characteristics of ground water in the Great Divide and Washakie Basins, Wyoming: Laramie, University of Wyoming, Water Resources Research Institute report to U.S. Environmental Protection Agency, Volume VI-A, 112 p.

Crawford, J.G., 1940, Oil-field waters of Wyoming and their relation to geological formations: American Association of Petroleum Geologists Bulletin, v. 24, no. 7, p. 1214-1329.
Crawford, J.G., 1953, Oil-field waters of the Laramie-HannaShirley Basins, Laramie Basin, Wyoming, and North Park, Colorado: Casper, Wyoming Geological Association 8th Annual Field Conference Guidebook, 1953, p. 126-134.

Crawford, J.G., and Davis, C.E., 1962, Some Cretaceous waters of Wyoming, in Enyert, R.L., and Curry, W.H., eds., Symposium on Early Cretaceous Rocks of Wyoming and Adjacent Areas: Casper, Wyoming Geological Association 17th Annual Field Conference Guidebook, 1962, p. 257-267.

Crist, M.A., 1990, A concept of the shallow ground-water system along the North Platte River, south-central Wyoming: U.S. Geological Survey Water-Resources Investigations Report 89-4078, 23 p.

Curry, W.H., III, 1962, Depositional environments in central Wyoming during the Early Cretaceous, in Enyert, R.L., and Curry, W.H., III, eds., Symposium on Early Cretaceous Rocks of Wyoming and Adjacent Areas: Casper, Wyoming Geological Association 17th Annual Field Conference Guidebook, 1962, p. 118-123.

Daly, Christopher, Neilson, R.P., and Phillips, D.L., 1994, A statistical-topographic model for mapping climatological precipitation over mountainous terrain: Journal of Applied Meteorology, v. 33, p. 140-158.

Darton, N.H., 1908, Paleozoic and Mesozoic of central Wyoming: Geological Society of America Bulletin, v. 19, p. 403-463.

Darton, N.H., and Siebenthal, C.E., 1909, Geology and mineral resources of the Laramie Basin, Wyoming - a preliminary report: U.S. Geological Survey Bulletin 364, 81 p.

De Bruin, R.H., 2002, Oil and gas map of Wyoming: Laramie, Wyoming State Geological Survey Map Series MS-55, 1 sheet, scale 1:500,000.

Denson, N.M., 1965, Miocene and Pliocene rocks of central Wyoming, in Cohee, G.V., and West, W.S., Changes in stratigraphic nomenclature by the U.S. Geological Survey, 1964: U.S. Geological Survey Bulletin 1224-A, p. A70-A77.

Denson, N.M., and Harshman, E.N., 1969, Map showing areal distribution of Tertiary rocks, Bates Hole-Shirley Basin area, south-central Wyoming: U.S. Geological Survey Miscellaneous Geologic Investigations Map I-570, 1 sheet, scale 1:125,000.

Dobbin, C.E., Bowen, C.F., and Hoots, H.W., 1929, Geology and coal and oil resources of the Hanna and Carbon Basins, Carbon County, Wyoming: U.S. Geological Survey Bulletin $804,88 \mathrm{p}$. 
Dobbin, C.E., Hoots, H.W., Dane, C.H., and Hancock, E.T., 1929, Geology of the Rock Creek oil field and adjacent areas, Carbon and Albany counties, Wyoming: U.S. Geological Survey Bulletin 806-D, p. 131-153.

Dorf, Erling, 1938, Upper Cretaceous floras of the Rocky Mountain region; 1, Stratigraphy and paleontology of the Fox Hills and Lower Medicine Bow Formations of southern Wyoming and northwestern Colorado: Washington, D.C., Carnegie Institute of Washington Publication 508, p. 1-78.

Driese, K.L., Reiners, W.A., Merrill, E.H., and Gerow, K.G., 1997, A digital land cover map of Wyoming, USA - A tool for vegetation analysis: Vegetation Science Journal, v. 8, no. 1, p. 133-146.

Driver, N.E., Norris, J.M., Kuhn, Gerhard, and others, 1984 [1987], Hydrology of Area 53, Northern Great Plains and Rocky Mountain Coal Provinces, Colorado, Wyoming, and Utah: U.S. Geological Survey Water-Resources Investigations/Open-File Report 83-765, 91 p.

Dufour, A.P., 1977, Escherichia coli-the fecal coliform, in Hoadley, A.W., and Dutka, B.J., eds., Bacterial indicators/ health hazards associated with water, 1977: American Society for Testing and Materials, ASTM STP 635, p. 48-58.

Eschner, T.R., Hadley, R.F., and Crowley, K.D., 1983, Hydrologic and morphologic changes in channels of the Platte River Basin in Colorado, Wyoming, and Nebraska-a historical perspective: U.S. Geological Survey Professional Paper 1277-A, 39 p.

Faires, L.M., 1993, Methods of analysis by the U.S. Geological Survey National Water Quality Laboratory-Determination of metals in water by inductively coupled plasma-mass spectrometry: U.S. Geological Survey Open-File Report 92-634, 28 p.

Fishman, M.J., ed., 1993, Methods of analysis by the U.S. Geological Survey National Water Quality LaboratoryDetermination of inorganic and organic constituents in water and fluvial sediments: U.S. Geological Survey Open-File Report 93-125, 217 p.

Fishman, M.J., and Friedman, L.C., eds., 1989, Methods for determination of inorganic substances in water and fluvial sediments (3d. ed.): U.S. Geological Survey Techniques of Water-Resources Investigations, book 5, chap. A1, 545 p.

Fisk, E.P., 1967, Groundwater geology and hydrology of the Great Divide and Washakie Basins, south central Wyoming: Los Angeles, University of Southern California, unpublished masters thesis, $132 \mathrm{p}$.
Flanagan, K.M., and Montagne, John, 1993, Neogene stratigraphy and tectonics of Wyoming, in Snoke, A.W., Steidtmann, J.R., and Roberts, S.M., eds., Geology of Wyoming: Laramie, Wyoming, Geological Survey of Wyoming Memoir No. 5, p. 572-607.

Freethey, G.W., 1988, Upper Colorado River Basin regional aquifer-system analysis-Mesozoic rocks in Colorado, Utah, and Wyoming, Arizona, and New Mexico, in McLean, J.S., and Johnson, A.I., eds., Regional aquifer systems of the United States, aquifers of the Western mountain area: American Water Resources Association Monograph Series No. 14, p. 57-70.

Freethey, G.W., and Cordy, G.E., 1991, Geohydrology of Mesozoic rocks in the Upper Colorado River Basin in Arizona, Colorado, New Mexico, Utah, and Wyoming, excluding the San Juan Basin: U.S. Geological Survey Professional Paper 1411-C, 118 p.

Freethey, G.W., Kimball, B.A., Wilberg, D.E., and Hood, J.W., 1988, General hydrogeology of the aquifers of Mesozoic age, Upper Colorado River Basin, excluding the San Juan Basin, Colorado, Utah, Wyoming, and Arizona: U.S. Geological Survey Hydrologic Investigations Atlas HA-698, 2 sheets, scale 1:2,500,000.

Freudenthal, P.B., 1979, Water-quality data for the Hanna and Carbon Basins, Wyoming: U.S. Geological Survey OpenFile Report 79-1277, 41 p.

Fuhrer, G.J., Gilliom, R.J., Hamilton, P.A., Morace, J.L., Nowell, L.H., Rinella, J.F., Stoner, J.D., and Wentz, D.A., 1999, The quality of our Nation's waters-Nutrients and pesticides: U.S. Geological Survey Circular 1225, 82 p.

Garbarino, J.R., 1999, Methods of analysis by the U.S. Geological Survey National Water Quality Laboratory -Determination of dissolved arsenic, boron, lithium, selenium, strontium, thallium, and vanadium using inductively coupled plasma-mass spectrometry: U.S. Geological Survey Open-File Report 99-093, 31 p.

Gaylord, D.R., 1982, Geologic history of the Ferris dune field, south-central Wyoming; interpretation of windflow characteristics from eolian landforms: Geological Society of America Special Paper 192, p. 65-82.

Gaylord, D.R., 1989, Field trip guide to the Ferris and Seminoe dune fields, in Eisert, J.L., ed., Gas resources of Wyoming: Casper, Wyo., Wyoming Geological Association 40th Field Conference Guidebook, 1989, p. 269-275.

Geldon, A.L., 2003, Hydrologic properties and ground-water flow systems of the Paleozoic rocks in the Upper Colorado River Basin in Arizona, Colorado, New Mexico, Utah, and Wyoming, excluding the San Juan Basin: U.S. Geological Survey Professional Paper 1411-B, 153 p. 
Gill, J.R., Merewether, E.A., and Cobban, W.A., 1970, Stratigraphy and nomenclature of some Upper Cretaceous and Lower Tertiary rocks in south-central Wyoming: U.S. Geological Survey Professional Paper 667, 53 p.

Glover, K.C., Naftz, D.L., and Martin, L.J., 1998, Geohydrology of Tertiary rocks in the Upper Colorado River Basin in Colorado, Utah, and Wyoming, excluding the San Juan Basin: U.S. Geological Survey Water-Resources Investigations Report 96-4105, 103 p.

Hale, L.A., 1961, Late Cretaceous (Montanan) stratigraphy, eastern Washakie Basin, Carbon County, Wyoming, in Wiloth, G.J., ed., Symposium on Late Cretaceous rocks, Wyoming and adjacent areas: Casper, Wyo., Wyoming Geological Association 16th Annual Field Conference, 1961, p. 129-137.

Hansen, W.R., 1984, Post-Laramide tectonic history of the eastern Uinta Mountains, Utah, Colorado, and Wyoming: The Mountain Geologist, v. 21, no. 1, p. 5-29.

Hansen, W.R., 1986, Neogene tectonics and geomorphology of the eastern Uinta Mountains in Utah, Colorado, and Wyoming: U.S. Geological Survey Professional Paper 1356, $78 \mathrm{p}$.

Harris, R.E., 1996, Industrial minerals and construction materials map of Wyoming: Laramie, Wyoming State Geological Survey Map Series MS-47, 1 sheet, scale 1:500,000.

Harris, R.E., and Meyer, J.E., 1986, Construction materials map of Wyoming: Laramie, Wyoming State Geological Survey Map Series MS-21, 1 sheet, scale 1:500,000.

Harris, R.E., Hausel, W.D., and Meyer, J.E., 1985, Metallic and industrial minerals map of Wyoming: Laramie, Geological Survey of Wyoming Map Series MS-14, 1 sheet, scale 1:500,000.

Harshman, E.N., 1968, Geologic map of the Shirley Basin area, Albany, Carbon, Converse, and Natrona Counties, Wyoming: U.S. Geological Survey Miscellaneous Geologic Investigations Map I-539, 1 sheet, scale 1:48,000.

Harshman, E.N., 1972, Geologic and uranium deposits, Shirley Basin area, Wyoming: U.S. Geological Survey Professional Paper 745, 82 p.

Hayden, F.V., 1869, Preliminary field report [third annual] of Colorado and New Mexico: U.S. Geological Survey of the Territories, $155 \mathrm{p}$.

Heath, R.C., 1983, Basic ground-water hydrology: U.S. Geological Survey Water-Supply Paper 2220, 84 p.

Helsel, D.R., and Cohn, T.A., 1988, Estimation of descriptive statistics for multiply censored water quality data: Water Resources Research, v. 24, no. 12, p. 1997-2004.
Helsel, D.R., and Hirsch, R.M., 1992, Statistical methods in water resources: New York, Elsevier Science Publishers, $522 \mathrm{p}$.

Hem, J.D., 1985, Study and interpretation of the chemical characteristics of natural water (3d. ed.): U.S. Geological Survey Water-Supply Paper 2254, 263 p.

High, L.R., Jr., and Picard, M.D., 1969, Stratigraphic relations within upper Chugwater Group (Triassic), Wyoming: American Association of Petroleum Geologists Bulletin, v. 53 , no. 5 , p. 1091-1104.

Hoffman, P.F., 1988, United plates of America, the birth of a craton-Early Proterozoic assembly and growth of Laurentia: Annual Reviews of Earth and Planetary Science, v. 16, p. 543-603.

Honey, J.G., and Izett, G.A., 1989, Paleontology, taphonomy, and stratigraphy of the Browns Park Formation (Oligocene and Miocene) near Maybell, Moffat County, Colorado: U.S. Geological Survey Professional Paper 1358, 52 p.

Houston, R.S., McCallum, M.E., King, J.S., Ruehr, B.B., Myers, W.G., Orback, C.J., King, J.R., Childers, M.O., Matus, Irwin, Currey, D.R., Gris, J.C., Stensrud, H.L., Catanzaro, E.J., Swetnam, M.N., Michalek, D.D., and Blackstone, D.L., Jr., 1968, A regional study of rocks of Precambrian age in that part of the Medicine Bow Mountains lying in southeastern Wyoming -With a chapter on the relationship between Precambrian and Laramide structure: Laramie, Geological Survey of Wyoming Memoir 1, 167 p., 1 plate under separate cover.

Howard, Needles, Tammen, and Bergendoff, 1984, Water supply for town of Encampment, Level II feasibility study: Casper, Wyoming, Final report prepared for Wyoming Water Development Commission, variable pagination.

Huntoon, P.W., 1976, Hydrogeologic properties of the Casper Formation in the vicinity of Laramie, Wyoming in Report on the availability of ground water for municipal use, Laramie, Wyoming: Laramie, Wyoming, report prepared for Banner Associates, 30 p.

Huntoon, P.W., and Lundy, D.A., 1979, Evolution of groundwater management policy for Laramie, Wyoming, 18691979: Ground Water, v. 17, p. 470-475.

Huntoon, P.W., McCormack, K.G., and Hasfurther, V.R., 1993, Assessment of reduced stream flows on ground water recharge and spring-discharge in the Little Snake River drainage basin, Wyoming: Laramie, Wyoming, report prepared for Wyoming Water Development Commission and University of Wyoming Water Resources Center, variable pagination. 
Hutson, S.S., Barber, N.L., Kenny, J.F., Linsey, K.S., Lumia, D.S., and Maupin, M.A., 2004, Estimated use of water in the United States in 2000: U.S. Geological Survey Circular 1268,46 p.

Hyden, H.J., McAndrews, Harry, and Tschudy, R.H., 1965, The Foote Creek and Dutton Creek Formations, two new formations in the north part of the Laramie Basin, Wyoming, in Contributions to stratigraphy, 1964: U.S. Geological Survey Bulletin 1194-K, p. K1-K12.

Izett, G.A., and Wilcox, R.E., 1982, Map showing localities and inferred distributions of the Huckleberry Ridge, Mesa Falls, and Lava Creek ash beds (Pearlette family ash beds) of Pliocene and Pleistocene age in the western United States and southern Canada: U.S. Geological Survey Miscellaneous Investigations Map I-1325, 1 sheet, scale 1:4,000,000.

James M. Montgomery Consulting Engineers, 1983, City of Rawlins, Wyoming, Final Report on hydrogeologic investigations for water supply development: report prepared for Wyoming Water Development Commission, variable pagination.

James M. Montgomery Consulting Engineers, 1986, Rawlins ground-water project-Level III Nugget aquifer report: report prepared for the City of Rawlins, variable pagination.

Johnson, S.A., and Huntoon, P.W., 1994, Permeability architecture and ground-water circulation along a fault-severed margin, northern Hanna Basin, Carbon County, Wyoming: Laramie, Wyoming, report prepared for University of Wyoming Water Resources Center, 115 p.

Jones, R.W., 1991, Coal map of Wyoming: Laramie, Wyoming State Geological Survey Map Series MS-34, 1 sheet, scale 1:500,000.

Keefer, W.R., and Van Lieu, J.A., 1966, Paleozoic formations in the Wind River Basin, Wyoming: U.S. Geological Survey Professional Paper 495-B, 60 p.

Krueger, M.L., 1960, Occurrence of natural gas in the western part of Green River Basin, in McGookey, D.P., and Miller, D.N., Jr., eds., Overthrust belt of southwestern Wyoming and adjacent areas, Wyoming Geological Association, 15th Annual Field Conference Guidebook: Wyoming Geological Association, p. 195-209.

Kuhn, Gerhard, Daddow, P.B., Craig, G.S., Jr., and others, 1983, Hydrology of Area 54, Northern Great Plains and Rocky Mountain Coal Provinces, Colorado and Wyoming: U.S. Geological Survey Water-Resources Investigations/ Open-File Report 83-146, 95 p.

Langbein, W.B., and others, 1949, Annual runoff in the United States: U.S. Geological Survey Circular 52, 14 p.
Langbein, W.B., and Schumm, S.A., 1958, Yield of sediment in relation to mean annual precipitation: American Geophysical Union Transactions, v. 39, p. 1076-1084.

Larson, L.R., 1984, Ground-water quality in Wyoming: U.S. Geological Survey Water-Resources Investigations Report 84-4034, 71 p.

Larson, L.R., 1988, Coal-spoil and ground-water chemical data for two coal mines: Hanna Basin and Powder River Basin, Wyoming: U.S. Geological Survey Open-File Report 88-481, 18 p.

Larson, L.R., and Zimmerman, E.A., 1981, Water resources of upper Separation Creek Basin, south-central Wyoming: U.S. Geological Survey Water-Resources Investigations Report 80-85, 69 p.

Lenfest, L.W., Jr., 1986, Ground-water levels and use of water for irrigation in the Saratoga Valley, south-central Wyoming, 1980-81: U.S. Geological Survey Water-Resources Investigations Report 84-4040, 24 p.

Lindner-Lunsford, J.B., Kimball, B.A., Chafin, D.T., and Bryant, C.G., 1989, Hydrogeology of aquifers of Paleozoic age, Upper Colorado River Basin, excluding the San Juan Basin, in Colorado, Utah, Wyoming, and Arizona: U.S. Geological Survey Hydrologic Investigations Atlas HA-702, 2 sheets, scale $1: 2,500,000$ and $1: 5,000,000$.

Love, J.D., 1961, Split Rock Formation (Miocene) and Moonstone Formation (Pliocene) in central Wyoming: U.S. Geological Survey Bulletin 1121-I, 37 p.

Love, J.D., 1963, Large uraniferous springs and associated uranium minerals, Shirley Mountains, Carbon County, Wyoming - a preliminary report: U.S. Geological Survey Open-File Report 63-86, 23 p.

Love, J.D., 1970, Cenozoic geology of the Granite Mountains area, central Wyoming: U.S. Geological Survey Professional Paper 495-C, 154 p.

Love, J.D., and Christiansen, A.C., 1985, Geologic map of Wyoming: U.S. Geological Survey, 3 sheets, scale 1:500,000.

Love, J.D., Christiansen, A.C., and Ver Ploeg, A.J., compilers, 1993, Stratigraphic chart showing Phanerozoic nomenclature for the State of Wyoming: Laramie, Geological Survey of Wyoming Map Series MS-41, 1 sheet.

Love, J.D., McGrew, P.O., and Thomas, H.D., 1963, Relationship of latest Cretaceous and Tertiary deposition and deformation to oil and gas in Wyoming, in Childs, O.E., and Beebe, B.W., eds., Backbone of the Americas-tectonic history from pole to pole, a symposium: American Association of Petroleum Geologists Memoir 2, p. 196-208. 
Lowham, H.W., Peterson, D.A., Larson, L.R., Zimmerman, E.A., Ringen, B.H., and Mora, K.L., 1985, Hydrology of Area 52, Rocky Mountain Coal Province, Wyoming, Colorado, Idaho, and Utah: U.S. Geological Survey WaterResources Investigations /Open-File Report 83-761, 96 p.

Lowry, M.E., Rucker, S.J., IV, and Wahl, K.L., 1973, Water resources of the Laramie, Shirley, Hanna Basins and adjacent areas, southeastern Wyoming: U.S. Geological Survey Hydrologic Investigations Atlas HA-471, 4 sheets, scale 1:250,000 and 1:750,000.

Lumb, A.M., Kittle, J.L., Jr., and Flynn, K.M., 1990, Users manual for ANNIE, a computer program for interactive hydrologic analyses and data management: U.S. Geological Survey Water-Resources Investigations Report 89-4080, $236 \mathrm{p}$.

Lundy, D.A., 1978, Hydrology and geochemistry of the Casper aquifer in the vicinity of Laramie, Albany County Wyoming: Laramie, University of Wyoming, Department of Geology, unpublished M.S. thesis, variable pagination.

Macke, D.L., 1993, Cambrian through Mississippian rocks of the Powder River Basin, Wyoming, Montana, and adjacent areas: U.S. Geological Survey Bulletin 1917-M, p. M1-M174, 2 pl.

Mallory, W.W., 1963, Pathfinder Uplift of Pennsylvanian age in southern Wyoming, in Geological Survey Research 1962: U.S. Geological Survey Professional Paper 450-E, p. E57-E60.

Mallory, W.W., 1967, Pennsylvanian and associated rocks in Wyoming: U.S. Geological Survey Professional Paper 554G, p. G1-G31, 3 pl.

Mallory, W.W., 1975, Middle and southern Rocky Mountains, Northern Colorado Plateau, and Eastern Great Basin Region: U.S. Geological Survey Professional Paper 853-N, p. $265-278$.

Mallory, W.W., 1979, Central Rocky Mountains and northern Colorado Plateau Region: U.S. Geological Survey Professional Paper 1010-M, p. 209-219.

Martin, L.J., 1996, Geohydrology of Tertiary rocks in the Green River Structural Basin in Wyoming, Utah, and Colorado: U.S. Geological Survey Water-Resources Investigations Report 92-4164, 43 p.

Martner, B.E., 1986, Wyoming climate atlas: Lincoln, University of Nebraska Press, 432 p.

Mason, J.P., and Miller, K.A., 2005, Water resources of Sweetwater County, Wyoming: U.S. Geological Survey Scientific Investigations Report 2004-5214, 188 p.
Mastromatteo, Ernest, and Sullivan, Frank, 2003, Summaryinternational symposium on the health effects of boron and its compounds: accessed August, 20 2003, at http://ehpnet1. niehs.nih.gov/docs/1994/Suppl-7/sullivan.html

Masursky, Harold, 1962, Uranium-bearing coal in the eastern part of the Red Desert area, Wyoming: U.S. Geological Survey Bulletin 1099-B, 152 p.

Maughan, E.K., 1963, Mississippian rocks in the Laramie Range, Wyoming, and adjacent areas, in Geological Survey Research 1963: U.S. Geological Survey Professional Paper 475-C, p. C23-C27.

Maughan, E.K., 1964, The Goose Egg Formation in the Laramie Range and adjacent parts of southeastern Wyoming, in Geological Survey Research 1964: U.S. Geological Survey Professional Paper 501-B, p. B53-B60.

Maughan, E.K., 1967, Eastern Wyoming, eastern Montana, and the Dakotas, in McKee, E.D., and Oriel, S.S., Paleotectonic investigations of the Permian system in the United States: U.S. Geological Survey Professional Paper 515, p. 125-152.

McGrew, P.O., 1951, Tertiary stratigraphy and paleontology of south-central Wyoming, in Brinker, W.F., and Blackstone, D.L., Jr., eds., South central Wyoming: Casper, Wyo., Wyoming Geological Association 6th Annual Field Conference Guidebook, 1951, p. 54-57.

McKelvey, V.E., Cheney, T.M., Cressman, E.R., Sheldon, R.P., Swanson, R.W., and Williams, J.S., 1959, The Phosphoria, Park City, and Shedhorn Formations in the western phosphate field: U.S. Geological Survey Professional Paper 313-A, p. 1-47.

McLain, Betty, 1993, Methods of analysis by the U.S. Geological Survey National Water Quality Laboratory-Determination of chromium in water by graphite furnace atomic absorption spectrophotometry: U.S. Geological Survey Open-File Report 93-449, 16 p.

Meade, R.H., Yuzyk, R.T., and Day, T.J., 1990, Movement and storage of sediment in rivers of the United States and Canada, in Wolman, M.G., and Riggs, H.C., eds., Surface water hydrology, The geology of North America, v. O-1: Boulder, Colorado, Geological Society of America, p. 255-280.

Mears, Brainerd, Jr., 1953, Quaternary features of the Medicine Bow Mountains, Wyoming, in Blackstone, D.L., Jr., and Van Gilder, H.R., eds., Laramie Basin, Wyoming and North Park, Colorado: Casper, Wyoming Geological Association 8th Annual Field Conference Guidebook, 1953, p. $81-84$. 
Mears, Brainerd, Jr., 2001, Glacial records in the Medicine Bow Mountains and Sierra Madre of southern Wyoming and adjacent Colorado, with a traveler's guide to their sites: Geological Survey of Wyoming Public Information Circular 41, 26 p.

Merewether, E.A., and Cobban, W.A., 1972, Unconformities within the Frontier Formation, northwestern Carbon County, Wyoming: U.S. Geological Survey Professional Paper 800-D, p. D57-D66.

Merewether, E.A., Cobban, W.A., and Cavanaugh, E.T., 1979, Geometry and history of petroleum-bearing sandstone units of early Late Cretaceous age in eastern Wyoming, in Geological Survey Research 1979: U.S. Geological Survey Professional Paper 1150, p. 25-26.

Merrill, E.H., Kohley, T.W., Herdendorf, M.E., Reiners, W.A., Driese, K.L., Marrs, R.W., and Anderson, S.H., 1996, The Wyoming Gap Analysis Project Final Report: Laramie, Wyo., Wyoming Cooperative Fish and Wildlife Research Unit, University of Wyoming.

Miller, K.A., 2003, Peak-flow characteristics of Wyoming streams: U.S. Geological Survey Water-Resources Investigations Report 03-4107, 79 p.

Montagne, John, 1991, Cenozoic history of the Saratoga Valley area, Wyoming and Colorado: Laramie, University of Wyoming, Contributions to Geology, v. 29, no. 1, p. 13-70.

Muth, R.T., Crist, L.W., LaGory, K.E., Hayse, J.W., Bestgen, K.R., Ryan, T.P., Lyons, J.K., and Valdez., R.A., 2000, Flow and temperature recommendations for endangered fishes in the Green River downstream of Flaming Gorge Dam: Final report, Upper Colorado River Endangered Fish Recovery Program, Project FG-53, September 2000, variable pagination, online version accessed September 29, 2003, at http:// www.ead.anl.gov/pub/doc/flaminggorgeflowrecs.pdf

Myers, D.M., and Sylvester, M.A., 1997, Biological indicators, fecal indicator bacteria, in Wilde, F.D., and Radtke, D.B., eds., National field manual for the collection of water-quality data: U.S. Geological Survey Techniques of Water-Resources Investigations, book 9, chap. A7, variable pagination.

Naftz, D.L., 1996, Geochemistry of selected aquifers in Tertiary rocks of the Upper Colorado River Basin in Wyoming, Colorado, and Utah: U.S. Geological Survey WaterResources Investigations Report 95-4065, 45 p.

Naftz, D.L., and Barclay, C.S.V., 1991, Selenium and associated trace elements in soil, rock, water, and streambed sediment of the proposed Sandstone Reservoir, south-central Wyoming: U.S. Geological Survey Water-Resources Investigations Report 91-4000, 69 p., 1 pl., scale 1:24,000.
National Research Council, 1999, Hydrologic hazards science at the U.S. Geological Survey: Committee on U.S. Geological Survey Water Resources Research, Water Science and Technology Board, Commission on Geosciences, Environment, and Resources, National Research Council, Washington, D.C., 79 p.

Natural Resources Conservation Service, 2005, SNOTEL (Snowpack Information) digital data: accessed March 29, 2005, at http://www.wcc.nrcs.usda.gov/cgibin/state-site. pl? state $=W Y \&$ report $=$ precsnotelmon

Newell, F.H., 1893, Water supply for irrigation, in Thirteenth Annual Report of the U.S. Geological Survey, 1891-92, Part III, Irrigation, p. 7-107.

Pedersen Planning Consultants, 2005, Carbon County Land Use Plan, variable pagination, online version accessed May 26, 2005, at http://carboncounty.wy.gov/landuseplan/

Peterson, Fred, 1994, Sand dunes, sabkhas, streams, and shallow seas: Jurassic paleogeography in the southern part of the Western Interior basin, in Caputo, M.V., Peterson, J.A., and Franczyk, K.J., eds., Mesozoic systems of the Rocky Mountain Region, USA: Society of Economic Paleontologists and Mineralogists, Rocky Mountain Section, p. 233-272.

Pipiringos, G.N., 1955, Tertiary rocks in the central part of the Great Divide Basin, Sweetwater County, Wyoming, in Anderman, G.G., ed., Green River Basin: Casper, Wyo., Wyoming Geological Association 10th Annual Field Conference Guidebook, 1955, p. 100-104.

Pipiringos, G.N., 1957, Stratigraphy of the Sundance, Nugget, and Jelm Formations in the Laramie Basin, Wyoming: Laramie, Geological Survey of Wyoming Bulletin 47, 63 p.

Pipiringos, G.N., 1961, Uranium-bearing coal in the central part of the Great Divide Basin: U.S. Geological Survey Bulletin 1099-A, 104 p.

Pipiringos, G.N., 1968, Correlation and nomenclature of some Triassic and Jurassic rocks in south-central Wyoming, in Shorter contributions to general geology, 1967: U.S. Geological Survey Professional Paper 594-D, p. D1-D26.

Pipiringos, G.N., and O’Sullivan, R.B., 1978, Principal unconformities in Triassic and Jurassic rocks, western interior United States - a preliminary survey: U.S. Geological Survey Professional Paper 1035-A, p. A1-A29.

Powell, J.W., 1876, Report on the geology of the eastern Uinta Mountains and a region of country adjacent thereto: U.S. Geological and Geographical Survey of the Territories (Powell), v. 7, 218 p. 
Raisz, Erwin, 1972, Physiographic provinces in the Rocky Mountain region and landforms of western United States: Denver, Colorado, Rocky Mountain Association of Geologists, Geologic atlas of the Rocky Mountain region, p. 30.

Rantz, S.E., and others, 1982, Measurement and computation of streamflow: U.S. Geological Survey Water-Supply Paper 2175, 631 p., 2 volumes.

Ray, L.L., 1940, Glacial chronology of the southern Rocky Mountains: Geological Society of America Bulletin, v. 51, no. 12 , p. 1851-1918.

Reynolds, M.W., 1966, Stratigraphic relations of Upper Cretaceous rocks, Lamont-Bairoil area, south-central Wyoming: U.S. Geological Survey Professional Paper 550-B, p. B69-B76.

Reynolds, M.W., 1967, Physical evidence for Late Cretaceous unconformity, south-central Wyoming: U.S. Geological Survey Professional Paper 575-D, p. D24-D28.

Richter, H.R., 1981, Occurrence and characteristics of ground water in the Laramie, Shirley, and Hanna Basins, Wyoming: Laramie, Wyoming Water Resources Research Institute, Volume III-A of a series of reports prepared for U.S. Environmental Protection Agency, variable pagination.

Rioux, R.L., and Staatz, M.H., 1974, Geologic map of the Ferris quadrangle, Carbon County, Wyoming: U.S. Geological Survey Geologic Quadrangle Map GQ-1124, scale 1:24,000.

Roehler, H.W., 1973, Stratigraphy of the Washakie Formation in the Washakie Basin, Wyoming: U.S. Geological Survey Bulletin 1369, 40 p.

Roehler, H.W., 1992, Correlation, composition, areal distribution, and thickness of Eocene stratigraphic units, Greater Green River Basin, Wyoming, Utah, and Colorado: U.S. Geological Survey Professional Paper 1506-E, 49 p.

Sando, W.J., and Sandberg, C.A., 1987, New interpretations of Paleozoic stratigraphy and history in the northern Laramie Range and vicinity, southeast Wyoming. U.S. Geological Survey Professional Paper 1450, 39 p.

Sando, W.J., Gordon, Mackenzie, Jr., and Dutro, J.T., Jr., 1975, Stratigraphy and geologic history of the Amsden Formation (Mississippian and Pennsylvanian) of Wyoming: U.S. Geological Survey Professional Paper 848-A, 83 p.

Saulnier, G.J., 1968, Ground-water resources and geomorphology of the Pass Creek Basin area, Albany and Carbon Counties, Wyoming: Laramie, University of Wyoming, Department of Geology, unpublished M.S. thesis, variable pagination.
Schumm, S.A., and Hadley, R.F., 1961, Progress in the application of landform analysis in studies of semiarid erosion: U.S. Geological Survey Circular 437, 14 p.

Schultz, A.R., 1909, The northern part of the Rock Springs coal field, Sweetwater County, Wyoming, in Taff, J.A., Contributions to economic geology, 1907, Part II, Coal and lignite-Coal Fields of Wyoming: U.S. Geological Survey Bulletin 341-B, p. 256-282.

Schultz, A.R., 1920, Oil possibilities in and around Baxter Basin, in the Rock Springs Uplift, Sweetwater County, Wyoming: U.S. Geological Survey Bulletin 702, 107 p.

Searcy, J.K., 1959, Flow-duration curves: U.S. Geological Survey Water-Supply Paper 1542-A, 33 p.

Sears, J.D., 1926, Geology of the Baxter Basin gas field, Sweetwater County, Wyoming: U.S. Geological Survey Bulletin 781-B, p. 13-27.

Simons, Li, and Associates, 1982, Riverside groundwater resources investigation and development: Fort Collins, Colorado, Final report submitted to Wyoming Water Development Commission, Cheyenne, Wyoming, variable pagination.

Snoke, A.W., 1993, Geologic history of Wyoming within the tectonic framework of the North American Cordillera, in Snoke, A.W., Steidtmann, J.R., and Roberts, S.M., eds., Geology of Wyoming: Laramie, Geological Survey of Wyoming Memoir No. 5, p. 2-56.

Taylor, O.J., Hood, J.W., and Zimmerman, E.A., 1986, Hydrogeologic framework of the Upper Colorado River Basinexcluding the San Juan Basin-Colorado, Utah, Wyoming, and Arizona: U.S. Geological Survey Hydrologic Investigations Atlas HA-687, 2 sheets, scale 1:3,000,000.

U.S. Census Bureau, 2003, Wyoming quickfacts: digital data accessed April 1, 2005, at http://quickfacts.census.gov/qfd/ states/56/56007.html

U.S. Environmental Protection Agency, 1976, Quality criteria for water: U.S. Environmental Protection Agency, Office of Water Planning and Standards, EPA 440-9-76-023, 537 p.

U.S. Environmental Protection Agency, 1980, Prescribed procedures for measurement of radioactivity in drinking water: U.S. Environmental Protection Agency, Environmental Monitoring and Support Laboratory, Office of Research and Development, EPA 600-4-80-032, August 1980, 133 p.

U.S. Environmental Protection Agency, 1986, Ambient water quality criteria for bacteria-1986: U.S. Environmental Protection Agency, Office of Water Regulation and Standards Division, EPA 821-R-97-004, 49 p. 
U.S. Environmental Protection Agency, 2000, The national water-quality inventory-1998 report to Congress: U.S. Environmental Protection Agency, Office of Water, EPA 841-F-00-006: accessed March 7, 2003, at http://www.epa. gov/ 305b/98report/

U.S. Environmental Protection Agency, 2002a, 2002 edition of the drinking water standards and health advisories: U.S. Environmental Protection Agency, Office of Water, EPA 822-R-02-038, Summer 2002: accessed February 23, 2004, at http://www.epa.gov/waterscience/drinking/standards/ dwstandards.pdf

U.S. Environmental Protection Agency, 2002b, Safe drinking-water information system (SDWIS), Carbon County, Wyoming: accessed February 26, 2002, at http://oaspub. epa.gov/enviro/sdw_form.create_page?state_abbr $=W Y$

U.S. Environmental Protection Agency, 2003, List of drinking water contaminants and MCLs: accessed July 25, 2003, at http://www.epa.gov/safewater/mcl.html

U.S. Environmental Protection Agency, 2005, Sole source aquifer determination for the Cloverly aquifer (Dakota and Lakota Sands): accessed May 25, 2005, at http://www.epa. gov/fedrgstr/EPA-WATER/1998/July/Day-15/w18865.htm

U.S. Geological Survey, 1997 to 2003, National field manual for the collection of water-quality data: U.S. Geological Survey Techniques of Water-Resources Investigations, book 9, chaps. A1-A9, 2 v., variously paged. [Also available online at http://pubs.water.usgs.gov/twri9A. Chapters originally were published during 1997-1999; updates and revisions are ongoing and are summarized at http://water. usgs.gov/owq/FieldManual/mastererrata.html]

U.S. Geological Survey, 2003, Principal aquifers of the 48 conterminous United States, Hawaii, Puerto Rico, and the U.S. Virgin Islands: accessed June 13, 2005, at http://water. usgs.gov/lookup/getspatial?aquifers_us

U.S. Geological Survey, 2005, digital data: accessed May 25, 2005, at http://water.usgs.gov/watuse/data/2000/index.html

Van Houten, F.B., 1964, Tertiary geology of the Beaver Rim area, Fremont and Natrona Counties, Wyoming: U.S. Geological Survey Bulletin 1164, 99 p.

Vine, J.D., and Prichard, G.E., 1954, Uranium in the Poison Basin area, Carbon County, Wyoming: U.S. Geological Survey Circular 344, 8 p.

Vine, J.D., and Prichard, G.E., 1959, Geology and uranium occurrences in the Miller Hill area, Carbon County, Wyoming: U.S. Geological Survey Bulletin 1074-F, p. 201-239.
Visher, F.N., 1952, Reconnaissance of the geology and ground-water resources of the Pass Creek Flats area, Carbon County, Wyoming, with a section on The chemical quality of the ground water by W.H. Durum: U.S. Geological Survey Circular 188, 19 p.

Walter, Heinrich, and Lieth, Helmut, 1967, KlimadiagramWeltatlas (translated: Climate Diagrams-World Atlas): Jena, Germany, VEB Gustav Fischer Verlag. [See "climate diagrams," accessed September 2, 2005, at http://www.zoolex. org/walter.html]

Weimer, R.J., and Guyton, J.W., 1961, Geology of the Muddy Gap-Lamont area, Wyoming, in Wiloth, G.J., ed., Symposium on Late Cretaceous rocks of Wyoming and adjacent areas: Casper, Wyoming Geological Association 16th Annual Field Conference Guidebook, 1961, p. 139-147.

Weitz, J.L., and Love, J.D., 1952, Geologic map of Carbon County, Wyoming: Laramie, Geological Survey of Wyoming, 1 sheet, scale 1:158,400.

Welder, G.E., 1968, Ground-water reconnaissance of the Green River Basin, southwestern Wyoming: U.S. Geological Survey Hydrologic Investigations Atlas HA-290, 2 sheets; accompanying text, 5 p.

Welder, G.E., and McGreevy, L.J., 1966, Ground-water reconnaissance of the Great Divide and Washakie Basins and some adjacent areas, southwestern Wyoming: U.S. Geological Survey Hydrologic Investigations Atlas HA-219, 3 sheets; accompanying text, 10 p.

Western Regional Climate Center, 2005a, digital data: accessed May 26, 2005, under "Monthly Totals" selection at http://www.wrcc.dri.edu/cgi-bin/cliMAIN.pl?wyrawl

Western Regional Climate Center, 2005b, digital data: accessed May 27, 2005, at http://www.wrcc.dri.edu/cgi-bin/ cliMAIN.pl?wyrawl

Weston Engineering, 1994, Elk Mountain water supply master plan interim report: Laramie, Wyoming, report prepared for Wyoming Water Development Commission and Town of Elk Mountain, variable pagination.

Whitcomb, H.A., and Lowry, M.E., 1968, Ground-water resources and geology of the Wind River Basin area, central Wyoming: U.S. Geological Survey Hydrologic Investigations Atlas HA-270, 3 sheets, scale 1:250,000, accompanying text, $13 \mathrm{p}$.

Whitehead, R.L., 1996, Ground-water atlas of the United States-Segment 8, Montana, North Dakota, South Dakota, Wyoming: U.S. Geological Survey Hydrologic Investigations Atlas 730-I, 24 oversize p. 
Wilson, L., 1973, Variations in mean annual sediment yield as a function of mean annual precipitation in Rodgers, J., and others, eds.: American Journal of Science, v. 273, p. 335-349.

Wyoming Department of Economic Planning and Development, 1982, Split Rock syncline project report: Cheyenne, Wyoming, report prepared for 1982 Wyoming State Legislature, $13 \mathrm{p}$.

Wyoming Department of Environmental Quality, 1976, State of Wyoming water quality inventory 305(b) report 1976: Wyoming Department of Environmental Quality, Water Quality Division, $60 \mathrm{p}$.

Wyoming Department of Environmental Quality, 1993, Quality standards for Wyoming groundwaters: Cheyenne, Wyoming Department of Environmental Quality, Chapter VIII, $87 \mathrm{p}$.

Wyoming Department of Environmental Quality, 2001, Wyoming surface water quality standards: Wyoming Department of Environmental Quality, Water Quality Rules and Standards, Chapter 1, 25 p., appendixes A through G.: accessed October 27, 2003, at http://deq.state.wy.us/wqd/ watershed/11567-doc.pdf

Wyoming Oil and Gas Conservation Commission, 2003, digital data: accessed January 5, 2003, at http://wogcc.state. wy.us/

Wyoming Oil and Gas Conservation Commission, 2004, digital data: accessed November 3, 2004, at http://wogcc.state. wy.us 



\section{Appendix 1. Monthly- and annual-streamflow characteristics, selected sites in and near Carbon County, Wyoming.}




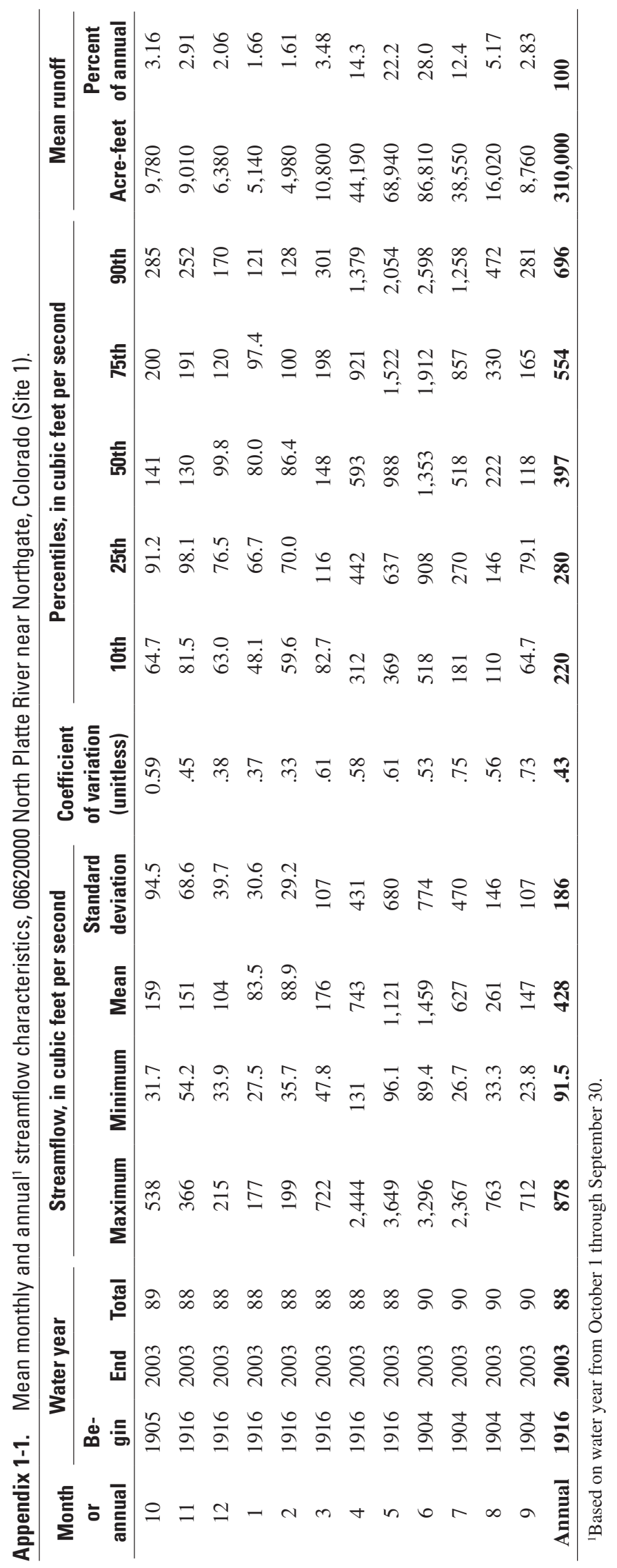

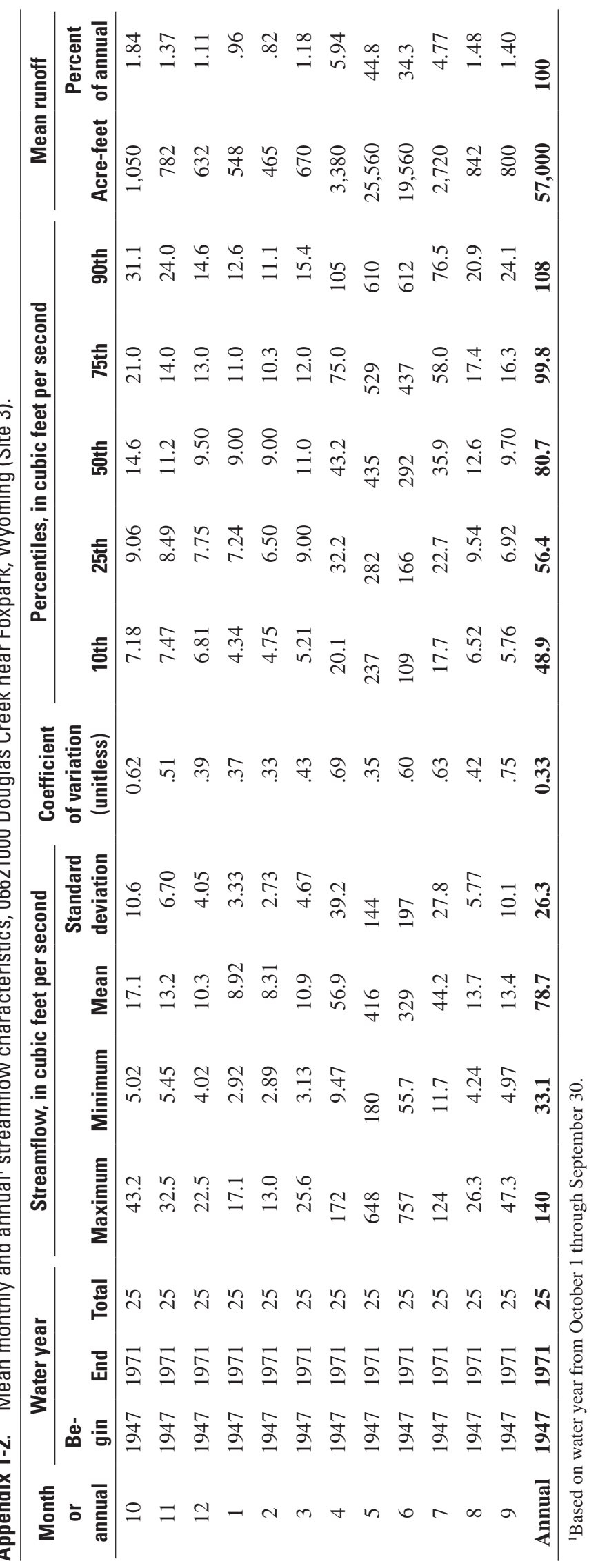



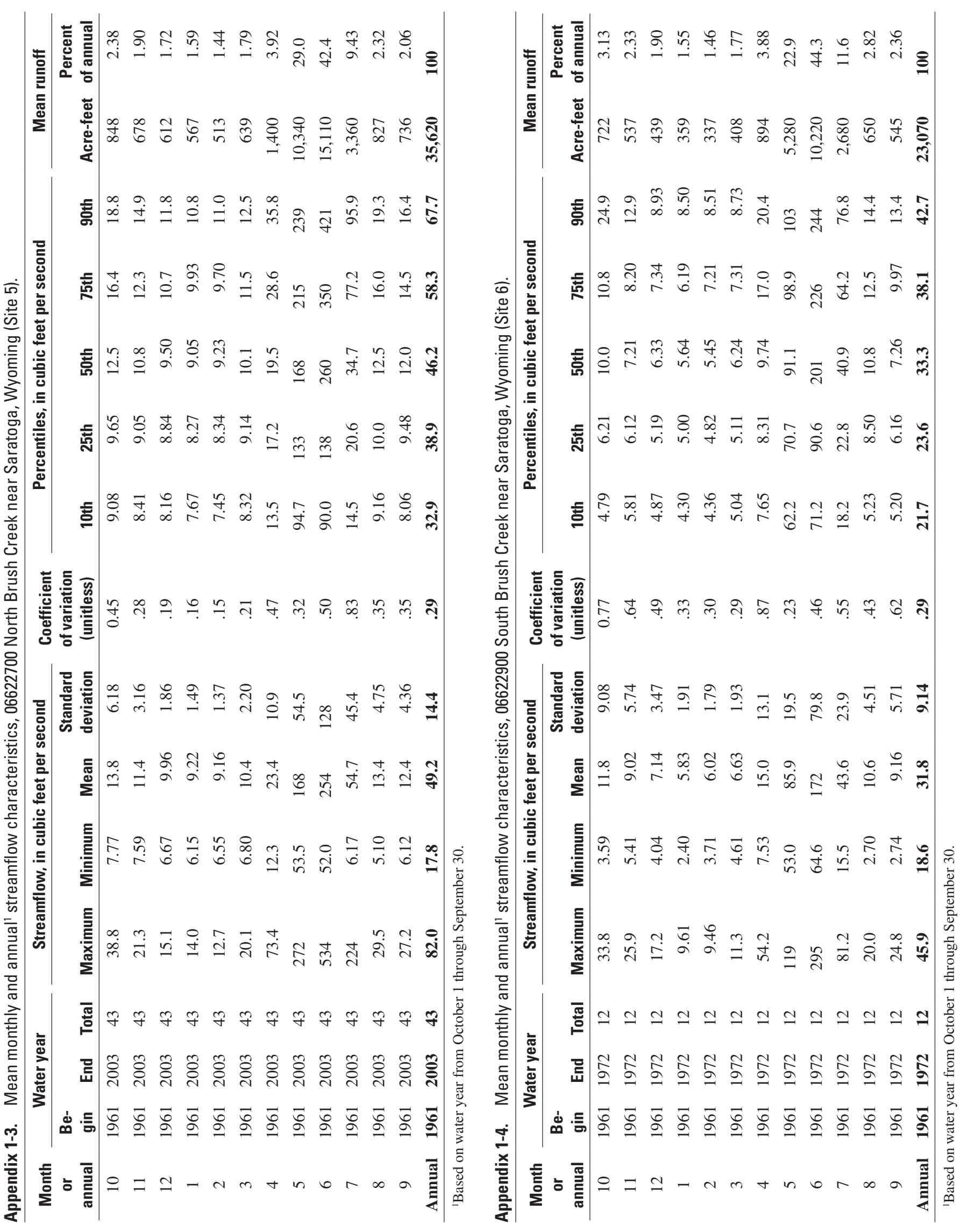

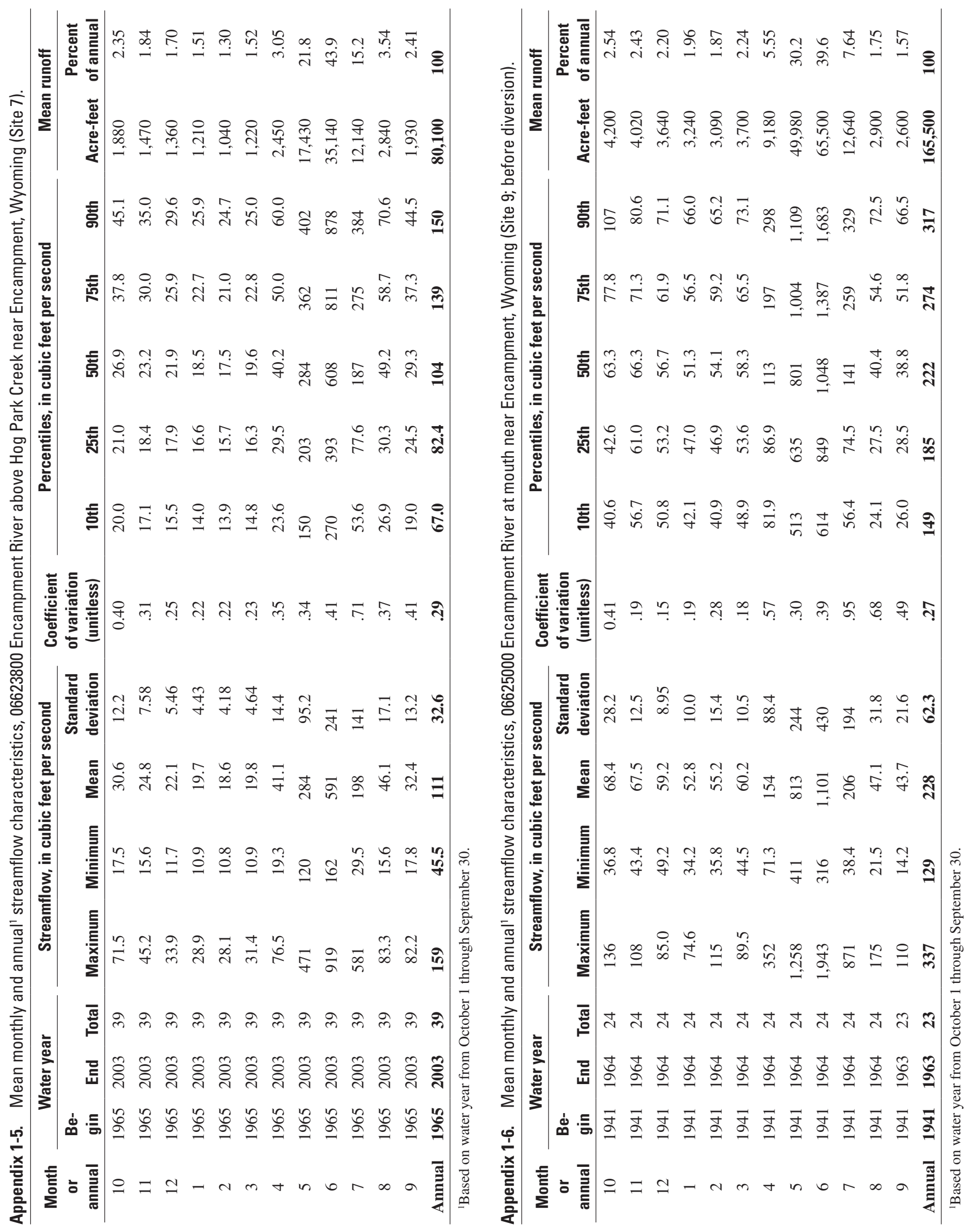

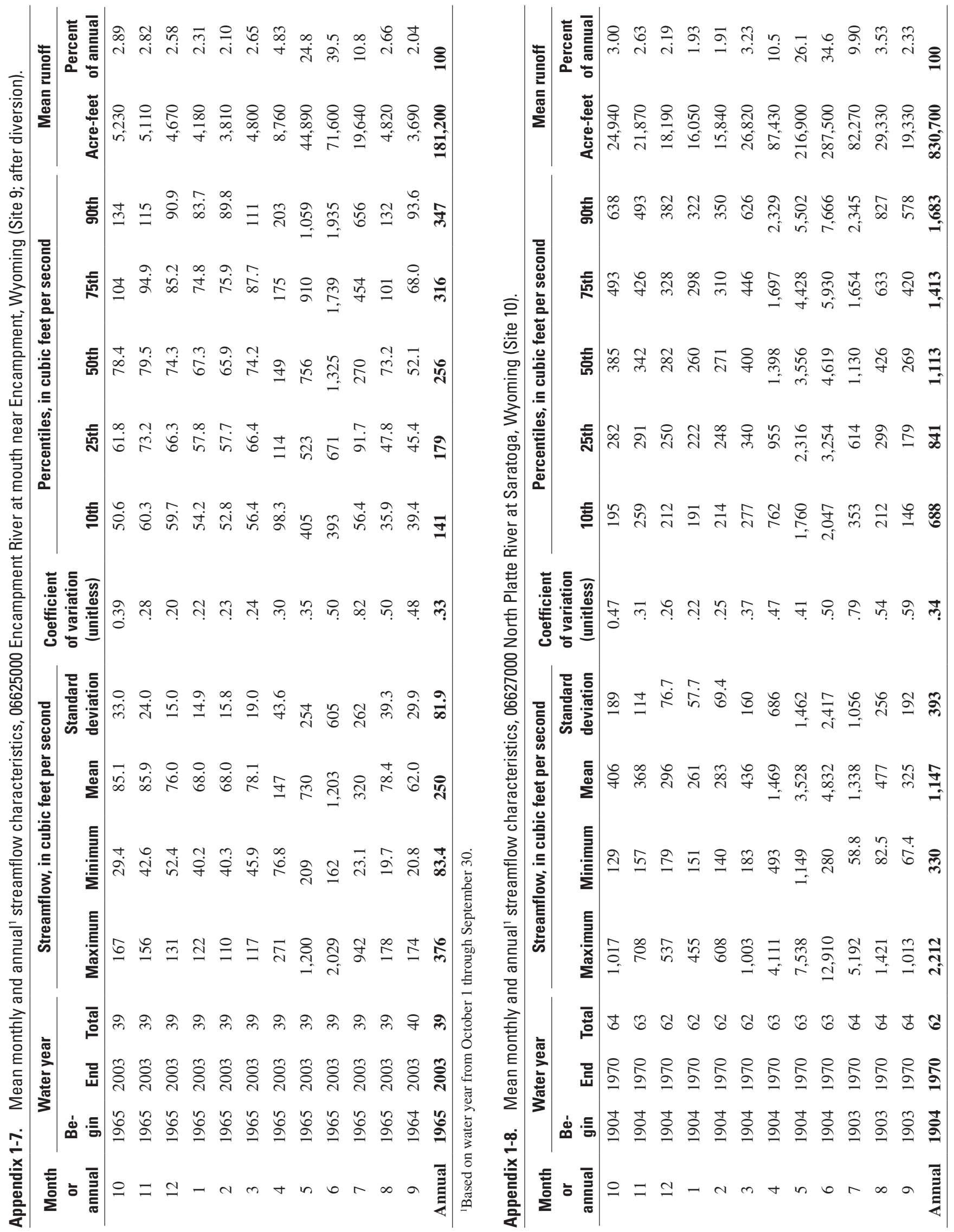

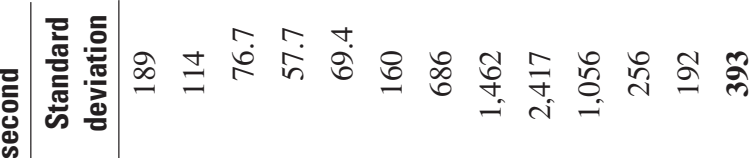

एँ⿱

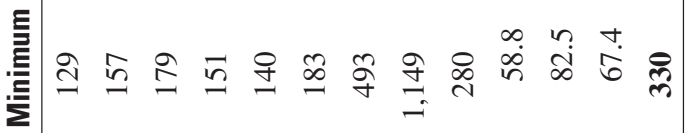
ह1

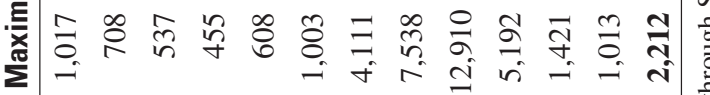

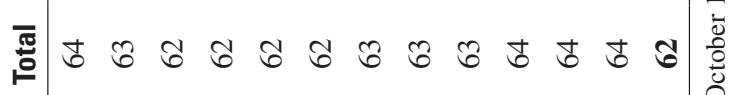

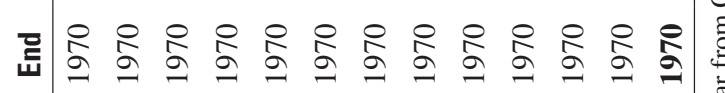

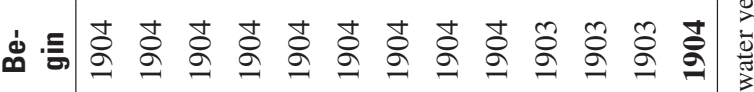

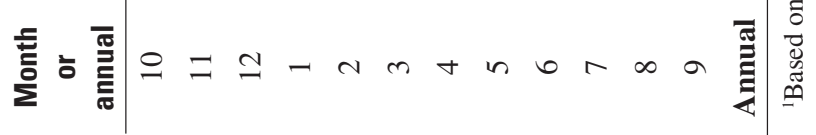



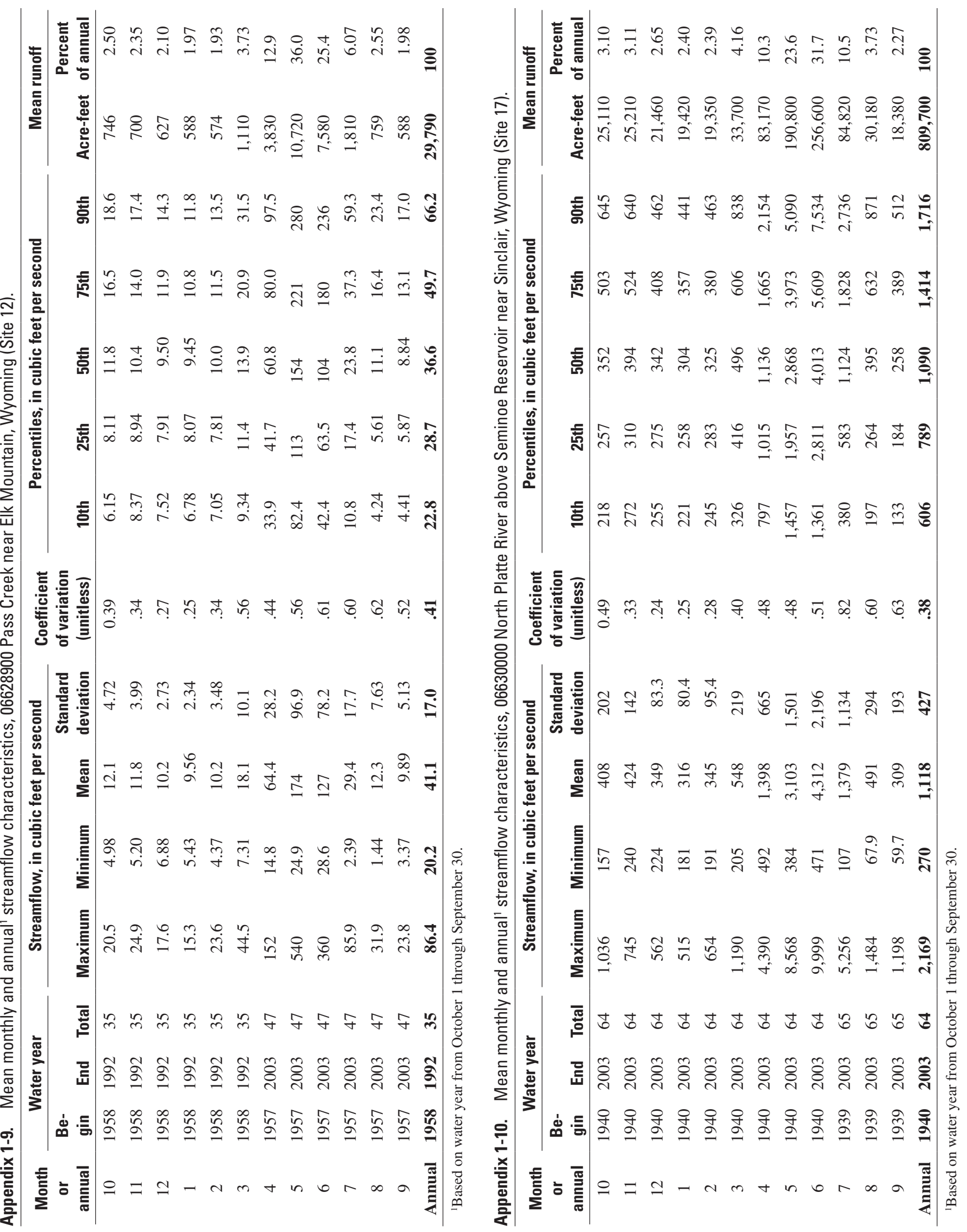

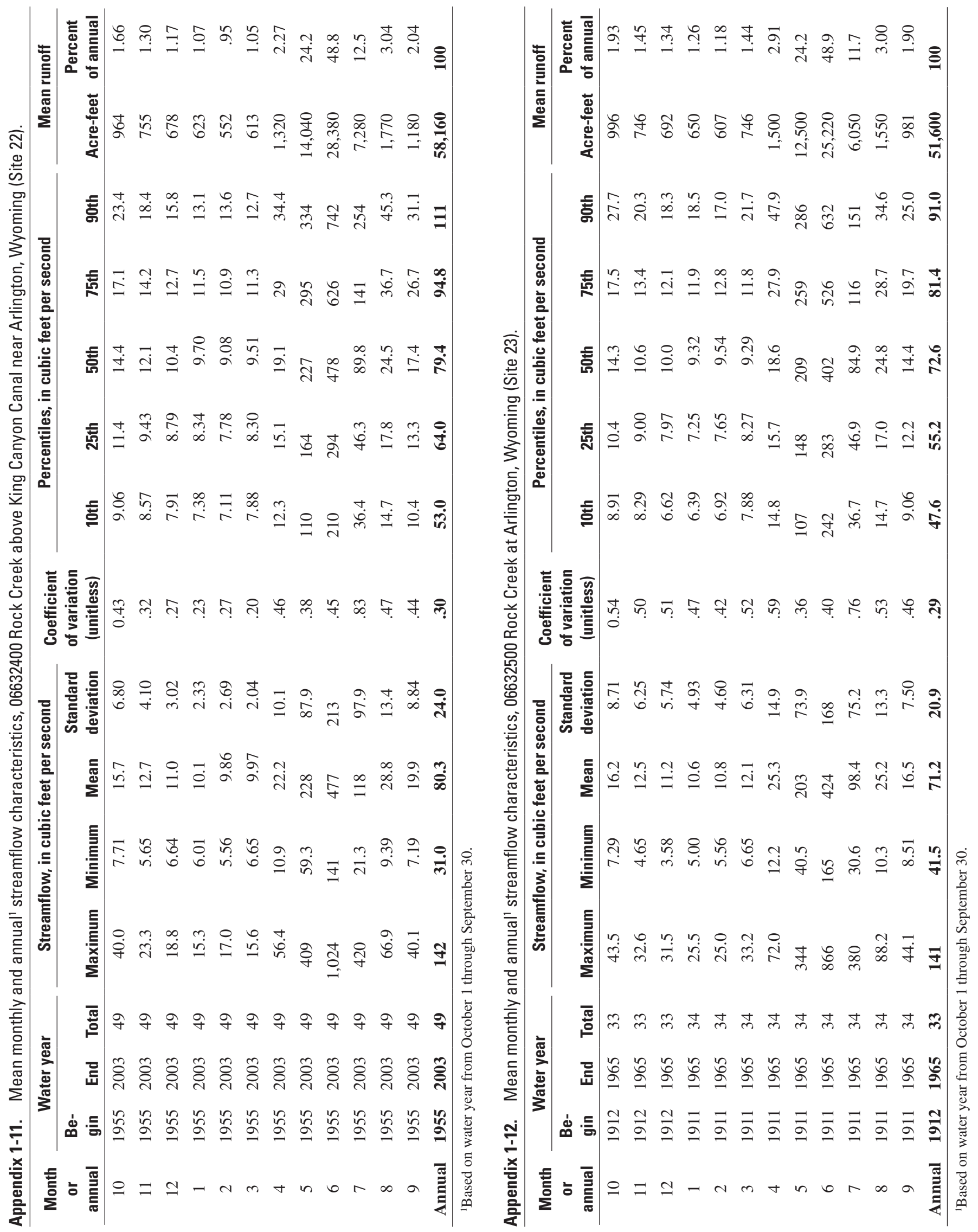

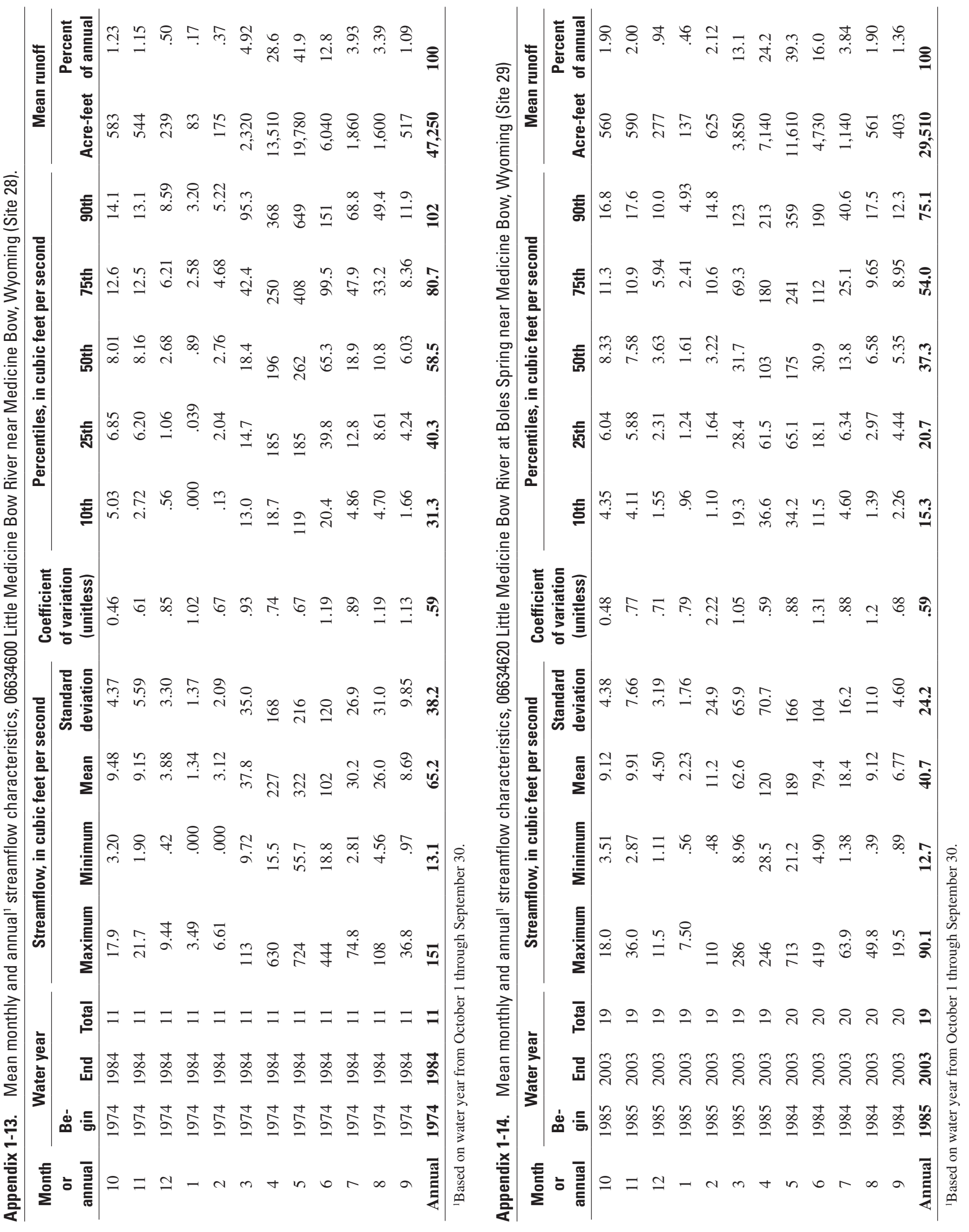


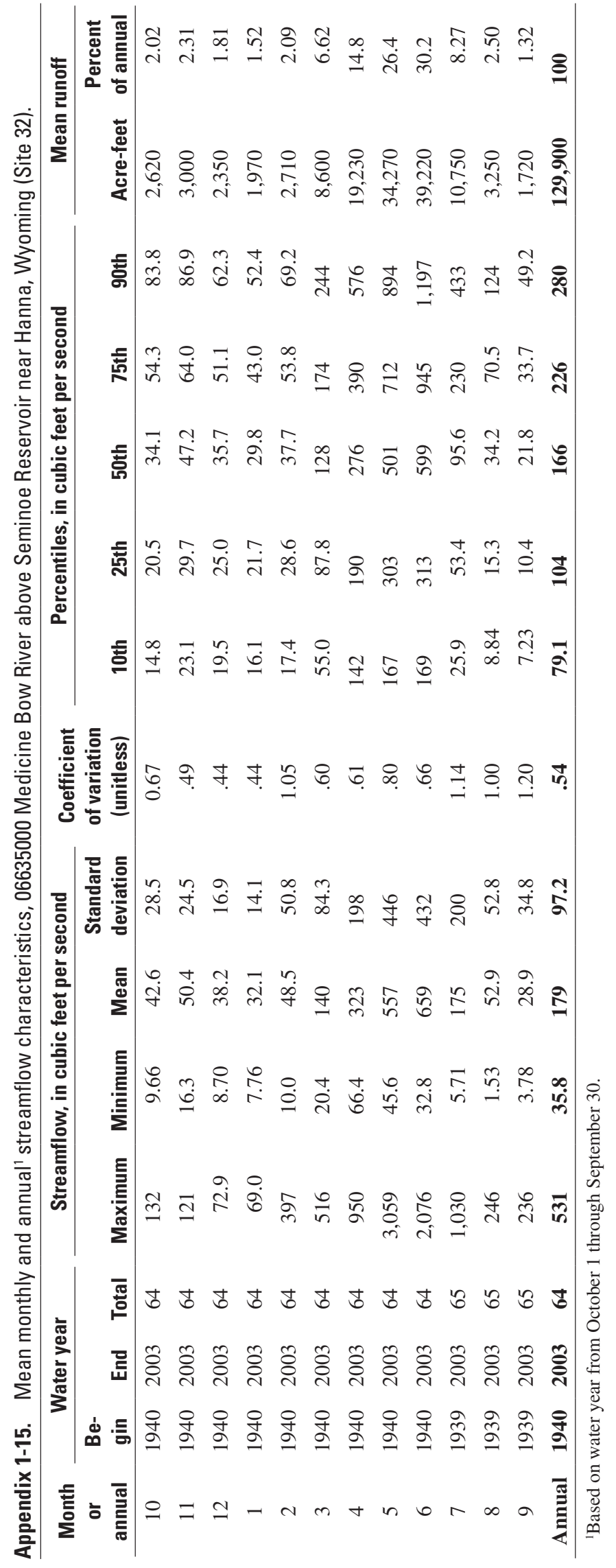

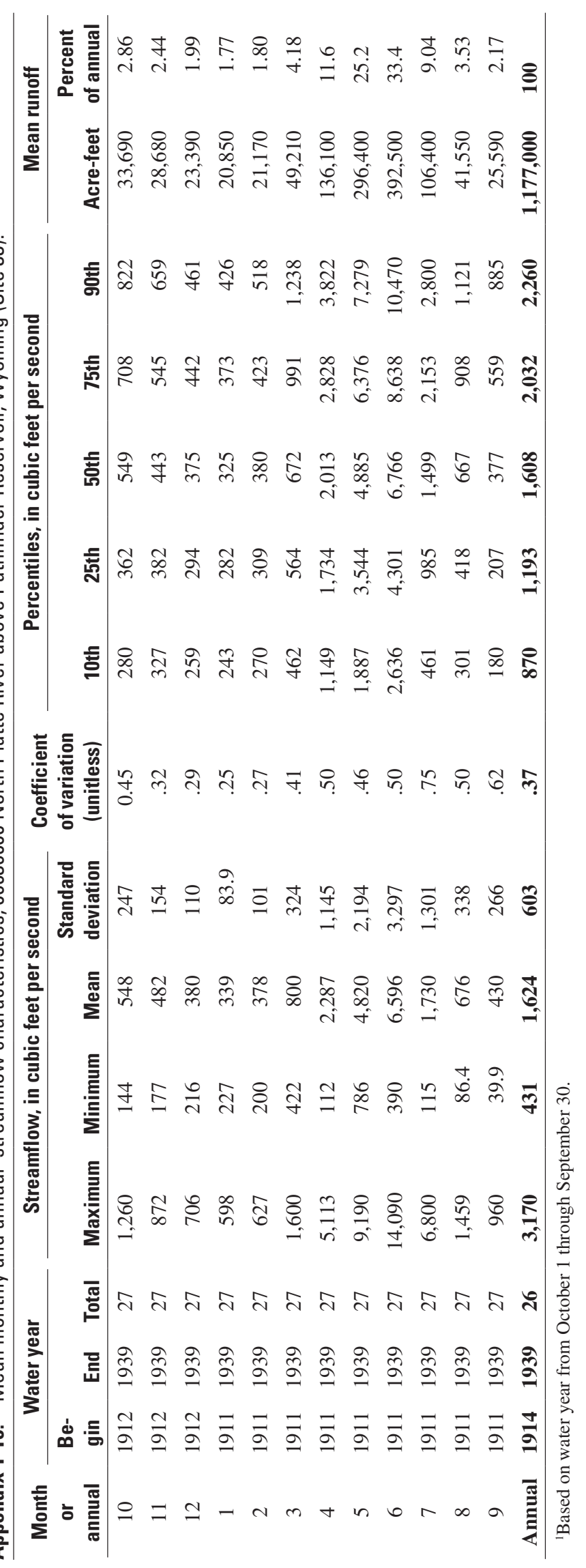




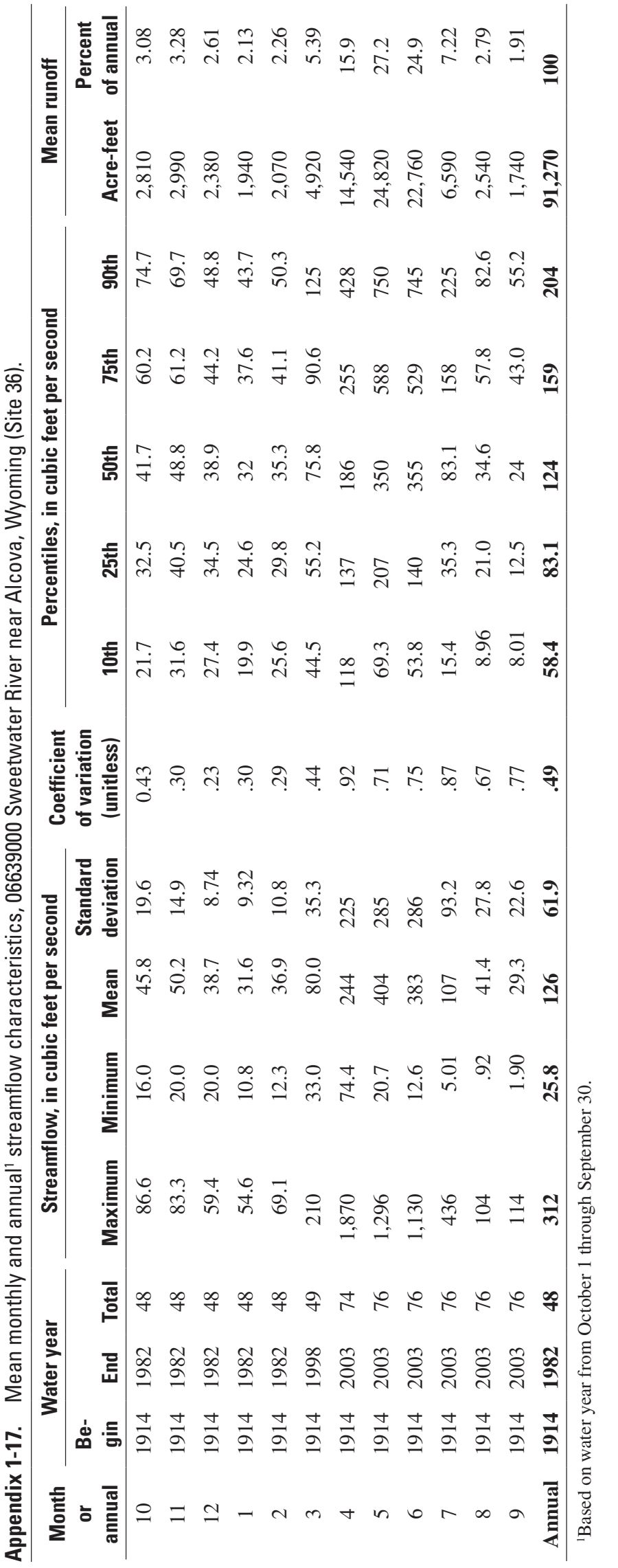

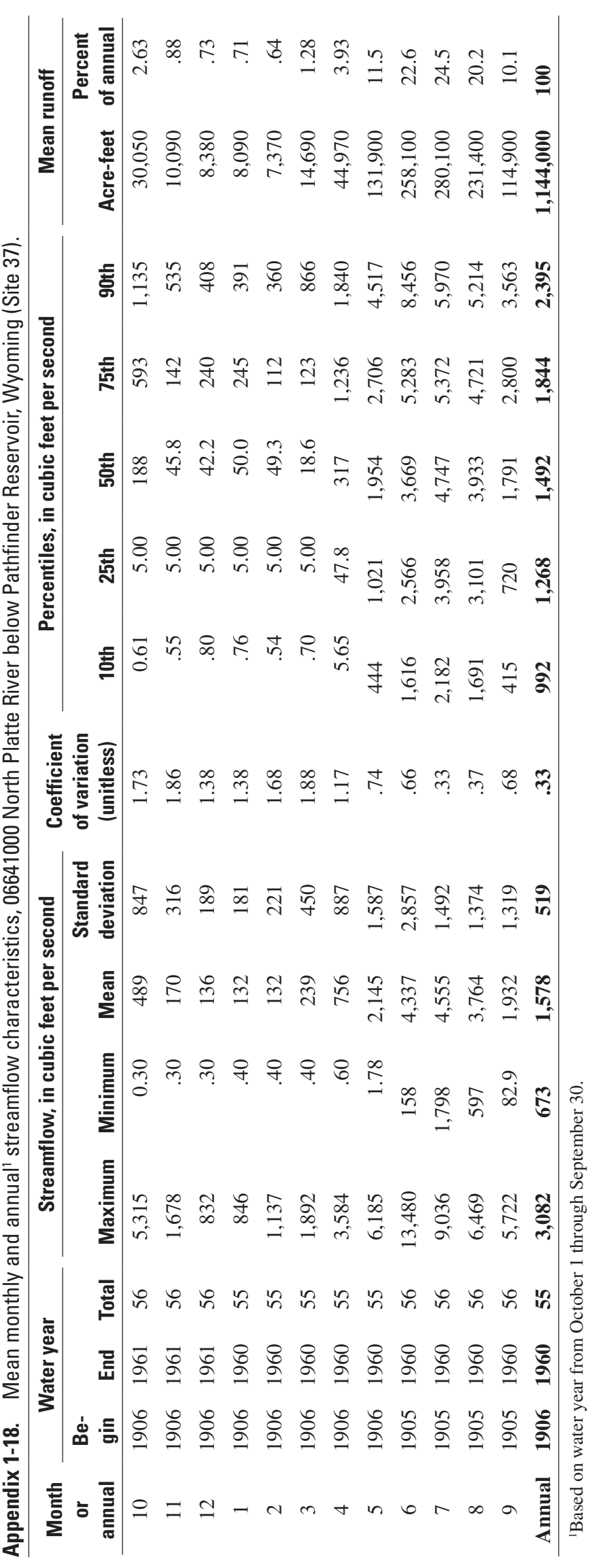



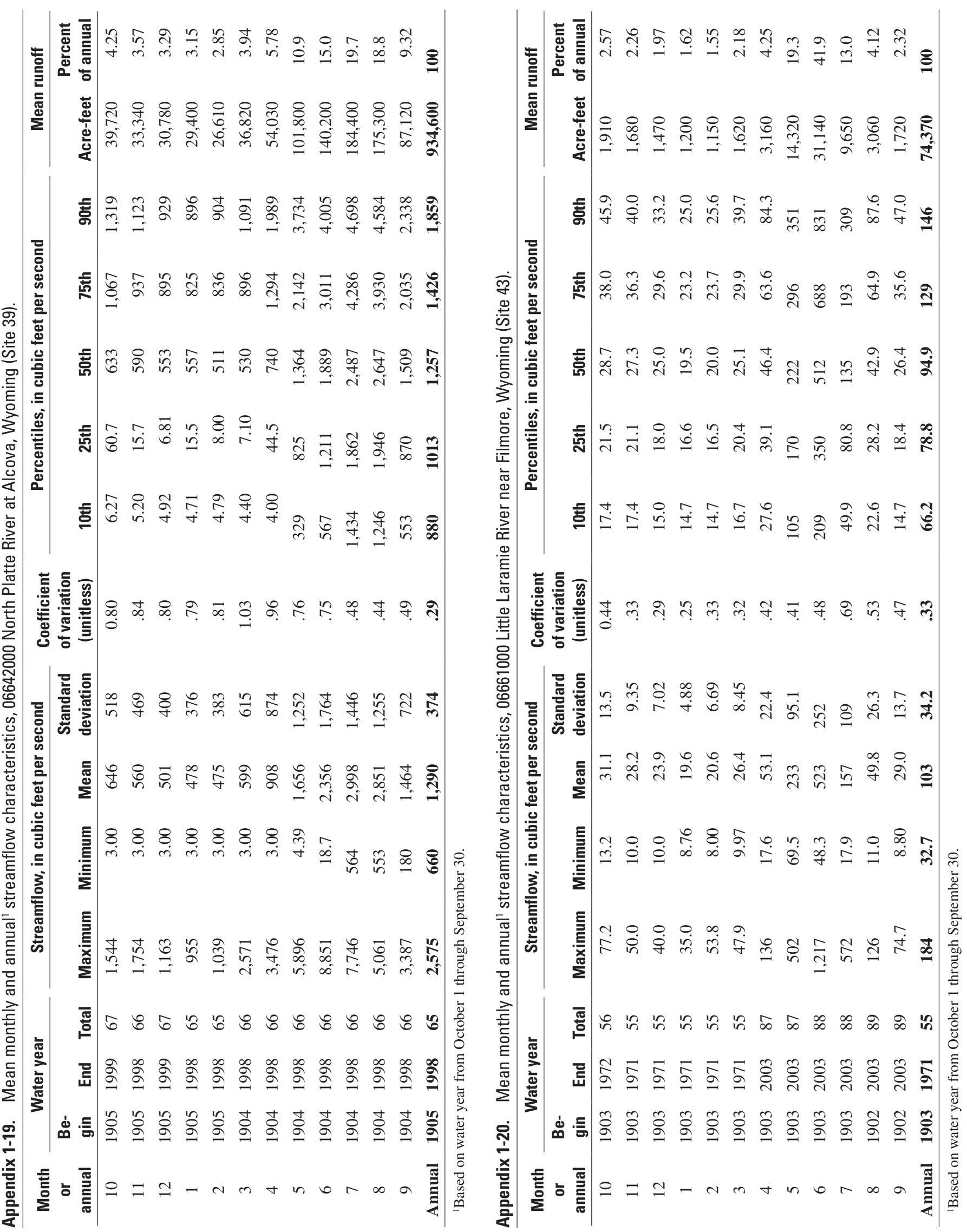


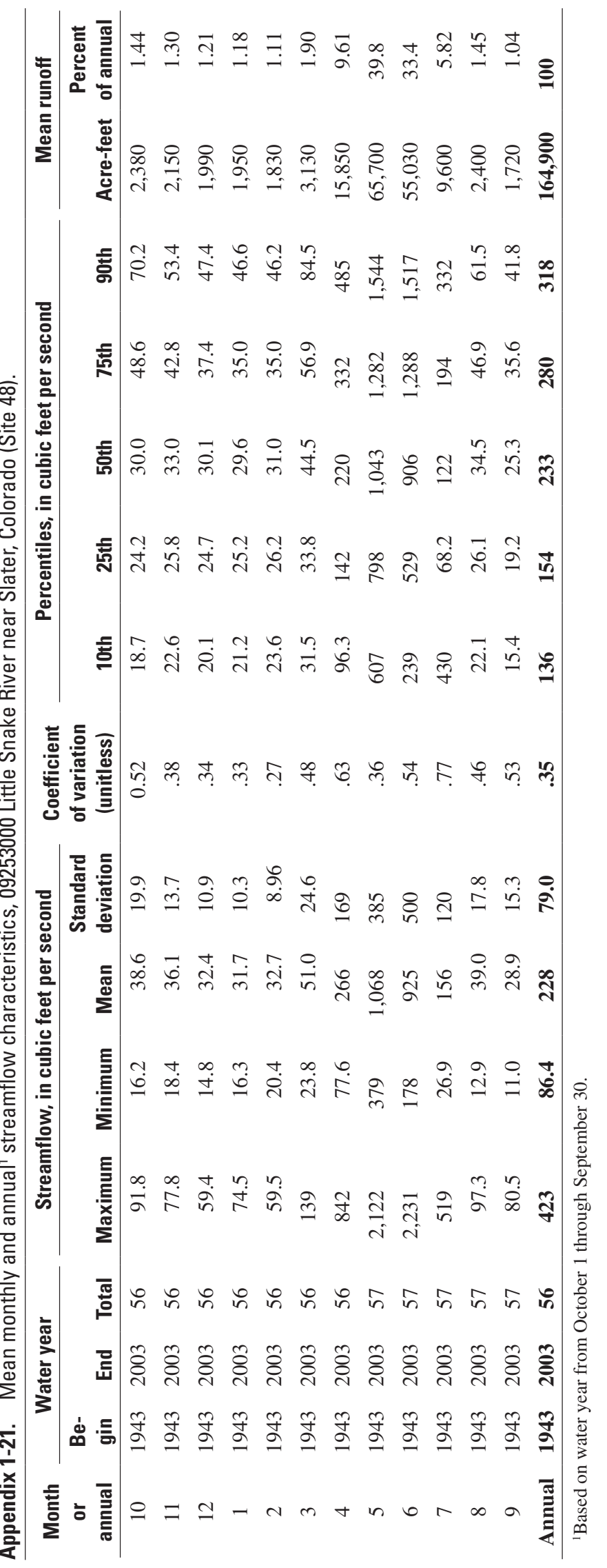

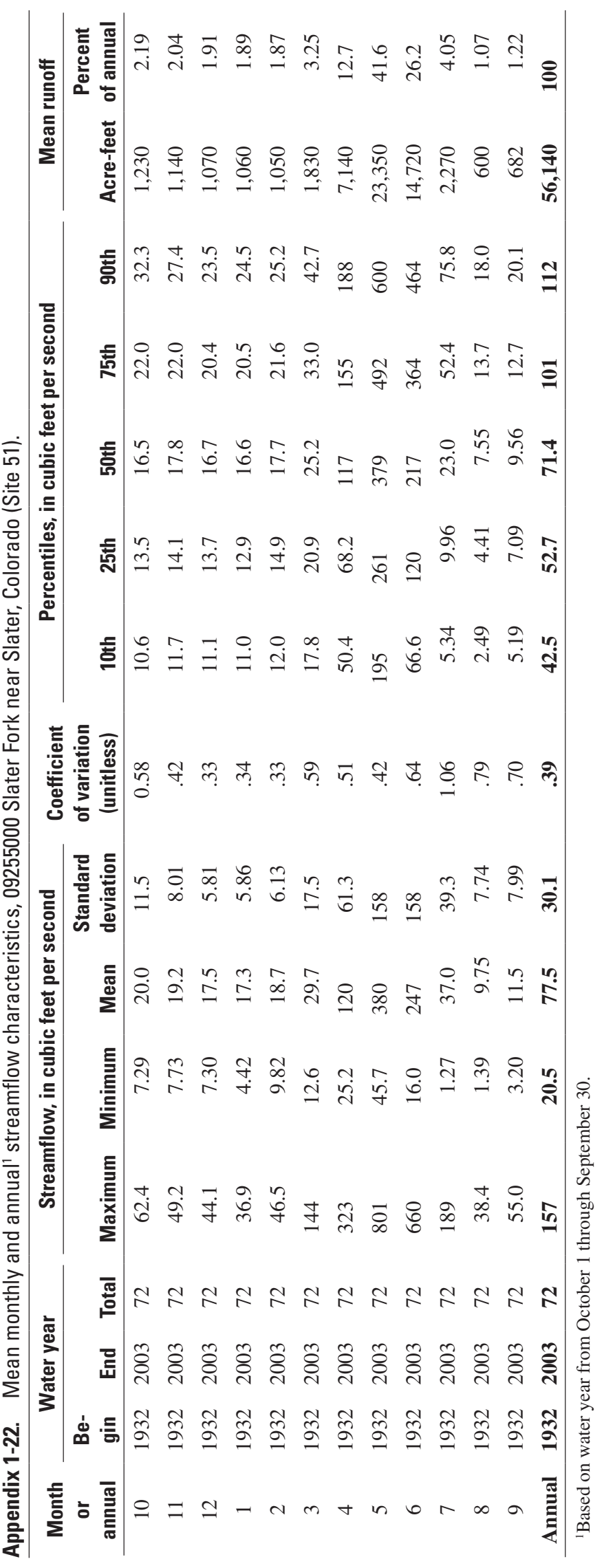



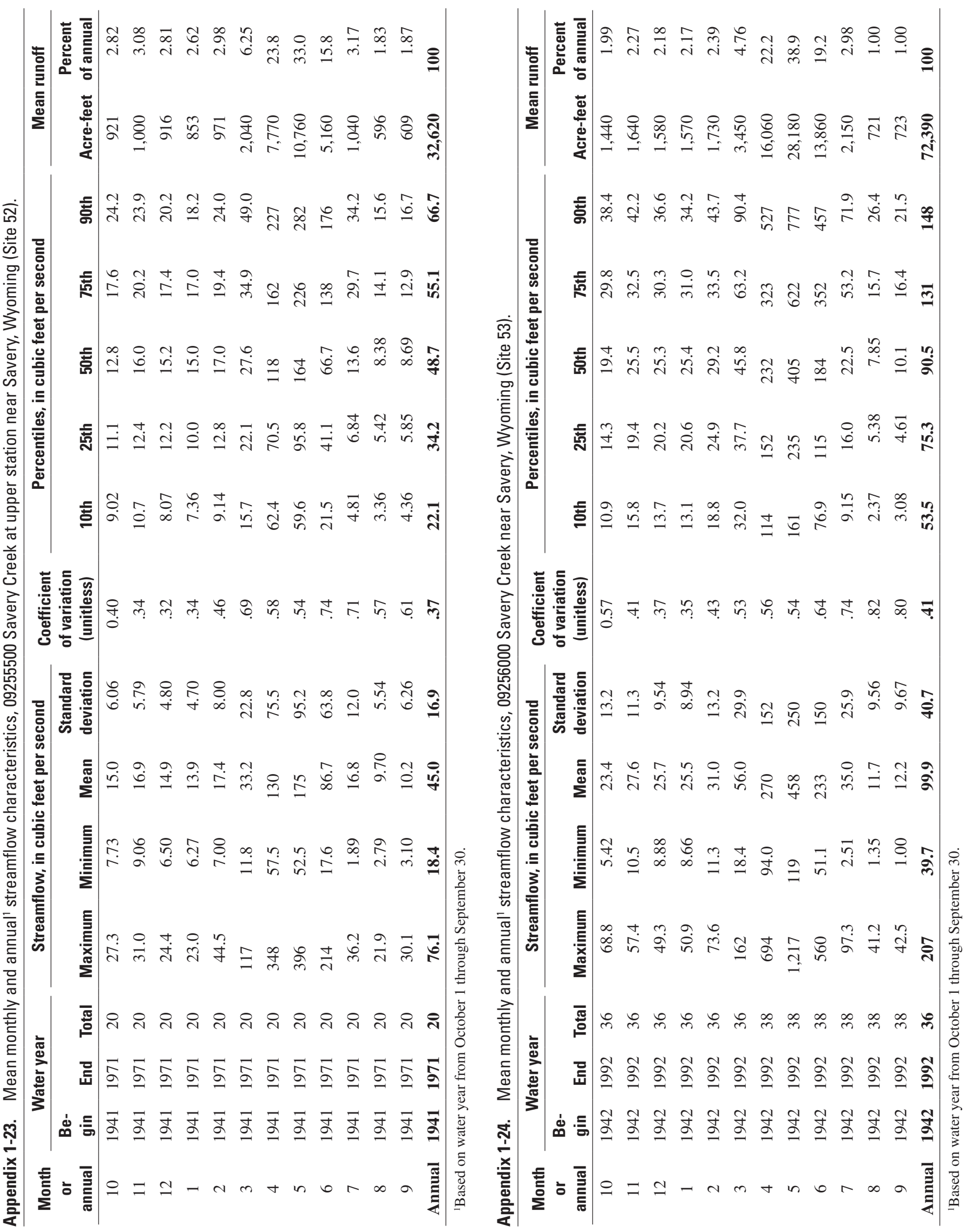


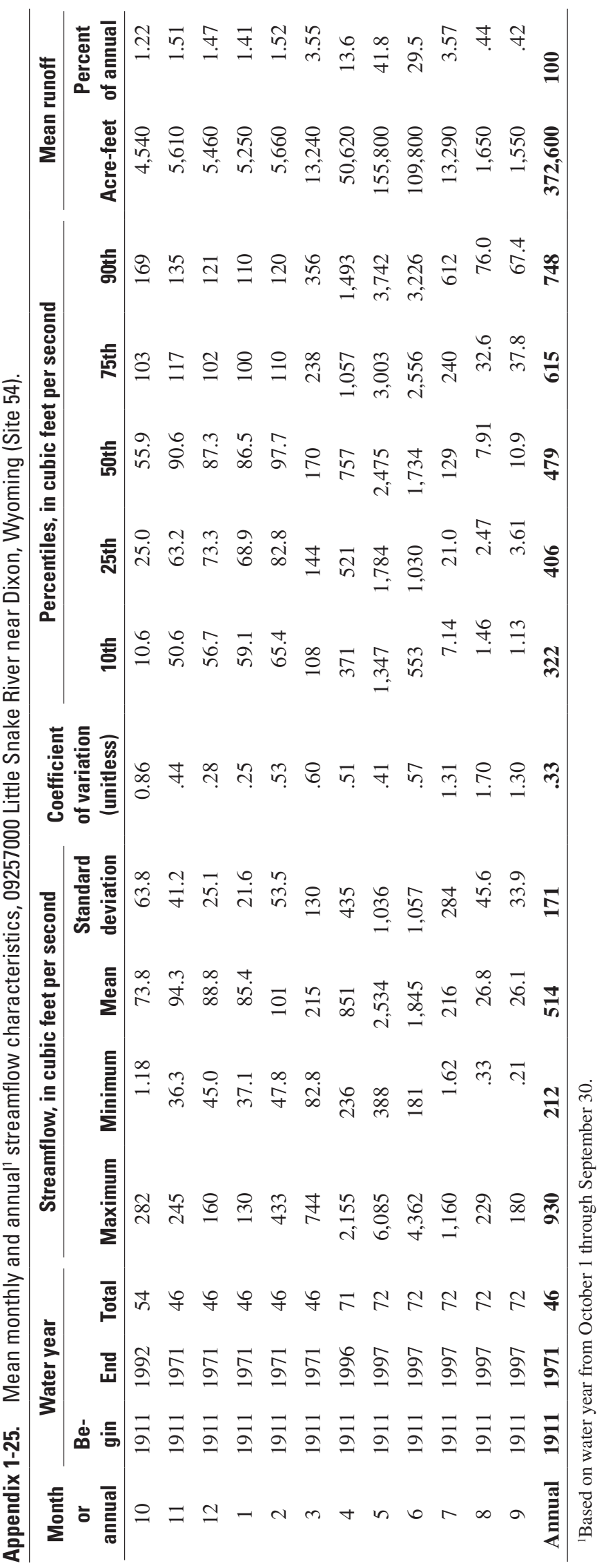

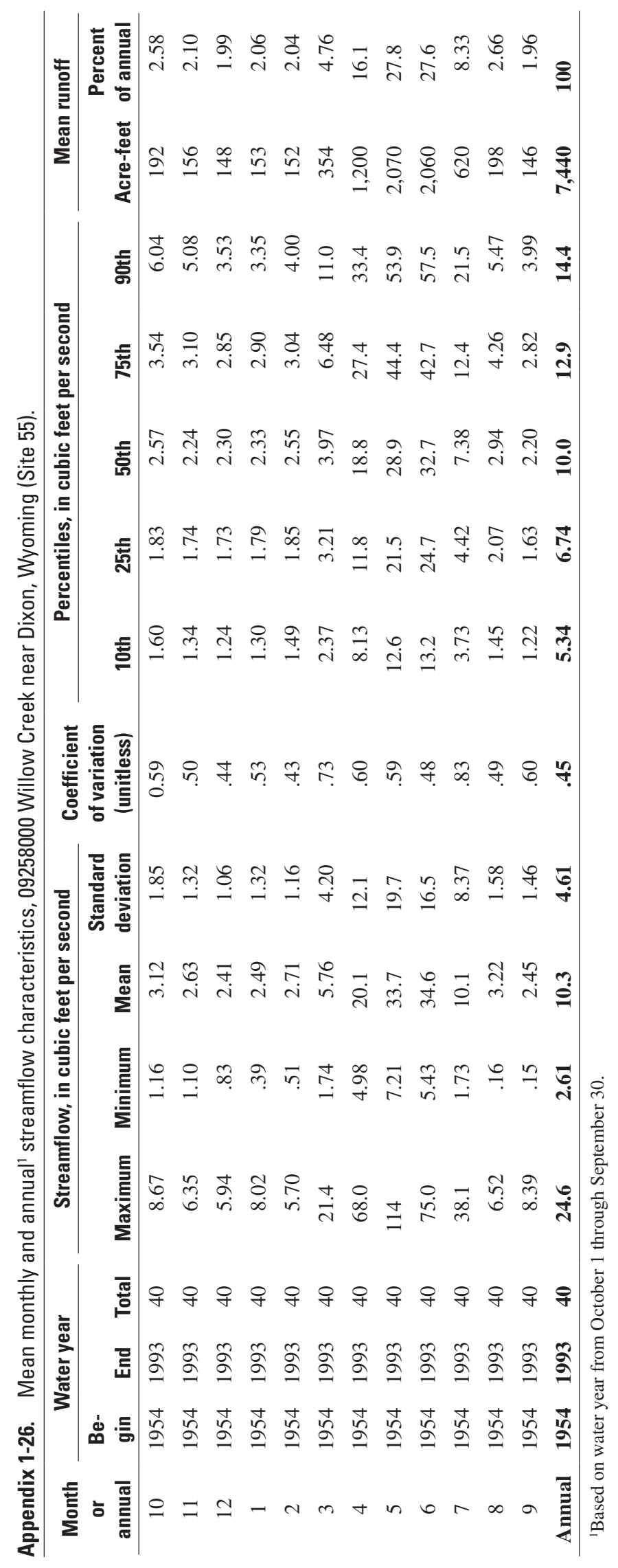


Appendix 2. Peak-flow characteristics, selected streamflow-gaging stations, in and near Carbon County, Wyoming. 


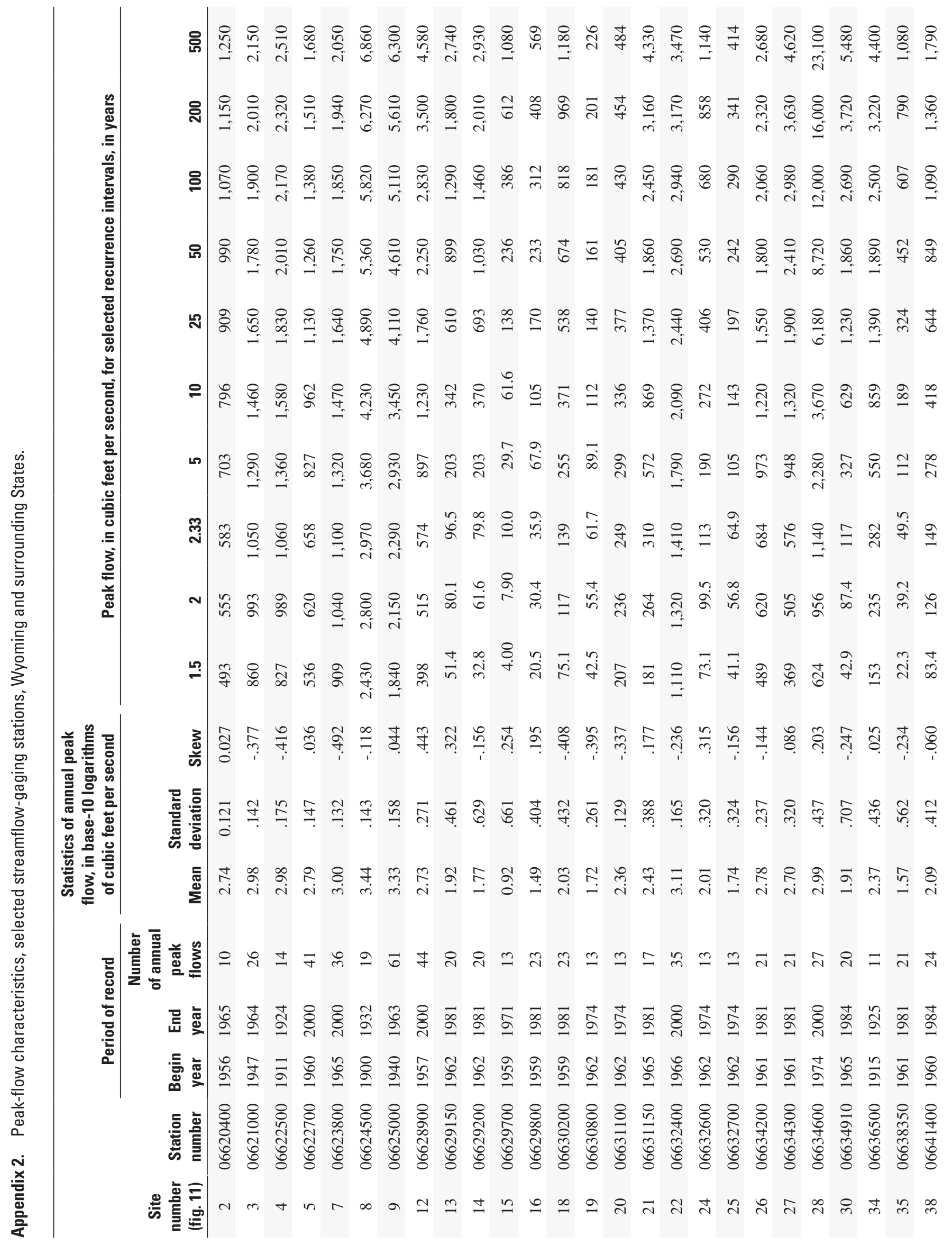




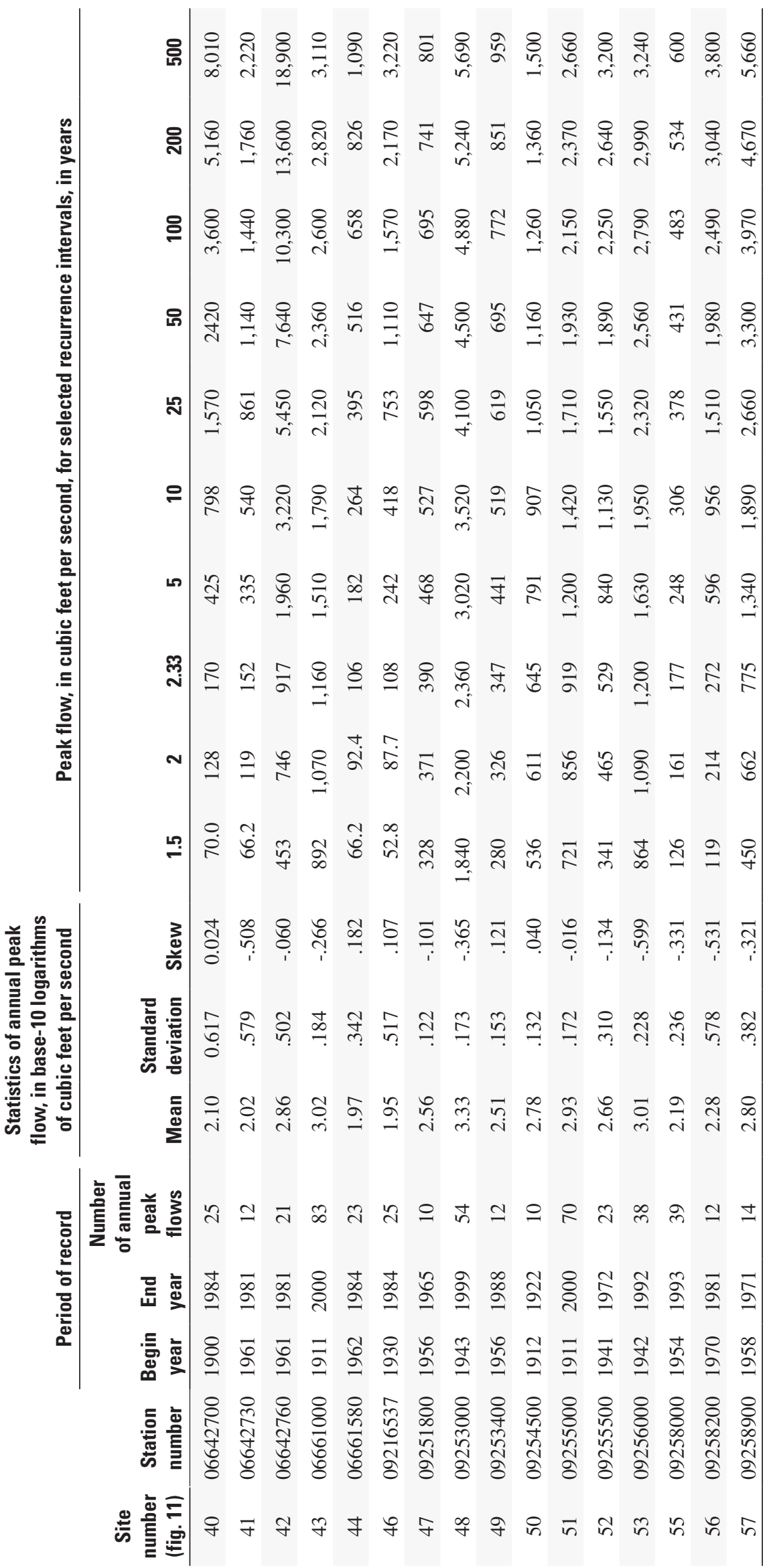




\section{Appendix 3. Annual low-flow characteristics, selected sites in and near Carbon County, Wyoming.}

Appendix 3-1. Annual' low-flow characteristics, 06620000 North Platte River near Northgate, Colorado (Site 1).

\begin{tabular}{|c|c|c|c|c|c|c|c|}
\hline \multirow{2}{*}{$\begin{array}{c}\text { Non-exceedance } \\
\text { probability }\end{array}$} & \multirow{2}{*}{$\begin{array}{c}\text { Recurrence interval } \\
\text { (years) }\end{array}$} & \multicolumn{6}{|c|}{ Mean streamflow, in cubic feet per second, for selected periods, in consecutive days } \\
\hline & & 3 & 7 & 10 & 30 & 60 & 90 \\
\hline 0.02 & 50 & 21.2 & 22.6 & 23.3 & 27.5 & 33.1 & 38.0 \\
\hline .10 & 10 & 32.0 & 33.8 & 34.9 & 40.4 & 46.4 & 51.8 \\
\hline .20 & 5 & 40.0 & 42.0 & 43.3 & 49.5 & 55.6 & 61.3 \\
\hline .50 & 2 & 59.6 & 62.0 & 63.6 & 70.4 & 76.7 & 83.0 \\
\hline .90 & 1.11 & 103 & 105 & 107 & 111 & 118 & 126 \\
\hline .99 & 1.01 & 151 & 154 & 153 & 152 & 159 & 170 \\
\hline
\end{tabular}

Appendix 3-2. Annual' low-flow characteristics, 06621000 Douglas Creek near Foxpark, Wyoming (Site 3).

\begin{tabular}{cccccccc}
\hline \multirow{2}{*}{$\begin{array}{c}\text { Non-exceedance } \\
\text { probability }\end{array}$} & $\begin{array}{c}\text { Recurrence interval } \\
\text { (years) }\end{array}$ & \multicolumn{5}{c}{ Mean streamflow, in cubic feet per second, for selected periods, in consecutive days } \\
\cline { 3 - 7 } & 20 & $\mathbf{3}$ & $\mathbf{7}$ & $\mathbf{1 0}$ & $\mathbf{3 0}$ & $\mathbf{6 0}$ \\
\hline .05 & 10 & 2.32 & 2.52 & 2.58 & 3.14 & 3.55 \\
.10 & 5 & 2.75 & 2.98 & 3.06 & 3.76 & 4.32 \\
.20 & 2 & 3.36 & 3.63 & 3.75 & 4.62 & 5.37 & 5.71 \\
.50 & 1.25 & 4.89 & 5.23 & 5.46 & 6.64 & 7.72 & 8.50 \\
.80 & 1.11 & 6.98 & 7.40 & 7.85 & 9.16 & 10.4 & 11.3 \\
.90 & 1.01 & 8.36 & 8.81 & 9.44 & 10.7 & 11.9 \\
.99 & 12.6 & 13.1 & 14.4 & 14.8 & 12.8 \\
\hline
\end{tabular}

Appendix 3-3. Annual' low-flow characteristics, 06622700 North Brush Creek near Saratoga, Wyoming (Site 5).

\begin{tabular}{|c|c|c|c|c|c|c|c|}
\hline \multirow{2}{*}{$\begin{array}{c}\text { Non-exceedance } \\
\text { probability }\end{array}$} & \multirow{2}{*}{$\begin{array}{c}\text { Recurrence interval } \\
\text { (years) }\end{array}$} & \multicolumn{6}{|c|}{ Mean streamflow, in cubic feet per second, for selected periods, in consecutive days } \\
\hline & & 3 & 7 & 10 & 30 & 60 & 90 \\
\hline 0.02 & 50 & 4.15 & 4.47 & 4.66 & 5.32 & 5.93 & 6.40 \\
\hline .10 & 10 & 5.12 & 5.43 & 5.62 & 6.47 & 6.93 & 7.29 \\
\hline .20 & 5 & 5.71 & 6.01 & 6.21 & 7.12 & 7.52 & 7.84 \\
\hline .50 & 2 & 6.93 & 7.20 & 7.40 & 8.34 & 8.71 & 8.99 \\
\hline .90 & 1.11 & 8.91 & 9.15 & 9.31 & 9.96 & 10.6 & 11.0 \\
\hline .99 & 1.01 & 10.5 & 10.8 & 10.9 & 11.0 & 12.1 & 13.0 \\
\hline
\end{tabular}

Appendix 3-4. Annual' low-flow characteristics, 06622900 South Brush Creek near Saratoga, Wyoming (Site 6).

\begin{tabular}{|c|c|c|c|c|c|c|c|}
\hline \multirow{2}{*}{$\begin{array}{c}\text { Non-exceedance } \\
\text { probability }\end{array}$} & \multirow{2}{*}{$\begin{array}{c}\text { Recurrence interval } \\
\text { (years) }\end{array}$} & \multicolumn{6}{|c|}{ Mean streamflow, in cubic feet per second, for selected periods, in consecutive days } \\
\hline & & 3 & 7 & 10 & 30 & 60 & 90 \\
\hline 0.05 & 20 & 0.92 & 0.94 & 1.08 & 2.04 & 2.80 & 3.37 \\
\hline .20 & 5 & 1.78 & 1.91 & 2.03 & 3.13 & 3.81 & 4.25 \\
\hline .50 & 2 & 3.10 & 3.42 & 3.52 & 4.64 & 5.18 & 5.50 \\
\hline .80 & 1.25 & 4.73 & 5.32 & 5.43 & 6.52 & 6.89 & 7.22 \\
\hline .99 & 1.01 & 7.63 & 8.64 & 9.23 & 10.5 & 10.9 & 12.1 \\
\hline
\end{tabular}


Appendix 3-5. Annual' low-flow characteristics, 06623800 Encampment River above Hog Park near Encampment, Wyoming (Site 7).

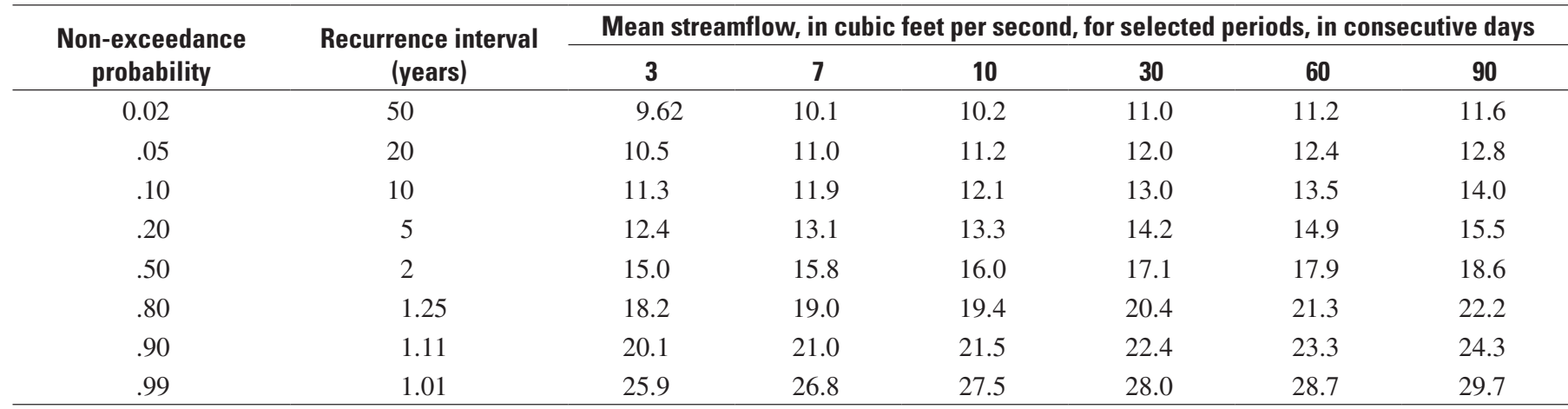

Appendix 3-6. Annual' low-flow characteristics, 06625000 Encampment River at mouth near Encampment, Wyoming (Site 9; before diversion).

\begin{tabular}{|c|c|c|c|c|c|c|c|}
\hline \multirow{2}{*}{$\begin{array}{c}\text { Non-exceedance } \\
\text { probability }\end{array}$} & \multirow{2}{*}{$\begin{array}{c}\text { Recurrence interval } \\
\text { (years) }\end{array}$} & \multicolumn{6}{|c|}{ Mean streamflow, in cubic feet per second, for selected periods, in consecutive days } \\
\hline & & 3 & 7 & 10 & 30 & 60 & 90 \\
\hline 0.05 & 20 & 11.2 & 12.6 & 13.0 & 15.6 & 20.9 & 26.0 \\
\hline .20 & 5 & 16.4 & 17.9 & 18.5 & 22.3 & 27.2 & 33.4 \\
\hline .50 & 2 & 23.4 & 24.8 & 25.6 & 30.4 & 35.0 & 42.5 \\
\hline .99 & 1.01 & 47.9 & 48.2 & 48.4 & 52.2 & 63.6 & 72.6 \\
\hline
\end{tabular}

Appendix 3-7. Annual ${ }^{1}$ low-flow characteristics, 06625000 Encampment River at mouth near Encampment, Wyoming (Site 9; after diversion).

\begin{tabular}{|c|c|c|c|c|c|c|c|}
\hline \multirow{2}{*}{$\begin{array}{c}\text { Non-exceedance } \\
\text { probability }\end{array}$} & \multirow{2}{*}{$\begin{array}{c}\text { Recurrence interval } \\
\text { (years) }\end{array}$} & \multicolumn{6}{|c|}{ Mean streamflow, in cubic feet per second, for selected periods, in consecutive days } \\
\hline & & 3 & 7 & 10 & 30 & 60 & 90 \\
\hline 0.02 & 50 & 10.2 & 11.1 & 11.8 & 15.3 & 21.3 & 25.7 \\
\hline .10 & 10 & 17.9 & 19.2 & 20.3 & 25.5 & 31.4 & 36.5 \\
\hline .20 & 5 & 23.6 & 25.1 & 26.5 & 32.6 & 38.2 & 43.5 \\
\hline .50 & 2 & 36.9 & 38.9 & 40.6 & 47.7 & 53.1 & 58.5 \\
\hline .90 & 1.11 & 59.8 & 62.8 & 64.4 & 70.0 & 78.3 & 83.1 \\
\hline .99 & 1.01 & 76.4 & 80.6 & 81.4 & 83.0 & 98.6 & 102 \\
\hline
\end{tabular}

Appendix 3-8. Annual ${ }^{1}$ low-flow characteristics, 06627000 North Platte River at Saratoga, Wyoming (Site 10).

[e, estimated]

\begin{tabular}{|c|c|c|c|c|c|c|c|}
\hline \multirow{2}{*}{$\begin{array}{c}\text { Non-exceedance } \\
\text { probability }\end{array}$} & \multirow{2}{*}{$\begin{array}{c}\text { Recurrence interval } \\
\text { (years) }\end{array}$} & \multicolumn{6}{|c|}{ Mean streamflow, in cubic feet per second, for selected periods, in consecutive days } \\
\hline & & 3 & 7 & 10 & 30 & 60 & 90 \\
\hline 0.02 & 50 & 59.3 & 62.8 & 65.6 & 81.1 & 105 & 113 \\
\hline .10 & 10 & 92.4 & 97.9 & 101 & 120 & 145 & 163 \\
\hline .20 & 5 & 116 & 123 & 126 & 146 & 172 & 194 \\
\hline .50 & 2 & 170 & 178 & 182 & 203 & 228 & 256 \\
\hline .90 & 1.11 & 271 & 276 & 278 & 299 & 324 & 342 \\
\hline .99 & 1.01 & e346 & e351 & 355 & 374 & e396 & e417 \\
\hline
\end{tabular}


Appendix 3-9. Annual' low-flow characteristics, 06628900 Pass Creek near Elk Mountain, Wyoming (Site 12).

\begin{tabular}{cccccccc}
\hline \multirow{2}{*}{$\begin{array}{c}\text { Non-exceedance } \\
\text { probability }\end{array}$} & $\begin{array}{c}\text { Recurrence interval } \\
\text { (years) }\end{array}$ & \multicolumn{6}{c}{ Mean streamflow, in cubic feet per second, for selected periods, in consecutive days } \\
\cline { 2 - 8 } & $\mathbf{3}$ & $\mathbf{7}$ & $\mathbf{1 0}$ & $\mathbf{3 0}$ & $\mathbf{6 0}$ & $\mathbf{9 0}$ \\
\hline 0.02 & 50 & 1.24 & 1.32 & 1.45 & 2.49 & 3.23 & 4.24 \\
.05 & 20 & 1.66 & 1.79 & 1.95 & 2.99 & 3.78 & 4.80 \\
.10 & 10 & 2.12 & 2.31 & 2.49 & 3.52 & 4.36 & 5.38 \\
.20 & 5 & 2.81 & 3.09 & 3.30 & 4.30 & 5.18 & 6.17 \\
.50 & 2 & 4.65 & 5.09 & 5.36 & 6.31 & 7.23 & 8.11 \\
.80 & 1.25 & 7.27 & 7.82 & 8.17 & 9.29 & 10.1 & 10.8 \\
.90 & 1.11 & 9.00 & 9.54 & 9.94 & 11.4 & 12.1 & 12.5 \\
.99 & 1.01 & 14.1 & 14.3 & 14.9 & 18.6 & 18.6 & 18.1 \\
\hline
\end{tabular}

Appendix 3-10. Annual' low-flow characteristics, 0663000 North Platte River above Seminoe Reservoir near Sinclair, Wyoming (Site 17).

[e, estimated]

\begin{tabular}{cccccccc}
\hline \multirow{2}{*}{$\begin{array}{c}\text { Non-exceedance } \\
\text { probability }\end{array}$} & $\begin{array}{c}\text { Recurrence interval } \\
\text { (years) }\end{array}$ & \multicolumn{6}{c}{ Mean streamflow, in cubic feet per second, for selected periods, in consecutive days } \\
\cline { 3 - 7 } & 50 & $\mathbf{3}$ & $\mathbf{7}$ & $\mathbf{1 0}$ & $\mathbf{3 0}$ & $\mathbf{6 0}$ & $\mathbf{9 0}$ \\
\hline 0.02 & 20 & 76.4 & 59.1 & 61.9 & 75.8 & 99.2 & 124 \\
.05 & 10 & 90.0 & 94.1 & 98.0 & 120 & 148 & 178 \\
.10 & 5 & 115 & 120 & 125 & 151 & 182 & 215 \\
.20 & 2 & 177 & 186 & 192 & 224 & 259 & 293 \\
.50 & 1.25 & 259 & 275 & 283 & 313 & 348 & 380 \\
.80 & 1.11 & 310 & 331 & 340 & 364 & 399 & 427 \\
.90 & 1.01 & 451 & $\mathrm{e} 458$ & $\mathrm{e} 462$ & 489 & 522 & $\mathrm{e} 550$ \\
.99 & & & & & & & \\
\hline
\end{tabular}

Appendix 3-11. Annual' low-flow characteristics, 06632400 Rock Creek above King Canyon Canal near Arlington, Wyoming (Site 22)

\begin{tabular}{cccccccc}
\hline \multirow{2}{*}{$\begin{array}{c}\text { Non-exceedance } \\
\text { probability }\end{array}$} & $\begin{array}{c}\text { Recurrence interval } \\
\text { (years) }\end{array}$ & \multicolumn{6}{c}{ Mean streamflow, in cubic feet per second, for selected periods, in consecutive days } \\
\cline { 3 - 8 } & 50 & $\mathbf{3}$ & $\mathbf{7}$ & $\mathbf{1 0}$ & $\mathbf{3 0}$ & $\mathbf{6 0}$ & $\mathbf{9 0}$ \\
\hline 0.02 & 20 & 5.00 & 5.41 & 5.61 & 6.00 & 6.27 & 6.51 \\
.05 & 10 & 5.68 & 5.74 & 5.94 & 6.38 & 6.70 & 6.96 \\
.10 & 5 & 6.14 & 6.07 & 6.27 & 6.75 & 7.13 & 7.42 \\
.20 & 2 & 7.21 & 7.57 & 7.72 & 7.27 & 7.71 & 8.03 \\
.50 & 1.25 & 8.59 & 8.96 & 9.16 & 8.49 & 9.05 & 9.44 \\
.80 & 1.11 & 9.47 & 9.85 & 10.1 & 11.1 & 10.8 & 11.3 \\
.90 & 1.01 & 12.2 & 12.6 & 12.8 & 14.3 & 1.9 & 12.4 \\
.99 & & & & & & 15.3 & 15.9 \\
\hline
\end{tabular}

Appendix 3-12. Annual' low-flow characteristics, 06632500 Rock Creek at Arlington, Wyoming (Site 23).

\begin{tabular}{cccccccc}
\hline \multirow{2}{*}{$\begin{array}{c}\text { Non-exceedance } \\
\text { probability }\end{array}$} & $\begin{array}{c}\text { Recurrence interval } \\
\text { (years) }\end{array}$ & \multicolumn{6}{c}{ Mean streamflow, in cubic feet per second, for selected periods, in consecutive days } \\
\cline { 3 - 7 } & 50 & $\mathbf{3}$ & $\mathbf{7}$ & $\mathbf{1 0}$ & $\mathbf{3 0}$ & $\mathbf{6 0}$ & $\mathbf{9 0}$ \\
\hline 0.02 & 20 & 2.92 & 2.47 & 2.59 & 3.32 & 4.94 & 5.65 \\
.05 & 10 & 3.49 & 4.24 & 3.38 & 4.10 & 5.38 & 6.00 \\
.10 & 5 & 4.57 & 5.05 & 4.18 & 4.87 & 5.85 & 6.40 \\
.20 & 2 & 6.74 & 7.16 & 7.42 & 8.13 & 8.36 & 8.77 \\
.50 & 1.25 & 8.56 & 9.14 & 9.51 & 10.5 & 11.1 & 11.7 \\
.80 & 1.11 & 9.24 & 10.0 & 10.4 & 11.8 & 13.2 & 14.0 \\
.90 & 1.01 & 10.1 & 11.5 & 12.1 & 14.5 & 20.7 & 23.4 \\
.99 & & & & & & & \\
\hline
\end{tabular}


Appendix 3-13. Annual' low-flow characteristics, 06634600 Little Medicine Bow River near Medicine Bow, Wyoming (Site 28).

[e, estimated]

\begin{tabular}{|c|c|c|c|c|c|c|c|}
\hline \multirow{2}{*}{$\begin{array}{c}\text { Non-exceedance } \\
\text { probability }\end{array}$} & \multirow{2}{*}{$\begin{array}{l}\text { Recurrence interval } \\
\text { (years) }\end{array}$} & \multicolumn{6}{|c|}{ Mean streamflow, in cubic feet per second, for selected periods, in consecutive days } \\
\hline & & 3 & 7 & 10 & 30 & 60 & 90 \\
\hline 0.05 & 20 & 0.00 & 0.00 & 0.00 & 0.00 & 0.00 & 0.16 \\
\hline .10 & 10 & .00 & .00 & .00 & .00 & .00 & .28 \\
\hline .20 & 5 & .00 & .00 & .00 & .00 & .09 & .52 \\
\hline .50 & 2 & .65 & .70 & .72 & $\mathrm{e} 1.0$ & $\mathrm{e} 1.2$ & 1.44 \\
\hline .80 & 1.25 & 1.10 & 1.17 & 1.19 & 2.52 & 2.68 & 3.26 \\
\hline .90 & 1.11 & 1.31 & 1.40 & 1.41 & 3.24 & 4.75 & e6.0 \\
\hline .99 & 1.01 & 1.83 & 1.94 & e2.2 & 3.71 & e 5.7 & e7.8 \\
\hline
\end{tabular}

Appendix 3-14. Annual' low-flow characteristics, 06634620 Little Medicine Bow River at Boles Spring near Medicine Bow, Wyoming (Site 29).

\begin{tabular}{|c|c|c|c|c|c|c|c|}
\hline \multirow{2}{*}{$\begin{array}{l}\text { Non-exceedance } \\
\text { probability }\end{array}$} & \multirow{2}{*}{$\begin{array}{c}\text { Recurrence interval } \\
\text { (years) }\end{array}$} & \multicolumn{6}{|c|}{ Mean streamflow, in cubic feet per second, for selected periods, in consecutive days } \\
\hline & & 3 & 7 & 10 & 30 & 60 & 90 \\
\hline 0.05 & 20 & 0.21 & 0.24 & 0.25 & 0.46 & 0.67 & 0.93 \\
\hline .10 & 10 & .28 & .32 & .35 & .56 & .80 & 1.14 \\
\hline .20 & 5 & .40 & .46 & .50 & .71 & 1.00 & 1.46 \\
\hline .50 & 2 & .71 & .80 & .86 & 1.10 & 1.57 & 2.44 \\
\hline .80 & 1.25 & 1.11 & 1.22 & 1.29 & 1.67 & 2.53 & 4.18 \\
\hline .90 & 1.11 & 1.34 & 1.46 & 1.52 & 2.06 & 3.28 & 5.62 \\
\hline .99 & 1.01 & 1.88 & 1.98 & 2.00 & 3.34 & 6.23 & 11.7 \\
\hline
\end{tabular}

Appendix 3-15. Annual' low-flow characteristics, 06635000 Medicine Bow River above Seminoe Reservoir near Hanna, Wyoming (Site 30).

\begin{tabular}{cccccccc}
\hline \multirow{2}{*}{$\begin{array}{c}\text { Non-exceedance } \\
\text { probability }\end{array}$} & $\begin{array}{c}\text { Recurrence interval } \\
\text { (years) }\end{array}$ & \multicolumn{6}{c}{ Mean streamflow, in cubic feet per second, for selected periods, in consecutive days } \\
\cline { 3 - 8 } & 50 & $\mathbf{3}$ & $\mathbf{7}$ & $\mathbf{1 0}$ & $\mathbf{3 0}$ & $\mathbf{6 0}$ & $\mathbf{9 0}$ \\
\hline 0.02 & 20 & .82 & 1.15 & 1.37 & 3.09 & 5.43 & 9.54 \\
.05 & 10 & 1.59 & 2.04 & 2.32 & 4.39 & 7.19 & 11.7 \\
.10 & 5 & 3.24 & 3.80 & 4.16 & 6.59 & 10.0 & 15.1 \\
.20 & 2 & 9.62 & 10.3 & 10.8 & 13.6 & 18.4 & 24.3 \\
.50 & 1.25 & 20.7 & 21.9 & 22.6 & 26.1 & 32.8 & 39.2 \\
.80 & 1.11 & 27.6 & 29.7 & 30.9 & 35.6 & 43.7 & 50.2 \\
.90 & 1.01 & 42.6 & 50.4 & 54.3 & 69.7 & 83.8 & 90.3 \\
.99 & & & & & & &
\end{tabular}

Appendix 3-16. Annual' low-flow characteristics, 06636000 North Platte River above Pathfinder Reservoir, Wyoming (Site 33).

[--, not determined]

\begin{tabular}{cccccccc}
\hline \multirow{2}{*}{$\begin{array}{c}\text { Non-exceedance } \\
\text { probability }\end{array}$} & $\begin{array}{c}\text { Recurrence interval } \\
\text { (years) }\end{array}$ & \multicolumn{6}{c}{ Mean streamflow, in cubic feet per second, for selected periods, in consecutive days } \\
\cline { 3 - 8 } & 50 & $\mathbf{3}$ & $\mathbf{7}$ & $\mathbf{1 0}$ & $\mathbf{3 0}$ & $\mathbf{6 0}$ & $\mathbf{9 0}$ \\
\hline 0.02 & 20 & 15.2 & 15.7 & 36.9 & 49.9 & 81.4 & 98.6 \\
.05 & 10 & 34.2 & 35.6 & 64.9 & 83.1 & 119 & 142 \\
.10 & 5 & 63.0 & 65.8 & 99.6 & 122 & 158 & 186 \\
.20 & 2 & 116 & 121 & 153 & 179 & 213 & 246 \\
.50 & 1.25 & -- & -- & -- & -- & -- & 355 \\
.80 & 1.11 & -- & -- & -- & -- & -- & -- \\
.90 & 1.01 & -- & -- & -- & -- & -- & -- \\
.99 & & & & & & 293 & - \\
\hline
\end{tabular}


Appendix 3-17. Annual' low-flow characteristics, 06639000 Sweetwater River near Alcova, Wyoming (Site 36).

$[--$, not determined $]$

\begin{tabular}{|c|c|c|c|c|c|c|c|}
\hline \multirow{2}{*}{$\begin{array}{c}\text { Non-exceedance } \\
\text { probability }\end{array}$} & \multirow{2}{*}{$\begin{array}{c}\text { Recurrence interval } \\
\text { (years) }\end{array}$} & \multicolumn{6}{|c|}{ Mean streamflow, in cubic feet per second, for selected periods, in consecutive day } \\
\hline & & 3 & 7 & 10 & 30 & 60 & 90 \\
\hline 0.02 & 50 & 0.57 & 0.59 & 0.61 & 0.95 & 1.88 & 3.78 \\
\hline .10 & 10 & 1.82 & 1.91 & 1.98 & 2.93 & 5.62 & 9.19 \\
\hline .20 & 5 & 3.32 & 3.47 & 3.61 & 5.15 & 9.39 & 13.9 \\
\hline .90 & 1.11 & 32.6 & 33.7 & 34.3 & 38.0 & 42.1 & 45.7 \\
\hline .99 & 1.01 & -- & -- & -- & -- & -- & -- \\
\hline
\end{tabular}

Appendix 3-18. Annual' low-flow characteristics, 06641000 North Platte River below Pathfinder Reservoir, Wyoming (Site 37).

$[--;$ not determined $]$

\begin{tabular}{|c|c|c|c|c|c|c|c|}
\hline \multirow{2}{*}{$\begin{array}{l}\text { Non-exceedance } \\
\text { probability }\end{array}$} & \multirow{2}{*}{$\begin{array}{c}\text { Recurrence interval } \\
\text { (years) }\end{array}$} & \multicolumn{6}{|c|}{ Mean streamflow, in cubic feet per second, for selected periods, in consecutive days } \\
\hline & & 3 & 7 & 10 & 30 & 60 & 90 \\
\hline 0.02 & 50 & -- & -- & -- & -- & -- & -- \\
\hline .05 & 20 & -- & -- & -- & -- & -- & -- \\
\hline .10 & 10 & 0.77 & 0.79 & 0.81 & 0.91 & 1.04 & 1.12 \\
\hline .20 & 5 & 1.42 & 1.52 & 1.55 & 2.03 & 2.65 & 3.06 \\
\hline .50 & 2 & 5.60 & 6.26 & 6.40 & 9.98 & 15.2 & 19.4 \\
\hline .80 & 1.25 & 29.1 & 32.8 & 33.7 & 53.1 & 82.4 & 110 \\
\hline .90 & 1.11 & 77.1 & 86.0 & 88.8 & 131 & 195 & 262 \\
\hline .99 & 1.01 & 1,100 & 1,130 & 1,190 & 1,240 & 1,420 & 1,830 \\
\hline
\end{tabular}

Appendix 3-19. Annual' low-flow characteristics, 06642000 North Platte River at Alcova, Wyoming (Site 39).

[e; estimated]

\begin{tabular}{cccccccc}
\hline \multirow{2}{*}{$\begin{array}{c}\text { Non-exceedance } \\
\text { probability }\end{array}$} & $\begin{array}{c}\text { Recurrence interval } \\
\text { (years) }\end{array}$ & \multicolumn{6}{c}{ Mean streamflow, in cubic feet per second, for selected periods, in consecutive days } \\
\cline { 3 - 8 } & 50 & $\mathbf{3}$ & $\mathbf{7}$ & $\mathbf{1 0}$ & $\mathbf{3 0}$ & $\mathbf{6 0}$ & $\mathbf{9 0}$ \\
\hline 0.02 & 20 & $\mathrm{e} 0.39$ & 0.40 & $\mathrm{e} 0.41$ & $\mathrm{e} 0.45$ & $\mathrm{e} 0.47$ & 0.49 \\
.05 & 10 & 3.96 & 1.40 & $\mathrm{e} 1.41$ & $\mathrm{e} 1.50$ & 1.70 & 1.90 \\
.10 & 5 & 12.8 & 13.99 & 4.02 & 4.18 & 5.14 & 5.82 \\
.20 & 2 & 96.0 & 101 & 13.4 & 14.6 & 17.9 & 20.3 \\
.50 & 1.25 & 533 & 575 & 603 & 122 & 147 & 165 \\
.80 & 1.11 & 1,170 & 1,280 & 1,340 & 1,670 & 1,900 & 1,990 \\
.90 & 1.01 & 5,660 & 6,360 & 6,700 & $\mathrm{e} 7,650$ & $\mathrm{e} 8,300$ & 8,620 \\
.99 & & & & & & & \\
\hline
\end{tabular}


Appendix 3-20. Annual' low-flow characteristics, 06661000 Little Laramie River near Filmore, Wyoming (Site 43).

[e; estimated]

\begin{tabular}{cccccccc}
\hline \multirow{2}{*}{$\begin{array}{c}\text { Non-exceedance } \\
\text { probability }\end{array}$} & $\begin{array}{c}\text { Recurrence interval } \\
\text { (years) }\end{array}$ & \multicolumn{6}{c}{ Mean streamflow, in cubic feet per second, for selected periods, in consecutive days } \\
\cline { 2 - 7 } & 50 & $\mathbf{3}$ & $\mathbf{7}$ & $\mathbf{1 0}$ & $\mathbf{3 0}$ & $\mathbf{6 0}$ & $\mathbf{9 0}$ \\
\hline 0.02 & 20 & 5.86 & 3.87 & 5.88 & 8.16 & 9.48 & 10.1 \\
.05 & 10 & 7.62 & 8.35 & 9.23 & 11.1 & 12.6 & 13.8 \\
.10 & 5 & 11.1 & 11.5 & $\mathrm{e} 11.8$ & 13.0 & 14.5 & 15.5 \\
.20 & 2 & $\mathrm{e} 15.5$ & $\mathrm{e} 15.9$ & 16.0 & 17.1 & 18.6 & 19.9 \\
.50 & 1.25 & 18.9 & 19.8 & 20.4 & 21.7 & 23.0 & 24.5 \\
.80 & 1.11 & 19.1 & 20.4 & $\mathrm{e} 21.2$ & 24.3 & 25.3 & 26.9 \\
.90 & 1.01 & 19.2 & 20.8 & $\mathrm{e} 22.0$ & $\mathrm{e} 25.8$ & 30.6 & 32.4 \\
.99 & & & & & & &
\end{tabular}

Appendix 3-21. Annual' low-flow characteristics, 09253000 Little Snake River near Slater, Colorado (Site 48).

\begin{tabular}{cccccccc}
\hline \multirow{2}{*}{$\begin{array}{c}\text { Non-exceedance } \\
\text { probability }\end{array}$} & $\begin{array}{c}\text { Recurrence interval } \\
\text { (years) }\end{array}$ & \multicolumn{6}{c}{ Mean streamflow, in cubic feet per second, for selected periods, in consecutive days } \\
\cline { 3 - 7 } & 50 & $\mathbf{3}$ & $\mathbf{7}$ & $\mathbf{1 0}$ & $\mathbf{3 0}$ & $\mathbf{6 0}$ & $\mathbf{9 0}$ \\
\hline 0.02 & 20 & 7.65 & 7.36 & 8.11 & 10.6 & 12.6 & 14.7 \\
.05 & 10 & 9.29 & 8.85 & 9.54 & 12.1 & 14.2 & 16.3 \\
.10 & 5 & 11.4 & 10.4 & 11.0 & 13.6 & 15.9 & 18.0 \\
.20 & 2 & 16.8 & 17.4 & 13.0 & 15.8 & 18.2 & 20.3 \\
.50 & 1.25 & 23.0 & 23.7 & 24.3 & 27.9 & 31.7 & 34.5 \\
.80 & 1.11 & 26.4 & 27.6 & 28.5 & 32.1 & 37.0 & 40.3 \\
.90 & 1.01 & 34.3 & 38.6 & 40.8 & 45.9 & 54.1 & 60.1 \\
.99 & & & & & & & \\
\hline
\end{tabular}

Appendix 3-22. Annual' low-flow characteristics, 09255000 Slater Fork near Slater, Colorado (Site 51).

\begin{tabular}{cccccccc}
\hline \multirow{2}{*}{$\begin{array}{c}\text { Non-exceedance } \\
\text { probability }\end{array}$} & $\begin{array}{c}\text { Recurrence interval } \\
\text { (years) }\end{array}$ & \multicolumn{6}{c}{ Mean streamflow, in cubic feet per second, for selected periods, in consecutive days } \\
\cline { 2 - 7 } & 50 & $\mathbf{3}$ & $\mathbf{7}$ & $\mathbf{1 0}$ & $\mathbf{3 0}$ & $\mathbf{6 0}$ & $\mathbf{9 0}$ \\
\hline 0.02 & 20 & .00 & 0.06 & 0.28 & 0.97 & 1.80 & 3.18 \\
.05 & 10 & .29 & .29 & .56 & 1.43 & 2.42 & 3.94 \\
.10 & 5 & .96 & 1.38 & .96 & 1.98 & 3.14 & 4.79 \\
.20 & 2 & 3.61 & 3.97 & 4.23 & 5.64 & 7.48 & 9.06 \\
.50 & 1.25 & 6.62 & 7.65 & 8.18 & 10.3 & 12.8 & 15.3 \\
.80 & 1.11 & 7.70 & 9.56 & 10.6 & 13.7 & 16.8 & 19.6 \\
.90 & 1.01 & 8.70 & 12.8 & 16.0 & 25.3 & 31.0 & 35.4 \\
.99 & & & & & & &
\end{tabular}

Appendix 3-23. Annual' low-flow characteristics, 09255500 Savery Creek at upper station near Savery, Wyoming (Site 52).

\begin{tabular}{cccccccc}
\hline \multirow{2}{*}{$\begin{array}{c}\text { Non-exceedance } \\
\text { probability }\end{array}$} & $\begin{array}{c}\text { Recurrence interval } \\
\text { (years) }\end{array}$ & \multicolumn{6}{c}{ Mean streamflow, in cubic feet per second, for selected periods, in consecutive days } \\
\cline { 3 - 8 } & 20 & $\mathbf{3}$ & $\mathbf{7}$ & $\mathbf{1 0}$ & $\mathbf{3 0}$ & $\mathbf{6 0}$ & $\mathbf{9 0}$ \\
\hline 0.05 & 10 & 1.64 & 0.78 & 0.90 & 1.69 & 2.49 & 3.24 \\
.10 & 5 & 1.70 & 1.20 & 1.35 & 2.26 & 3.12 & 3.97 \\
.20 & 2 & 4.04 & 4.42 & 2.14 & 3.17 & 4.11 & 5.07 \\
.50 & 1.25 & 8.23 & 8.82 & 9.68 & 5.85 & 6.93 & 8.10 \\
.80 & 1.11 & 11.3 & 12.0 & 12.4 & 10.3 & 11.6 & 12.9 \\
.90 & 1.01 & 20.6 & 22.2 & 22.8 & 24.6 & 15.3 & 16.5 \\
.99 & & & & & & &
\end{tabular}


Appendix 3-24. Annual' low-flow characteristics, 09256000 Savery Creek near Savery, Wyoming (Site 53).

\begin{tabular}{|c|c|c|c|c|c|c|c|}
\hline \multirow{2}{*}{$\begin{array}{c}\text { Non-exceedance } \\
\text { probability }\end{array}$} & \multirow{2}{*}{$\begin{array}{c}\text { Recurrence interval } \\
\text { (years) }\end{array}$} & \multicolumn{6}{|c|}{ Mean streamflow, in cubic feet per second, for selected periods, in consecutive days } \\
\hline & & 3 & 7 & 10 & 30 & 60 & 90 \\
\hline 0.02 & 50 & 0.00 & 0.00 & 0.00 & 0.43 & 1.07 & 2.33 \\
\hline .10 & 10 & .41 & .44 & .50 & 1.24 & 2.33 & 4.12 \\
\hline .20 & 5 & 1.05 & 1.10 & 1.21 & 2.15 & 3.54 & 5.68 \\
\hline .50 & 2 & 3.64 & 4.01 & 4.27 & 5.57 & 7.58 & 10.4 \\
\hline .90 & 1.11 & 14.1 & 15.4 & 15.9 & 18.7 & 21.7 & 26.0 \\
\hline .99 & 1.01 & e30 & 31.4 & 32.1 & 41.1 & 46.7 & 53.7 \\
\hline
\end{tabular}

Appendix 3-25. Annual' low-flow characteristics, 09257000 Little Snake River near Dixon, Wyoming (Site 54).

\begin{tabular}{|c|c|c|c|c|c|c|c|}
\hline \multirow{2}{*}{$\begin{array}{l}\text { Non-exceedance } \\
\text { probability }\end{array}$} & \multirow{2}{*}{$\begin{array}{l}\text { Recurrence interval } \\
\text { (years) }\end{array}$} & \multicolumn{6}{|c|}{ Mean streamflow, in cubic feet per second, for selected periods, in consecutive days } \\
\hline & & 3 & 7 & 10 & 30 & 60 & 90 \\
\hline 0.02 & 50 & 0.20 & 0.29 & 0.37 & 0.59 & 0.87 & 1.43 \\
\hline .05 & 20 & .35 & .48 & .60 & .92 & 1.41 & 2.45 \\
\hline .10 & 10 & .60 & .78 & .92 & 1.39 & 2.17 & 3.89 \\
\hline .20 & 5 & 1.12 & 1.40 & 1.60 & 2.33 & 3.70 & 6.74 \\
\hline .50 & 2 & 3.81 & 4.43 & 4.81 & 6.69 & 10.5 & 18.5 \\
\hline .80 & 1.25 & 13.2 & 14.7 & 15.5 & 20.9 & 30.6 & 48.0 \\
\hline .90 & 1.11 & 25.4 & 28.1 & 29.4 & 39.1 & 54.3 & 77.6 \\
\hline .99 & 1.01 & 123 & 137 & 146 & 192 & 219 & 229 \\
\hline
\end{tabular}

Appendix 3-26. Annual' low-flow characteristics, 09258000 Willow Creek near Dixon, Wyoming (Site 55).

[e, estimated; --, not determined]

\begin{tabular}{|c|c|c|c|c|c|c|c|}
\hline \multirow{2}{*}{$\begin{array}{c}\text { Non-exceedance } \\
\text { probability }\end{array}$} & \multirow{2}{*}{$\begin{array}{c}\text { Recurrence interval } \\
\text { (years) }\end{array}$} & \multicolumn{6}{|c|}{ Mean streamflow, in cubic feet per second, for selected periods, in consecutive days } \\
\hline & & 3 & 7 & 10 & 30 & 60 & 90 \\
\hline 0.02 & 50 & 0.00 & 0.00 & 0.00 & 0.23 & 0.30 & 0.68 \\
\hline .05 & 20 & .00 & .00 & .07 & .37 & .48 & 0.84 \\
\hline .10 & 10 & .00 & .10 & .18 & .53 & .71 & 1.01 \\
\hline .20 & 5 & .32 & .34 & .42 & .79 & 1.05 & 1.26 \\
\hline .50 & 2 & .83 & e1.0 & 1.12 & 1.47 & 1.84 & $\mathrm{e} 2.0$ \\
\hline .80 & 1.25 & 1.54 & 1.77 & 1.90 & 2.30 & 2.58 & 2.67 \\
\hline .90 & 1.11 & 2.00 & $\mathrm{e} 2.1$ & 2.22 & 2.74 & 2.87 & 3.20 \\
\hline .99 & 1.01 & -- & -- & -- & -- & -- & -- \\
\hline
\end{tabular}

${ }^{1}$ Based on climate year from April 1 through March 31. 


\section{Appendix 4. Streamflow duration statistics, selected sites in and near Carbon County, Wyoming.}

Appendix 4-1. Streamflow duration statistics, 06620000 North Platte River near Northgate, Colorado (Site 1).

\begin{tabular}{|c|c|}
\hline \multicolumn{2}{|c|}{ Daily mean streamflow } \\
\hline $\begin{array}{c}\text { Cubic feet per } \\
\text { second }\end{array}$ & $\begin{array}{c}\text { Percentage of } \\
\text { time equaled or } \\
\text { exceeded }\end{array}$ \\
\hline 36.4 & 99 \\
\hline 44.1 & 98 \\
\hline 55.2 & 95 \\
\hline 67.4 & 90 \\
\hline 76.4 & 85 \\
\hline 84.6 & 80 \\
\hline 92.8 & 75 \\
\hline 103 & 70 \\
\hline 114 & 65 \\
\hline 128 & 60 \\
\hline 142 & 55 \\
\hline 161 & 50 \\
\hline 190 & 45 \\
\hline 226 & 40 \\
\hline 275 & 35 \\
\hline 341 & 30 \\
\hline 451 & 25 \\
\hline 602 & 20 \\
\hline 848 & 15 \\
\hline 1,208 & 10 \\
\hline 1,821 & 5 \\
\hline 2,542 & 2 \\
\hline 3,122 & 1 \\
\hline
\end{tabular}

Appendix 4-2. Streamflow duration statistics, 06621000 Douglas Creek near Foxpark, Wyoming (Site 3).

\begin{tabular}{cc}
\hline \multicolumn{2}{c}{ Daily mean streamflow } \\
\hline $\begin{array}{c}\text { Cubic feet per } \\
\text { second }\end{array}$ & $\begin{array}{c}\text { Percentage of } \\
\text { time equaled or } \\
\text { exceeded }\end{array}$ \\
\hline 3.20 & 99 \\
3.60 & 98 \\
4.60 & 95 \\
6.04 & 90 \\
7.00 & 85 \\
7.88 & 80 \\
8.72 & 75 \\
9.59 & 70 \\
10.5 & 65 \\
11.4 & 60 \\
12.3 & 55 \\
13.4 & 50 \\
15.0 & 45 \\
17.0 & 40 \\
21.4 & 35 \\
27.6 & 30 \\
38.9 & 25 \\
65.0 & 20 \\
120 & 15 \\
245 & 10 \\
498 & 5 \\
723 & 2 \\
877 & 1 \\
\hline & \\
\hline & \\
\hline
\end{tabular}

Appendix 4-3. Streamflow duration statistics, 06622700 North Brush Creek near Saratoga, Wyoming (Site 5).

\begin{tabular}{cc}
\hline \multicolumn{2}{c}{ Daily mean streamflow } \\
\hline $\begin{array}{c}\text { Cubic feet per } \\
\text { second }\end{array}$ & $\begin{array}{c}\text { Percentage of } \\
\text { time equaled or } \\
\text { exceeded }\end{array}$ \\
\hline 5.93 & 99 \\
6.40 & 98 \\
7.35 & 95 \\
7.89 & 90 \\
8.44 & 85 \\
8.88 & 80 \\
9.27 & 75 \\
9.67 & 70 \\
10.1 & 65 \\
10.8 & 60 \\
11.5 & 55 \\
12.3 & 50 \\
13.3 & 45 \\
14.5 & 40 \\
16.3 & 35 \\
19.3 & 30 \\
24.7 & 25 \\
38.0 & 20 \\
74.0 & 15 \\
154 & 10 \\
286 & 5 \\
409 & 2 \\
488 & 1 \\
\hline &
\end{tabular}


Appendix 4-4. Streamflow duration statistics, 06622900 South Brush Creek near Saratoga, Wyoming (Site 6).

\begin{tabular}{|c|c|}
\hline \multicolumn{2}{|c|}{ Daily mean streamflow } \\
\hline $\begin{array}{l}\text { Cubic feet per } \\
\text { second }\end{array}$ & $\begin{array}{l}\text { Percentage of } \\
\text { time equaled or } \\
\text { exceeded }\end{array}$ \\
\hline 1.93 & 99 \\
\hline 2.55 & 98 \\
\hline 3.98 & 95 \\
\hline 4.71 & 90 \\
\hline 5.07 & 85 \\
\hline 5.44 & 80 \\
\hline 5.82 & 75 \\
\hline 6.21 & 70 \\
\hline 6.60 & 65 \\
\hline 7.09 & 60 \\
\hline 7.67 & 55 \\
\hline 8.25 & 50 \\
\hline 9.20 & 45 \\
\hline 10.5 & 40 \\
\hline 13.0 & 35 \\
\hline 15.8 & 30 \\
\hline 22.6 & 25 \\
\hline 32.3 & 20 \\
\hline 53.9 & 15 \\
\hline 94.7 & 10 \\
\hline 174 & 5 \\
\hline 261 & 2 \\
\hline 308 & 1 \\
\hline
\end{tabular}

Appendix 4-5. Streamflow duration statistics, 06623800 Encampment River above Hog Park Creek near Encampment, Wyoming (Site 7).

\begin{tabular}{cc}
\hline \multicolumn{2}{c}{ Daily mean streamflow } \\
\hline $\begin{array}{c}\text { Cubic feet per } \\
\text { second }\end{array}$ & $\begin{array}{c}\text { Percentage of } \\
\text { time equaled or } \\
\text { exceeded }\end{array}$ \\
\hline 12.0 & 99 \\
13.2 & 98 \\
15.1 & 95 \\
16.7 & 90 \\
18.0 & 85 \\
19.1 & 80 \\
20.3 & 75 \\
21.6 & 70 \\
22.9 & 65 \\
24.5 & 60 \\
26.2 & 55 \\
28.4 & 50 \\
31.2 & 45 \\
35.0 & 40 \\
40.7 & 35 \\
50.7 & 30 \\
68.2 & 25 \\
106 & 20 \\
193 & 15 \\
371 & 10 \\
614 & 5 \\
856 & 2 \\
979 & \\
\hline
\end{tabular}

Appendix 4-6. Streamflow duration statistics, 06625000 Encampment River at mouth near Encampment, Wyoming (Site 9; before diversion).

\begin{tabular}{|c|c|}
\hline \multicolumn{2}{|c|}{ Daily mean streamflow } \\
\hline $\begin{array}{c}\text { Cubic feet per } \\
\text { second }\end{array}$ & $\begin{array}{c}\text { Percentage of } \\
\text { time equaled or } \\
\text { exceeded }\end{array}$ \\
\hline 19.6 & 99 \\
\hline 22.6 & 98 \\
\hline 28.2 & 95 \\
\hline 34.9 & 90 \\
\hline 40.3 & 85 \\
\hline 44.5 & 80 \\
\hline 48.2 & 75 \\
\hline 51.7 & 70 \\
\hline 54.6 & 65 \\
\hline 57.4 & 60 \\
\hline 60.3 & 55 \\
\hline 63.7 & 50 \\
\hline 68.0 & 45 \\
\hline 72.3 & 40 \\
\hline 79.4 & 35 \\
\hline 88.5 & 30 \\
\hline 118 & 25 \\
\hline 209 & 20 \\
\hline 435 & 15 \\
\hline 781 & 10 \\
\hline 1,197 & 5 \\
\hline 1,684 & 2 \\
\hline 1,982 & 1 \\
\hline
\end{tabular}


Appendix 4-7. Streamflow duration statistics, 06625000 Encampment River at mouth near Encampment, Wyoming (Site after diversion).

\begin{tabular}{|c|c|}
\hline \multicolumn{2}{|c|}{ Daily mean streamflow } \\
\hline $\begin{array}{c}\text { Cubic feet per } \\
\text { second }\end{array}$ & $\begin{array}{c}\text { Percentage of } \\
\text { time equaled or } \\
\text { exceeded }\end{array}$ \\
\hline 21.2 & 99 \\
\hline 28.4 & 98 \\
\hline 39.1 & 95 \\
\hline 47.7 & 90 \\
\hline 53.6 & 85 \\
\hline 58.4 & 80 \\
\hline 62.9 & 75 \\
\hline 66.5 & 70 \\
\hline 70.1 & 65 \\
\hline 73.7 & 60 \\
\hline 78.6 & 55 \\
\hline 83.6 & 50 \\
\hline 88.6 & 45 \\
\hline 98.2 & 40 \\
\hline 108 & 35 \\
\hline 124 & 30 \\
\hline 152 & 25 \\
\hline 224 & 20 \\
\hline 392 & 15 \\
\hline 770 & 10 \\
\hline 1,358 & 5 \\
\hline 1,850 & 2 \\
\hline 2,099 & 1 \\
\hline
\end{tabular}

Appendix 4-8. Streamflow duration statistics, 06627000 North Platte River at Saratoga, Wyoming (Site 10).

\begin{tabular}{cc}
\hline \multicolumn{2}{c}{ Daily mean streamflow } \\
\hline $\begin{array}{c}\text { Cubic feet per } \\
\text { second }\end{array}$ & $\begin{array}{c}\text { Percentage of } \\
\text { time equaled or } \\
\text { exceeded }\end{array}$ \\
\hline 113 & 99 \\
136 & 98 \\
171 & 95 \\
206 & 90 \\
232 & 85 \\
251 & 80 \\
270 & 75 \\
289 & 70 \\
310 & 65 \\
330 & 60 \\
362 & 55 \\
395 & 50 \\
440 & 45 \\
494 & 40 \\
594 & 35 \\
760 & 30 \\
1,035 & 25 \\
1,528 & 20 \\
2,273 & 15 \\
3,395 & 10 \\
5,154 & 5 \\
7,100 & 2 \\
8,682 & 1 \\
&
\end{tabular}

Appendix 4-9. Streamflow duration statistics, 06628900 Pass Creek near Elk Mountain, Wyoming (Site 12).

\begin{tabular}{|c|c|}
\hline \multicolumn{2}{|c|}{ Daily mean streamflow } \\
\hline $\begin{array}{c}\text { Cubic feet per } \\
\text { second }\end{array}$ & $\begin{array}{c}\text { Percentage of } \\
\text { time equaled or } \\
\text { exceeded }\end{array}$ \\
\hline 3.19 & 99 \\
\hline 3.75 & 98 \\
\hline 4.94 & 95 \\
\hline 6.36 & 90 \\
\hline 7.40 & 85 \\
\hline 8.04 & 80 \\
\hline 8.68 & 75 \\
\hline 9.38 & 70 \\
\hline 10.3 & 65 \\
\hline 11.3 & 60 \\
\hline 12.3 & 55 \\
\hline 13.6 & 50 \\
\hline 15.0 & 45 \\
\hline 17.1 & 40 \\
\hline 20.2 & 35 \\
\hline 25.1 & 30 \\
\hline 34.1 & 25 \\
\hline 50.0 & 20 \\
\hline 73.7 & 15 \\
\hline 116 & 10 \\
\hline 187 & 5 \\
\hline 280 & 2 \\
\hline 363 & 1 \\
\hline
\end{tabular}


Appendix 4-10. Streamflow duration statistics, 06630000 North Platte River above Seminoe Reservoir near Sinclair, Wyoming (Site 17).

\begin{tabular}{|c|c|}
\hline \multicolumn{2}{|c|}{ Daily mean streamflow } \\
\hline $\begin{array}{c}\text { Cubic feet per } \\
\text { second }\end{array}$ & $\begin{array}{c}\text { Percentage of } \\
\text { time equaled or } \\
\text { exceeded }\end{array}$ \\
\hline 111 & 99 \\
\hline 140 & 98 \\
\hline 188 & 95 \\
\hline 228 & 90 \\
\hline 254 & 85 \\
\hline 279 & 80 \\
\hline 303 & 75 \\
\hline 327 & 70 \\
\hline 353 & 65 \\
\hline 380 & 60 \\
\hline 412 & 55 \\
\hline 447 & 50 \\
\hline 492 & 45 \\
\hline 554 & 40 \\
\hline 660 & 35 \\
\hline 803 & 30 \\
\hline 1,042 & 25 \\
\hline 1,445 & 20 \\
\hline 2,107 & 15 \\
\hline 3,128 & 10 \\
\hline 4,851 & 5 \\
\hline 6,774 & 2 \\
\hline 8,032 & 1 \\
\hline
\end{tabular}

Appendix 4-11. Streamflow duration statistics, 06632400 Rock Creek above King Canyon Canal near Arlington, Wyoming (Site 22).

\begin{tabular}{|c|c|}
\hline \multicolumn{2}{|c|}{ Daily mean streamflow } \\
\hline $\begin{array}{c}\text { Cubic feet per } \\
\text { second }\end{array}$ & $\begin{array}{c}\text { Percentage of } \\
\text { time equaled or } \\
\text { exceeded }\end{array}$ \\
\hline 6.03 & 99 \\
\hline 6.67 & 98 \\
\hline 7.27 & 95 \\
\hline 8.17 & 90 \\
\hline 8.81 & 85 \\
\hline 9.44 & 80 \\
\hline 10.3 & 75 \\
\hline 11.2 & 70 \\
\hline 12.2 & 65 \\
\hline 13.0 & 60 \\
\hline 13.9 & 55 \\
\hline 15.3 & 50 \\
\hline 16.7 & 45 \\
\hline 19.1 & 40 \\
\hline 22.8 & 35 \\
\hline 29.3 & 30 \\
\hline 40.4 & 25 \\
\hline 63.7 & 20 \\
\hline 123 & 15 \\
\hline 260 & 10 \\
\hline 479 & 5 \\
\hline 720 & 2 \\
\hline 876 & 1 \\
\hline
\end{tabular}

Appendix 4-12. Streamflow duration statistics, 06632500 Rock Creek at Arlington, Wyoming (Site 23).

\begin{tabular}{cc}
\hline \multicolumn{2}{c}{ Daily mean streamflow } \\
\hline $\begin{array}{c}\text { Cubic feet per } \\
\text { second }\end{array}$ & $\begin{array}{c}\text { Percentage of } \\
\text { time equaled or } \\
\text { exceeded }\end{array}$ \\
\hline 4.79 & 99 \\
5.64 & 98 \\
6.47 & 95 \\
7.49 & 90 \\
8.24 & 85 \\
9.02 & 80 \\
9.93 & 75 \\
10.8 & 70 \\
11.8 & 65 \\
12.8 & 60 \\
13.7 & 55 \\
15.4 & 50 \\
17.6 & 45 \\
20.4 & 40 \\
24.1 & 35 \\
29.7 & 30 \\
39.0 & 25 \\
61.8 & 20 \\
118 & 15 \\
227 & 10 \\
400 & 5 \\
618 & 2 \\
775 & 1 \\
\hline
\end{tabular}


Appendix 4-13. Streamflow duration statistics, 06634600 Little Medicine Bow River near Medicine Bow, Wyoming (Site 28).

\begin{tabular}{|c|c|}
\hline \multicolumn{2}{|c|}{ Daily mean streamflow } \\
\hline $\begin{array}{c}\text { Cubic feet per } \\
\text { second }\end{array}$ & $\begin{array}{c}\text { Percentage of } \\
\text { time equaled or } \\
\text { exceeded }\end{array}$ \\
\hline 0.00 & 99 \\
\hline .00 & 98 \\
\hline .10 & 95 \\
\hline .93 & 90 \\
\hline 1.57 & 85 \\
\hline 2.30 & 80 \\
\hline 3.13 & 75 \\
\hline 4.06 & 70 \\
\hline 5.14 & 65 \\
\hline 6.25 & 60 \\
\hline 7.41 & 55 \\
\hline 8.72 & 50 \\
\hline 11.0 & 45 \\
\hline 13.4 & 40 \\
\hline 16.6 & 35 \\
\hline 21.8 & 30 \\
\hline 35.3 & 25 \\
\hline 65.5 & 20 \\
\hline 120 & 15 \\
\hline 195 & 10 \\
\hline 336 & 5 \\
\hline 574 & 2 \\
\hline 808 & 1 \\
\hline
\end{tabular}

Appendix 4-14. Streamflow duration statistics, 06634620 Little Medicine Bow River at Boles Spring near Medicine Bow, Wyoming (Site 29).

\begin{tabular}{|c|c|}
\hline \multicolumn{2}{|c|}{ Daily mean streamflow } \\
\hline $\begin{array}{l}\text { Cubic feet per } \\
\text { second }\end{array}$ & $\begin{array}{l}\text { Percentage of } \\
\text { time equaled or } \\
\text { exceeded }\end{array}$ \\
\hline 0.41 & 99 \\
\hline .57 & 98 \\
\hline .93 & 95 \\
\hline 1.30 & 90 \\
\hline 1.65 & 85 \\
\hline 2.17 & 80 \\
\hline 3.05 & 75 \\
\hline 3.89 & 70 \\
\hline 4.75 & 65 \\
\hline 5.72 & 60 \\
\hline 6.79 & 55 \\
\hline 8.20 & 50 \\
\hline 10.0 & 45 \\
\hline 12.6 & 40 \\
\hline 15.8 & 35 \\
\hline 21.3 & 30 \\
\hline 30.3 & 25 \\
\hline 44.9 & 20 \\
\hline 73.6 & 15 \\
\hline 124 & 10 \\
\hline 219 & 5 \\
\hline 335 & 2 \\
\hline 438 & 1 \\
\hline
\end{tabular}

Appendix 4-15. Streamflow duration statistics, 06635000 Medicine Bow River above Seminoe Reservoir near Hanna, Wyoming (Site 32).

\begin{tabular}{|c|c|}
\hline \multicolumn{2}{|c|}{ Daily mean streamflow } \\
\hline $\begin{array}{c}\text { Cubic feet per } \\
\text { second }\end{array}$ & $\begin{array}{c}\text { Percentage of } \\
\text { time equaled or } \\
\text { exceeded }\end{array}$ \\
\hline 3.57 & 99 \\
\hline 5.90 & 98 \\
\hline 9.59 & 95 \\
\hline 14.9 & 90 \\
\hline 19.1 & 85 \\
\hline 22.9 & 80 \\
\hline 26.7 & 75 \\
\hline 30.7 & 70 \\
\hline 34.7 & 65 \\
\hline 40.0 & 60 \\
\hline 46.0 & 55 \\
\hline 52.6 & 50 \\
\hline 62.3 & 45 \\
\hline 71.9 & 40 \\
\hline 91.5 & 35 \\
\hline 125 & 30 \\
\hline 174 & 25 \\
\hline 248 & 20 \\
\hline 358 & 15 \\
\hline 533 & 10 \\
\hline 833 & 5 \\
\hline 1,258 & 2 \\
\hline 1,631 & 1 \\
\hline
\end{tabular}


Appendix 4-16. Streamflow duration statistics, 06636000 North Platte River above Pathfinder Reservoir, Wyoming (Site 33).

\begin{tabular}{|c|c|}
\hline \multicolumn{2}{|c|}{ Daily mean streamflow } \\
\hline $\begin{array}{c}\text { Cubic feet per } \\
\text { second }\end{array}$ & $\begin{array}{c}\text { Percentage of } \\
\text { time equaled or } \\
\text { exceeded }\end{array}$ \\
\hline 22.0 & 99 \\
\hline 87.4 & 98 \\
\hline 187 & 95 \\
\hline 248 & 90 \\
\hline 290 & 85 \\
\hline 325 & 80 \\
\hline 358 & 75 \\
\hline 391 & 70 \\
\hline 425 & 65 \\
\hline 466 & 60 \\
\hline 508 & 55 \\
\hline 568 & 50 \\
\hline 637 & 45 \\
\hline 750 & 40 \\
\hline 895 & 35 \\
\hline 1,137 & 30 \\
\hline 1,610 & 25 \\
\hline 2,227 & 20 \\
\hline 3,130 & 15 \\
\hline 4,832 & 10 \\
\hline 7,110 & 5 \\
\hline 9,817 & 2 \\
\hline 12,620 & 1 \\
\hline
\end{tabular}

Appendix 4-17. Streamflow duration statistics, 06639000 Sweetwater River near Alcova, Wyoming (Site 36).

\begin{tabular}{|c|c|}
\hline \multicolumn{2}{|c|}{ Daily mean streamflow } \\
\hline $\begin{array}{l}\text { Cubic feet per } \\
\text { second }\end{array}$ & $\begin{array}{l}\text { Percentage of } \\
\text { time equaled or } \\
\text { exceeded }\end{array}$ \\
\hline 2.23 & 99 \\
\hline 3.44 & 98 \\
\hline 10.5 & 95 \\
\hline 18.6 & 90 \\
\hline 23.3 & 85 \\
\hline 27.5 & 80 \\
\hline 31.5 & 75 \\
\hline 34.6 & 70 \\
\hline 37.7 & 65 \\
\hline 41.1 & 60 \\
\hline 45.4 & 55 \\
\hline 49.6 & 50 \\
\hline 54.7 & 45 \\
\hline 63.1 & 40 \\
\hline 72.3 & 35 \\
\hline 85.0 & 30 \\
\hline 108 & 25 \\
\hline 156 & 20 \\
\hline 233 & 15 \\
\hline 342 & 10 \\
\hline 557 & 5 \\
\hline 836 & 2 \\
\hline 1,060 & 1 \\
\hline
\end{tabular}

Appendix 4-18. Streamflow duration statistics, 06641000 North Platte River below Pathfinder Reservoir, Wyoming (Site 37).

\begin{tabular}{cc}
\hline \multicolumn{2}{c}{ Daily mean streamflow } \\
$\begin{array}{c}\text { Cubic feet per } \\
\text { second }\end{array}$ & $\begin{array}{c}\text { Percentage of } \\
\text { time equaled or } \\
\text { exceeded }\end{array}$ \\
\hline 0.36 & 99 \\
.42 & 98 \\
.57 & 95 \\
4.44 & 90 \\
4.94 & 85 \\
5.44 & 80 \\
5.94 & 75 \\
16.7 & 70 \\
57.0 & 65 \\
89.4 & 60 \\
150 & 55 \\
351 & 50 \\
553 & 45 \\
925 & 40 \\
1,456 & 35 \\
2,052 & 30 \\
2,774 & 25 \\
3,612 & 20 \\
4,320 & 15 \\
5,046 & 10 \\
6,188 & 5 \\
6,873 & 2 \\
8,958 & 1 \\
\hline &
\end{tabular}


Appendix 4-19. Streamflow duration statistics, 06642000 North Platte River at Alcova, Wyoming (Site 39).

\begin{tabular}{|c|c|}
\hline \multicolumn{2}{|c|}{ Daily mean streamflow } \\
\hline $\begin{array}{c}\text { Cubic feet per } \\
\text { second }\end{array}$ & $\begin{array}{c}\text { Percentage of } \\
\text { time equaled or } \\
\text { exceeded }\end{array}$ \\
\hline 3.15 & 99 \\
\hline 3.30 & 98 \\
\hline 3.76 & 95 \\
\hline 5.46 & 90 \\
\hline 6.39 & 85 \\
\hline 41.9 & 80 \\
\hline 301 & 75 \\
\hline 511 & 70 \\
\hline 583 & 65 \\
\hline 670 & 60 \\
\hline 789 & 55 \\
\hline 864 & 50 \\
\hline 930 & 45 \\
\hline 996 & 40 \\
\hline 1,248 & 35 \\
\hline 1,525 & 30 \\
\hline 1,832 & 25 \\
\hline 2,163 & 20 \\
\hline 2,673 & 15 \\
\hline 3,474 & 10 \\
\hline 4,481 & 5 \\
\hline 5,529 & 2 \\
\hline 6,009 & 1 \\
\hline
\end{tabular}

Appendix 4-20. Streamflow duration statistics, 06661000 Little Laramie River near Filmore, Wyoming (Site 43).

\begin{tabular}{cc}
\hline \multicolumn{2}{c}{ Daily mean streamflow } \\
$\begin{array}{c}\text { Cubic feet per } \\
\text { second }\end{array}$ & $\begin{array}{c}\text { Percentage of } \\
\text { time equaled or } \\
\text { exceeded }\end{array}$ \\
\hline 9.69 & 99 \\
11.6 & 98 \\
14.0 & 95 \\
16.3 & 90 \\
18.0 & 85 \\
19.4 & 80 \\
20.8 & 75 \\
22.6 & 70 \\
24.5 & 65 \\
26.4 & 60 \\
29.0 & 55 \\
32.1 & 50 \\
35.8 & 45 \\
40.4 & 40 \\
46.2 & 35 \\
55.4 & 30 \\
73.9 & 25 \\
103 & 20 \\
162 & 15 \\
275 & 10 \\
518 & 5 \\
816 & 2 \\
1,067 & 1 \\
\hline
\end{tabular}

Appendix 4-21. Streamflow duration statistics, 09253000 Little Snake River near Slater, Colorado (Site 48).

\begin{tabular}{cc}
\hline \multicolumn{2}{c}{ Daily mean streamflow } \\
$\begin{array}{c}\text { Cubic feet per } \\
\text { second }\end{array}$ & $\begin{array}{c}\text { Percentage of } \\
\text { time equaled or } \\
\text { exceeded }\end{array}$ \\
\hline 12.9 & 99 \\
14.8 & 98 \\
17.9 & 95 \\
21.2 & 90 \\
23.5 & 85 \\
25.8 & 80 \\
27.8 & 75 \\
29.8 & 70 \\
31.8 & 65 \\
34.5 & 60 \\
37.4 & 55 \\
41.3 & 50 \\
46.4 & 45 \\
54.0 & 40 \\
64.6 & 35 \\
82.9 & 30 \\
126 & 25 \\
236 & 20 \\
463 & 15 \\
825 & 10 \\
1,310 & 5 \\
1,802 & 2 \\
2,080 & 1 \\
\hline
\end{tabular}


Appendix 4-22. Streamflow duration statistics, 09255000 Slater Fork near Slater, Colorado (Site 51).

\begin{tabular}{|c|c|}
\hline \multicolumn{2}{|c|}{ Daily mean streamflow } \\
\hline $\begin{array}{c}\text { Cubic feet per } \\
\text { second }\end{array}$ & $\begin{array}{c}\text { Percentage of } \\
\text { time equaled or } \\
\text { exceeded }\end{array}$ \\
\hline 1.59 & 99 \\
\hline 2.44 & 98 \\
\hline 4.31 & 95 \\
\hline 7.01 & 90 \\
\hline 9.38 & 85 \\
\hline 11.2 & 80 \\
\hline 12.8 & 75 \\
\hline 14.4 & 70 \\
\hline 15.9 & 65 \\
\hline 17.3 & 60 \\
\hline 18.7 & 55 \\
\hline 20.3 & 50 \\
\hline 22.8 & 45 \\
\hline 25.2 & 40 \\
\hline 27.6 & 35 \\
\hline 35.4 & 30 \\
\hline 48.7 & 25 \\
\hline 81.6 & 20 \\
\hline 150 & 15 \\
\hline 253 & 10 \\
\hline 428 & 5 \\
\hline 620 & 2 \\
\hline 723 & 1 \\
\hline
\end{tabular}

Appendix 4-23. Streamflow duration statistics, 09255500 Savery Creek at upper station near Savery, Wyoming (Site 52).

\begin{tabular}{|c|c|}
\hline \multicolumn{2}{|c|}{ Daily mean streamflow } \\
\hline $\begin{array}{l}\text { Cubic feet per } \\
\text { second }\end{array}$ & $\begin{array}{c}\text { Percentage of } \\
\text { time equaled or } \\
\text { exceeded }\end{array}$ \\
\hline 1.83 & 99 \\
\hline 2.98 & 98 \\
\hline 4.64 & 95 \\
\hline 6.45 & 90 \\
\hline 7.94 & 85 \\
\hline 9.63 & 80 \\
\hline 11.1 & 75 \\
\hline 12.3 & 70 \\
\hline 13.6 & 65 \\
\hline 14.8 & 60 \\
\hline 16.1 & 55 \\
\hline 17.4 & 50 \\
\hline 19.0 & 45 \\
\hline 20.9 & 40 \\
\hline 23.6 & 35 \\
\hline 27.5 & 30 \\
\hline 37.7 & 25 \\
\hline 55.4 & 20 \\
\hline 81.7 & 15 \\
\hline 127 & 10 \\
\hline 204 & 5 \\
\hline 305 & 2 \\
\hline 368 & 1 \\
\hline
\end{tabular}

Appendix 4-24. Streamflow duration statistics, 09256000 Savery Creek near Savery, Wyoming (Site 53).

\begin{tabular}{cc}
\hline \multicolumn{2}{c}{ Daily mean streamflow } \\
$\begin{array}{c}\text { Cubic feet per } \\
\text { second }\end{array}$ & $\begin{array}{c}\text { Percentage of } \\
\text { time equaled or } \\
\text { exceeded }\end{array}$ \\
\hline 0.95 & 99 \\
2.00 & 98 \\
4.04 & 95 \\
7.48 & 90 \\
10.8 & 85 \\
14.0 & 80 \\
17.1 & 75 \\
19.8 & 70 \\
22.3 & 65 \\
24.8 & 60 \\
27.4 & 55 \\
30.6 & 50 \\
33.7 & 45 \\
36.8 & 40 \\
42.1 & 35 \\
52.4 & 30 \\
76.9 & 25 \\
124 & 20 \\
190 & 15 \\
300 & 10 \\
502 & 5 \\
758 & 2 \\
993 & 1 \\
\hline
\end{tabular}


Appendix 4-25. Streamflow duration statistics, 09257000 Little Snake River near Dixon, Wyoming (Site 54).

\begin{tabular}{cc}
\hline \multicolumn{2}{c}{ Daily mean streamflow } \\
\hline $\begin{array}{c}\text { Cubic feet per } \\
\text { second }\end{array}$ & $\begin{array}{c}\text { Percentage of } \\
\text { time equaled or } \\
\text { exceeded }\end{array}$ \\
\hline 1.21 & 99 \\
1.73 & 98 \\
3.61 & 95 \\
8.13 & 90 \\
17.2 & 85 \\
35.5 & 80 \\
52.4 & 75 \\
64.9 & 70 \\
74.7 & 65 \\
83.3 & 60 \\
91.9 & 55 \\
102 & 50 \\
114 & 45 \\
125 & 40 \\
152 & 35 \\
207 & 30 \\
336 & 25 \\
636 & 20 \\
1,173 & 15 \\
1,860 & 10 \\
2,897 & 5 \\
4,050 & 2 \\
4,692 & 1 \\
\hline &
\end{tabular}

Appendix 4-26. Streamflow duration statistics, 09258000 Willow Creek near Dixon, Wyoming (Site 55).

\begin{tabular}{cc}
\hline \multicolumn{2}{c}{ Daily mean streamflow } \\
\hline $\begin{array}{c}\text { Cubic feet per } \\
\text { second }\end{array}$ & $\begin{array}{c}\text { Percentage of } \\
\text { time equaled or } \\
\text { exceeded }\end{array}$ \\
\hline 0.33 & 99 \\
.65 & 98 \\
1.10 & 95 \\
1.42 & 90 \\
1.65 & 85 \\
1.88 & 80 \\
2.10 & 75 \\
2.31 & 70 \\
2.52 & 65 \\
2.74 & 60 \\
3.02 & 55 \\
3.29 & 50 \\
3.57 & 45 \\
4.39 & 40 \\
5.41 & 35 \\
6.68 & 30 \\
9.08 & 25 \\
14.3 & 20 \\
21.9 & 15 \\
32.3 & 10 \\
47.7 & 5 \\
67.9 & 2 \\
79.0 & 1 \\
&
\end{tabular}




\section{Appendix 5. Graphs showing statistical summaries of major-ion concentra- tions in analyses of water-quality samples, selected surface-water sites in and near Carbon County, Wyoming.}

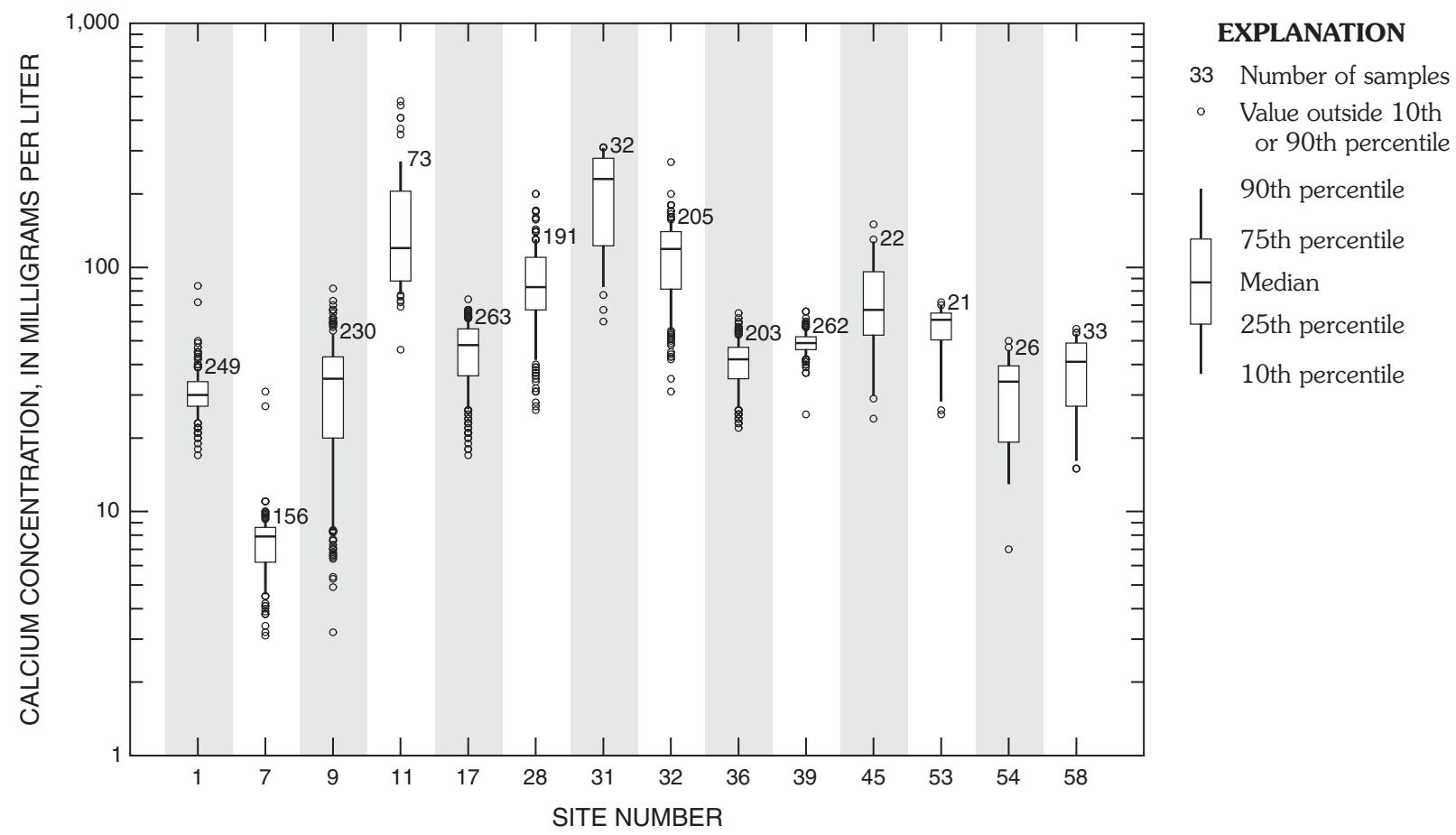

Appendix 5-1. Statistics of dissolved calcium concentrations from selected stream sites, in or near Carbon County, Wyoming, water years 1966-86.

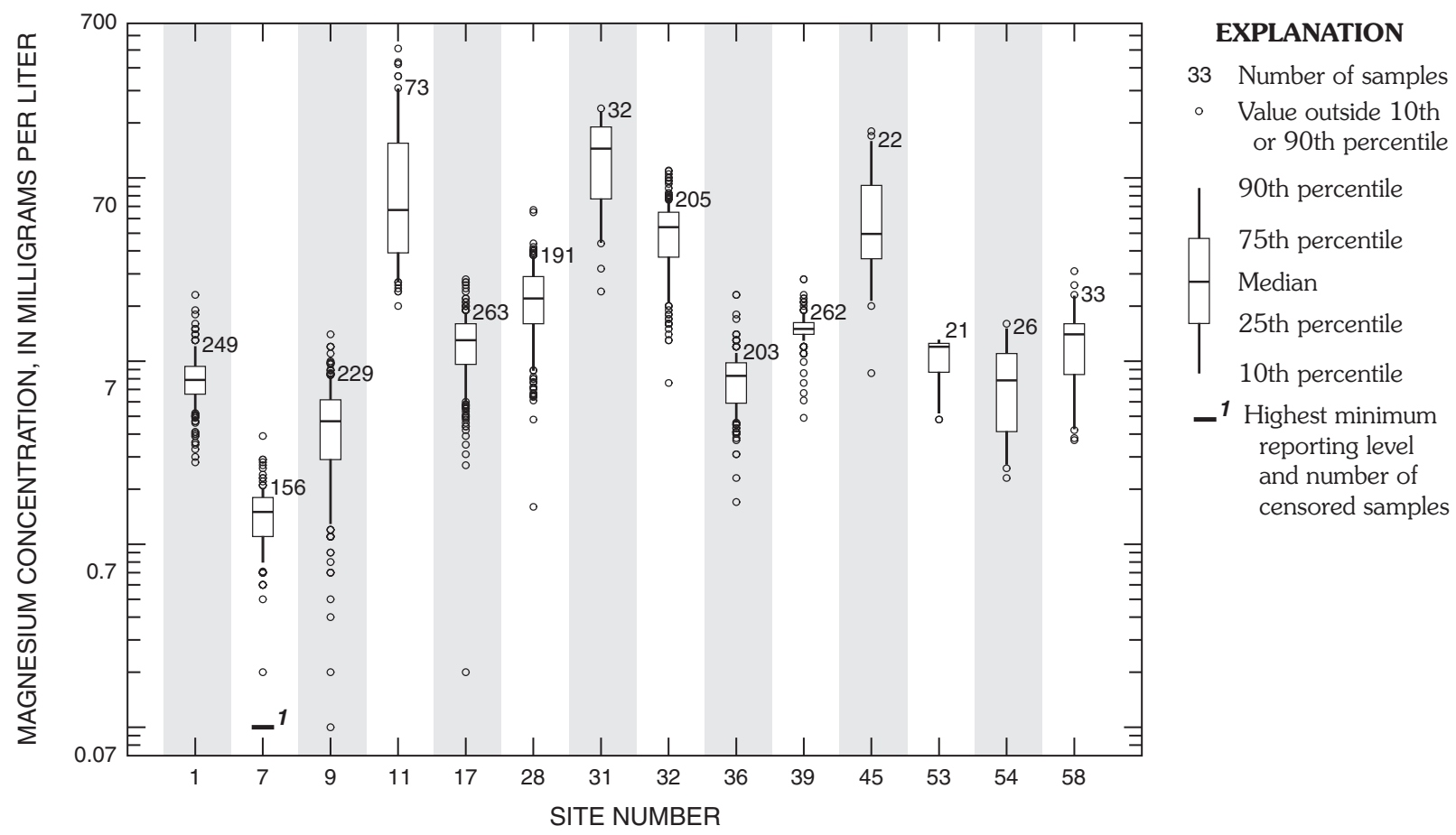

Appendix 5-2. Statistics of dissolved magnesium concentrations from selected stream sites, in or near Carbon County, Wyoming, water years 1966-86. 


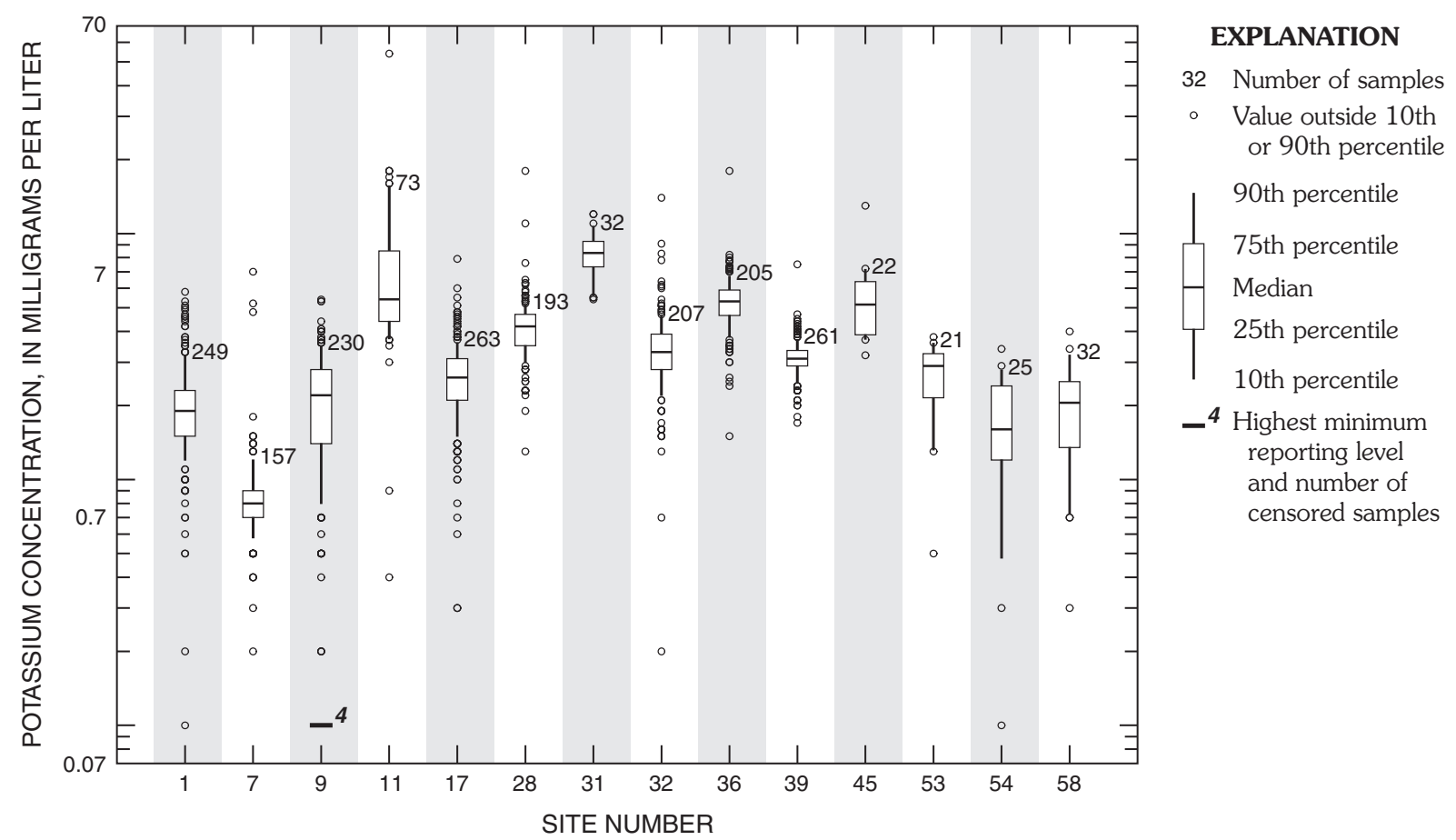

Appendix 5-3. Statistics of dissolved potassium concentrations from selected stream sites, in or near Carbon County, Wyoming, water years 1966-86.

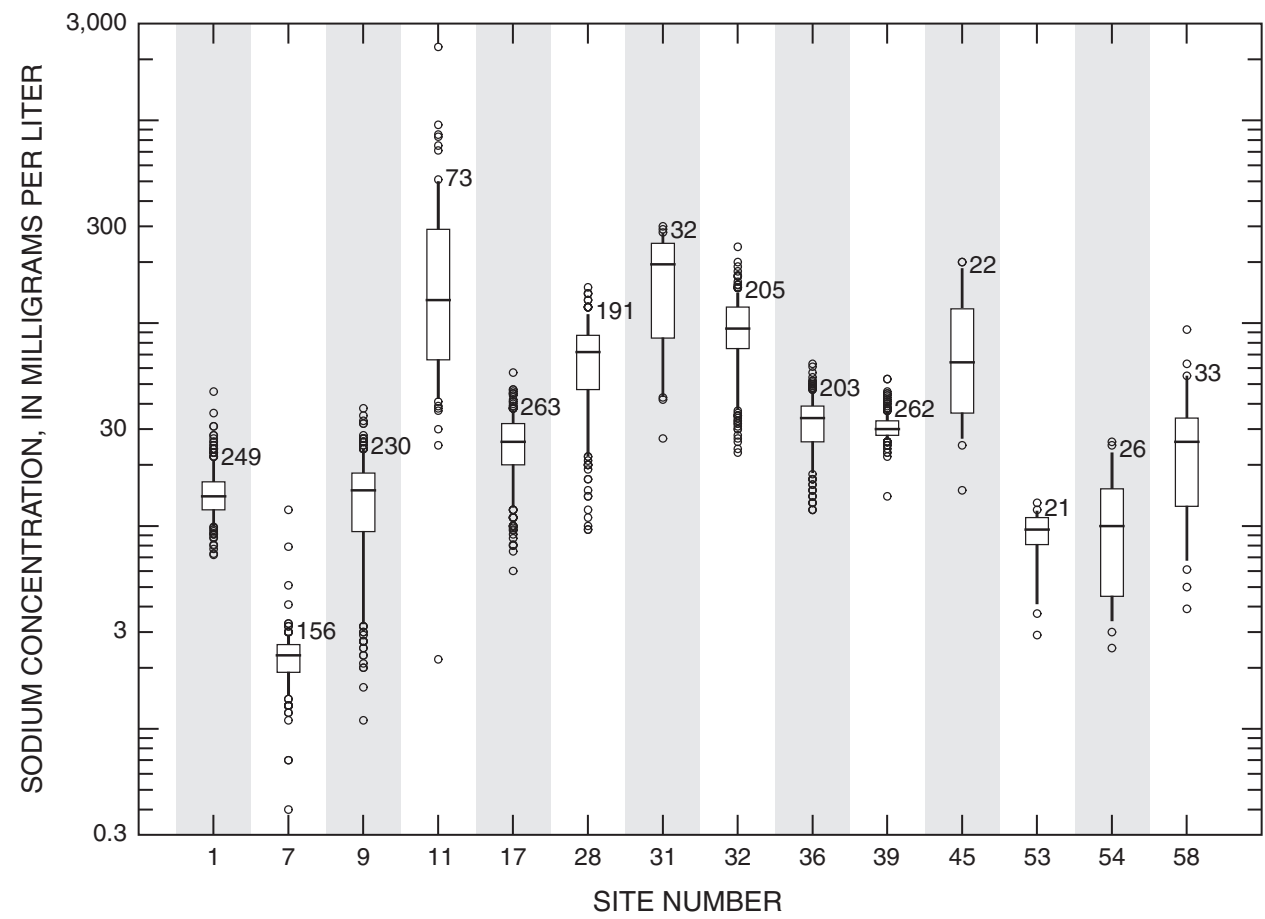

\section{EXPLANATION}

33 Number of samples

- Value outside 10th or 90 th percentile

90th percentile

75th percentile Median

25th percentile

10th percentile

Appendix 5-4. Statistics of dissolved sodium concentrations from selected stream sites, in or near Carbon County, Wyoming, water years 1966-86. 


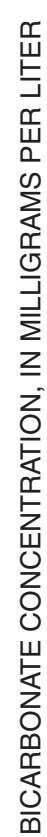

EXPLANATION

33 Number of samples

- Value outside 10th

or 90th percentile

90th percentile

75th percentile

Median

25th percentile

10th percentile

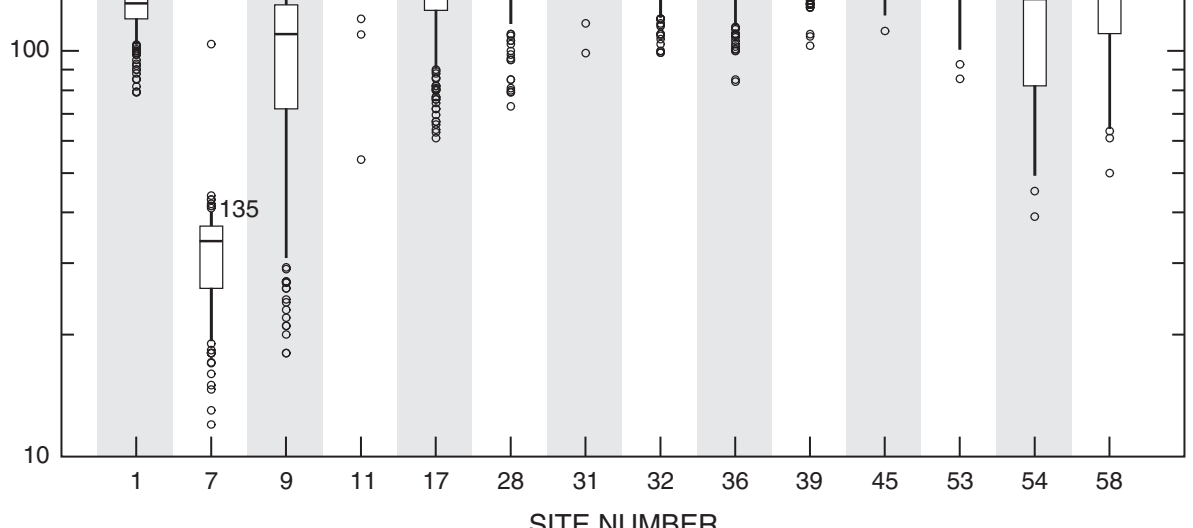

SITE NUMBER

Appendix 5-5. Statistics of dissolved bicarbonate concentrations from selected stream sites, in or near Carbon County, Wyoming, water years 1966-86.

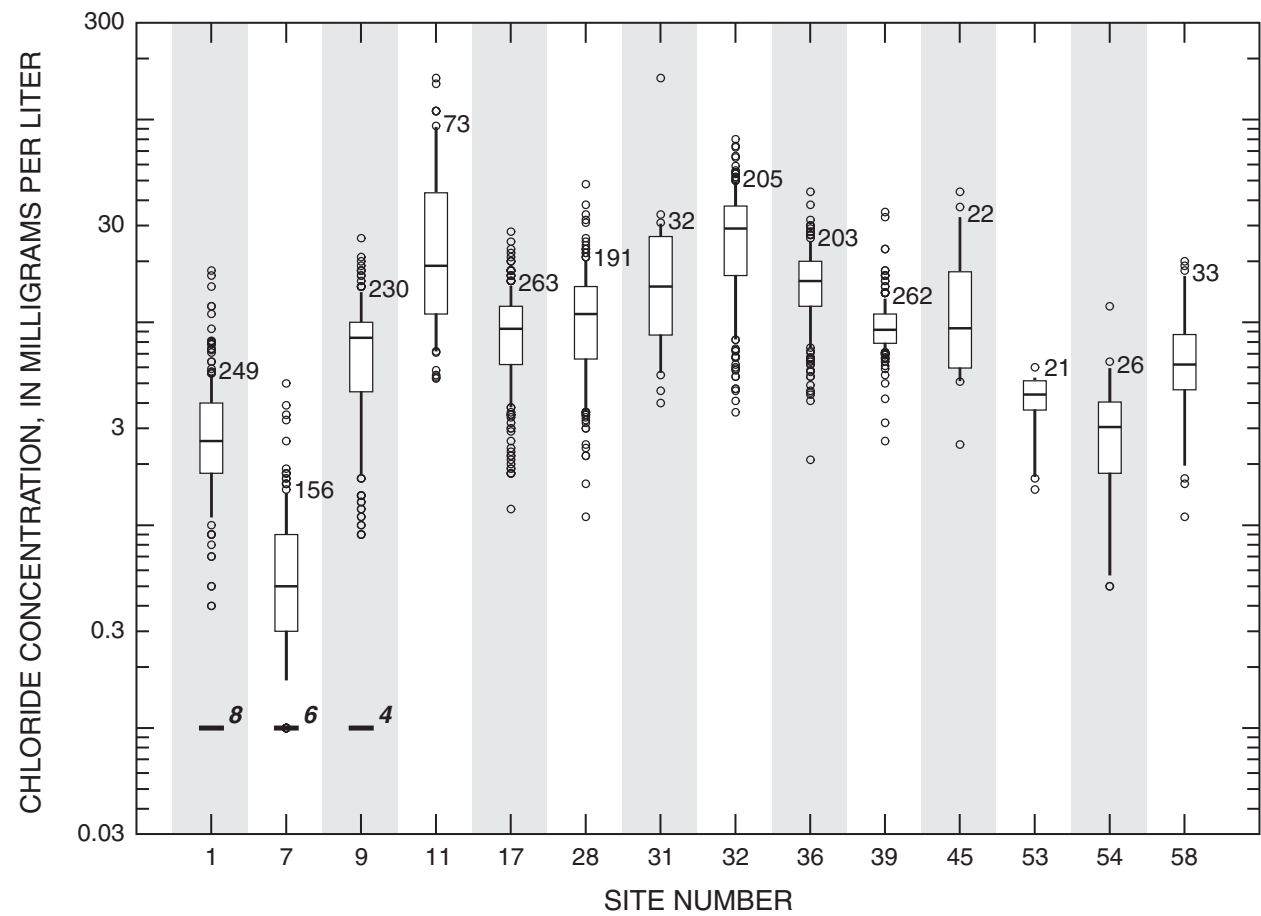

EXPLANATION

33 Number of samples

- Value outside 10th or 90 th percentile

90th percentile

75th percentile

Median

25th percentile

10th percentile

${ }^{4}$ Highest minimum reporting level and number of censored samples

Appendix 5-6. Statistics of dissolved chloride concentrations from selected stream sites, in or near Carbon County, Wyoming, water years 1966-86. 


\section{Appendix 6. Ground-water quality data, Carbon County, Wyoming.}

Hydrogeologic units listed in Appendixes 6-1 through 6-6 (parentheses indicates equivalent names in figures 8-10):

\author{
111ALVM Holocene alluvium \\ 121BRPK Browns Park aquifer (Formation) \\ 122MOCN Undifferentiated Miocene rocks \\ 124BSPG Battle Springs aquifer (Formation) \\ 124CLMN Coalmont aquifer (Formation) \\ 124HANN Hanna aquifer (Formation) \\ 124TPTN Tipton Shale Member of the Green River \\ Formation \\ 124WSTC Wasatch aquifer (Formation) \\ 125FRUN Fort Union aquifer (Formation) \\ 211CODY Cody Shale
}

\author{
211LNCE Lance aquifer (Formation) \\ 211LWIS Lewis Shale \\ 211MVRD Mesaverde aquifer (Formation or Group) \\ 211STEL Steele Shale \\ 217CLVL Cloverly aquifer (Formation) \\ 221SNDC Sundance aquifer (Formation) \\ 231CGTR Chugwater Formation \\ 237GSEG Goose Egg Formation \\ 317TSLP Tensleep aquifer (Sandstone) \\ 331MDSN Madison aquifer (Limestone) \\ 400PCMB Precambrian hydrogeologic units
}

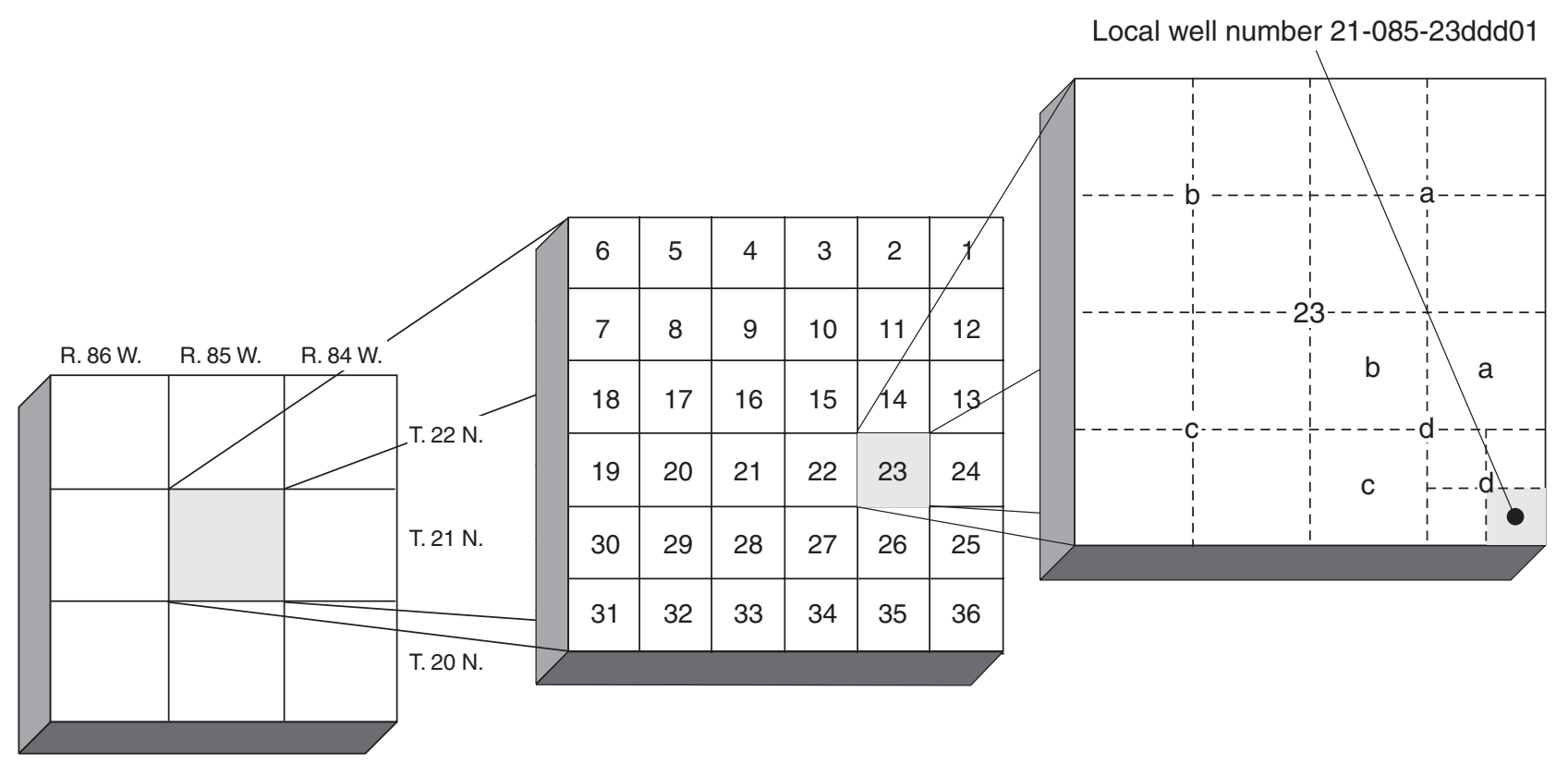

System for numbering wells in surveyed townships. 
Appendix 6-1. Characteristics of sampled wells.

[USGS, U.S. Geological Survey; number below the characteristic is the data parameter code, which is a five-digit number used in the USGS computerized data system, National Water Information System (NWIS), to uniquely identify a characteristic, constituent, or property; H, domestic; S, stock; C, commercial; N, industrial (water used for well drilling and completion); U, unused; K, mining; P, public supply; --, not available]

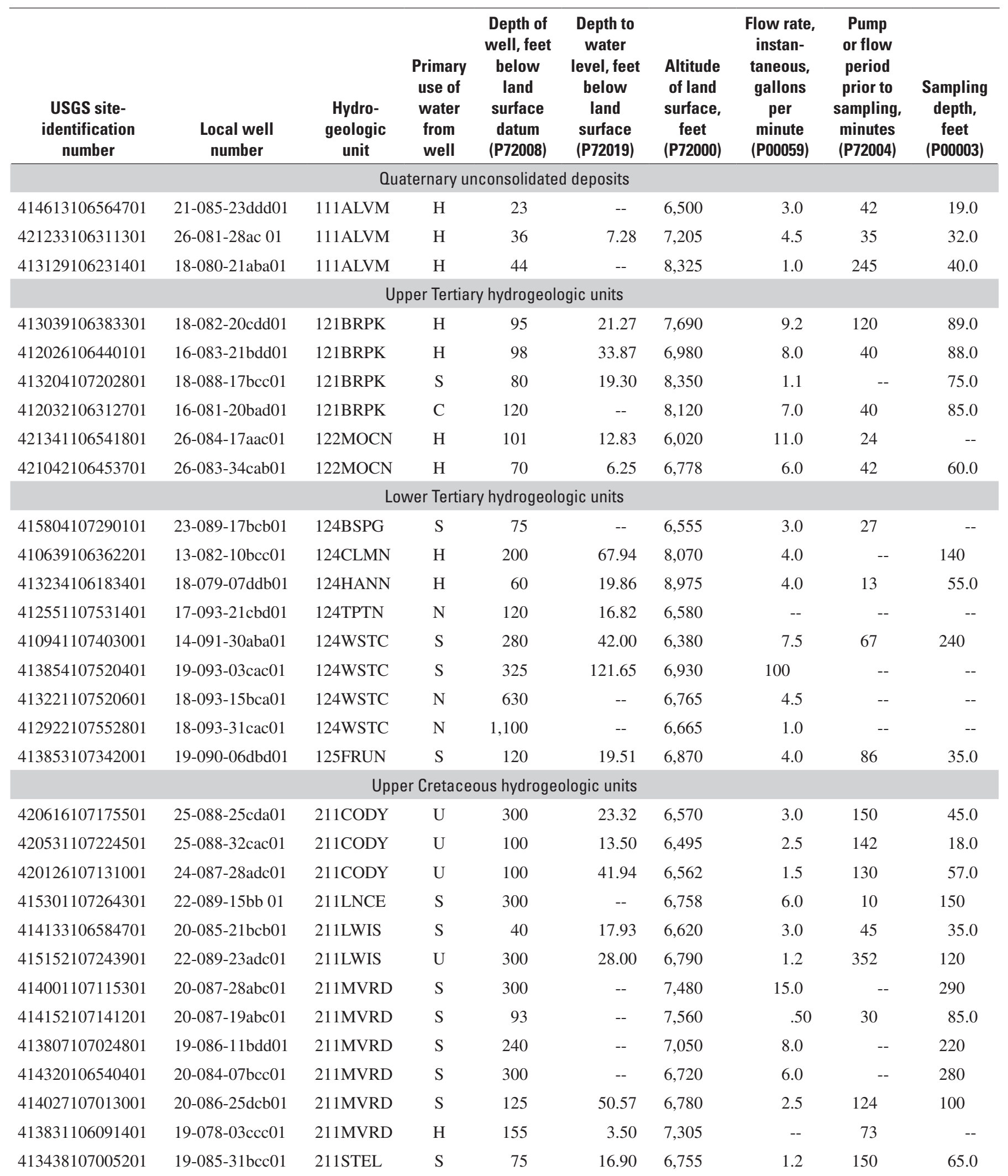


Appendix 6-1. Characteristics of sampled wells.-Continued.

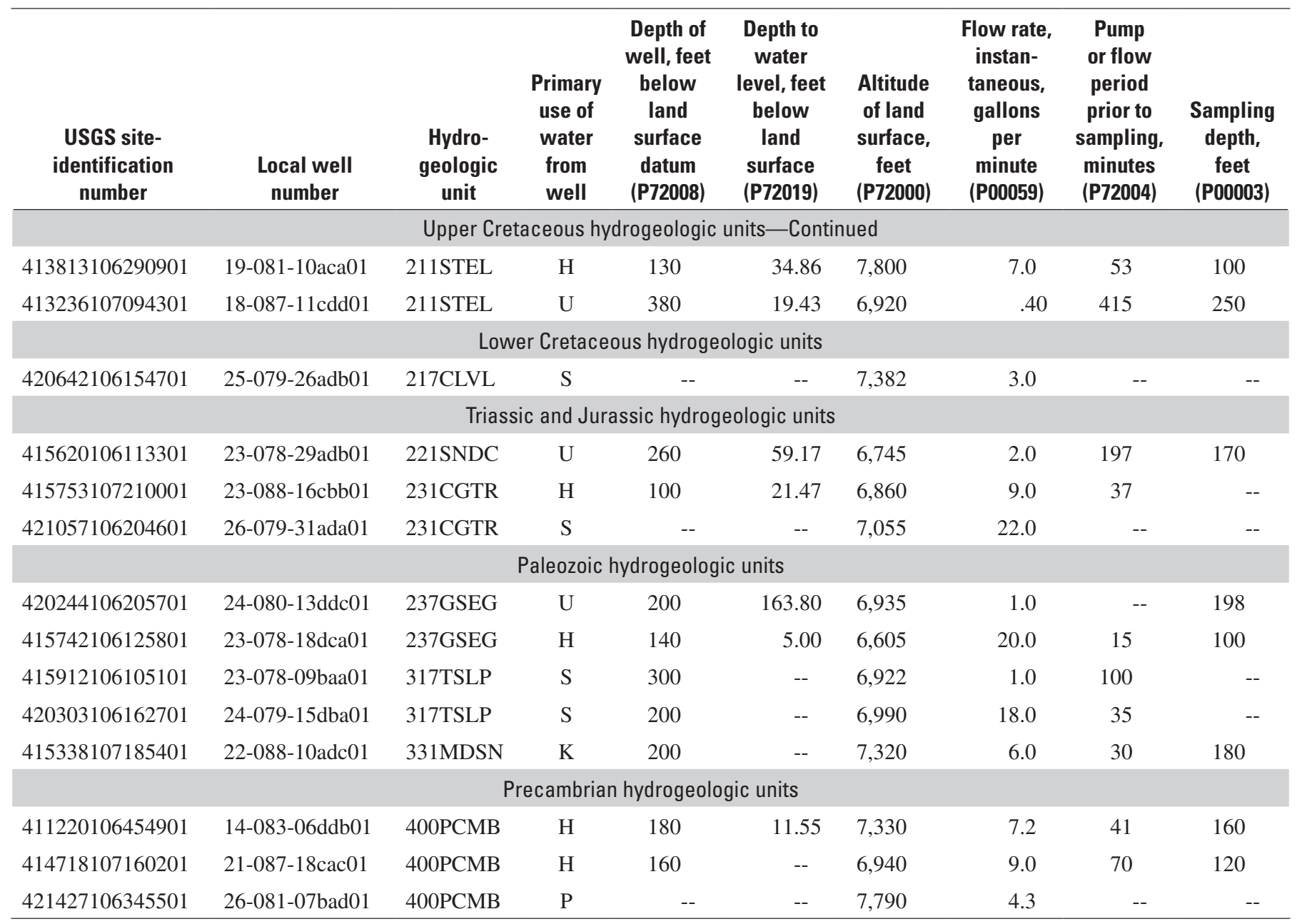




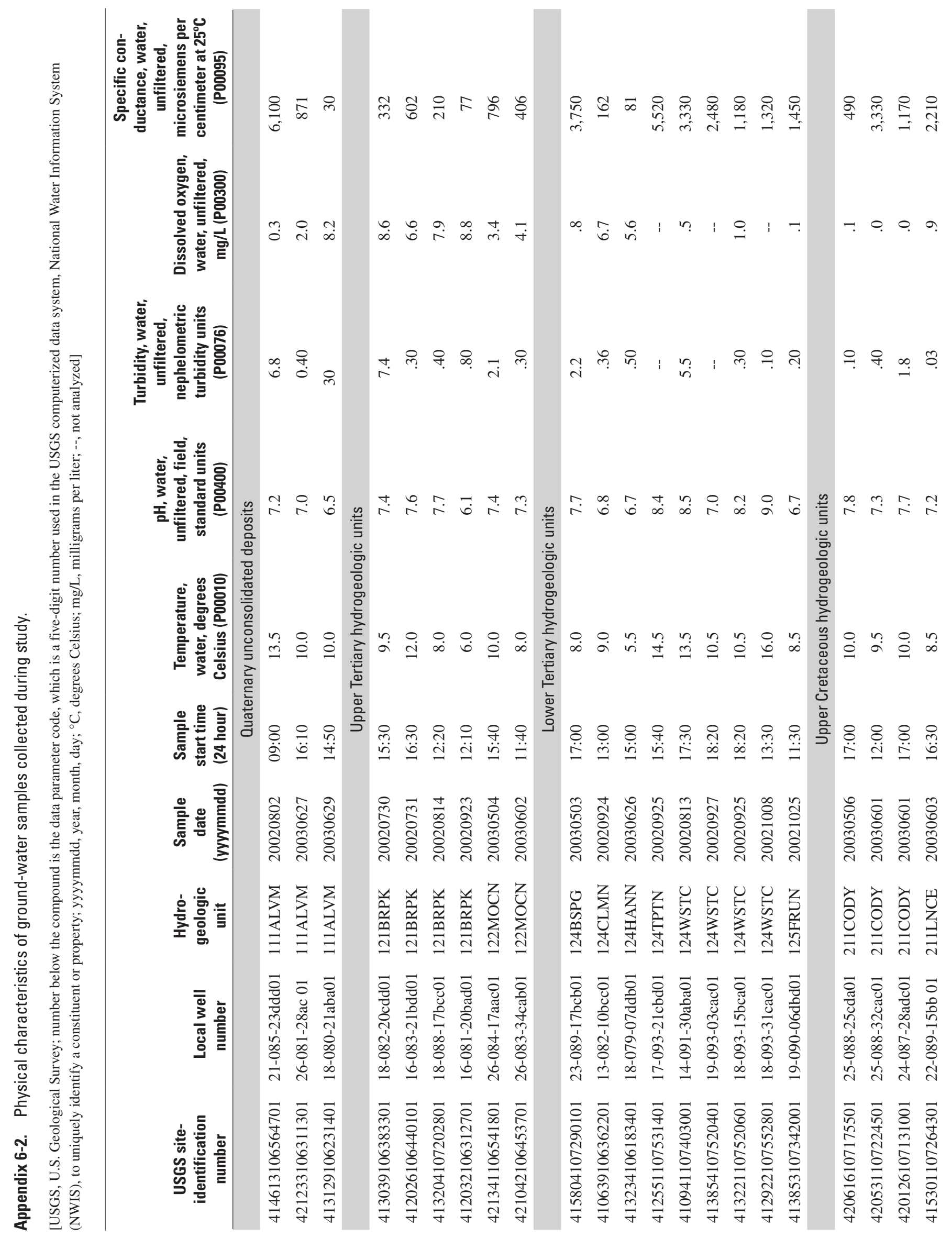




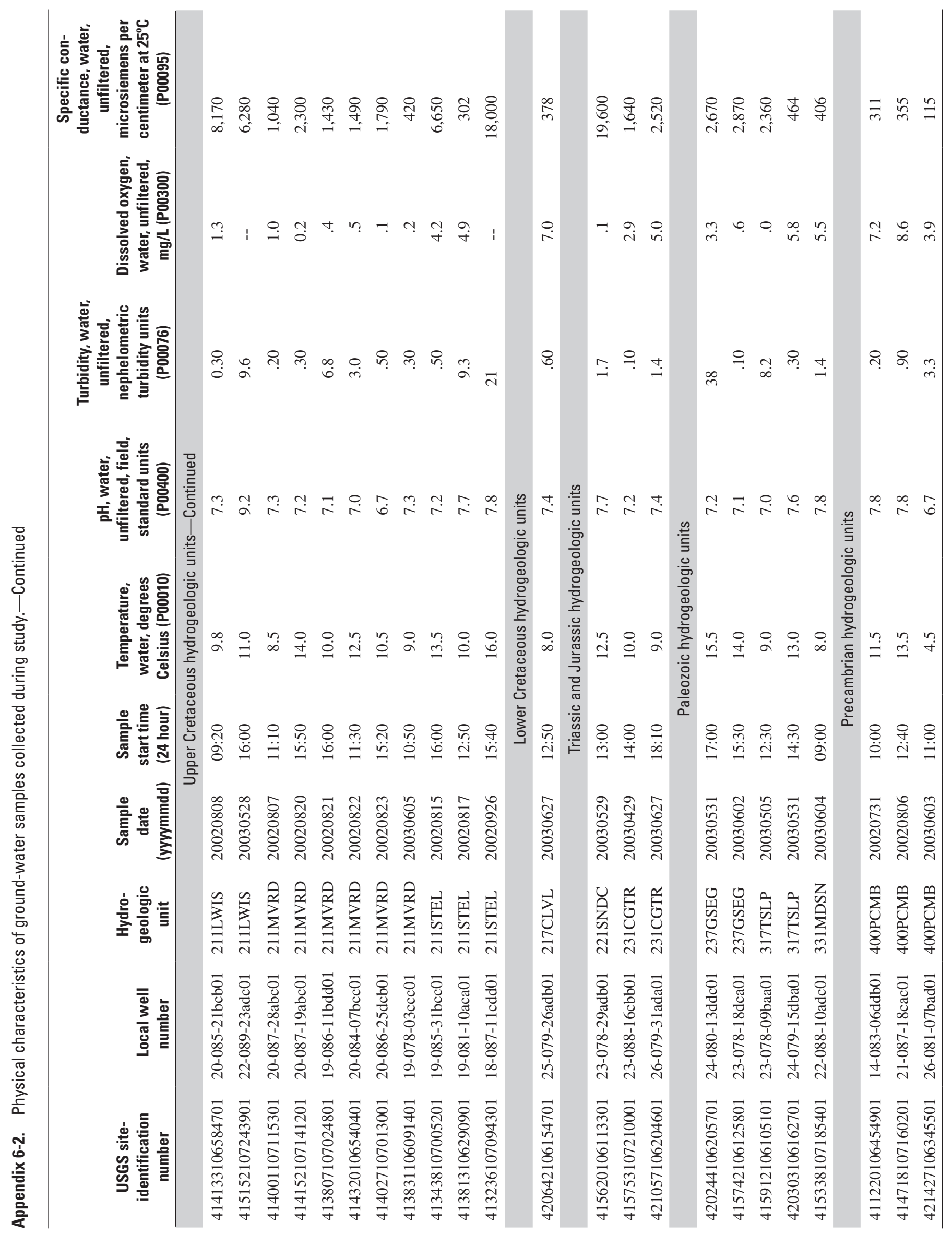


Appendix 6-3. Major ions in ground-water samples collected during study and related water-quality characteristics.

[USGS, U.S. Geological Survey; number below the compound is the data parameter code, which is a five-digit number used in the USGS computerized data system, National Water Information System (NWIS), to uniquely identify a constituent or property; yyyymmdd, year, month, day; ${ }^{\circ} \mathrm{C}$, degrees Celsius; mg/L, milligrams per liter; --, not analyzed; E, estimated concentration; <, less than]

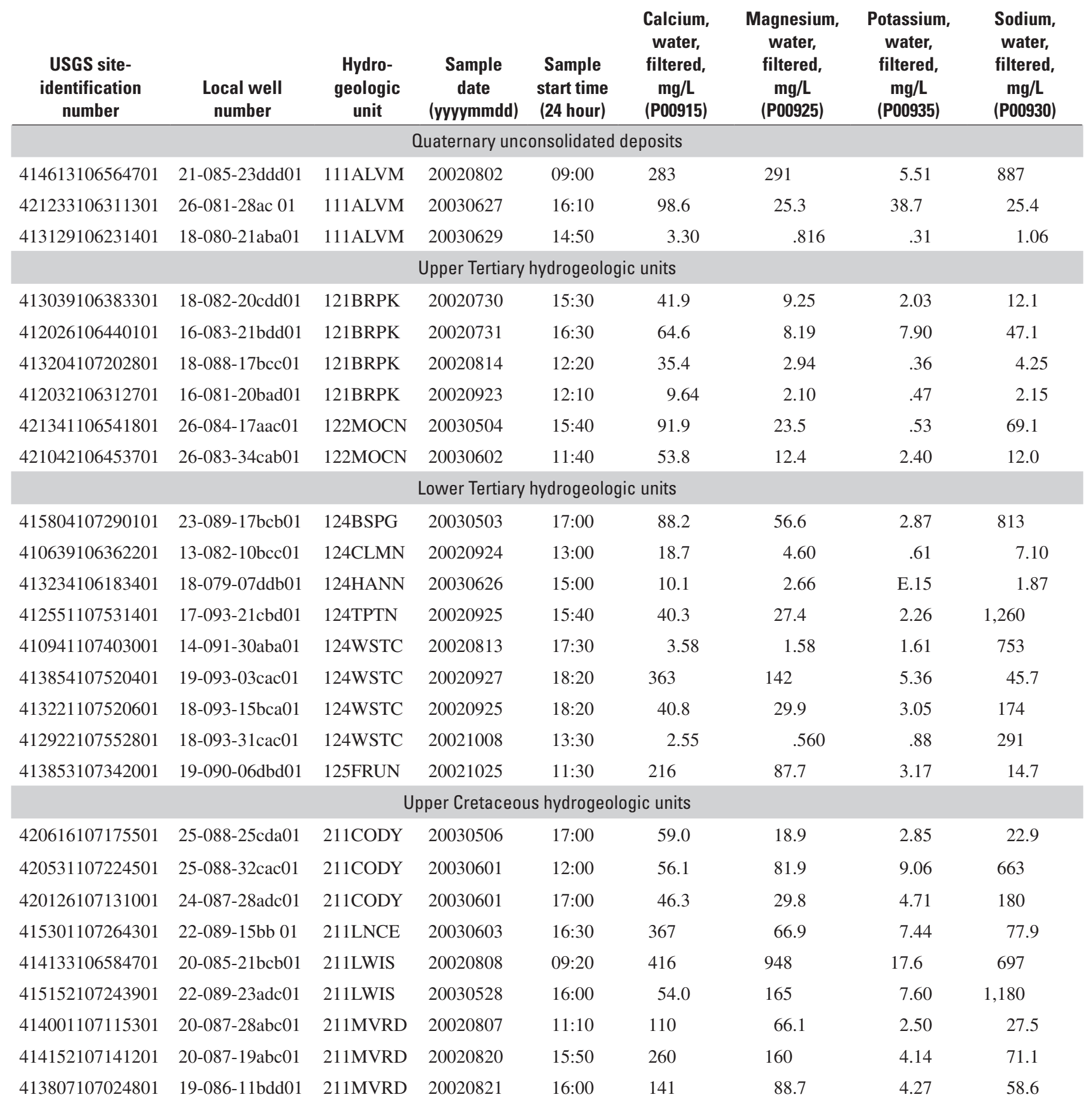


Appendix 6-3. Major ions in ground-water samples collected during study and related water-quality characteristics.-Continued

\begin{tabular}{|c|c|c|c|c|c|c|c|c|c|}
\hline $\begin{array}{l}\text { Alkalinity, } \\
\text { water, } \\
\text { filtered, } \\
\text { fixed end- } \\
\text { point } \\
\text { (pH 4.5) } \\
\text { titration, } \\
\text { laboratory, } \\
\text { mg/L as } \\
\text { calcium } \\
\text { carbonate } \\
\text { (P29801) }\end{array}$ & $\begin{array}{c}\text { Alkalinity, } \\
\text { water, } \\
\text { filtered, } \\
\text { incremen- } \\
\text { tal titration, } \\
\text { field, } \\
\text { mg/L as } \\
\text { calcium } \\
\text { carbonate } \\
\text { (P39086) }\end{array}$ & $\begin{array}{c}\text { Bicarbon- } \\
\text { ate, } \\
\text { water, } \\
\text { filtered, } \\
\text { incremen- } \\
\text { tal titration, } \\
\text { field, } \\
\text { mg/L } \\
\text { (P00453) }\end{array}$ & $\begin{array}{c}\text { Carbonate, } \\
\text { water, } \\
\text { filtered, } \\
\text { incremen- } \\
\text { tal titration, } \\
\text { field, } \\
\text { mg/L } \\
\text { (P00452) }\end{array}$ & $\begin{array}{c}\text { Chloride, } \\
\text { water, } \\
\text { filtered, } \\
\text { mg/L } \\
\text { (P00940) }\end{array}$ & $\begin{array}{c}\text { Fluoride, } \\
\text { water, } \\
\text { filtered, } \\
\text { mg/L } \\
\text { (P00950) }\end{array}$ & $\begin{array}{c}\text { Silica, } \\
\text { water, } \\
\text { filtered, } \\
\text { mg/L } \\
\text { (P00955) }\end{array}$ & $\begin{array}{c}\text { Sulfate, } \\
\text { water, } \\
\text { filtered, } \\
\text { mg/L } \\
\text { (P00945) }\end{array}$ & $\begin{array}{c}\text { Residue on } \\
\text { evapora- } \\
\text { tion, } \\
\text { dried at } \\
180^{\circ} \mathrm{C}, \\
\text { water, } \\
\text { filtered, } \\
\text { mg/L } \\
\text { (P70300) }\end{array}$ & $\begin{array}{c}\text { Hardness, } \\
\text { mg/L as } \\
\text { calcium } \\
\text { carbonate } \\
\left(\mathrm{CaCO}_{3}\right) \\
\text { (P00900) }\end{array}$ \\
\hline \multicolumn{10}{|c|}{ Quaternary unconsolidated deposits } \\
\hline 387 & -- & -- & -- & 184 & 0.44 & 17.9 & 3,190 & 5,560 & 1,911 \\
\hline 150 & -- & -- & -- & 6.27 & .27 & 17.6 & 16.2 & 198 & 143 \\
\hline 202 & -- & -- & -- & 9.99 & .71 & 61.5 & 104 & 443 & 196 \\
\hline 103 & -- & -- & -- & 1.32 & E.09 & 21.8 & 4.6 & 133 & 101 \\
\hline E37 & -- & -- & -- & .43 & $<.10$ & 9.49 & 1.8 & 45 & 32.8 \\
\hline 328 & 324 & 394 & -- & 11.0 & .43 & 23.3 & 142 & 536 & 327 \\
\hline 179 & 173 & 211 & -- & 3.93 & .3 & 16.1 & 27.8 & 236 & 187 \\
\hline \multicolumn{10}{|c|}{ Lower Tertiary hydrogeologic units } \\
\hline 331 & 283 & 342 & 2 & 237 & 2.42 & 9.52 & 1,420 & 2,820 & 455 \\
\hline $\mathrm{E} 235$ & -- & -- & -- & 15.4 & 1.06 & 10.8 & 367 & 843 & 8.75 \\
\hline E321 & -- & -- & -- & 3.45 & .19 & 22.5 & 188 & 1,020 & 902 \\
\hline \multicolumn{10}{|c|}{ Upper Cretaceous hydrogeologic units } \\
\hline-- & 291 & 352 & 1 & 3.26 & .28 & 14.2 & 25.6 & 291 & 226 \\
\hline 583 & 585 & 711 & -- & 143 & 1.7 & 11.5 & 987 & 2,340 & 480 \\
\hline 330 & 285 & 345 & -- & 32.8 & 1.7 & 9.72 & 247 & 744 & 239 \\
\hline 145 & 167 & 204 & -- & 31.0 & .5 & 14.4 & 1,160 & 2,000 & 1,193 \\
\hline 510 & -- & -- & -- & 98.0 & .94 & 11.6 & 5,590 & 9,180 & 4,952 \\
\hline 274 & -- & -- & -- & 147 & .3 & 5.36 & 3,000 & 5,040 & 815 \\
\hline 323 & -- & -- & -- & 6.91 & .28 & 13.4 & 262 & 724 & 549 \\
\hline 248 & -- & -- & -- & 7.40 & .11 & 14.0 & 1,200 & 2,080 & 1,313 \\
\hline 600 & -- & -- & -- & 6.27 & .20 & 23.3 & 253 & 974 & 719 \\
\hline
\end{tabular}


Appendix 6-3. Major ions in ground-water samples collected during study and related water-quality characteristics.-Continued

\begin{tabular}{|c|c|c|c|c|c|c|c|c|}
\hline $\begin{array}{c}\text { USGS site- } \\
\text { identification } \\
\text { number }\end{array}$ & $\begin{array}{c}\text { Local well } \\
\text { number }\end{array}$ & $\begin{array}{l}\text { Hydro- } \\
\text { geologic } \\
\text { unit }\end{array}$ & $\begin{array}{c}\text { Sample } \\
\text { date } \\
\text { (yyyymmdd) }\end{array}$ & $\begin{array}{c}\text { Sample } \\
\text { start time } \\
\text { (24 hour) }\end{array}$ & $\begin{array}{c}\text { Calcium, } \\
\text { water, } \\
\text { filtered, } \\
\mathrm{mg} / \mathrm{L} \\
\text { (P00915) }\end{array}$ & $\begin{array}{c}\text { Magnesium, } \\
\text { water, } \\
\text { filtered, } \\
\text { mg/L } \\
\text { (P00925) }\end{array}$ & $\begin{array}{c}\text { Potassium, } \\
\text { water, } \\
\text { filtered, } \\
\text { mg/L } \\
\text { (P00935) }\end{array}$ & $\begin{array}{c}\text { Sodium, } \\
\text { water, } \\
\text { filtered, } \\
\mathrm{mg} / \mathrm{L} \\
\text { (P00930) }\end{array}$ \\
\hline \multicolumn{9}{|c|}{ Upper Cretaceous hydrogeologic units-Continued } \\
\hline 414320106540401 & 20-084-07bcc01 & 211MVRD & 20020822 & $11: 30$ & 154 & 55.8 & 3.89 & 104 \\
\hline 414027107013001 & 20-086-25dcb01 & 211MVRD & 20020823 & $15: 20$ & 210 & 102 & 6.79 & 58.8 \\
\hline 413831106091401 & 19-078-03ссс01 & 211MVRD & 20030605 & $10: 50$ & 47.2 & 14.3 & 2.40 & 19.0 \\
\hline 413438107005201 & 19-085-31bcc01 & 211STEL & 20020815 & $16: 00$ & 295 & 348 & 10.8 & 1,040 \\
\hline 413813106290901 & 19-081-10aca01 & 211STEL & 20020817 & $12: 50$ & 35.6 & 12.0 & 1.01 & 8.84 \\
\hline 413236107094301 & 18-087-11cdd01 & 211STEL & 20020926 & $15: 40$ & 366 & 873 & 13.2 & 3,500 \\
\hline \multicolumn{9}{|c|}{ Lower Cretaceous hydrogeologic units } \\
\hline 420642106154701 & 25-079-26adb01 & 217CLVL & 20030627 & $12: 50$ & 47.6 & 11.8 & 2.03 & 9.73 \\
\hline \multicolumn{9}{|c|}{ Triassic and Jurassic hydrogeologic units } \\
\hline 415620106113301 & 23-078-29adb01 & 221SNDC & 20030529 & 13:00 & 274 & 161 & 11.8 & 4,780 \\
\hline 415753107210001 & 23-088-16cbb01 & 231CGTR & 20030429 & 14:00 & 277 & 78.8 & 2.21 & 28.7 \\
\hline 421057106204601 & 26-079-31ada01 & 231CGTR & 20030627 & 18:10 & 611 & 86.9 & 3.97 & 18.5 \\
\hline \multicolumn{9}{|c|}{ Paleozoic hydrogeologic units } \\
\hline 420244106205701 & 24-080-13ddc01 & 237GSEG & 20030531 & 17:00 & 550 & 119 & 4.55 & 13.7 \\
\hline 415742106125801 & 23-078-18dca01 & 237GSEG & 20030602 & $15: 30$ & 402 & 105 & 8.44 & 154 \\
\hline 415912106105101 & 23-078-09baa01 & 317TSLP & 20030505 & $12: 30$ & 371 & 145 & 7.00 & 27.3 \\
\hline 420303106162701 & 24-079-15dba01 & 317TSLP & 20030531 & $14: 30$ & 70.9 & 18.9 & 1.64 & 3.08 \\
\hline 415338107185401 & 22-088-10adc01 & 331MDSN & 20030604 & 09:00 & 55.7 & 16.2 & .61 & 3.59 \\
\hline \multicolumn{9}{|c|}{ Precambrian hydrogeologic units } \\
\hline 411220106454901 & 14-083-06ddb01 & 400РCMB & 20020731 & 10:00 & 37.1 & 5.92 & 1.60 & 18.7 \\
\hline 414718107160201 & 21-087-18cac01 & 400РCMB & 20020806 & $12: 40$ & 44.6 & 10.5 & 1.88 & 14.3 \\
\hline 421427106345501 & 26-081-07bad01 & 400PCMB & 20030603 & 11:00 & 13.8 & 3.38 & .79 & 4.26 \\
\hline
\end{tabular}


Appendix 6-3. Major ions in ground-water samples collected during study and related water-quality characteristics. - Continued

\begin{tabular}{|c|c|c|c|c|c|c|c|c|c|}
\hline $\begin{array}{c}\text { Alkalinity, } \\
\text { water, } \\
\text { filtered, } \\
\text { fixed end- } \\
\text { point } \\
\text { (pH 4.5) } \\
\text { titration, } \\
\text { laboratory, } \\
\text { mg/L as } \\
\text { calcium } \\
\text { carbonate } \\
\text { (P29801) }\end{array}$ & $\begin{array}{l}\text { Alkalinity, } \\
\text { water, } \\
\text { filtered, } \\
\text { incremen- } \\
\text { tal titration, } \\
\text { field, } \\
\text { mg/L as } \\
\text { calcium } \\
\text { carbonate } \\
\text { (P39086) }\end{array}$ & $\begin{array}{c}\text { Bicarbon- } \\
\text { ate, } \\
\text { water, } \\
\text { filtered, } \\
\text { incremen- } \\
\text { tal titration, } \\
\text { field, } \\
\text { mg/L } \\
\text { (P00453) }\end{array}$ & $\begin{array}{c}\text { Carbonate, } \\
\text { water, } \\
\text { filtered, } \\
\text { incremen- } \\
\text { tal titration, } \\
\text { field, } \\
\text { mg/L } \\
\text { (P00452) }\end{array}$ & $\begin{array}{c}\text { Chloride, } \\
\text { water, } \\
\text { filtered, } \\
\text { mg/L } \\
\text { (P00940) }\end{array}$ & $\begin{array}{c}\text { Fluoride, } \\
\text { water, } \\
\text { filtered, } \\
\text { mg/L } \\
\text { (P00950) }\end{array}$ & $\begin{array}{c}\text { Silica, } \\
\text { water, } \\
\text { filtered, } \\
\text { mg/L } \\
\text { (P00955) }\end{array}$ & $\begin{array}{c}\text { Sulfate, } \\
\text { water, } \\
\text { filtered, } \\
\text { mg/L } \\
\text { (P00945) }\end{array}$ & $\begin{array}{c}\text { Residue on } \\
\text { evapora- } \\
\text { tion, } \\
\text { dried at } \\
180^{\circ} \mathrm{C}, \\
\text { water, } \\
\text { filtered, } \\
\text { mg/L } \\
\text { (P70300) }\end{array}$ & $\begin{array}{c}\text { Hardness, } \\
\text { mg/L as } \\
\text { calcium } \\
\text { carbonate } \\
\text { (CaCO }) \\
\text { (P00900) }\end{array}$ \\
\hline \multicolumn{10}{|c|}{ Upper Cretaceous hydrogeologic units-Continued } \\
\hline 465 & -- & -- & -- & 10.2 & 0.46 & 21.1 & 374 & 1,040 & 618 \\
\hline 336 & -- & -- & -- & 15.3 & .57 & 14.8 & 703 & 1,440 & 947 \\
\hline 184 & 212 & 258 & -- & 12.4 & .5 & 13.6 & 14.2 & 248 & 177 \\
\hline 349 & -- & -- & -- & 29.5 & .30 & 7.88 & 3,920 & 6,440 & 2,176 \\
\hline 150 & -- & -- & -- & .98 & .12 & 13.1 & 12.9 & 175 & 139 \\
\hline E899 & -- & -- & -- & 659 & .51 & 11.4 & 10,600 & 17,900 & 4,523 \\
\hline \multicolumn{10}{|c|}{ Lower Cretaceous hydrogeologic units } \\
\hline 101 & -- & -- & -- & 3.65 & .2 & 12.3 & 82.8 & 241 & 168 \\
\hline \multicolumn{10}{|c|}{ Triassic and Jurassic hydrogeologic units } \\
\hline 142 & -- & -- & -- & 3,550 & .7 & 7.50 & 5,910 & 14,800 & 1,358 \\
\hline 184 & 165 & 201 & -- & 9.24 & .27 & 15.1 & 776 & 1,420 & 1,020 \\
\hline 121 & -- & -- & -- & 5.63 & .2 & 8.09 & 1,520 & 2,440 & 1,894 \\
\hline \multicolumn{10}{|c|}{ Paleozoic hydrogeologic units } \\
\hline 123 & 129 & 157 & -- & 10.3 & .4 & 11.2 & 1,650 & 2,690 & 1,869 \\
\hline 184 & 180 & 218 & -- & 189 & .5 & 13.2 & 1,280 & 2,430 & 1,442 \\
\hline 592 & 526 & 641 & -- & 7.99 & .28 & 8.28 & 1,100 & 2,210 & 1,525 \\
\hline 151 & 172 & 209 & -- & 2.67 & $<.2$ & 8.40 & 85.1 & 303 & 255 \\
\hline 186 & 213 & 258 & -- & 8.14 & $<.2$ & 9.11 & 15.2 & 233 & 206 \\
\hline \multicolumn{10}{|c|}{ Precambrian hydrogeologic units } \\
\hline 139 & -- & -- & -- & 5.69 & 1.75 & 20.0 & 10.6 & 186 & 117 \\
\hline 151 & -- & -- & -- & 7.79 & .50 & 17.3 & 19.0 & 208 & 155 \\
\hline 53 & 58 & 71 & -- & .68 & $<.2$ & 14.7 & 4.8 & 79 & 48.6 \\
\hline
\end{tabular}


Appendix 6-4. Trace elements in ground-water samples collected during study.

[USGS, U.S. Geological Survey; number below the compound is the data parameter code, which is a five-digit number used in the USGS computerized data system, National Water Information System (NWIS), to uniquely identify a constituent or property; yyyymmdd, year, month, day; $\mu \mathrm{g} / \mathrm{L}$, micrograms per liter; mg/L, milligrams per liter; --, not analyzed; E, estimated concentration; <, less than; $\mathrm{M}$, constituent detected but not quantified]

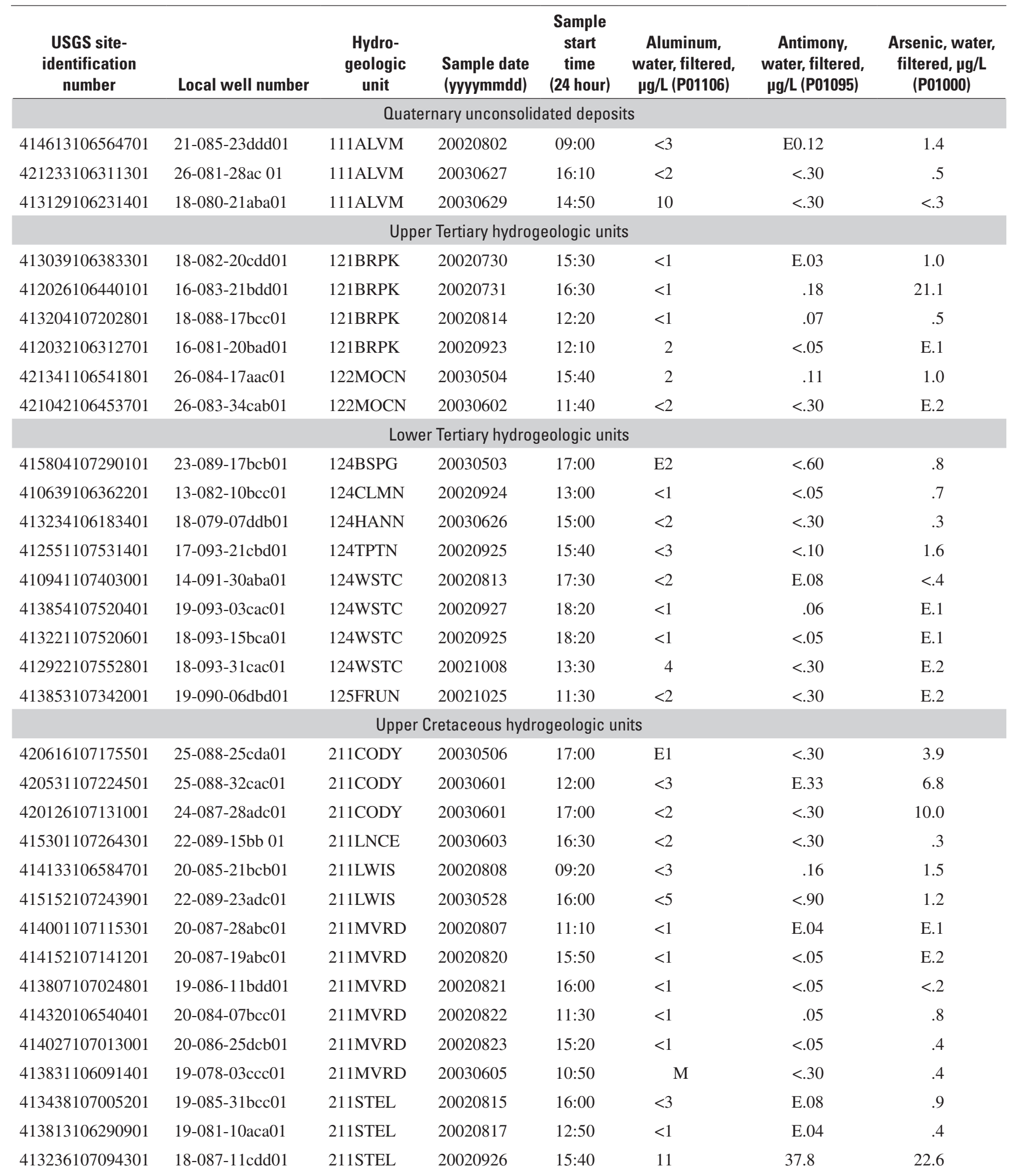


Appendix 6-4. Trace elements in ground-water samples collected during study-Continued

\begin{tabular}{|c|c|c|c|c|c|c|c|c|}
\hline $\begin{array}{c}\text { Barium, } \\
\text { water, } \\
\text { filtered, } \mu \mathrm{g} / \mathrm{L} \\
\text { (P01005) }\end{array}$ & $\begin{array}{c}\text { Beryl- } \\
\text { lium, water, } \\
\text { filtered, } \mu \mathrm{g} / \mathrm{L} \\
(\mathrm{P01010})\end{array}$ & $\begin{array}{l}\text { Boron, water, } \\
\text { filtered, } \mu \mathrm{g} / \mathrm{L} \\
(\mathrm{P01020})\end{array}$ & $\begin{array}{c}\text { Bromide, } \\
\text { water, } \\
\text { filtered, mg/L } \\
\text { (P71870) }\end{array}$ & $\begin{array}{l}\text { Cadmium, } \\
\text { water, } \\
\text { filtered, } \mu \mathrm{g} / \mathrm{L} \\
\text { (P01025) }\end{array}$ & $\begin{array}{l}\text { Chromium, } \\
\text { water, } \\
\text { filtered, } \mu \mathrm{g} / \mathrm{L} \\
\text { (P01030) }\end{array}$ & $\begin{array}{c}\text { Cobalt, } \\
\text { water, } \\
\text { filtered, } \mu \mathrm{g} / \mathrm{L} \\
\text { (P01035) }\end{array}$ & $\begin{array}{c}\text { Copper, } \\
\text { water, } \\
\text { filtered, } \mu \mathrm{g} / \mathrm{L} \\
(\mathrm{P01040)}\end{array}$ & $\begin{array}{l}\text { Iron, water, } \\
\text { filtered, } \mu \mathrm{g} / \mathrm{L} \\
\text { (P01046) }\end{array}$ \\
\hline \multicolumn{9}{|c|}{ Quaternary unconsolidated deposits } \\
\hline 23 & $<0.20$ & 87 & 0.77 & E0.06 & 1.5 & 1.30 & 22.4 & 9,720 \\
\hline 196 & $<.06$ & 69 & .19 & .04 & $<.8$ & .267 & 57.7 & $<8$ \\
\hline 5 & $<.06$ & 8 & -- & $<.04$ & $<.8$ & .036 & 1.9 & 32 \\
\hline \multicolumn{9}{|c|}{ Upper Tertiary hydrogeologic units } \\
\hline 112 & $<.06$ & 13 & .06 & $<.04$ & 1.6 & .112 & 1.1 & $<10$ \\
\hline 37 & $<.06$ & 76 & .11 & $<.04$ & E.7 & .149 & 2.9 & $<10$ \\
\hline 13 & $<.06$ & 7 & $<.03$ & $<.04$ & $<.8$ & .063 & .8 & $<10$ \\
\hline 22 & $<.06$ & $<7$ & $<.03$ & .04 & E. 8 & .040 & 1.7 & $<10$ \\
\hline 43 & $<.06$ & 102 & .13 & E.03 & $<.8$ & .254 & 2.0 & $<10$ \\
\hline 75 & $<.06$ & 31 & .03 & $<.04$ & $<.8$ & .168 & 1.5 & E8 \\
\hline \multicolumn{9}{|c|}{ Lower Tertiary hydrogeologic units } \\
\hline 8 & $<.12$ & 117 & .46 & $<.07$ & $<.8$ & .300 & 6.3 & 272 \\
\hline 94 & $<.06$ & 9 & .04 & $<.04$ & $<.8$ & .047 & 3.5 & $<10$ \\
\hline 5 & $<.06$ & E5 & $<.02$ & $<.04$ & 1.0 & .030 & 4.6 & 29 \\
\hline 6 & $<.20$ & 49 & .24 & $<.10$ & $<.8$ & .200 & 15.0 & E19 \\
\hline 8 & $<.10$ & 184 & .18 & E.07 & $<.8$ & E.020 & 2.5 & $<30$ \\
\hline 8 & E.04 & 47 & .04 & $<.04$ & $<.8$ & .669 & 6.1 & 2,520 \\
\hline 7 & $<.06$ & 29 & .05 & $<.04$ & $<.8$ & .107 & 3.1 & 1,030 \\
\hline 14 & $<.06$ & 63 & .12 & $<.04$ & $<.8$ & E.010 & 1.3 & 35 \\
\hline 18 & E.03 & 78 & .04 & $<.04$ & $<.8$ & .540 & 1.2 & 2,470 \\
\hline \multicolumn{9}{|c|}{ Upper Cretaceous hydrogeologic units } \\
\hline 102 & $<.06$ & 56 & .05 & $<.04$ & $<.8$ & .294 & .4 & 47 \\
\hline 46 & $<.12$ & 426 & 1.02 & E.06 & $<.8$ & .300 & 3.7 & 141 \\
\hline 23 & $<.06$ & 228 & .26 & .07 & $<.8$ & .566 & 1.0 & 299 \\
\hline 5 & $<.06$ & 30 & .22 & .08 & $<.8$ & 2.69 & 5.4 & 9,340 \\
\hline 5 & $<.20$ & 591 & .48 & $<.10$ & $<.8$ & .790 & 19.1 & $<50$ \\
\hline 6 & $<.18$ & 611 & .56 & $<.11$ & $<.8$ & .190 & 11.7 & 29 \\
\hline 23 & $<.06$ & 99 & .06 & $<.04$ & $<.8$ & .195 & 1.5 & 32 \\
\hline 5 & $<.06$ & 167 & .04 & E.02 & $<.8$ & .494 & 2.8 & 1,510 \\
\hline 13 & E.06 & 60 & .06 & $<.04$ & $<.8$ & .305 & 1.0 & 1,510 \\
\hline 21 & $<.06$ & 189 & .07 & .42 & $<.8$ & 1.11 & 1.3 & 4,760 \\
\hline 8 & E.04 & 90 & .07 & $<.04$ & $<.8$ & .672 & 1.9 & 5,140 \\
\hline 110 & $<.06$ & 35 & .04 & $<.04$ & $<.8$ & .217 & 4.4 & 19 \\
\hline 4 & $<.20$ & 459 & .22 & $<.10$ & $<.8$ & .540 & 13.7 & 509 \\
\hline 121 & $<.06$ & 19 & $<.03$ & $<.04$ & $<.8$ & .068 & 11.5 & $<10$ \\
\hline 70 & $<.40$ & 1,040 & 3.55 & 1.16 & $<1.6$ & 55.5 & 165 & E51 \\
\hline
\end{tabular}


Appendix 6-4. Trace elements in ground-water samples collected during study.-Continued

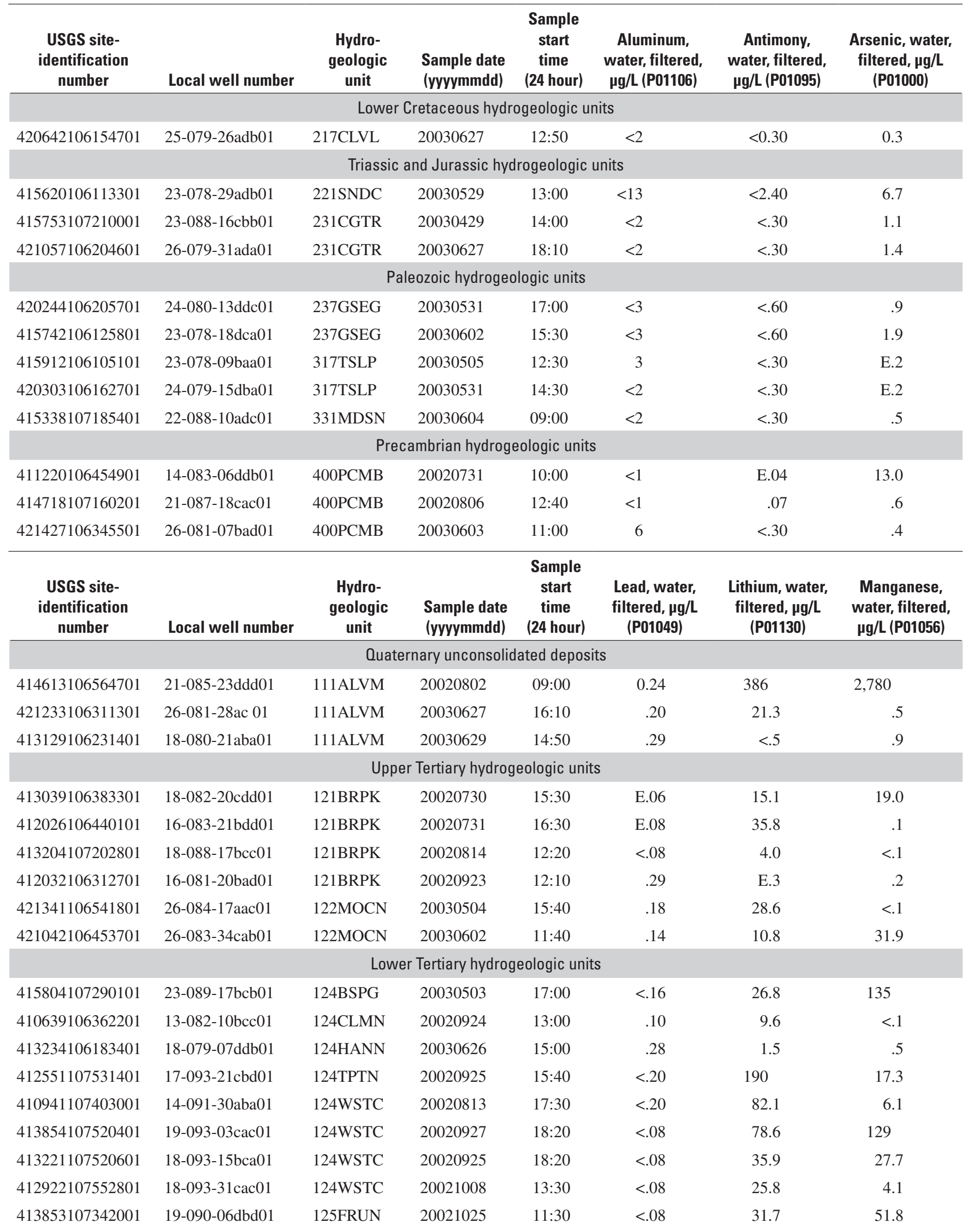


Appendix 6-4. Trace elements in ground-water samples collected during study-Continued

\begin{tabular}{|c|c|c|c|c|c|c|c|c|}
\hline $\begin{array}{c}\text { Barium, } \\
\text { water, } \\
\text { filtered, } \mu \mathrm{g} / \mathrm{L} \\
(\mathrm{P01005)}\end{array}$ & $\begin{array}{c}\text { Beryl- } \\
\text { lium, water, } \\
\text { filtered, } \mu \mathrm{g} / \mathrm{L} \\
(\mathrm{P} 01010)\end{array}$ & $\begin{array}{l}\text { Boron, water, } \\
\text { filtered, } \mu \mathrm{g} / \mathrm{L} \\
\text { (P01020) }\end{array}$ & $\begin{array}{c}\text { Bromide, } \\
\text { water, } \\
\text { filtered, } \mathrm{mg} / \mathrm{L} \\
\text { (P71870) }\end{array}$ & $\begin{array}{c}\text { Cadmium, } \\
\text { water, } \\
\text { filtered, } \mu \mathrm{g} / \mathrm{L} \\
\text { (P01025) }\end{array}$ & $\begin{array}{l}\text { Chromium, } \\
\text { water, } \\
\text { filtered, } \mu \mathrm{g} / \mathrm{L} \\
\text { (P01030) }\end{array}$ & $\begin{array}{c}\text { Cobalt, } \\
\text { water, } \\
\text { filtered, } \mu \mathrm{g} / \mathrm{L} \\
\text { (P01035) }\end{array}$ & $\begin{array}{c}\text { Copper, } \\
\text { water, } \\
\text { filtered, } \mu \mathrm{g} / \mathrm{L} \\
(\mathrm{P01040)}\end{array}$ & $\begin{array}{l}\text { Iron, water, } \\
\text { filtered, } \mu \mathrm{g} / \mathrm{L} \\
\text { (P01046) }\end{array}$ \\
\hline \multicolumn{9}{|c|}{ Lower Cretaceous hydrogeologic units } \\
\hline 57 & $<0.06$ & 56 & 0.03 & E0.02 & $<0.8$ & 0.135 & 0.8 & $<8$ \\
\hline \multicolumn{9}{|c|}{ Triassic and Jurassic hydrogeologic units } \\
\hline 4 & $<.48$ & 1,650 & 10.7 & E.16 & 90.4 & .760 & 33.8 & 296 \\
\hline 9 & $<.06$ & 134 & .08 & $<.04$ & $<.8$ & .496 & 2.9 & 16 \\
\hline 8 & $<.06$ & 146 & .05 & $<.04$ & $<.8$ & 1.00 & 5.1 & $<24$ \\
\hline \multicolumn{9}{|c|}{ Paleozoic hydrogeologic units } \\
\hline 8 & $<.12$ & 191 & .10 & $<.07$ & $<.8$ & 2.58 & 6.2 & E21 \\
\hline 10 & $<.12$ & 135 & .22 & $<.07$ & $<.8$ & 1.07 & 8.0 & 47 \\
\hline 7 & .09 & 123 & .03 & $<.04$ & $<.8$ & 1.27 & 7.3 & 14,100 \\
\hline$<.050$ & $<.06$ & 17 & .04 & E.02 & $<.8$ & .178 & 1.7 & E4 \\
\hline 67 & $<.06$ & 9 & .09 & $<.04$ & $<.8$ & .168 & 8.2 & $<8$ \\
\hline \multicolumn{9}{|c|}{ Precambrian hydrogeologic units } \\
\hline 11 & $<.06$ & 35 & .09 & $<.04$ & $<.8$ & .083 & .4 & $<10$ \\
\hline 29 & $<.06$ & 44 & .07 & E.02 & $<.8$ & .080 & 1.4 & $<10$ \\
\hline 6 & .07 & E4 & -- & $<.04$ & $<.8$ & .100 & 2.3 & 17 \\
\hline $\begin{array}{c}\text { Molybde- } \\
\text { num, water, } \\
\text { filtered, } \mu \mathrm{g} / \mathrm{L} \\
(\mathrm{P01060})\end{array}$ & $\begin{array}{c}\text { Nickel, } \\
\text { water, } \\
\text { filtered, } \mu \mathrm{g} / \mathrm{L} \\
\text { (P01065) }\end{array}$ & $\begin{array}{c}\text { Selenium, } \\
\text { water, fil- } \\
\text { tered, } \mu \mathrm{g} / \mathrm{L} \\
\text { (P01145) }\end{array}$ & $\begin{array}{l}\text { Silver, water, } \\
\text { filtered, } \mu \mathrm{g} / \mathrm{L} \\
\text { (P01075) }\end{array}$ & $\begin{array}{c}\text { Strontium, } \\
\text { water, } \\
\text { filtered, } \mu \mathrm{g} / \mathrm{L} \\
\text { (P01080) }\end{array}$ & $\begin{array}{c}\text { Thallium, } \\
\text { water, fil- } \\
\text { tered, } \mu \mathrm{g} / \mathrm{L} \\
\text { (P01057) }\end{array}$ & $\begin{array}{c}\text { Vanadium, } \\
\text { water, fil- } \\
\text { tered, } \mu \mathrm{g} / \mathrm{L} \\
\text { (P01085) }\end{array}$ & $\begin{array}{l}\text { Zinc, water, } \\
\text { filtered, } \mu \mathrm{g} / \mathrm{L} \\
\text { (P01090) }\end{array}$ & \\
\hline \multicolumn{9}{|c|}{ Quaternary unconsolidated deposits } \\
\hline 4.1 & 5.62 & 3.9 & $<3.0$ & 3,430 & $<0.10$ & 1.6 & 36.7 & \\
\hline 2.0 & 3.75 & 4.5 & $<.2$ & 462 & .04 & .8 & 6.6 & \\
\hline$<.3$ & .38 & $<.5$ & $<.2$ & 12.3 & $<.04$ & .2 & 9.5 & \\
\hline \multicolumn{9}{|c|}{ Upper Tertiary hydrogeologic units } \\
\hline 1.1 & .80 & 1.0 & $<1.0$ & 285 & $<.04$ & 2.4 & 3.6 & \\
\hline 4.9 & .62 & 2.8 & $<1.0$ & 507 & $<.04$ & 23.5 & 2.4 & \\
\hline 1.8 & .07 & .5 & $<1.0$ & 88.8 & $<.04$ & .5 & $<1.0$ & \\
\hline$<.2$ & .74 & $<.3$ & $<1.0$ & 35.3 & $<.04$ & .7 & 49.2 & \\
\hline 6.6 & 1.79 & 1.9 & $<1.0$ & 443 & $<.04$ & 3.3 & 14.4 & \\
\hline 1.7 & 1.36 & .6 & $<.2$ & 445 & $<.04$ & .4 & 3.3 & \\
\hline \multicolumn{9}{|c|}{ Lower Tertiary hydrogeologic units } \\
\hline 3.3 & 2.46 & 2.8 & $<.4$ & 1,780 & $<.08$ & $<.3$ & 11.3 & \\
\hline .3 & .68 & .5 & $<1.0$ & 117 & $<.04$ & 3.1 & $<1.0$ & \\
\hline$<.3$ & .95 & $<.5$ & $<.2$ & 30.0 & $<.04$ & .8 & 24.3 & \\
\hline 1.0 & 2.08 & 5.3 & $<3.0$ & 936 & $<.10$ & $<.6$ & 10.0 & \\
\hline 30.5 & E.07 & $<.7$ & $<2.0$ & 55.7 & $<.08$ & 2.1 & $<2.0$ & \\
\hline .8 & 1.70 & .4 & $<1.0$ & 12,300 & $<.04$ & .8 & 4.4 & \\
\hline 2.7 & 1.64 & .5 & $<1.0$ & 1,860 & $<.04$ & .4 & 1.7 & \\
\hline 2.4 & .12 & $<.5$ & $<.2$ & 49.0 & $<.04$ & $<.1$ & E. 9 & \\
\hline .5 & 11.8 & E. 3 & $<.2$ & 1,310 & $<.04$ & 2.8 & E.6 & \\
\hline
\end{tabular}


Appendix 6-4. Trace elements in ground-water samples collected during study-Continued

\begin{tabular}{|c|c|c|c|c|c|c|c|}
\hline $\begin{array}{c}\text { USGS site- } \\
\text { identification } \\
\text { number }\end{array}$ & Local well number & $\begin{array}{l}\text { Hydro- } \\
\text { geologic } \\
\text { unit }\end{array}$ & $\begin{array}{l}\text { Sample date } \\
\text { (yyyymmdd) }\end{array}$ & $\begin{array}{c}\text { Sample } \\
\text { start } \\
\text { time } \\
\text { (24 hour) }\end{array}$ & $\begin{array}{l}\text { Lead, water, } \\
\text { filtered, } \mu \mathrm{g} / \mathrm{L} \\
\text { (P01049) }\end{array}$ & $\begin{array}{l}\text { Lithium, water, } \\
\text { filtered, } \mu \mathrm{g} / \mathrm{L} \\
\text { (P01130) }\end{array}$ & $\begin{array}{c}\text { Manganese, } \\
\text { water, filtered, } \\
\mu \mathrm{g} / \mathrm{L} \text { (P01056) }\end{array}$ \\
\hline \multicolumn{8}{|c|}{ Upper Cretaceous hydrogeologic units } \\
\hline 420616107175501 & $25-088-25 \mathrm{cda} 01$ & 211CODY & 20030506 & $17: 00$ & $<0.08$ & 14.3 & 89.6 \\
\hline 420531107224501 & 25-088-32cac01 & 211CODY & 20030601 & $12: 00$ & $<.16$ & 95.9 & 565 \\
\hline 415301107264301 & 22-089-15bb 01 & 211LNCE & 20030603 & $16: 30$ & .13 & 32.4 & 892 \\
\hline 414133106584701 & 20-085-21bcb01 & 211LWIS & 20020808 & 09:20 & $<.20$ & 585 & 53.2 \\
\hline 415152107243901 & 22-089-23adc01 & 211LWIS & 20030528 & $16: 00$ & $<.24$ & 292 & 47.5 \\
\hline 414001107115301 & 20-087-28abc01 & 211MVRD & 20020807 & $11: 10$ & .50 & 16.9 & 1.9 \\
\hline 414027107013001 & $20-086-25 \mathrm{dcb} 01$ & 211MVRD & 20020823 & $15: 20$ & $<.08$ & 87.0 & 188 \\
\hline 413831106091401 & $19-078-03 \operatorname{ccc} 01$ & 211MVRD & 20030605 & $10: 50$ & E.07 & 4.5 & 25.7 \\
\hline 413438107005201 & 19-085-31bcc01 & 211STEL & 20020815 & $16: 00$ & $<.20$ & 606 & 261 \\
\hline 413813106290901 & 19-081-10aca01 & 211STEL & 20020817 & $12: 50$ & .54 & 7.1 & 10.5 \\
\hline 413236107094301 & 18-087-11cdd01 & 211STEL & 20020926 & $15: 40$ & E. 33 & 3,200 & 15,600 \\
\hline \multicolumn{8}{|c|}{ Lower Cretaceous hydrogeologic units } \\
\hline 420642106154701 & 25-079-26adb01 & 217CLVL & 20030627 & $12: 50$ & $<.08$ & 18.7 & $<.2$ \\
\hline \multicolumn{8}{|c|}{ Triassic and Jurassic hydrogeologic units } \\
\hline 415912106105101 & 23-078-09baa01 & 317TSLP & 20030505 & $12: 30$ & $<.08$ & 39.0 & 71.9 \\
\hline 420303106162701 & $24-079-15 \mathrm{dba0} 01$ & 317TSLP & 20030531 & $14: 30$ & 2.43 & 4.8 & .4 \\
\hline 415338107185401 & 22-088-10adc01 & 331MDSN & 20030604 & 09:00 & E.07 & 2.9 & $<.2$ \\
\hline \multicolumn{8}{|c|}{ Precambrian hydrogeologic units } \\
\hline 411220106454901 & 14-083-06ddb01 & 400РCMB & 20020731 & $10: 00$ & $<.08$ & 55.9 & $<.1$ \\
\hline 414718107160201 & 21-087-18cac01 & 400РCMB & 20020806 & $12: 40$ & .69 & 18.8 & .3 \\
\hline 421427106345501 & 26-081-07bad01 & 400РCMB & 20030603 & $11: 00$ & E.04 & 2.2 & $<.2$ \\
\hline
\end{tabular}


Appendix 6-4. Trace elements in ground-water samples collected during study-Continued

\begin{tabular}{|c|c|c|c|c|c|c|c|}
\hline $\begin{array}{l}\text { Molybde- } \\
\text { num, water, } \\
\text { filtered, } \mu \mathrm{g} / \mathrm{L} \\
\text { (P01060) }\end{array}$ & $\begin{array}{c}\text { Nickel, } \\
\text { water, } \\
\text { filtered, } \mu \mathrm{g} / \mathrm{L} \\
\text { (P01065) }\end{array}$ & $\begin{array}{c}\text { Selenium, } \\
\text { water, fil- } \\
\text { tered, } \mu \mathrm{g} / \mathrm{L} \\
\text { (P01145) }\end{array}$ & $\begin{array}{l}\text { Silver, water, } \\
\text { filtered, } \mu \mathrm{g} / \mathrm{L} \\
\text { (P01075) }\end{array}$ & $\begin{array}{c}\text { Strontium, } \\
\text { water, } \\
\text { filtered, } \mu \mathrm{g} / \mathrm{L} \\
\text { (P01080) }\end{array}$ & $\begin{array}{c}\text { Thallium, } \\
\text { water, fil- } \\
\text { tered, } \mu \mathrm{g} / \mathrm{L} \\
\text { (P01057) }\end{array}$ & $\begin{array}{c}\text { Vanadium, } \\
\text { water, fil- } \\
\text { tered, } \mu \mathrm{g} / \mathrm{L} \\
\text { (P01085) }\end{array}$ & $\begin{array}{c}\text { Zinc, water, } \\
\text { filtered, } \mu \mathrm{g} / \mathrm{L} \\
\text { (P01090) }\end{array}$ \\
\hline \multicolumn{8}{|c|}{ Upper Cretaceous hydrogeologic units } \\
\hline 2.3 & 1.37 & $<0.5$ & $<0.2$ & 473 & $<0.04$ & 1.1 & $<1.0$ \\
\hline 29.1 & 2.49 & 17.7 & $<.4$ & 2,030 & $<.08$ & 3.6 & 3.5 \\
\hline 34.0 & 2.38 & E. 4 & $<.2$ & 697 & $<.04$ & .5 & E.9 \\
\hline$<.3$ & 6.59 & 1.4 & $<.2$ & 1,310 & $<.04$ & .3 & 162 \\
\hline 2.7 & 6.41 & 8.5 & $<3.0$ & 6,820 & $<.10$ & 3.3 & 10.9 \\
\hline 2.5 & 1.95 & 4.8 & $<.6$ & 1,850 & $<.12$ & .6 & 5.0 \\
\hline .6 & $<.06$ & .7 & $<1.0$ & 1,350 & $<.04$ & 1.2 & 96.1 \\
\hline$<.2$ & 2.22 & 6 & $<1.0$ & 4,910 & $<.04$ & 1.0 & 493 \\
\hline .3 & 1.88 & $<.3$ & $<1.0$ & 1,310 & $<.04$ & 2.6 & 521 \\
\hline 1.5 & 2.16 & .4 & $<1.0$ & 1,510 & $<.04$ & 1.6 & 4,030 \\
\hline .3 & 2.38 & .8 & $<1.0$ & 962 & $<.04$ & 2.2 & 2.1 \\
\hline 1.5 & .93 & $<.5$ & $<.2$ & 348 & $<.04$ & .4 & 9.4 \\
\hline 1.8 & $<.20$ & 2.6 & $<3.0$ & 6,410 & $<.10$ & 3.5 & 9.4 \\
\hline .5 & .35 & $<.3$ & $<1.0$ & 329 & $<.04$ & E.1 & 19.7 \\
\hline 222 & 354 & 227 & $<7.0$ & 13,300 & .41 & 64.5 & 89.8 \\
\hline \multicolumn{8}{|c|}{ Lower Cretaceous hydrogeologic units } \\
\hline 2.4 & 1.98 & 2.6 & $<.2$ & 719 & E.03 & .3 & E.5 \\
\hline \multicolumn{8}{|c|}{ Triassic and Jurassic hydrogeologic units } \\
\hline 27.4 & 9.12 & 27.7 & $<1.6$ & 8,240 & $<.33$ & $<1.0$ & 26.3 \\
\hline 3.3 & 8.43 & 5.8 & $<.2$ & 4,550 & $<.04$ & 10.8 & 3.2 \\
\hline 6.0 & 16.5 & 13.3 & $<.2$ & 8,260 & $<.04$ & 3.1 & 2.9 \\
\hline \multicolumn{8}{|c|}{ Paleozoic hydrogeologic units } \\
\hline 5.0 & 28.6 & 11.8 & $<.4$ & 4,330 & $<.08$ & 1.1 & 8.2 \\
\hline 7.5 & 8.28 & 1.4 & $<.4$ & 5,190 & $<.08$ & $<.3$ & 26.1 \\
\hline$<.3$ & 8.03 & .9 & $<.2$ & 1,620 & $<.04$ & 3.5 & 33.5 \\
\hline 4.9 & 1.73 & 2.8 & $<.2$ & 150 & .46 & .3 & 159 \\
\hline .6 & .71 & 1.4 & $<.2$ & 125 & $<.04$ & 2.0 & 9.3 \\
\hline \multicolumn{8}{|c|}{ Precambrian hydrogeologic units } \\
\hline 2.0 & $<.06$ & 1.0 & $<1.0$ & 383 & E.02 & 2.4 & 1.8 \\
\hline 6.5 & .13 & 1.5 & $<1.0$ & 316 & $<.04$ & 1.3 & 8.8 \\
\hline .9 & 1.29 & $<.5$ & $<.2$ & 45.8 & $<.04$ & 1.6 & $<1.0$ \\
\hline
\end{tabular}


Appendix 6-5. Nutrients in ground-water samples collected during study.

[USGS, U.S. Geological Survey; number below the compound is the data parameter code, which is a five-digit number used in the USGS computerized data system, National Water Information System (NWIS), to uniquely identify a constituent or property; yyyymmdd, year, month, day; $\mu \mathrm{g} / \mathrm{L}$, micrograms per liter; mg/L, milligrams per liter; --, not analyzed; E, estimated concentration; <, less than]

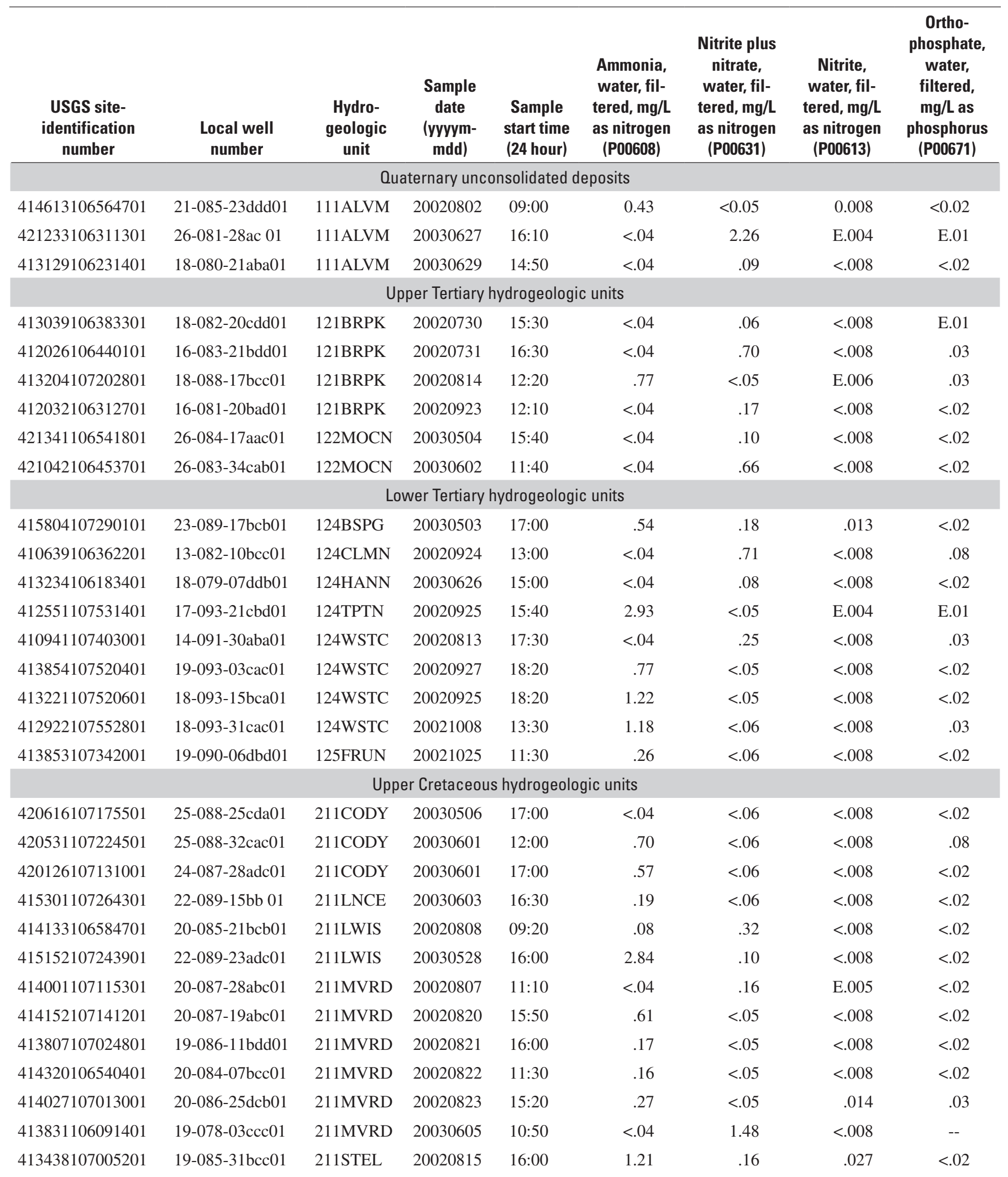


Appendix 6-5. Nutrients in ground-water samples collected during study.-Continued

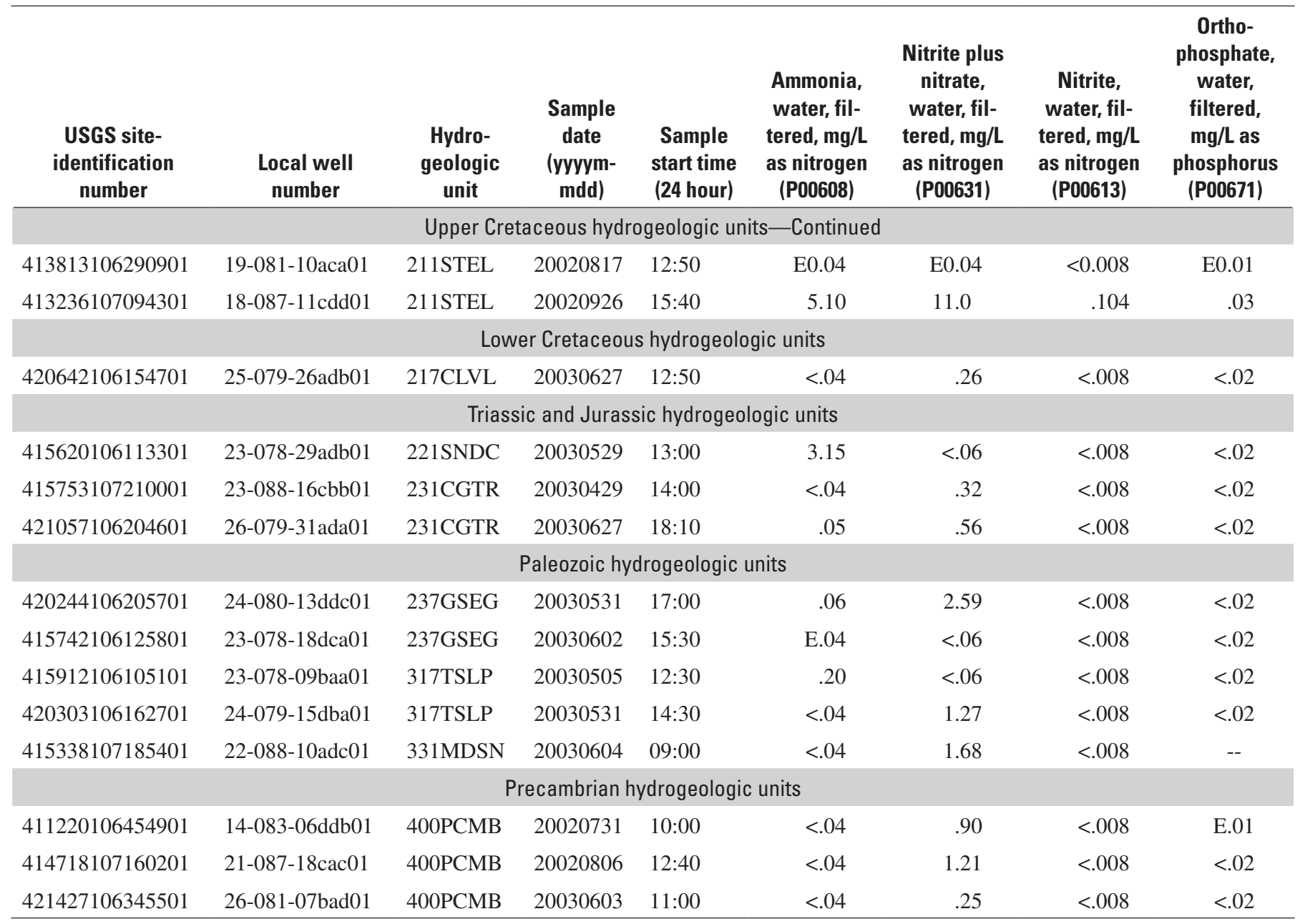


Appendix 6-6. Radionuclides in ground-water samples collected during study.

[USGS, U.S. Geological Survey; number below the compound is the data parameter code, which is a five-digit number used in the USGS computerized data system, National Water Information System (NWIS), to uniquely identify a constituent or property; yyyymmdd, year, month, day;

pCi/L, picocuries per liter; mg/L, milligrams per liter; --, not analyzed; E, estimated concentration; <, less than; M, constituent detected but not quantified]

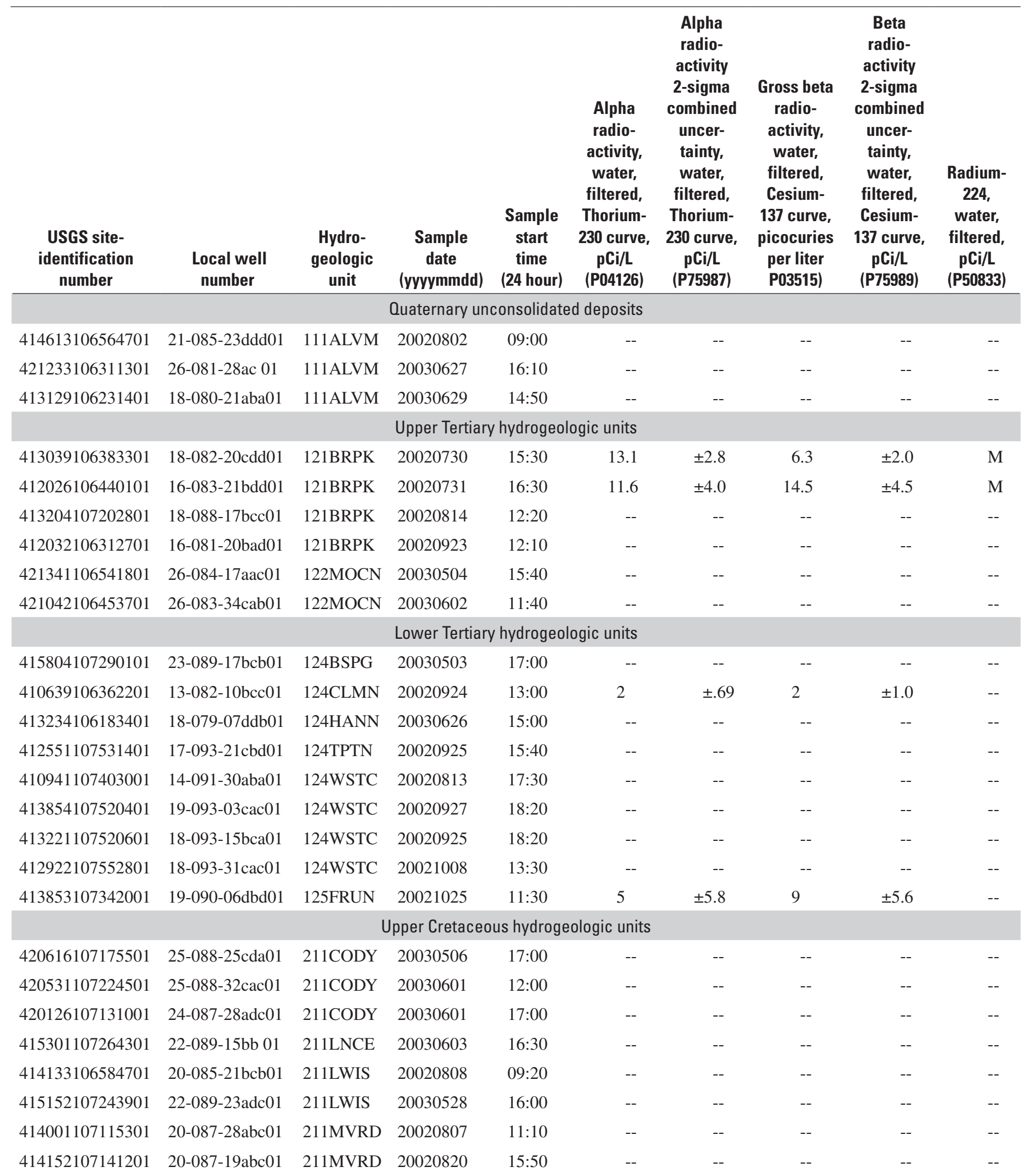


Appendix 6-6. Radionuclides in ground-water samples collected during study.-Continued

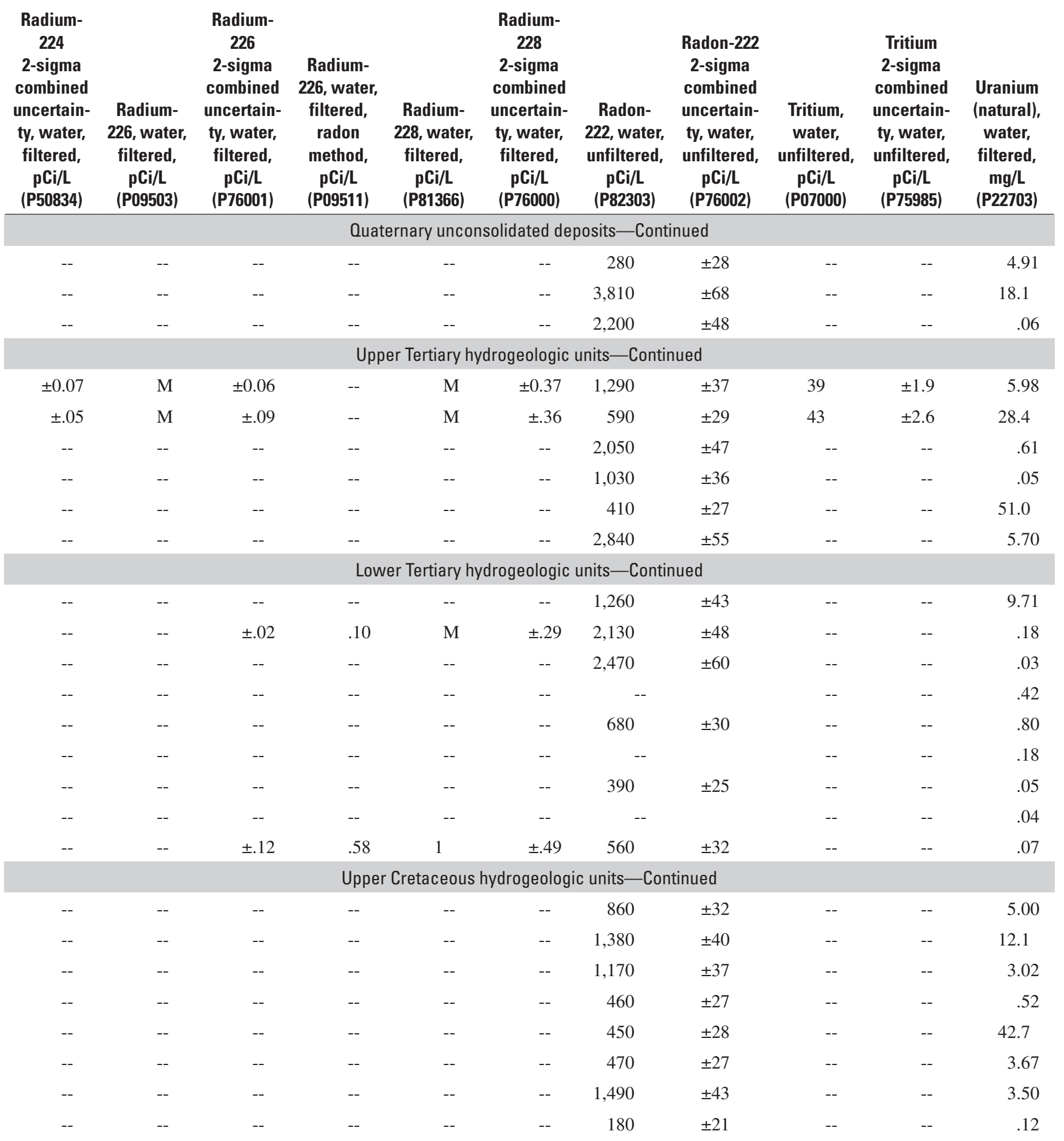


Appendix 6-6. Radionuclides in ground-water samples collected during study--Continued

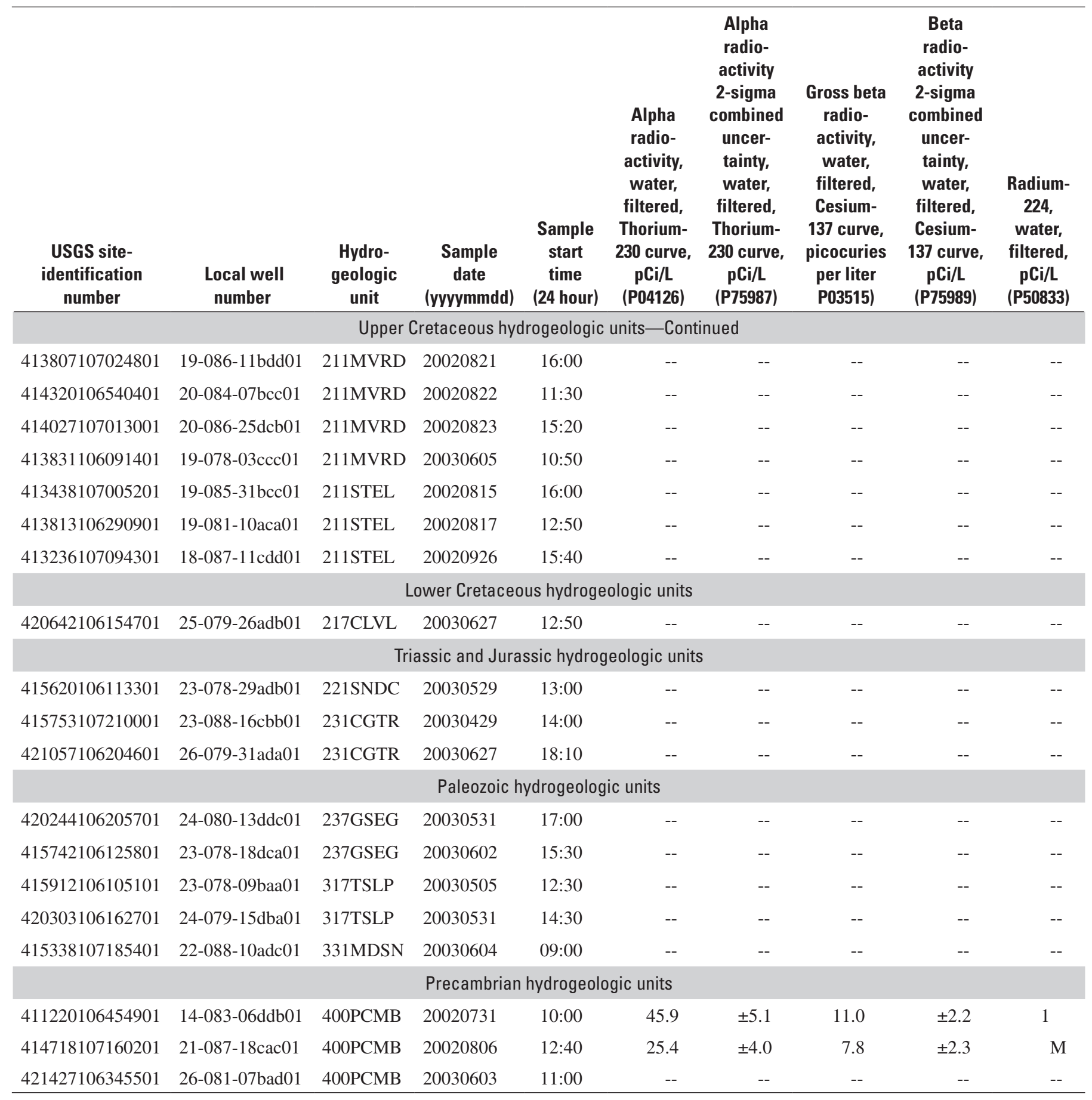


Appendix 6-6. Radionuclides in ground-water samples collected during study.-Continued

\begin{tabular}{|c|c|c|c|c|c|c|c|c|c|c|}
\hline $\begin{array}{c}\text { Radium- } \\
224 \\
\text { 2-sigma } \\
\text { combined } \\
\text { uncertain- } \\
\text { ty, water, } \\
\text { filtered, } \\
\mathrm{pCi} / \mathrm{L} \\
\text { (P50834) }\end{array}$ & $\begin{array}{c}\text { Radium- } \\
\text { 226, water, } \\
\text { filtered, } \\
\text { pCi/L } \\
\text { (P09503) }\end{array}$ & $\begin{array}{c}\text { Radium- } \\
226 \\
\text { 2-sigma } \\
\text { combined } \\
\text { uncertain- } \\
\text { ty, water, } \\
\text { filtered, } \\
\text { pCi/L } \\
\text { (P76001) }\end{array}$ & $\begin{array}{c}\text { Radium- } \\
\text { 226, water, } \\
\text { filtered, } \\
\text { radon } \\
\text { method, } \\
\text { pCi/L } \\
\text { (P09511) }\end{array}$ & $\begin{array}{c}\text { Radium- } \\
\text { 228, water, } \\
\text { filtered, } \\
\text { pCi/L } \\
\text { (P81366) }\end{array}$ & $\begin{array}{c}\text { Radium- } \\
228 \\
\text { 2-sigma } \\
\text { combined } \\
\text { uncertain- } \\
\text { ty, water, } \\
\text { filtered, } \\
\text { pCi/L } \\
\text { (P76000) }\end{array}$ & $\begin{array}{c}\text { Radon- } \\
\text { 222, water, } \\
\text { unfiltered, } \\
\text { pCi/L } \\
\text { (P82303) }\end{array}$ & $\begin{array}{l}\text { Radon-222 } \\
\text { 2-sigma } \\
\text { combined } \\
\text { uncertain- } \\
\text { ty, water, } \\
\text { unfiltered, } \\
\text { pCi/L } \\
\text { (P76002) }\end{array}$ & $\begin{array}{c}\text { Tritium, } \\
\text { water, } \\
\text { unfiltered, } \\
\text { pCi/L } \\
\text { (P07000) }\end{array}$ & $\begin{array}{c}\text { Tritium } \\
\text { 2-sigma } \\
\text { combined } \\
\text { uncertain- } \\
\text { ty, water, } \\
\text { unfiltered, } \\
\text { pCi/L } \\
\text { (P75985) }\end{array}$ & $\begin{array}{c}\text { Uranium } \\
\text { (natural), } \\
\text { water, } \\
\text { filtered, } \\
\text { mg/L } \\
\text { (P22703) }\end{array}$ \\
\hline \multicolumn{11}{|c|}{ Upper Cretaceous hydrogeologic units-Continued } \\
\hline-- & -- & -- & -- & -- & -- & 420 & \pm 28 & -- & -- & 0.38 \\
\hline-- & -- & -- & -- & -- & -- & 1,260 & \pm 48 & -- & -- & 6.22 \\
\hline-- & -- & -- & -- & -- & -- & 90 & \pm 26 & -- & -- & .97 \\
\hline-- & -- & -- & -- & -- & -- & 980 & \pm 31 & -- & -- & 2.68 \\
\hline-- & -- & -- & -- & -- & -- & 140 & \pm 26 & -- & -- & 3.77 \\
\hline-- & -- & -- & -- & -- & -- & 1,090 & \pm 39 & -- & -- & .08 \\
\hline-- & -- & -- & -- & -- & -- & 70 & \pm 26 & -- & -- & 349 \\
\hline \multicolumn{11}{|c|}{ Lower Cretaceous hydrogeologic units-Continued } \\
\hline-- & -- & -- & -- & -- & -- & 6,940 & \pm 87 & -- & -- & 8.20 \\
\hline \multicolumn{11}{|c|}{ Triassic and Jurassic hydrogeologic units-Continued } \\
\hline-- & -- & -- & -- & -- & -- & 670 & \pm 40 & -- & -- & . 15 \\
\hline -- & -- & -- & -- & -- & -- & 2,010 & \pm 46 & -- & -- & 9.06 \\
\hline-- & -- & -- & -- & -- & -- & 1,150 & \pm 41 & -- & -- & 7.58 \\
\hline \multicolumn{11}{|c|}{ Paleozoic hydrogeologic units-Continued } \\
\hline-- & -- & -- & -- & -- & -- & 280 & \pm 28 & -- & -- & 13.9 \\
\hline-- & -- & -- & -- & -- & -- & 1,340 & \pm 39 & -- & -- & 11.5 \\
\hline-- & -- & -- & -- & -- & -- & 120 & \pm 20 & -- & -- & E.02 \\
\hline-- & -- & -- & -- & -- & -- & 650 & \pm 34 & -- & -- & 2.94 \\
\hline-- & -- & -- & -- & -- & -- & 610 & \pm 29 & -- & -- & 2.26 \\
\hline \multicolumn{11}{|c|}{ Precambrian hydrogeologic units-Continued } \\
\hline \pm 0.78 & M & \pm 0.13 & -- & 2 & \pm 0.56 & 4,120 & \pm 58 & 3 & \pm 1.0 & 12.8 \\
\hline \pm .44 & M & \pm .17 & -- & 2 & \pm .60 & 3,790 & \pm 64 & 9 & \pm 1.0 & 7.05 \\
\hline-- & -- & -- & -- & -- & -- & 2,340 & \pm 51 & -- & -- & 1.58 \\
\hline
\end{tabular}




\section{Appendix 7. Boxplots showing concentrations of constituents in water samples collected from aquifers in hydrogeologic units, Carbon County, Wyoming.}

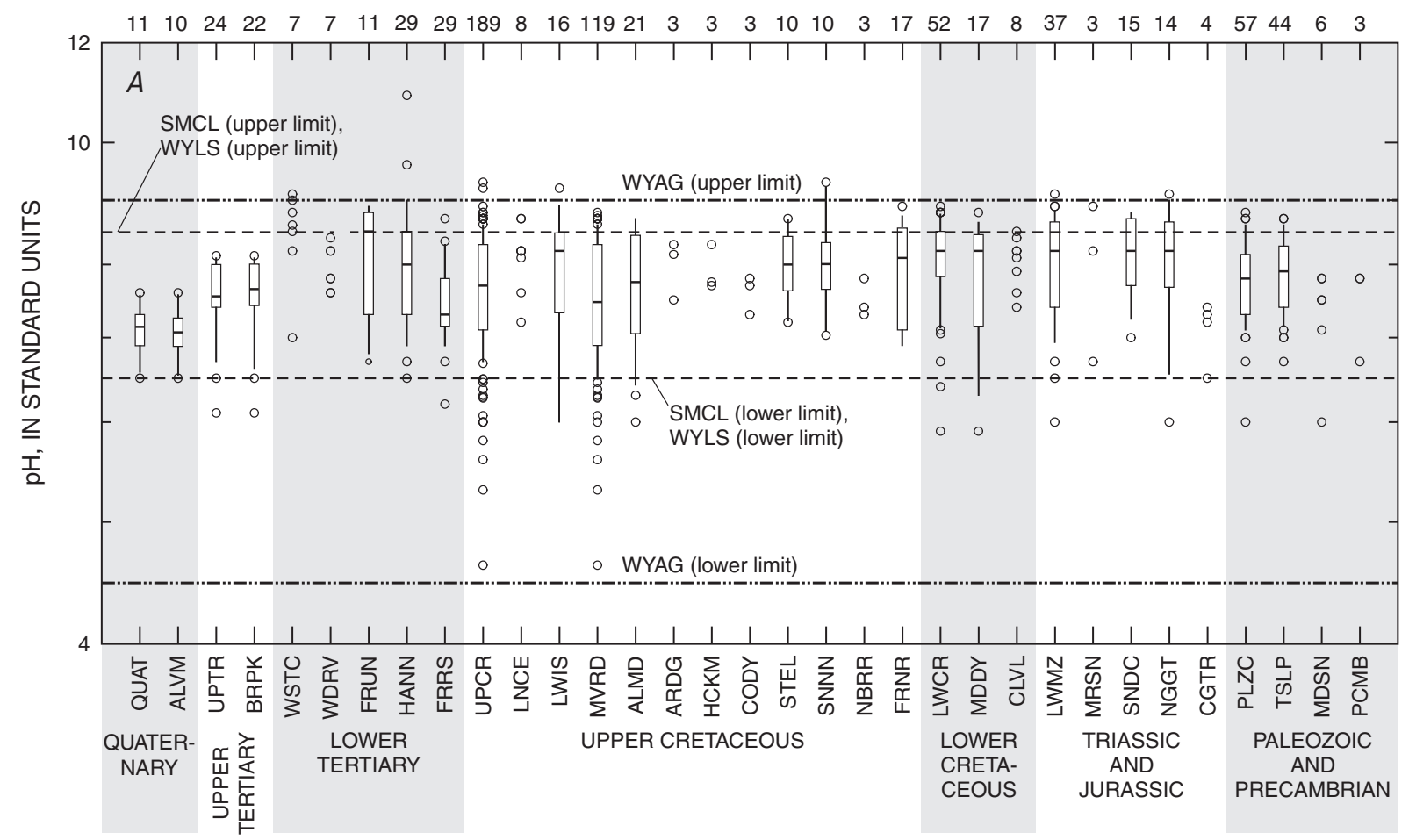

HYDROGEOLOGIC UNIT

\section{EXPLANATION}

11 Number of samples

- Value outside 10th or 90th percentile 90th percentile

75th percentile

Median

25th percentile

10th percentile

$\underline{\mathrm{MCL}}$ U.S. Environmental Protection Agency (USEPA) Maximum

Contaminant Level or proposed Lifetime Health Advisory Level

SMCL

USEPA Secondary Maximum

Contaminant Level

WYAG

Wyoming Department of Environmental Quality (WDEQ) Class II ground-water standard for agricultural use

WYLS

WDEQ Class III ground-water standard for livestock use

\section{HYDROGEOLOGIC UNITS:} Quaternary;

QUAT, Quaternary unconsolidated deposits

ALVM, Alluvium

SNDD, Dune sand (eolian) deposits Tertiary;

UPTR, all Upper Tertiary hydrogeologic units

MOCN, undifferentiated Miocene rocks BRPK, Browns Park aquifer (Formation) WRVR, White River aquifer (Formation) WGBD, Wagon Bed aquifer (Formation) WSTC, Wasatch aquifer (Formation) WDRV, Wind River aquifer (Formation) FRUN, Fort Union aquifer (Formation) HANN, Hanna aquifer (Formation)

FRRS, Ferris aquifer (Formation) Upper Cretaceous;

UPCR, all Upper Cretaceous hydrogeologic units

LNCE, Lance aquifer (Formation)

LWIS, Lewis Shale

MVRD, Mesaverde aquifer (Formation or Group)

ALMD, Almond Formation
ARDG, Allen Ridge Formation HCKM, Haystack Mountains Formation CODY, Cody Shale

STEL, Steele Shale

SNNN, Shannon Sandstone

NBRR, Niobrara Formation

FRNR, Frontier aquifer (Formation)

Lower Cretaceous;

LWCR, all Lower Cretaceous hydrogeologic units

MDDY, Muddy Sandstone

CLVL, Cloverly aquifer (Formation)

Triassic and Jurassic;

LWMZ, all Triassic and Jurassic hydrogeologic units

MRSN, Morrison Formation

SNDC, Sundance aquifer (Formation)

NGGT, Nugget aquifer (Formation)

CGTR, Chugwater Formation

Paleozoic and Precambrian;

PLZC, all Paleozoic hydrogeologic units

TSLP, Tensleep aquifer (Sandstone) MDSN, Madison aquifer (Limestone)

PCMB, Precambrian hydrogeologic units

Appendix 7-1. Boxplots showing $A, \mathrm{pH}, B$, total dissolved-solids concentrations, and $C$, sodium-adsorption ratios in samples from aquifers in hydrogeologic units in Carbon County, Wyoming. 


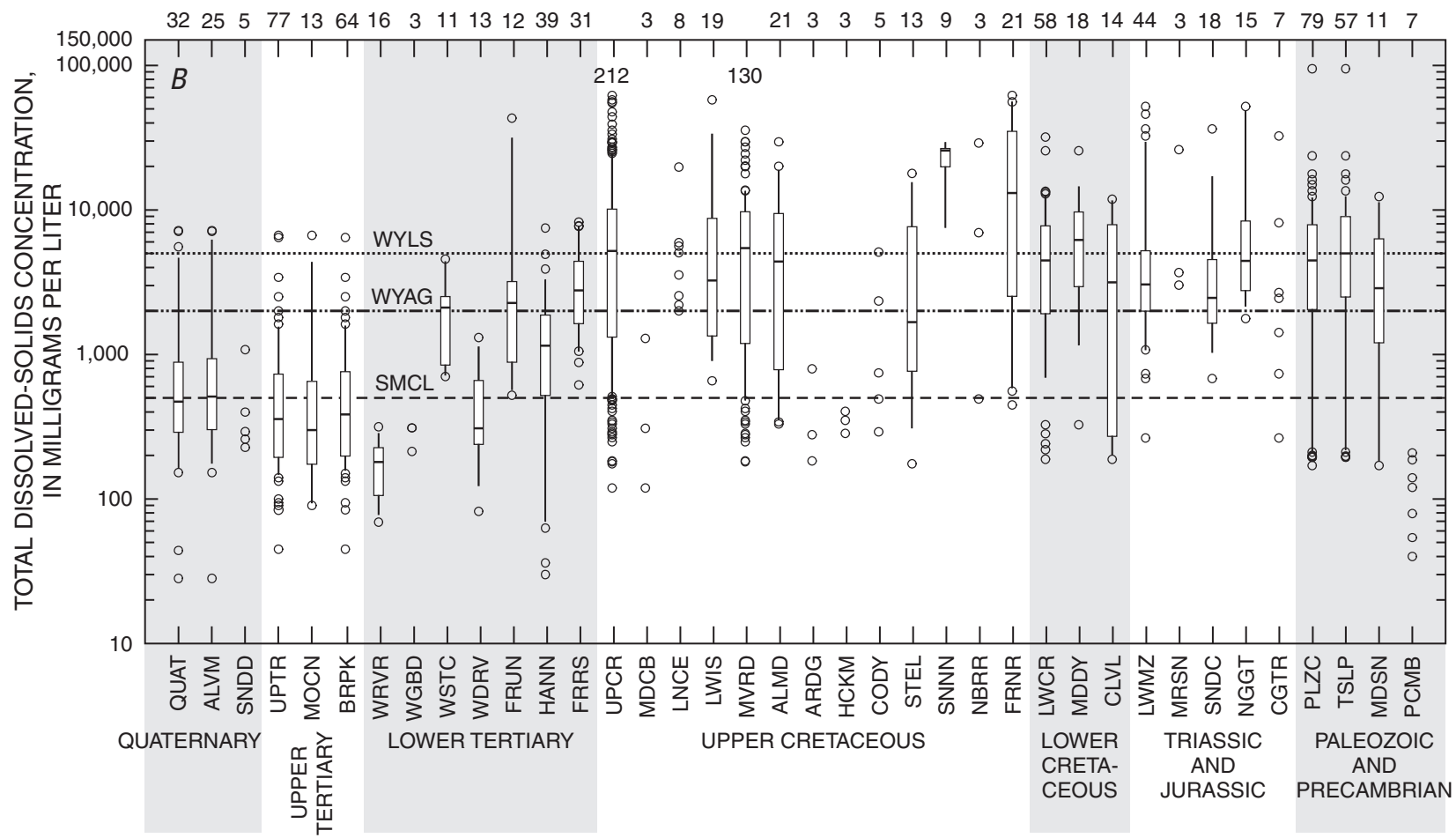

HYDROGEOLOGIC UNIT

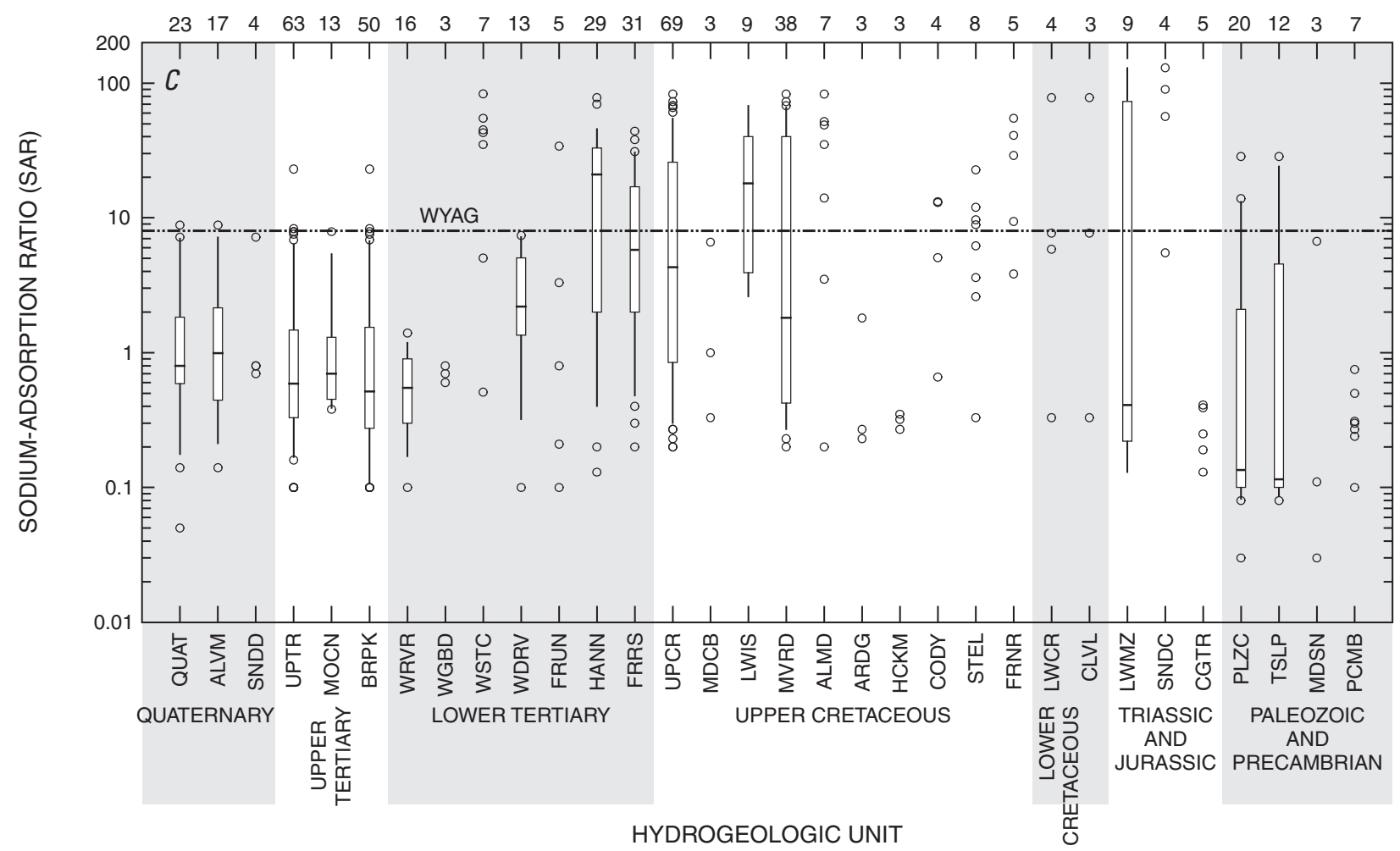

Appendix 7-1. Boxplots showing $A, \mathrm{pH}, B$, total dissolved-solids concentrations, and $C$, sodium-adsorption ratios in samples from aquifers in hydrogeologic units in Carbon County, Wyoming.-Continued 


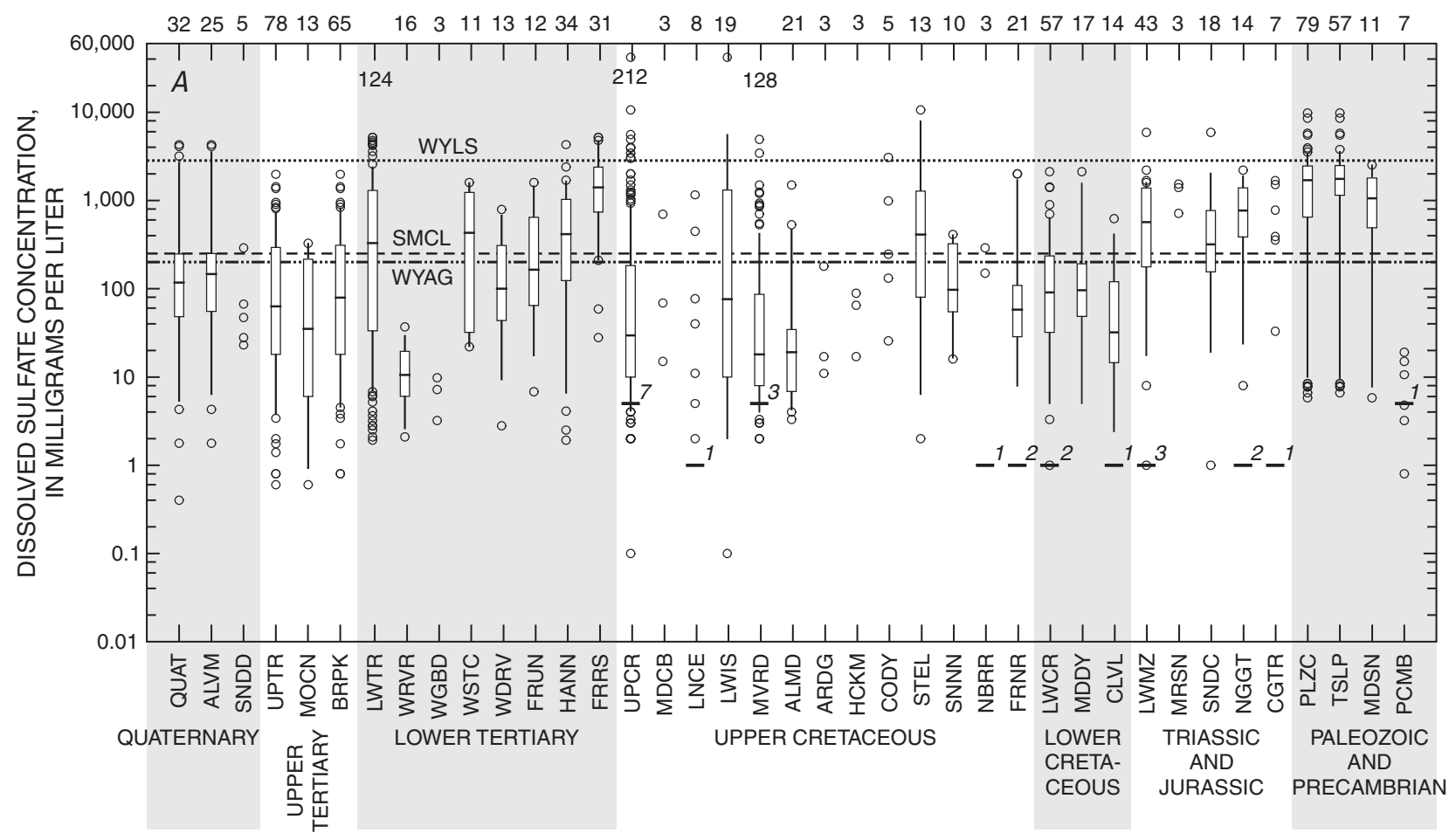

HYDROGEOLOGIC UNIT

32 Number of samples

- Value outside 10th or 90th percentile

* $\quad$ More than one-half the samples were censored

90th percentile

75th percentile

Median

25th percentile

-1 Highest minimum reporting level and number of censored samples

10th percentile

$\underline{\mathrm{MCL}}$

U.S. Environmental Protection Agency (USEPA) Maximum

Contaminant Level or proposed

Lifetime Health Advisory Level

SMCL

USEPA Secondary Maximum Contaminant Level

WYAG Wyoming Department of Environmental Quality (WDEQ) Class II ground-water standard for agricultural use

WYLS

WDEQ Class III ground-water standard for livestock use

\section{EXPLANATION}

HYDROGEOLOGIC UNITS:

Quaternary;

QUAT, Quaternary unconsolidated deposits

ALVM, Alluvium

SNDD, Dune sand (eolian) deposits

Tertiary;

UPTR, all Upper Tertiary hydrogeologic units

MOCN, undifferentiated Miocene rocks

BRPK, Browns Park aquifer (Formation)

LWTR, all Lower Tertiary hydrogeologic units

WRVR, White River aquifer (Formation) WGBD, Wagon Bed aquifer (Formation) WSTC, Wasatch aquifer (Formation) WDRV, Wind River aquifer (Formation) FRUN, Fort Union aquifer (Formation) HANN, Hanna aquifer (Formation) FRRS, Ferris aquifer (Formation)

\section{Upper Cretaceous;}

UPCR, all Upper Cretaceous hydrogeologic units

MDCB, Medicine Bow aquifer (Formation) LNCE, Lance aquifer (Formation)

LWIS, Lewis Shale

MVRD, Mesaverde aquifer (Formation or Group)
ALMD, Almond Formation ARDG, Allen Ridge Formation HCKM, Haystack Mountains Formation CODY, Cody Shale

STEL, Steele Shale

SNNN, Shannon Sandstone NBRR, Niobrara Formation

FRNR, Frontier aquifer (Formation)

\section{Lower Cretaceous;}

LWCR, all Lower Cretaceous hydrogeologic units

MDDY, Muddy Sandstone

CLVL, Cloverly aquifer (Formation)

Triassic and Jurassic;

LWMZ, all Triassic and Jurassic hydrogeologic units

MRSN, Morrison Formation

SNDC, Sundance aquifer (Formation)

NGGT, Nugget aquifer (Formation)

CGTR, Chugwater Formation

Paleozoic and Precambrian;

PLZC, all Paleozoic hydrogeologic units

TSLP, Tensleep aquifer (Sandstone) MDSN, Madison aquifer (Limestone)

PCMB, Precambrian hydrogeologic units

Appendix 7-2. Boxplots showing $A$, sulfate concentrations, $B$, chloride concentrations, and $C$, fluoride concentrations in samples from aquifers in hydrogeologic units in Carbon County, Wyoming. 


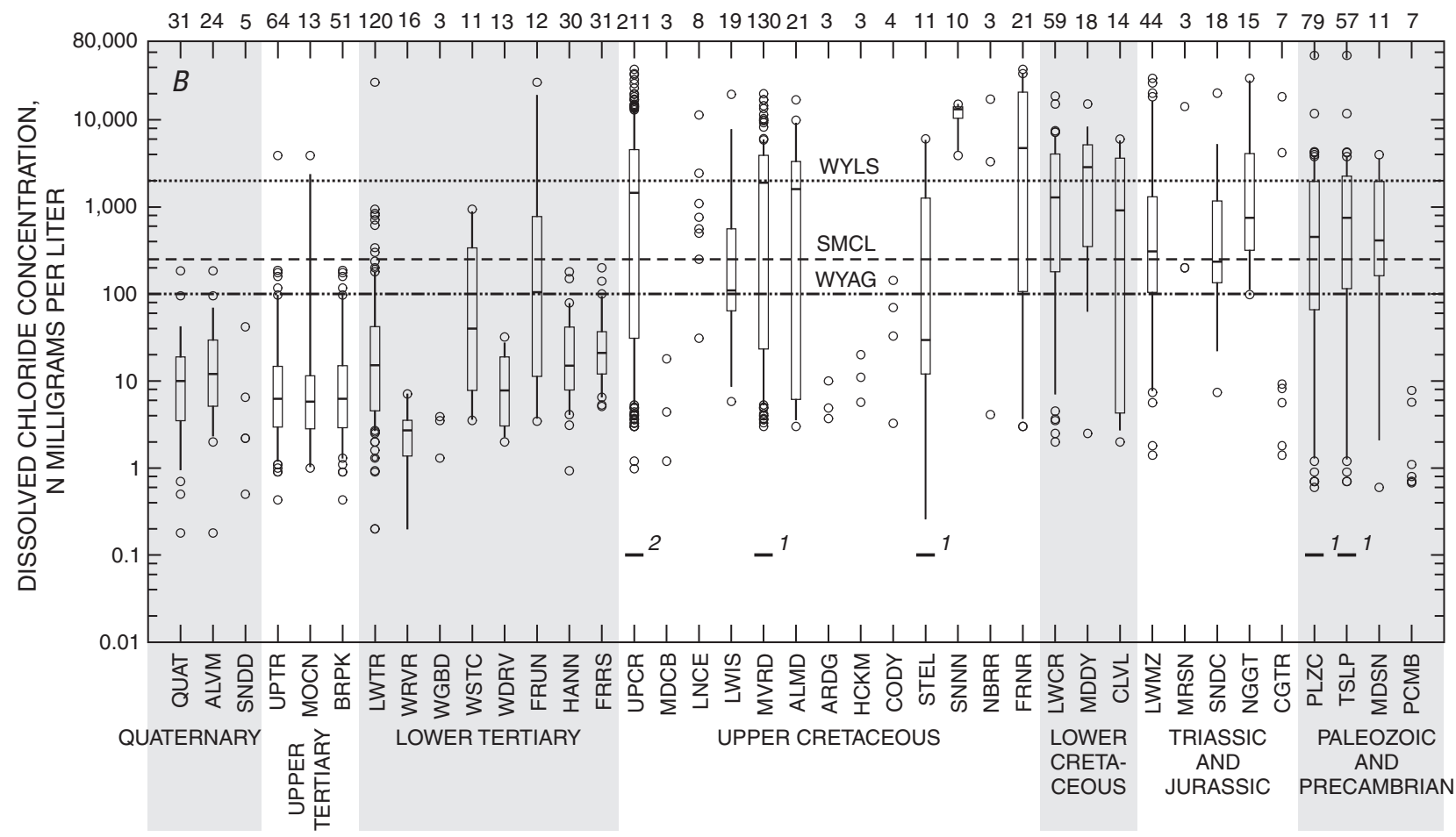

HYDROGEOLOGIC UNIT

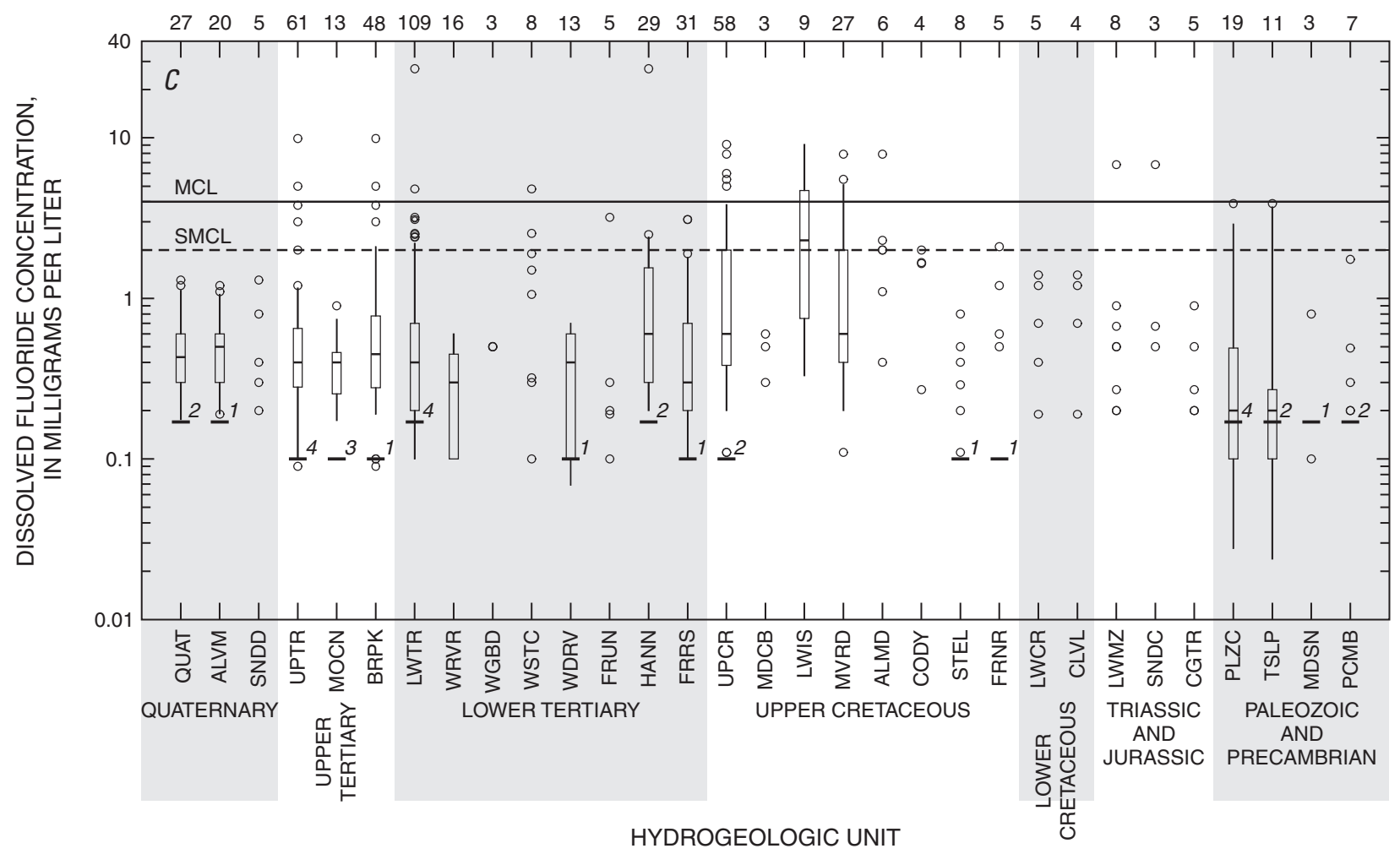

Appendix 7-2. Boxplots showing $A$, sulfate concentrations, $B$, chloride concentrations, and $C$, fluoride concentrations in samples from aquifers in hydrogeologic units in Carbon County, Wyoming.-Continued 


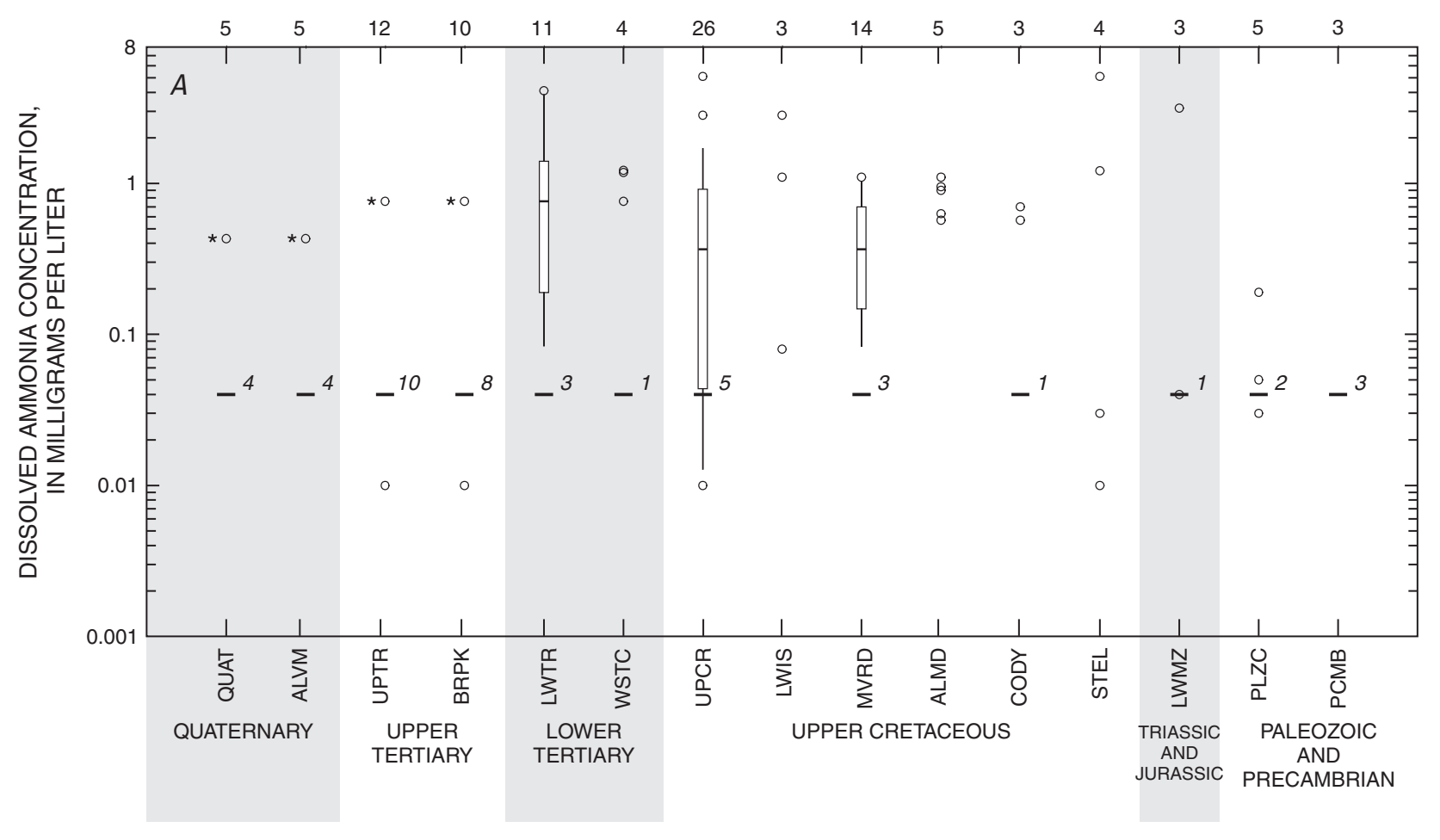

HYDROGEOLOGIC UNITS

5 Number of samples

- Value outside 10 th or 90 th percentile

* More than one-half the samples were censored

90th percentile

75th percentile

Median

25th percentile

-3 Highest minimum reporting level and number of censored samples

10th percentile

MCL U.S. Environmental Protection Agency (USEPA) Maximum Contaminant Level or proposed Lifetime Health Advisory Level

WYLS

WDEQ Class III ground-water standard for livestock use

\section{EXPLANATION}

\section{HYDROGEOLOGIC UNITS:}

Quaternary;

QUAT, Quaternary unconsolidated deposits

ALVM, Alluvium

SNDD, Dune sand (eolian) deposits

Tertiary;

UPTR, all Upper Tertiary hydrogeologic units

MOCN, undifferentiated Miocene rocks BRPK, Browns Park aquifer (Formation) LWTR, all Lower Tertiary hydrogeologic units

WRVR, White River aquifer (Formation) WGBD, Wagon Bed aquifer (Formation) WSTC, Wasatch aquifer (Formation) FRUN, Fort Union aquifer (Formation) WDRV, Wind River aquifer (Formation) HANN, Hanna aquifer (Formation)
Upper Cretaceous;

UPCR, all Upper Cretaceous hydrogeologic units

LWIS, Lewis Shale

MVRD, Mesaverde aquifer (Formation or Group)

ALMD, Almond Formation

ARDG, Allen Ridge Formation

HCKM, Haystack Mountains Formation

CODY, Cody Shale

STEL, Steele Shale

FRNR, Frontier aquifer (Formation)

Triassic and Jurassic;

LWMZ, all Triassic and Jurassic hydrogeologic units

CLVL, Cloverly aquifer (Formation)

Paleozoic and Precambrian;

PLZC, all Paleozoic hydrogeologic units

TSLP, Tensleep aquifer (Sandstone)

PCMB, Precambrian rocks

Appendix 7-3. Boxplots showing $A$, ammonia concentrations, $B$, nitrate concentrations, and $C$, nitrite plus nitrate concentrations in samples from aquifers in hydrogeologic units in Carbon County, Wyoming. 


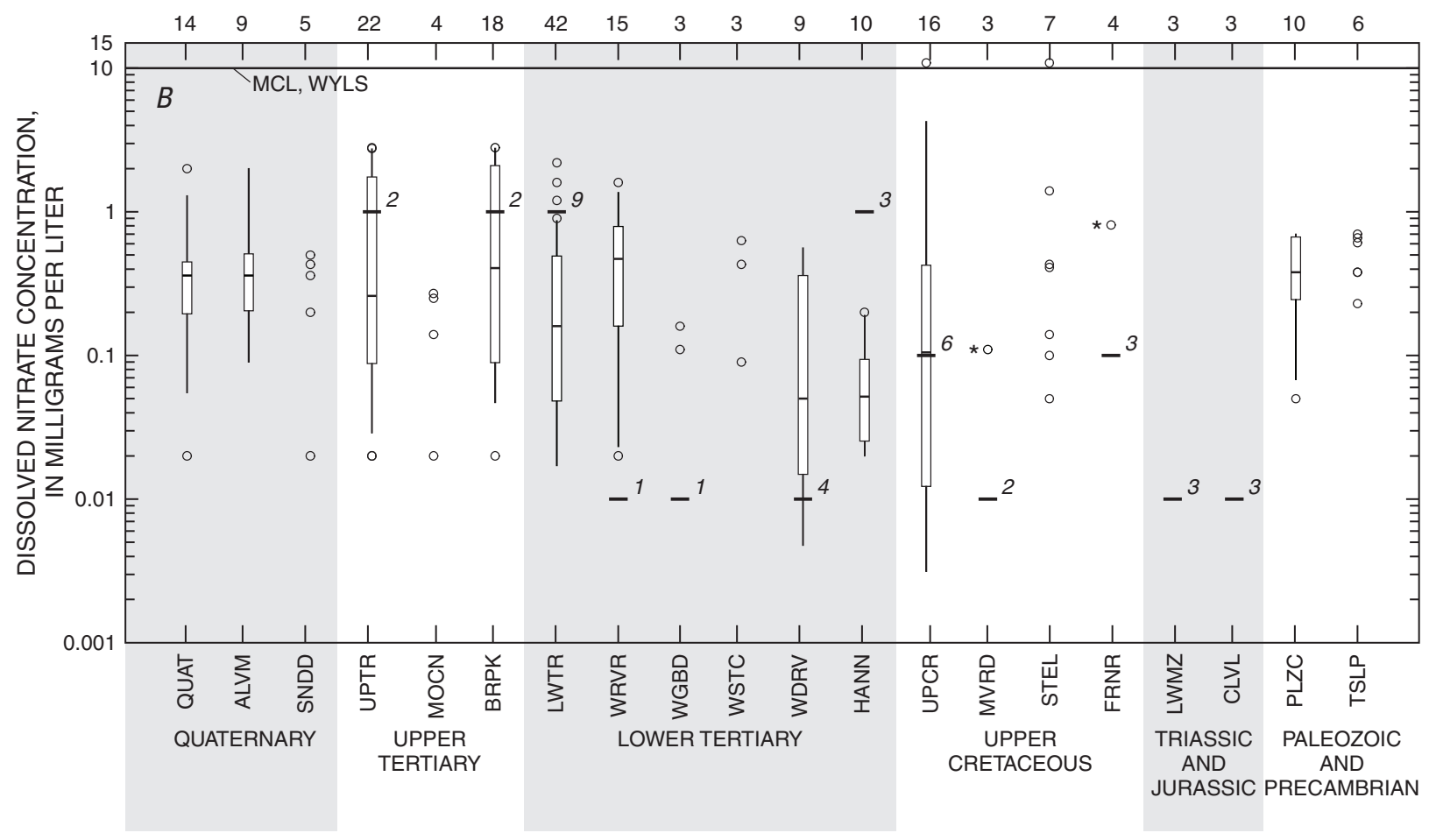

HYDROGEOLOGIC UNIT

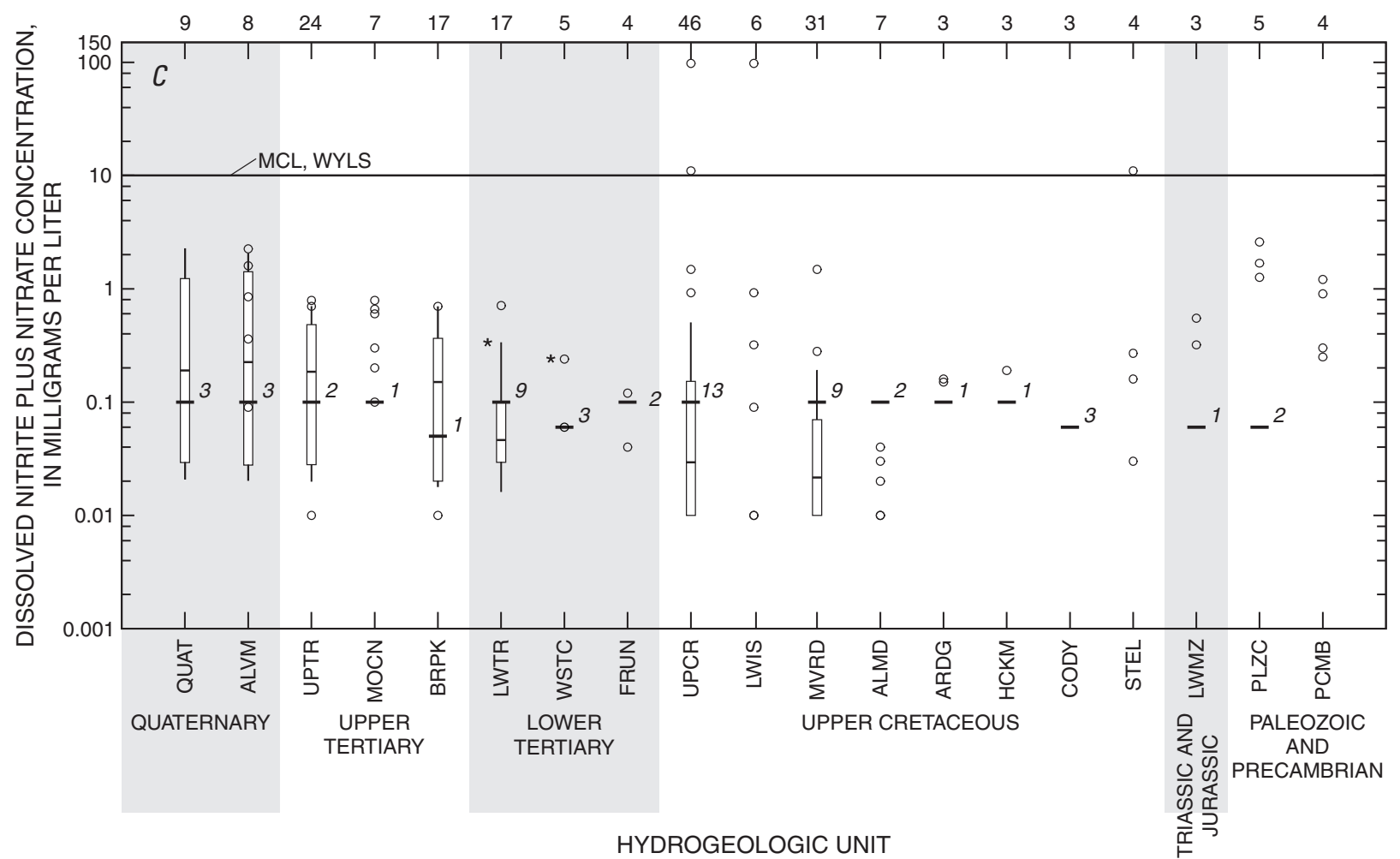

Appendix 7-3. Boxplots showing $A$, ammonia concentrations, $B$, nitrate concentrations, and $C$, nitrite plus nitrate concentrations in samples from aquifers in hydrogeologic units in Carbon County, Wyoming.-Continued 


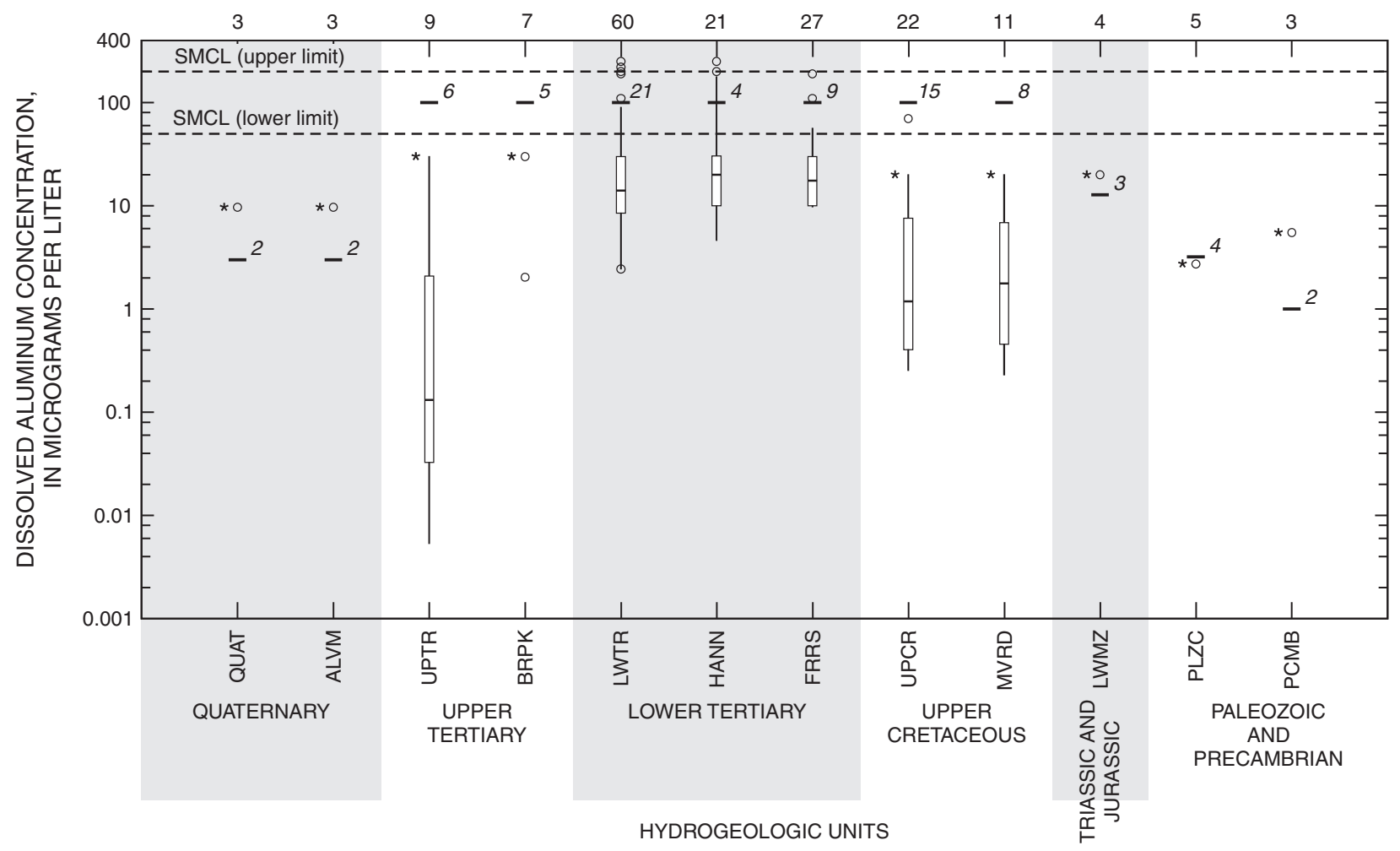

3 Number of samples

- Value outside 10th or 90th percentile

* More than one-half the samples were censored

90th percentile

75th percentile

Median

25th percentile

-2 Highest minimum reporting level and number of censored samples

10th percentile

MCL U.S. Environmental Protection Agency (USEPA) Maximum Contaminant Level (MCL) or proposed Lifetime Health Advisory Level (PHAL) or Lifetime Health Advisory Level (HAL)

PMCL는

U.S. Environmental Protection Agency (USEPA) proposed Maximum Contaminant Level (PMCL) or proposed alternate Maximum Contaminant Level (AMCL) for radon-222

SMCL

USEPA Secondary Maximum Contaminant Level

Wyoming Department of Environmental Quality (WDEQ) Class II ground-water standard for agricultural use

WYLS

WDEQ Class III ground-water standard for livestock use

\section{EXPLANATION}

\section{HYDROGEOLOGIC UNITS:}

Quaternary;

QUAT, Quaternary unconsolidated deposits

ALVM, Alluvium

SNDD, Dune sand (eolian) deposits

Tertiary;

UPTR, all Upper Tertiary hydrogeologic units

MOCN, undifferentiated Miocene rocks

BRPK, Browns Park aquifer (Formation)

LWTR, all Lower Tertiary hydrogeologic units

WSTC, Wasatch aquifer (Formation) WDRV, Wind River aquifer (Formation)

FRUN, Fort Union aquifer (Formation)

HANN, Hanna aquifer (Formation)

FRRS, Ferris aquifer (Formation)

\section{Upper Cretaceous;}

UPCR, all Upper Cretaceous

hydrogeologic units

LWIS, Lewis Shale

MVRD, Mesaverde aquifer (Formation or Group)

ALMD, Almond Formation

ARDG, Allen Ridge Formation

HCKM, Haystack Mountains Formation

CODY, Cody Shale

STEL, Steele Shale

FRNR, Frontier aquifer (Formation)

Appendix 7-4. Boxplots showing selected trace-element and radionuclide concentrations in samples from aquifers in hydrogeologic units in Carbon County, Wyoming. 

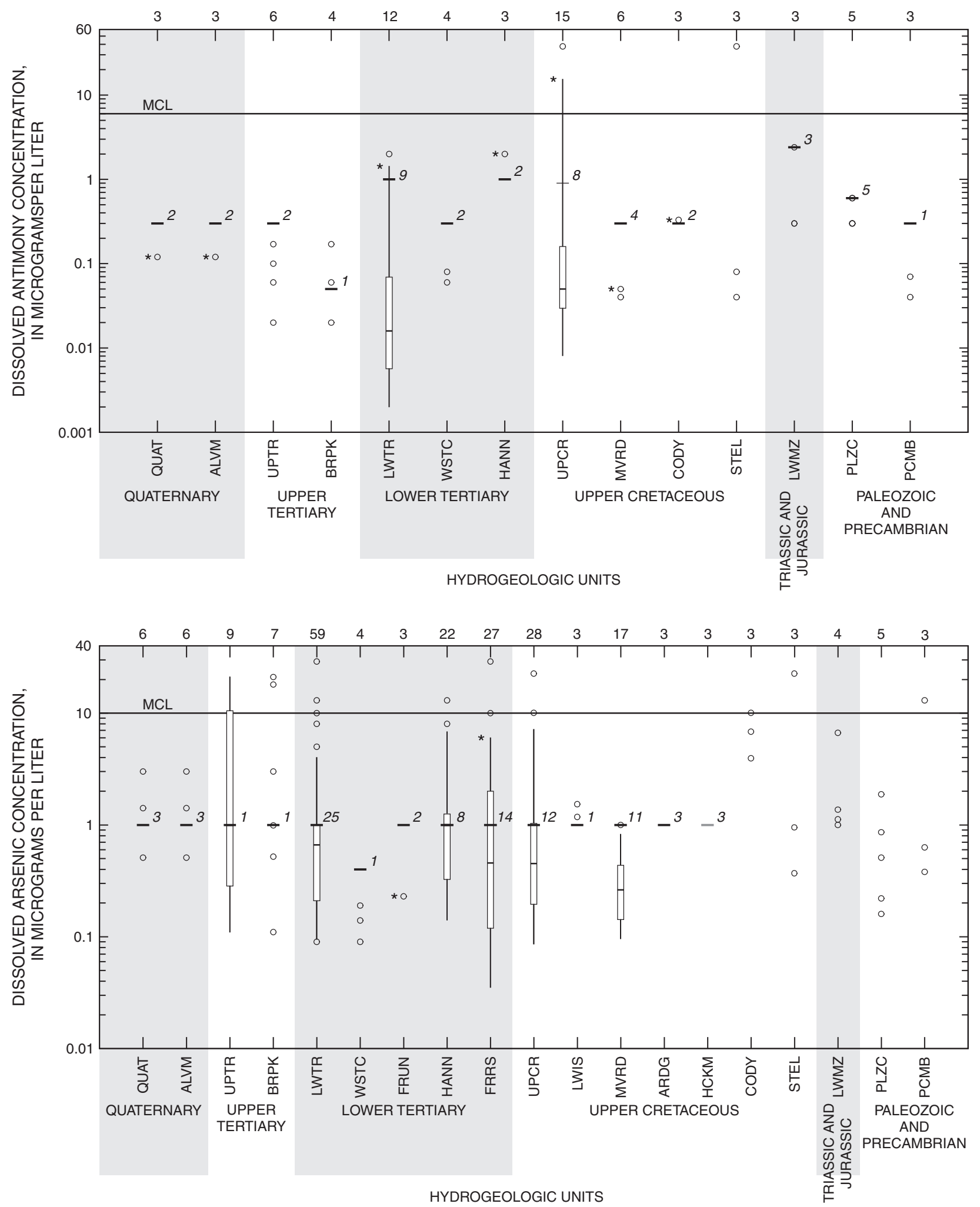

Appendix 7-4. Boxplots showing selected trace-element and radionuclide concentrations in samples from aquifers in hydrogeologic units in Carbon County, Wyoming.-Continued 

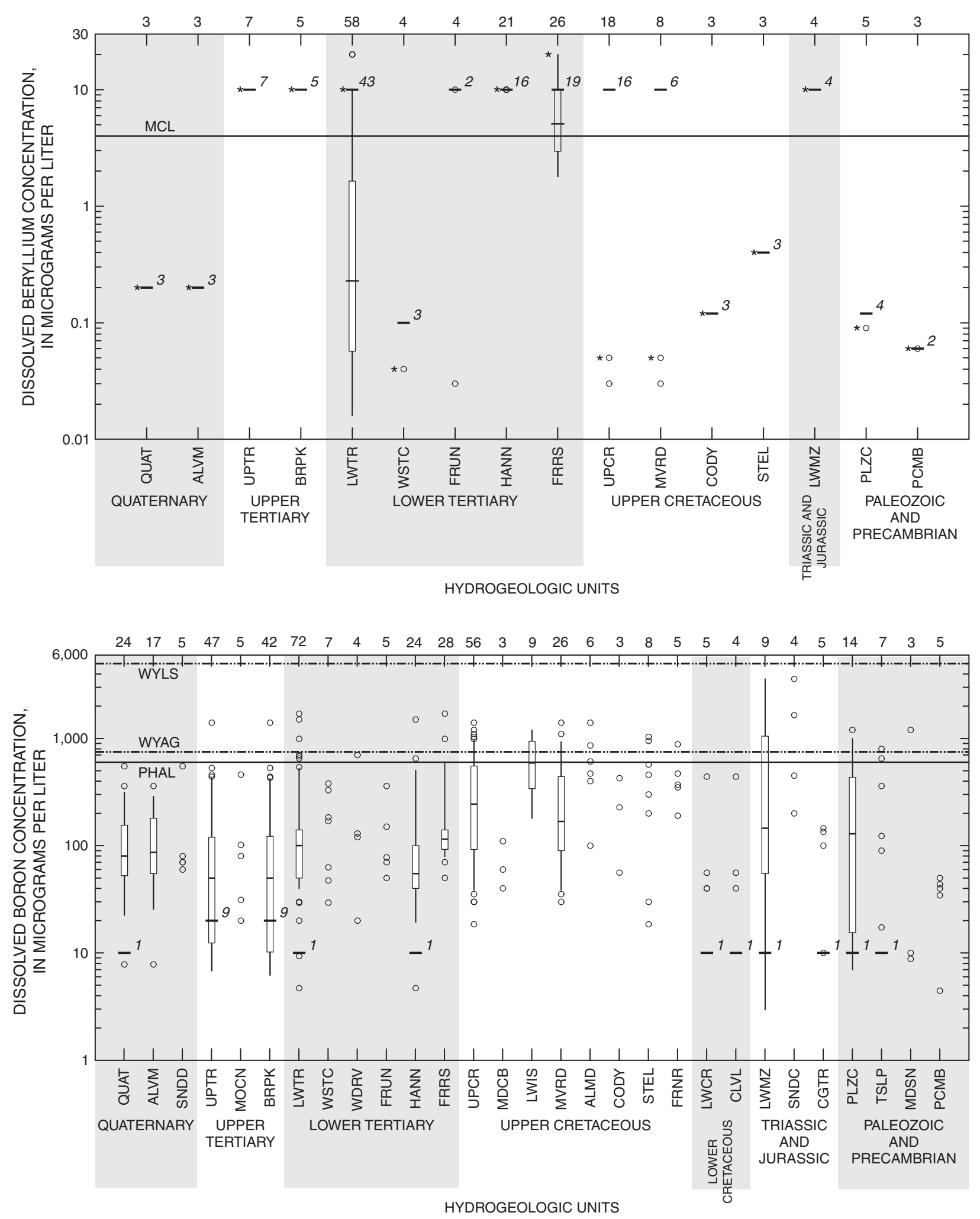

Appendix 7-4. Boxplots showing selected trace-element and radionuclide concentrations in samples from aquifers in hydrogeologic units in Carbon County, Wyoming.-Continued 

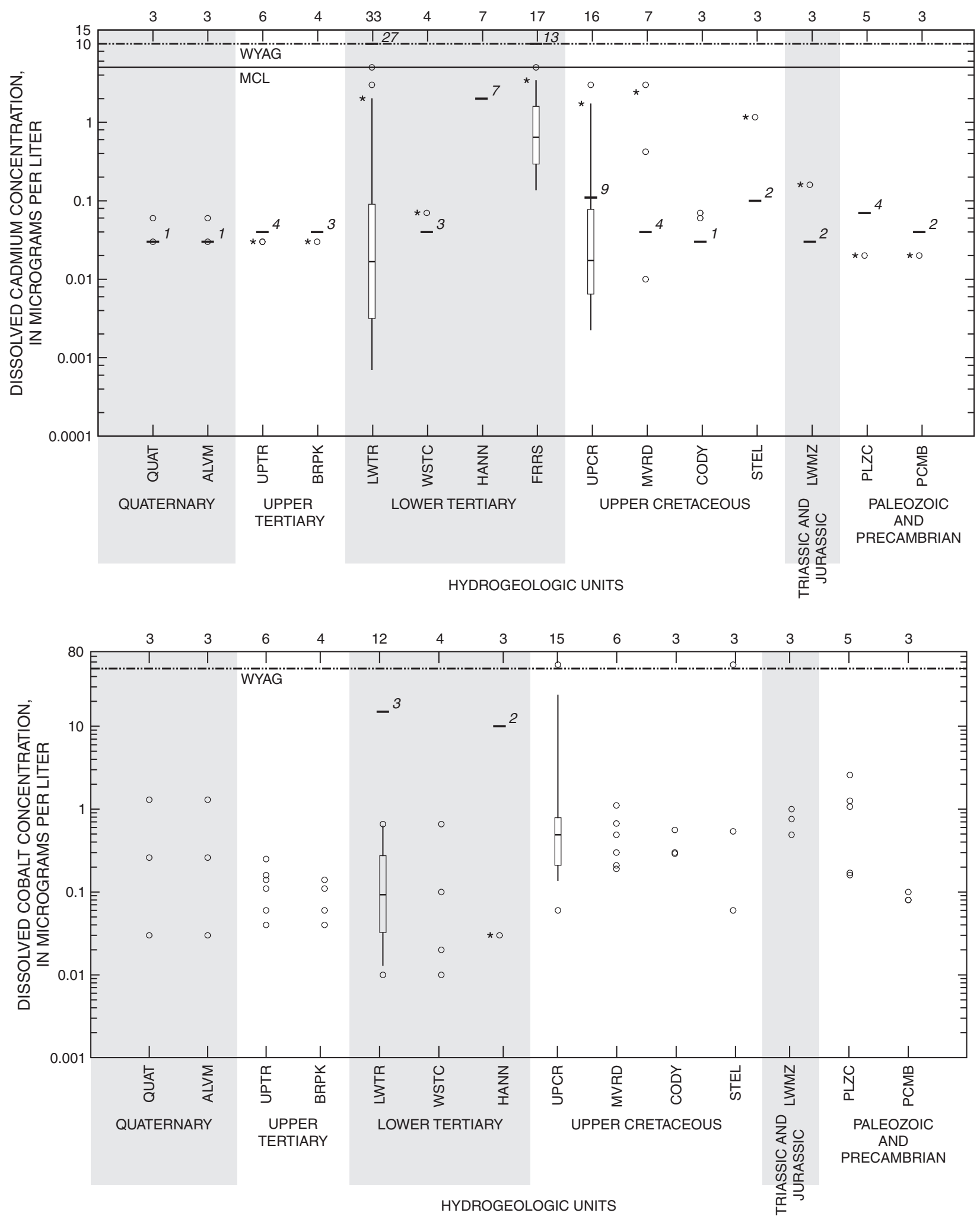

Appendix 7-4. Boxplots showing selected trace-element and radionuclide concentrations in samples from aquifers in hydrogeologic units in Carbon County, Wyoming.-Continued 

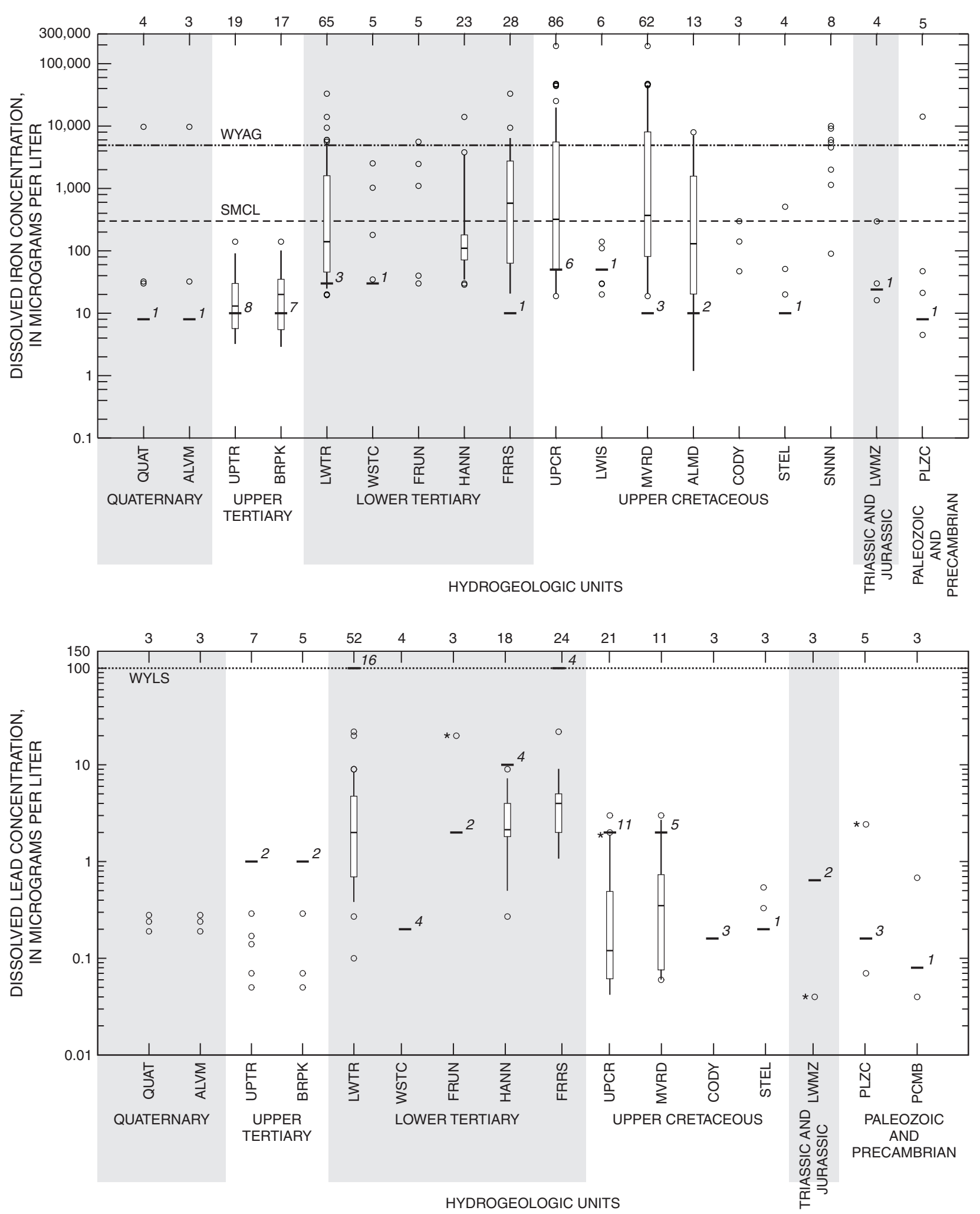

Appendix 7-4. Boxplots showing selected trace-element and radionuclide concentrations in samples from aquifers in hydrogeologic units in Carbon County, Wyoming.-Continued 

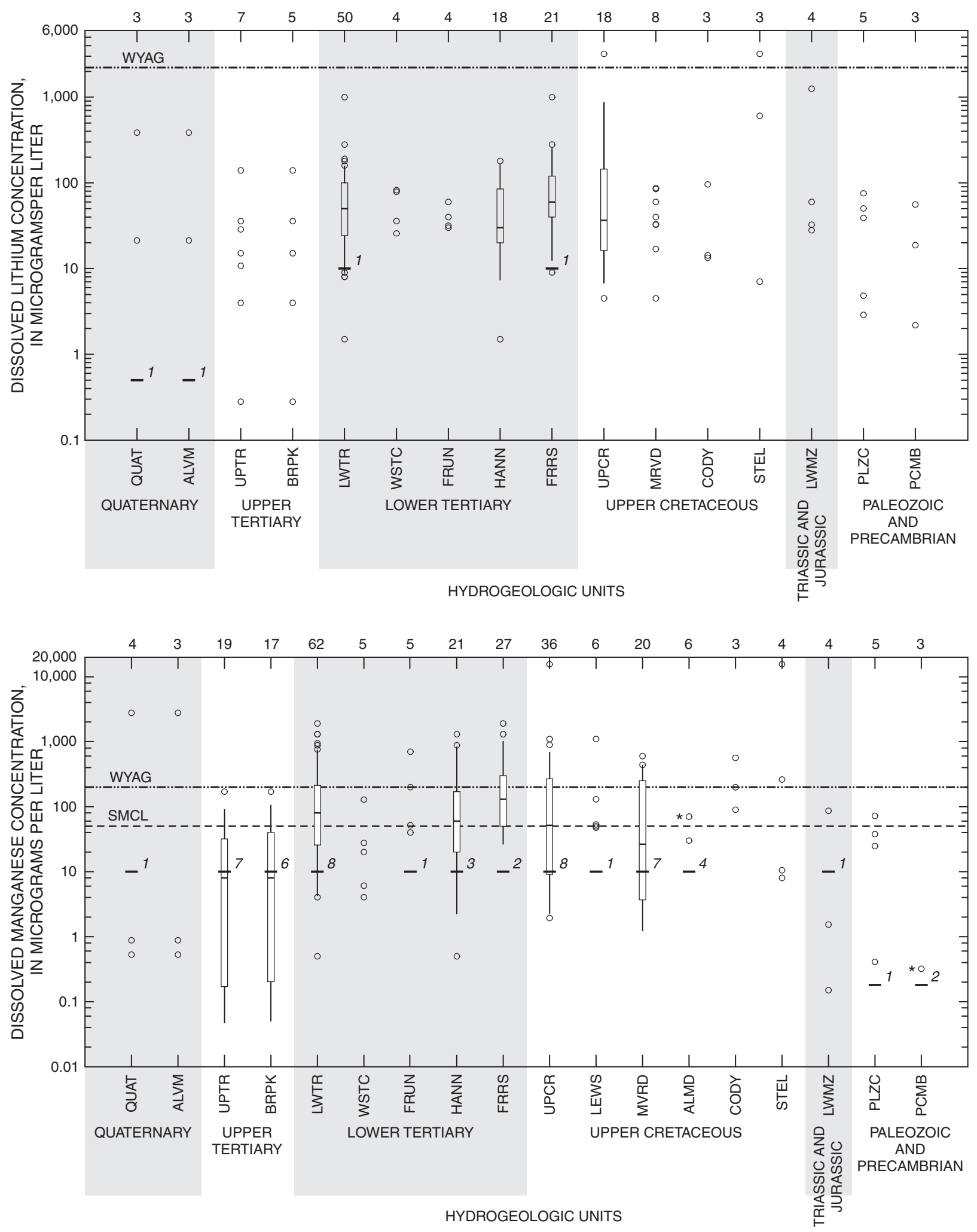

Appendix 7-4. Boxplots showing selected trace-element and radionuclide concentrations in samples from aquifers in hydrogeologic units in Carbon County, Wyoming.-Continued 

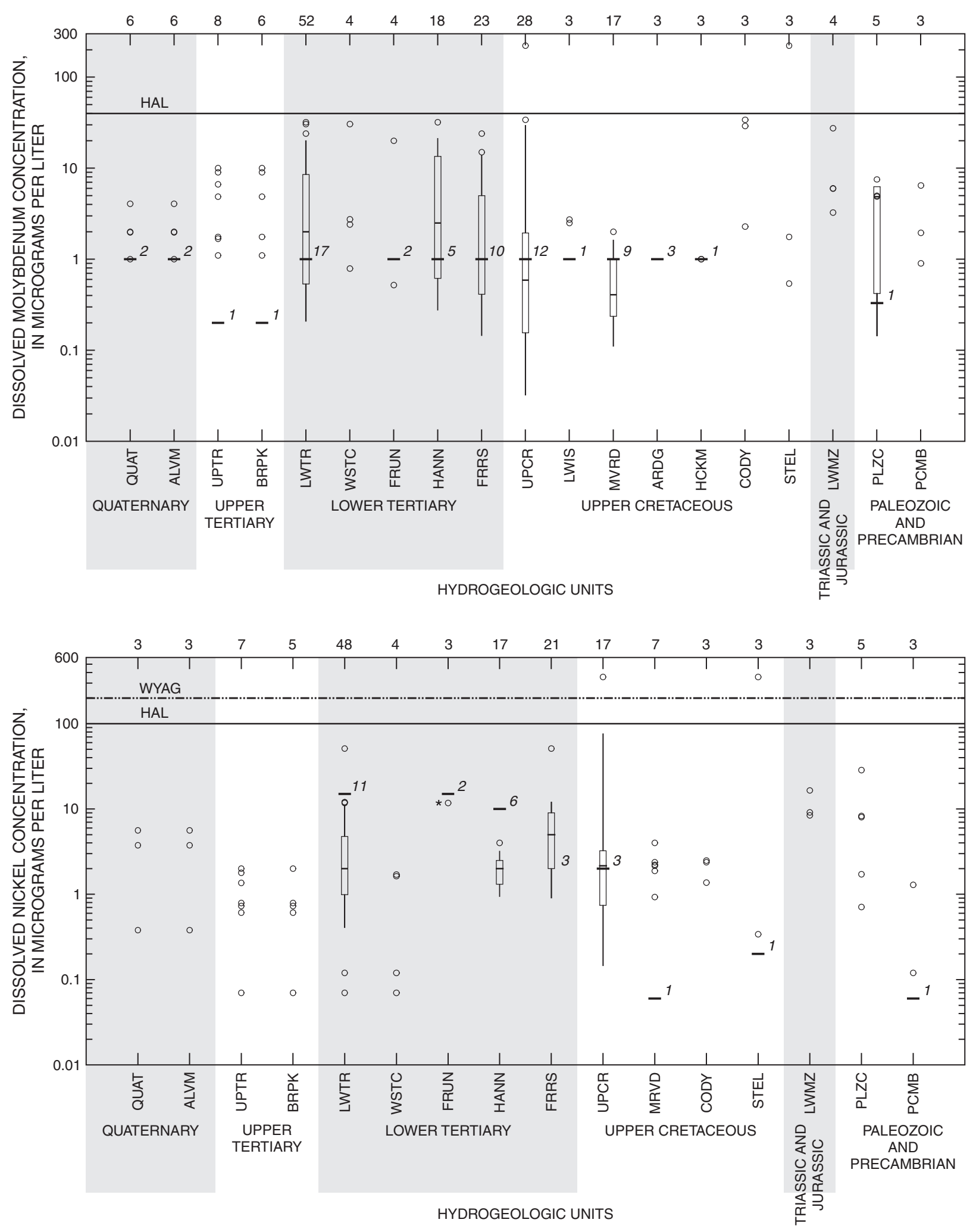

Appendix 7-4. Boxplots showing selected trace-element and radionuclide concentrations in samples from aquifers in hydrogeologic units in Carbon County, Wyoming.-Continued 

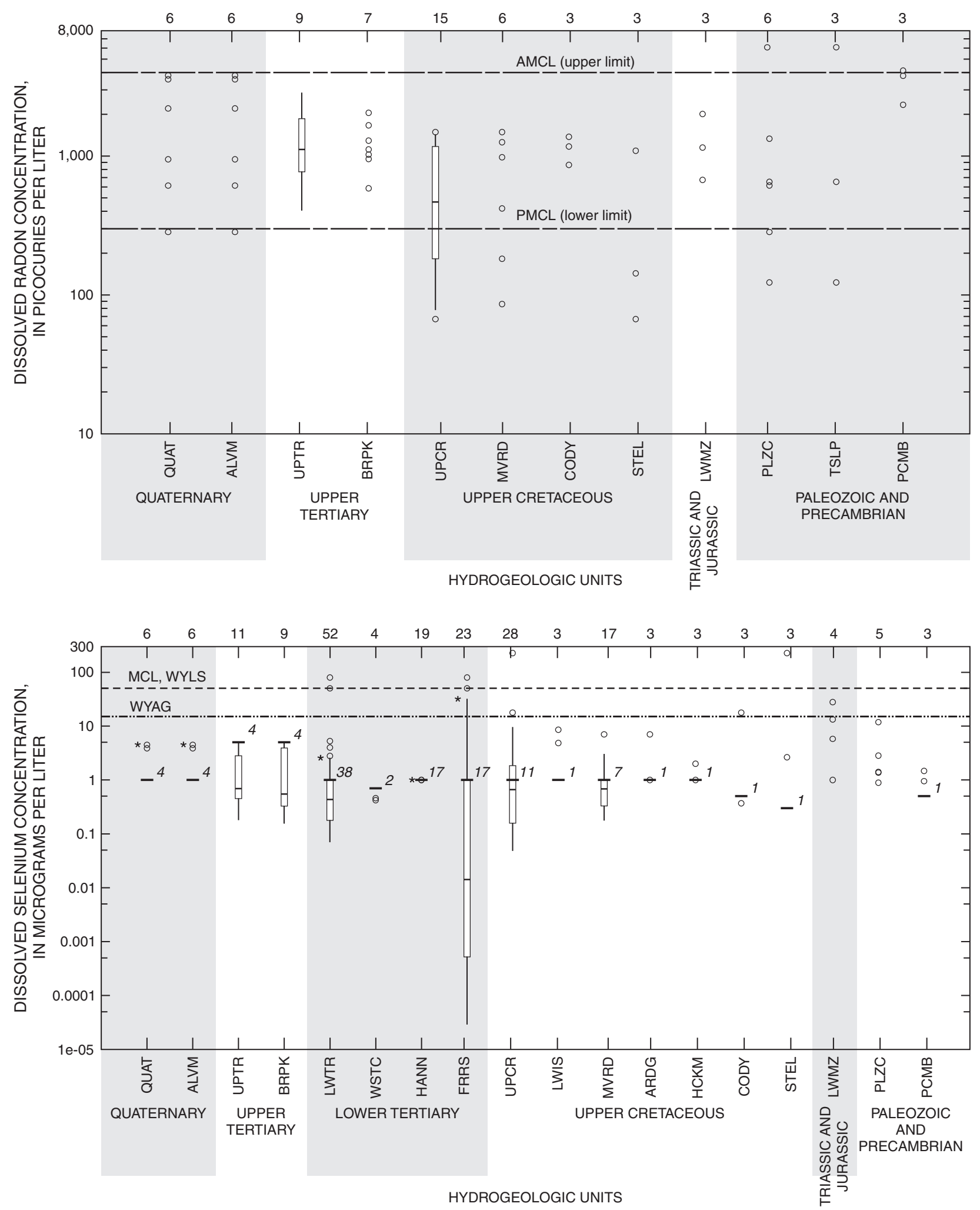

Appendix 7-4. Boxplots showing selected trace-element and radionuclide concentrations in samples from aquifers in hydrogeologic units in Carbon County, Wyoming.-Continued 

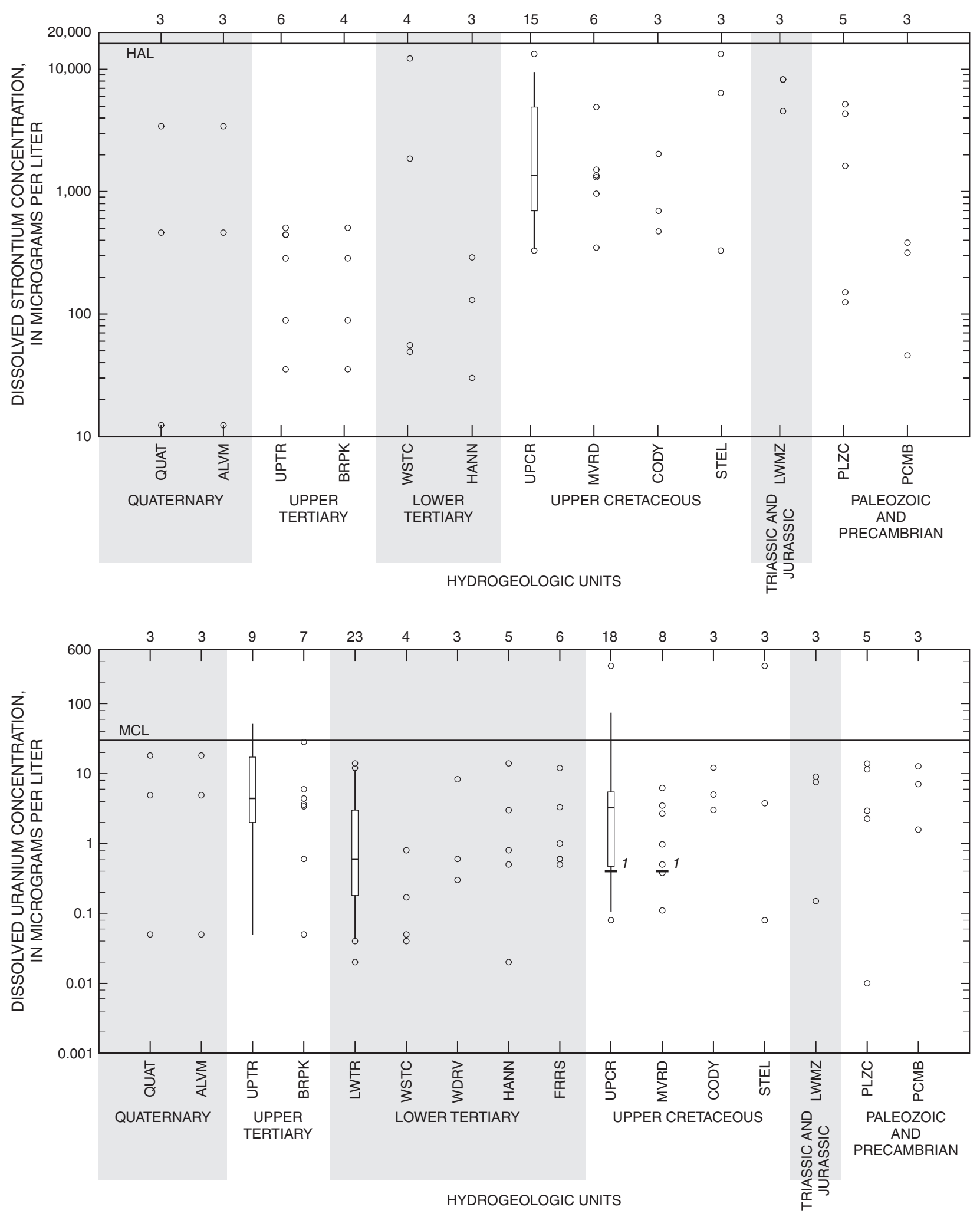

Appendix 7-4. Boxplots showing selected trace-element and radionuclide concentrations in samples from aquifers in hydrogeologic units in Carbon County, Wyoming.-Continued 


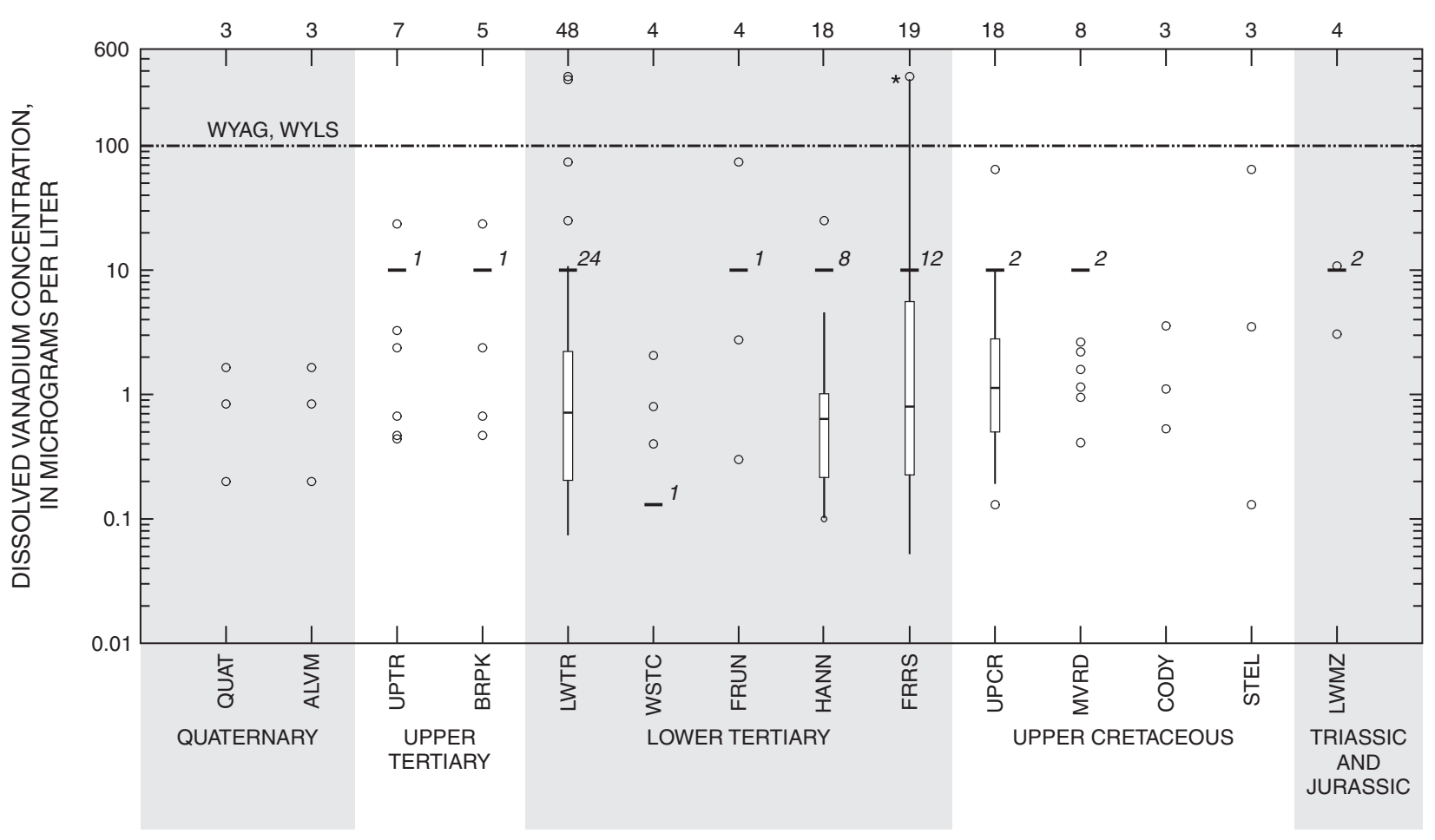

HYDROGEOLOGIC UNITS

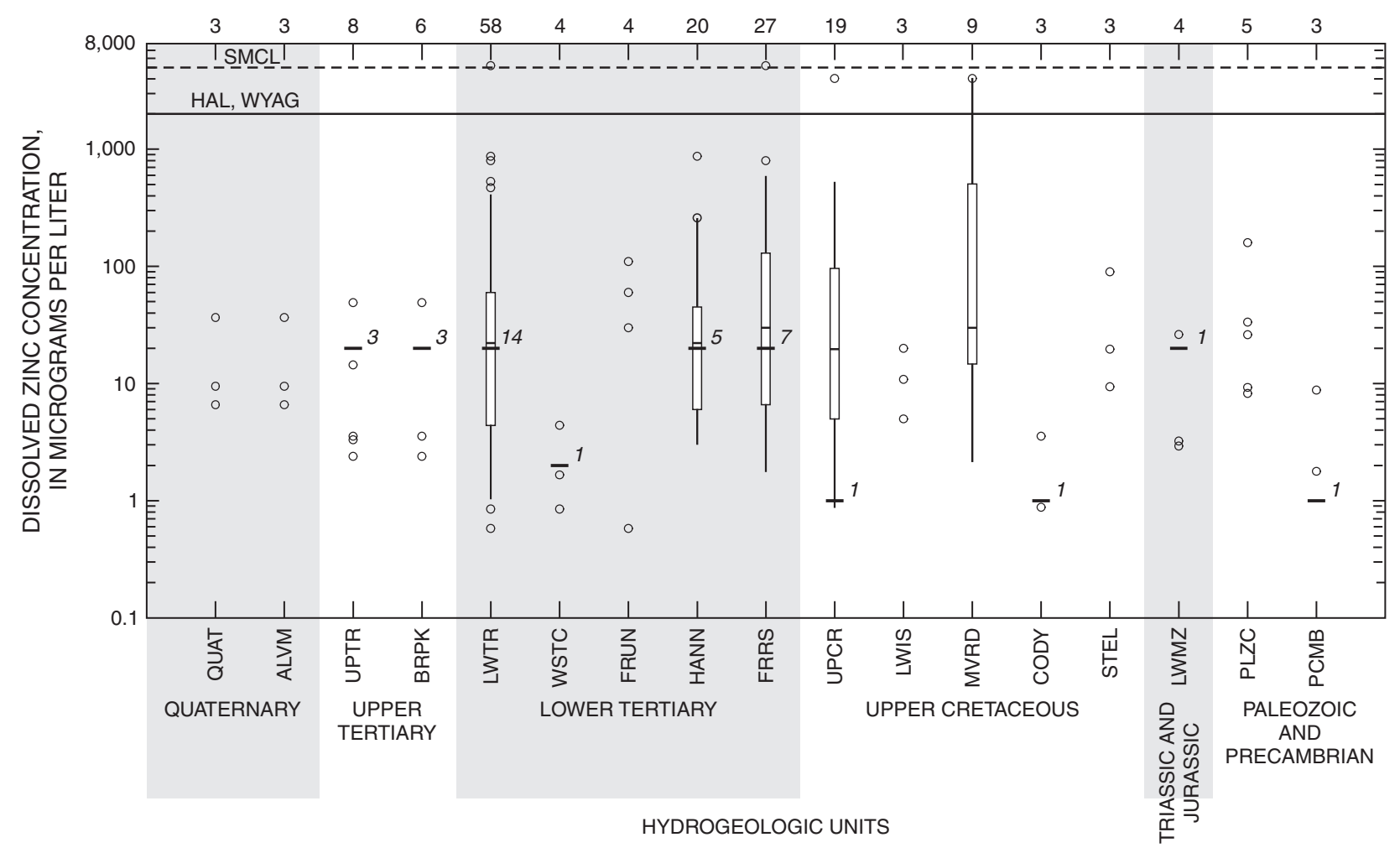

Appendix 7-4. Boxplots showing selected trace-element and radionuclide concentrations in samples from aquifers in hydrogeologic units in Carbon County, Wyoming.-Continued 


\section{Appendix 8. Selected ground-water quality constituents in relation to well depth, Carbon County, Wyoming.}

Appendix 8. Kendall's tau correlation coefficients and resulting probabilities (p-values) between constituents and well depth.

[TDS, total dissolved solids; bold text indicates statistically significant correlation with a p-value less than 0.05]

\begin{tabular}{|c|c|c|c|c|}
\hline Hydrogeologic units & Constituent & $\begin{array}{l}\text { Number of } \\
\text { samples }\end{array}$ & Probability (p-value) & $\begin{array}{c}\text { Kendall's tau correlation } \\
\text { coefficient }\end{array}$ \\
\hline \multirow{10}{*}{$\begin{array}{l}\text { Quaternary unconsolidated } \\
\text { deposits }\end{array}$} & Bicarbonate & 31 & 0.8764 & 0.0194 \\
\hline & Hardness & 33 & .7773 & .0341 \\
\hline & Calcium, dissolved & 30 & .217 & -.1563 \\
\hline & Magnesium, dissolved & 30 & .5126 & -.0828 \\
\hline & Sodium, dissolved & 24 & .3291 & .1413 \\
\hline & Potassium, dissolved & 23 & .6308 & .0711 \\
\hline & Chloride, dissolved & 31 & .1116 & .1979 \\
\hline & Sulfate, dissolved & 32 & .5319 & .0766 \\
\hline & Fluoride, dissolved & 27 & .3167 & -.1339 \\
\hline & TDS & 32 & .3657 & .1109 \\
\hline \multirow[t]{10}{*}{ Quaternary alluvium } & Bicarbonate & 24 & .98 & -.0036 \\
\hline & Hardness & 26 & .6244 & .0677 \\
\hline & Calcium, dissolved & 23 & .4547 & -.1107 \\
\hline & Magnesium, dissolved & 23 & .3763 & -.1304 \\
\hline & Sodium, dissolved & 18 & .6746 & .0719 \\
\hline & Potassium, dissolved & 17 & .5591 & .1029 \\
\hline & Chloride, dissolved & 24 & .53 & .0906 \\
\hline & Sulfate, dissolved & 25 & .869 & .0233 \\
\hline & Fluoride, dissolved & 20 & .0966 & -.2632 \\
\hline & TDS & 25 & .6209 & .0700 \\
\hline \multirow{10}{*}{$\begin{array}{l}\text { All Upper Tertiary hydrogeologic } \\
\text { units }\end{array}$} & Bicarbonate & 60 & .4512 & -.0650 \\
\hline & Hardness & 73 & .436 & .0613 \\
\hline & Calcium, dissolved & 57 & .4406 & .0683 \\
\hline & Magnesium, dissolved & 57 & .5242 & .0564 \\
\hline & Sodium, dissolved & 64 & .0033 & .2465 \\
\hline & Potassium, dissolved & 58 & .006 & .2414 \\
\hline & Chloride, dissolved & 60 & .0011 & .2814 \\
\hline & Sulfate, dissolved & 72 & .0103 & .2034 \\
\hline & Fluoride, dissolved & 57 & .0615 & .1642 \\
\hline & TDS & 70 & .0043 & .2298 \\
\hline
\end{tabular}


Appendix 8. Kendall's tau correlation coefficients and resulting probabilities (p-values) between constituents and well depth.-Continued

\begin{tabular}{|c|c|c|c|c|}
\hline Hydrogeologic units & Constituent & $\begin{array}{l}\text { Number of } \\
\text { samples }\end{array}$ & Probability (p-value) & $\begin{array}{c}\text { Kendall's tau correlation } \\
\text { coefficient }\end{array}$ \\
\hline \multirow[t]{10}{*}{ Undifferentiated Miocene rocks } & Bicarbonate & 12 & 0.9413 & -0.0152 \\
\hline & Hardness & 12 & .2376 & .2424 \\
\hline & Calcium, dissolved & 12 & .2105 & .2576 \\
\hline & Magnesium, dissolved & 12 & .2105 & .2576 \\
\hline & Sodium, dissolved & 12 & .3383 & .1970 \\
\hline & Potassium, dissolved & 12 & .0903 & .3485 \\
\hline & Chloride, dissolved & 12 & .1617 & .2879 \\
\hline & Sulfate, dissolved & 12 & .2105 & .2576 \\
\hline & Fluoride, dissolved & 12 & .2936 & -.2121 \\
\hline & TDS & 12 & .2105 & .2576 \\
\hline \multirow[t]{10}{*}{ Browns Park aquifer } & Bicarbonate & 48 & .7303 & -.0337 \\
\hline & Hardness & 61 & .6191 & .0432 \\
\hline & Calcium, dissolved & 45 & .7117 & .0374 \\
\hline & Magnesium, dissolved & 45 & .5964 & .0535 \\
\hline & Sodium, dissolved & 52 & .0075 & .2519 \\
\hline & Potassium, dissolved & 46 & .0379 & .2077 \\
\hline & Chloride, dissolved & 48 & .0065 & .2660 \\
\hline & Sulfate, dissolved & 60 & .0267 & .1944 \\
\hline & Fluoride, dissolved & 45 & .0175 & .2374 \\
\hline & TDS & 58 & .0133 & .2208 \\
\hline \multirow{10}{*}{$\begin{array}{l}\text { All Lower Tertiary hydrogeologic } \\
\text { units }\end{array}$} & Bicarbonate & 108 & $\mathbf{0}$ & .2714 \\
\hline & Hardness & 116 & .2111 & .0783 \\
\hline & Calcium, dissolved & 108 & .761 & .0197 \\
\hline & Magnesium, dissolved & 108 & .6812 & .0267 \\
\hline & Sodium, dissolved & 106 & $\mathbf{0}$ & .3375 \\
\hline & Potassium, dissolved & 105 & .0001 & .2641 \\
\hline & Chloride, dissolved & 108 & $\mathbf{0}$ & .2870 \\
\hline & Sulfate, dissolved & 112 & .0039 & .1840 \\
\hline & Fluoride, dissolved & 98 & .1085 & .1086 \\
\hline & TDS & 116 & $\mathbf{0}$ & .3262 \\
\hline
\end{tabular}


Appendix 8. Kendall's tau correlation coefficients and resulting probabilities ( $p$-values) between constituents and well depth.-Continued

\begin{tabular}{|c|c|c|c|c|}
\hline Hydrogeologic units & Constituent & $\begin{array}{l}\text { Number of } \\
\text { samples }\end{array}$ & Probability (p-value) & $\begin{array}{c}\text { Kendall's tau correlation } \\
\text { coefficient }\end{array}$ \\
\hline \multirow[t]{10}{*}{ White River aquifer } & Bicarbonate & 15 & 0.3545 & 0.0762 \\
\hline & Hardness & 15 & .2955 & .0857 \\
\hline & Calcium, dissolved & 15 & .2963 & .0857 \\
\hline & Magnesium, dissolved & 15 & .4867 & .0571 \\
\hline & Sodium, dissolved & 15 & .817 & .0190 \\
\hline & Potassium, dissolved & 15 & .8166 & -.0190 \\
\hline & Chloride, dissolved & 15 & 1 & .0000 \\
\hline & Sulfate, dissolved & 15 & .6434 & -.0381 \\
\hline & Fluoride, dissolved & 15 & .283 & .0857 \\
\hline & TDS & 15 & .817 & .0190 \\
\hline \multirow[t]{10}{*}{ Wasatch aquifer } & Bicarbonate & 11 & .1599 & .3273 \\
\hline & Hardness & 11 & .8153 & -.0545 \\
\hline & Calcium, dissolved & 11 & .6394 & -.1091 \\
\hline & Magnesium, dissolved & 11 & .9379 & -.0182 \\
\hline & Sodium, dissolved & 10 & .4208 & .2000 \\
\hline & Potassium, dissolved & 9 & .4042 & .2222 \\
\hline & Chloride, dissolved & 11 & .5858 & .1273 \\
\hline & Sulfate, dissolved & 11 & .0102 & -.6000 \\
\hline & Fluoride, dissolved & 8 & .6207 & -.1429 \\
\hline & TDS & 11 & .5858 & .1273 \\
\hline \multirow[t]{10}{*}{ Wind River aquifer } & Bicarbonate & 13 & .0763 & .3718 \\
\hline & Hardness & 13 & .5403 & -.1282 \\
\hline & Calcium, dissolved & 13 & .3895 & -.1795 \\
\hline & Magnesium, dissolved & 13 & .6676 & -.0897 \\
\hline & Sodium, dissolved & 13 & .0143 & .5128 \\
\hline & Potassium, dissolved & 13 & .0572 & .3974 \\
\hline & Chloride, dissolved & 13 & .4624 & .1538 \\
\hline & Sulfate, dissolved & 13 & .7133 & .0769 \\
\hline & Fluoride, dissolved & 13 & .5331 & -.1282 \\
\hline & TDS & 13 & .2455 & .2436 \\
\hline \multirow[t]{10}{*}{ Hanna aquifer } & Bicarbonate & 22 & .6718 & -.0649 \\
\hline & Hardness & 30 & .0124 & .3218 \\
\hline & Calcium, dissolved & 22 & .5525 & .0909 \\
\hline & Magnesium, dissolved & 22 & .3513 & .1429 \\
\hline & Sodium, dissolved & 22 & .1573 & .2165 \\
\hline & Potassium, dissolved & 22 & .3225 & .1515 \\
\hline & Chloride, dissolved & 22 & .7561 & .0476 \\
\hline & Sulfate, dissolved & 26 & .0027 & .4185 \\
\hline & Fluoride, dissolved & 22 & .3629 & .1385 \\
\hline & TDS & 30 & $\mathbf{0}$ & .5471 \\
\hline
\end{tabular}


Appendix 8. Kendall's tau correlation coefficients and resulting probabilities ( $p$-values) between constituents and well depth.-Continued

\begin{tabular}{|c|c|c|c|c|}
\hline Hydrogeologic units & Constituent & $\begin{array}{l}\text { Number of } \\
\text { samples }\end{array}$ & Probability (p-value) & $\begin{array}{c}\text { Kendall's tau correlation } \\
\text { coefficient }\end{array}$ \\
\hline \multirow[t]{9}{*}{ Fort Union aquifer } & Bicarbonate & 11 & 0.1021 & 0.3818 \\
\hline & Hardness & 11 & .4835 & -.1636 \\
\hline & Calcium, dissolved & 11 & .6971 & -.0909 \\
\hline & Magnesium, dissolved & 11 & .2115 & -.2909 \\
\hline & Sodium, dissolved & 10 & .1284 & .3778 \\
\hline & Potassium, dissolved & 10 & .0458 & .4889 \\
\hline & Chloride, dissolved & 11 & .1391 & .3455 \\
\hline & Sulfate, dissolved & 11 & .4835 & .1636 \\
\hline & TDS & 11 & .024 & .5273 \\
\hline \multirow[t]{10}{*}{ Ferris aquifer } & Bicarbonate & 29 & .7491 & .0419 \\
\hline & Hardness & 29 & .7777 & -.0369 \\
\hline & Calcium, dissolved & 29 & .5849 & -.0714 \\
\hline & Magnesium, dissolved & 29 & .7632 & -.0394 \\
\hline & Sodium, dissolved & 29 & .3763 & .1158 \\
\hline & Potassium, dissolved & 29 & .8213 & .0296 \\
\hline & Chloride, dissolved & 29 & .8066 & -.0320 \\
\hline & Sulfate, dissolved & 29 & .8506 & -.0246 \\
\hline & Fluoride, dissolved & 29 & .0697 & .2340 \\
\hline & TDS & 29 & .8507 & .0246 \\
\hline \multirow{10}{*}{$\begin{array}{l}\text { All Upper Cretaceous } \\
\text { hydrogeologic units }\end{array}$} & Bicarbonate & 171 & $\mathbf{0}$ & .3761 \\
\hline & Hardness & 174 & .001 & -.1676 \\
\hline & Calcium, dissolved & 170 & .0106 & -.1318 \\
\hline & Magnesium, dissolved & 170 & $\mathbf{0}$ & -.2398 \\
\hline & Sodium, dissolved & 171 & $\mathbf{0}$ & .4509 \\
\hline & Potassium, dissolved & 150 & $\mathbf{0}$ & .3498 \\
\hline & Chloride, dissolved & 171 & $\mathbf{0}$ & .4726 \\
\hline & Sulfate, dissolved & 172 & $\mathbf{0}$ & -.3502 \\
\hline & Fluoride, dissolved & 55 & .9006 & .0114 \\
\hline & TDS & 174 & $\mathbf{0}$ & .4175 \\
\hline \multirow[t]{10}{*}{ Lewis Shale } & Bicarbonate & 16 & .1461 & .2667 \\
\hline & Hardness & 16 & .8557 & -.0333 \\
\hline & Calcium, dissolved & 16 & .4941 & -.1250 \\
\hline & Magnesium, dissolved & 16 & .8202 & -.0417 \\
\hline & Sodium, dissolved & 16 & .011 & .4667 \\
\hline & Potassium, dissolved & 15 & .1469 & .2762 \\
\hline & Chloride, dissolved & 16 & .011 & .4667 \\
\hline & Sulfate, dissolved & 16 & .3636 & -.1667 \\
\hline & Fluoride, dissolved & 9 & .2733 & -.2778 \\
\hline & TDS & 16 & .0456 & .3667 \\
\hline
\end{tabular}


Appendix 8. Kendall's tau correlation coefficients and resulting probabilities ( $p$-values) between constituents and well depth.-Continued

\begin{tabular}{|c|c|c|c|c|}
\hline Hydrogeologic units & Constituent & $\begin{array}{l}\text { Number of } \\
\text { samples }\end{array}$ & Probability (p-value) & $\begin{array}{c}\text { Kendall's tau correlation } \\
\text { coefficient }\end{array}$ \\
\hline \multirow[t]{10}{*}{ Mesaverde aquifer } & Bicarbonate & 97 & $\mathbf{0}$ & 0.4070 \\
\hline & Hardness & 97 & 0.0145 & -.1684 \\
\hline & Calcium, dissolved & 97 & .0685 & -.1254 \\
\hline & Magnesium, dissolved & 97 & $\mathbf{0}$ & -.2848 \\
\hline & Sodium, dissolved & 96 & $\mathbf{0}$ & .5252 \\
\hline & Potassium, dissolved & 87 & $\mathbf{0}$ & .4237 \\
\hline & Chloride, dissolved & 97 & $\mathbf{0}$ & .5159 \\
\hline & Sulfate, dissolved & 95 & $\mathbf{0}$ & -.3095 \\
\hline & Fluoride, dissolved & 24 & .072 & .2609 \\
\hline & TDS & 97 & $\mathbf{0}$ & .4961 \\
\hline \multirow[t]{9}{*}{ Almond Formation } & Bicarbonate & 11 & .0423 & .4727 \\
\hline & Hardness & 11 & .8153 & .0545 \\
\hline & Calcium, dissolved & 11 & .6971 & .0909 \\
\hline & Magnesium, dissolved & 11 & .8153 & .0545 \\
\hline & Sodium, dissolved & 11 & .0516 & .4545 \\
\hline & Potassium, dissolved & 11 & .0356 & .4909 \\
\hline & Chloride, dissolved & 11 & .1183 & .3636 \\
\hline & Sulfate, dissolved & 11 & .5322 & -.1455 \\
\hline & TDS & 11 & .1021 & .3818 \\
\hline \multirow[t]{10}{*}{ Steele Shale } & Bicarbonate & 11 & .0658 & .4182 \\
\hline & Hardness & 13 & .2148 & -.2564 \\
\hline & Calcium, dissolved & 11 & .379 & -.2000 \\
\hline & Magnesium, dissolved & 11 & .6884 & -.0909 \\
\hline & Sodium, dissolved & 12 & .1235 & .3333 \\
\hline & Potassium, dissolved & 9 & .0797 & .4444 \\
\hline & Chloride, dissolved & 11 & .0204 & .5273 \\
\hline & Sulfate, dissolved & 13 & .1366 & -.3077 \\
\hline & Fluoride, dissolved & 8 & .6882 & .1071 \\
\hline & TDS & 13 & .2148 & .2564 \\
\hline \multirow[t]{9}{*}{ Shannon Sandstone } & Bicarbonate & 10 & .3252 & .2444 \\
\hline & Hardness & 10 & .6547 & .1111 \\
\hline & Calcium, dissolved & 10 & .8575 & -.0444 \\
\hline & Magnesium, dissolved & 10 & .3252 & .2444 \\
\hline & Sodium, dissolved & 10 & .0253 & .5556 \\
\hline & Potassium, dissolved & 8 & .8046 & -.0714 \\
\hline & Chloride, dissolved & 10 & .0253 & .5556 \\
\hline & Sulfate, dissolved & 10 & .0725 & .4444 \\
\hline & TDS & 10 & .0397 & .5111 \\
\hline
\end{tabular}


Appendix 8. Kendall's tau correlation coefficients and resulting probabilities (p-values) between constituents and well depth.-Continued

\begin{tabular}{|c|c|c|c|c|}
\hline Hydrogeologic units & Constituent & $\begin{array}{c}\text { Number of } \\
\text { samples }\end{array}$ & Probability (p-value) & $\begin{array}{c}\text { Kendall's tau correlation } \\
\text { coefficient }\end{array}$ \\
\hline \multirow[t]{9}{*}{ Frontier aquifer } & Bicarbonate & 18 & 0.272 & 0.1895 \\
\hline & Hardness & 18 & .0045 & .4902 \\
\hline & Calcium, dissolved & 17 & .0107 & .4559 \\
\hline & Magnesium, dissolved & 17 & .0319 & .3824 \\
\hline & Sodium, dissolved & 18 & $\mathbf{0}$ & .7386 \\
\hline & Potassium, dissolved & 14 & .0085 & .5275 \\
\hline & Chloride, dissolved & 18 & $\mathbf{0}$ & .7320 \\
\hline & Sulfate, dissolved & 18 & .037 & -.3595 \\
\hline & TDS & 18 & .0002 & .6340 \\
\hline \multirow{9}{*}{$\begin{array}{l}\text { All Lower Cretaceous } \\
\text { hydrogeologic units }\end{array}$} & Bicarbonate & 51 & .022 & .2212 \\
\hline & Hardness & 51 & .2872 & .1027 \\
\hline & Calcium, dissolved & 50 & .4462 & .0743 \\
\hline & Magnesium, dissolved & 50 & .4917 & .0669 \\
\hline & Sodium, dissolved & 50 & .0943 & .1633 \\
\hline & Potassium, dissolved & 24 & .0113 & .3696 \\
\hline & Chloride, dissolved & 51 & .1673 & .1333 \\
\hline & Sulfate, dissolved & 50 & .0657 & .1796 \\
\hline & TDS & 51 & .0629 & .1796 \\
\hline \multirow[t]{9}{*}{ Muddy Sandstone } & Bicarbonate & 14 & .2983 & .2088 \\
\hline & Hardness & 14 & .7843 & .0549 \\
\hline & Calcium, dissolved & 14 & .7016 & .0769 \\
\hline & Magnesium, dissolved & 14 & .9563 & .0110 \\
\hline & Sodium, dissolved & 14 & .1124 & .3187 \\
\hline & Potassium, dissolved & 10 & .3692 & .2222 \\
\hline & Chloride, dissolved & 14 & .2503 & .2308 \\
\hline & Sulfate, dissolved & 13 & .6688 & -.0897 \\
\hline & TDS & 14 & .208 & .2527 \\
\hline \multirow[t]{8}{*}{ Cloverly aquifer } & Bicarbonate & 14 & .0037 & .5824 \\
\hline & Hardness & 14 & .1711 & .2747 \\
\hline & Calcium, dissolved & 13 & .1993 & .2692 \\
\hline & Magnesium, dissolved & 13 & .1127 & .3333 \\
\hline & Sodium, dissolved & 13 & .005 & .5897 \\
\hline & Chloride, dissolved & 14 & .0052 & .5604 \\
\hline & Sulfate, dissolved & 14 & .8695 & .0330 \\
\hline & TDS & 14 & .0026 & 6044 \\
\hline
\end{tabular}


Appendix 8. Kendall's tau correlation coefficients and resulting probabilities (p-values) between constituents and well depth.-Continued

\begin{tabular}{|c|c|c|c|c|}
\hline Hydrogeologic units & Constituent & $\begin{array}{l}\text { Number of } \\
\text { samples }\end{array}$ & Probability (p-value) & $\begin{array}{c}\text { Kendall's tau correlation } \\
\text { coefficient }\end{array}$ \\
\hline \multirow{9}{*}{$\begin{array}{l}\text { All Triassic and Jurassic } \\
\text { hydrogeologic units }\end{array}$} & Bicarbonate & 39 & 0.0144 & 0.2726 \\
\hline & Hardness & 39 & .7345 & .0378 \\
\hline & Calcium, dissolved & 39 & .5856 & .0607 \\
\hline & Magnesium, dissolved & 39 & .7064 & .0418 \\
\hline & Sodium, dissolved & 39 & $\mathbf{0}$ & .4669 \\
\hline & Potassium, dissolved & 20 & .0001 & .6316 \\
\hline & Chloride, dissolved & 39 & .0002 & .4089 \\
\hline & Sulfate, dissolved & 38 & .0453 & .2262 \\
\hline & TDS & 39 & .0002 & .4224 \\
\hline \multirow[t]{8}{*}{ Sundance aquifer } & Bicarbonate & 16 & .4436 & .1417 \\
\hline & Hardness & 16 & .7871 & .0500 \\
\hline & Calcium, dissolved & 16 & .7866 & .0500 \\
\hline & Magnesium, dissolved & 16 & .5849 & .1000 \\
\hline & Sodium, dissolved & 16 & .9641 & .0083 \\
\hline & Chloride, dissolved & 16 & .558 & .1083 \\
\hline & Sulfate, dissolved & 16 & .3219 & .1833 \\
\hline & TDS & 16 & .9283 & .0167 \\
\hline \multirow[t]{8}{*}{ Nugget aquifer } & Bicarbonate & 14 & .7016 & -.0769 \\
\hline & Hardness & 14 & .0248 & .4506 \\
\hline & Calcium, dissolved & 14 & .0052 & .5604 \\
\hline & Magnesium, dissolved & 14 & .1099 & .3187 \\
\hline & Sodium, dissolved & 14 & .0186 & .4725 \\
\hline & Chloride, dissolved & 14 & .6222 & .0989 \\
\hline & Sulfate, dissolved & 13 & .0009 & .6923 \\
\hline & TDS & 14 & .0138 & .4945 \\
\hline \multirow{10}{*}{$\begin{array}{l}\text { All Paleozoic hydrogeologic } \\
\text { units }\end{array}$} & Bicarbonate & 71 & .0294 & .1763 \\
\hline & Hardness & 71 & .155 & .1151 \\
\hline & Calcium, dissolved & 71 & .1197 & .1260 \\
\hline & Magnesium, dissolved & 71 & .2446 & .0942 \\
\hline & Sodium, dissolved & 71 & $\mathbf{0}$ & .4141 \\
\hline & Potassium, dissolved & 36 & $\mathbf{0}$ & .6841 \\
\hline & Chloride, dissolved & 71 & $\mathbf{0}$ & .4016 \\
\hline & Sulfate, dissolved & 71 & .0015 & .2575 \\
\hline & Fluoride, dissolved & 18 & .003 & .4379 \\
\hline & TDS & 71 & $\mathbf{0}$ & .3666 \\
\hline
\end{tabular}


Appendix 8. Kendall's tau correlation coefficients and resulting probabilities ( $p$-values) between constituents and well depth.-Continued

\begin{tabular}{llccc}
\hline \multicolumn{1}{c}{ Hydrogeologic units } & \multicolumn{1}{c}{ Constituent } & $\begin{array}{c}\text { Number of } \\
\text { samples }\end{array}$ & Probability (p-value) & $\begin{array}{c}\text { Kendall's tau correlation } \\
\text { coefficient }\end{array}$ \\
\hline Tensleep aquifer & Bicarbonate & 52 & $\mathbf{0 . 0 2 1 5}$ & $\mathbf{0 . 2 1 9 5}$ \\
& Hardness & 52 & .8744 & .0151 \\
& Calcium, dissolved & 52 & .7579 & .0294 \\
& Magnesium, dissolved & 52 & .4021 & .0799 \\
Sodium, dissolved & 52 & $\mathbf{. 0 0 0 1}$ & $\mathbf{. 3 7 4 8}$ \\
& Potassium, dissolved & 23 & $\mathbf{0}$ & $\mathbf{. 6 7 9 8}$ \\
Chloride, dissolved & 52 & $\mathbf{. 0 0 0 1}$ & $\mathbf{. 3 6 5 8}$ \\
& Sulfate, dissolved & 52 & .0611 & .1787 \\
Fluoride, dissolved & 10 & .1215 & .2889 \\
TDS & 52 & $\mathbf{. 0 0 0 8}$ & $\mathbf{. 3 2 0 5}$ \\
\hline Madison aquifer & Bicarbonate & 9 & .5316 & -.1667 \\
& Hardness & 9 & $\mathbf{. 0 1 2 3}$ & $\mathbf{. 6 6 6 7}$ \\
Calcium, dissolved & 9 & $\mathbf{. 0 2 1 8}$ & $\mathbf{. 6 1 1 1}$ \\
& Magnesium, dissolved & 9 & .0953 & .4444 \\
Sodium, dissolved & 9 & $\mathbf{. 0 3 7 1}$ & $\mathbf{. 5 5 5 6}$ \\
& Chloride, dissolved & 9 & $\mathbf{. 0 2 1 8}$ & $\mathbf{. 6 1 1 1}$ \\
Sulfate, dissolved & 9 & $\mathbf{. 0 3 7 1}$ & $\mathbf{. 5 5 5 6}$ \\
TDS & 9 & $\mathbf{. 0 3 7 1}$ & $\mathbf{. 5 5 5 6}$ \\
\hline
\end{tabular}



Prepared by the Wyoming Water Science Center of the USGS.

Edited by Janet M. Carter.

Manuscript and graphics prepared by Suzanne C. Roberts.

Cover photographs by Jon P. Mason and Jodi R. Norris.

For more information concerning the research in this report, contact:

Director

Wyoming Water Science Center

U.S. Geological Survey

2617 E. Lincolnway, Suite B

Cheyenne, Wyoming 82001-5662

(307) 778-2931

http://wy.water.usgs.gov/ 


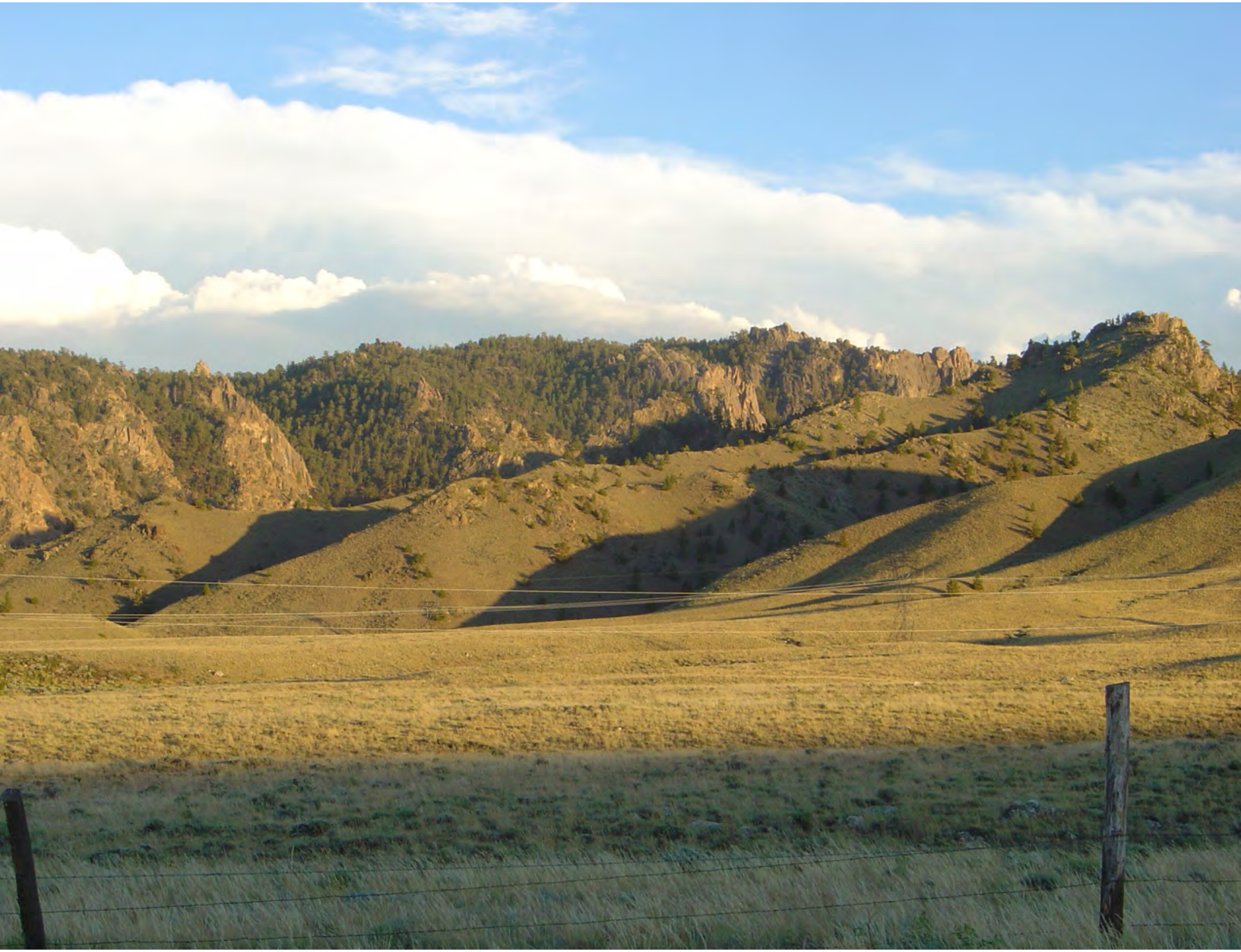

Printed on recycled paper 